\title{
A instrução pública nas vozes dos portadores de futuros (Brasil - séculos XIX e XX)
}

Carlos Monarcha

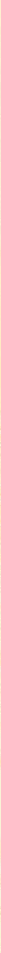



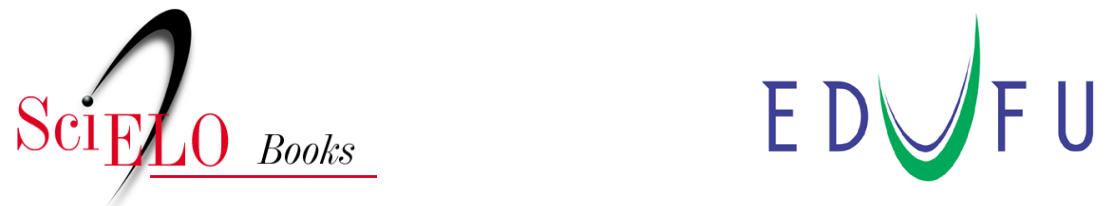

\section{A instrução pública nas vozes dos portadores de futuros (Brasil - séculos XIX e XX)}

Carlos Monarcha

\section{SciELO Books / SciELO Livros / SciELO Libros}

MONARCHA, C. A instrução pública nas vozes dos portadores de futuros (Brasil - séculos XIX e XX) [online]. Uberlândia: EDUFU, 2016, 424 p. História, Pensamento, Educação collection. Novas investigações series, vol. 8. ISBN: 978-857078-500-8. Available from: http://books.scielo.org/id/8fr26. http://doi.org/10.14393/EDUFU-978-85-7078-500-8.

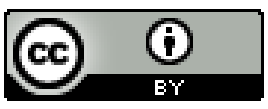

All the contents of this work, except where otherwise noted, is licensed under a Creative Commons Attribution 4.0 International license.

Todo o conteúdo deste trabalho, exceto quando houver ressalva, é publicado sob a licença Creative Commons Atribição 4.0.

Todo el contenido de esta obra, excepto donde se indique lo contrario, está bajo licencia de la licencia Creative Commons Reconocimento 4.0. 


\section{A instrução pública nas vozes dos portadores de futuros (Brasil - séculos XIX e XX)}


UUFU

niversidad

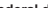

Uberlândia

REITOR

Elmiro Santos Resende

VICE-REITOR

Eduardo Nunes Guimarães

DIRETORA DA EDUFU

Joana Luiza Muylaert de Araújo

CONSELHO EDITORIAL

Alessandro Alves Santana

Carlos Eugênio Pereira

Cibele Crispim

Francisco José Torres de Aquino

Guilherme Fromm

Lília Gonçalves Neves

Luiz Fernando Moreira Izidoro

Narciso Larangeira Telles da Silva

Reginaldo Pedroso dos Santos

Sílvio Carlos Rodrigues

EDITORA DE PUBLICAÇÕES

Maria Amália Rocha

REVISÃO

Zeila Abdala de Sá e Souza

\section{EDITORAÇÃO E CAPA}

Eduardo Warpechowski

REVISÃO DAS REFERÊNCIAS

BIBLIOGRÁFICAS

Maira Nani França

\section{$E D \cup F U$}

Editora da Universidade Federal de Uberlândia

Av. João Naves de Ávila, 2121

Campus Santa Mônica

Bloco 1S - Térreo

Cep 38400-902

Uberlândia - Minas Gerais - Brasil

Tel: (34) 3239-4293

www.edufu.ufu.br

\section{NÚCLEO DE ESTUDOS E PESQUISAS EM HISTÓRIA E HISTORIOGRAFIA DA EDUCAÇÃO}

\section{COLEÇÃO}

"História, Pensamento e Educação"

\section{DIREÇÃO}

Décio Gatti Júnior e Geraldo Inácio Filho

\section{CONSELHO EDITORIAL}

Adrián Ascolani - Univ. Nacional de Rosario Ana Waleska Pollo Campos Mendonça - PUC-Rio Antón Costa Rico - Univ. Santiago de Compostela António Gomes Ferreira - Universidade de Coimbra Carlos Monarcha - UNESP (Araraquara)

Denice Bárbara Catani - USP

Ester Buffa - Uninove/UFSCar

Eurize Caldas Pessanha - UFMS

Flávia Werle - UNISINOS

Gabriela Ossenbach - Univ. Nac. de Educ. a Distancia Jaime Caiceo Escudero - Univ. de Santiago de Chile Joaquim Pintassilgo - Universidade de Lisboa

José António M. M. Afonso - Universidade do Minho Justino Magalhães - Universidade de Lisboa

Luís Alberto Marques Alves - Universidade do Porto

Karl M. Lorenz - Sacred Heart University

Maria Adelina Arredondo Lopez - U. A. E. Morelos

Maria Cristina Gomes Machado - UEM

Maria Helena Camara Bastos - PUC-RS/UFRGS

Marta Maria de Araújo - UFRN

Paolo Bianchini - Università degli Studi di Torino

SÉRIE

"Novas Investigações"

DIREÇÃO

Armindo Quillici Neto e Décio Gatti Júnior

VOLUME 8

A instrução pública nas vozes dos portadores de futuros (Brasil - séculos XIX e XX)

\section{AUTOR}

Carlos Monarcha

\section{IMAGEM CAPA}

Escola-Modelo Masculina anexa à Escola Normal da Praça (Arquivo Público do Estado de São Paulo)

IMPRESSÃO E ACABAMENTO

DIGRA - Divisão Gráfica da UFU 
Carlos Monarcha

\section{A instrução pública nas vozes dos portadores de futuros \\ (Brasil - séculos XIX e XX)}

Coleção

História, Pensamento

e Educação
Série

Novas Investigações

Volume 8
$E D \cup F U$ 


\section{EDUFU}

Editora da Universidade Federal de Uberlândia

Copyright 2016 C Edufu - Editora da Universidade Federal de Uberlândia/MG

Todos os direitos reservados.

Permitido fazer download e compartilhar desde que dado o devido crédito ao autor e à Edufu.

Proibido utilizar para fins comerciais ou fazer qualquer forma de alteração/derivação.

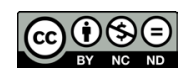

Dados Internacionais de Catalogação na Publicação (CIP)

M734i Monarcha, Carlos, 1949-

A instrução pública nas vozes dos portadores de futuros (Brasil séculos XIX e XX) [recurso eletrônico] / Carlos Monarcha. - Uberlândia : EDUFU, 2019.

424 p. : il. - (Coleção História, Pensamento, Educação. Série Novas Investigações, v. 8).

ISBN: 978-85-7078-500-8 (e-book)

Inclui bibliografia.

Modo de acesso: Internet.

Disponível em: http://www.edufu.ufu.br/

Publicado no formato impresso em 2016.

1. Educação - História - Brasil. 2. Intelectuais. 3. Discursos, alocuções, etc. I. Núcleo de Estudos e Pesquisas em História e Historiografia da Educação (NEPHE). II. Título. 


\section{Sumário}

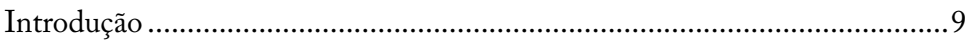

Parte I

Da Assembleia Nacional Constituinte à consolidação do Império

A instrução pública às vésperas de si..................................................19

A estabilidade institucional....................................................................33

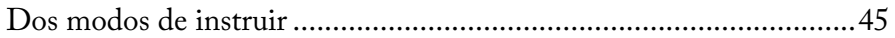

Parte II

Do apogeu ao fim do Segundo Reinado

No "plano inclinado" da monarquia .......................................................

Duas figuras de reformadores ............................................................73

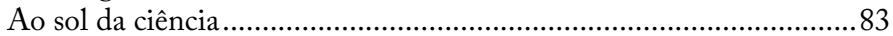

De mestre-escola a professor primário..................................................99

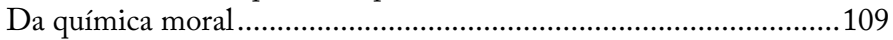

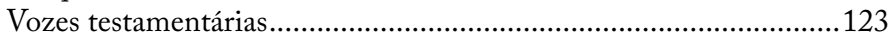

Parte III

Do Governo Provisório republicano à virada do século

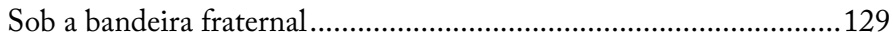

Republicanismo educativo …………….........................................141

Regeneração didática .................................................................149

Parte IV

Da política dos governadores à década dos centenários

Sobre a natureza do bom e do mau governo ......................................169

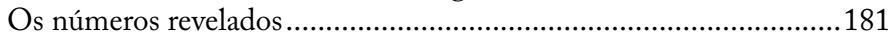

E continuam a revelar.....................................................................191

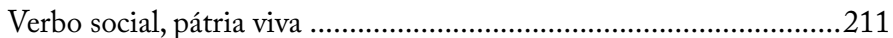

Hermeneutas da República iletrada ................................................227 
Parte V

Do imediato pós-30 à mitologia do Estado Novo

Sentido do Brasil, república agrícola............................................245

Da escola de instrução primária e seu magistério ...........................263

Marcha territorial .....................................................................279

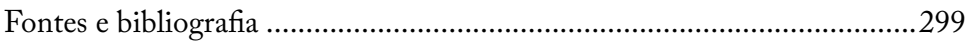

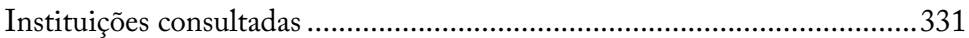

Apêndice A - Outras tabelas...............................................................333

Apêndice B - Imagens antigas, quase esquecidas ..................................349

Crédito das imagens ......................................................................4 413

Índice onomástico ..............................................................................4 415 


\section{O Brasil é um presente do século XVI, oferecido ao futuro pelo acaso.}

(Santa'Anna Nery, Le pays des Amazones: l'El-Dorado, les terres à caoutchouc, 1899) 



\section{Introdução}

\section{Questão}

Certamente, provém do século XIX brasileiro - momento em que se consuma a doutrina liberal como fundamento jurídicopolítico do regime dinástico, constitucional e representativo - a determinação mais clara de engendrar coletividades harmoniosas pela via da instrução pública. Assemelhada a uma estrutura profunda, melhor, marco de esperança cravado em presentes passados, incólume, a confiança no halo da instrução, antiga figura fractal, atravessará in extenso as temporalidades do Império e da República.

$\mathrm{Na}$ tempestividade das épocas, comungantes, e em coextensão especulativa, homens públicos da monarquia e da república, conquanto discordantes na praça de guerra das doutrinas societárias, ao se debaterem por atos fundados na moral, ética, razão, virtude, justiça, e, sobretudo, ao reivindicarem para si a autoconsciência do tempo vivido, precipitam-se nas cenas como portadores de futuros possíveis.

Nas vozes e nas atitudes de sujeitos encarnados porta-vozes dos interesses gerais, escritores, políticos, jornalistas, professores, bacharéis, funcionários, médicos, militares, politécnicos, juristas, administradores, em suma frações da inteligência brasileira, irmanam-se numa comunidade de propósitos: instruir a massa bruta de analfabetos, cuja linguagem, dizia-se, recordava à infância das primeiras sociedades e os costumes de uma humanidade vivente no subsolo da história. 
Nas visões desdobradas, a luz geral a ser propagada pelo mestre de escola do Império e pelo professor primário da República eliminaria a parte malsã dos regimes constitucionais e representativos consubstanciados em pacto de união e/ou corpo político estável. Entrementes, malformada e exígua, a instrução pública é a metonímia de um país perplexo de si, o analfabetismo nacional, o torniquete.

Compartindo o investimento de formar súditos da monarquia ou cidadãos da república, irrequietos e desacomodados, ora em chave realista ora fantasiosa, publicistas provindos de horizontes diversos, guardadas as ipseidades, convergem na urgência de uma instrução primária de Estado, gratuita e obrigatória (e no evoluir do tempo, laica), como marco da estratégia geral de governo pacificado e de liberação de forças produtivas. Desnecessário afirmar que nesses voos a instrução popular aparece como propedêutica ao homem social pela efetividade da cultura. No aglomerado de vozes, paz pública, razão de Estado e economia política se entrecruzam. Endosso prático e anteparo firme viriam da mediação da instrução organizada como instituição nacional, valioso tonificante, poderoso moto-contínuo, adorável anjo da paz. Eis, leitor, o todo e o porquê de $A$ instrução pública nas vozes dos portadores de futuros (Brasil séculos $X I X$ e XX).

\section{Procedimentos}

Para Veyne (1971), a história pode ser narrada por uma pluralidade de enredos, o que por certo não significa afirmar que a sua escrita não aspire à veracidade e à objetividade. Considerando a efetividade dessa formulação, a história da instrução pública no Brasil, nos séculos XIX e XX, pode ser igualmente narrada de diversos modos e maneiras, de sorte que o enredo por mim definido implica a abordagem de um dos temas centrais da cultura política, a saber, a variação das formas e fins públicos da instrução popular nas vozes de sujeitos que tomaram para si o partido da instrução primária de Estado. 
Abordagem abarcante, sem abdicar das minúcias e pormenores vivos, extensamente documentado e perspectivado sob a ótica da história social das ideias (e práxis nelas nucleadas), o livro ora apresentado ao leitor preocupa-se em compreender e explicar os modos pelos quais diferentes sujeitos (e suas ideias-força), em diferentes tempos e em diferentes lugares, agiram e reagiram às circunstâncias, visando transformar um mundo percebido como paradoxal e contraditório ${ }^{1}$. Donde meu empenho em apreender, nas dimensões diacrônica e sincrônica, as fluentes pressões políticas, sociais, culturais, econômicas e demográficas nos domínios da instrução pública; para tanto, periodizei as épocas situadas entre a ordenação jurídico-política do Brasil como Estado-nação, o pós-independência e o ápice da Era Getuliana, o Estado Novo.

A periodização identifica continuidades e rupturas; abre caminho para a interpretação. Ela torna a história não propriamente inteligível, mas, pelo menos suscetível de ser pensada. [...] $\mathrm{Na}$ construção da história, vê-se a importância decisiva do trabalho sobre o tempo. Além de uma colocação em ordem, de uma classificação cronológica e de uma estrutura em períodos, trata-se de uma hierarquização dos fenômenos em função do rito da mudança de cada um por uma sucessão de períodos, nem mesmo um plano: as linhas entrecruzadas por ele compõem um relevo. Ele tem espessura e profundidade (Prost, 2008, p.108-114).

$\mathrm{Na}$ busca do essencial dedutível, movimento-me do mais amplo e mais geral para o mais particular e mais específico. $\mathrm{O}$ curso das investigações, de uma parte, volta-se para o como e o porquê

\footnotetext{
${ }^{1}$ Por conseguinte, não se trata aqui de traçar uma historiografia das ideias nos moldes dos estudos das ideologias e/ou difusão de ideias, ou a relação imaginária dos indivíduos com as condições reais de existência. $\mathrm{Na}$ ampla literatura acadêmica respeitante, as controvérsias sobre o estatuto historiográfico dos modelos e métodos concernente à história das ideias, história intelectual, história das mentalidades, ver Duby (1976), Falcon (1997) e Vovelle (1991). Sobre a renovação e revalorização da história política, ver Rémond (2003).
} 
das continuidades e descontinuidades nas formas e fins públicos da instrução popular; de outra, os procedimentos heurísticos remetem à formulação ativa de temas contíguos e conexos entre si, articuladamente a efeitos de sentido. Ademais, insertas no corpo dos quadros narrativos, o recurso às citações de sujeitos de época não visa à produção de efeitos de realidade ou certificação de argumentos teóricos, ao contrário, são evocações de experiências vividas num mundo transitório e instável.

\section{Plano do livro}

O livro progride com recurso a quadros narrativos perspectivados, podendo ser lidos autonomamente. Na primeira parte, "Da Assembleia Nacional Constituinte à consolidação do Império”, abordo a ordenação jurídico-política da nação, e nela a organização da instrução pública; passo seguinte, detenho-me na compreensão da "onda liberal" e do regresso conservador com seu inequívoco apelo à centralização político-administrativa. No emaranhado de acontecimentos, procuro determinar o lugar da instrução pública e as práticas correlacionadas. Nesse recorrido, noto que o fôlego especulativo estima a vida unitária pelo ângulo da luz geral propagada pela instrução, alados, os voos de imaginação são altos e irretorquíveis.

Na segunda parte, "Do apogeu do Segundo Reinado à queda da monarquia", detenho-me no "plano inclinado" do Império, as décadas de 1870 e 1880, nelas se avolumam planos de reforma da vida nacional e muito especialmente da instrução e métodos de processuação do ensino herdados da tradição. Nesse Segundo Reinado, em que insertas na grande política encontram-se as preocupações com os modos de instruir razão e volição do povo pé-descalço, com efeito, essa parece ser a nova tábua da lei. Paralelamente, o vozerio republicano, ao respaldar novas teorias societárias, avoluma o tom, adquire corpo e força. No quadro conflituoso entre liberdade e autoridade, a República aparece como bela totalidade; no mais, a construção nacional pela via de 
uma primeira instrução de Estado, cujo efeito de atração redobrara, manifesta-se severo corretivo da malformação do país e suas gentes.

Na terceira parte, "Do Governo Provisório republicano à virada do século", reporto-me ao advento da República; como modo de ser, o novo regime aparece como objetivação da razão na história, irrupção angelical, sobremodo imanência da moral virtuosa. Nesse governo dos homens pelos homens, cujos fundamentos são tidos como racionais porquanto não sobrenaturais, sobreleva-se a integração na bela totalidade ética. Regime de governo baseado na representação popular, a República é figurada como objetivação do gênio da Liberdade, em tese, consumava-a vontade geral constituída de sujeitos portadores de direitos sociais e políticos. No preâmbulo heroico do novo regime, em uníssono, ouvem-se os apelos das esperanças da razão, o elogio do Estado de direito e do federalismo estadualista. Assiste-se à explosão do partido da liberdade, igualdade civil, fraternidade, felicidade, no léxico acalorado por uma espécie de fé secular, pátria, povo e instrução são os temas bem-queridos. Nessa nova idade da história nacional, prossegue a regeneração didática, deflagrada nas décadas precedentes e, por ser promessa de venturoso porvir, cultua-se a infância, donde os investimentos de energia a fim de desbarbarizar o banco escolar.

Em "Da política dos governadores à fenomenologia das festas centenárias”, quarta parte, refiro-me ao acumulado de indagações a frio dos erros e regressões da República e seus governantes. Chegara o tempo de irreversível desconfiança. Sem meias-tintas, no espelho das reflexões, é a vez e a hora de a vaga ensaística colocar em exame o desgoverno dos governantes, a bulimia da República e a inexistência de povo político.

$\mathrm{Na}$ tela expectante animada por infindáveis coros de vozes acusadores das disfunções, os irredutíveis publicistas fazem das praças públicas tribunas, obstinados confrontam quer um passado de males quer um presente de incoerências os quais parecem não diferir entre si. De par, o verbo fácil de certos cruzados da instrução popular agita realidades supraindividuais, com efeito, exubera-se a boa natureza, a proficuidade do território, o espírito do povo, o afeto entre irmãos, 
mais do que antes, e isso é indubitável - sobredita-se a pedagogia do cidadão e da cidadania. Chamejantes, as visões substancialistas de pátria e povo são perfilhadas. Instruir a prole da nação, estender a ação social da escola faz por vibrar as cordas ideológicas. Novamente é o momento da fuga para o futuro do presente. Passo seguinte, detenhome na aclimatação da ciência estatística. Algo é indiscutível, pareceme, ao circunstanciar a descrição da população, economia e cultura: a sede de números engendra fartas visões do Brasil e dos brasileiros.

No clima de opiniões, indormida desde o Império e primórdios da República, retorna a questão excruciante da obrigatoriedade escolar e, como outrora, a ela, se atribui o a cristalização da escola societária. Cumulativamente, ocorrem as celebrações dos fatos e feitos referidos à formação da nacionalidade. À primeira vista, na década de 1920, parece haver um excesso de lugares de memória; com efeito, é a década das celebrações dos centenários, dentre muitos, da Independência e da lei de criação das escolas de primeiras letras.

Vem em seguida, a quinta parte, "Do imediato pós-30 à mitologia do Estado Novo". Passo por passo, objetivando consorciar homem e terra, pertinazes, os portadores de futuros possíveis reclamam a proteção de Ceres, deusa da colheita e da abundância, na praça pública das doutrinas societárias, aos borbotões, os sujeitos e suas vozes dão livre curso às volições pessoais. E sempre em pé-de-guerra, convictos, testemunham a favor do agrocentrismo - sentido e substância do país, sob a premência de estancar a depopulação em áreas rurais, efloresce com simplificação a teoria fisiocrata e sua economia política. De sorte que as consignas oitocentistas de Felix Méline - "retour à la terre" e "salut par la terre" - ao agitarem mentes e corações fixam o destino do país como república agrícola, condizer a escola com os ambientes naturais e neles fixar professorado e alunado são as divisas benquistas, assim parece.

Fixo o término da narrativa com a análise da empresa de ocupação do Brasil distante de si. No escuro meio-dia da Era Getuliana, o Estado Novo, redobra a determinação de colonizar as funduras baldias da territorialidade interior. Para legitimar a marcha territorial 
do poder de Estado, a "marcha para o azul", evoca-se a audácia das bandeiras e bandeirantismo coloniais - o intento, trazer as regiões ignotas e imóveis para a racionalidade da civilização do valor de troca. De súbito, e isso é certeza, o recitativo das origens míticas e porvires futurosos resplandecem; o sertão remoto, bruto, enfurnado, um Brasil proscrito, distante de si, é ressituado como anteparo firme da nação e da nacionalidade em vias de fusão. Pensadores nacionais, tratadistas, literatos, autoridades públicas - em suma, a inteligência brasileira na sua diversidade - patenteiam mesmíssimas certezas: superar o ermamento das populações inconscientes de si e dos outros, expandir as fronteiras agrícolas, dilatar fronteiras políticas e culturais. Diga-se, assim, que o "batismo cultural" de Goiânia, Cidade radiosa, formaliza o portal de redescoberta e reconquista do assoalho nu - o interior, o campo, o sertão. Escolarizar os vazios é um dos anseios gerais, talvez o mais esperançoso, talvez o mais congraçador.

No desenrolar da pátria monárquica e da pátria republicana, entre paixões desconcertantes, litígios de interesses, intrigas capciosas, devoções ardentes, projeções utópicas, incessantemente a cultura política das épocas ritualizará na ordem das certezas, a instrução como sumo civilizatório, valor comunitário, fonte de melhoramento material, fator de concórdia. E não obstante empenhado em pensar e conhecer as continuidades e descontinuidades das formas e fins públicos da instrução, não há nas páginas a seguir o propósito de oferecer panoramas históricos completos - atitude que, por certo, implica escolhas (e escolhas são sempre discutíveis) -, ademais, na sua pluralidade, os quadros narrativos não conduzem a sínteses gerais o que não pretendo. Incontestavelmente, leitor, a última palavra está longe de ser ditada. Por último, diga-se tão só que a roda deste livro expressa o desejo de recordar os impasses e as contradições, insolúveis em aparência, concernentes a uma herança inalienável e universalmente reconhecida, à educação popular. 



\section{Parte I}

\section{Da Assembleia Nacional Constituinte à consolidação do Império}





\section{A instrução pública às vésperas de si}

\section{Da herança colonial}

No conhecidíssimo artigo "A instrução pública nos tempos coloniais”, Manuel Duarte Moreira de Azevedo, ao sopesar o descaso da metrópole portuguesa quanto à "vida espiritual” da colônia, julgava o estado de coisas concernente à instrução.

Se com a vinda do rei para o Brasil criaram-se algumas escolas em uma ou outra cidade ou vila das mais importantes da colônia, não se tratou de regularizar o ensino, da boa escolha dos professores e de quem lhes fiscalizasse o procedimento. Ensinava cada um do modo que lhe parecia mais cômodo. E não havia método nem sistema, ou plano, organizado pelo Governo.

Os mestres eram nomeados sem concurso, e sem que fosse avaliada a moralidade de suas ideias e costumes. Raros eram os livros que circulavam, e não havia o menor gosto pela leitura. As escolas eram muito poucas e mal dirigidas, havia diminuta frequência de alunos e geralmente as mulheres não aprendiam a ler (Moreira de Azevedo, 1892, p.20).

Do Brasil-Reino de D. João VI, a ex-colônia herdara poucas aulas primárias de iniciativa eclesiástica e alguns seminários episcopais, mais as escolas menores e aulas régias dos tempos do 
marquês de Pombal e sob o comando dos "mestres-régios, "useiros e vezeiros na férula e na chibata, discricionariamente empregadas consoante o bom ou mau humor do momento", como outrora depôs Nestor Lima (1927, p.27). Seja qual for a versão dos fatos, algo é indiscutível, por rotina, ao deter-se quase exclusivamente no conhecimento da Doutrina cristã, o exame dos candidatos às cadeiras de primeiras letras estava aquém das expectativas.

Naquele Brasil inicial, a territorialidade é heteróclita e provisória. Com efeito, acompanhemos vivíssimos números: a população geral beirava a 3.167 .900 habitantes, dos quais 843 mil brancos, 426 mil mestiços libertos, 202 mil mestiços escravos, 159.500 pretos forros, 1.727.080 pretos cativos e 254.400 índios aldeados. Tão só nas capitais do Pará, Maranhão, Bahia, Rio de Janeiro, São Paulo, Minas Gerais, Mato Grosso, havia "professores de primeiras letras e, quando muito, de latim, retórica, filosofia, acrescendo as de grego, comércio, desenho, línguas vivas no Rio de Janeiro, bem como as de matemáticas e grego na Bahia”, avaliaria Carlos Leôncio de Carvalho, por volta de 1884.

\section{Da ordem jurídica}

$\mathrm{Na}$ abertura da Assembleia Nacional Constituinte e Legislativa, D. Pedro I, na Fala do Trono, semeava apreensão. "Espero que a Constituição, que façais mereça a minha imperial aceitação, seja tão sábia e tão justa quanto apropriada à localidade e civilização do povo brasileiro." Cerca de 10 províncias fiéis à independência enviam deputações à assembleia sediada no Rio de Janeiro. Pará e Maranhão, províncias próximas a Portugal, Piauí e Cisplatina mantêm-se fiéis à metrópole; verdade seja dita, pela primeira vez reuniam-se homens eleitos nas mais distantes regiões do país. ${ }^{2}$

${ }^{2}$ Ao todo estavam reunidos 90 constituintes eleitos por catorze províncias, entre
eles, 23 bacharéis em direito, sete doutores em direito canônico, três médicos,
dezenove padres, entre os quais um bispo, três marechais de campo e dois
brigadeiros, além de proprietários rurais e funcionários públicos. "Eleitos de
forma indireta e através do voto censitário, náo representavam certamente a massa 
O início do Brasil como país independente presencia discussões meritórias a respeito da "promoção da educação física, moral e intelectual da mocidade brasileira", a ponto de o padre Belchior Pinheiro de Oliveira, deputado por Minas Gerais, propor o título de Benemérito da Pátria e condecorar com a Ordem do Cruzeiro do Sul a quem apresentasse, até o final de 1823, o "melhor trabalho sobre a educação da mocidade".

A expensas do Governo Imperial, a Comissão de Instrução Pública decide editar Necessidade de uma instrução geral e mais conforme com os deveres do homem na sociedade, insuficiência da atual sobre a reforma dos estudos menores da capitânia de São Paulo, memória elaborada à época do Brasil-Reino, pelo agora deputado e membro da Comissão de Instrução, Martim Francisco Ribeiro de Andrada Machado. Calçado num ponto de vista político-contratual de teor liberal-iluminista, no manuscrito, o paulista disserta acerca dos primeiros graus da instrução comum, métodos pedagógicos, compêndios e mestres. $\mathrm{Na}$ abertura do documento, solene declaratória.

§1 - A instrução pública é um dever do soberano para com os seus vassalos, é uma obrigação contraída no nascimento das sociedades políticas, entre o governante, e os governados, e que manifestamente redunda em proveito de ambos: a instrução pública, igual, e geralmente espalhada por todos os membros de qualquer Estado, nivela pouco mais ou menos suas faculdades intelectuais; aumenta sem prejuízo a superioridade daqueles, que a natureza dotou de uma organização mais feliz; aniquila esta dependência real, triste monopólio, que as luzes de uma classe exercitarão sobre a cega ignorância da totalidade; destrói a desigualdade que nasce da diferença de sentimentos morais; facilita a cada um o gozo dos bens, que a sociedade confere; corta pela raiz os

de excluídos por aquele sistema. Representavam, na verdade, em grande parte, os interesses da aristocracia rural. Em um país cuja unidade territorial ainda seria objeto de disputa por muitos anos, contudo representavam suas diversas partes pela primeira vez reunidas" (Lustosa, 2006, p.160). 
males e brandões da discórdia, com que a ignorância em diferentes épocas tem abusado o mundo, e dos quais estão cheios de páginas da história; e finalmente, conspira a promover a prosperidade dos Estados e a torná-los firmes, e estáveis pela reunião das forças morais com as físicas (Memória..., 1945 [1816], p.466). ${ }^{3}$

Os constituintes encaminham as propostas da Comissão de Instrução. "Artigo 250 - Haverá no Império escolas primárias em cada termo, ginásios em cada comarca e universidades nos mais apropriados locais. Artigo 251 - Leis e regulamentos marcarão o número e a constituição desses úteis estabelecimentos. Art. 252 É livre a cada cidadão abrir aulas para o ensino público, contando que responda pelos abusos." Essas disposições atestam a doutrinação de Antonio Carlos, José Bonifácio, Januário Pereira da Cunha, Bittencourt Sá, Araújo Lima, Aguiar de Andrade, e Muniz Tavares, notórios membros da comissão.

$\mathrm{Na}$ retórica incitante envolvida na consolidação jurídico-política e territorial do recém-surgido Estado-Nação, imperativo virtuoso, as luzes do entendimento assegurariam a moralidade pública, igualdade civil, prosperidade da nação. Em suma, o esclarecimento propiciaria o partejamento da consciência de alteridade. Demais um truísmo de ontem e sempre, o advento de sociedades políticas fundadas no sufrágio e representação popular requer uma primeira instrução comum distribuída pelo Estado, e assim requeriam os letrados gravemente, seriamente dispostos a efetivarem a fórmula monárquica dinástica, constitucional e representativa.

Conhecido como "projeto Antonio Carlos" em alusão aos irmãos Andrada - Antonio Carlos, Martim Francisco, José Bonifácio, homens públicos amadurecidos na cultura da Ilustração

\footnotetext{
${ }^{3}$ Como se sabe, o texto manuscrito é decalcado de Cinco memórias sobre a instrução pública, de Condorcet. Lourenço Filho (1944, p.11) avaliava diferentemente. "As ideias de educação, que expóe, Martim Francisco as bebeu nos 'filantropistas' para os quais o fim principal da educação era o 'de fazer do homem o instrumento de sua própria felicidade”. Obviamente um engano.
} 
portuguesa, porquanto afeitos às ciências naturais e às "letras jurídicas", o anteprojeto da Constituição expressa os interesses dos deputados liberais moderados. Dentre outros, postulavam sistema eleitoral censitário e indireto, limitação dos direitos dos portugueses residentes no país e aquilo que será o pomo da discórdia, limitação do poder do imperador. ${ }^{4}$ Nas narrativas dos intérpretes do passado, as sessões da Assembleia Constituinte testemunharam refregas entre o "partido Português" favorável à união do Brasil com Portugal e o "partido Brasileiro" adepto da monarquia constitucional. Querelavase, a supremacia seria do Legislativo ou do Executivo? Quem de fato iria gerir a máquina estatal?

Um ato ominoso, um feito iliberal. Retornando ao absolutismo, D. Pedro I dissolve a Assembleia Nacional e Geral. Nesse passo, os Andrada fundam O Tamoio, jornal de oposição ao imperador e ao "partido Português", com outros deputados, os dissidentes são deportados. Das versões. Em A Revolução de 7 de abril de 1831 e Evaristo Ferreira da Veiga, livro-crônica assinado "por um fluminense amante da Constituição", o autor prefere o anonimato, assim autentica o acontecimento.

D. Pedro veio então à testa de um corpo de cavalaria, e, fazendo o general Moraes cercar a Câmara, com peças de artilharia, ordenou que a Assembleia se dissolvesse imediatamente. Ante o direito da força curvou-se a força do direito, e Antonio Carlos, Martim Francisco, Rocha, Montezuma e o padre Belchior Pinheiro são presos ao saírem da Câmara, assim como José Bonifácio, que o tinha sido em sua casa, e transportados todos para a França, D. Pedro, no decreto de dissolução, tratou de justificar a sua prepotência e assegurou que submeteria à Assembleia que ia ser convocada, um projeto de Constituição duas vezes mais liberal do que a projetada pela Assembleia Constituinte (A Revolução..., 1862, p.15). ${ }^{5}$

\footnotetext{
${ }^{4}$ Cf. Basile (2000) e Mota (1999).

${ }^{5}$ Comenta Rodrigues (1974, p.22): "A inspiração de uma Assembleia Constituinte vinha da França Revolucionária e nunca foi bem aceita pelos conservadores”.
} 
Como ratifica a tradição historiadora, o imperador arroga para si o direito de convocar a Assembleia Nacional Constituinte e Legislativa com o suposto de repropor o código jurídico-político. Surge o "Projeto de Constituição para o Império do Brasil, organizado no Conselho de Estado sob as bases apresentadas por sua Majestade Imperial o senhor D. Pedro I, Imperador Constitucional e Defensor Perpétuo do Brasil”. No adentrar do século XX, John Armitage (1914, p.331) escreveria: "A admissão do título 'Defensor Perpétuo do Brasil' aplicado ao Imperador na constituição, também parece algum tanto incompatível com as instituições de um povo livre, que deve ser defensor de si mesmo".

25 de março de 1824: outorgava-se a Constituição Política do Império do Brasil, na rotação do tempo, os dispositivos centralizadores serão objeto de contestações. De imediato, o ato de inconformismo parte do norte do país, a Confederação do Equador, ato contínuo, reconvertem-se as capitanias reais em províncias, 18 no conjunto: Alagoas, Bahia, Ceará, Espírito Santo, Goiás, Maranhão, Mato Grosso, Minas Gerais, Pará, Paraíba, Pernambuco, Piauí, Rio de Janeiro, Rio Grande do Norte, São Pedro do Rio Grande do Sul, Santa Catarina, São Paulo, Sergipe. Nesse Brasil por fazer-se, as fronteiras internas são mal delimitadas. ${ }^{6}$ No mais se queria solidarizar homens e mulheres que a Independência tão só aglomerara. E, embora muitos dissessem que os homens nasciam livres e iguais, à exceção de Representação à Assembleia Geral Constituinte e Legislativa do Império do Brasil sobre a escravatura e Apontamentos para a civilização dos indios bravos do Império do Brasil, ambos da lavra de José Bonifácio, pouco se disse e pouco se fez a respeito de escravos e índios.

Do código outorgado, sobrevém a definição do Império como associação política de todos os brasileiros, a legitimação jurídica do governo monárquico, dinástico, constitucional, e representativo, a divisão do poder em três instâncias: Executivo, Legislativo (Senado e Câmara), Judiciário, conjugadamente se instituía uma instância protoabsolutista,

${ }^{6}$ Cf. Escobar (1995 [1940]). 
o Poder Moderador, a Coroa, ou seja, D. Pedro I nomearia, sem aprovação do Legislativo, ministros de Estado, presidentes de províncias, magistrados, e escolheria os senadores eleitos em listas tríplices.

As instâncias político-administrativas são estruturadas em três níveis: municípios, províncias e governo central. E será na fé, no sobrenatural que a razão de Estado procura respaldar a sua superioridade moral, assim oficializa-se o catolicismo apostólico romano como religião de Estado, permitindo-se o culto particular de outras confissões religiosas, "sem forma alguma exterior de templo". Da Carta Política, sobrevém a representação da unidade entre EstadoNação-Coroa-Igreja.

Aos homens maiores de 25 de anos, mesmo se analfabetos, reserva-se o direito de votar; o voto é censitário e em "dois graus", no plano local, vota-se para os Conselhos-Gerais Provinciais, as Câmaras Municipais, e Juízes de Paz. No plano maior, vota-se para a Assembleia Geral, deputados e senadores, o mandato dos primeiros é temporário, dos últimos, vitalício. Para os cargos locais, as eleições são diretas; para os gerais, indiretas. Os votantes elegem eleitores que por sua vez elegem deputados e senadores. Votantes e eleitores declaram renda anual de 100 e 200 mil réis, libertos votam apenas nas eleições de primeiro grau. ${ }^{7}$ Alijados da massa de cidadãos ativos, aqueles com renda anual inferior a 100 mil réis, menores de 25 anos, mas é possível votar aos 21 se casado ou oficial militar. Para clérigos e bacharéis, não há limite de idades; sem direito ao alistamento eleitoral, criados de servir, filhos-família moradores com os pais, religiosos em regime claustral, mulheres. Décadas adiante, ao exigir a assinatura na ata eleitoral e elevar o censo pecuniário para 200 e 400 mil réis, a Lei de 19 de agosto de 1846 inicia a lenta exclusão dos analfabetos. Se há um ideário liberal, esse é mais doutrina da ordem e menos da liberdade, ou melhor, de ordem estamental.

No código de estruturação jurídico-política do Estado nacional, as preocupações com o ensino clausulavam o "direito do cidadão à

${ }^{7}$ Cf. Carvalho (2012) e Nicolau (2012). 
gratuidade da instrução primária”, ousadia para a época. De fato, o artigo 179 estipula a inviolabilidade dos direitos civis e políticos dos cidadãos brasileiros - a liberdade, a segurança individual e a propriedade, além de garantir instrução primária gratuita a todos, ademais previa-se a instalação de colégios e universidades para o ensino de "elementos das ciências, belas-letras e artes". A bem de ver, a Constituição configura uma esfera pública em moldes da doutrina liberal, a grande lei velaria pelas liberdades pessoais, religiosas, trabalho, imprensa, igualdade perante a lei e inviolabilidade da propriedade. ${ }^{8}$ Agora otimista, Manuel Duarte Moreira de Azevedo (1892, p.158) assim comentava: "O desenvolvimento da vida cívica fez alargar a esfera do ensino; tratou-se de educar os homens para se tornarem livres." Num país de povoamento escasso, com populações esquecidas em territórios desmesurados, dissociados entre si, cuja economia se sustentava no latifúndio e na escravaria, a instrução primária, poderoso agente civilizatório, no tempo representaria um marco fatigante a ser materializado.

\section{O utilitarismo de Americus}

Dentre as intenções de dar forma aos "estudos menores" segundo os preceitos da civilização do momento, cabe citar o Projeto sobre o estabelecimento e organização da instrução pública no Brasil, do tenentegeneral Francisco de Borja Garção Stockler, 1808, avançar um pouco mais com Necessidade de uma instrução geral e mais conforme com os deveres do homem na sociedade, insuficiência da atual sobre a reforma dos estudos menores da capitânia de São Paulo, a sempre relembrada "Memória", de Martim Francisco Ribeiro de Andrada Machado, 1816, prosseguir com "Ideias elementares sobre um sistema de educação nacional", de

\footnotetext{
${ }^{8}$ Casalecchi (1987, p.247): "A partir da independência, o ideário liberal se impõe como referência necessária à constituição do Estado Nacional. A partir daí, e pelo menos até o final da Primeira República, ele contribuiu para as mudanças, desde que não se enquadrassem no rol das transformações mais ousadas".
} 
Americus, e culminar com o projeto da Comissão de Instrução Pública presidida por Januário da Cunha Barbosa, 1826.

Por agora, convém citar o deslembrado "Ideias elementares sobre um sistema de educação nacional”, de Americus, pseudônimo, constante em Cartas políticas $\left(1825,2\right.$ t. in- $\left.8^{\circ}\right)$. Os tomos reúnem as cartas do autor publicadas em Padre Amaro, ou sovela política, periódico "dedicado a todos os portugueses de todos os mundos", editado em Londres por Joaquim Ferreira de Freitas. O plano consta na carta 12, tomo 1, e indicia a mentalidade utilitarista dos homens do Reino; de saída, Americus declara sua verdade, por sinal merecedora de atenção, pois quer responder a dilemas postos pela época: Qual o alcance do esclarecimento? Teria o esclarecimento limite ou nenhum limite? A quem o esclarecimento tornaria virtuoso e civil?

Todavia ainda hoje há quem afirme que a inteligência, e as luzes são qualidades, que não é muito para desejar sejam possuídas pela grande massa do povo! Não sei como há quem tenha tanto medo às luzes; só se isso vem de que, sendo certo que o saber é poder [...] há muitos que temem este poder, porque pode dar ao mecanismo político da associação uma nova forma, que transforme uma certa ordem de interesses. Por certo que em a massa geral de uma sociedade sendo ilustrada, deixará de se dividir (como até aqui) em duas classes somente, uma das quais oprima, e a outra sofra. Este foi o estado do Brasil até um certo período; mas (Deus graças) novus rerum nascitur ordo ... (Americus, 1825, t.1, p.5, grifo do autor).

Utilitarista, não por acaso Americus recorre à deontologia de Jeremy Bentham e Stuart Mill, ao justificar o ensino aplicado aos "usos da vida", teoricista, retoma Hartly e Condillac, a associação de ideias fundamenta a educação moral e intelectual, ilustrado, cita Helvécio, qualquer indivíduo saudável de regular perfeição orgânica alcança maior ou menor perfectibilidade moral e mental, convicto, corrobora Hobbes, Locke, Hume, diz, filosofar acerca do espírito 
humano é descrever a ordem e sucessão das sensações. Cauteloso, admite as descobertas fisiológicas de Darwin e Cabanis, as quais, nalguma medida, elucidavam o homem físico e moral. E ao cabo da exposição, o cânon virtuoso, a educação é o instrumento da felicidade individual e de todos os viventes em comunhão civil. "O grande embaraço, porém sobre esta matéria consiste em que, não havendo ideias exatas sobre qual seja verdadeiramente a felicidade temporal do homem, é forçoso que se empreguem diversos meios para obter um fim, que não é para todos uniforme".

O "plano de ensino público e nacional" ou "plano de educação intelectual elementar" de Americus envolve o cultivo físico, moral e intelectual e, ao diferenciar os níveis de instrução conforme a destinação profissional e a utilidade social das pessoas, ele revalida argumentos utilitaristas ao mesmo tempo revive aspectos inerentes às sociedades de ordens.

A "primeira escola" se destinaria a "rapazes de seis anos até os nove" para além do ler, escrever, contar, acrescentar-se-ia um catecismo religioso e uma "cartilha universal", contendo "útil coleção de verdades populares" relativamente à história natural, química, botânica e fenômenos naturais. Critérios de idade e grau de proficiência ordenariam o agrupamento de meninos em classes regidas pelo modo de Lancaster - "que essencialmente não é outra coisa mais do que o método dos decurióes das escolas jesuíticas mais aperfeiçoado" (p.221 - grifo do autor). Endereçada aos rapazes de 9 a 11 anos, filhos da "classe média da sociedade", comerciantes, lavradores, fabricantes, artistas, a "segunda escola ou escola média" ensinaria a língua materna, o francês e as ciências pelo "sistema das tábuas crestomáticas de Mr. Bentham”, isto é, catecismos curtos com máximas sobre o sistema solar, geografia, cronologia histórica, ética, moralidade, mineralogia, botânica, química e mecânica. Por último, recomendava um catecismo político explicativo da Constituição e dos direitos afiançados e obrigações dos cidadãos, e outro de história contendo fatos desde a "criação do mundo até agora". 
A variedade das matérias assustará tão somente a quem não refletir, que cada um desses quadros deve ser muito resumido, e que podendo ser ensinados pelo método de Lancaster podem ser aprendidos com a maior facilidade; o caso todo é que cada um destes catecismos seja um composto onde entre na mesma proporção doutrina suficiente, concisão e clareza" (Americus, 1825, p.229-230, grifo do autor).

Na cimeira do plano, a "terceira escola" ou "escola superior" para rapazes de 11 a 14 anos, destinados às profissóes científicas, a saber, teologia, jurisprudência, arte militar, política, medicina e filosofia natural; com a intercessão de compêndios "mais extensos", seria cometido o estudo da língua materna, francês, inglês, grego, latim, geometria, álgebra, história, geografia, mitologia, cronologia geral e portuguesa. Nas tantas idealidades utilitaristas de Americus, a instrução popular, ao dar a conhecer o mundo e a vida, aparece como atividade prática, daí a necessidade de criar as primeiras escolas em freguesias, e segundas e terceiras escolas em cidades e vilas notáveis. Quem é Americus? Para Sacramento Blake, tratava-se de Miguel Calmon du Pin e Almeida, então vivente na Suíça, o futuro marquês de Abrantes, político-chave nos jogos conservadores da monarquia; para Lourenço Filho (1944), era Martim Francisco Ribeiro de Andrada, outro engano.

\section{Plano geral de instrução pública}

Reaberto o parlamento, reunida a magistratura, em 1826, retornam os assuntos da instrução, Antonio Ferreira França, cônegos Januário da Cunha Barbosa, José Cardoso Pereira Mello, membros da Comissão da Instrução Pública, encaminham projeto de lei dispondo o ensino em quatro graus: Pedagogias, ensino elementar hierarquizado em três classes, prevendo-se escolas para habilitação de alunos-mestres, Liceus com três anos de curso e programa científico - Pedagogias e Liceus seriam gratuitos -, Ginásios, curso de humanidades regido por 12 mestres para as cadeiras a serem criadas de Filosofia especulativa, Geografia e História 
civil, Línguas latina e francesa, e num futuro próximo, Hermenêutica e numismática, Italiano, Grego, Alemão e Inglês. No cume, Academias abrangendo as escolas superiores existentes e aquela a ser instalada a escola superior de ciências sociais e jurídicas. "Seria também criado o Instituto Imperial do Brasil, organismo semelhante ao Institut de França" (Rodrigues, 1938, p.256). Esse "plano nacional de educaçáo" não prospera, jazendo nas "catacumbas parlamentares" conforme sentença condenatória de Primitivo Moacyr (1936, 1938). ${ }^{\text {? }}$

É de supor que o projeto retomasse os acumulados constantes nas memórias da instrução de Garção Stockler e Martim Afonso, o plano de educação nacional de Americus, assim como as propostas da Comissão de Instrução capitaneada pelos Andrada. Projeto mais modesto será encaminhado à Câmara dos Deputados, versando tão só a criação de escolas de primeiras letras. Referendada pelo ministro do Império, visconde de São Leopoldo, e pelo imperador, promulgava-se a lei geral de 15 de outubro de 1827, 17 artigos enxutos em cujo caput se enunciava. “D. Pedro I, por graça de Deus e unânime aclamaçáo dos povos, Imperador Constitucional e Defensor Perpétuo do Brasil: Fazemos saber a todos os nossos súditos que a Assembleia Geral decretou e nós queremos a Lei seguinte".

Os termos do decreto-legislativo denotam a força agregadora imputada à instrução elementar pela relevância histórica, por si só é um marco legal memorioso, revisitado e recomentado pelos intérpretes do passado, convêm citar as disposiçóes, pois, de certo modo, inaugurava-se o intento de ofertar um plano geral de instrução elementar para todo o Império. Dentre outros, o decreto-legislativo estipulava a criação de escolas de primeiras letras nas "cidades, vilas e lugares populosos", "proporcionado à compreensão dos meninos", o ensino pelo método mútuo, ou seja, as operaçôes de aritmética, noçôes de geometria prática, gramática da língua nacional, princípios de moral cristã, doutrina da religião católica, leitura da Constituição do Império. Outras disposiçôes ousadas: instrução para meninas, vitaliciedade do magistério, gratificação anual não excedente

${ }^{9}$ Cf. também Moraes Filho (1959). 
à "terça parte do ordenado", aos professores distinguidos por mais de 12 anos, "por prudência, desvelo, grande número e aproveitamento dos discípulos", iguais vencimentos e gratificaçóes para mestras e mestres.

Como explica a tradição historiadora, durante um século ou mais, a lei imperial de 15 de outubro de 1827 será o único dispositivo geral e de conjunto sobre a instrução elementar; outras leis orgânicas apareceriam no século XX, quer em decretos do Executivo quer em decretos-leis expedidos em governos discricionários. Nas muitas avaliaçóes, a lei de 1827 aspirara a verdades prematuras, de qualquer modo, e isso é louvável, esse código primordial expressa o intento de ofertar ensino a todos. E, naquele mesmo ano de 1827, para formar quadros capazes de administrar e zelar pela ordem jurídica e, sobretudo, mover a máquina do Estado Nacional, instalavam-se os cursos de Ciências Jurídicas e Sociais em São Paulo e Olinda.

$\mathrm{Na}$ cultura política dos estadistas, a instrução pública ao separar o homem do estado de natureza, aparece como via de entendimento das instituições sociais e da formação da nacionalidade, mormente, modo de regular as novas geraçōes por intermédio de uma instrução elementar de Estado. ${ }^{10}$ Numa palavra, desde a Constituinte, alardeavase a existência de um povo inferior a ser educado para o usufruto das conquistas do liberalismo político e dos costumes da civilização moderna. ${ }^{11}$ Mas acautele-se a palavra, uma vez que é necessário distinguir a lei e a sua aplicação, valer dizer, entre o aparecer e o ser. Após dez anos de independência, a estatística oficial registrava a existência de 162 escolas para meninos e 18 para meninas. Dessas escolas, comentava José Ricardo Pires de Almeida (1989 [1889]), 40 careciam de mestres, dentre as dificuldades, a inexistência de pessoas habilitadas a processuar o modo lancasteriano de ensino. "Foi preciso improvisar professores e atraí-los pelo vulto das vantagens e promessas de recompensas para eles

\footnotetext{
10 "Menos de vinte anos depois da outorga da lei básica do Império, já se alastrava tấo bem a opiniáo típica do século de que o progresso no saber era a fonte milagrosa de todas as virtudes cívicas e privadas, que não se julgava sequer lícito pôr em discussão essa crença”" (Buarque de Holanda, 1960, p.184).

${ }^{11}$ Cf. Rodrigues (1974).
} 
se aventurassem à nova profissão legalmente disciplinada" (Lima, 1927, p.45). Nessa formação econômico-social, $90 \%$ da população habitam as zonas rurais, boa parte em regime de servidão, as populaçôes de livres e escravos, a "plebe rural", para recordar a formulação cara a Oliveira Vianna, distribuíam-se diversamente. ${ }^{12}$

Tabela 1 - População do Brasil em 1819

\begin{tabular}{l|r|r|r}
\hline \multicolumn{1}{c}{ Regiões } & \multicolumn{1}{c}{ Livres } & \multicolumn{1}{c}{ Escravos } & \multicolumn{1}{c}{ Total } \\
\hline Norte & 104.211 & 39.040 & 143.251 \\
\hline Nordeste & 716.468 & 393.735 & 1.110 .203 \\
\hline Leste & 1.299 .287 & 508.351 & 1.807 .638 \\
\hline Sul & 309.193 & 125.283 & 434.476 \\
\hline Centro-oeste & 59.584 & 40.980 & 100.564 \\
\hline Total & 2.488 .743 & 1.107 .389 & 3.596 .132 \\
\hline
\end{tabular}

Fonte: Silva J.N.S. Investigações sobre os recenseamentos da população geral do Império e de cada Província de per si. Relatório do Ministério dos Negócios do Império (1870). Rio de Janeiro: Tipografia Nacional (1870) e Velloso (1866) apud Marcílio (1986).

12 "Entre escravos e senhores, existia uma população legalmente livre, mas a que faltava quase todas as condiçóes para o exercício dos direitos civis, sobretudo a educação" (Carvalho, 2001, p.21). 


\section{A estabilidade institucional}

\section{A “onda liberal”, a descentralização}

Em abril de 1831, o imperador abdicava, entre a abdicação e o coroamento de Pedro de Alcântara, regentes governam o país. Desde a Independência, falava-se em federalismo, óbvia reação aos excessos do poder central. ${ }^{13}$ No teatro da política imperial, predominam as discussões acerca da descentralização do poder, bem como o grau de autonomia a ser concedido às províncias.

A Lei no 16 de 12 de agosto de 1834 adita "alterações e adições" à Constituição Política do Império, a Câmara dos Deputados extingue o Conselho de Estado, introduz a regência una eletiva e temporária, renovável a cada quadriênio, enquanto perdurar a menoridade de Pedro de Alcântara. Ademais se concedia autonomia às províncias ao transformar os Conselhos-Gerais em Assembleias Legislativas, além de alterar a divisão de rendas entre governo central, províncias e municípios. De teor monárquico e federativo, e conduzido por liberais moderados, Diogo Antonio Feijó, Bernardo Pereira de Vasconcelos, Evaristo da Veiga, o Ato Adicional, ao conjugar interesses opostos, apazigua as demandas das classes senhoriais: poderes Executivo e Legislativo, fortes no âmbito do poder central, e as demandas descentralizadoras das províncias.

${ }^{13}$ Cf. Iglésias (1993). 
As adições na Carta Política modificam as competências relativas aos serviços de instrução, o governo central administraria e manteria o ensino primário e secundário na Corte, além do ensino superior existente país afora; aos governos provinciais, competiria a instrução pública, não compreendendo as faculdades de Medicina, e cursos Jurídicos, e quaisquer outros estabelecimentos criados por lei geral. Embora a hermenêutica jurídica no futuro viesse a concluir pela competência concorrente entre poder central e os poderes provinciais, tal interpretação não prevalece, de sorte que a querela atravessa o Império e a República. Nas contendas jurídico-políticas, a presença da União no sustento e extensão da instrução popular será insuficiente quer pela centralização fiscal quer pela insuficiência de recursos. Contrafeito, na Fala do Trono de 1834, Diogo Antonio Feijó vergastava.

Os brasileiros têm necessidade de uma educação nacional: sem está nunca teremos acordo nos pontos mais vitais da sociedade. E se no sistema representativo só as maiorias decidem dos negócios mais importantes, quanto não é necessário generalizar certas máximas, para que elas possam predominar em maior número.

Senhores, sem educação e sem moral, não é possível haver uma verdadeira civilização (Falas..., 1977 [1889], p.110).

Nos lotes de dias e anos que hão de vir, a descentralização das competências soará como ato de abandono do poder central na franquia de uma cultura inicial e uniforme destinada a formar o homem brasileiro, ação considerada prioritária num país recém-liberto do jugo colonial. Irremovível divisor de águas, pois tema controverso nos anais historiográficos, o Ato Adicional, sem dúvida, determinaria os caminhos ulteriores: em vez de um sistema geral, como previsto na lei de 15 de outubro, haveria "aparelhos didáticos" paralelos, o central e os provinciais/estaduais. ${ }^{14}$

\footnotetext{
${ }^{14}$ Ver a respeito as cronologias de Bittencourt (1946, 1953), Mello (1996) e Venancio Filho (1945). A diversidade de legislaçóes provinciais consta em Bello (1978), Bittencourt (1981), Leite (1970), Marcílio (1963) e Olympio (1922).
} 


\section{Do regresso conservador}

"Mas... aí veio a lei de 12 de maio de 1840, amputou-se o Ato Adicional" (Tavares Bastos, 1937 [1870], p.148). Os estremecimentos separatistas ameaçam a integridade política e territorialidade do Império, com isso desperta o “desejo de ordem nacional”. Às vésperas da declaração da maioridade de Pedro de Alcântara, por iniciativa do regente Pedro de Araújo Lima, futuro marquês de Olinda, a "Lei de interpretação" do Ato Adicional dará lugar ao "regresso conservador". Com efeito, ao recentralizar o aparato administrativo e judiciário, a tenaz denominada "Lei de Interpretação", revisão das competências dos governos provinciais, restaura o Conselho de Estado e altera o Código de Processo Criminal. ${ }^{15}$ Em “Esquisse de l'histoire du Brésil', José Maria da Silva Paranhos, o barão de Rio Branco, revê os fatos. "Um projeto de lei interpretativa do Ato Adicional, tendo por objetivo fixar mais precisamente as atribuições das legislaturas provinciais, para por fim as usurpações do poder central, ou da autonomia comunal, por essas assembleias, foi debatido no parlamento de 1828 a 1840, e adotado somente neste último ano - a Lei de 12 de maio de 1840" (Paranhos, 1889, p.70). Mas, antes disso, no sistema intelectual, ecoavam as palavras de Gonçalves Dias, futuro conselheiro do Império. "A legislação provincial, relativa à instrução, aos seus efeitos até hoje, à previsão do que será no futuro pelo que tem sido no passado, dezessete anos enfim de experiências baldas bastam, segundo penso, para nos convencerem de que em matérias de instrução - nada absolutamente nada se pode esperar das Assembleias Provinciais" (Gonçalves Dias, 1957 [1852], p.340).

$\mathrm{E}$, ao mesmo tempo em que se presenciava o advento das formas políticas contemporâneas, a saber, constitucionalismo,

${ }^{15}$ Cf. Dolhnikoff (2005). Para Alonso (2002, p.52): “O status quo imperial esteve mais representado em modos de pensar e agir do que em doutrinas explicitamente formuladas. O Império não contou com um texto de fundação. Seus princípios básicos estão na Lei de Interpretação do Ato Adicional de 1841 (sic), que não toma mais que duas páginas. Os valores estavam encarnados nas próprias práticas políticas." 
representação popular, divisão dos poderes, liberalismo (conservador) e "parlamentarismo", no chão histórico remanesciam as estruturas coloniais, a monocultura, o latifúndio, o escravismo, o tráfico negreiro, numa palavra, o colonialismo sobrevivia no Império. ${ }^{16}$ Viventes nesse chão movediço, homens públicos, homens do Império, liberais e conservadores batem-se pelo partido da instrução, figurando-a santelmo das públicas liberdades e coroamento da obra civilizadora do Império. E, ao apelarem para a instrução como via "da União Cristã e da Sociedade Civil", idealizam o povo como "razão nacional que governa”. Na cultura política reforçava-se a confiança no halo de uma primeira instrução distribuída pelo Estado. Quaisquer que sejam os teores dos embates, quaisquer que sejam as concretizações, cravava-se no tempo severo princípio na cultura política - a instrução popular, a instrução do povo branco, do povo mestiço, do povo pé-descalço, do povo votante, ao propiciar inesgotável fonte de benefícios sociais e melhoramentos materiais, garantiriam a estabilidade social e a perpetuação das instituições liberais.

\section{Um decreto de longa duração}

Cartório do Brasil, na Corte, autenticam-se e consorciam-se as utopias políticas em benefício da realidade, dos jogos de força saltam planos do ser e dever ser das finalidades públicas da instrução. É lícito supor que a irradiação das disposições reformadoras pelos quadrantes do país em vias de formação deve-se à ronda incessante dos presidentes de províncias, delegados do Imperador, que, ao tomarem para si os atos legais codificados na Corte, atuassem na consolidação dos poderes locais. Referidas à capital do Império, as iniciativas de reforma social e cultural remontam ao "Ministério da conciliação" presidido pelo marquês do Paraná, Honório Hermeto Carneiro Leão, prosseguindo em 1854, ano de inauguração dos telégrafos e iluminação a gás, no Rio de Janeiro, com Luiz Pedreira do Couto Ferraz, ministro de Estado dos Negócios do Império.

${ }^{16}$ Cf. Prado Júnior (2011). 
Couto Ferraz, "gentil-homem da imperial câmara" e dos "primeiros beneméritos da pátria", no dizer afortunado de Sacramento Blake, diplomara-se em Direito na academia de São Paulo. Nela viria a ser catedrático, e no tempo ocuparia postos de mando e prestígio deputado e senador pelo Rio de Janeiro, presidente da província do Espírito Santo, conselheiro de Estado, presidente do Instituto Histórico e Geográfico Brasileiro e Instituto Fluminense de Agricultura, vicepresidente da Associação Protetora da Infância Desvalida.

O Decreto no 1.331-A, de 17 de fevereiro de 1854, baixado por iniciativa de Couto Ferraz, regulamenta a reforma do ensino primário e secundário da Corte; minucioso e centralizador, o dispositivo comporta 135 artigos. E a um tempo normatiza a inspeção dos estabelecimentos públicos e particulares, nomeação e demissão de professores, sanções disciplinares, programas e métodos de ensino. No mais, incorpora disposições da reforma Guizot, 1833, ou seja, a criação de um sistema escolar de Estado, do projeto Carnot, 1848, ou seja, a lealdade ao ensino gratuito e obrigatório, da lei Falloux, 1850, o desprezo pelas escolas normais e reforço do serviço de inspeção. ${ }^{17}$

Robustecido, o corpo de inspeção seria integrado pelo ministro e o secretário de Estado dos Negócios do Império, ambos secundados pelo inspetor-geral, conselho diretor e inspetores distritais. Operadorchave, ao inspetor-geral delegavam-se muitíssimas obrigações: examinar candidatos ao magistério, aplicar penas disciplinares, autorizar abertura de escolas, elaborar mapas estatísticos e orçamentos anuais, expedir diretivas para inspetores e professores, propor sistemas práticos de ensino, por fim, revisar compêndios escolares. ${ }^{18}$ Inovava-se. Ensino primário obrigatório, sanções para pais, tutores

${ }^{17}$ Ecos da legislação decretada por Guizot e Falloux, nos planos de reforma, são constatados por Chizzotti (1975) e Moreira (1955). Quanto ao cenário francês, ver Gontard (1981).

18 "Pode-se dizer que o também Decreto-Lei Couto Ferraz, de 1854, é um ponto de inflexão nas políticas públicas de educação ao longo do Império. Foi ele quem estabeleceu pela primeira vez uma estruturaçáo funcional da educaçáo, que vinha sendo requisitada desde a primeira lei de educação, de 1827" (Rocha, 2010, p.126). 
e curadores recalcitrantes no tocante à matrícula e à frequência dos filhos e pupilos, doação de material e vestuário para crianças pobres, criação de asilos-escola para menores abandonados. Para o exercício do magistério, o candidato deveria comprovar idoneidade moral e capacidade profissional, em contraparte instituía o direito à aposentadoria aos 25 anos de docência. Relativamente à pedagogia escolar, sancionava o método simultâneo e, além de encaminhar a criação de "escolas de $1^{\circ}$ e $2^{\circ}$ grau", introduzia a figura do professoradjunto a ser recrutado entre filhos de professores e/ou alunos pobres maiores de 12 anos.

O Regulamento do Ensino Primário e Secundário da Corte de 1854 , a sua vez, estipulava o ensino de instrução moral e religiosa, leitura e escrita, noções de gramática, princípios de aritmética, sistema de pesos e medidas. A esses conteúdos acrescentava-se a leitura dos Evangelhos, notícias de História Sagrada, elementos de história e geografia do Brasil, noções de ciências físicas e história natural "aplicáveis aos usos da vida", geometria, agrimensura, desenho linear, noções de música, exercícios de canto e ginástica; por fim, introduzia o ensino da metrologia francesa. No futuro, ao balancear positivamente as realizações do Segundo Reinado, Franklin Menezes Dória, o pertinaz barão de Loreto, louvaria a reforma capitaneada por Couto Ferraz. "Breve, o ministro do Império Luiz Pedreira do Couto Ferraz, visconde de Bom Retiro, organiza a instrução primária e, com o Decreto de 17 de fevereiro de 1854, conquista para si verdadeira glória, comparável a que de Guizot, em França, a sua lei de 28 de junho de 1833" (Dória, 1899, p.15).

E por ventura não será despropositado, se agora acrescentássemos os dizeres contrastantes (e otimistas) de José Manoel Garcia, autor de proficiente parecer sobre a questão "Das escolas primárias, disciplinas que devem ser ensinadas, material escolar" encaminhado ao Primeiro Congresso da Instrução Pública do Rio de Janeiro, anunciado para 1884, mas não realizado. Ao avaliar os desdobramentos do Ato Adicional, José Manoel Garcia, assim, argumentava, conquanto o artigo 10, 
$2^{\circ}$ do ato aditivo houvesse quebrado a unidade da educação nacional, não prejudicara "o acréscimo das escolas primárias, ao contrário, não obstante os movimentos revolucionários de diversas províncias ao norte e ao sul do Império, as guerras com as repúblicas vizinhas, as secas e as epidemias que têm exaurido os cofres gerais e provinciais, elevaram-se cada vez mais" (Garcia, 1884a, p.2-3). Otimista declinava números positivos, ainda que insuficientes, na medida em que indiciam escolarização mínima das populações infantis.

Tabela 2 - Evolução do número de escolas públicas e matrícula geral $-1838-1873$

\begin{tabular}{c|c|c}
\hline & Escolas públicas & Alunos \\
\hline 1838 & 607 & 11.445 \\
\hline 1845 & 835 & 26.584 \\
\hline 1852 & 1.246 & 43.829 \\
\hline 1864 & 2.038 & 83.884 \\
\hline 1873 & $3.875^{*}$ & $154.351^{* *}$ \\
\hline & *Diurnas-3.792 & **Diurno-154.351 \\
& *Noturnas-83 & **Noturno - 21.113 \\
\hline
\end{tabular}

Fonte: GARCIA, José Manoel. 5a questão: das escolas primárias, disciplinas que devem ser ensinadas, material escolar. Parecer do Dr. José Manoel Garcia. In: ATAS e pareceres do Congresso de Instrução Pública do Rio de Janeiro. Rio de Janeiro: Tipografia Nacional, 1884.

\section{Cultura da razão e da vontade}

Ao notificar um plano de matérias para as escolas do Império, a lei de 1827 oficializava o "sistema de Lancastre" ou de "Lencastre" ou "lancastrino", o qual, note-se, inovava ao ensinar a ler e a escrever simultaneamente. No Brasil, um dos começos da aclimatação do "método mutualista" remete ao Decreto de $1^{\circ}$ março de 1823, promulgado por D. Pedro - "Hei por bem mandar criar nesta Corte uma escola de primeiras letras, na qual se ensinará pelo método do ensino mútuo, sendo em benefício, não somente dos militares 
do Exército, mas de todas as classes dos meus súditos que queiram aproveitar-se de tão vantajoso estabelecimento.”

Outras iniciativas episódicas remontam a José Paulino Soares de Souza, visconde de Uruguai, por sua diligência, instalava-se em 1835, a Escola Normal de Niterói para habilitar mestres conforme o método. ${ }^{19}$ Iniciativa relevante, desde a expulsão dos jesuítas no século XVIII pelo ministério pombalino, improvisavam-se mestres de escola, qualquer pessoa poderia abrir escolas ou nelas ensinar. Demais iniciativas concernem à Lei no 76 de 24 de julho de 1838, promulgada por Vicente Tomás Pires de Figueiredo Camargo, presidente da província do Maranhão, autorizando mandar à França "um sujeito de reconhecida e indisputável habilidade a fim de aprender praticamente o ensino pelo método Lencastrino, o qual assim instruído venha reger uma Escola Normal na capital da Província." A escolha recai na pessoa de Felipe Benício de Oliveira Conduru. "Tal Escola constituía uma novidade no ensino público do país. Precedíamos, no assunto, à província de S. Paulo, que só teve uma escola deste gênero, em 1846, quando já fracassava entre nós o novo método. Anexa ao Liceu, orientada pelo diretor deste estabelecimento, a Escola teve os seus dias de prosperidade, e tanto que, por diversas vezes, se pensou em separar os dois institutos" (Viveiros, 1952, p.80).

Explica-se diversamente a origem desse método, em que o mestre atua como espectador e inspetor, contudo um dado é certo, embora de olhar filantropicamente esclarecido e cristão, a escola lancasteriana inserese na órbita da neutralidade religiosa. Como narram os intérpretes do passado, o "método", "sistema" ou "modo" estabelecera-se na Inglaterra após relato de Andrew Bell a respeito da aplicação exitosa em Madras, Índia, e propagara-se graças a Joseph Lancaster. Tratados como Exposição do novo método de ensino mútuo seguido nas escolas militares de primeiras letras em Portugal, de João Crisóstomo do Couto Melo, e Leenseignement mutuel "ou histoire de l'introduction et de la propagation de cette méthode par les soins du docteur Bell, de J. Lancaster et d'aufres", de Joseph Hamel, no qual há singular esboço histórico do método, concorreram na popularização da lógica de aplicação e rendimento do método.

${ }^{19}$ Cf. Lacerda (1938) e Villela (1990). 
O novo método de ensino é conhecido por diversos nomes. Nós o chamamos de método de Bell ou de Madras porque o doutor Bell o concebe primeiramente em Madras (na costa de Coromandel), e método de Lancaster, pois M. Lancaster foi o primeiro que de fato o aplicou e que teve sucesso, de forma zelosa e ativa, em fazer com que fosse adotado por toda a Inglaterra.

$\mathrm{Na}$ França, o designamos por seu próprio objeto, e o nome do método de ensino mútuo é sem dúvida o mais convencional, uma vez que caracteriza o modo de educação, sem admitir uma alusão ao menos incerta, seja a um inventor do processo, seja aos lugares onde tenha surgido. Desse modo, encontra-se, na verdade, resolvida a questão da economia do ensino elementar, uma vez que é suficiente um único professor para dirigir a educação de um grande número de crianças: chega-se mais rápido ao objetivo e sua instituição exige menos despesas (Hamel, 1818, p.3-4, grifo do autor).

Ao esmiuçar a prática do ensino mútuo, algo complexo, o autor acentuava argumentos simpáticos ao "método de Bell ou de Madras" e/ou "método de Lancaster".

Os antigos métodos resultam na perda de um tempo precioso. Com eles, passa-se às vezes três ou quatro meses antes que as crianças conheçam seu alfabeto, e alguns anos antes que elas saibam ler fluentemente e escrever de forma legível.

Se há cinquenta alunos em uma escola onde toma-se três horas pela manhã e duas horas durante a tarde, admitindo-se que não se perde sequer um segundo (e essa suposição é extrema), o professor não poderá jamais dedicar mais que seis minutos a cada uma das crianças, e o restante do tempo será quase que perdido por elas. Mesmo que em um ano haja trezentos dias de aula, cada criança terá apenas trinta horas de ensino (Hamel, 1818, p.3-4).

De uma parte, a recepção do método deve-se à tomada de consciência do valor econômico da instrução e da escassez de professores; para uns, a instrução salvaguardaria a civilização, ordem 
pública e bons costumes; para outros, incrementaria a produtividade manufatureira e agrícola; no mais, a recepção auspiciosa devia-se à propalada economia de recursos, um mestre, num local avantajado secundado por alunos-monitores, ensinaria centenas de crianças. Grosso modo, o princípio metodológico baseia-se na reciprocidade do ensino, os mais aptos servem de mestres aos menos aptos, assim todos avançariam gradualmente. ${ }^{20}$ Diretividade de comandos, divisão de responsabilidades, exercícios maquinais, processos mnemônicos e o mais assemelham os procedimentos às normas das casernas e fábricas. De resto, as expectativas convergem para o ato de suprir a baixos custos a falta de mestres, muito embora a necessidade de espaços amplos e a panóplia de utensílios didáticos implicassem gastos.

Vice-reitor da Universidade de Paris, membro da Academia Francesa, Octave Gréard em Éducation et instruction, no findar o século XIX, descrevia o essencial da cena lancasteriana, para ele relíquia de um passado em desuso. Acompanhemos a descrição. Em toda a extensão, no meio da sala, filas de bancos de 15 a 20 lugares, à direita o púlpito do monitor, a série de modelos para escrita; "uma espécie de telégrafo" emissor de comandos une a sequência de fileiras. Junto às paredes laterais, semicírculos para agrupamentos de alunos, "à meia altura e ao alcance da mão”, quadros-negros para exercícios de cálculo e quadros murais para leitura e gramática.

Lá do fundo do salão, sobre um vasto e elevado estrado, com vários degraus e rodeado de balaustres, a cadeira do professor, que a seu turno, valendo-se da voz, do bastão ou do apito, fiscaliza os quadros e os grupos distribuindo os incitamentos e as reprimendas e, em uma palavra, regulando, como o capitão de navio na ponte de comando, toda a manobra do ensino (Gréard, 1889, p.26-27).

${ }^{20}$ Cf. Dussel e Caruso (1999) e Lesage (1981). Sobre a adoção e usos do método monitorial/mútuo nas províncias do Império, ver Bastos e Faria Filho (1999). 
Médico e cronista dos fatos educacionais no Império, José Ricardo Pires de Almeida, ao circunstanciar o uso do método em solo nacional, certamente ajuda a matizar um tanto mais a análise.

Apesar do eclipse da grande voga do ensino mútuo na Inglaterra, os liberais brasileiros, propugnadores do método, pensaram então que a liberdade de abrir de abrir escolas, sem exames prévios e sem autorização, unida a um novo sistema de instrução, difundiria rapidamente, até aos mais distantes pontos do Império, a necessária instrução primária às massas (Pires de Almeida, 1989 [1889], p.57).

Desde meados de 1830, deplorava-se a condição das escolas lancasterianas, por regra refugiadas em locais impróprios, desprovidas de mestres aptos na técnica e utensílios, compêndios. "Em seus relatórios, os ministros de então, Campos Vergueiro, Chichorro da Gama, Inácio Borges e Bernardo de Vasconcellos, fulminavam o sistema lancasteriano, em voga para as nossas escolas de primeiras letras" (Fleiuss, 1922, p.1.999). Estabelecimentos de instrução idealizados para meios urbanos, neles há populações relativamente adensadas, as escolas lancasterianas guardariam vigência até o segundo quartel do século XIX. Na província de São Paulo, o método deixa de vigorar em 1846; já no Espírito Santo, o Regulamento Geral da Instrução Pública assim estatuía. "Artigo 25 - Não é permitido o sistema de ensino por decuriões ou monitores, e o professor é obrigado a lecionar pessoalmente todos os seus alunos.” Em plena República, disposição análoga consta no Regulamento da Instrução Pública do Estado de Mato Grosso de 1910. "Art. 22 - Não é permitido o sistema de ensino por decuriões ou monitores, pelo que o professor que não tenha adjunto é obrigado a lecionar pessoalmente todos os seus alunos”. 



\section{Dos modos de instruir}

Desmobiliadas, improvisavam-se as "casas públicas de instrução e educação" em saletas na casa do mestre, onde, por vezes, funcionava uma venda ou em cantos de cadeias e igrejas. Médico e pastor da colônia inglesa na Corte, Robert Walsh, em Notícias do Brasil, narra cena em nada lisonjeira. "A venda era mantida por um homem instruído, que também mantinha uma escola."

Quando entramos, fomos saudados pelo animado murmúrio de crianças, que recitavam em coro a lição num cômodo contíguo. Fomos até lá e deparamos com dez ou doze meninos sentados em bancos decentemente trajados, todos lendo junto em voz alta. Seus livros não passavam de cartas comerciais recebidas pelo seu mestre e tratando de vários assuntos relativos aos seus negócios, sendo cada folha protegida de maneira que manuscritos tão preciosos não sofressem com o manuseio dos meninos.

O professor via-se forçado a se valer desse recurso porque não dispunha de livros, e dessa forma seus alunos aprendem a ler textos manuscritos antes dos impressos. Algumas cartas eram quase incompreensíveis e muito mal escritas, e em minha opinião teriam confundido qualquer escrivão do Registro Público (Walsh, 1985 [1830], p.54).

No geral, os mestres de escolas manejam a relação mestre-aluno ou mestre-classe pelo método individual ou simultâneo, por regra as aulas ocorrem em duas jornadas diárias uma pela manhã, outra à 
tarde. ${ }^{21}$ Exemplo ideal-típico de emprego de tempo e distribuição de lições consta no relatório manuscrito de 15 de julho de 1868 de Bernardino de Carvalho, professor na província de São Paulo.

Período da manhã

Todos os dias

- caligrafia: das 8 às $83 / 4$

- aritmética prática: das $83 / 4$ às $9 \frac{1 / 2}{2}$

- leitura de impressos

- lições de doutrina de gramática inclusive o tempo da tomada das lições das $9 \frac{1}{2} 2$ às $101 \frac{1}{2}$

Escola da tarde

Todos os dias

- caligrafia: das 2 às $23 / 4$

- aritmética prática: das $2 \frac{3 / 4}{4}$ às $3 \frac{1}{2}$

- leitura dos manuscritos e lições de tabuadas (cada aluno em particular)

- teoria da aritmética e sistema métrico (inclusive o tempo das tomadas de lição) das $3 \frac{1}{2}$ as $4 \frac{1}{2}$ (Carvalho apud Neves, 2003)..$^{22}$

O senso prático, assim, recomendava: apenas se começa a escrever quando o aprendiz souber soletrar e ler e a fazer contas. Não há aulas aos domingos e dias santificados ou de grande gala, igualmente nos dias de Entrudo, Quarta-feira de Cinzas ou entre Domingo de Ramos e Páscoa, o mesmo para Finados. As férias abarcavam da primeira semana de dezembro à primeira de janeiro; salvo nalgumas escolas agrupadas na Corte, as aulas públicas são as mais simples, uma classe, um mestre. Não se admitiam menores de cinco anos, meninas em escolas de meninos e vice-versa, crianças com moléstias contagiosas anteriormente expulsas por incorrigíveis.

${ }^{21}$ Cf. Kubo (1986) e Vechia (2004).

${ }^{22}$ Para apreciação das formas escolares no período, ver Marcílio (2005). 
Quanto aos escravos, a postura das autoridades é idêntica à declinada em Documentos com que ilustríssimo e excelentissimo senhor Dr. José Antonio Saraiva, Presidente da Provincia de S. Paulo, instruiu o relatório da abertura da Assembleia Legislativa Provincial no dia 15 de fevereiro de 1855.

Suscitou-me dúvida se eram admitidos à matrícula os escravos, ou indivíduos, sobre cuja liberdade não havia certeza. Visto que as famílias repugnam mandar as escolas públicas seus filhos se essa qualidade de alunos fosse aceita, e atendendo aos perigos de derramar a instrução pela classe escrava, ordenei que não fossem recebidos nos estabelecimentos de instrução pública senão os meninos, que os Professores reconhecessem como livres, ou que provassem essa qualidade (Documentos..., 1855, p.48).

Desnecessário redizer que a instrução elementar, assim se crê, constitui propedêutica à cultura em sentido antropológico, ou seja, conjunto de ideias, signos, modos de comportamento, comunicação e sobremodo propedêutica ao homem social pela efetividade da cultura, donde o anelo de transcender o círculo restrito do ler-escrever-contar pelo ensino de noções literárias e científicas, acrescidos de edificantes valores morais, sãs virtudes da fé e modos civis.

\section{Conhecimentos epitomizados}

Numa época demarcada por fenômeno relativamente inédito, qual seja, as relações entre ensinante e aprendizes, mediatizadas tanto pela palavra do mestre, execução de cópias, ditados, cálculos numéricos quanto pela leitura de manuscritos e impressos, cresce a procura de compêndios. Índice fortuito consta na "memória" do coronel e bacharel em Filosofia e Matemáticas, Martim Francisco Ribeiro d'Andrada. 
Os compêndios destinados para o primeiro grau de instrução, encerrando em si elementos mais simples, e princípios de verdade geralmente reconhecida, que nunca experimentam a influência das novas descobertas, devem ser compostos debaixo da vigilância, e inspeção do Estado, porque desta forma sua doutrina nunca será desnaturalizada, pela superstição ou negligência, e por isso hão de ser de necessidade melhores (Memória..., 1945 [1816], p.470).

Outro ângulo, outra voz. Nos meados do século XIX, o governo imperial encarrega Antonio Gonçalves Dias de inspecionar estabelecimentos de instrução das províncias do norte. Do périplo ajustado, vinha à tona Instrução pública nas provincias do Pará, Maranhão, Ceará, Rio Grande, Paraíba, Pernambuco e Babia, documentário ímpar a desdizer as aparências pelas realidades. Estupefato, o poeta maranhense cujo romantismo-indianismo desde cedo à meninice aprendera a admirar, deplorava. "Um dos defeitos é a falta de Compêndios no interior porque os não há, nas Capitais, porque não há escolha, ou foi mal feita; porque a escola não é suprida, e os pais relutam em dar os livros exigidos, ou repugnam aos mestres os admitidos pelas autoridades" (Gonçalves Dias, 1957 [1852], p.362).

\section{Quais compêndios? Quais autores? Quais lugares?}

Terra-a-terra, os passos de vida escolar no Primeiro Reinado, Regências e início do Segundo Reinado, de algum modo, faziam-se acompanhar dum sortimento de obras didáticas, hoje quase esquecidas, conquanto saudadas como expressivas de técnicas intelectuais do entendimento da ordem natural das coisas e dos homens. ${ }^{23}$ Lento e lento assistia-se à integração da escola de instrução primária em

${ }^{23}$ Quanto à escolarização dos saberes com vista a propiciar "aprendizagens elementares" e a "trilogia ler-escrever-contar", escreve Hébrard (1999, p.66): “Em suma, trata-se de ver como essa trilogia, a nossos olhos táo natural, é produzida na e pela escolarização". 
paisagens sociais diversas, além de certa familiarização do ensino letrado com recurso a impressos revestidos de ditaticidade. É de supor que, porventura, nos lugares nos quais se vivenciava a experiência escolar, que a combinatória ensino/texto/imagem se viabiliza consoante edições esporádicas ou repisadas de compêndios impressos em tipografias locais ou em editoras a caminho do prestígio comercial. Se tal combinatória é circunstanciada por imperativos técnicos e potenciais de consumo, sem dúvida, o é também pela renúncia ao recurso único da memória, faculdade superior, mas susceptível de elisões.

Como os trabalhadores do mundo físico, os do mundo moral, para não perderem suas forças em vão, precisavam de um depósito que recolhesse e guardasse os seus produtos. $\mathrm{O}$ depósito que para se inventou foi o livro. O livro, portanto, está para o mundo moral na mesma razão que o celeiro está para o mundo físico. Como o celeiro guarda o alimento do corpo, o livro guarda o alimento do espírito, ou é o depositório das ciências, das leis, da memória, dos acontecimentos, dos usos, dos hábitos e dos costumes (Oliveira, 1874, p.361).

Sem pretender estabelecer copioso censo editorial ou declarar título a título, autor a autor ou ainda contabilizar produção, uso e recepção, convém nomear alguns títulos e autores, assim o rol indexado a seguir é tão só primeira escavação em solo rico em despojos.

Nos cantos e recantos do Império, para ensinar a ler, recorre-se às "cartas de $\mathrm{ABC}$ ", cartões com as letras do alfabeto, leitura e cópia de manuscritos, cartilhas quando houver. Para "ler correntemente", convém relembrar: Primeira coleção de cartas para os meninos e meninas aprenderem a ler, de Alexandre Balmat (Rio de Janeiro, 1840); Arte de ler e de escrever em pouco tempo, ou razão filosófica da verdadeira ortografia, desinfetada dos prejuizos da ortografia barbaresca, de Marcelino Pinto Ribeiro Duarte (Niterói, 1842); Novas cartas para aprender a ler, nas quais se mostra que não é necessário estudar as sílabas isoladas dos nomes, como se ensina pelas antigas cartas, de Salvador Henrique de 
Albuquerque (Pernambuco, 1842); Plano para o ensino das primeiras letras, aproveitando os três métodos: mútuo, individual e simultâneo, de Antonio Gentil Ibirapitanga (Bahia, 1846); Cartilha do porvo, de José Inácio de Abreu e Lima (Pernambuco, 1849), Traslados caligráficos, de Cirilo Delermando (Rio de Janeiro, 1854). E a muito bem divulgada cartilha portuguesa, Método Castilho para o ensino rápido e aprazivel do ler impresso, manuscrito, e numeração e do escrever, de António Feliciano de Castilho (Lisboa, 2ed., 1853), propagandeada no Brasil pelo autor sob incentivo de Pedro II, com o intuito de recomendá-lo como "método nacional de alfabetização."

Diremos de passagem que este era o método ideado por Antonio Feliciano de Castilho, para ensinar a leitura: "ele punha de parte inteiramente, a relação entre o nome e o valor das letras, para dar, como deu a cada uma, o nome de uma pessoa ou de um objeto, com os quais organizava um "conto", em que a graça era um meio de "fixar" e a analogia um meio de "derivar". A era um mandrião; $B$ - boi, $C$ - cortesão" (Lições de pedagogia, do autor, 1919) (Lima, 1927, p.153, grifo do autor).

Ainda nesse gênero: Silabário brasileiro para aprender facilmente a ler, "confeccionado por" Francisco de Paula Soares e Carlos Koeffer (Porto Alegre,1858), Manual explicativo do método de leitura denominado Escola Brasileira, oferecido à classe de Professores de Primeiras Letras, de Francisco Alves da Silva Castilho (Rio de Janeiro, 1859); Compêndio de gramática portuguesa, por Policarpio José Dias da Cruz, "corrigido e emendado de acordo com os Srs. professores públicos da Corte” (Rio de Janeiro, 1860), Iris clássico, do citado Antonio Feliciano de Castilho, dedicado "A Sua Majestade o Senhor D. Pedro Segundo, Imperador do Brasil" e "ordenado e oferecido aos mestres e aos alunos das escolas brasileiras"; Método facilimo para aprender a ler e escrever no mais curto espaço de tempo possivel tanto a letra redonda quanto a letra manuscrita, de Emilio Achilles Monteverde (Lisboa, 1865); Gramática da infância dedicada aos srs. Professores de instrução primária (Rio de Janeiro, 1864). 
Na modalidade "crestomatia", ou seja, "estudo das coisas úteis" e "recolha de excertos de autores": Crestomatia brasileira, "adotada pelo Conselho de Instrução Pública da Província, para uso das classes de leitura e análise", por Francisco de Paula Soares e Carlos Koeffer (Porto Alegre, 1859); O livro dos meninos. Curso elementar de instrução primária, de António Rego (Maranhão, 1864), e o singularíssimo Livro do povo, de Antonio Marques Rodrigues, inspetor da Instrução Pública, "conselheiro do professorado; animando a uns, admoestando a outros, fiscalizando a todos” (Maranhão, 1861).

O Livro do povo - volume de perto de 300 páginas em tipo compacto e intercalado de muitas gravuras - vendia-se por 400 réis e continha os seguintes capítulos: Vida de Cristo, $\mathrm{O}$ vigário, Descrição de alguns mamíferos, $\mathrm{O}$ bom homem Ricardo, Descrição de algumas aves e répteis, $\mathrm{O}$ professor primário, Moral prática, Evangelho de lavradores, Máximas e sentenças, Regras de higiene, Os astros, Extrato de Simão de Nantua, Corografia do Brasil.

Não satisfeito com o preço insignificante de 400 réis, que mal dava para cobrir as despesas da impressão, tirava Marques Rodrigues edições especiais desse livrinho para distribuição gratuita. E assim o Livro do povo foi o livro de leitura da infância maranhense do segundo reinado, que quase toda ela aprendeu a ler as lições ditadas pelo espírito bom e generoso de Antônio Marques Rodrigues (Viveiros, 1952, p.80).

Quanto à "matéria escrever correntemente", lembrando que se aprendia a escrever copiando e desenhando letras, recorrendo-se a exercícios caligráficos como: bastardo, bastardinho e cursivo, ortografia, cópia, ditado e, quando possível, à composição de períodos.

Para "contar e calcular": Liçôes de aritmética, por "Um brasileiro" (Rio de Janeiro, 1825), Compêndio aritmético ou Tabuada curiosa para os meninos, onde se explica em diálogo os principais fundamentos da aritmética, e outras coisas curiosas, e necessárias, de P. Plancher-Seignot (Rio de Janeiro, 1827); Compêndio de aritmética, por Candido Batista 
de Oliveira, "para uso das nossas Escolas de instrução primária, especialmente de ensino mútuo"(Rio de Janeiro, 1832); Compêndio de matemáticas elementares, por Henrique Luiz de Niemeyer Bellegarde (Rio de Janeiro, 1831); Compêndio cientifico para a mocidade brasileira, "Destinado ao uso das escolas dos dois sexos, ornado de nove estampas acomodadas as artes, e ciências de que nele se trata, tiradas por litografia", "por um cidadão agradecido" [pseudônimo de José Paulo de Figueroa Nabuco de Araújo] (Rio de Janeiro, 1838); Aritmética para meninos, contendo unicamente o que é indispensável e se pode ensinar nas primeiras letras, de Antonio Álvares Pereira Coruja (Rio de Janeiro, 1850).

Quanto à fruição da consciência histórico-geográfica: Resumo da história do Brasil até 1818, "traduzido de M. Denis, corrigido e aumentado", por Henrique Luiz de Niemeyer Bellegarde, "adaptado pelo governo para uso das escolas” (Rio de Janeiro, 1831), Compêndio de geografia universal, contendo a descrição particular de todas as regiões do mundo conhecido e com especialidade do Império do Brasil, "composto e dedicado à mocidade brasileira, por um oficial General do Exército”, de Jacques Antonio Marcos de Beaurepaire (Rio de Janeiro, 1835); Compêndio de geografia elementar, de José Saturnino da Costa Pereira (Rio de Janeiro, 1836); Compêndio das eras da provincia do Pará, de Antonio Ladislau Monteiro Baena (Pará, 1838); Historia universal resumida para uso das escolas, de Parley (pseudônimo de Daniel Hawthorne), tradução do desembargador Lourenço José Ribeiro (Rio de Janeiro, 1838); Introdução coreográfica à história do Brasil, por Pedro D’Alcântara Bellegarde (Rio de Janeiro, 1840); Compêndio de geografia, de Tomás Pompeu de Souza Brasil (Ceará, 1856); Compêndio de geografia da Provincia do Rio Grande do Sul, de Eudoro Brasileiro Berlinck (Porto Alegre, 1863).

Para conter a frouxidão da índole das gerações nascentes, formar seres virtuosos mediante controle das pulsões e comportamentos hostis (afinal, toda educação tem seu preço), recomenda-se a leitura e a cópia de civilidades, a memorização de conselhos e a vivência de 
máximas morais. Dentre os códigos de decoro, fenômeno expressivo de uma ortopedia moral nascente, o bem-fadado $A$ ciência do bom homem Ricardo ou meios de fazer fortuna, de Benjamin Franklin (Rio de Janeiro, 1835), sisudo repositório de conselhos contrários à vadiação. É do autor o conhecidíssimo adágio burguês - "tempo é dinheiro".

Mas se amais a vida, diz outra vez o bom homem Ricardo, não desperdiceis o tempo, porque ele é o estofo da vida. Quanto tempo não damos ao sono além do necessário? Não nos esqueçamos de que a raposa que dorme não apanha galinhas. Se o tempo é o mais precioso dos bens, desperdiçá-lo é o maior das loucuras, diz o bom homem Ricardo, pois diz ele em outro lugar: o tempo perdido não recupera, e o que nós dizemos tempo bastante sempre é pouco (Franklin, 1825, p.4, grifo do autor).

No solo reescavado, mais ao fundo, o Fabulista da mocidade ou fábulas seletas de Esopo, de La Fontaine, tradução de Tristão da Cunha Portugal (Lisboa, 1837), Coleção de Fábulas (imitadas de Esopo e de La Fontaine: dedicadas a S. M. o Imperador D. Pedro II), de Justiniano José de Souza (Rio de Janeiro, 1852); Tesouro de meninos: obra clássica dividida em três partes: moral, virtude, civilidade, de Pedro Blanchard, "vertida em português e oferecida à mocidade estudiosa" por Mateus José da Rocha (Lisboa, 16. ed. 1861); Educador da mocidade, de Alexandre J. Melo Morais (Bahia, 1852); Guia de leitura e máximas gerais de conduta, por Antonio Alves Branco Moniz Barreto (Rio de Janeiro, 1854).

No engrossado das civilidades: Cartas de uma americana sobre a educação de meninas, tradução de João Cândido de Deus e Silva (Rio de Janeiro, 1838); Noçôes gerais acerca da educação da mocidade brasileira, de João Henrique Freeze (Rio de Janeiro, 1850); Tesouro de meninas ou Diálogos entre uma sábia aia e suas discípulas, de Jeanne Marie Leprince de Beaumont, tradução de Joaquim Inácio de Frias, do original Magasin des enfants ou dialogues entre une sage gouvernante et plusieurs de ses élèves de grande distinction (Lisboa, 1846, 2v.). 
Nos quais refletem e falam as meninas, segundo o gênio, temperamento, e inclinações de cada uma; e representando-se os defeitos da sua idade, se mostra de que modo se podem emendar. Compreende também esta obra um compêndio da História Sagrada, da Fábula, e da Geografia, e alguns contos morais, para entreter as meninas agradavelmente, sendo tudo escrito em estilo simples, e proporcionado aos seus tenros anos (Leprince de Beaumont, 1846, p.26).

Nas páginas instrutivas, outro conselho de Leprince de Beaumont. "Primeiramente deveis pedir a Deus todas as manhãs, e noites nas vossas orações graças para vós emendares, porque nós não podemos nada sem o seu socorro; mas é preciso pedirlhe esta graça com eficácia, é como vós pedis a vossa mãe o que mais desejais" (Leprince de Beaumont, 1846, p.46). Para propiciar experiência cristã de vida e, claro, exaltar a aliança entre Trono e Altar, coexistem o empenho de escolarizar as verdades do cristianismo, cujo propósito reside na anunciação de prêmios e castigos da vida sobrenatural: Escola brasileira, ou instrução útil a todas as classes, extraida da Sagrada Escritura para uso da mocidade, por José da Silva Lisboa, visconde de Cairu, "membro da Sociedade Filosófica de Filadélfia” (Rio de Janeiro, 1827), dedicado "Ao mui alto e poderoso senhor d. Pedro I - Imperador constitucional e Defensor Perpétuo do Brasil".

Sendo constante em um e outro hemisfério a porfia dos infiéis em subverterem o Altar e o Trono, pela introdução de maus livros, em que se desluz a Sagrada Escritura parece conveniente à firmeza e estabilidade do Edifício Político, de que Vossa Majestade foi o glorioso Fundador na Terra de Santa Cruz, que, para se exterminar dela o contágio do século, se instrua e fortifique o espírito dos meninos no Ensino de Primeiras Letras com a lição de originais ditames dos Livros, que dão a evidência da Divina Revelação (Lisboa, 1827, p.10). 
Partilhando do princípio que assevera a religião como salvaguarda da moralidade dos povos, vem a público Cartilha da escola brasileira para instrução elementar na religião do Brasil, de José da Silva Lisboa, visconde de Cairu (Rio de Janeiro, 1831).

P. Meninos, que Religião professas?

R. A Religião do Estado.

P. Que ensina esta Religião?

R. A Lei de Deus, conforme a Doutrina Evangélica e Tradição Apostólica, interpretada e certificada pela Igreja de Roma.

P. Sois cristãos?

R. Sim, e católico pela Graça.

P. Quem é Deus?

R. É um Espírito Eterno, Poder invisível, Imenso, Criador, Conservador, e Regedor do Universo, infinitamente Sábio e Perfeito, Remunerador dos Bons, e Castigador dos maus (Lisboa, 1831, p.143).

Depois viriam Harmonias da criação, de Caetano Lopes de Moura (Paris, 1846); Catecismo da doutrina cristã, do cônego Joaquim Caetano Fernandes Pinheiro (Rio de Janeiro, 1855); Catecismo (doutrinas cristãs) de Fleury, tradução de Joaquim José da Silveira (Rio de Janeiro, 1866) e, por último, recendiam os evangelhos e os catecismos de Montepelier e Fleury. Na superfície da escavação, o popularíssimo História de Simão de Nantua ou o mercador de feiras, de Laurent Pierre de Jussieu, tradução de Felipe Ferreira de Araújo Castro (Lisboa, 1832), seguidos de Mimo à infância ou Manual de história sagrada para uso das crianças "Que frequentam as aulas, tanto em Portugal como no Brasil”, por Emílio Aquiles Monteverde (Lisboa, 1859).

Sobre a saúde fisica e moral, educação fisica, mais regras higiênicas, as belas obras, o volumoso Tratado de educação físico-moral dos meninos, de Joaquim Jerônimo Serpa, "extraído das obras de Mr. Gardien, doutor em medicina” (Pernambuco, 1828), título original Traité d'accouchemens, de maladies des feuvres, et de maladies propres a 
cetage, Generalidades acerca da educação física dos meninos, de Joaquim Pedro de Melo (Rio de Janeiro, 1846); Relações sobre a educação física e moral da infância, de Xavier Inácio Firmo (Rio de Janeiro, 1854); A educação física das meninas, de Casimiro José de Morais Sarmento (Rio de Janeiro, 1858). Por fim, o estudo memorizado da Constituição do Império, conforme prescrição legislada, complementa o rol de leituras recomendadas. Para formação de professores, nalguma medida recorrese ao Curso normal para professores de primeiras letras, subintitulado "Direções relativas à educação física, moral e intelectual nas escolas primárias” (Niterói, 1839).

\section{Regulações dos compêndios}

O marco inicial da regulagem da afluição de compêndios é, certamente, o Decreto no 1.331-A, de 17 de fevereiro de 1854, o qual "Aprova o Regulamento para a reforma do ensino primário e secundário da Corte". Em conformidade com o artigo 2º parágrafo $4^{\circ}$, ao Inspetor Geral compete "Rever os compêndios adotados nas escolas públicas, corrigi-los ou fazê-los corrigir, e substituí-los, quando for necessário"; regulação expandida no artigo $11^{\circ}$ - "O Conselho Diretor tomará parte em todos os negócios em que a sua intervenção é exigida por esse Regulamento. Terá especialmente a seu cuidado: $1^{\circ}-$ O exame dos melhores métodos e sistemas práticos de ensino. $2^{\circ}-\mathrm{A}$ designação e revisão dos compêndios na forma do Art. 40".

Desdobramentos desse marco inicial remetem ao Código de Instrução Pública da província de São Paulo, 1857, elaborado por sujeitos notáveis, Antonio Joaquim Ribas, João Dabney de Avellar Brotero, Diogo de Mendonça Pinto, inspetor-geral da Instrução. Ao inspetor compete "Prescrever os livros, compêndios e modelos que devem ser adotados no ensino público, e vedar ao ensino privado os que forem contrários à religião, à moral, ou às leis"; e proibir "qualquer traslado, livro ou método, que não estejam completamente autorizados". Conforme o artigo 159, o poder público atuaria como indutor de 
cultura, encomendando a pessoas ilustradas compêndios "adaptados à compreensão dos alunos" para o ensino de moral, religião católica apostólica romana, aritmética, gramática; aos autores se concederia gratificação não excedente a 600 mil réis, revertendo-se à província a propriedade intelectual. $\mathrm{Na}$ sequência, uma comissão decidiria haver ou não a necessidade de revisar os conteúdos, depois viria a impressão de "número avultado de exemplares, a fim de que possam ser expostos à venda por preço módico.”

Para a instrução média, o mesmo artigo estipula gratificação não excedente a 1:000 $\$ 000$ réis para autores de compêndios de geografia, história, história natural, física, igualmente "adaptados à compreensão dos alunos cuja propriedade ficará pertencendo à Província”. Ainda que dispersamente, ainda que localizadamente, esses são os atos de edição e regulação de compêndios efetuados numa conjuntura de escolarizarão de conhecimentos. 



\section{Parte II \\ Do apogeu ao fim do Segundo Reinado}

Pouco depois este aborrecimento legítimo teve uma distração que acabou com ele: puseram-na escola. Era inteligente, ou, como dizia D. Feliciana às suas amigas contando-lhes as qualidades da filha, tinha boa memória, e fez progressos.

Ao cabo de dois anos saiu da escola sabendo o catecismo, lendo Simão de Nantua e o Tesouro de menina e escrevendo sem muita ortografia, com letra bonita, mas banal, do geral das obidenses.

José Veríssimo, Cenas da vida amazônica (1886) 



\section{No "plano inclinado" da monarquia}

\section{Brasil mental}

Não há lugar aqui para expor todos os aspectos do esgotamento da fórmula monárquica, mas tão somente assinalar os fatos momentosos associados a sua agonia, os quais, quando reunidos, compõem o "plano inclinado" da monarquia. ${ }^{24}$ Em poucas palavras, tanto a forma patrimonial do Estado quanto o liberalismo estamental/ aristocrático e o regime de trabalho escravo entram em desagregação. Nos imprevisíveis últimos decênios do regime, o inconformismo com a ordem dinástica e a consciência dos embaraços do país abalam a autoridade das instituições. No mais e sobretudo, desde a década de 1870, alvoroçava-se a dissintonia do regime de governo, dentre outros, dado por incapaz de desembaraçar o povo vivente ao léu.

A maioria da população vegeta na mais triste miséria. A parte que não vive na miséria, afetada pela solidariedade dos interesses sociais, não está contente com a sua sorte, e debalde procura melhorá-la. Semelhante a um carro atrelado por trás e pela frente, a sociedade acha-se presa por forças opostas, e nesse estado penosamente ensaia algum passo no caminho das suas aspirações. Parte do sul, do Norte, do Centro do Império uma voz uníssona se levanta, como um grito de

${ }^{24}$ A formulação "plano inclinado" é de Sérgio Buarque de Holanda (1960), no estudo das disfunções da política parlamentar monárquica, entre 1870 e 1880. 
dor, e deplora a situação do país votado pela providência aos mais altos destinos (Oliveira, 1874, p.24).

$\mathrm{Na}$ conjuntura, de uma parte, a negação da legitimidade do Poder Moderador, Senado vitalício, Conselho de Estado, trabalho servil, privilégios senhoriais, mormente recusa do trabalho escravo, regras do exercício do voto e, é evidente, a crítica ao estado da instrução pública; de outra, a edição das leis abolicionistas, a introdução do trabalho livre, as ondas imigratórias, a extensão de linhas férreas, o travejar das aspirações republicanas, os progressos econômicos do centro-sul, o declínio econômico do Nordeste e os investimentos estrangeiros no país. "Solto, pois o trono dos alicerces fundamentais, visceralmente abalados pela abolição dos escravos, perigava, sobremodo, a manutenção da realeza. E viria fatalmente o desequilíbrio econômico e financeiro como veio a República" (Cardoso, 1924b, p.1.089).

No quadro de investimentos de energias, firmava-se a instrução popular como tema consabido do repertório dos valores modernos, o intuito, materializar a igualdade formal ditada em lei. "Em verdade, o mais digno objeto das cogitações dos brasileiros é, depois da emancipação do trabalho, a emancipação do espírito cativo da ignorância sob o ponto de vista da própria instrução elementar (e não falemos do estudo das ciências), nosso povo não entrou ainda na órbita do mundo civilizado" (Tavares Bastos, 1937 [1870], p.33).

Inatual aos olhos dos anticonformistas, venturosos partidários de soluções positivas para o Brasil social, o cânon imperial, isto é, a ordem dinástica, estamental, patrimonial estava aquém do moderno viver. Nesse final do Segundo Reinado com seus rituais próprios de uma sociedade de corte, a solução monárquica aparece como passado a caminho da extinção. Nas visões de futuro, um sistema político e social entrara em extinção, e outro alcançara a maturidade; outro invariavelmente explicado com recurso aos discursos analíticos e impessoais, isto é, as teleologias imanentes e suas leis de evolução da humanidade e do conhecimento, - a "lei dos três estados", o 
teológico, o metafísico, o positivo ou científico (Comte). Ou a "lei de heterocronia": mudanças evolutivas positivas pela ação do superior, isto é, o mais desenvolvido, sobre o inferior (Spencer). Chaves de entendimento, a teleológica visão de mundo desenrola a gramática das formas de pensar e modos de sentir, querer e agir da humanidade.

Tendo começado por uma reação aparente contra os princípios dos Enciclopedistas, contra as doutrinas dos terroristas de 93, nosso século será provavelmente assinalado na história por haver feito triunfar definitivamente na intuição geral, dos espíritos a doutrina da evolução lenta e gradativa de todos os fenômenos econômicos, biológicos, políticos, artísticos e sociais (Romero, 1898, p.14, grifo do autor).

Heterodoxa, a autoridade moralizante das teleológicas visões de mundo impõe-se, e embora a motilidade das mentalidades representacionais seja notória, a meta é consensual-, superar a imediação da vida, desdobrar a substancialidade das teorias construtivistas de Estado, vida coletiva e melhoramentos materiais. Socialmente heterogênea, no decênio de 1870, adentravam na conjuntura políticocultural, simultaneamente anticlerical, antirromântica, antimetafísica, as fileiras de sectários alistados nos torrenciais sistemas de pensamento científico, sistemas próprios de uma época que se via rica de tesouros da ciência e técnica. "Foi o Século XIX, pois, que nos deu o conhecimento total e completo do nosso planeta, quer no passado, quer no presente. Tudo o que possa fazer de futuro, e sob este aspecto pouco será, está nele em germe. E é quase certo que novas descobertas no domínio da erudição ou da geografia, em nada alterarão o nosso quase cabal conhecimento dele" (Veríssimo, 1981 [1899], p.120).

Nos enunciados da "geração de 1870", a percepção de um tempo social imóvel, de um passado que não quer passar, ou se se preferir do esgotamento de experiências malsucedidas ou inatuais, patenteiam os benefícios da instrução. $\mathrm{Na}$ cena da Corte, nas cenas provinciais, cativantes, acotovelavam-se lidadores, libelistas, ativistas, 
doutrinários, todos a compendiar o corpo e a alma do Brasil, sobretudo, os modos de pensar e os usos das políticas nacionais. Numa eflorescência de ações contenciosas, tomam lugar na hierarquia do sistema intelectual as figuras de Aarão Reis, Alberto Salles, Américo Braziliense, Antonio da Silva Jardim, Benjamin Constant, Godofredo Furtado, Joaquim Nabuco, José Feliciano de Oliveira, José Veríssimo, Júlio de Mesquita, Lauro Muller, Lauro Sodré, Lopes Trovão, Miguel Lemos, Miranda Azevedo, Muniz Barreto, Luiz Pereira Barreto, Prudente José de Morais Barros, Quintino Bocaiúva, Raimundo Teixeira Mendes, Rangel Pestana, Silvio Romero, Tobias Barreto, para mencionar alguns poucos.

Em termos ideal-típicos, ainda que fracionada e heterogênea, na "geração de 1870", o campo intelectual douto se funde com as doutrinas de uso político, muitos se inclinam ao republicanismo liberal-federalista, outros ao republicanismo positivista-ditatorial, outros mais, ao jacobinismo. Da recusa aos dogmas turvados da tradição, desprendem-se propósitos de intervenção teórico-ativa. Para a "geração de 1870", segundo usual formulação acadêmica ${ }^{25}$, a inteligibilidade da mecânica do mundo e seus fenômenos não repousam nas revelações transcendentais da fé religiosa, cujo passado mítico se perdera ou da filosofia espiritualista e eclética ou por ventura da burocrática orientação liberal, mas na atualidade da ciência organizada em sistemas de pensamento. Nas dogmáticas de teor indutivo inerente às doutrinas iniciáticas, a realidade sensível e seus objetos desfrutam de transparência e incolumidade.

${ }^{25} \mathrm{Na}$ tradição historiográfica, ver Cruz Costa (1950) e Lins (1967). Revisão do tema "geração de 1870" consta em Alonso (2002, p.32), segundo a autora: "Categorias como 'darwinismo', 'positivismo', 'spencerismo', 'liberalismo' sofreram apropriações, redefinições, usos políticos. Isso é evidente nas polêmicas entre facções: termos como 'positivistas laffitistas' e 'littreístas', 'darwinistas' e 'spencerianos', 'liberais' e 'conservadores' foram criados nas controvérsias. As categorias são contrastivas, exprimem relações entre grupos: a própria nomeação é uma arma em meio a conflitos de definição de identidades.” 
A essa geração de ânimo alteado, nela processava-se a intelectualização dos processos conflitivos (e emocionais) - bacharéis, escritores, juristas, médicos, militares, políticos, professores, em suma, mestres-pensadores contemporâneos não só dos êxitos das ciências convertidos em técnicas aplicadas, mas também das tempestades sociais -, coube impulsionar a analítica dos descaminhos da fórmula monárquica e, nalguma medida, suportar o afluxo das campanhas abolicionistas e republicanas. Transluzidas, as escolhas cientistas não se reduzem às modas intelectuais do momento ou a entusiasmos doutrinários passageiros, ao contrário, alicerçam projetos de intervenção na vida cultural e política. De sorte que as filosofias sociais caudatárias do "espírito do século XIX", o materialismo de Taine, o transformismo de Lamarck e Darwin, o evolucionismo biológico de Spencer, a teoria filogenética de Haeckel, o positivismo de Comte, com vivo sentimento, exteriorizam as profundidades das novíssimas teorias societárias para as quais homens e coisas inteligíveis são objetos cognoscíveis na sua totalidade. Escreve Euclides da Cunha (1975 [1909], p.196-197).

As novas correntes, forças conjugadas de todos os princípios e de todas as escolas - do comtismo ortodoxo ao positivismo desafogado de Littré, das conclusões restritas de Darwin às generalizações ousadas de Spencer -, o que nos trouxeram, de fato, não foram os seus princípios abstratos, ou leis incompreensíveis à grande maioria, mas as grandes conquistas liberais do nosso século; e estas compondo-se com uma aspiração antiga e não encontrando entre nós arraigadas tradições monárquicas, removeram, naturalmente, sem ruído - no espaço de uma manhã - um trono que encontraram.

Da primazia concedida à língua cientista, deflui a homologia entre evolução e progresso, experiência social e melhoramento material. Com o fito de clarear o destino social da política moderna, exorbita-se a crítica moral, donde a difusão da analítica das relações entre meio natural, raça, cultura e instituições. 
Ciência e procedimentos de observação levariam a descoberta de objetividades pré-existentes à consciência dos sujeitos, isto é, para tais ideologias científicas, nos objetos reside a verdade, que a seu turno dirige pensamentos, convicções e sentidos dos homens. Para lidadores, libelistas, ativistas, doutrinários, a língua cientista substitui o Deus da religião, justo e reto, pela Razão esclarecida e ativa, ou se preferir, substitui a luz reveladora da fé, pela luz da ciência falante da língua do amanhã.

Na praça de guerra, hinos à claridade

É tempo de saltar da boca dos heróis

O hino da vitória:

Os Novos Ideais, brilhantes como sóis

Surgem... são visões fantásticas da glória!

Dois atletas estão lutando em agonia:

A Treva com a Luz... a Noite com o Dia.

De um lado - a Ignorância, o pavoroso abutre

Que rasga o próprio seio e com seu sangue nutre

Os filhos do furor, do desespero insano

Que chama-se miséria - o grande Pelicano!...

Doutro lado a Instrução, a boa mãe, que ensina

O caminho da Escola, as portas da Oficina, Aos filhos varonis, que a trabalhar sem susto, Seguem para o futuro, alegres e robustos.

Não tarda a começar a Liberdade a Missa

No templo da Razão:

Vai-se desenvolver o tema da Justiça, À luz da Nova Ideia, ao sol - Revolução!... 
Mais do que simples curiosidade ou demonstração de apreço ao gênio do autor dessas poéticas e viris efusões, cujo lirismo doutrinário, desnecessário dizer, enche os olhos e fere os ouvidos. "Novos ideais", de Múcio Teixeira (1880, p.35), estetiza os sobrepoderes da instrução capazes de mover o "espírito brasileiro" em direção à luz do século. Figurando a si como homens da civilização do momento, os críticos de um passado histórico indébito anunciam a passagem dos obscurecimentos aos renascimentos. Para eles, a crise não era senão entrechoques de movimentos e de mentalidades. "Dois atletas estão lutando em agonia. A Treva com a Luz... a Noite com o Dia”, nos termos de Múcio Teixeira ou nos termos não menos sonoros de Luiz Pereira Barreto. "O mundo antigo é um tecido de milagres, e o milagre é a negação das leis naturais; o mundo moderno é o filho da ciência, e a ciência nada mais é que a sistematização das leis naturais. A incompatibilidade é completa e irremediável entre a tradição e a noção científica. Toda a tentativa, por consequência, de aquartelar na mesma cabeça o mundo antigo e o mundo moderno é uma desnaturada." Nas palavras desse mestrepensador, diplomado em ciências naturais e medicina pela Universidade de Bruxelas, convicto positivista, ainda que heterodoxo.

Ao tratar-se, pois, da questão da instrução e da educação, o problema, que temos a resolver, é da distinção entre os elementos vivos e os elementos mortos do organismo social. Trata-se na realidade de saber se os elementos psíquicos que já se desintegraram da economia mental, terão a preferência da conservação sobre os elementos vivos, ou se estes deverão ter a exclusiva supremacia na direção teórica e prática do movimento social. Temos de um lado partes vivas e funções ativas; de outro, partes mortas, envolvidas no silêncio da inércia (Pereira Barreto in Barros, 2003, p.364).

É de se supor que os malditosos índices de analfabetismo geral, fenômeno propagador da escuridão, senão maculador do Brasil social, constituíssem a fonte dos elogios à vara mágica da instrução, apetitiva 
matéria, cuja contrapartida lógica propicia a troca dos juízos e noções ilusórias pelo entendimento objetivo. Donde, mais do que antes, a urgência de uma primeira instrução de Estado ajustada às normas da vida civil, distribuída como serviço gratuito e obrigatório, porquanto propriedade comum, pois toda educação, dizia-se, é educação para as normas da vida civil. Nesse quadro de valores e críticas, o republicanismo educativo arma-se para enfrentar o contencioso que há de vir. "E nesta crença que julgamos de máximo alcance a educação pública, gérmen da regeneração do país uma sólida base onde se firmará uma nova ordem de coisas nascida do progresso e consciência da nação, quando convencida da esterilidade do primeiro e segundo império" (Braziliense, 1878, p.85).

Agitava-se a equação formulada pelos sujeitos do republicanismo federalista:centralização=desmembramento,descentralização=unidade. $\mathrm{Na}$ revisão geral do país, em substituição ao centralismo monárquico, cogitam-se as qualidades do liberalismo localista como apregoa o Manifesto Republicano de 1870. "Somos da América, e queremos ser americanos. A nossa forma de governo é, em sua essência e em sua prática, autônoma e hostil ao direito e aos interesses dos estados americanos". Doutrina forte e falante, o republicanismo engendra o ativismo político nos setores médios urbanos e cafeicultores do Sudeste. No programa de atualização das estruturas, o desmerecimento do Trono e do Altar redunda na valoração das teorias contratualistas, o país seria livre para transformar-se por vontade própria. Solidamente distribuída, grande benefício em si, a instrução popular, "arredando os perigos das comoções sociais", constituiria a "base mais sólida das sociedades civis", "necessidade urgente dos povos regidos pelo sistema constitucional”, no dizer arroubado de um figurão da época.

\section{Retração dos direitos, o fosso civil aumenta}

Excluam o homem da participação na soberania popular, e a liberdade ou a igualdade deixarão de ser um direito para ele, e se tornarão em mera concessão e tolerância de uma tirania mais 
ou menos generosa. Inexplicável aberração! Pugnam pelo sistema representativo, e o destroem; querem a eleição popular, e excluem dela o povo; apreciam os movimentos generosos da multidão, e põem à margem essa mesma multidão de cujos entusiasmos tudo confiam (Alencar, 1997 [1868], p.85).

Asseverava José de Alencar,em Sistema representativo. ${ }^{26}$ Expressão bem-acabada do indianismo oitocentista, sem o saber, o autor de $O$ guarani futurava o que de fato viria a acontecer. De maioria liberal, a Câmara dos Deputados aprovava em janeiro de 1881 a Lei no 3.029. A reforma da legislação eleitoral visa a converter o voto em algo aceitável, entrementes, note-se, não constam referências às defraudações habituais praticadas por coronéis e seus agentes, os emboladores, os calígrafos e os cabalistas. Nos discursos intermináveis, nas incontáveis sessões parlamentares, predominam os sorites: instrução bem difundida=boas eleições=democracia=bom regime representativo.

Após debates intensos, aprovava-se a "Lei Saraiva" (ou "Lei do Censo"), em referência ao idealizador do projeto conselheiro José Antonio Saraiva a sua vez secundado pelo deputado Rui Barbosa. Com efeito, a Lei Saraiva altera substancialmente as regras de representação política ao instituir eleições diretas para todos os cargos, extinguir a distinção entre votantes e eleitores, introduzir o voto facultativo para senadores, deputados gerais e provinciais e o "censo pecuniário", ou seja, para alistar-se como eleitor, a pessoa comprovaria renda anual de 400 mil réis, atestada por terceiros.

À Lei Saraiva acresceu-se o "censo literário", os novos eleitores comprovariam ser alfabetizados (com isso inviabiliza-se o alistamento dos libertos). Por conseguinte, reduziu-se drasticamente o alistamento eleitoral. ${ }^{27}$ Conforme o levantamento da diretoria-geral de Estatística, em 1874, a "população eleitoral" totalizava 1.114.066 indivíduos, ou seja, $11 \%$ da população total e $13 \%$ da população livre, aprovada a

\footnotetext{
${ }^{26}$ Cf. Alencar (1997 [1868], p.83 et seq.).

${ }^{27}$ Cf. Carvalho $(2011,2012)$.
} 
Lei Saraiva, "população eleitoral" caia para 145.296. ${ }^{28}$ "E a situação não mudará apreciavelmente nos 40 anos que se seguirem à queda do regime" (Buarque de Holanda, 1948 [1936], p.84). Para aquela que seria a última participação do Brasil nas exposições universais do século XIX, a de Paris, alusiva ao centenário da Revolução Francesa e à inauguração da Torre Eiffel, o barão de Santa-Anna Nery, Frederico José de Santa-Anna Nery, autor do Le pays des amazones, rasgado elogio ao maravilhoso da região norte do país, organizara Le Brésil en 1889, volumoso relato dos progressos materiais e espirituais do Segundo Reinado. Recordativo, esse dublê de jornalista e aristocrata vazava o contraditório.

Eleitorado. O Império do Brasil está dividido em 125 distritos eleitorais, que elegem 125 representantes temporários (deputados eleitos para 4 anos), 60 representantes vitalícios (senadores) e 641 membros das assembleias provinciais (eleitos por dois anos).

Esses 125 distritos compreendem 20 províncias e 892 municípios, com 330 cidades, 562 burgos (vilas) e 1.886 paróquias.

Até a revisão de 1887, o número de eleitores no Brasil era de mais ou menos 220.000 , numa proporção de 1,5 para cada 100 habitantes da população total. Trata-se de um dos menores eleitorados que se conhece (Santa-Anna Nery, 1889, p.202).

Como é visto, o constitucionalismo exigia a representação legitimada pelo voto, conquanto no dia a dia se desconhecesse em extensão e profundidade o seu livre exercício. Numa palavra, a Lei Saraiva não amplia os direitos, mas os restringe. Sujeito adverso aos ditames da reforma eleitoral, o deputado José Bonifácio de Andrada e Silva, o moço, em discurso memorável proferido em 28 de maio de 1879 , discurso maiêutico que adentrará nos anais do parlamento brasileiro, tempesteava.

${ }^{28}$ Cf. Nicolau (2012). 
Saber ler e escrever é a questão pela questão. Como se define essa quantidade certa? Em quê a leitura e a escrita por si só afirmam os conhecimentos necessários para votar? Forçar a instrução se necessário, ou disseminá-la para que todos cheguem, compreende-se, mas esquecê-la, excluir em nome da Democracia a massa do povo, é de um liberalismo, que em honra dos nossos maiores, não conheceu a Constituição do Império (Andrada e Silva, 1879, p.435).

Malcontente, José Bonifácio exteriorizava sonoro anátema. "Neste país a pirâmide do poder assenta sobre o vértice, em vez de assentar sobre a base". 



\section{Duas figuras de reformadores}

Se aceitarmos os documentários compilados por Primitivo Moacyr $A$ instrução e o império: reformas do ensino e $A$ instrução e o império: subsidios para a história da educação no Brasil, poder-se-ia dizer que, no Segundo Reinado, não escassearam iniciativas dos estadistas da monarquia. Nas compilações, Moacyr arrola projetos, regimentos e regulamentos elaborados pela ronda de conselheiros de Estado, ministros do Império, presidentes de províncias, senadores, deputados gerais e provinciais, bem como de marqueses, barões, duques, condes e viscondes. ${ }^{29}$

Num tratado memorável, pleno de dados e comentários finos, A instrução pública no Brasil, Liberato Barroso, ex-ministro e secretário de Estado dos Negócios do Império, ao minutar o ensino primário, secundário, superior, profissional, militar, declinava números restritivos: matrícula escolar geral, 107.500 de alunos, numa população livre de 8.830.000.

29 "A multiplicação de projetos de reforma do ensino coincide com as duas últimas décadas do regime imperial e, através deles, podemos observar a intensificação das preocupações com o problema educativo em fase das transformações que vinha sofrendo a sociedade brasileira, bem como, a influência das ideias liberais em geral e suas consequências com respeito às ideias educativas" (Paiva, 1973, p.71). 
As Assembleias Provinciais não têm curado dos importantes interesses da instrução pública: o ensino oficial oferece ainda esse espetáculo de anomalia e desordem que assusta os espíritos mais intrépidos e porque nele contemplam o descalabro e a ruína moral do país. Tem sido contestada a necessidade da intervenção do Estado no ensino e instrução popular. A seita dos economistas, que seguem à risca o princípio do laissez faire, laissez passer, e os católicos retrógrados, que pretendem entregar o ensino à direção exclusiva da Igreja, a combatem (Liberato Barroso, 1867, p.59-64).

Se na base material do Segundo Reinado coexistiam a estrutura de latifúndio e a exploração do trabalho servil ou prevalecem os costumes patriarcais, ou ainda se a formação intelectual das elites fosse o alvo prioritário, é inegável que nalguma medida a instrução evoluíra nas dimensões teóricas e práticas. No período assiste-se a um conjunto significativo de planos de reforma da instrução na Corte e nas províncias, neles, quase toda força propositiva, quase todo ímpeto legislador, quase todo trabalho de imaginação dirigemse à instrução elementar. Enfim, sem forçar a nota em demasia, é lícito supor que os belos planos apregoados na sala de leilóes de ideias fustigassem a imaginação dos homens do reino. $\mathrm{Na}$ galeria, há uma série de planos, alguns com os usuais artifícios da retórica política, outros determinados a estatuir o grão de conhecimento a ser dado à prole do povo. Planos que, ao partilharem de um léxico comum, neles pressentem-se afinidades, levam à compreensão de que, para além do ler-escrever-contar, coexistia o afã de instituir a escola societária destinada revelar os méritos individuais pelo cultivo das faculdades naturais (é demasiado dizer que o elogio da instrução, como fato e valor, funcionasse como metáfora sublimadora da sociedade real?).

Nos belos planos, a consciência de antecipação do futuro anuncia a inevitabilidade da reforma da instrução. Os ares do tempo, falava-se, haviam trazido nas suas asas um estado social particular animado por 
outras atitudes e sentimentos. Nesses planos fiéis à causa social, há exalação de fluidos humanitaristas: a meta fazer da instrução popular propriedade comum.

Por exemplo, quer por desvelo aos interesses sociais quer pelos progressos das luzes, Tavares Bastos, em palavras inspiradas, incitava a extensão da instrução e sua obrigatoriedade com recurso a um imposto justificado como auxílio moral para anular a "ignorância e a rudeza do povo". Cauteloso, não quer ferir o princípio constitucional da gratuidade, a "taxa escolar" não incidiria no ato da matrícula, o meio seria outro, as províncias adicionariam um percentual aos impostos diretos. A arrecadação custearia salários, aposentadorias de professores e seus adjuntos, aluguéis de casas, onde inexistissem prédios escolares, assistência aos meninos indigentes, elaboração de compêndios "acomodados aos métodos", criação de bibliotecas populares, cursos noturnos para adultos e escolas normais. De olho nos sistemas escolares estadunidenses e seus teóricos, em particular, Horace Man predicava. "Não são escolas elementares do abc, como as atuais, que recomendamos às províncias. $\mathrm{O}$ sistema que imaginamos, é muito mais vasto."

É ensino primário completo como nos Estados Unidos, único suficiente para dar aos filhos do povo uma educação que todos permita abraçar qualquer profissão, e prepare para o altos estudos científicos aqueles que puderem frequentá-los. Dispam-se de prejuízos europeus os reformadores brasileiros: imitemos a América. A Escola moderna, a escola sem espírito de seita, a escola comum, a escola mista, a escola livre, é a obra original da democracia do Novo Mundo (Tavares Bastos, 1937 [1870], p.233).

Sintomático desejo, melhor ainda, aspiração falante, desde o decênio de 1870 reclamavam-se planos para a educação popular organizada em associação nacional. Pela exemplaridade, convém relembrar Instrução pública e educação nacional, de Joaquim Inácio 
Silveira da Mota; Educação nacional, de Afonso Herculano Lima; Questôes relativas à educação nacional, de Joaquim Teixeira de Macedo e O ensino primário e secundário em um "Plano Nacional de Ensino", de Antonio Cândido Leitão. Como é de se notar, o qualificativo "nacional" volta a colorir a retórica dos escritos de cultura política.

Nas cogitações, a notificação de reforma forra os títulos dos relatórios oficiais, projetos de leis e estudos tais como: Projeto de reforma da instrução na Babia, de Antonio Ferrão Muniz; O ensino público primário, de Manuel José Pereira Frazão; Reforma do ensino primário: parecer e projeto, de Januário da Cunha Barbosa; Estudo sobre o ensino público, de Aprígio Justiniano da Silva Guimarães; A instrução pública em Minas Gerais, de Alcides Catão da Rocha Medrado; Ideias sobre a instrução primária e secundária, de Afonso Celso de Assis Figueiredo; Colonização e ensino popular, de Guilherme Francisco Cruz; Ensino primário, de César Augusto Viana de Lima; O Brasil para a instrução primária, de Alberto Brandão.

$\mathrm{Na}$ cultura política, firmava-se o ideal de uma escola societária sustentada nacionalmente pelos poderes públicos. Sem incorrer no risco de efetuar ultraleitura ou sobressignificar fontes textuais, é licito supor que, na série de planos encaixilhados em ideias esclarecidas, destacam-se as figuras de Carlos Leôncio de Carvalho e Rui Barbosa.

De iniciativa de Leôncio de Carvalho, ministro de Estado dos Negócios do Império no gabinete liberal de 1878, o Decreto de $\mathrm{n}^{\circ}$ 7.247, de 19 de abril de 1879, do qual muito se disse e se continuará a dizer, reforma o ensino primário e secundário no município da Corte e o superior em todo o Império. Nas palavras de um contemporâneo, "liberal com assomos de republicano", Leôncio de Carvalho, bacharel em Direito pela academia de São Paulo, nela viria a ser professor catedrático, e deputado pela mesma província, na legislatura de 1881 . A decretação da reforma ocorre em meio às vagas liberais encabeçadas por dissidentes, clamava-se pela limitação dos poderes do Conselho de Estado, garantia de liberdade de consciência, ensino livre, livreconcorrência no comércio e indústria e autonomia provincial. 
Sancionado ad referendum do Poder Legislativo, o Decreto no 7.247 estipula o ensino livre. "Art. $1^{\text {o }}$ - É completamente livre o ensino primário e o secundário no município da Corte e o superior em todo o Império, salvo a inspeção necessária para garantir as condições de moralidade e higiene."

No nível superior, o ensino livre redundava na desobrigação de frequência ao mesmo tempo em que eximia a interferência do Estado, na criação de faculdades e recrutamento de professores. ${ }^{30}$ Dentre as disposições complementares, a obrigatoriedade da instrução elementar, organização escolar em $1^{\circ}$ e $2^{\circ}$ graus, dispensa dos acatólicos das aulas de religião, coeducação até a idade de dez anos, jardins de infância, contrato de professores ambulantes "à moda sueca" e ensino normal. Em conformidade com os ares do tempo, revogava-se a proibição da matrícula de escravos. Encaminhadas à Câmara como fato consumado, as medidas são bem aceitas pela imprensa liberal e setores estudantis. ${ }^{31}$

Nas escolas de $1^{\circ}$ e $2^{\circ}$ graus, no modo de "noções" e "princípios elementares" com recurso aos métodos intuitivos, ensinar-se-iam conteúdos de gramática, história, geografia, moral, organização política, aritmética, álgebra, geometria, sistema de pesos e medidas, física, química e história natural, noções e princípios completados com o ensino dos deveres do homem e cidadão, economia social e doméstica, lavoura e horticultura e prática de oficio para meninos. Como bem explica a historiografia acadêmica, a queda do Gabinete Sinimbu precipita a demissão de Carlos Leôncio de Carvalho, com isso inviabilizava-se a apreciação do decreto por parte da Comissão de Instrução Pública, de modo que vingam tão somente as medidas da alçada do Executivo consubstanciadas no Aviso de 21 de abril de

${ }^{30} \mathrm{Em}$ 1868, Felício dos Santos encaminha à Assembleia Geral projeto favorável à liberdade de ensino: "A partir de então, o movimento favorável à liberdade de ensino iniciado nas províncias e até então quase que exclusivamente baseado em considerações de natureza prática encontra decisivo apoio nas ideias liberais que se radicalizam e nos princípios positivistas que difundem celeremente, conquistando definitivamente os espíritos" (Haidar, 1972, p.72). ${ }^{31}$ Cf. Buarque de Holanda (1960). 
1879, a saber, faculdades livres, desobrigação de frequência, liberdade de exames, livre-docência, suspensão do juramento de catolicidade, vale dizer, o Estado e suas instituições se eximiam de julgar métodos e doutrinas, ademais inovava ao conceder "a liberdade e o direito de a mulher frequentar os cursos das faculdades e obter título acadêmico". ${ }^{32}$

Tais medidas guardariam vigência até a reforma conduzida por Benjamin Constant Botelho de Magalhães, no governo provisório republicano. Na década de 1890, o já citado barão de Loreto renderia tributos à monarquia. "A reforma esboçada nesse ato reúne em si traços notáveis de uma constituição liberal do ensino público, e está, em geral, na altura das maiores verdades e das mais inteligentes aspirações contemporâneas" (Dória, 1899, p.20). E não será de todo desnecessário retornar ao ajuizamento expresso na Notícia histórica dos serviços, instituições e estabelecimentos pertencentes a esta repartição, publicada por ordem do ministro Amaro Cavalcanti. "A reforma veio iniciar no país uma fase de progresso e preparo do terreno à adoção de ideias sobre o ensino principalmente nas escolas primárias, que deviam frutificar mais tarde" (Brasil, 1898a, p.64). Mas, antes disso, com veemência e erudição sensíveis, Leôncio de Carvalho voltaria à carga na "Seção filosófica" do relatório Primeira Exposição Pedagógica, conforme Sacramento Blake. "É um grosso volume em que o Dr. Leôncio, numa introdução de 259 páginas, trata dos fatos mais notáveis da exposição e mostra, com o estudo das legislações e dos pareceres aí exibidos, quais os princípios geralmente adotados na organização do ensino primário" (Sacramento Blake, 1883-1902, p.82-83). De fato, num longo exórdio liberal e liberalizante, o ex-ministro querelava ponto a ponto as restrições ao seu plano reformador, as quais, como se sabe, estão na origem dos sempiternos pareceres ruianos. E ainda que os belos planos e a profusão de ações inovassem, na Corte, centro da grande política, normas de bom-tom no vestir e falar e das vogas científico-literárias, numa palavra, lugar de condensação da vida civil ilustrada, nela habitava uma população de $50 \%$ de analfabetos.

${ }^{32}$ Cf. Briquet (1946, 1949). 


\section{Momento Rui}

Por último, convém deter-se nos pareceres da Comissão de Instrução Pública da Câmara dos Deputados, composta pelos deputados Rui Barbosa, relator, Tomás do Bomfim Espínola e Ulisses Machado Pereira Viana, encaminhados como substitutivos ao Decreto $\mathrm{n}^{\circ}$ 7.247. "É um trabalho do longo fôlego devido à pena do Dr. Rui somente", comentava Sacramento Blake. Entalhados com erudição científica e retórica política invejáveis, Reforma do ensino primário e várias instituiçôes complementares da Instrução Pública e Reforma do ensino secundário e superior são escritos sociais ímpares; em ambos, exterioriza-se a instrução como fundamento da vida viva (e da vara do poder). "Se quereis, pois, cimentar a ordem necessária das sociedades em classes estáveis, é na escola que as deveis lançar” (Barbosa, 1947 [1882], p.53). Fulgurantes, esses escritos denotam um estadista arrebatado pelas coisas do ensino. Pré-cognição do amanhã, os pareceres clareiam um porvir anticlerical e científico para a instrução popular (e a cultura nacional). Ostentosos, neles a imaginação do tribuno faísca ao prescrever modalidades de ensino concatenadas em nível elementar, médio e superior, facundos, endereçam reflexões consoantes às verdades das recém-surgidas ciências do homem.

O parecer sobre ensino primário e normal remói as implicações científicas, políticas e filosóficas, ao mesmo tempo em que remói os programas de matérias e processos de ensino em suas profundidades teóricas. Propugnador, sobre isso não há dúvidas, o parecer bate-se pela criação de um ministério de Instrução Pública, Museu Pedagógico Nacional, Fundo Escolar, com receita vinculada à arrecadação, recenseamento anual da população em idade escolar, e frequência obrigatória no Município Neutro. Palmo por palmo, o jurista descortina os cenários educacionais da França, Inglaterra, Alemanha e Estados Unidos. Propositivo, esmiúça um nunca-acabar de aspectos vitais: mobiliário escolar, efetivos das classes, horários, métodos, construções escolares, higiene da visão, educação moral, física e 
sanitária, metodologia da linguagem, aritmética, geografia, história, ciências físicas e naturais, desenho, música, metodologia do "Jardim de Crianças" e técnicas de aferição do rendimento escolar.

$\mathrm{Na}$ apreciação de diferentes sujeitos, de diferentes épocas, os pareceres transparecem um pensador liberal contrário à abstenção do Estado na esfera social. Acolhidos como repositórios de obstinada presciência do amanhã, nas décadas seguintes, as idealidades ruianas constituiram referências vivas para Benjamim Constant, Vicente Licínio Cardoso, Azevedo Sodré, Afrânio Peixoto, Lourenço Filho e tantos mais. Em síntese e sobremodo, igualmente a outros sujeitos cosmopolitas e cidadãos, o pensamento liberal-social de Rui Barbosa, um estadista da monarquia, manifesta uma doutrina de invertidos sinais: não é a defesa do indivíduo contra o poder despótico, tal como no entendimento iluminista, mas projeto civilizador num país inculto (e bárbaro), donde a tendência de pelo Alto reformar o Baixo e arrastá-lo para a civilização política consubstanciada em pacto social. "A nosso ver a chave misteriosa das desgraças, que nos afligem, é esta, e só esta: a ignorância popular, mãe da servilidade e da miséria. Eis a grande ameaça contra a existência constitucional e livre da nação; eis o formidável inimigo, o inimigo intestino, que se asila nas entranhas do país" (1947 [1882], p.47). E, porventura, não será de todo inoportuno retornar à severidade cortante de Vicente Licínio Cardoso (1927, p.1.075, grifo do autor).

Não esqueci Rui Barbosa. Apenas o seu procedimento me parece de todo inexplicável. Aquele relatório de 1882 é de fato monumental: modelar nas medidas sugeridas; admirável na oportunidade do diagnóstico; opulento no propósito dos alvitres propostos. Quem esquece o relatório foi o Rui republicano, o tribuno, o jornalista, o político, o colaborador robusto da Constituinte, o senador de três décadas republicanas, o candidato várias vezes à presidência da República. Foi ele próprio quem nunca mais falou naquele seu programa magistral, molde oracular em que podia ter sido vasto o idealismo orgânico da República. 
$\mathrm{Na}$ série de planos anunciados na sala de leilões de ideias sociais, belo objeto, a instrução popular não é apregoada como tema contingencialmente político, mas sim constitutivamente. 



\section{Ao sol da ciência}

\section{Fundar a educação nas ciências do homem}

Um dos aspectos chamativos da cultura intelectual do Segundo Reinado refere-se à importância atribuída às ciências do homem, no estudo do fato educativo. Isso numa época sobre-excitada pelas invenções mecânicas e domínio da natureza pela inteligência técnica. No campo intelectual, expande-se a orientação utilitarista e antimetafísica, sobrevalorada, a ciência do útil dá o tom nos debates sobre os rumos futuros do país. Frutíferas, as recentes verdades da antropologia física, fisiologia, biologia, psicologia estimulam o armamento da pedagogia prática com as teorias endossadas pela indução, observação e experimentação. O clima mental de renovação e de contrastes acentua as manifestações a favor da vinculação do ensino aos sistemas de pensamento científico; ou por outra, o tempo da ciência, até então dado por incógnito, fazia a sua aparição. "Não pode haver dúvida: podendo e devendo apoiar-se hoje em princípios científicos, a educação entrou também na sua fase positiva" (Veríssimo, 1901, p.67). No intento de dar uso inteligível à cultivação das novas gerações, efetiva-se o duplo sentido de educação quer como processo quer como resultado.

Direta ou indiretamente, os evolucionismos moldam as análises caldeadas nas sínteses dos progressos da educação na história da humanidade e, por ventura, do conhecimento. Acompanhemos José Afonso de Paula e Costa, professor primário na província de São Paulo, autor da Dissertação pedagógica: ligeiro estudo sobre 
a arte da leitura, manuscrito apresentado à comissão examinadora da Escola Normal de São Paulo, presidida por Antonio Carlos Ribeiro de Andrada Machado e Silva. Em acelerada rotação de palavras, o professor desembaralhava as mentalidades temporais, ao situá-las em ordem de sucessão, assertivo escandia à aventura do autodesenvolvimento humano.

A educação varia com o tempo, porque está subordinada ao conjunto de ideias que dominam uma época. Assim, ela tem o cunho do sistema filosófico predominante; e como cada época deteve sua doutrina especial, sua forma de religião, a educação em cada uma dessas épocas era feita sob modo diverso, mas consentâneo com as ideias gerais, políticas e religiosas de então.

$\mathrm{Na}$ época fetichista, que é comum a todos os povos, a educação dirigia-se a atividade; na politeica, representada pela Grécia, ocupavase da inteligência; na monoteica, especialmente sob a influência do catolicismo, cuidara do sentimento; e finalmente na época positivista, que é a época normal, a educação há de abranger três partes: será física, intelectual e moral.

A estes dois últimos períodos interpõe-se a transição revolucionária que hoje nos assola, e na qual a educação - como tudo o mais - é anárquico e dissolvente. São ainda os restos dos resultados negativos da Revolução Francesa, dessa grande crise, a qual devemos o aniquilamento do regime antigo - a teologia e a guerra - e o levantamento gradual do novo regime caracterizado pela Ciência e pelo Trabalho (Costa, 1884, p.2-3, grifo do autor).

Operador dos métodos de ensino dignos de ciência, isto é, em correspondência com os sistemas filosóficos do momento, José Afonso de Paula e Costa, ao dissertar sobre a questão "Qual método de leitura é verdadeiramente científico?", encadeava argumentos a favor da palavração, "estado definitivo" dos métodos de aquisição da leitura e escrita, como bem quisera João de Deus, em Cartilha maternal. 
Sínteses cientistas análogas, suportadas na concepção de etapas causalmente ordenadas, constam em Dissertação pedagógica que para obter diploma de professor normalista apresentou em janeiro de 1884, de Antonio Victor Macedo, e em Educação física: dissertação pedagógica apresentada à Escola Normal de S. Paulo em dezembro de 1883, de João Batista Freitas. Em meio à realidade trêfega, generaliza-se a demanda por uma instrução esteada na ossatura da ciência, de pronto imune à arbitrariedade, de pronto em sintonia com a marcha do espírito humano, porquanto a favor de uma pedagogia do interesse, do concreto, da observação, da atividade, da intuição, porquanto em harmonia com a fisiologia do organismo, logo habilitada a remover os obstáculos ao desenvolvimento natural das aptidões.

Nas primeiras linhas dessa trincheira inquieta a favor dos benefícios coletivos proporcionados pela instrução imbuída de ciência, abriga-se Abílio César Borges, didata de projeção, médico pela faculdade de Medicina do Rio de Janeiro, bem-sucedido proprietário de colégios na Bahia, em Minas Gerais e na Corte, mormente autor de libelos irrepreensíveis (e sempre relembrados) - Vinte anos de propaganda contra a palmatória e outros meios aviltantes no ensino da mocidade, opúsculo de distribuição gratuita, do qual extraímos esta sentença moral. "Não haverá meio de reger a alma humana senão fazendo padecer o corpo? A ciência é coisa que se introduza no espírito à força de pancadas? É o corpo ou a alma que aprende ou sente?" (Borges, 1876, p.6); ou como futurava, em Dissertação lida no Congresso Pedagógico Internacional de Buenos Aires em 2 de maio de 1882, escrito social a versar a influência benéfica dos internatos e os meios de excitar o gosto pela instrução.

E o que é que quer, senhores, o ensino moderno, intuitivo, razoável, positivo, natural e, portanto, agradável e convidativo, tão brilhantemente descrito e proclamado aqui, desta tribuna, por alguns dos ilustrados membros deste Congresso? 
Quer redimir a infância da materialidade e das torturas do velho ensino: quer aliviá-la dos vexames, do martírio do ensino rotineiro, além de indigesto e amargoso, imposto pela violência; quer fazer dos mestres prestantes obreiros do progresso da instrução dos povos, em vez de tristes mantenedores da rotina; - quer tornar a escola amada, agradável e feliz, tanto para quem ensina como para quem aprende; - quer que os meninos as busquem em vez de fugir delas; em suma, senhores:

- Quer esclarecer as inteligências,

- Quer formar os corações,

— Quer fundar o império da razão (Borges, 1884, p.22-23). ${ }^{33}$

Demandas essas intensificadas noutras conjunturas da vida do país quando retornam os debates sobre a instrução como nervo vital do corpo coletivo, a saber, nos primórdios da República, no nacionalismo do pós-guerra e na Era Getuliana, em tais conjunturas políticas multiplicam-se os planos de formação reta das novas gerações, com recurso a uma pedagogia do interesse, do concreto, da observação, da atividade e da intuição. De sorte que a sensibilidade cientista assim dispõe ao suavizar a dor das dores da aprendizagem, visto que a relação professor-aluno não deve ser intimidativa, mas colaborativa, seria possível desatar o nó saudável da emulação e do interesse pelo estudo. Para esse ponto de vista humanitarista, métodos e processos de ensino naturais são coextensão da essência biopsicológica da pessoa.

Tito Lívio de Castro, jovem médico, estudioso da psicologia, economia política, história, antropologia, psiquiatria, filosofia, poesia, literatura, leitor assíduo de teoristas arquicitados - Buckle, Darwin, Galton, Haeckel, Le Bon, Lombroso, Maudsley, Ribot, Spencer, Tarde, em $A$ mulher e a sociogenia, tratado médico-científico longamente prefaciado por Silvio Romero, ao concentrar-se na análise do paralelismo entre ontogênese e psicogênese, psicogênese e

${ }^{33}$ Sobre esse importante proprietário de estabelecimentos de instrução e teórico do ensino, ver Alves (1924) e "Notas sobre o finado Barão de Macaúbas” (1892). 
sociogênese e seus desdobramentos na pedagogia escolar, dardejava argumentos críticos.

$\mathrm{Na}$ escola a criança nada encontra de atraente, ela só deseja brincar e em vez de encaminhar-se a força excessiva do organismo para um estudo que não tenha a aparência de estudo (do atual, ao menos) procura-se reprimir o que é fisiológico, o que absolutamente indispensável para o desenvolvimento regular do indivíduo, procura-se pelo medo aniquilar-se-lhe a espontaneidade orgânica diante de um mestre que não lhe entende e que a obriga a trabalhos sistematicamente penosos, deprimentes nocivos (Castro, 1893, p.68).

Num Rui Barbosa tocado pelas hipóteses evolucionistas, os métodos de ensino científicos correspondem aos processos psicogênicos. "Haveis de educar o menino como a natureza educou o gênero humano" (1947 [1882], p.100). Denotadoras, nos enunciados esclarecidos habitam aspirações concernentes a um ensino ético-moral isento de férula, isso sob suposto de guiar brandamente pensamentos e condutas. Tudo levava a crer que, ao transitar da teoria à prática, a humanidade entrara no período viril, logo capaz de refletir racionalmente as coisas da vida e dos negócios públicos. Dotado de fascínio sutil, o anteriormente descrito, resulta na negação dos protocolos de ensino suportados na palavra do professor, na leitura mecânica, no recurso da memória -, protocolos condenáveis, pois contrários à autoeducação, isso por habituarem as novas gerações a ler, ver e sentir o mundo pelo olhar alheio e experiência de outrem, assim dizia-se.

Entrava em curso outra denegação, a da psicologia das faculdades da alma, grupo inato de potências residentes no sujeito empírico, ou seja, inteligência, volição e sensibilidade, operações elevadas do espírito, dadas como produtoras da atividade mental; donde a recusa da pedagogia consuetudinária, dita rígida, mnemônica, dogmática, disciplinar, donde ainda o estudo da natureza infantil como objeto 
(científico) legítimo. Efloresce o desejo de regular os passos do ensino conforme o desenvolvimento psicofisiológico e o crescimento físico da criança; como rota didática, apregoa-se a percepção das imagens das coisas existentes e seus nomes, isto é, os signos. Ora bem, posto o problema desse modo, é facultado dizer que triunfava o associacionismo empirista para o qual as experiências sensoriais condicionam o conhecimento e o pensamento.

Uma das primeiras expressões desse estado de espírito é Antonio de Almeida Oliveira, deputado paraense pelo Partido Liberal, homem público empático ao gênio das técnicas pedagógicas norte-americanas, nação por ele conhecida de viso em excursão por aquele país-continente. Num livro sobrecarregado de análises e dedicado ao nascente republicanismo, $O$ ensino público, Almeida Oliveira recomendava o uso das "lições das coisas", método por ele observado nos Estados Unidos da América, sob a denominação de object lessons, lesson on objects, teaching objects. "As lições das coisas as acostumarão a ver bem, a observar, a distinguir, a julgar, a comparar e a raciocinar. As lições das coisas ainda não constituem a ciência, mas preparam maravilhosamente o espírito para um ensino científico" (Oliveira, 1874, p.139).

No plano global, Europa e Estados Unidos, ao lado da organização dos sistemas nacionais de educação, ensaiava-se o nascimento de uma pedagogia científica e experimental, domínio de conhecimento cumulativo mediatizado pelos domínios disciplinares da antropologia física, biologia, fisiologia, história, psicologia, sociologia e estatística. Pedagogista, no entendimento esclarecido, é o conhecedor da natureza da puerícia, da gênese e formação de ideias, das fases ontológicas da pessoa e claro das etapas de crescimento físico. No cerne dessa pedagogia à procura de status científico, aloja-se a ideia de "maturação do organismo", noção conceitual chave na regulagem da processuação dos métodos de ensino objetivos.

Em Education as science, 1872, obra traduzida para o francês e português por iniciativa de Gabriel Compayrè e Adolfo Portela, 
Alexander Bain desposava ideias. E, com efeito para ele, a "educação dos sentidos" exercitava a faculdade superior de discriminação das sensações e, ao discernir cores, cheiros, gostos, tatos, lograr-seia melhor memória para vistas, sons e sabores, melhor distinção e retenção das formas aparentes, propriedades e grandezas das coisas. Diferentemente da instrução sob a severidade externa do professor, a associação de emoções, sensações, volições constituiriam a "matéria" da vida mental,ou por outra, a educação dos sentidos implica autoeducação (self-government).

A denegação do escolasticismo encorpa-se com a tradução e adaptação de Rui Barbosa "para os países de língua portuguesa", do manual para professores Primary object lessons for training the senses and developing the faculties of children, de Norman Allison Calkins, sob o título Primeiras liçóes de coisas. "Obra unanimemente aprovada pelo Conselho Superior da Instrução Pública da Bahia, pelo Conselho Diretor da Corte, e adotada pelo governo imperial", a época de Carlos Leôncio de Carvalho à frente da pasta ministerial. Para o tradutoradaptador, o método intuitivo não se reduz às "lições de coisas", ao contrário, é o cerne de uma presumível didática geral. Rui despertara para esse "manual de ensino intuitivo aplicável a todas as matérias", ao ler Rapport sur l'instruction primaire à l'Exposition Universelle de Philadelphie, de Ferdinand Buisson, secretário da comissão de estatística do ensino primário da França. ${ }^{34}$ Nessa exposição alusiva ao centenário de Independência dos Estados Unidos da América, em que D. Pedro II se fizera presente, ${ }^{35}$ o ensino intuitivo fora posto em evidência por corresponder às faculdades perceptivas da pessoa.

Primeiras liçôes de coisas ou "método de Calkins" como popularizado, prescreve o ensino pela observação e atividades refletidas. "O ensino pelo aspecto, pela realidade, pela intuição sensível, pelo exercício reflexivo dos sentidos, pelo cultivo complexo das faculdades de observações está destinado a suceder triunfantemente aos processos

\footnotetext{
${ }^{34}$ Cf. Lourenço Filho (2001 [1954]).

${ }^{35}$ Cf. Pesavento (1994).
} 
verbalistas, ao absurdo formalismo da escola antiga" (Barbosa, 1886, p.5). Dessa forma, para o ensino intuitivo em classes de instrução primária, circulavam coleções para "lições de objetos" e "noções de coisas": "O museu Escolar - Caixa Saffray para lições de coisas", reunião metódica de coleções de objetos comuns; Lições de coisas, de Manoel José da Silva Guanabara; Liçôes de coisas: sentido, formas, cores (método de Calkins), de Luiz Carlos Duque-Estrada; Noções de coisas, de Uchoa Cavalcanti e Lições de coisas pelo Dr. Saffray.

Este livro tem por fim servir-vos de um companheiro, de um amigo. Abri-o nas horas de ócio, levai-o para os passeios, lede-o enfim quando puderdes que não vós enfastiareis, por isso que ele vos ensinará constantemente coisas que vos são mais ou menos familiares; não o desprezareis, porque haveis de compreender que ele vos é útil, e aumenta os vossos conhecimentos, ensinando-vos a apreciar e a julgar aquilo que vos cerca (Saffray, 1881, p.6).

Em pauta, a aprendizagem pela observação sensível e visível, melhor, pelo sensorialmente perceptível, antiga e irretorquível recomendação esteada nas autoridades de Locke, Condillac, Rousseau e Spencer, e nas práticas conceituais de Pestalozzi e Fröebel. Entre brasileiros, temperava-se tal entendimento com as reflexões de Vitor Cousin, conselhos práticos de Hippeau, filantropismo de Basedow e, não menos importante, a legislação instituinte da escola primária francesa. É de então a urgência de um ensino atualizado conforme a civilização do momento de modo a incutir naquele que ensina o despertar da vontade por meio de recursos ativos, desenvolver as faculdades intelectuais e sobremodo formar bons corações, como bem quer Antonio Jansen de Mattos Pereira, presidente da província do Maranhão.

Porque há de ficar limitado o conhecimento dos que frequentam as escolas - da província - a esse ler, escrever e contar, a essa gramática e catecismo, que se antigamente foram o máximo da instrução, hoje não 
se podem ser, porque as aspirações do espírito moderno são outras? Porque não dar nas escolas - por meio de um estudo conveniente noções de fisica, química e história natural, pelo menos com explicação de suas principais aplicações à indústria e aos usos da vida?

Porque negar aos meninos noções gerais dos deveres do homem e do cidadão? Porque não falar-lhes na higiene? Porque não dar a eles um conhecimento - ainda sucinto - da nossa organização política? Porque não instruí-los desde logo no que toca a economia social, a lavoura e horticultura? Porque desprezar a música e o canto, de que bons resultados se tem colhido, e essas liçôes de coisas de que tanto falam os educadores, por isso que estendem-se a tudo o que serve à vida e a todas as ações da natureza? (Mattos Pereira apud Fernandes, 1929, p.240-241, grifo do autor).

Se, porventura, os fatos até aqui descritos e narrados não representam o princípio e o fim das continuidades e descontinuidades da instrução pública, ainda que as cifras e os diagnósticos desconsolem, ainda que os belos planos permaneçam imaterializados, ainda que a instrução nacional seja simples alínea a encabeçar as Falas do Trono ou ainda que inexistam ações emanadas de um centro nacional, sem sombra de dúvidas, há uma pedagogia escolar em movimento.

\section{Mediadores da relação mestre-aluno, os compêndios}

Ao passar a limpo o panorama do final do Império, José Ricardo Pires de Almeida constatava a existência de certos grupos de publicações: obras gerais de educação para "institutores, institutoras e professores", obras dirigidas aos "alunos, meninos e meninas", "obras administrativas" - leis e regulamentos da instrução pública.

Os livros do primeiro grupo são pouco numerosos, o que é uma prova deplorável da indiferença em que a ciência da educação se encontra entre nós; e infelizmente, pecam pela qualidade, mais 
ainda pelo número. Há alguns que, por, por títulos diversos, fazem uma honrosa exceção e desfrutam de reconhecido mérito junto aos professores" (Pires de Almeida, 1989 [1889], p.158).

$\mathrm{Na}$ sua explicação, os métodos de leitura dividiam-se em ortográficos, composição da palavra e sílaba "em todos os seus elementos, consoantes e vogais", métodos novos, "admitindo apenas dois elementos, os sons e as articulações”, métodos “que se apoiam ou pretendem apoiarse nestes dois sistemas", "métodos ditos fonomímicos ou datilógicos"-os sons e articulações de sons correspondem aos sinais da mão ou gestos do corpo, apreensíveis pelos olhos, destinando-se aos surdos-mudos; "para ensinar pelos olhos", os "aparelhos escolares": letras móveis, silabários, contadores mecânicos, aritmômetros, material de Fröebel, mostradores de ponteiros de relógio, quadro de pesos e medidas, cores do espectro solar, ofícios e profissões, história natural, "retratos de grandes homens do Brasil". Quer dizer requeriam-se outras vias, em vez da "verbiagem", o "realismo", em vez das abstrações, a intuição e os sentidos, em vez do salmodiar, a imaginação imaginativa. Aduzidas de uma pedagogia que se quer científica, nessas preocupações subjazem as dimensões do homem social, donde a recusa da figura do prático em pedagogia, o mestre-escola régio, pois os saberes a respeito da infância encareciam novas atitudes, donde o descrédito do anexim legitimado pelo costume: "Só se sabe bem o que se aprende dificilmente".

Se, no plano geral, retomam-se as discussões da urgência de uma educação nacional, no plano particular da pedagogia escolar, incrementam-se as edições de compêndios a ostentarem, cada qual com as suas palavras e modos, a vinculação entre ciência da educação e arte de ensinar. E, mais do que antes, o compêndio é chamado a interceder nas relações mestre-discípulo, e mais do que antes, o bom compêndio é o legitimado pela experiênciação do autor na condição de professor. ${ }^{36} \mathrm{E}$,

36 "A partir do século XIX, com a constituição dos estados nacionais e com o
desenvolvimento, nesse contexto, dos principais sistemas educativos, o livro
didático se afirmou como um dos vetores essenciais da língua, da cultura e 
por paradoxo, a pedagogia do concreto, do interesse, da observação, da intutição e da atividade não prescinde de compêndios, muito embora se sabe hoje mais arejados e refinados com ilustrações, cores e tipos gráficos variados. Breve reportação de títulos e autores transparece o empenho na elaboração de "obras acomodadas à inteligência dos meninos”, em maioria, formuladas em linguagem a gabar os méritos do raciocínio, observação e experimentação, sobremodo aplicáveis aos "usos da vida". Associadamente à fixação e à elevação do status dos autores didáticos, em maior parte, vinculados ao magistério, instalamse instâncias de controle da adoção, aquisição e distribuição de livros de leitura, cartilhas e cadernos de caligrafia.

Por precaução, convém dizer que, ao lado dos avanços, há escolhos dos mais graves. No parecer "Métodos e programas de ensino nas escolas primárias, adoção de compêndios”, encaminhado à Primeira Exposição Pedagógica, Manoel Olímpio Rodrigues da Costa pronunciava palavras duras. "A história do ensino, em nosso país, mostra-nos que compêndios imprestáveis e inúteis à instrução primária, só pela importância social de seus proprietários, são aprovados e vendidos a altos preços, e distribuídos pelas escolas, muitas vezes para pasto de traças”(Costa,1884, p.4). Noutro parecer, José Manoel Garcia problematizava mais ainda. "O Estado tem incontestável obrigação de prevenir que, nas escolas primárias tanto públicas como particulares, sobre as quais a lei the confere o direito de inspeção, se leia por livros subversivos dos bons princípios da sociedade, da moral, da religião fundamental."

Cumpre-lhe ainda, em relação nos destinados ao ensino, que não contenham doutrinas ofensivas daqueles princípios, evitar a adoção dos que, por sua incorreção e viciosa locução, só servem para barbarizar o idioma nacional em vez de concorrerem para criar gosto e fazer

dos valores das classes dirigentes. Instrumento privilegiado de construção de identidade, geralmente ele é reconhecido, assim como a moeda e a bandeira, como um símbolo da soberania nacional e, nesse sentido, assume um importante papel político" (Choppin, 2004, p.553). 
conhecidos os primores e opulência da língua vernácula. Devem esses livros ser: $1^{\circ}$, metódicos e apropriados aos programas de ensino, já na linguagem, já na extensão e na intensidade das matérias; $2^{\circ}$, bem impressos e devidamente corretos; $2^{\circ}$, de preço módico, a fim de que se facilite a todas as posses a sua aquisição (Garcia, 1884b, p.6).

Seja do modo que for, somados aos títulos e autores citados em capítulo anterior, o rol declinado a seguir não deve ser negligenciado como quinquilharia passadista. Em atenção ao ato de ler articuladamente as polêmicas quanto à aquisição da leitura pelo método da soletração ou sibilação ou da palavração, circulavam: Bacadafá, ou método de leitura abreviada, de Antonio Pinheiro Aguiar (Rio de Janeiro, 1870); Método de leitura oferecido à infância e ao povo, de Otaviano Hudson (São Paulo, 1875); Silabário ou primeiro livro de leitura, de Manuel Ribeiro de Almeida (Rio de Janeiro, 1875), título premiado pelo governo imperial; Silabário português ou novo método para aprender a ler em breve tempo a lingua portuguesa e o sistema métrico ilustrado com numerosas estampas, "traduzido e composto" por J. R. Galvão, “à venda no Rio de Janeiro, Bahia, Pernambuco e S. Paulo" (1879); Método racional e rápido para aprender a ler sem soletrar, dedicado à infância e ao povo brasileiro, de João Köpke (São Paulo, 1879); Cartilha da infância, de Tomás Paulo do Bom Sucesso Galhardo (São Paulo, 1880); Cartas de nomes para se ensinar em pouco tempo a ler e a escrever, figurado a pronúncia do Brasil, dedicada aos mestres e pais brasileiros, de José Jorge Paranhos da Silva (Rio de Janeiro, 1880); Abecedário Mascarenhas ou método repentino de aprender a ler, organizado e dedicado à infância brasileira, de Francisco de Paula Mascarenhas (Rio de Janeiro, 1881); Lições no lar $\left(1^{\circ}\right.$ livro - Silabário, $2^{\circ}$ livro - Contos e diálogos, $3^{\circ}$ livro - Conhecimentos úteis e $4^{\circ}$ livro - Estudos de homens e coisas), de Hilário Ribeiro (Pelotas, 1881, 28ed. 1893), "adotado no Rio Grande do Sul, Santa Catarina e Paraná”; Escola primária. Lições à infância baseadas nos princípios fisiológicos da linguagem articulada para aprender a ler sem soletrar, de Manuel Paulino de Assunção (Rio de Janeiro, 1882); Silabário nacional ou novo método de aprender a ler, imitado e composto, de Antonio de Araújo Ferreira Jacobina 
(Rio de Janeiro, 1883); e Cartilha maternal ou arte da leitura, de João de Deus (Lisboa, 1881).

É ao Dr. Zeferino Candido, diretor do Colégio São Pedro de Alcântara, que deve a introdução e real aplicação do método de leitura chamado Método de João de Deus ou Método intuitivo e apreensivel intelectual. Cartilha maternal, principal livro de João de Deus, é uma das maiores obras de ensino moderno. Este livro abriu uma nova via aos institutores, levou-os a ensinar pela inteligência mais que pela memória, reduzida ao papel de colaboradora e instrumento de conservação dos conhecimentos. Se, a Cartilha Maternal não está ainda espalhada por todo o país, pode-se, entretanto, considerar como generalizada, apesar das diversas modificações introduzidas na forma em que se apresenta hoje (Pires de Almeida, 1989 [1889], p.170-171). ${ }^{37}$

Nesse rol adventício, a novidade consiste nas "cartilhas nacionais", por exemplo, Cartilha nacional ou novo primeiro livro de leitura, de Hilário Ribeiro (Rio de Janeiro, 9ed. 1887), título premiado na Exposição de Objetos Escolares e Medalha de Prata na Exposição de Paris de 1889. Destinada ao "ensino simultâneo de leitura e escrita", ornamentada com belas gravuras, na abertura da cartilha consta breve nota metodológica.

A Cartilha Nacional tem por fim ensinar simultaneamente a ler e a escrever. Como a arte da leitura é a análise da fala, levemos desde logo o aluno a conhecer os valores fônicos das letras, porque é com o valor que há de ler e não com o nome delas.

Uma vez que o aluno conheça perfeitamente o elemento fônico correspondente a cada vogal, começará o professor a ensinar-lhe a

${ }^{37}$ Quanto às campanhas do sectário do positivismo de Comte, Zeferino Candido, visando ao uso da Cartilha maternal, ver Monarcha (1999); quanto à experiência de aculturação da cartilha, ver Trindade (2004). 
escrever com giz, no quadro preto, primeiro o i, que é a vogal mais elementar, e sucessivamente o u, e, o, e o a (Ribeiro, 1887, p.5, grifo do autor).

Bem-sucedido autor didático, Hilário Ribeiro publica também a série graduada de leitura Cenário infantil, Na terra, no mar e no espaço, e Pátria e dever. Elementos de educação física e moral (Rio de Janeiro, 1884, 1885, 1887).

Pois bem, para o ensino de português, circulam "seletas" e "florilégios": Florilégio brasileiro da infância "destinado ao exercício de leitura de verso e de manuscritos nas escolas públicas primárias", de João Rodrigues da Fonseca Jordão, "Obra adotada pelo Conselho Superior da Instrução Pública, com aprovação do Governo Imperial, para uso das escolas públicas do ensino primário e do Imperial Colégio de Pedro II, e composto com diferentes tipos de letras impressas e manuscritas" (Rio de Janeiro, 1874).

Para a aritmética: Tabuada segundo o método Pestalozzi, de José Ramos Paz e Guia pedagógico de cálculo mental e uso do contador mecânico ou aritmômetro no ensino elementar da aritmética, de Brazilicus [pseudônimo] (Rio de Janeiro, 1882), premiado pelo júri da Exposição Pedagógica.

Num contexto histórico de relativização do ensino de história sagrada e valoração da história nacional, observando que alguns autores são publicistas republicanos, outros monarquistas, apareciam Lições de história pátria, do prócer republicano Américo Braziliense (Campinas, 1876); História do Brasil contada aos meninos, de Estácio de Sá e Menezes (Rio de Janeiro, 1880); Pequena história do Brasil por perguntas e respostas, de Joaquim Maria de Lacerda e Resumo da história do Brasil para uso das escolas primárias, de Maria Guilhermina Loureiro de Andrade (Boston, 1888).

Para o ensino da geografia do Brasil e das províncias: Noções de geografia e de história do Brasil para uso das escolas de instrução primária da provincia do Pará, de Joaquim Pedro Corrêa de Freitas (Pará, 1879); Compêndio de corografia do Brasil para uso das escolas de instrução primária, de Brito Aranha (Lisboa, 1872); Noções de geografia do Brasil para uso da 
mocidade brasileira, de Manuel José Pereira Frazão (Rio de Janeiro, 1883) e Geografia da Provincia do Rio Grande do Sul, de Hilário Ribeiro, "adaptado às classes elementares, adornado de oito mapas coloridos e acompanhado de noções sobre a América do Sul e a do Norte" (Pelotas, 1881). Em nota introdutória, o didata deblaterava. "Uma reforma tem custado muito, e vai lentamente: é a da escola primária, por isso que ameaça a tranquila imbecilidade dos espíritos chatos e rotineiros que fogem à discussão e à verdade e temem a luz da civilização e da história”.

Os gregos e os atenienses esmeravam-se na educação intelectual e física das crianças; para eles o movimento do espírito não era menos útil e necessário que o movimento dos músculos. Diferentemente procedemos. Nem vida do pensamento, nem a atividade física!

A memória imobilizando as faculdades ativas, atrofiando a palavra e o raciocínio; e, onde a memória, que faz parte do entendimento, não se utiliza em proveito da inteligência e de si mesma, pode ser exaltada muito embora pelo pai imprevidente e pelo mestre ignorante, mas em verdade sua ação não produz senão imbecis e idiotas (Ribeiro, 1881, p.3).

Dentre os códigos de decoro, manuais de civilidade, melhor é dizer, controle da imediatez dos instintos e formação de suditos-cidadãos responsáveis e de boa índole, Deveres do homem, de Eusébio Vanerio; e Ensino de moral e religião nas escolas primárias, secundárias e normais, de Rodolfo Epifânio de Souza Dantas (Rio de Janeiro, 1884). Para o ensino de diversas matérias, em moldes de crestomatias: Novo método de ensino a ler e escrever, acrescentado da Civilidade de Chantal, de um resumo da doutrina cristã, extraído do catecismo histórico de Fleury e das primeiras noções de cálculo, de Augusto Freire da Silva (Paris, 1875); Lições de coisas inanimadas e animadas, de Emílio Zaluar (Rio de Janeiro, 1875); Compêndio de doutrina cristã, "coligido, aumentado e publicado", por José Dias da Cruz Lima (Rio de Janeiro, 1875) e o bem-acolhido Noções de direito para as escolas primárias, de Antonio Francisco Bandeira Júnior (Rio de Janeiro, 1885), elogiado por Machado de Assis e Quintino Bocaiúva. Tirantes esses 
títulos e autores, há os tratados de exercícios ginásticos: Da educação física, intelectual e moral da mocidade no Rio de Janeiro, de A. F. M. Andrade (Rio de Janeiro, 1874) e Tratado elementar da ginástica escolar, de Pedro Manoel Borges (Rio de Janeiro, 1888).

Uma última observação, quanto ao conhecimento do corpo da pátria, o Instituto Filomático, sediado no Rio de Janeiro, publicava o Atlas do Império do Brasil, em 1868, do político, jurista e geógrafo maranhense Candido Mendes de Almeida, ex-professor de Geografia e de História do Liceu de São Luis na Província do Maranhão. Uma das primeiras representações cartográficas mais fiéis, o atlas reproduzia as divisões administrativas, eclesiásticas, eleitorais e judiciárias, e fora elaborado mediante consultas a mapas, documentos antigos, relatos de viagens, expedições e alvarás régios. ${ }^{38}$ Com efeito, no Atlas do Império do Brasil constavam as novas divisões administrativas, as províncias do Amazonas e Paraná, desmembradas do Pará e São Paulo, em 1853 e 1854.

$\mathrm{E}$ a disposição territorial das províncias setentrionais: Amazonas, Grão-Pará, Maranhão, Piauí, províncias orientais, Ceará, Rio Grande do Norte, Paraiba do Norte, Pernambuco, Alagoas, Sergipe, Bahia, EspíritoSanto; das províncias meridionais: Município Neutro, Rio de Janeiro, São Paulo, Paraná, Santa Catarina, São Pedro e das províncias ocidentais: Minas Gerais, Goiás, Mato Grosso. Ademais, Mendes de Almeida propõe a elevação da parte setentrional do Grão-Pará à categoria de província autônoma, sob a denominação de Pinsonia (hoje, Rondônia). Em síntese, a edição do atlas ofertava a percepção inteiriça do Império do Brasil.

Contudo, certas fronteiras externas e internas bem como certos aspectos naturais permaneciam indeterminados, de fato, em $O$ ensino público, o paraense Antonio de Almeida Oliveira (1873,p.15) lamentava - “Seus rios ainda ninguém pode contar e descrever". Que conclusões podem ser extraídas dos argumentos antes expostos? Tema fecundo, na edição de obras didáticas incidem demandas de ordem educacional e pedagógica, fatores econômicos e tecnológicos, injunções de ordem política e científicas.

${ }^{38}$ Cf. Guerra e Santos (2011). 


\section{De mestre-escola a professor primário}

Seria possível contrabalançar certos quadros aflitivos e cenas desencantadas no tocante a figura do mestre de escola e sua desconfortável rotina? Melhor, referir-se ao declinar da palmatória que, por antonomásia, se apelidava de "Santa Luzia", por ter "olhos ou buracos no centro", donde o mote - "Santa Luzia de cinco buracos, que tira a mandinga de todos velhacos". Como colocar em estado de suspensão as narrativas que esbatem a fisionomia patibular do mestre de escola quer em relatos de viagens e explorações quer em recordações tardias de ex-alunos e ex-professores quer ainda na literatura de ficção?

Nessas narrativas, a catadura do mestre punitivo retorna como imagem da infelicidade da puerícia. Em registro desafortunado, narra o anônimo autor de História da pedagogia compilado por um professor. "Submetidos ao regime dos castigos corporais, aos péssimos métodos instrutivos e educativos preconizados pelos jesuítas, os meninos tinham horror à escola, que consideravam um instrumento de insuportável martírio. Ainda mesmo em nossos dias há muita gente que se recorda com aperto de coração das tão célebres escolas régias, que ainda proliferam nalguns Estados Brasileiros" (História..., 1914, p.251, grifo do autor). Por sua vez, em inspirado impulso autobiográfico, Candido Mota, em São Paulo e a República, retraz os idos desolados da infância escolar.

Como essa eram as demais escolas primárias, nas próprias residências dos professores, que ficavam assim à vontade. Quase 
de chinelos, sem meias, cabelos em desalinho, acolitados por uma inclemente "Santa Luzia" de forte cabriúva, nome esse dado à palmatória de cinco furos, e que era o terror da meninada. De longe ouvia-se o eco do vozerio dos alunos obrigados a cantar, em tom invariável, a tabuada; e, às sextas-feiras o "sois cristãos"; meio esse mais prático encontrado para manter a ordem, sem o emprego da tal santa, dos puxões de orelhas ou cocorotes que deixavam sinal no couro cabeludo (Mota, 1935, p.49, grifo do autor).

Esses recorridos desconsoladores, esses ajuizamentos do desamparo da puerícia, e deles há um rol sem fim, não esgotam a interpretação, nalguma medida, é preciso colocar em causa as visões demasiadamente hegemônicas a respeito do estado de coisas no Segundo Reinado. Se a instrução elementar atravessa o antigo regime descridamente pelos vaivéns de ministros de Estado e presidentes de províncias, exiguidade de recursos, desencontros entre Executivo e Legislativo, extensão territorial e dispersão demográfica, por certo não significa concluir que tal situação pesarosa encerre toda interpretação do passado.

\section{Da formação de professores}

De raro em raro, os marcos escolares provinciais ganhariam alguma diversidade, por exemplo, com a criação de escolas normais. Premidas por injunções e eventualidades, abrindo e fechando a qualquer momento, com professores recrutados entre bacharéis, engenheiros, médicos, esses estabelecimentos conhecem existência conturbada. Contudo, o Brasil situa-se entre os primeiros países da América a instalar escolas normais mantidas pelos poderes públicos, pátria-mãe das escolas normais, a França instala estabelecimentos de preparação profissional para o magistério apenas na Revolução de Julho de $1830 .{ }^{39}$

${ }^{39}$ Cf. Bowen (1986). 
No Brasil, conforme cronologia estabelecida, ainda que porventura haja discrepâncias, a sequência espiralada e cambaleante de manifestações da tomada de consciência quanto à preparação profissional de mestres é esta: Niterói e Minas Gerais -1835, Bahia - 1836, Pará - 1839, São Paulo - 1846, Pernambuco - 1864, Piauí - 1864, Paraíba - 1864, Rio Grande do Sul - 1869, Pará, Paraná e Sergipe - 1870; e mais adiante, Amazonas - 1872, Espírito Santo e Rio Grande do Norte - 1873, Maranhão e Mato Grosso - 1874, Santa Catarina e Município da Corte - 1880, Goiás - 1881, Ceará - $1884 .{ }^{40}$

Como regra medianamente geral, o aspirante à matrícula deveria comprovar ser maior de 17 ou 18 anos, homem, e 14 ou 15, "sendo senhora"; ambos instruiriam a petição com certidão de batismo, atestado de moralidade autenticado por párocos ou autoridade policial, atestado médico comprovando estar livre de moléstias ou defeito físico incompatível com o magistério, certidão de vacinação e revacinação, licença do pai ou marido, se menor de idade ou mulher casada. Os conteúdos de ensino abarcavam agrimensura, aritmética, caligrafia, desenho linear, gramática, história e geografia pátria, história e doutrina sagrada, música, sistema métrico. Quanto às matérias profissionalizantes, estudava-se didática, metodologia e pedagogia, com exercícios de aplicação em escolas anexas ou outras quaisquer.

A bem dizer, o programa da matéria Moral, Doutrina Cristã e Pedagogia, organizado pela diretoria da Sociedade Onze de Agosto, da província do Maranhão, em conformidade com o artigo $4^{\circ}$ da Lei no 1.089 , de 17 de julho de 1874, assinado pelo vice-presidente José Francisco de Viveiros, exemplifica o ideal-tipo de mestre a ser regrado em conformidade com a Religião de Estado.

1. Fundamento da moral. A consciência, distinções, fundamentos entre o bem e o mal, apreciação dos sistemas que tentam explicar o fundamento da moral; a lei moral, lei eterna, natural e positiva e lei humana. Diversos motivos de nossas ações. Sanção moral. Destino do

\footnotetext{
${ }^{40}$ Sobre o tema a produção memorialística e acadêmica é extensa e profícua, entre outros, ver Araújo, Freitas e Lopes (2008) e Neves (2002).
} 
homem. Imortalidade da alma. Moral religiosa ou deveres do homem para com Deus. Culto interno, externo, público. Moral individual. Deveres para com a alma, inteligência, vontade e sensibilidade. Deveres para com o homem em geral, com a família e o Estado. Doutrina cristã. Preliminares. Símbolo dos apóstolos. Deus-Trindade. Anjos-Homem e sua queda. Mistério da encarnação-Jesus Cristo-Redenção. Espírito Santo-Igreja. Virtudes teologais. Decálogo. Religião. Mandamentos da Igreja. Meios que Deus estabeleceu para a santificação do homem - Graça - Orações, Sacramentos.

2. O que é pedagogia, sua divisão em suas partes. Didática e metodologia. O professor, sua missão, seus deveres, suas qualidades naturais quanto ao físico e à alma, suas qualidades morais: bondade, firmeza, regularidade, zelo, pureza de costumes, boa educação, civilidade, modéstia, piedade, prudência, recolhimento, pudor, caridade, justiça, desinteresse, amor pelo estudo.

Quanto à ordenação jurídico-política do Império, na Escola Normal da Corte, ensinava-se os seguintes conteúdos de educação cívica: a nação, a divisão, a forma de governo, a dinastia e a religião.

Os cidadãos brasileiros. Poderes e representação nacional. Poder Legislativo e suas atribuições. Eleições. Poder Moderador. Poder Executivo. Família Imperial. Conselho de Estado. Força Militar. Poder Judicial. Administração e economia das províncias. Municípios. Direitos civis e políticos dos cidadãos brasileiros. ${ }^{41}$

Novamente é preciso não sobre-estimar o andamento dos acontecimentos: ao lado dos professores provindos das escolas normais, por sinal, sempre em número insuficiente, há os mestres recrutados em exames encabeçados por comissões de notáveis, e considerados dignos de estima, como recomendava a Lei no 1.089 , de 17 de julho de 1874, sancionada pelo presidente do Maranhão, João Antonio Coqueiro. "Se alguns dos atuais professores públicos catedráticos do município da capital, de um e de outro sexo, quiser frequentar as aulas do Curso Normal, terá assento em lugar especial ao lado da mesa do professor."

${ }^{41}$ Cf. Pereira Júnior (1889). 


\section{Pedagogia compendiada}

A fim de transcender o restrito círculo das rotinas empíricas, surte efeito uma demanda de manuais de pedagogia a versar a teoria e a prática de princípios, métodos e processos de ensino, elaborados por autores nacionais e estrangeiros: $O$ ensino Praxedes, compêndio de didática para ensino das matérias, de Praxedes Pacheco (Rio de Janeiro, 1861); Curso prático de pedagogia destinado aos alunos-mestres das escolas normais primárias e aos instituidores em exercício, de Daligault, em tradução de Joaquim Pires Machado Portella (Recife, 1865); Compendio de pedagogia, de Carlos Augusto Soares, (Rio de Janeiro, 1878); Compêndio de pedagogia para uso dos alunos da escola normal do Rio de Janeiro, de Antonio Marciano da Silva Pontes (Niterói, 1881); Doutrinas pedagógicas e elementos de instruf̧ão pública para uso das escolas de ensino primário, especialmente das provincias do Amazonas e Pará, de Joaquim Maria Nascentes de Azambuja (Pará, 1884); Pedagogia e metodologia: teoria e prática, de Camilo Passalácqua (São Paulo, 1887); Tratado de metodologia coordenada, para uso de professores e alunos das escolas normais, de Felisberto Rodrigues Pereira Carvalho (Rio de Janeiro, 1888); Liçôes de coisas, de João Barbalho Uchoa Cavalcante, "guia prático para uso dos professores e aspirantes ao magistério, contendo preceitos e regras do método intuitivo acompanhado de lições e exercícios de aplicação" (Pernambuco, 1888), Catecismo de economia política para uso das escolas normais do Império, de Pedro Autran da Matta e Albuquerque (Rio de Janeiro, 1888) e Princípios de pedagogia, de Augusto Coelho (São Paulo, 1891-1893), alentado tratado em quatro tomos e dois volumes, decalcado de $A$ educação intelectual, moral e física de Spencer.

Quanto às "lições de coisas", convém acrescentar aos já citados Primeiras liçôes de coisas, de Calkins; Liçôes de coisas, de Manoel José da Silva Guanabara; Lições de coisas: sentido, formas, cores (método de Calkins), de Luiz Carlos Duque-Estrada; Noçôes de coisas, de Uchoa Cavalcanti e Liçôes de coisas pelo Dr. Saffray. No geral, os autores 
didáticos indiciam crucialidades: formar mestres com domínio de conteúdos para além de aqueles a serem ensinados, fazer a escola servir à criança, conceber a sala de aula como banco de ensaios.

\section{A realidade e suas antinomias}

Se ao mestre de escola, a princípio fiel auxiliar do padre e do médico, delega-se a sustentação dos alicerces da identidade nacional centrada na aliança entre Estado, Coroa e Igreja, monotonamente, no espacejar dos anos, os relatórios de ministros do Império, presidentes de províncias e inspetores gerais esbatem idênticas queixas: relaxação dos costumes dos mestres, imerecimento literário dos aspirantes ao magistério, extemporaneidade dos métodos e processos de ensino, inadequação dos locais de ensino, abusiva presença de leigos no magistério, mesquinhez de ordenados.

No mais, as fileiras do magistério nacional são exíguas e assim permaneceriam nos presentes vindouros, fato que não impede de relembrar a nota de bom-senso declinada em Americus: cartas politicas extraídas do Padre Amaro. "Não pode haver boas escolas sem bons mestres e nem pode haver bons mestres sem lhes pagar bem. $\mathrm{Na}$ fundação de um Estado tudo quanto se poupar neste objeto é economia ainda mais absurda que a do avaro que nega a si próprio o pão de cada dia" (Americus, 1825, t.1, p.54).

Minas Gerais e Bahia, de longe as províncias mais populosas, 1.669.276 e 1.211.792 habitantes, possuíam tão somente 1.453 e 771 professores respectivamente. ${ }^{42}$ Essa "estatística moral", isto é, a correlação entre o número de professores e a população geral, é acolhida pelas falas oraculares centradas nos sobrepoderes da instrução primária de Estado, mais concretamente, pelos sujeitos dispostos a modificar a condição subjetiva da nação e da nacionalidade infusa. Mal pago, malquerido e mal-ouvido, o dia a dia do mestre-escola, comumente designado "proprietário da cadeira da escola", ou melhor, aquele que

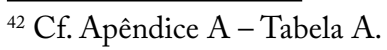


oferta "quilates de luz", no dizer arroubado de certo figurão, não desfruta de melhores condições de vida. Na Fala de 13 de março de 1886, endereçada à Assembleia Provincial do Maranhão, o conselheiro Bandeira de Mello ponderava.

Em meu conceito, dois meios há de remediar estes males, e é robusta a fé que alimento de que a ação combinada de ambos dará novo impulso à instrução popular, o melhor benefício que podeis fazer as classes menos felizes de vossos concidadãos. São esses meios: o aumento de ordenado, e a criação de uma escola normal.

Pelo primeiro, tornareis o professorado uma carreira procurada da gente honesta e laboriosa, que tenha sentimento da própria responsabilidade, e queira servir com honra; pelo segundo apurareis as vocações, e serão por uma vez expelidos do magistério a ignorância protegida, os incapazes, que as outras carreiras repelem (Mello apud Fernandes, 1929, p.243).

Vice-diretor e professor de matemáticas do "Colégio do Exmo. Sr. Barão de Tautphoeus”, professor da $1^{\text {a }}$ cadeira da freguesia do Sacramento na Corte, membro da Imperial Sociedade Amante da Instrução, credenciais dignas de atenção, Manoel José Pereira Frazão desabafa, em Cartas do professor da roça, série de artigos relativos à instrução pública da Corte, publicada no jornal Constitucional.

Agora (aqui para nós) qual é o papel que representa um professor, propriamente tal, perante uma sociedade como a nossa? De que importância goza? Obrigado pelas circunstâncias a resignarse a uma tarefa tão espinhosa quão inglória, e tendo como garantia única seus pingues ordenados, não perde por certo a ocasião de se deixar devorar por algum dos minotauros de que acima lhe falei. $\mathrm{O}$ professorado hoje é a pior das recomendações! Perguntai a um pai o que é o professor de seu filho, e ele vos responderá: "Um criado de ensinar meninos" (Frazão, 1864, p.31, grifo do autor). 
No palavrear de Tavares Bastos em Cartas de solitário, intelectual de proa e contundente crítico da monarquia. "Pois um moço, no Amazonas, ou no Paraná, ou em Goiás que saiba ler, escrever, aritmética, doutrina, elementos de Geografia e Gramática nacional, prestar-se-á a ensinar meninos por $400 \$$ anuais? De certo que não. Vai aprender latim e formar-se em Direito ou procura logo um emprego público de certa ordem, ou, finalmente, é escolhido delegado de polícia, eleito vereador, nomeado membro de assembleia" (Tavares Bastos, 1863, p.70). Saído das camadas populares, aos poucos o mestre de escola teria sua imagem social reconfigurada para além de fiel auxiliar do padre e do médico, seria rebatizado professor primário, e a esse prometeico intermediário da cultura atribuiu-se o exercício de uma profissão eminentemente intelectual.

\section{Comparar a diferença}

Em atos de pensamento e projeções mentais, monarquistas e republicanos ritualizam o halo da instrução pública como fundamento da civilização política, donde pensar e medir o Brasil por comparação, comumente os bons exemplos recaem no sistema escolar da Prússia ou no modelo político e social da Terceira República francesa ou ainda no progressimo liberal-federalista dos Estados Unidos. Monarquistas e republicanos, os homens públicos acompanham a ordenação dos sistemas escolares unitários, centralizados e legislados pelas burocracias dos Estados nacionais.

Em âmbito internacional, o método comparativo, cujo uso é perceptível nos estudos das línguas, folclore, costumes, direito, política, comparece nos estudos dos sistemas de ensino e certamente ganha maior visibilidade nas exposições universais de Viena, Áustria, Filadélfia, Estados Unidos, em que constavam seções de Instrução Pública. São desse período, os célebres estudos do republicano Ferdinand Buisson, a saber, Rapport sur l'instruction primaire à l'Exposition Universelle de Vienne en 1873, Rapport sur l'instruction 
primaire à l'Exposition Universelle de Philadelphie en 1876 e Conférence sur l'enseignement intuitif, faite aux Instituteurs délégués à L'Exposition Universelle en $1878 .^{43}$

No Brasil, a voga comparativa desperta nos idos de 1870 com a tradução e edição pela Imprensa Nacional dos relatórios de Celéstin Hippeau, Rapport sur l'instruction publique aux États Únis e L'instruction publique en Angleterre. Tal voga assenta a recolha de modelos e experiências dos sistemas nacionais de educação próprios das nações liberais. Conjugadamente, a literatura político-sociológica publicada no Brasil intensifica a busca de fontes exteriores de inspiração. É de então o incremento de estudos prescritivos e relatos de viagens de observação patrocinados pelas autoridades, no amplo repertório, dentre muitos, O ensino primário no Reino Unido da GrãBretanha e Irlanda, por César Augusto Viana Lima; O ensino público primário em Portugal, Espanha, França e Bélgica, por Luis Augusto Reis; O ensino público primário na Itália, Suiça, Suécia, Bélgica, Inglaterra e França, por Manoel José Pereira Frazão; O ensino público primário em França, Espanha e Portugal, por Luisa Leopoldina Tavares PortoCarrero; O jardim infantil: sua natureza, seu fim e seus meios de ação, por Antonio Herculano de Souza Bandeira, abarcando França, Áustria, Alemanha e Suíça; Estudo sobre o ensino primário no Reino Unido da Grã-Bretanha e Irlanda, por César Augusto Viana de Lima; Exposição e crítica da legislação alemã sobre as escolas normais e jardins da infância, por Dias da Silva Júnior e O ensino público primário na Itália, França e Bélgica, por Amélia Fernandes da Costa. Desse primigênio de estudos comparados, deduziam-se ações e iniciativas reformadoras.

Pela repercussão obtida, sobreleva-se a obra ampla de Joaquim Teixeira de Macedo, aliás, premiada na Primeira Exposição Pedagógica do Rio de Janeiro: A instrução pública na Prússia, O ensino normal primário na Prússia, Breves apontamentos para o estudo das questóes relativas ao ensino normal primário e a educação popular, Novos apontamentos de origem alemã para o estudo das questóes relativas à educação nacional.

${ }^{43}$ Cf. Bastos (2013). 
No intento de melhorar a administração escolar, vem a público um rol de estudos aqui impossível de entremostrar à exaustão: Coeducação dos sexos nas escolas primárias, normais e secundárias, por João Barbalho Uchoa Cavalcanti; Medidas conducentes a tornar efetiva a inspeção do ensino, por Josino do Nascimento Silva; Sistema disciplinar e meios de emulação nas escolas de diversos graus, por Augusto Cândido Xavier Cony; Jardim das crianças, de W. Hacilman, "tradução de G. L. A.", exposição do sistema de Fröebel; Organização dos jardins de infância, por Joaquim José de Meneses; Organização dos jardins de infância, por Maria Guilhermina de Andrade e Regulamento geral e programas do ensino e horários das escolas normais primárias, por João José Barbosa de Oliveira. Da infância ao limiar da idade adulta, cria-se ser possível envolver a infância e a adolescência num sistema de ensino uniforme e eficiente. Isto é, sente-se a infância e a adolescência como etapas dotadas de faculdades próprias, para essa despontante sensibilidade, as crianças não nascem homens, tornam-se, antecâmara da vida social, a instrução, força cultural politicamente relevante, certificaria a agregação à esfera convivial e mundana. 


\section{Da química moral}

A gestão dos serviços públicos demanda dados quantitativos. No ministério do Barão de Rio Branco, mais exatamente em 1872, a recéminstalada diretoria-geral de Estatística efetuava a única contagem geral da população no Império. À primeira vista, parece ser impensável realizar um censo demográfico geral num país de territorialidade infindável, rural, escravocrata e, claro, destituído de comunicações e transportes. No escrutínio dos atributos da população, aplicaram-se "boletins de família", indagando-se nome, sexo, idade, "raça" (definida pela cor, branco, preto, pardo, caboclo), estado civil, naturalidade, nacionalidade, residência, religião, defeitos físicos, enfermidades e grau de instrução.

Ao final de 1876, o relatório apresentado pelo diretor-geral, conselheiro Manoel Francisco Correia, revelava os índices definidores da demografia do país: massa da população - 9.930.478 almas, sendo 8.419.672 livres e 1.510.806 escravos; "raças": branca - 3.787.288, negra - 1.954.452, indígena - 386.944, parda (mulatos e mestiços) - 3.801.782. Províncias "mais bem povoadas": Rio de Janeiro, Ceará, Pernambuco, Alagoas, Sergipe; "menos povoadas": Amazonas, Mato Grosso - "cinquenta quilômetros quadrados para cada pessoa". Nas palavras do conselheiro. "É pouco animador o quadro da estatística intelectual; mas o impulso que entre nós vai tendo a instrução popular faz esperar que não decorrerá muito tempo sem que varie para melhor proporção ora existente entre os que sabem e os que não sabem ler" (Brasil, 1877, p.19-20). 
Na massa da população livre, 1.563.078 "sabem ler e escrever", 6.856.000 "não sabem ler e escrever". Entre os que "sabem ler": 1.012.097 são homens, 550.981 mulheres; analfabetos $80 \%$ da população livre e $99,9 \%$ da população escrava. Províncias nas quais avultam analfabetos: Alagoas, Amazonas, Ceará, Goiás, Minas Gerais, Paraíba; em situação menos acabrunhante: Rio de Janeiro, Rio Grande do Sul, Paraná, Maranhão. Há variação relativa na coluna "Instruídos" se observamos que os percentuais incluem a população de 0 a 6 anos de idade. ${ }^{44}$ Das populações em atividade, $80 \%$ se dedicam ao setor agrícola, $13 \%$ ao de serviços e $7 \%$ à indústria. Na categoria "serviços", mais da metade referia-se a empregados domésticos. ${ }^{45}$

\section{Da obrigatoriedade}

Uma das províncias do Império em que a instrução está mais generalizada é a do Rio de Janeiro. Pois bem, leia-se o relatório do Sr. visconde de Prados, ver-se-á qual a distribuição das escolas e quais as facilidades que lá mesmo encontram para aprender a ler e escrever. Há perímetros de tal extensão, em que os moradores das extremidades precisariam do dia inteiro para ir às escolas e voltar das apetecidas lições.

José Bonifácio de Andrada e Silva, o moço, discurso de 28 de maio de 1879 .

O artigo 179, §32, da Constituição Política do Império estipulara a gratuidade da instrução primária, mas não a obrigatoriedade. Desde

44 "Mesmo descontando-se o fato de que os percentuais se referem à população total, sem excluir crianças nos primeiros anos de vida, eles são bastante elevados. Apurou-se que somente $16,85 \%$ da população entre seis e quinze anos frequentavam escolas. Havia apenas 12 mil alunos matriculados em colégios secundários. Entretanto, calcula-se que chegava a 8 mil o número de pessoas com educação superior no país. Um abismo separava, pois, a elite letrada da grande massa de analfabetos e gente com educação rudimentar" (Fausto, 2000, p.237).

${ }^{45}$ Cf. Apêndice A - Tabela B. 
o decênio de 1840, os relatórios das públicas autoridades debatiam o estatuto da obrigatoriedade escolar, só assim, dizia-se, as crianças estariam a salvo da ignorância e indiferença dos pais, tutores e amos. Dentre os argumentos, a convicção herdada dos reis-filósofos e seu esclarecido despotismo, a necessidade de compelir as massas humanas para formas de vida civilizadas.

O vozerio dos homens hábeis da monarquia, vozerio a defrontar o embotamento popular, enuncia com veemência o estatuto da obrigatoriedade, assunto pertinente à razão de Estado, dele, o estatuto dependeria o aperfeiçoamento da sociedade civil, donde a ênfase nas luzes do conhecimento para o bem do Estado e suas instituições políticas. Ou por outra, pela obrigatoriedade, o longo braço do Estado alcançaria franjas sociais e rincões, os mais longínquos, a escola primária não apenas alfabetizaria, mas também ensinaria maneiras, moralidades e significado das estruturas jurídicas e institucionais. ${ }^{46}$ Se assim for, ativada por propósitos políticos nacionais, a instrução pública forjaria a identidade nacional (empresa fartamente compartilhada, note-se, pelos conselheiros José de Alencar e Gonçalves de Magalhães em suas respectivas obras literárias). $\mathrm{Na}$ construção identitária, a nação (e o Estado), expurgada as contradições, aparece como síntese americana de brancos europeus, negros africanos e indígenas.

\section{Formar o espírito público}

Num âmbito mais significativo, o marco legislador referencial do estatuto da obrigatoriedade escolar é, mormente, o regulamento da instrução primária e secundária do Município Neutro, Decreto no 1.331-

\footnotetext{
${ }^{46}$ Inexistindo a separação entre Estado e Igreja, o catolicismo é a religião oficial, a Igreja atua onde o braço do Estado não logra interiorizar-se, e exercia parte das funções administrativas e políticas. No dizer do visconde de Bom Retiro, Luís Pedreira do Couto Ferraz, o catolicismo "[...] esclarecendo a população de nossos sertões e do interior do Brasil que, em geral, pouco ilustrada, tanto carece de autoridades e a chame ao caminho legal." Atas do Conselho de Estado, 1875, citado por Alonso (2002, p.64).
} 
A, de 17 de fevereiro de 1854, de iniciativa de Luiz Pedreira do Couto Ferraz. Além da gratuidade, o decreto estatuía a obrigatoriedade, reforçada pela aplicação de penalidades aos responsáveis omissos e contumazes.

Art. 64 - Os pais, tutores, curadores ou protetores que tiverem em sua companhia meninos maiores de sete anos sem impedimento físico ou moral, e lhes não derem o ensino pelo menos de primeiro grau, incorrerão na multa de $20 \$$ a $100 \$$ conforme as circunstâncias.

A primeira multa será dobrada na reincidência, verificada de seis meses. O processo nestes casos terá lugar ex officio, da mesma sorte que se pratica nos crimes policiais.

Art. 65 - O Inspetor Geral, por si e por seus Delegados, velará eficazmente na execução dos artigos antecedentes; e para este fim haverá das Autoridades locais as listas das famílias, contendo os nomes e idades dos meninos pertencentes a cada uma (Brasil, 1854, art. 64-65).

$\mathrm{Na}$ interpretação de José Ricardo Pires de Almeida. "O ensino obrigatório estava, depois de 1854, inscrito na imortal reorganização elaborada, sob o olhar do imperador, por aquele que se tornou mais tarde visconde de Bom Retiro." Mais à frente, o ministro Carlos Leôncio de Carvalho, pelo Decreto no 7.247, de 19 de abril de 1879, reativaria a obrigatoriedade nas escolas primárias de $1^{\circ}$ grau, fazendo-a acompanhar de penalidades aos recalcitrantes.

Art. 2 - Até se mostrarem habilitados em todas as disciplinas que constituem o programa das escolas primárias do $1^{\circ}$ grau, são obrigados a frequentá-las, no município da Corte, os indivíduos de um e outro sexo, de 7 a 14 anos de idade.

Esta obrigação não compreende os que seus pais, tutores ou protetores provarem que recebem a instrução conveniente em escolas particulares ou em suas próprias casas, e os que residirem à distância maior, da escola pública ou subsidiada mais próxima, de 1⁄1/2 quilômetro para os meninos, e de 1 quilômetro para as meninas (Brasil, 1879, art. 2). 
Os responsáveis omissos sujeitavam-se a multas de 20 a $100 \$ 000$, meninos chegados aos 14 anos sem concluir a escola de $1^{\circ}$ grau prosseguiriam em paróquias, se houvesse ensino para adultos. No mais, pelos atos dos presidentes de províncias, o estatuto da obrigatoriedade é retomado como parte da afirmação do poder público, em âmbito local.

Orgulhosa de si, a publicação oficial, O Império do Brasil na Exposição Universal de $1876 \mathrm{em}$ Filadélfia, atestava a gratuidade do ensino público primário articuladamente à tendência à obrigatoriedade, no Brasil império, segundo a publicação, o "fato deixara de ser proclamado para ser fato praticado”.

Como em todo o mundo civilizado, ocupa a atenção dos governos geral e provinciais a necessidade de tornar efetiva esta medida, e, pois, tratam de prover as sua execução atentando as suas dificuldades provenientes das grandes distâncias, e da variedade da lavoura nos distritos rurais, em que nossos meninos de certa idade auxiliam os pais, nos trabalhos de campo (O Império..., 1875, p.133).

Conforme os dados da publicação, o país contava com 20 províncias, 685 municípios, incluindo o Município Neutro, 255 cidades, 460 vilas, 1.553 paróquias, 12 dioceses. Ceará, Maranhão, Mato Grosso, Minas Gerais, Pará, Paraná, Piauí, Pernambuco, Santa Catarina, São Paulo, Sergipe estatuíam a frequentação obrigatória, Rio Grande do Norte a circunscrevia às sedes das cidades, vilas e povoações. À época, certas províncias fixam a idade escolar entre a idade de 7 e 10 anos outras de 7 e 12 ou ainda de 7 e 14 e 7 e 15 . Entrementes, era frequente condenar as escolas por contrariarem a moralidade exigida pelas famílias. "As crianças das classes razoavelmente abastadas não vão à escola pública porque seus pais têm, mais ou menos, o preconceito de cor ou porque temem, e com razão, pela moralidade de seus filhos, em contato com esta multidão de garotos cujos pais os enviam à escola apenas para se verem longe deles algumas horas (Pires de Almeida, 1989 [1889], p.90). Assim como é frequente invocar a precisão dos filhos, no 
ganha-pão da família, contudo há outro dado a ser considerado nos lugares sob o predomínio da oralidade como meio de comunicação pessoal e da aprendizagem imitativa e intracomunitária, isto é, com adultos, remanesce certa indisposição quanto a matrícula e frequentação, a escola aparece como algo ostentatório e desviante, a letradice, cria-se, acabaria por desmerecer o trabalho no campo e na oficina.

\section{"Boa é a lei se dela faz uso legítimo"}

O Código de Instrução da província de São Paulo, 1857, é um dos bons exemplos dos extremos da legislação provincial quanto à escolarização das populações alheias à alfabetização, ao mesmo tempo em que ilustra a perfeição a tese da construção do poder local. Entre os tantos propósitos do código, consta o enquadramento das populações ralas viventes em rotinas obscuras e pertinazes, ensimesmadas em sobradões ou dispersas em casebres de taipa rude em chácaras e lugarejos à beira de estradas, então a província guardava antiquíssima fisionomia colonial. ${ }^{47}$

Elaborado por conhecedores do Direito Público, Antonio Joaquim Ribas, João Dabney de Avelar Brotero e Diogo de Mendonça Pinto, ${ }^{48}$ o código, pela abrangência das disposições, 493 artigos, dezenas de capítulos, centena de parágrafos, quer galgar o Céu e abraçar a Terra. Para fins de inspeção, o dispositivo legal segmenta a província em Círculos Literários com sedes nas cabeças de comarcas; em cada círculo, um inspetor literário nomeado dentre os residentes, se graduados em Letras ou Ciências ou se professores distinguidos pela aplicação.

Aos subinspetores reserva-se a tarefa de "Inculcar nos pais de família a necessidade de mandarem seus filhos à escola de primeiras letras, e dispor de meios adaptados a fazê-los sentir a necessidade de se estender, e progredir a instrução primária."

\footnotetext{
${ }^{47}$ Cf. Marcílio (2014).

${ }^{48}$ Cf. Sacramento Blake (1883-1902).
} 
O capítulo "Da obrigatoriedade do ensino" estatui a obrigatoriedade entre 7 e 15 anos de idade para crianças residentes no raio de $1 / 4$ de légua da povoação em que houvesse escola pública ou particular. Os subinspetores requisitariam às autoridades policiais do Distrito uma relação dos menores de 15 anos residentes no raio da obrigatoriedade, certificariam nome, idade e naturalidade do menor, se era analfabeto, se completara a instrução primária ou se apenas a começara. No caso de ser menor órfão ou não residir com os pais, seria anotado o nome do tutor, curador, amo ou pessoa com a qual residia. "Sendo o menor filho natural, e não querendo os pais serem conhecidos, se lançará a nota - filho de pais incógnitos."

O subinspetor corrigiria as inexatidões e omissões nas relações nominais dos contumazes, em seguida solicitaria informações aos párocos, Juízes de $\mathrm{Paz}$ e demais autoridades. Se necessário, convocaria os menores, acompanhado de um professor, pároco ou pessoa habilitada, verificaria se a criança é analfabeta ou de instrução incompleta. Em editais nos jornais ou afixados em escolas e igrejas, o subinspetor comunicaria os resultados da verificação aos responsáveis pelo menor. Findo o prazo, intimaria pessoalmente os responsáveis, impondo-lhes multas, se refratários, sujeitar-se-iam à duplicação cumulativa do valor previsto, se ausentes pais e amos, as mães saldariam os débitos. Se preciso fosse, o subinspetor requisitaria aos Juízes de Órfãos a nomeação de tutores ou curadores para órfãos e filhos de pais suspensos do pátrio poder ou portadores de "defeitos intelectuais ou morais"; nesses casos, os juízes colocariam os menores à soldada, cabendo aos novos amos mandá-los à escola ao "menos uma vez por dia”. No fecho do capítulo, severa disposição: autoridades policiais, da instrução pública, ou quaisquer outras, descumpridoras das disposições, sujeitavam-se à multas de $50 \$ 000$ a $100 \$ 000$ réis.

Apesar das disposições severas, a realidade do dia a dia prossegue ao arrepio da lei, por décadas, os relatórios do inspetor-geral, crônicas documentadas da vida na província, Diogo de Mendonça Pinto, realçam o quadro mazelado. Tirocínio inepto e moralidade frágil dos 
mestres, cadeiras vagas ou ocupadas minoritariamente por professores "definitivos" e majoritariamente por interinos, ordenados mesquinhos, métodos ineficazes, falta de utensílios, resistência em mandar a meninice à escola. ${ }^{49} \mathrm{E}$, muito embora os apelos se repetissem, "Prevaleçase a Autoridade Pública do seu direito de forçar aos Cidadãos dos povoados que se instruam", como ditara Antonio Saraiva, presidente da província de S. Paulo, apelo reforçado por João Theodoro Xavier, também presidente de S. Paulo, na Lei no 9, de 22 de março de 1877, o estatuto da obrigatoriedade permanece na estaca, numa frase, a lei é dura, mas a aplicação é flácida.

\section{Não à "liberdade de persistir na ignorância"}

Os "homens do mais avançado espírito", empenhados em demonstrar que a natureza humana pode ser aperfeiçoada, avizinhamse na imposição do ensino público. No contencioso das doutrinas jurídicas, nos embates sobre o dobramento autoridade/liberdade, liberdade/autoridade, as posições são excludentes. Para uns, "o direito de fazer o que era contra o direito natural da pessoa era inadmissível”, para esse ponto de vista, o Estado deveria fiar os direitos conaturais da pessoa. "Tão legítimo, como é legítimo o pátrio poder, o qual não envolve certamente o direito desumano de roubar ao filho o alimento do espírito, - o ensino obrigatório é às vezes o único meio de mover pais e tutores remissos ao cumprimento de um dever sagrado. Nas cidades, por exemplo, onde haja escolas suficientes, como não sujeitálos a multas, ou a trabalhos e prisão no caso de reincidência" (Tavares Bastos, 1937 [1870], p.139).

Posição semelhante demonstrara Liberato Barroso, exministro da Justiça no gabinete de Francisco José Furtado. Convicto monarquista, sincero abolicionista, a seu turno, o conselheiro João Alfredo expressava idêntico ponto de vista (apud Oliveira, 1874, p.133-134). "O Estado tem o direito de obrigar os pais, tutores,

${ }^{49}$ Cf. Kubo (1986) e Monarcha (1999). 
todos os que, enfim estão encarregados de qualquer indivíduo em idade de frequentar a escola, de fazê-lo aprender a ler e escrever. Este direito decorre da proteção devida pelo poder público àquele que tem necessidade de intervenção da sociedade, para gozar das garantias que lhe são conferidas pela lei.” Em conferência literária na Glória, 1873, Afonso Celso de Assis Figueiredo, visconde de Ouro Preto, compartia idêntica convicção. "Da instrução pública depende a aspiração suprema das sociedades modernas, a liberdade consorciada com a ordem"; e citava Laveley, autor de L'instruction du peuple. "A criação da escola importa a supressão da cadeia: o Estado que não instrui, carece amedrontar, porque os dois grandes mantenedores da ordem social são - o carrasco e o professor público'. Não pode haver hesitação na escolha, senhores”.

Se o pai degenerado, que seus filhos dos alimentos, é responsável perante a lei, que intervindo em favor das míseras crenças, lhe pede severas contas e o obriga a cumprir tão sagrado dever, não há razão para que não seja igualmente responsável, não preste as mesmas severas contas, quando deixa de satisfazer necessidades muito mais importantes que as físicas. Demais, senhores, as conveniências gerais, o interesse de todos exige por vezes a sujeição da vontade individual à vontade da lei (Figueiredo, 1924, p.268).

Ademais o visconde introduzia uma interpelação crucial, a instrução dos libertos. "Se não cuidarmos de proporcionar os meios para a educação dos libertos, teremos em poucos anos um crescido número de brasileiros, que, vegetando na ignorância e na miséria, irão povoar as enxovias ou os hospitais, depois de terem sido elemento de desordem e perversão." Para Afonso Celso, nas províncias de populações aglomeradas em cidades, vilas, aldeias e povoados, a exigência de frequentação assomava como algo factível. "Mas, nas nossas vastas províncias, onde se dizem vizinhos indivíduos residentes a cinco e mais léguas uns dos outros, e fazenda há que ficam a 10 
e 20 das povoações mais próximas, claro é que uma exigência seria impossível" (Figueiredo, 1924, p.268, grifo do autor).

Por seu lado, ao colocar o estatuto da obrigatoriedade no espelho da reflexão, Rui Barbosa sentenciava. "Assim como a obrigação escolar pressupõe, em boa doutrina que, aliás, a prática nem sempre tem observado, a gratuidade da escola, assim a escola gratuita sem a frequência imperativa representa uma instituição mutilada” (1947 [1882], p.181). Para outros tantos, a ação do Estado contrariava a liberdade individual. "A instrução e a educação obrigatórias são exorbitantes da missão natural do Estado e atentatórias ao direito de personalidade e aos direitos da família." Doutrinava José Maria Correia de Sá e Benevides em Elementos de filosofia do Direito privado (1884, p.35).

Noutro plano, questionava-se a inconstitucionalidade do estatuto da obrigatoriedade face às franquias provinciais, o poder legislativo geral não teria legitimidade para fixar leis comuns para as províncias. De qualquer modo, no decênio de 1870, firmavam-se certezas, a lógica da boa organização escolar recomendava a gratuidade e a obrigatoriedade. Dogma social benquisto, o "regime coercivo" representaria ato de proteção perante os cometimentos paternos. Grosso modo, os debates remetem à decretação da obrigatoriedade, respeitando-se a distância entre a moradia e a escola.

Num ato de generosidade, o Estado, províncias e municípios forneceriam aos "meninos filhos das classes pobres", roupas, compêndios, utensílios; aos pais, tutores e protetores desidiosos seriam aplicadas penalidades gradualmente mais fortes, por exemplo, a infração acarretaria perda de direitos políticos ou prisão, em caso de reincidência. Acompanhemos os termos do Regulamento geral da instrução do Espírito Santo, baixado em 1882, no governo de Herculano Marcos Inglês de Souza.

Artigo $3^{\circ}-\mathrm{O}$ ensino elementar é obrigatório para todas as crianças de 7 a 10 anos de idade. Para eximirem os filhos e tutelados da frequência da escola elementar, os pais e tutores provarão: 
$\S 1^{\circ}-$ Que no seio da família, ou em aula particular, se lhes ministra o ensino exigido por esse regulamento;

$\S 2^{\circ}$ - Que os filhos tutelados têm moléstias ou defeito físico que os inibem de ir à escola;

Artigo $4^{\circ}$ - Para esse fim os pais e tutores são obrigados a comunicar a autoridade competente, logo que seus filhos e tutelados atingirem a idade prescrita, que os estão instruindo em casa ou em aula particular, ou a participar o motivo porque não lhes proporciona o ensino (Espírito Santo, 1882, art. 3-4).

Considera-se a obrigatoriedade arrimo das instituições sociais e políticas, figura-se a escola primária de Estado como crisol da consciência civil. Em defesa do estatuto da obrigatoriedade, evocava-se o exemplo das "nações esclarecidas", Bélgica, Dinamarca, Espanha, França, Holanda, Inglaterra, Itália, Portugal, Prússia, Suécia, Suíça, Estados da união americana. De fato, assistia-se à aprovação quase universal da obrigatoriedade escolar (e da conscrição militar), mais pontualmente, Prússia e França assomavam como faróis-guias em matéria de organização e pedagogia escolar. E não raramente se imputava ao estatuto da obrigatoriedade a causa do soerguimento da Prússia abatida pelas tropas de Napoleão I, donde repetir-se a exaustão uma sentença atribuída a Bismarck. "Quereis saber o que tem levantado a Prússia? São duas coisas: a obrigação do serviço militar e a obrigação do serviço escolar."

Variantes dessa frase proverbial, ecoam no tempo longo: "Creio ter sido Guilherme II quem afirmou dever a Alemanha a sua fulminante vitória de 70 ao mestre-escola e ao sargento" (Camargo, 1931, p.56). E, de algum modo, a Primeira Exposição Pedagógica, as atas e os pareceres do malogrado Congresso da Instrução condensam as expectativas vigentes. ${ }^{50}$ Exarados por Silvio Romero, Antonio Bahia da Silva Araújo e Antonio da Cunha Leitão, os pareceres sobre o ensino obrigatório e os meios de efetivá-lo, simulavam cartas rogatórias a favor da autoridade pública, justiça e penalidades. ${ }^{51}$

\footnotetext{
${ }^{50}$ Cf. Collichio (1987).

${ }^{51}$ Cf. Atas... (1884).
} 
Rogava Silvio Romero. "Os meios práticos de tornar efetiva a obrigatoriedade de ensino são de três ordens: a sua gratuidade aos pobres, a difusão de escolas por todo o país, especialmente nos centros populosos, e imposição de penas aos pais, tutores, protetores que não mandarem seus filhos, pupilos e protegidos" (Atas..., 1884, p.2). Rogava Antonio Bahia da Silva Araújo. "Obrigado pela lei civil a alimentar os filhos, não menos obrigado deve ser o pai a prestar-lhes o alimento do espírito, as antigas leis do direito romano colocavam a prole como propriedade do pai, no direito moderno aos pais cumprem o dever de cumprir o que natureza lhes impõe em relação à prole" (Atas..., 1884, p.3). No mesmo diapasão, Antonio da Cunha Leitão. “O ensino obrigatório não é uma utopia, como pretendem alguns, é não só praticável, como eficaz. A lei não pode ser indiferente ao cumprimento deste dever, que tão de perto afeta os interesses do Estado; e como a principal mantenedora da ordem social, tem o direito, que também assume as proporções de um dever, de exigir que o pai cuide do primeiro desenvolvimento intelectual dos filhos, não só para preparálos afim de bem poderem desempenhar os ônus da cidadania, como também em benefício da própria sociedade de que eles têm de fazer parte" (Atas..., 1884, p.15).

Em escala modesta, nem por isso menos significativa, nas províncias multiplicam-se opúsculos e conferências referidos à liberdade de ensino e à obrigatoriedade escolar. Breve balanço permite situar a circulação de escritos sociais em tom de manifesto de opinião: $O$ ensino obrigatório, carta aberta endereçada à Assembleia Provincial de Santa Catarina, por Joaquim dos Remédios Monteiro; Ensino obrigatório, de Oliveira Fernandes, discursos na Assembleia Provincial Legislativa de São Paulo; Ensino obrigatório, de Manuel Francisco Correia, conselheiro do Império, conferência sobre a legitimidade das Assembleias Provinciais na imposição de penalidades. E, apesar das diferenças inter-regionais, os presidentes de províncias operam idênticos dispositivos jurídicos; mas aqui é preciso acautelar a palavra e distinguir a lei formal da aplicação real.Se a legitimidade dos regimes 
representativos demanda a manifestação da vontade do povo, fazia-se preciso ofertar serviços de instrução pelo Estado. Na rotação do tempo, firmar-se-ia tripla convicção, formação da nacionalidade, segurança do Estado e funcionamento das instituições dependeriam de uma primeira instrução de Estado comum a todos. Em tom teratológico, replica hábil estadista da monarquia, Alfredo do Nascimento Silva, em "Um átomo de história pátria. Histórico da Sociedade Amante da Instrução". "A higiene social tem de proceder do mesmo modo, vigiando de perto a podridão, queimando as pústulas sociais, sacrificando os membros para salvar o corpo e, sobretudo, amparando na queda os que tombam, sendo mãe da orfandade e regaço dos abandonados, fortificando os espíritos, lhes difundindo a instrução, e pregando-lhes a moral!" (Silva, 1892, p.102). Para reviver metáforas e anseios da época, purificar costumes, fecundar corações, distribuir benefícios da lavoura, comércio e indústria, promover higiene social, emancipar a pessoa pela assunção do autogoverno, engrandecer o país e cimentar os laços provinciais, seriam fins alcançáveis pelo alastramento de uma luz geral entre as massas analfabetas viventes em franjas sociais e confins territoriais. 



\section{Vozes testamentárias}

$\mathrm{Na}$ antemanhã da República, o estado da instrução era este: ensino primário, secundário no Município Neutro e superior em todo o país a cargo do governo central e gerido pelo ministro do Império; ensino primário, normal e profissional sob a alçada dos poderes locais, legislados pelas Assembleias provinciais e administrados pelas inspetorias gerais. $\mathrm{E}$ como a contradizer os avanços civilizacionais do Segundo Reinado, Carlos Leôncio de Carvalho, sincero estadista liberal, eriçava reflexões.

Um dos maiores benefícios da Exposição Pedagógica foi patentear o estado da nossa instrução primária, que muitos ignoravam. Pouco se cuida da educação do sexo feminino, para o qual apenas existem em todo o país 1.315 escolas. Os meninos que ainda não têm atingido a idade escolar (7 anos) vagam pelas ruas, contraindo maus hábitos, importunando os transeuntes, atropelados pela polícia, que não sabe o que fazer deles (Carvalho, 1884, p.34-35).

Às análises especulativas, Leôncio de Carvalho encarrilhava números ao mesmo tempo comprobatórios e restritivos: massa da população - 9.930.478 habitantes, analfabetos -8.365 .997 , população em idade escolar de 6 a 15 anos - 1.902.454, frequência escolar 321.449 alunos; escolas públicas - 4.486; escolas particulares - 913; colégios - 286; para adultos analfabetos, 4/5 da população, 47 escolas frequentadas por 1.121 discípulos. 
Grande parte dos mestres não possuía as habilitações necessárias ao exercício do magistério, "cabendo a culpa disso aos poderes públicos, que não lhes querem dar escolas normais. São demasiadamente mesquinhos os vencimentos do magistério primário; paga-se a um professor menos do que a empregados subalternos de muitas repartições." A essas condenatórias, Leôncio de Carvalho acrescia a intolerância com os acatólicos, a inexistência de matérias para educação intelectual, moral e física, a ausência de inspeção escolar, os métodos de ensino "morosos e difíceis", a jornada escolar em dois períodos separados por longo intervalo obrigando os pais a mandarem os filhos duas vezes a escola.

Num exercício de educação comparada, a querer demonstrar o atraso nas coisas da instrução, o liberalista Leôncio de Carvalho alude às realidades progressivas da Alemanha, Austrália, Áustria, Bélgica, Canadá, Escócia, Hungria, Inglaterra e Irlanda. E por essas coisas do destino, sempre insondável, sempre imprevisível senão surpreendente, ao barão de Santa-Anna Nery, na companhia do barão de Saboia, Luiz Cruls e do contra-almirante barão de Teffé, coube oficializar o derradeiro balanço do Segundo Reinado em Le Brésil en 1889, obra organizada para documentar a participação do Brasil na Exposição Universal de Paris em 1889. No introito “Le Brésil actuel”, Santa-Anna Nery enfileira imagens afirmativas. "Não há mais, senão cidadãos livres submetidos aos mesmos deveres e gozando dos mesmos direitos", "O Brasil veio a Paris não para se impor, mas fazer a velha Europa constatar que ele não é indigno, pelos progressos que realizou, de entrar mais profundamente ainda no concerto econômico dos grandes Estados." Na sequência, sólidos capítulos de hidrologia, climatologia, mineralogia, estatística, história, geografia, demografia, agricultura, comércio, indústria, finanças, ferrovias, migração e artes, assinados por grandes nomes, Henri Gorceix, José Maria da Silva Paranhos, André Rebouças, Leitão da Cunha, Eduardo Prado e outros mais. No capítulo "Instruction publique", repertório extenso, Santa-Anna Nery estocava dados significativos. 
No Brasil, o ensino primário é de responsabilidade da província e das municipalidades, exceto no Município Neutro onde a responsabilidade é do ministério do Império. $\mathrm{O}$ ensino secundário parte dos governos provinciais, mas o Estado mantém duas escolas secundárias em duas províncias; e, no Rio de Janeiro, esse ensino, da mesma forma que a instrução primária, parte do Estado. Apenas o ensino superior constitui, de fato, um monopólio do Estado, que distribui os programas e dispõe dos estabelecimentos especiais onde esse ensino é dado.

Nossos municípios e, sobretudo nossas províncias são livres na escolha do pessoal do ensino, na fixação dos programas, na adoção dos métodos e na criação de escolas. O Estado não impõe a eles nenhum encargo administrativo, nenhum direito de inspeção.

\section{E estocava mais ainda.}

O ensino primário é gratuito para todos, em virtude do artigo 179, parágrafos 32 e 33, título VIII da Constituição brasileira de 25 de março de 1824; e o Ato Adicional de 12 de agosto de 1834 declarou que é parte das Assembleias Provinciais legislar sobre a instrução pública e sobre os estabelecimentos aptos a distribuí-la, exceção feita aos estabelecimentos de instrução superior então existentes como também a todos os outros que seriam criados no futuro por uma lei geral do Estado.

O ensino primário é obrigatório em certas províncias; em outras torna-se facultativo. Quanto à laicidade, essa palavra não está ainda em nosso vocabulário pedagógico. A instrução religiosa é dada em quase todos os estabelecimentos escolares, e, mais frequentemente, pelos laicos, sem que seja resultado até aqui de graves inconvenientes. Fora da capital, todas as províncias se colocam como um dever e como um ponto de honra possuir, e manter, ao menos uma escola secundária e uma escola normal primária na sua cidade principal (Santa-Anna Nery, 1889, p.231 - grifo do autor). 
Nesse ano de 1889, mais exatamente no mês de maio, na Fala do Trono, abertura da quarta sessão da vigésima legislatura, solene e elevada, a voz monárquica de Pedro II sugere à Assembleia Geral Legislativa a criação de um ministério da Instrução e demais ações necessárias à instrução pública, algumas, note-se, debatidas por ocasião da Assembleia Geral Constituinte.

Entre as exigências da instrução pública, sobressai a criação de escolas técnicas adaptadas às condições e conveniências locais; a de duas universidades, uma ao sul e outra ao norte do Império, para centros de organismo científico e proveitosa emulação, donde partirá o impulso vigoroso e harmônico de que tanto carece o ensino; assim como a de faculdades de ciências e letras, que, apropriadas às províncias, se vinculariam ao sistema universitário, assentando tudo livre e firmemente na instrução primária e secundária (Falas do Trono..., 1977 [1889], p.145).

Meses depois, na Câmara Municipal do Rio de Janeiro, José do Patrocínio confirmava a proclamação da República. A essa altura dos fatos, viria a público o decreto de banimento da família real redigido por Rui Barbosa. Exilada, a família real, embarca para a Europa no vapor "Alagoas" escoltado pelo couraçado "Riachuelo"; no bolso da sobrecasaca, conta-se, o imperador guardava um exemplar de Cenas da vida amazônica, de José Veríssimo. $\mathrm{Na}$ comitiva, uns tantos poucos desventurados, o engenheiro negro André Rebouças, os barões de Loreto e de Muritiba. Num breve e melancólico ato, encerrava-se o teatro do mundo monárquico. No mais, entre silabários, cartilhas, cartas do ABC, compêndios, crestomatias, livros de leitura, catecismos, métodos de ensino os mais diversos, processava-se a escolarização de parcelas de crianças brasileiras. 


\section{Parte III}

\section{Do Governo Provisório republicano à virada do século}

Nós tivemos já a reforma radical no governo, cumpre-nos completar a obra da revolução pela reforma profunda da nossa educação nacional. José Veríssimo, A educação nacional (1890) 



\section{Sob a bandeira fraternal}

Liberdade! Liberdade!

Abre as asas sobre nós,

Das lutas na tempestade

Dá que ouçamos tua voz

Nós nem cremos que escravos outrora

Tenha havido em tão nobre País...

Hoje o rubro lampejo da aurora

Acha irmãos, não tiranos hostis.

Hino à Proclamação da República do Brasil

Letra de Medeiros e Albuquerque. Música de Leopoldo Miguez

\section{O povo como sujeito de direito}

Em uníssono, os instituidores da República elaboram versões dos fatos da hora. No arrazoado de vozes, o contrato social anterior convertera-se em alvo de desafeição; corroída pelo tempo, a solução monárquica, dinástica e constitucional atestara o declínio dos padrões públicos. Nova forma de legalidade, a República, consciência de si feita razão, aparece como governo revolucionário e de bem-estar, a seu favor, dizia-se, estava a jornada de futuro, daí a figuração da república como bela totalidade e governo bem-acabado.

Votivas e embelezadoras, as fórmulas sagradas herdadas da Revolução Francesa retornam à cena política; "Cidadão", "Saúde 
e Fraternidade" auguram o futuro do presente. Como solução reconciliatória, concretizava-se a ideia obstinada de res publica. Perquirição absorvente dos últimos e incondicionados valores, o novo regime tornou-se realidade ao reunir frações ideológicas diversas, cada qual a prodigalizar doutrinas opostas: republicanos radicais, positivistas, maçons, liberais e, claro, adesistas de última hora. No contra-ataque, os monarquistas aclamam outras versões dos acontecimentos, com efeito, nomeiam o "episódio de 15 de novembro de 1889" como "sedição militar", "exortação às armas" e "golpe de Estado".

Magnificado como aurora da civilização política, "dilúvio de luz" no dizer extravasado de um contemporâneo, em tese o novo regime afiançava o começo de uma era de livre associação. No imaginário prometeico, espécie de lição de energia ministrada pelos revolucionários, a república concentrava em si o encontro da razão com a história. Nessa teleologia da perfectibilidade, a figura do Povosoberano desponta como herói coletivo, ente legislador e fonte da legitimidade do poder. Daí em diante, os publicistas iriam propor às massas os motivos constitutivos da trindade republicana - liberdade, igualdade, felicidade.

Se a Independência despedira o jugo colonial, se a monarquia demitira o trabalho servil, a República fora mais além, ao despedir o Poder Moderador, a vitaliciedade do Senado, a eleição à base de renda, a escolha dos governantes locais pelo poder central, os privilégios de nascimento, a nobreza titulada e o estatuto do padroado. E, mais ainda, num gesto de fraternidade universal, naturalizara os estrangeiros residentes no país. Porquanto, instituíase uma república democrática e social - a igualdade na forma de liberdade, o governo pelo consentimento dos governados. Em tese, ao vencer duro percurso, virava-se uma página da história; para o imaginário político, o mar de escolhos, ficara para trás, o presente figurava-se inteligível, o porvir, dizível. Diz Euclides da Cunha (1975 [1909], p.45). 
Impertinente em 1822, inoportuna em 1831, abortícia em 1848, era-o a República, sobretudo porque se não podia inverter a série natural da evolução humana. Aspiração política, requeria que lhe propiciasse o advento do desenvolvimento social. A sociedade não a repelia; prorrogava-a. E a partir da de 1875 começou a incorporá-la.

$\mathrm{Na}$ passagem de um estado de coisas, marcado pela agonia para outro imarcescível, os doutrinários aprofundam o sentido dos acontecimentos, em oposição à monarquia, ao absolutismo, ao centralismo e ao arbítrio do privilégio, triunfara a soberania popular pela representação política, o consentimento espontâneo e a coesão coletiva constituiriam os vigamentos do novo regime. Experimentava-se solene vontade cívica; ao profetizar o vir a ser, as consciências republicanas pressentiam decididas evoluções, uma vez que os direitos usurpados pela monarquia eram devolvidos ao povo. No mais, a exaltação vitalista do povo levava a interpretar a República como recomeço determinado pela vontade geral. ${ }^{52}$ Inaudito, o estado de coisas aparece como correlato de revolução. ${ }^{53}$

Regime fundado sob o primado da isonomia, a República, em termos ideais, exterioriza a majestade do governo popular, melhor, materialização da vontade política racional. Tomados pela exaltação vitalista do Povo-soberano, os sujeitos auguram o devir de um governo fundado num contrato social livre de contingências, donde o empenho em transfigurar o povo em corpo político juridicamente regulado, porquanto sede física da soberania. Invocava-se a magistratura

\footnotetext{
${ }^{52}$ Cf. Monarcha (1989).

${ }^{53} \mathrm{O}$ tema da revolução representado como ato de fundação (e construção) de um novo corpo político expressivo de novos valores sociais, como liberdade e felicidade públicas, próprios de sociedades populares e analisado por Arendt (1988). Para a autora: "O conceito moderno de revolução, inextricavelmente ligado à noção de que o curso da História começa subitamente de um novo rumo, de que, uma História inteira nova, uma História nunca antes conhecida ou narrada está para se desenrolar, era desconhecido antes das duas grandes revoluções no final do século XVIII" (p.23).
} 
da história, a verdade da consciência de si, de súbito, a linguagem enriquece-se com dísticos absolutos-moralidade, liberdade, felicidade, fraternidade, justiça, ordem, progresso, igualdade civil, paz pública. Multiplicam-se as preocupações com a vida nacional em suas diferentes manifestações: instituições, política, Estado, cultura, melhoramentos de material, agregação coletiva. $\mathrm{O}$ novo regime, imaginava-se, abrigaria a nação laica e igualitária, a federação harmoniosa e progressiva, ao outorgar existência política ao povo, retiraria do anonimato homens e mulheres comuns, alçando-os à cidadania política. Em síntese, o feixe de aspirações gira em torno do discurso autorreferencial da República como regime antecipatório da humanidade futura.

\section{Dos relatos e versões}

Em cena aparentemente captada em oitiva, o republicano radical, Alexandre Dias Ferreira Júnior, descrevia os acontecimentos da hora.

O Marechal Deodoro e Quintino Bocaiuva, aureolados de glória, se puseram à frente de 4.000 soldados, e percorreram as principais ruas do Rio de Janeiro, erguendo frenéticos vivas a República, aclamando a deposição da monarquia. A passagem dos batalhões o povo abria alas e saudava o exército vitorioso, atirando sobre ele radiantes grinaldas, que estrelavam majestosamente o solo por onde transitavam, jubilosos, pelo triunfo da grandiosa causa da liberdade da pátria.

Nas ruas. Durante todo o dia e até alta hora da noite o povo percorreu as ruas do centro da cidade, formando diversos grupos precedidos de bandas de música. Expansiva em seu entusiasmo, a população erguia vivas e saudações à imprensa livre, aos bravos do exército e da armada, ao Marechal Deodoro, a Quintino Bocaiúva, ao país e à República Brasileira (Ferreira Júnior, 1890, p.68).

De resto, coube a Henrique Bernardelli oficializar na tela "Proclamação da República" a iconografia do "15 de novembro". Em 
perspectiva ultrarrealista, ele figurava a passagem ao ato. No centro da tela, a cavalo, num gesto decidido, Deodoro da Fonseca alça o barrete militar e proclama a República; o cenário, o Campo de Santana em manhã radiosa, ao fundo Quintino Bocaiúva, Aristides Lobo e Benjamin Constant Botelho de Magalhães. Recorrentemente estampada nos compêndios escolares, tal iconografia visa testemunhar o gesto pacífico e decidido do marechal.

Para a historiografia acadêmica, a República não resultou de uma revolução social e popular, mas da ação militar circundada por pacto de recomposição das classes dominantes, imprensa e povo teriam saudado o acontecimento com moderado entusiasmo. "Nem nesse momento nem ao deixar o portão do quartel-general, estava certo Deodoro de que as oligarquias monárquicas pertenciam ao passado, e ia começar o tempo da oligarquia republicana” (Buarque de Holanda, 1960, p.360).

"Parada original" no dizer de uns, "ato revolucionário" no dizer de outros, um dado é inegável: as descontinuidades. A República aparece como aula nova ao instituir o sistema federalista, a autonomia local, o casamento civil, a secularização dos cemitérios. Os atos inaugurais culminam com a reforma do código penal, a oficialização da instrução laica, a liberdade de culto religioso, ao extinguir o Padroado, separava Estado e Igreja. E, ao se reinventarem os símbolos e as armas nacionais, no pavilhão nacional, ainda que mantidas as cores da bandeira imperial, gravava-se a divisa regeneradora de Augusto Comte, "Ordem e Progresso", divisa a indiciar resumo e coroamento dos modernos regimes de governo social.

\section{República, ato de criação dos homens}

Instalava-se o Governo Provisório e, nele, as figuras de primeira plana, Deodoro da Fonseca - chefe do Governo; Aristides da Silveira Lobo - ministro do Interior; Rui Barbosa - Fazenda; tenente-coronel Benjamin Constant Botelho de Magalhães - Guerra; Eduardo Wandenkolk - Marinha; Quintino Bocaiúva - Relações Exteriores; 
Demétrio Ribeiro - Agricultura, Comércio e Obras Públicas; Campos Salles - Justiça. De imediato no entrançado da hora, encaminha-se a organização de um sistema visível de governo. O Decreto $n^{\circ} 1$, de 15 de novembro de 1889, funda o governo em moldes de República Federativa, com isso pretendia assinalar um armistício produtivo entre os poderes central e locais, reunidas em laço da federação, as ex-províncias constituíam os Estados Unidos do Brasil. ${ }^{54}$ No mais, o novo regime ganharia existência jurídica pelas mãos de um mestrepensador. "Rui Barbosa vai ser, na nova ordem de coisas, o centro de gravitação de todas as consciências verdadeiramente liberais" (Oliveira Vianna, 1923, p.297).

Não cabe aqui pormenorizar os embates tensos ocorridos durante o Congresso Constituinte..$^{55}$ A comissão integrada por Saldanha Marinho, Rangel Pestana, Antônio Luiz dos Santos Werneck, Américo Braziliense e José Antônio Pedreira de Magalhães Castro redige o anteprojeto, Rui Barbosa revisa o texto. Feitas as discussões e as emendas, a Assembleia Nacional, com Prudente José de Moraes Barros, presidente do congresso e senador por São Paulo, promulga a

\footnotetext{
54 "Se a política foi marcada, ainda na Colônia, pela dicotomia centralizaçãodescentralização, o processo é mantido no Império apesar do caráter unitário da Carta de 1824. A questão ganha vivacidade na República, em 1889, com adoção do federalismo. Há uma dialética na alternância do predomínio do centro sobre o todo ou em concessões por vezes bem determinadas às várias partes" (Iglésias, 1993, p.243).

${ }^{55}$ Para análise detalhada dos embates relativamente aos trabalhos constituintes, ver Cury (2001). Na analítica de Carvalho (1987, p.45): “A República ou os vitoriosos da República fizeram muito pouco em termos de expansão de direitos civis e políticos. O que foi feito já era demanda do liberalismo imperial. Podese dizer que houve até retrocesso no que se refere a direitos sociais. Algumas mudanças, como a eliminação do Poder Moderador, do Senado vitalício e do Conselho de Estado e a introdução do federalismo, tinham sem dúvida inspiração democratizante na medida em que buscavam desconcentrar o exercícios do poder. Mas, não vindo acompanhadas por expansão significativa da cidadania política, resultaram em entregar o governo mais diretamente nas mãos dos setores dominantes tanto rurais quanto urbanos. $\mathrm{O}$ Estado republicano passou a não impedir a atuação das forças sociais, ou, antes, a favorecer as mais fortes, no melhor estilo spenceriano.”
} 
Constituição em 1891, assim legitima-se o regime presidencialista, o federalismo, a triparticipação do poder, a representação popular.

Moldada a nova Constituição brasileira sobre a da República norte-americana, nossos estudiosos de Direito passaram a inspirarse direta ou indiretamente em tratadistas norte-americanos; a intensificação de relações políticas e econômicas entre os dois países foi também refletindo-se em nossa literatura política, econômica e pedagógica. Os livros, panfletos e documentos do período estão salpicados de sugestões norte-americanas; às vezes de revolta contra norte-americanismos (Freyre, 1949, p.675).

O Estado assoma como órgão de governo de uma sociedade regida por valores solidaristas, as instituições políticas, como órgãos de gestão e de representação popular, ambos, Estado e instituições, garantiriam os direitos do homem e da cidadania; o regime continuaria a ser bicameral, Senado e Câmara dos Deputados; os presidentes de estados seriam eleitos. Ato contínuo, o Congresso Nacional elege Deodoro da Fonseca e Floriano Peixoto, presidente e vice-presidente. $\mathrm{Na}$ conjuntura política, o grande acontecimento refere-se ao "Encilhamento": Rui Barbosa, ministro da Fazenda, facilita a obtenção de crédito e emissão de moeda a fim de promover o capitalismo industrial, como se sabe, operação frustrada pela especulação.

No entendimento dos constituintes, embora detendo o monopólio da força, o melhor poder de Estado é o alheio às intervenções, à exceção das situações de desordem civil, ameaça à inviolabilidade da propriedade privada e constrangimento das liberdades individuais. Resumidamente, a Carta Política legitima o complexo democraciarepública-federação-laicicismo (malgrado as declarações de princípios, a mão pesada do Estado, sua coorte de funcionários, sua polícia, sua máquina de arrecadação, mão providencial fiadora da autoconservação, mão protetora da vara do poder, virá a ser realidade profunda na vida das pessoas). Ao Governo Federal compete arrecadar impostos de 
importação, criar bancos emissores de moeda, organizar e comandar Exército e Marinha; aos Estados, adjudicavam-se poderes e direitos amplos: organização das forças públicas, contratos de empréstimos no exterior, criação de impostos e justiça própria. Por conseguinte, a fórmula federativa soa compatível com um país sobrecarregado de diversidades antropogeográficas e às voltas com o imperativo da unidade territorial.

Instituía-se o voto direto, poderiam se alistar como eleitores, nos pleitos para câmaras gerais, estaduais e municipais, os cidadãos maiores de 21 anos no gozo dos direitos civis e políticos, desde que soubessem ler e escrever. Aos abaixo de 21 anos, esses poderiam votar se casados ou alunos de escolas militares ou superiores, vetado o alistamento eleitoral de filhos-famílias, mendigos, analfabetos, praças de pré, e religiosos em regime de claustro, por fim desconsiderava-se o voto da mulher. ${ }^{56}$ Direito individual com função social, o voto continua aberto, o alistamento eleitoral e o voto não são obrigatórios. ${ }^{57}$ Como bem explica a historiografia acadêmica, no transcurso da Primeira República, os coeficientes de votantes e taxas de comparecimento nas eleições seriam reduzidos, de outro modo estava ausente o símbolo da democracia, qual seja o sufrágio universal e seu livre exercício.

Quanto à educação e cultura, a Constituição assim estatuía: a União legislaria o ensino superior, na Capital da República, dando-lhe, não privativamente, atribuições de animar no país o desenvolvimento

\footnotetext{
${ }^{56} \mathrm{Na}$ fase do governo provisório, o Decreto no 200A, de 8 de fevereiro de 1890 , no artigo 24, assim estipulava: "Em todos os casos em que a comissão ignorar ou tiver dúvidas se o cidadão sabe ler ou escrever, convidá-lo a lançar em uma folha de papel, perante ela, a data, o dia, seguido de sua assinatura ou procederá a qualquer outro exame, sempre rápido, que julgar conveniente".

57 "Os novos eleitores deveriam requerer individualmente a sua inscrição. Para tal, era preciso apresentar algum documento que comprovasse a idade e ainda demonstrar que se sabia ler e escrever, servindo de prova a assinatura no requerimento (com firma reconhecida) ou a assinatura feita no momento da solicitação. Depois de cadastrados, os eleitores recebiam um novo título eleitoral" (Nicolau, 2012, p.55).
} 
das letras, artes e ciências, criar instituições de ensino superior e secundário nos estados, prover a instrução primária e secundária no Distrito Federal e, cumulativamente com os governos federados, criar instituições de ensino secundário e superior nos estados. Ademais, lembremo-nos, o ensino livre introduzido no Segundo Reinado por Leôncio de Carvalho, note-se, facilitara a expansão do ensino superior pela via das faculdades livres de Direito, Medicina e Engenharia.

Quanto à instrução primária, em tese, as convicções pautadas no princípio da pessoa como responsável por si mesma e por seu destino derrotavam os princípios da gratuidade e da obrigatoriedade escolar, as unidades federadas decidiriam por si a adoção ou não de tais princípios. Em suma, desatava-se o enredo republicano e, ao lado da defesa dos direitos civis primordiais - vida, liberdade, propriedade -, a instrução popular era um valor dos mais aclamados: por ela, a instrução, ao religar numa mesma moral as gerações e as classes sociais, instituir-seia a Boa Sociedade, isto é, livre da necessidade desafortunada.

\section{Antinomias da doutrina liberal}

A cosmologia republicana apoia-se no elogio das liberdades individuais. Ideia em ato de criação, os publicistas estipulam a vinculação contratual fundada na livre convergência das autonomias individuais, note-se, mergulhadas na determinação e promoção de si, conquanto concordantes a respeito de um princípio comum, a saber, a moral individual conforme a unidade de direitos: é de então o jogo semântico com as expressões "liberdade política" e "liberdade econômica". Se assim for, a eloquência destemerada dos doutrinadores, homens graves, numes tutelares permanentemente citados pela exemplaridade, concebe o indivíduo como sujeito de direitos, e o corpo coletivo como ente virtuoso (isto é, a república é o grande teatro em que se confrontam termos opostos - individualidade e fraternidade, livres e iguais, os indivíduos por decisão voluntária pactuam entre si um contrato político-existencial). 
Agravava-se a simbolização da unidade pelo Estado e a universalidade abstrata do cidadão, daí ser a sociedade civil o lugar das vontades particulares e das iniciativas individuais em livreconcorrência pelo "pão de cada dia", vale dizer, da força atomizada de cada indivíduo portador de direitos, defluem os melhoramentos coletivos. E, muito mais do que antes, a paixão pelo recomeço exorbita a doutrinação de François Quesnay: laissez-faire, laissezpasser, le monde va de lui-même ("deixai fazer, deixai passar, que o mundo vai por si mesmo”). É lícito dizer que o entrejogo do ser e do parecer dilui a grave antinomia inerente à doutrina liberal. Melhor dito, da associação egoísta das necessidades e dos interesses individuais, derivaria a associação atraente de homens regenerados pela sanidade social, por fim e sobretudo, os caprichos do acaso decidiriam os vencedores da competição (para além dos circunlóquios dialéticos próprios de uma retórica em ebulição, fica a questão: como falar em satisfação de apetites privados, comunidade de interesses e felicidade individual e coletiva?). Entrementes, é preciso não confundir forma de governo com administração de governo: tanto a criação do Povo-novo, as populações humanas em vias de fusão, quanto a elevação do indivíduo indeterminado ao status de cidadão e da multiterritorialidade ao status de pátria, demandam reforço do poder público e da centralização da autoridade.

Não obstante, o que parecia contido, a instalação de um poder executivo forte retorna à cena, quer por cisões parlamentares quer pelo prestígio crescente de Prudente de Moraes, líder do PRP; acossado, Deodoro da Fonseca veta o projeto de lei que define os crimes de responsabilidade do supremo mandatário da República. Em novembro de 1891, o marechal-presidente dissolve o Congresso Nacional, deslegitimado pelos setores civis, militares e políticos, renuncia. À frente do contragolpe, Floriano Peixoto, em cujo redor se aglutina a oficialidade formada na Escola Militar, logo sensível à doutrinação positivista, donde o engajamento na concretização de uma república forte, centralizada, sobremodo energicamente jacobina. 


\section{Quantos somos?}

Sob a bandeira da República, Aristides Lobo trouxera para si a primeira operação censitária. Ainda na fase do Governo Provisório, o Decreto no 113, de 2 de janeiro de 1890, restabelece a diretoria-geral de Estatística com o propósito de recensear a população na data de 31 de janeiro de 1890. Em formato de "boletim ou lista de família", o questionário inquire sexo, raça, estado civil, nacionalidade, filiação de culto, grau de instrução, defeitos físicos, títulos científicos, literários e artísticos, profissões, estatística predial e outros mais.

A exacerbação federalista da primeira hora condicionanegativamente a coleta de dados. Alguns estados resistem às ordens emanadas do Distrito Federal, a conjuntura interna é instável, mesmo assim realizava-se o recenseamento cuja exatidão será contestada nas décadas seguintes. ${ }^{58}$ Seja como for, um dos quesitos inquire a "habilitação intelectual" da pessoa, se sabia ler e escrever, se tinha instrução secundária ou superior, se possuía título ou diploma científico, literário ou artístico; igualmente a 1872, o recenseamento de 1890 não separava a população por grupos de idade. Em 1898, a diretoria-geral da Estatística estampa a esperada sinopse. Os dados consolidados revelavam que o país possuía 1.024 municípios, 3.236 distritos, 1.883 paróquias, massa geral da população: 14.333 .915 habitantes. Estados mais populosos: Minas Gerais - 3.184.099 habitantes, Bahia - 1.919.802, São Paulo - 1.384.753, Pernambuco - 1.030.224; nas demais unidades, menos de um milhão de habitantes. Completava-se a toada numérica com os índices gerais de analfabetismo: do total geral da população, "sabem ler e escrever" - 2.120.559, "não sabem ler e escrever" - 12.213.356. Nas diferentes instâncias políticas e intelectuais, tencionase idêntica profecia, República com povo analfabeto era um salto no desconhecido, podendo resvalar abismo abaixo. Ideia de futuro e força em progressão, das preocupações cidadãs advinha grave expectativa, causa fundamental, a instrução elementar, laica, gratuita, obrigatória representava o pilar da democracia política e social.

${ }^{58}$ Cf. Senra (2006). 



\section{Republicanismo educativo}

A despeito dos fatos afogados em sangue, as tantas insurreições como a Revolução Federalista, a Revolta da Armada, Canudos, o primeiro decênio republicano coloca em evidência grupos influentes de homens de cultura convictos da instrução de um novo pupilo, o povo político. Das visões de mundo teleológicas, visões desdobradas do ser dos homens e das coisas, defluem técnicas de direção da consciência coletiva. Ora bem, na passagem do centralismo autocrático e dinástico ao federalismo democrático, quer pela religião da república quer pela mística do progresso infinito, as vontades acometidas pelo espírito de reforma, ritualizam o calor vital da instrução como fonte de felicidade, utilidade e riqueza comum.

Anseio claramente expresso por Franklin Ramiz Galvão, inspetorgeral da Instrução do Distrito Federal, em relatório ao ministro Benjamin Constant. "O analfabeto é um elemento pernicioso no seio da nação, e a república jamais será uma realidade auspiciosa e feliz, se a educação do povo lhe não trouxer a base substancial e estável por excelência" (Ramiz Galvão, 1890, p.9). Seja como for no chão fraterno em que medram os moralizantes laços imaginários, liberais, maçons, jacobinos, positivistas, spencerianos, elites doutrinárias concorrentes entre si, sobrelevam o significado do republicanismo educativo. $\mathrm{Na}$ medida em que o regime se objetiva em instituições, na medida em que o ativismo apossa-se das variadas cabeças, expande-se a crença nos poderes superlativos da instrução como elemento formativo do cidadão completo por ser capaz 
de, por si mesmo, querer, discernir e julgar (em poucas palavras, dotado de entendimento, o homem é fórmula de si).

A outorga da função educativa ao Estado, instituição ilusoriamente acima e além das classes sociais, o converte em preceptor universal dos pupilos recém-chegados a este mundo por nascimento, a meta, promover o trânsito da esfera privada, familiar e afetiva para o mundo da civilização política. Porquanto, o republicanismo educativo soa como amor paternal pela grande sociedade, donde sucessões ininterruptas de palavras quentes e sacudidas. Em exposição ao presidente do estado, Prudente de Moraes, Antonio Caetano de Campos, homem hábil na arte de falar sobre o povo, mas não para o povo, ao correr da pena, pleiteava um plano de ensino coletivo e popular consoante o momento. "A vida do povo desaparece sob as guerras dos potentados. Só mui gradualmente consegue o proletariado adquirir um pouco de ar e de luz, e isso se dá quando ele se vai apoderando dos princípios científicos”. Nas figuras de retórica do professor de Biologia e diretor da Escola Normal de São Paulo, na República, o povo, fonte de soberania, conduz. "Senhor governador".

Já que a revolução entregou ao povo a direção de si mesmo, nada é mais urgente do que cultivar-lhe o espírito, dar-lhe a elevação moral de que ele precisa, formar-lhe o caráter, para que saiba querer. Dantes pagava a Nação os professores dos príncipes sob o pretexto de que estes careciam de uma instrução fora do comum para saber dirigi-la. Hoje o príncipe é o povo, e urge que ele alcance o self-governmentpois só pela convicção científica pode ser levado, desde que não há que zelar o interesse de uma família privilegiada. A instrução do povo é, portanto sua maior necessidade.

Para o Governo educar o povo é um dever e um interesse; dever, porque a gerência dos dinheiros públicos acarreta a obrigação de formar escolas; interesse, porque só é independente quem tem o espírito culto, e a educação cria, avigora e mantém a posse da liberdade (Caetano de Campos, 1891, p.4). 
De mais a mais advinda da pressão dos positivistas, a separação do Estado e da Igreja encaminha a educação ao laicismo e ao enciclopedismo científico, portanto, à neutralidade confessional e à instrução integral. Nesse primeiro decênio republicano, encantados pelas filosofias sociais, vogam os lidadores do republicanismo educativo.

\section{Avenidas da instrução (e sua linguagem materialista)}

Nas intelecções teóricas, mecanicamente os sujeitos relacionam valores republicanos, ciência, laicidade, democracia, pátria com o ser e estar no mundo ao ensinar o povo a operar os negócios públicos, em suma, a ter noção positiva da vida de todos os dias e das coisas animadas e inanimadas. Os anseios convergem para um princípio dinâmico e automotivo, qual seja formar o indivíduo pela veridicidade das ciências fundamentais.

Com efeito, usuários de uma linguagem materialista, os mentores da forma republicana alvoroçam programas de matérias legitimados pela classificação das ciências, assim postulam um ensino esteado na recapitulação dos progressos do entendimento humano, com essa eficácia, selava-se o vínculo entre instrução e cientismos do momento. Discursa Antonio Caetano de Campos na formatura dos professores normalistas. "A educação do homem moderno exige uma notável soma de conhecimentos, que resultam sinteticamente das noções enciclopédicas hauridas em diversos ramos do estudo" (Caetano de Campos, 1891, p.5). Prestigioso professor primário, combativo dirigente do Grêmio do Professorado Paulista, Arthur Breves, em artigo no Diário Popular, edição de 23 de fevereiro de 1891, ao incitar vontades, partilhava do mesmo recitativo.

Saber ler, escrever e contar não é instrução, é simples instrumento de aquisição. Se é verdade, porém, que o ensino primário estende-se às noções de todas as ciências, não é menos que tais noções obedecem uma lei de classificação. 
Hoje, seja qual for o credo que se adote, não é dado a ninguém contestar que cada ciência se apóia sobre verdades das ciências que a precedem; que os fatos sociais dependem das condições da vida animal e estas dependem das leis do mundo inorgânico; é esta a ordem das matérias, esta é, portanto, a lei dos programas. Subordinando-se assim a uma lei, o programa de ensino, é um fato científico, é problema que não admite muitas soluções.

No intuito de dissipar a inconsciência das massas em fusão, esse é o elo entre a escola e a república, certos preceptores da forma republicana batem-se pelas sínteses explicativas escoradas ou na classificação das ciências de Augusto Comte ou de Herbert Spencer. Como é bem sabido, em Comte, a lógica divisionária das ciências fundamentais parte do estudo dos fenômenos mais gerais para os mais complexos: da matemática à astronomia, à física, à química, à biologia e por fim, à física social (sociologia). Cada ramo do saber é irredutível a outro, cada patamar científico é base para o seguinte: a matemática oferece o paradigma da cientificidade, a astronomia, o procedimento da observação, a química, a arte da nomenclatura, a física, o recurso da experimentação, a biologia, a observação comparada, a sociologia, por excelência ciência moral, a comparação histórica afere a progressão da Humanidade. ${ }^{59}$ Quanto à psicologia, Comte não a reconhece como saber objetivo, situando-a na esfera da especulação religiosa e da filosofia metafísica.

Outra lógica divisionária é justificada por Spencer: "ciências abstratas": lógica e matemática; "ciências abstrato-concretas": mecânica, física e química; "ciências concretas": astronomia, geologia, biologia, psicologia e sociologia. ${ }^{60}$ Diversamente de Comte, Spencer vê a psicologia como disciplina autônoma duplamente centrada no estudo das conexões dos fenômenos internos e externos e das estruturas e funções do sistema nervoso. Ciência experimental, a

\footnotetext{
${ }^{59}$ Cf. Verdenal (1981).

${ }^{60}$ Cf. Ferrarotti (1975).
} 
psicologia identifica, descreve e classifica as sensações e as formas de pensamentos na evolução mental, lenta e contínua, operada na passagem do homem primitivo ao civilizado. Populares entre as elites dirigentes, as teorizações spenceristas versam a passagem do estado de homogeneidade incoerente a heterogeneidade coerente e/ou convergente.

Seja o que for e como for, em que pesem as diferenças desses sistemas de pensamento, há mesmíssimo escopo especulativo: o progresso das ciências está em consonância com a lei da complicação crescente e generalidade decrescente, porquanto em correspondência com a marcha do entendimento das regiões fenomênicas, porquanto ainda, na pedagogia escolar genuinamente científica, caberia o estudo dos temas mundo, homem e sociedade. Espécie de reação ao abstracionismo escolástico o intento de instrução integral atinge altitudes inimagináveis. Se o entendimento é o caráter divinal do gênero humano, sabia-se que esse atributo é tão só estrutura virtual para materializar-se demandava obstinado cultivo. Ao ver dos sectários dos exuberantes sistemas evolucionistas, a escola popular é terra de missão civilizadora, compreendendo-se por civilização, como dito noutro lugar, não apenas o abrandamento de costumes, como se sabe civil e civilidade estão na origem do vocábulo, mas também elevação dos espíritos, progresso das artes, melhoramentos no comércio, indústria, agricultura e conforto material.

\section{"Cosmopolitismo do futuro"}

Não por acaso, de imediato os esforços manifestantes do espírito de reforma partem da Capital Federal, lugar apreciado como paradigma civilizador da nação, e de São Paulo, paradigma do moderno progresso. De par, Minas Gerais, Rio Grande do Sul, Paraná, Santa Catarina experimentam reformas da instrução pública. As expectativas gerais aludem a um futuro próximo quando as diretrizes emanadas dos marcos citadinos atingiriam latitudes e longitudes do território 
nacional por iniciativa de administradores vivazes e competentes. Ao findar o decênio vulcânico, a primeira década republicana, certos marcos escolares encontravam-se acometidos por realizações consoantes a nova ordem de certezas, a saber, implantação de núcleos oficiais de cultura estruturados em modalidades verticais de ensino e classes de idades, programas de matérias unificados e graduados, legislação específica para aprovação de compêndios e regulação de horários, calendários escolares, controle de frequência, mobiliário moderno, carreira do magistério e, sobretudo, elevação contínua, ainda que insatisfatória, da matrícula escolar geral. De par, certos mestrespensadores aclamam a reconciliação das classes sociais, para eles a instrução de Estado comum a todos religaria gerações e pessoas numa mesma moral.

Uma das causas do antagonismo das classes sociais é que elas não se conhecem e não se podem apreciar, visto que não se encontram em um terreno comum e não têm por isso, umas em relação às outras o sentimento das dificuldades em face das quais se acham colocadas.

Certo, no estado atual das coisas, se o futuro operário ombreou nos bancos da escola primária com o futuro burguês, poderá apreciar as vantagens que este tiver obtido pela sua evolução intelectual e poderá estimá-lo no seu justo valor. Mas, onde aprendeu o burguês a conhecer o operário e o seu valor? Em parte alguma. Desde a infância o perdeu de vista, e não sabe quanta habilidade exige o exercício de uma profissão, não conhece as dificuldades que há na construção de um vigamento ou no corte de uma pedra (Prestes, 1892, p.51). ${ }^{61}$

${ }^{61}$ Calorosa, essa profissão de fé de Gabriel Prestes nalguma medida retraduz a fé do grande Michelet em O povo (1988, p.178): "Se duas crianças, a pobre e a rica, se assentassem aos bancos de uma mesma escola, e, ligadas por amizade, divididas pela carreira, se vissem frequentemente, fariam mais entre elas que todas as políticas, todas as morais do mundo. Conservariam em sua amizade desinteressada, inocente, o nó sagrado da Cidade... O rico conheceria a vida, a desigualdade, e as lamentaria; todo seu esforço visaria a partilha. O pobre se tocaria e consolaria o rico de ser rico." 
Diferentemente dos tempos idos e vividos, a figura do mestre de escola, agora rebatizada de professor primário, em tese, superava em definitivo a função de auxiliar incensado do padre, muito embora é bom lembrar, sobre seus ombros recaísse a tarefa de missionar o amor republicano pelas instituições. Sagrava-se a "educação liberal": no lugar do ensino das abstrações, conhecimento útil atinente à vida e aos negócios, quer dizer, entendimento do mundo, do homem e da sociedade. E não será por demais dizer que em certos marcos regionais arde a grave determinação de envolver as almas em formação no estudo, introspecção e atividades físicas, e sobremaneira no culto respeitoso dos símbolos pátrios, a Bandeira Nacional, o Hino Nacional, o Escudo de Armas, na reverência aos heróis emergentes - Tiradentes, o “cristo cívico”, Silva Jardim, “o tribuno da República”. Todo esse republicanismo educativo levará Silvio Romero a palavrear em História do Brasil ensinada pela biografia de seus heróis.

Nós somos entusiastas convictos da ilustre nação americana; mas sonhamos missão ainda mais fulgente para nossa pátria; queremos formar aqui a mansão democrática do congraçamento não dos deserdados da Europa somente, mas dos deserdados de todo mundo e, pela reunião, pela igualdade de todos, formar o povo do porvir, o tipo novo, que não é oriundo, do exclusivismo europeu, ou africano, ou asiático, ou americano, o tipo novo que há de ser a mais perfeita encarnação do cosmopolitismo do futuro (Romero, 1892, p.22).

Virada do século XIX ao XX, duplamente momento de afirmação e percalços do Estado republicano, a escola elementar tende a integrar-se nas estruturas societárias regionais denotadamente nas áreas de economia aberta e de mercado. Se a Bandeira Nacional é o pendão da esperança e símbolo augusto da paz, a escola laica e científica é o penhor da vida civil e melhoramento material. $\mathrm{Na}$ conjuntura comocionada, as vozes dos homens públicos, homens hábeis, numes tutelares, sistematizam a instrução em módulos 
articulados e hierarquizados. Para melhor sorte do republicanismo político, trata-se de compartir valores comuns, visando à efetuação de relações contratuais estáveis, logo cidadãs, logo abertas à fraternidade, logo dispostas à igualdade, logo ainda menos reservadas. É quando afloram mais nitidamente as singularidades da escola moderna, instituição social cujo real potencial emancipador é permanente objeto de debates à medida que nela se acentua mais a ordem do que a liberdade, ainda que em nome dela, a liberdade. 


\section{Regeneração didática}

\section{Na Capital Federal, Benjamin Constant, "formador de almas"}

Baixado no Governo Provisório, o Decreto no 346, de 19 de abril de 1890 cria a secretaria de Estado dos Negócios da Instrução Pública, Correios e Telégrafos.

De status ministerial, a pasta é entregue ao tenente-coronel Benjamin Constant Botelho de Magalhães, ex-professor na Escola Militar, fundador da Escola Normal da Corte, sectário da doutrina de Augusto Comte, embora não extremado. Nas versões aceitas de Dunshee de Abranches, Eduardo Prado e José Veríssimo, a pasta fora criada em meio a manipulações, por conveniência, a esperteza política decidira afastar Benjamin Constant do ministério da Guerra.

Aos olhos dos discípulos, ele assoma como professor-cientista, cujas ideias conduziriam o país ao rumo certo; essa é a imagem idealizada por Oscar de Araújo, em Le fondateur de la Republique brésilienne, Benjamin Constant (1891), e Raimundo Teixeira Mendes, em Benjamin Constant: esboço de uma apreciação sintética da vida e da obra do fundador da república. "Exaltado no seu ardor republicano, pregou os sãos princípios inspirados no sentimento da fraternidade universal, preparou os moços que mais tarde haveriam de acompanhá-lo ao campo da glória, executou o plano que idealizara, sendo, então, o primeiro estadista do mundo que implantou o regime republicano sobre bases científicas" (Teixeira Mendes, 1937, p.5). Já na fria apreciação de Vicente Licínio Cardoso. 
Benjamin Constant ilustra, talvez, um caso único na história: o de uma revolução política dirigida por um professor de matemática. O fundador da República Brasileira foi, de fato, antes de tudo um professor.

$\mathrm{Na}$ composição do título do Ministério, ficou apenas arquivado esse receio, e conservado até agora vergonhosamente pela república, em tratar diretamente o problema político magno do Brasil, qual aquele que se refere a instruir um povo composto dos milhões apavarontes e deprimentes de analfabetos qual é o nosso (Cardoso, 1924a, p.308, grifo do autor).

Sob as normas do positivismo de Comte, para quem ciência, progresso e ordem moral são elos duma mesma corrente, Benjamin Constant vê na instrução científica o vigamento de uma república social virtuosa. No ministério da Guerra, na pele do reformador, expande a atividade doutrinária ao revisar a didática das escolas militares. Já à frente da Secretaria da Instrução Pública, apoiado pelos majores Lauro Sodré e João Bittencourt Costa, promove modificações substanciais nas modalidades de ensino. Num jorro de decretações, regulava no Distrito Federal o ensino primário, a Escola Normal, o Colégio Nacional, exPedro II, o ensino superior no âmbito maior da federação, as escolas Politécnica, de Minas de Ouro Preto e de Belas Artes, as faculdades de Direito e de Medicina e o Conservatório de Música. Convicto de si, concede sobrevida à "desoficialização do ensino" superior deflagrada por Leôncio de Carvalho. "Os primeiros atos do ministro da Instrução do Governo Provisório, mais que justificar, autorizavam a suposição de que havíamos enfim entrado no período de ouro da educação nacional” (Mennucci, 1932a, p.47). ${ }^{62}$

62 "Três dias depois (do encontro de Benjamin com Deodoro em 05/11/1890), consumava-se a reforma da instrução pública. Como queria, antes das comemorações do primeiro aniversário da República. O novo regulamento da Instrução Primária e Secundária do Distrito Federal equacionou algumas das questões gerais que haviam polarizado as discussões sobre o ensino na última década. Por exemplo, o caráter livre, gratuito e leigo da instrução primária 
O Decreto no 407, de 17 de maio de 1890, regulamenta a Escola Normal, para tanto Benjamin Constant retoma as ideias exaradas em "Escolas Normais. Sua organização, plano de estudo, métodos e programas de ensino", parecer encaminhado ao Congresso de Instrução do Rio de Janeiro, 1884. No caput do decreto, solene expectativa, a formação intelectual, moral e prática dos alunos-mestres regeneraria progressivamente a escola pública de instrução primária. De óbvia orientação enciclopédica, isto é, sob a dependência lógica das ciências, o programa de matérias da Escola Normal requeria 18 professores lotados no "Curso de "Ciências e Letras" e no "Curso de Artes". O programa abarcava os elementos da "suprema coordenação científica": ao estudo do "mundo inorgânico" ou "ordem material" corresponderia à matemática, à astronomia, à física, à química; ao "mundo orgânico" ou "ordem humana", à biologia, à sociologia e à moral. A biologia atua como prolegômeno da sociologia, a moral, como culminância.

Repercutindo a voga dos museus pedagógicos nacionais, note-se de passagem, voga difundida nas exposições universais, os decretos $\mathrm{n}^{\circ}$ 667 de 16 de agosto e no 980 de 8 de novembro de 1890 instituem o Pedagogium, inicialmente dirigido por Joaquim José Menezes Vieira, secretariado por Felisberto de Carvalho. Nas palavras do diretor, dentre as funções previstas, a intenção de informar a administração pública e o corpo do magistério dos progressos nacionais e estrangeiros, em matéria de instrução primária e secundária, clarear e fortificar os conhecimentos do professorado primário "A fim de exercer a delicada função de educador do povo”, e fraternizar o magistério na obra nacional. De curta existência, o Pedagogium é dirigido por Menezes Vieira, José Veríssimo, Manoel Bomfim, Olavo Bilac e José Barbosa Sobrinho. Veríssimo, a sua vez, define o Pedagogium como agente da unidade na variedade e fator consciente da obra de unificação moral.

oferecida pelo governo na capital federal. Fez-se, também, uma opção clara em relação à diretriz filosófica do plano de ensino secundário, com a adoção do modelo positivista [...] Essas eram as reformas que Benjamin Constant reputava essenciais à fase de 'regeneração' da sociedade brasileira" (Lemos, 1999, p.517). 
$\mathrm{Na}$ virada do século, transferiu-se o estabelecimento para a alçada da Intendência Municipal, cambaleante, pois inexistiam sede apropriada, verbas e quadro de funcionários, é encerrado por "custosa inutilidade".

Por seu turno, o Decreto no 981, de 8 de novembro de 1890, visa dar forma positiva aos ensinos primário e secundário. $\mathrm{O}$ primário é formalizado como livre, leigo, gratuito, mas não obrigatório, a coeducação vigoraria até a idade de oito anos. Para imprimir feição integral ao ensino, seriam criadas escolas primárias de $1^{\circ}$ e $2^{\circ}$ graus para crianças de 7 a 13 anos e de 13 a 15 anos. Graduada em três níveis, a escola de $1^{\circ}$ grau comportaria curso elementar, de 7 a 9 anos, regido por professoras, curso médio, de 9 a 11, e curso superior, de 11 a 13. De essência altruísta, a instrução moral e cívica consistiria em preleções e leituras sobre atitudes morais opostas: generosidade e egoísmo, economia e avareza, atividade e preguiça, moderação e ira, amor e ódio, benevolência e inveja, sinceridade e hipocrisia, prazeres e dores físicas e morais. Recomendações: o método intuitivo serviria de didática geral, os compêndios apenas auxiliariam a execução dos programas de matérias por muitos, note-se, considerados belos, porém inabordáveis.

Quanto ao ensino secundário, seria concedido o título de bacharel em Ciências e Letras aos diplomados pelo Ginásio Nacional, o programa de matérias seguiria a lei do desenvolvimento do espírito humano: começaria na matemática e culminaria na sociologia e moral - "foco único de luz capaz de alumiar e esclarecer o destino racional de todas as concepções humanas." Com fundamento nas interrelações dos ramos do saber, tal programa situa o ensino secundário na antecâmara das Escolas Politécnicas e afins. ${ }^{63}$

\section{Espólio inacabado e controverso}

Morto Benjamin Constant, janeiro de 1891, o Decreto $\mathrm{n}^{\circ}$ 1.160, de 6 de dezembro de 1892, extingue o ministério híbrido;

${ }^{63}$ Para um estudo amplo das reformas aventadas por Benjamin Constant, ver Cartolano 1994. 
passo seguinte, os serviços são realocados na secretaria da Instrução do ministério da Justiça e Negócios Interiores. Sem sucesso, em 1894, o deputado Medeiros e Albuquerque tenta aprovar a criação de um ministério de Instrução Pública e Belas Artes. Que sentido poderá ser atribuído às ações do construtor austero e doutrinador pertinaz? Teria se equivocado José Veríssimo ao contabilizar restritivamente o ativo reformador?

Como todos os seus antecessores no dificílimo encargo de dirigir o ensino público no Brasil, também ele não compreendeu, ou esqueceu, que a instrução é uma função de ordem moral, em cujos órgãos não se deve exigir somente capacidade técnica ou estritamente profissional, nem mesmo o exato cumprimento do dever regulamentar, mas também uma convicção filosófica dos seus efeitos, o devotamento de apóstolos na sua execução e um ideal nos seus propósitos (Veríssimo, 1906, p.19-20).

Teria acertado Bulhões Carvalho ao inventariar meritoriamente as iniciativas do reformador no introito da Estatística da Instrução?

Mas, se as reformas empreendidas por Benjamin Constant não lograram realizar as esperanças dele, retalhadas e esfaceladas que foram, logo após a sua morte, sem sequer poderem passar pela prova de uma experiência leal, do conjunto de seus esforços frustrados, de suas tentativas infelizes, de suas dolorosas decepções, fique-nos ao menos, uma lição, que bem merece ser aproveitada: a de que, em matéria de ensino, o que há de fazer, de mais essencial, de mais urgente, é começar pelo princípio, é estender à generalidade dos filhos da terra os benefícios das luzes que no presente podem cobrar a todos, é ministrar-lhe a instrução primária, que o futuro integrará, sem dúvida, nas atribuições maternas, em nossos dias, por força do estado social, cumpre figurar ainda entre os encargos mais sérios dos poderes públicos (Bulhões Carvalho, 1916, p.xiv). 
Um dado é inegável, qual seja a determinação invulgar do reformador na construção de um núcleo estatal de ensino a servir de modelo as demais unidades federadas. Como designada nos anais historiográficos, a "reforma Benjamin Constant" selava o Distrito Federal como vitrine da pedagogia escolar. No respeitante à concepção e estruturação do ensino, há, sem dúvida, tendência tecnocrática própria do positivismo comtiano, fato delatado na linguagem performativa dos decretos, neles transparecem a supremacia da razão prática e da ideia pura de lei.

Virada do século, apurada em 1898 pela 3a seção da diretoriageral da Intendência Municipal do Rio de Janeiro, a estatística escolar expõe dados constrangedores, conquanto a frase de Jules Simon, em L'école - "O povo que tem as primeiras escolas é o primeiro povo; se não é hoje, sê-lo-á amanha” - epigrafasse os discursos engajados. Total da população escolar: 106.390 crianças de 7 a 15 anos, matriculados 19.067 alunos. A matrícula nas primárias particulares iguala-se à matrícula das escolas públicas; o coeficiente geral de matrícula atinge $40 \%$ das crianças em idade escolar. Nas palavras e cifras do barão de Loreto, Franklin Menezes Dória, na publicação monarquizada $A$ década republicana (1899), outra realidade: a frequência regular não ultrapassava 600 alunos por 1000 .

\section{Em São Paulo, Antonio Caetano de Campos}

Igualmente na fase do Governo Provisório, São Paulo reorganiza os serviços de saneamento, saúde e instrução. No quadro de racionalização administrativa, sob as diretivas do PRP hegemonizado pelos "fazendeiros republicanos", a vontade de reforma dirige-se à Escola Normal. Com Prudente de Moraes no governo do Estado, e injunções de Rangel Pestana, arquiteto do plano reformador, baixava-se o Decreto no 27 , de março de 1890 . No caput do decreto, valoroso princípio. 
A instrução bem dirigida é o mais forte e eficaz elemento do progresso e ao governo incumbe o rigoroso dever de promover o seu desenvolvimento, e de todos os fatores da instrução popular o mais vital, poderoso e indispensável é a instrução primária largamente difundida e convenientemente ensinada (São Paulo, 1890).

Por recomendação de Rangel Pestana, Prudente de Moraes nomeia Antonio Caetano de Campos executor dos planos de ação, inicialmente cogitara-se o nome de João Köpke. Durante 20 meses, a partir de janeiro de 1890, Caetano de Campos conduz a cadeira de Biologia e a direção da Escola Normal. ${ }^{64}$

Outrora médico clínico na Santa Casa de Misericórdia e Beneficência Portuguesa, professor na Sociedade Propagadora da Instrução, Colégio Pestana e Escola Primária Neutralidade, de propriedade de João Köpke e em sociedade com o "tribuno da República", Antonio da Silva Jardim, Caetano de Campos, é personalidade em evidência. Na juventude, sob a proteção do barão de Tautphoeus, cursa os estudos preliminares com o propósito de ingressar na faculdade de Medicina do Rio de Janeiro. Diplomado, atua como cirurgião da Armada na Guerra do Paraguai, ao retornar à vida civil, inscreve-se no concurso para professor na Faculdade de Medicina: aprovado, não vê o direito reconhecido, contrariado, transfere-se para São Paulo.

Grosso modo, o liberal-federalismo das vanguardas intelectuais e das elites proprietárias paulistas compartilha as fórmulas metafóricas desdobradas dos cientismos vogantes - "darwinismo social", "sobrevivência do mais apto" e outras mais. Ao redor do editor e livreiro Abílio A. S. Marques, por exemplo, reúnem-se políticos e intelectuais de calibre: Américo de Campos, Américo Braziliense, Joaquim Ribeiro de Mendonça, Miranda Azevedo, Silvio Romero, José Leão. Na "Biblioteca útil”, empreendimento editorial orquestrado

${ }^{64}$ Pensamento científico, estrutura curricular, formação de professores, dimensões da Escola Normal constam em Monarcha (1999), Reis Filho (1981) e Tanuri (1979). 
por Abílio A. S. Marques, são publicados Do espírito novo, de Augusto Comte, Traços gerais de linguística, de Júlio Ribeiro, Soluçôes positivas da politica brasileira, de Luiz Pereira Barreto, Da educação, de França Leite, Darwinismo, de Caetano de Campos, e A teoria da seleção aplicada à sociedade, de Rangel Pestana, conforme anúncio n'O Estado de S. Paulo. Bem seja, no modelo materialista de Caetano de Campos, convergem as fontes teóricas de um ensino condizente com a fisiologia do organismo humano. "Já não há empirismo; há ciência da educação do homem. É da psicologia da infância que se deve deduzir o melhor modo de ensiná-la" (Caetano de Campos, 1891, p.5). O reformador pleiteia uma reforma consoante a civilização do momento. "A educação do homem moderno exige uma notável soma de conhecimentos, que resultam sinteticamente das noções enciclopédicas hauridas em diversos ramos do estudo."

Setembro de 1891. A morte prematura irmana Caetano de Campos à sina de Benjamin Constant, igualmente o canteiro de obras quedará incompleto. Anexa à Escola Normal, visando desenvolver as faculdades intelectivas dos alunos, a Escola-modelo continuara a demonstrar métodos e processos de ensino menos teóricos e mais empíricos, menos escolásticos e mais ativos. $\mathrm{Na}$ direção da seção feminina, Maria Guilhermina Loureiro de Andrade, na seção masculina, Márcia Browne, ambas indicadas por Horace Lane, diretor da Escola Americana. No tempo republicano, os métodos de ensino e os processos didáticos ali demonstrados e praticados conquistariam propagadores apaixonados.

\section{Gabriel Prestes conclui o canteiro de obras}

Desde os debates na Comissão de Instrução Pública do Congresso Estadual, Gabriel Prestes, professor primário diplomado pela Escola Normal, afervora o poder agregador da escola. "É preciso que, como Garfield, vejamos a escola o único meio de evitar a ruína da República, e que baseados nesse pensamento, sigamos os exemplos 
dos povos que melhor souberam compreender essa verdade" (Prestes, 1893, p.17). Tocado pela experiência francesa, Gabriel Prestes reclama a criação de uma escola normal superior dotada de museu pedagógico. E sob o lema - "bem aprender a fim de bem ensinar", denega os "antigos processos metafísicos"; no lugar da pedagogia escolástica, preconiza o modo correto. "Partir do simples para o composto; do indefinido para o definido; do concreto para o abstrato; do empírico para o racional, ensinando pouco e fazendo descobrir muito" (Prestes, 1893, p.64). Promulgada a Constituição Estadual, em 1891, fixava-se a competência do Congresso para legislar o ensino primário, secundário, superior e profissional. Mudanças na política conduzem Bernardino de Campos ao governo estadual. ${ }^{65}$

Em sua eloquência, a Lei no 8 , de 8 setembro de 1892, reorganiza o ensino público sob as seguintes bases: curso primário modulado em preliminar, obrigatório até a idade de 12 anos, e complementar. Nas localidades com 20 a 40 alunos matriculáveis, constaria uma escola preliminar; em havendo menos de 20 alunos, apenas uma escola mista; para cada dez escolas preliminares, haveria uma complementar; a juízo do Conselho da Instrução Pública seriam criadas escolas ambulantes e escolas para adultos. Para formar professores dos cursos preliminares e complementares, seriam instaladas quatro escolas normais primárias; em anexo à Escola Normal, seria instalado um Curso Superior para formar professores de escolas normais primárias e ginásios.

Anualmente, o governo consagraria 500:000\$000 para a construção de edifícios escolares, preferindo-se os municípios que contribuíssem pecuniária e materialmente. A direção do ensino caberia ao presidente do Estado, auxiliado pelo Conselho Superior de Instrução integrado por inspetores distritais, diretor-geral, diretores de escolas normais e escolas-modelo, um professor eleito pelo professorado primário e outro pelo professorado ginasial. O governo contrataria a impressão de livros e mapas, forneceria gratuitamente cadernos, pedras, lápis e objetos escolares, compêndios adotados e objetos escolares.

${ }^{65}$ Cf. Motta (1947) e Rodrigues (1945). 
Embalada pelo ativismo republicano, a Lei no 169 , de 7 de agosto de 1893, adita disposições à Lei no 88, dentre outras, sanciona a criação de um curso normal de quatro anos e programa de matérias alocado em 17 cadeiras. É quando Gabriel Prestes assume a direção da Escola Normal. Organizado em tópicos, por exemplo, o programa da $14^{\text {a }}$ Cadeira, Pedagogia, é por assim dizer, dotado de valor de demonstração das aspirações esclarecidas sancionadas pelos antepassados da pedagogia.

$1^{\text {o }}$ - Ideia sumária da evolução social e mental das sociedades humanas. Sua evolução pedagógica, solidariedade existente entre uma evolução e outra. Lei fundamental da evolução pedagógica. $2^{\circ}$ - A evolução pedagógica na antiguidade oriental e no período clássico. $3^{\circ}-$ A evolução pedagógica na Idade Média e Moderna. $4^{\circ}$ - Pedagogistas célebres: Comenius, Locke, Rousseau. $5^{\circ}$ - Ação pedagógica da Revolução. Pestalozzi, sua ação pedagógica, sua influência na escola popular. $6^{\circ}$ - Fröebel: caráter pedagógico de sua concepção. Comparação entre Comenius, Rousseau, Pestalozzi e Fröebel. $7^{\circ}-$ Herbert Spencer. Situação atual da evolução pedagógica. Instituição da Ciência da Educação. ${ }^{66}$

Dispositivos legais minuciosos, Regimento Interno das Escolas Públicas e Regulamento da Instrução Pública sobreditam o ritmo dos afazeres diários. Neles, os dispositivos, reverenciadas como "colaboradores da felicidade nacional", conclamam as fileiras do magistério a aderirem aos programas matérias e métodos de ensino utilizados nas escolas-modelo.

Tratava-se de prevalecer o tirocínio concreto dos alunos, como bem apregoava A Escola Pública, subintitulada "Pedagogia prática", revista com lições-modelo de linguagem, aritmética, ciências naturais. Ademais, note-se, os programas dos grupos escolares e das escolas provisórias preliminares são organizados de acordo com a trilogia spencerista. O programa de educação física previa marchas e o ensino com armas: noções da nomenclatura da arma, manejo da arma com

${ }^{66}$ Cf. Prestes (1894). 
sabre-baioneta armado ou desarmado. $\mathrm{O}$ de educação moral, deveres da moral individual: temperança, prudência, coragem, sinceridade, cumprimento da palavra, dignidade, trabalho. $\mathrm{O}$ de moral social: deveres de justiça, caridade, familiar, profissional, cívico e das nações entre si. Enciclopédico, o programa de educação intelectual envolvia leitura, linguagem, caligrafia, aritmética, geometria, desenho, geografia, cosmografia, história do Brasil, educação cívica, botânica, zoologia, física, química, geologia, leitura de música e canto.

Nas vestes simples de apóstolo do futuro, o imperativo moral parece devorá-lo, a Gabriel Prestes, arquétipo do republicanismo na República, não bastava falar em instrução, era preciso vivê-la intensa e racionalmente. Respeitável professor de Astronomia na Escola Normal, proeminente sectário da Sociedade Positivista de São Paulo, para José Feliciano de Oliveira, a gestão de Prestes representou o "período áureo" da instrução paulista. "Num lustro ou mesmo sete anos (1892-1899), que ele consagrou a reformas e a direção do ensino público, Gabriel Prestes, sem contestação documental, tornou-se o primeiro 'educacionista' de São Paulo, como disse Valentim Magalhães” (Oliveira, 1932, p.11).

\section{Demais inovações}

Desde a última década do Império, Gabriel Prestes debatia a organização funcional do ensino elementar, desde então propugnava a instalação de "escolas centrais" organizadas em ciclos. Em discurso na Câmara dos Deputados, exalta a superioridade da organização empírica das escolas centrais de Lisboa, Porto, Bruxelas e certas capitais da América. "Para criá-las não é preciso nada mais do que reunir em um só prédio as diversas escolas que funcionem no mesmo bairro, acrescentando ainda a circunstância de ficar ao Governo a mais ampla liberdade para organizá-las convenientemente, atendendo e remediando as deficiências que só a prática pode indicar" (Prestes, 1893, p.11). 
A Lei no 169 concretiza tais aspirações. Em efeito, ao existir mais de uma escola no raio fixado para a obrigatoriedade, o Conselho Superior poderia fazê-las funcionar em um único prédio. Surgem os grupos escolares, a "criação mais feliz da República" na voz de um contemporâneo dos acontecimentos. Os novíssimos estabelecimentos singularizam-se pela "metódica distribuição do ensino" -, um professor por classe, gestão unificada na pessoa do professor nomeado pelo governo, investido de poder diretivo e função pedagógica. No palavreado douto de Alfredo Pujol, secretário dos Negócios do Interior.

A reunião de escolas, sob a denominação de Grupos Escolares, tem produzido resultado fecundo, quer pelo lado do aproveitamento, quer pelo da disciplina: o ensino. Dividido em cinco anos, cada qual a cargo de um professor, oferece incontestáveis vantagens; revive a emulação entre os mestres, mantêm-se o estímulo entre as crianças, facilita-se a inspeção, diminuem-se os encargos do Estado, quanto à construção dos prédios escolares (Pujol, 1896, p.39).

Como resposta à pressão demográfica, instalavam-se grupos em aglomerados urbanos da capital e do interior do estado; nas zonas de populações rarefeitas, prevaleciam as escolas reunidas e isoladas. Em 1893, o Decreto no 218, de 27 de novembro, aprova o Regulamento da Instrução para execução das leis no 88 e no 169 . Dentre outros, regula os cursos complementares de Itapetininga, Piracicaba e o curso anexo à Escola Normal da capital. Na sequência, o Decreto no 400, de 16 de novembro de 1896, sanciona fatos da realidade.

As escolas complementares são estabelecimentos de ensino público, destinados a explicar e completar o ensino primário de modo a facilitar a formação de professores preliminares mediante a necessária prática didática nas escolas-modelo do Estado (artigo $1^{\circ} \S 3^{\circ}$, da Lei no 88 e artigo $1^{\text {o }} \S$ único da Lei no 371$)$. 
Seja como for, na década de 1910, em severo processo de adensamento demográfico, adotava-se o desdobramento e tresdobramento de turnos dos grupos escolares. E fosse a quantidade que fosse de estabelecimentos, muitos afogados em dificuldades, afloravam os vincos demarcatórios da escola paulista (e brasileira): evolução positiva da matrícula inicial, seguida de reprovação, abstinência e deserção de alunos.

\section{Teofania republicana, o ativo reformador.}

Da potência prática e inventiva dos planos, da condensação retórico-discursiva de Benjamin Constant, Rangel Pestana, Caetano de Campos e Gabriel Prestes, entre tantos mais, professores laicos e missionários dos valores de "15 de novembro de 1889", a ânsia de uma Humanidade fraterna une os preceptores do homem-povo. E sob o pressuposto de uma pedagogia atraente, firmava-se a ubiquação pragmática da instrução popular cujos axiomas assim podem ser enunciados: "professor da nação", o Estado incentiva as virtudes privadas e públicas; a escola pública como via e meio de iniciação social; a educação da infância em correspondência, quer no modo quer na ordem, com a evolução da humanidade considerada biológica e historicamente; processos atraentes de autoeducação, quer dizer, ativos, concretos, intuitivos. E suma, força centrípeta, a instrução integral fiaria a ordem contratual e velaria a concórdia social; noutros termos, pela instrução primária de Estado, o eu individual se converte em o nós social. No tempo histórico e seu trabalho de diferença, instituiçãochave, a escola primária de Estado abrir-se-ia às massas.

\section{Da obrigatoriedade}

Na primeira década republicana, a demanda de obrigatoriedade de uma escolaridade comum a todos retorna, atentos à providência social, legisladores e administradores estaduais revalidam o estatuto 
da obrigatoriedade outrora formulado pelos estadistas da monarquia. No Pará, o governo de Justo Leite Chermont, com José Veríssimo à frente da diretoria-geral da Instrução, aprova o Regulamento de 7 de maio de 1890 ao declarar a obrigatoriedade de frequência em escolas públicas das cidades, vilas, povoações para crianças de 6 a 13 anos. Ficariam desobrigadas crianças portadoras de incapacidade física e mental, indigência ou aquelas que recebessem instrução em casa ou de escolas particulares; pais tutores, professores, proprietários, gerentes de estabelecimentos omissos penalizados com multas de $30 \$ 000$, se admoestados por escrito pela autoridade, em $50 \$ 000$, se reincidentes, em 100\$000, se despossuídos de recursos, prisão de 24 a 48 horas.

Em São Paulo, o presidente do estado, Bernardino de Campos, secundado por Cesário Motta Júnior, amparado nas leis $n^{\circ} 88$, de 8 de setembro de 1892 e no 169, de 7 de agosto de 1893, aprova o Regulamento da Instrução, Decreto no 218, de 27 de novembro de 1893, 529 artigos e centenas de parágrafos. O regulamento estatui a obrigatoriedade em 17 artigos desdobrados em parágrafos imperativos: obrigadas as crianças de idade entre 7 e 12 anos, à exceção das residentes a dois quilômetros da escola mais próxima, se meninos, e um quilômetro, se meninas. Isentadas as que sofressem de inabilidade física ou intelectual ou instruídas em casa ou em escolas particulares. Mais ainda, o regulamento determina o recenseamento escolar anual, a cargo do inspetor do distrito, comunicando-se os resultados aos presidentes das municipalidades, cabendo-lhes executar matrículas ex officio, aplicar multas, realizar exames em crianças instruídas em domicílios. Além mais, os inspetores distritais provocariam as autoridades municipais a proclamarem em editais públicos a abertura das aulas, locais horários de funcionamento das escolas. Passados 30 dias da abertura das aulas, a falta de declarações dos pais, tutores e patrões quanto à educação dos filhos, tutelados, curatelados, empregados, importaria em matrícula ex officio, e multa de $10 \$ 000$, duplicada na reincidência.

No Maranhão, o presidente, capitão-tenente Manuel Inácio Belfort Vieira, aprova o Decreto no 94 , de $1^{\circ}$ de setembro de 1891, 
dentre outros, proíbe os castigos corporais, e declara o ensino primário leigo, gratuito, obrigatório. "Mas essa obrigatoriedade era toda platônica, porquanto não encontrava sanção em lei. $\mathrm{O}$ bacharel Alfredo da Cunha Martins reorganiza o ensino de acordo com a lei de 15 de maio de 1893, que no artigo 7o determinava ser o ensino primário gratuito, sem cogitar, porém da obrigatoriedade desse." Conforme notação de Henrique Costa Fernandes (1929, p.247), em Administraçôes maranhenses: 1822-1929. É de supor que a vida social e/ou comunitária circunscreve-se ao raio da obrigatoriedade escolar. Igualmente ao Império, o estatuto da obrigatoriedade continuaria a ser debatido no âmbito das relações humanas, políticas e jurídicas. Para muitos e muitos, a emancipação do Brasil mental e social começaria pelo aclaramento das consciências individuais. Nessa ordem de certezas, a instrução pública, divisa mágica a palpitar no entendimento ilustrado, é o baluarte das instituições políticas e dos melhoramentos materiais.

\section{Do contraditório}

$\mathrm{Na}$ virada do século, dispostos a intervirem no curso dos acontecimentos republicanos, Raimundo Teixeira Mendes, Miguel Lemos, diretores do Apostolado Positivista do Brasil e demais sectários da Religião da Humanidade, e de Augusto Comte contraditam a obrigatoriedade escolar, em circulares do Apostolado Positivista e em artigos na imprensa. Apareciam Bases de uma constituição ditatorial federativa para a república brasileira, Exposição da doutrina positivista em relação à obrigatoriedade do ensino (1890), de Mariano Oliveira, Contra o ensino obrigatório (1902, 1ed. 1885), A obrigatoriedade do ensino (1890), Ainda contra o ensino obrigatório, a propósito do projeto apresentado ao conselho municipal desta cidade estabelecendo o ensino primário obrigatório (1908) e O Ensino primário oficial e a regeneração bumana (1913).

Consoante a singular dogmática positivista, a ingerência coerciva dos poderes públicos na vida familiar anula a função materna na formação 
da moral altruísta da prole. Tutelada pela mãe, a educação das primeira e segunda infâncias deve ser estética. No modo da Religião da Humanidade, o comtismo exalta as figuras da mulher e da família, pilares da ordem afetiva e doméstica, a sua vez, pilares da ordem pública. Pois bem aos olhos dos sectários da Religião da Humanidade, ao usurpar os direitos maternos, a instrução pelo Estado embarga a liberdade espiritual.

A obrigatoriedade do ensino, isto é, exigir que a criança frequente a escola consiste em uma agressão a organização familiar: destinado à segunda infância, semelhante ensino é um apanágio insubstituível das Mães. A escola primária é uma instituição dissolvente da Família, por isso que constitui uma usurpação das funções maternas.

Cada criança deve ser instruída, até a adolescência por sua Mãe, porque só a solicitude materna pode, - e, na Família, - reunir o conjunto de condições afetivas e mentais indispensáveis ao preparo da inteligência infantil (Teixeira Mendes, 1908, p.67).

Dos 14 anos em diante, o ensino instruiria o conhecimento sintético do mundo, sociedade, homem e natureza com recurso ao estudo sucessivo da matemática, astronomia, física, química, biologia, sociologia e moral.A essa etapa formativa, sucederia o ensino profissional em meios práticos de trabalho. Noutros termos, a dogmática singular recusa os conhecimentos regulados pelo Estado ou crenças religiosas: pensar e conhecer implica a livre adesão a uma das doutrinas codificadas em sistemas de pensamento, dentre elas o positivismo de Augusto Comte. Em tom de crítica social e grande estilo argumentativo, querse dotar a República de arcabouço intelectual, espiritual e político, Teixeira Mendes contraditava. A formação dogmática levava-o a recusar a obrigatoriedade, grave obstáculo à cultivação de sentimentos altruístas necessários à regeneração da Humanidade.

A escola primária, como a creche, o asilo, o hospital, etc., são instituições atestando a miséria extrema em que se acha a família 
proletária, em virtude da dissolução geral da sociedade. Todas essas instituições resultam de tal dissolução, e tendem a fomentá-la, quando não se tomam as cautelas necessárias. Porque as paixões egoístas e a cegueira das classes dominantes as levam a erigir tristes expedientes, sugeridos por uma época de profunda e imensa subversão social, em instituições normais, destinadas a manter as posições burguesocratas (Teixeira Mendes, 1908, p.67).

Ou por outra, elaborada sob a doutrina positivista, a Constituição do Rio Grande do Sul, território de circulação e aprovação da moral política sobreditada pelo comtismo, por decisão dos líderes do Partido Republicano Rio-grandense, Júlio de Castilhos, Demétrio Ribeiro, Borges de Medeiros, sancionava a prevalência do Poder Executivo, a liberdade espiritual, o ensino livre, a liberdade de profissões pela supressão dos privilégios escolásticos ou acadêmicos e a não obrigatoriedade.

\section{A boa didática}

Por assim dizer, a primeira década do novo regime assiste à celebração compensatória da vida nacional e da moral republicana, quer dizer não do estrito combate ao passado corroído, mas do ensino do amanhã. $O$ afã de uma humanidade fraterna une os sujeitos do republicanismo educativo, regenerada pelo saber científico, a pedagogia escolar aparece como sábia invenção técnico-normativa por assim dizer; para insinuar-se na alma infantil, o bom autor didático associaria a mestria da palavra às leis da evolução mental da criança e seu grau de cultura. Esse é o instante feliz dos compêndios in- $8^{\circ}$ no formato de brochura ou capa cartonada ilustrada com cenas evocativas.

Nos critérios das comissões do livro didático, a boa didaticidade reside na linguagem escorreita, na propriedade do assunto, no método e na clareza de exposição. O modelo-fundador é Cuore de Amicis, primoroso produto do Risorgimento italiano em tradução de João Ribeiro, narrativa original em primeira pessoa no formato de diário, cujos valores 
atiçam a brasa do amor à pátria e família e, claro, dedicação à escola. ${ }^{67} \mathrm{E}$ de então os bem-sucedidos, Cartilha das mães, de Arnaldo de Oliveira Barreto; Cartilha da infância, de Tomás do Bonsucesso Galhardo; Cartilha infantil, de Gomes Cardim; Cartilha analitico-sintética, de Mariano de Oliveira; Prática da língua portuguesa, de Olavo Bilac; Gramática portuguesa, de João Ribeiro; Princípios de composição, de Guilherme Prado; Aritmética escolar, de Ramon Rocca Dordal; Meu livro, de Theodoro de Moraes; Leituras morais e instrutivas para uso das escolas primárias e Grande pátria, ambos de João Köpke; Leituras morais, de Arnaldo de Oliveira Barreto; Coisas brasileiras, de Romão Puiggari; Primeiro livro de leitura, de Guilhermina de Andrade; Contos infantis, de Adelina Lopes e Júlia Almeida; História de São Paulo e Geografia elementar, ambos de Tancredo do Amaral; A terra fluminense (educação cívica), de Coelho Neto e Olavo Bilac, "unanimemente aprovado pelo Conselho Superior de Instrução do Estado do Rio de Janeiro" - "Neste livro, a História e a Fantasia andam unidas; e procuramos aproveitar os assuntos, de maneira que pudessem eles interessar não somente a inteligência, mas também o coração das crianças" (Coelho Neto; Bilac, 1898, p.10).

No rol comum dos cânticos de vitória, Festas nacionais de Rodrigo Otávio destoa com a esquentada (senão desiludida) carta-prefácio de Raul Pompeia, agregada ao compêndio. "A alma nacional segue sofrendo, dia a dia, o suplício de todas as dores” (1893, p.5). No mais, esse é o instante do método intuitivo, da didática centrada nas faculdades sensoriais a induzir a percepção das propriedades das coisas: forma, cor, som, grandeza, número, movimento, percepção acompanhada de expressão pictórica e escrita. Nas tantas idealidades, acatava-se a trilogia ler-escrever-calcular como propedêutica à educação integral de seres viventes em condição de isonomia. Comocionadas, as vozes dos homens públicos, vozes sonoras senão altissonantes, ritualizavam a urgência de uma instrução insertada em sistemas articulados em níveis e hierarquizados. Virada do século, a escola de instrução primária tende a integrar-se nas estruturas gerais do país.

${ }^{67}$ Cf. D’Ávila (1946). 


\section{Parte IV}

\section{Da política dos governadores à década dos centenários}

O Brasil é um mosaico. No espaço e no tempo. Geograficamente, já mais de uma vez tem sido apontado que este país é constituído por uma contiguidade territorial que não significa continuidade. Do "inferno verde" amazônico às planícies pampianas do Rio Grande do Sul, dos areais litorâneos nordestinos aos pantanais de Mato Grosso, todos os climas e todos os aspectos geofísicos se acotovelam na vastidão brasileira.

Através do tempo, a história pátria é formada de episódios destacados, de capítulos mal cosidos, de evoluções distintas que obedecem a ritmos diversos, uns mais acelerados, tardos e lentos outros, a tornar confuso e duvidoso o paralelismo de suas diretrizes.

Vivaldo Coaracy, “O caso de São Paulo” (1931) 



\section{Sobre a natureza do bom e do mau governo}

O entrelaçado da Primeira República é por assim dizer traumático. Os desnorteios da ordem federativa agitam descontentamentos, vem à tona o requisitório do avesso da "coisa pública". Numa espécie de maiêutica ensimesmada, questionava-se: Que há feito a República para elevar o nível moral do povo? O país está à altura dos usos civilizados? Onde a grandeza do republicanismo?

Conforme os tratados historiográficos acerca das refregas políticas, a fase dos presidentes militares sucede à ordem civil de conteúdo político pragmático e acomodatício dos interesses locais, à "política dos governadores", arranjo consolidado nos mandatos presidenciais de Campos Sales e Rodrigues Alves, neles acionara-se a máquina hegemonizada pelos mandatários dos partidos republicanos estaduais. "É de lá [dos estados] que se governa a República, por cima das multidões que tumultuam, agitadas, nas ruas da capital da União", verbera Campos Sales (1983 [1908], p.23) em Da propaganda à presidência.

A descentralização e/ou federalização, conjugadamente à apropriação da receita de exportação, gera blocos oligárquicos abrigados nos PRs. Em termos histórico-sociais, transitava-se do mandonismo do Império ao coronelismo da República, em essência, o fenômeno é o mesmo, o chefe político local e o município como esteios do jogo político. ${ }^{68}$ Ao assegurar consenso interoligárquico

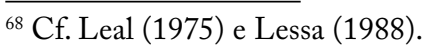


relativamente às eleições presidenciais, a política de reciprocidade reduz a presença do poder federal nos Estados. De mais a mais, não constava a obrigatoriedade de voto e, por não ser secreto, assujeitava-se à pressão dos coronéis e caudilhos, via de regra, convertia-se em objeto de troca entre pequenos e grandes.

Em nome da fórmula definitiva da civilização do momento, liberalismos e regionalismos seriam colocados de lado pela Revolução de Outubro de 1930. Enquanto isso não acontecia, a hegemonia nos processos decisórios, protagonizada por São Paulo e Minas Gerais, interrompe-se momentaneamente em 1910 por ocasião das primeiras eleições presidenciais competitivas: num lado, marechal Hermes da Fonseca, apoiado por Minas Gerais e pelo gaúcho Pinheiro Machado, noutro lado, Rui Barbosa e a "campanha civilista" apoiada por São Paulo e Bahia. Durante o mandato presidencial, o marechal deflagra as "salvações nacionais", ao destituir as oligarquias no poder em Pernambuco, Bahia, Ceará e Alagoas. O mandato transcorre entre dissidências, crise nas finanças, insurgências e motins - Revolta da Chibata, criação do Partido Republicano Conservador por Pinheiro Machado, levantes de setores do Exército, Sedição de Juazeiro e Guerra do Contestado.

\section{Amarguras dos veteranos da "República de 89"}

Os arranjos na grande política colocam em xeque a doutrina do governo do povo, para o povo e pelo povo, deletério, o primarismo dos profissionais da política corrói o regime. A exteriorização das contradições internas, crises extensas e profundas das estruturas tornase perceptível aos olhos dos contraditores. ${ }^{69}$ Do pacto adstrito das elites contestatárias emanam chamamentos à comunhão nacional, nas muitas análises atribui-se o definhamento do regime ao liberalismo de cópia, ao federalismo excessivo, à anarquia mental e ao desregramento

${ }^{69}$ Cf. Carone (1976, 1977) e Fausto (1970). 
originado pela politicagem. ${ }^{70}$ Entalhada com argumentos bempensantes a retórica dos contraditores promove a intelecção das malquistadas disfunções do Brasil social -, nas muitas vozes, o regime desmentia-se, no Alto, entre as elites, ambição incontida de mando e insobriedade, no Baixo, entre as classes populares, ausência de vontade e alheamento nos processos decisórios. $\mathrm{Na}$ retórica crítico-negativa, o país aparece tardio, melhor, atrasado na corrente civilizatória, afastado do espírito do século, a vagar em lento desmoronar. Intimorato crítico social, diretor da Instrução Pública, professor de Psicologia e Pedagogia na Escola Normal do Distrito Federal, Manoel Bomfim verberava, a República encontrava-se sob o domínio de um gênio maligno, entidade fabricante de ilusões.

Adota-se o regime republicano para possuir-se esta coisa mirífica - República! [...] não pensam que tal regime tenha sido adotado por aquele capaz de dar ao povo a maior dose de felicidade, e que é por isso, unicamente e exclusivamente por isso, que ela deve existir. Era um estado social melhor que se pedia, quando se pedia República. Sim, esta palavra, só ela transportava os corações, porque em cada letra ardia um ideal: justiça, reparação, solidariedade, beleza nas almas e nas coisas (Bomfim, 1993 [1905], p.201, grifo do autor).

\section{No meio do fórum, troantes as vozes engajadas}

No âmbito das relações internacionais, a Grande Guerra colocara em xeque a estabilidade da civilização ocidental e, em

70 "Esvaziado o ideário republicano pelo progressivo afastamento dos ideólogos, a República, que não tivera tempo de se popularizar, nem razões para a conquista de prestígio junto ao povo foi tragada pelos que dela fizeram apenas um expediente continuísta para os interesses econômicos e políticos estabelecidos. Dessa maneira, quando a historiografia republicana refere-se à República oligárquica, tal denominação encerra um dado de realidade, ou seja, uma verdade objetiva, mas também uma avaliação implícita da derrota do ideário republicano" (Penna, 1999, p.88). 
muitos países, entravam em andamento programas de reforço e centralização do aparato estatal. No Brasil, em particular, o Estado, esteado na doutrina liberal, convertera-se em alvo de contestação, recrudescia o chamamento por um poder indivisível, fiador de interesses gerais, promotor e provedor de melhoramentos materiais, enfim um poder racional.

Se o gênio da República se encontrava em declínio solar, se o regime estava em estado de glaciação, se os governantes recorriam a contraverdades, se o Estado não detinha a função de governo geral, se a democracia era ilusória, se o país era episódico, se a nação não falava de si e por si, se o povo era vazio de pensamento, era preciso, assim se imaginava, que alguém tomasse o poder da palavra e a eficácia da ação. Em efeito, na sua multiplicidade visionária, homens públicos de talentos multiformes trazem para si os exames das antinomias da realidade. Em linguagem breve, exteriorizavam a intelectualização dos processos socioculturais conflitivos no intento de dominá-los e solucioná-los. $\mathrm{Na}$ intelectualização, prevalece o elogio do poder de Estado, instrumento agregador num território geograficamente delimitado e do culto a Nação, comunidade humana, historicamente constituída e unificada pela língua e cultura. Entrava em andamento a investidura de homens públicos provenientes de horizontes e firmamentos distantes conquanto entrelaçados por desejos comuns, a saber, endireitar os caminhos nacionais. Vozeava-se para que pensar o Brasil senão para oferecer-lhe significações e valores virtuosos, senão para cessar a debilitação do senso moral, senão para conformar um destino isento de parcialidades políticas.

$\mathrm{Na}$ conflagração dos discursos formulados em linguagem de profecias, tornara-se evidente que a mecânica cega das vontades únicas tornara-se anacrônica. Da refutação ao abstencionismo do Estado, os contraditores evoluem para a doutrina do Estado como centro unitário e da nação como sentido do país. O que por certo não significa dizer que o Estado estivesse ao largo das questões econômicas, políticas e sociais, basta citar o Convênio de Taubaté, as leis de imprensa, o combate às 
sublevações militares, a repressão política, as decretações de estado de sítio, a outorga da legislação social. Dispostos a protagonizarem um Brasil renovado, reconhecendo-se como parentes, diferentes sujeitos, em diferentes lugares e propósitos, trazem para si o imperativo da ação transformadora. Proliferam interpretações das realidades mais gerais, algumas de maior fôlego, outras nem tanto, algumas originais, outras não, contudo irmanadas na pré-figuração de uma "nação imaginada". ${ }^{71}$ E, ao delatar o contraditório entre a "República das altas esferas institucionais" e a "República do povo", entre a nação juridicamente idealizada e o país das franjas urbanas e grotões habitados por populações alheias à vida coletiva e ao sentimento comum. Voluptuoso, o verbo social quer atingir o fundo sólido da vida civil, por essa e outras razões, multiplicam-se as interpretações da vida social, quase sempre excessivamente retóricas, quase sempre excessivamente declamatórias. Nelas, as interpretações, uma impetuosidade, expor o país inteiriço, desvelar, guiar, tirar a venda, purgar o corpo enfermiço.

A República aparece aferrolhada à imagem da decadência, o federalismo rodeado de suspeitas, o analfabetismo o grande mal. E, aos motivos constitutivos da trindade republicana, liberdade, igualdade, felicidade, acrescenta-se o motivo da unidade-unitária pela ação social da instrução elementar constituída e instituída em dimensão nacional. Nos contraditórios infindáveis, a função catalisadora antes concedida à ideia de civilização dará lugar às noções de civilização industrial e, sobretudo, de modernização.

No movimento difuso, aspirações de democracia, progresso, voto esclarecido, recrudesce o apelo à agregação moral pela via da escola primária de Estado. "Compreende-se, por ventura, uma democracia donde $90 \%$ dos indivíduos são excluídos por analfabetos. Povo, consciente de sua existência, tal como o exige uma democracia, não existe aqui; é preciso fazê-lo" (Bomfim, 1993 [1905], p.46-47). Desde que organizada e coordenada num sistema nacional, cogitava-se, a instrução popular exerceria efeitos dinamogênicos sobre as energias

${ }^{71}$ Cf. Anderson (1991, 2007). 
sociais. Nos chamamentos, o sinete do momento: despertar o país do sono comatoso, cessar o indiferentismo, abrandar os costumes, dirigir o povo inculto, modernizar as estruturas, esclarecer o voto, combater o analfabetismo. E, ao assumir a extensão da escola como salvaguarda da nacionalidade, os portadores de futuros possíveis firmam a identidade reputada de sujeitos sabedores dos meios (e técnicas) congregantes do corpo coletivo.

\section{Capital Federal, observatório da vida coletiva}

Intérminos, os debates e juízos sobre passado, presente e futuro concentram-se na Capital Federal, lugar determinante dos modos de pensar o país, sua história, sociedade, cultura, e claro, transes coletivos. Intentando elevar a Capital Federal à altura da civilização do momento, realizavam-se reformas urbanísticas, obras de saneamento e combate aos surtos de febre amarela, cólera, tuberculose, varíola e peste bubônica. ${ }^{72}$ No front sobressaem Oswaldo Cruz, médico sanitarista, Lauro Muller, Paulo de Frontin, engenheiros, e Francisco Pereira Passos, prefeito conhecedor da reforma de Paris executada por Haussmann, engenheiro-prefeito designado por Napoleão III.

No sóbrio dizer de um cronista da Belle Époque carioca, "o Rio civiliza-se”, breve apreciação assinaladora de transformações de hábitos e costumes, o que, por ventura, não significa hoje atestar realidades róseas; sem meias-tintas, Azevedo Sodré, diretor-geral da Instrução Pública, exarava duras palavras. " $\mathrm{Na}$ sua quase totalidade, as nossas escolas públicas se acham instaladas em prédios de aluguel, construídos para residências particulares, e onde as classes funcionam em saletas, quartos, copas, cozinhas e porões, em flagrante divórcio com os mais rudimentares preceitos da higiene e da pedagogia" (Sodré apud Corrêa, 1916, p.51).

Como dito, em maior parte da Capital Federal, emanam os ajuizamentos dos movimentos milenaristas, bem como denúncias

${ }^{72}$ Cf. Pechman e Fritsch (1985). 
dos descaminhos do regime, equívocos dos governos civis e militares e, sobretudo, das condições sanitárias dos sertões extensos e das cidades densamente povoadas. Nas muitas análises, nas muitas vozes, confrontam-se as imagens dos desequilíbrios. No dizer de Euclides da Cunha (1907, p.30. "O verdadeiro Brasil nos aterra; trocamo-lo de bom grado pela civilização mirrada que nos acotovela na Rua do Ouvidor.”

Nos lotes interpretativos das realidades do país, baldados os esforços, tirante a orla litorânea onde se concentravam as grandes e médias cidades, constatava-se a existência de um país distante de si, melhor, de lugares minados por falares engrolados, tradições semicoloniais e modos desusados de trabalhar e viver. Realistas aos olhos dos contraditores, o Brasil, continente distendido e indeterminado, de territorialidade vasta e inculta, era frágil Estado geográfico e prénacional. Nos circuitos intelectuais, literários e políticos, enfim nos circuitos da inteligência brasileira, debatia-se a difícil territorialização do poder de Estado, num país de impressionantes diversidades étnicoculturais e profundas desigualdades sociais. ${ }^{73}$ Para a razão racionalista que articula conhecimento, planificação e intervenção, desde que provido de instituições sociais e técnicas de governabilidade, o Estado exerceria um poder corretivo aos excessos e desníveis desagregadores.

\section{Nação enferma, país no microscópio}

As projeções mentais sobre-excedem a crueza dos fatos de realidade e, embora cada intérprete os descrevessem a bel-prazer, havia consensos: riscos de cissiparidade, escassez de comunicações, territórios escandalosamente desamparados, depauperação do povo, bruteza de modos de viver, individualismo desordenado, perversão do senso moral.

73 "Em outras palavras, para construir um tipo específico de nação, os líderes precisariam estender o alcance do governo brasileiro àqueles que, a exemplo do perplexo fazendeiro de Santa Catarina, não reconheciam nenhum dos símbolos da nação nem seu governo" (Diacon, 2006, p.22). Para o autor, a rigor existiam duas instituições nacionais, o Exército e a Igreja católica. 
Fecho os olhos, um momento, e passam nitidamente na tela da minha memória, as praias do Norte, de coqueirais, sussurrantes, com a sua população de impaludosos e catequéticos, tremendo de maleitas, o dia inteiro, ou certos trechos dos sertões do sul, terras malditas de barbeiros e opilados.

E aqui, ali, por toda a parte, sob o sol ardente do Norte, ou sob o frio dos sertões paranaenses, a mesma sub-raça de indolentes e vencidos, vivendo ao Deus dará, esquecidos dos senhores do país, cem anos distanciados da civilização contemporânea (Bello, 1918, p.124, grifo do autor).

Decretavam-se judiciosas ordens de certezas, na sua escassez, a instrução e a saúde flagelavam a nacionalidade, de modo que as inauditas formulações - "instruir para sanear" e "saneamento pela educação" - estalavam nas línguas dos partidários de um poder central no aprovisionamento de serviços públicos. De sorte que nas primeiras décadas do século XX, o sanitarismo fez-se presente pelas ações dos cientistas-expedicionários do Instituto de Oswaldo Cruz, "Manguinhos". A rigor palmilham áreas da Bahia, Ceará, Goiás, Minas Gerais, Pernambuco, Piauí, São Paulo, Amazônia e vales dos rios São Francisco e Tocantins, inspecionando as regiões-sedes de projetos em grande escala - hidrelétricas da Companhia Docas de Santos e Ligth and Power, reservatórios de água, prolongamentos ou construções de estradas de ferro, Central do Brasil, Noroeste do Brasil e Madeira-Mamoré. De par, efetuam estudos encomendados pelas superintendências de Obras Contra a Seca e de Defesa da Borracha.

De caráter ativo e documentário, um dos resultados das expedições consiste na elaboração de surpreendentes relatórios médicos, etnográficos e sociológicos. ${ }^{74}$ Obra-prima do registro documentalista Viagem cientifica pelo norte da Babia, sudoeste de Pernambuco, sul do Piauí $e$ de norte a sul de Goiás, dos médicos-sanitaristas Belizário Penna e Arthur Neiva é o melhor exemplo. "Os sertões que conhecemos, quer

${ }^{74}$ Cf. A ciência a caminho da roça... (1991). 
os do extremo norte quer os centrais quer os do norte de Minas, são pedaços do purgatório, como no-lo pintam os padres, onde se purgam os pecados em vida, sem outra compensação que a inconsciência em que cai o desgraçado que nele se afunda” (Neiva; Penna, 1916, p.35). $\mathrm{E}$, ao delatarem as misérias físicas e morais das populações, deploram quadros fantasmáticos. Desse registro documentalista, defluem análises médico-etnográficas concernentes aos modos de viver a vida do país interior. Convictos de si, médicos higienistas, sanitaristas desencadeiam campanhas visando à constituição de populações hígidas, imunes às doenças tropicais e à ignorância. Tal como bem quis Aleixo de Vasconcellos (1924) em Luta contra o analfabetismo, de como esta campanha favorece o saneamento do Brasil. E apreciados em si mesmos como tonificantes, os temas saneamento e instrução são nacionalmente cadastrados sob o ângulo da economia política. Elucidava o médico Miguel Couto, em “A educação nos sertões”.

Pondo de parte outras causas possíveis de aviltamento na espécie, como certas doenças regionais, malária, doença de Chagas, a nutrição insuficiente ou avitamonósica e monótona, etc. três são, como acabamos de ver, as origens gerais da corrupção que campeiam nos nossos sertões, entrelaçadas, gerando-se e complicando-se mutuamente e indefinidamente: a verminose, o alcoolismo e a incultura. Se me perguntarem qual a maior, a pior, a genetriz, a que primeiro deve ser combatida com todas as forças concentradas, eu não hesito em responder: a incultura (Couto, 1937, p.108).

E prosseguia no encadeamento de soluções. "No que concerne a educação, não avanço porque ignoro, presumo apenas. Discutese pedagogia pelo menos desde Platão e Aristóteles; mas apesar da incessante produção de obras notáveis em todas as línguas e da diversidade de sistemas, de país a país, no que toca aos princípios gerais, J.-J. Rousseau, Basedow, Pestalozzi, podiam ser servidos e seguidos ainda hoje" (Couto, 1937, p.50-51). 
De mais a mais, em sua ambição terapêutica, o sanitarismo fez-se presente nas frentes de combate e propaganda de salubridade médicosocial: as ligas Contra o Analfabetismo, Pró-Saneamento do Brasil, Defesa Nacional, Nacionalista de São Paulo, Brasileira de Higiene Mental, Sociedade Brasileira de Higiene, Associação Brasileira de Educação e Sociedade Eugênica de São Paulo, ou seja, em associações civis dispostas a eliminar os extremos negativos.

Dentre outros, data de 1919, a criação do Departamento Nacional de Saúde Pública e do Serviço de Profilaxia Rural. Ao ministério da Justiça e Negócios Interiores, competiam os assuntos da instrução, para tanto era auxiliado pelo Conselho Superior de Ensino, substituído pelo Conselho Nacional de Ensino, em 1911, e posteriormente pelo Departamento Nacional de Ensino, em 1925. Unissonamente se reconhece e proclama a importância da instrução elementar nas democracias, único regime de liberdade.

São meras fiç̧ões legais os regimes democráticos que não se firmam no esclarecimento da pública opinião. Democracia e analfabetismo são termos que se excluem, são expressões antitéticas. Só pode ser chamado, a justo título, republicano o país cujos cidadãos estão em condições de cultura mental embora rudimentar de discernir o que é o interesse público (Medeiros, 1918, p.215).

As insuficiências do "aparelho didático" nacional legitimam os argumentos circulantes no Congresso Nacional, imprensa e estudos, a favor da participação do poder central nos serviços de instrução. Sobrinho e homônimo do marquês de Abrantes, e ex-ministro da Viação e Obras Públicas e da Agricultura, Indústria e Comércio, Miguel Calmon Pin e Almeida - a ele se deve a permissão de Maria Montessori para verter em língua portuguesa Método da pedagogia cientifica aplicado a educação infantil nas "Casas dos Meninos", replicava em As promessas e os resultados da pedagogia moderna. 
Mas, não é só aqui, nem só agora, que isso se vê: alunos semteto e professores sem-pão, de muito, que nos são familiares! Onde se viram escolas, construídas pelo povo e para o povo, desviadas dos seus lídimos fins, e até demolidas?! Onde se iniciam obras de grupos escolares, que se não acabam, despertando, nos moços, a impressão de que um povo acometido de caquexia precoce?! (Almeida, 1915, p.3).

Fosse por vaga humanidade, fosse por razões políticas, nacionalismo, patriotismo e civismo popular constituem os temas encampados pela inteligência brasileira nas primeiras décadas do século XX quando, talvez mais do que antes, retornam as teses respeitantes à capacidade generativa da instrução popular, como via de enfrentamento dos aspectos associais e da superação do atraso. Com efeito, desde a virada do século, as vozes mais autorizadas apelavam para a intervenção da União na extensão do ensino primário, que, por costume, isto é, desde a monarquia, decidira-se ser competência das províncias e dos municípios, demanda essa interrompida com a instituição do federalismo republicano.

Se, para uns, é preciso banir a ideia do "Estado-professor", para outros, o Estado não seria indiferente à extensão do ensino, "um dos grandes elementos da prosperidade das nações”, no dizer entusiástico de um contemporâneo. Para uns mais, o encargo vigoraria até a eliminação do analfabetismo, para outros mais, essencial e indeclinável, o encargo seria permanente. Por iniciativa do Poder Legislativo ou de atos ministeriais em determinadas conjunturas, o Congresso Nacional abandona momentaneamente a rigidez liberal federalista ao autorizar emendas no orçamento geral a fim de subsidiar a instrução popular nos Estados. Se a Carta de 1891 instituíra a descentralização político-administrativa, conquanto isso não se autoriza a concluir que as demandas de coordenação nacional da instrução popular estivessem ausentes nos debates parlamentares, nos quais sobressaem José Augusto, Monteiro de Sousa, Passos de Miranda Filho, Barbosa Lima Sobrinho, José Bonifácio. Ademais, ministros da Justiça e de Negócios 
do Interior, como Tavares de Lira e Esmeraldino Bandeira, alinhavamse a favor da participação direta e imediata da União no provimento da instrução popular. ${ }^{75}$

No âmbito legislativo, a Lei no 1.617, de 30 de dezembro de 1906, autoriza a União a auxiliar os estados que despendessem 10\% da receita anual com vencimentos de professores que ministrassem instrução leiga e gratuita.

Em mandato presidencial impetuosamente centralizador, Hermes da Fonseca edita as leis orçamentárias no 2.356, de dezembro de 1910, 2.544, de janeiro de 1912. A sua vez, a Lei no 2.738 , de 4 de janeiro de 1913, autoriza o governo a promover e animar o ensino primário mediante acordos estaduais, a União auxiliaria os estados com 20\% do montante despendido no ensino primário, leigo e gratuito, podendo elevá-lo a $25 \%$, desde que as unidades acordantes despendessem pelo menos $10 \%$ da receita geral. Incluso, subvencionaria as associações estrangeiras ou nacionais capazes de ofertarem instrução elementar, contudo as autorizações em lei não se concretizam. E a despeito de tudo, um fato é inegável: assistia-se ao crescimento da importância social e extensão da escola, fenômeno descontinuado e mais expressivo nas áreas abertas à economia de mercado. Nos centros urbanos, escolas-modelo anexas às escolas normais, grupos escolares, escolas reunidas oferecem condições de conforto e higiene; nos núcleos de baixa densidade demográfica, escolas isoladas sob a regência de um professor, invariavelmente desmobiliadas e refugiadas em locais improvisados; nas regiões remotas, escolas ambulantes, escolas de emergência e outras ditas rudimentares.

${ }^{75}$ Cf. Moacyr (1916). 


\section{Os números revelados}

Médico, demógrafo e redator da revista Brasil Médico, José Luiz Sayão de Bulhões Carvalho, no introito do relatório apresentado a João Pandiá Calógeras, ministro da Agricultura, Indústria e Comércio, endereçava argumentos a favor da lei dos números e sua utilidade. "A estatística, considerada por alguns uma ciência, um método por outros, é indubitavelmente uma especialidade técnica, cuja aplicação facilita o conhecimento dos fatos sociais, susceptíveis de estudo pela comparação numérica”.

Não é apenas um método prático para o estudo comparativo de algarismos. Serve também de base ao progresso da ciência relacionada com os fatos sociais, quer sob o ponto de vista físico ou material, quer sob o ponto de vista intelectual e moral. Com esse objetivo os países mais civilizados organizaram repartições de estatística, destinadas a coligir, elaborar, coordenar e publicar toda sorte de informações relacionadas com o estado físico, político, administrativo, demográfico, econômico, intelectual e moral dos respectivos domínios (Bulhões Carvalho, 1915, p.39).

Nas décadas inicias do século XX brasileiro, a afirmação da atividade estatística, em diversos domínios da formação social, materializa em números as ditas realidades nacionais. É sob esse aspecto que se recruta um saber objetivo a serviço das políticas públicas que afetam as 
populações consideradas como agregados naturais dotados de atributos próprios. De modo geral, os números consolidados correlacionam gentes e coisas submetidas à contagem (por certo, ao revelar cifras globais, o saber estatístico adquire ares de pesquisa social); dentre outros, concluíase que a instrução, fenômeno de massa, pode ser objetivamente descrita e avaliada com recurso aos números.

\section{Das cifras}

Entre 28 de janeiro e 15 de novembro de 1908, na cidade do Rio de Janeiro, realizou-se a Exposição Nacional Comemorativa da Abertura dos Portos, evento solene recamado de efeitos de teatralidade, nele exibiam-se os índices de progressos na "Agricultura, Indústrias e Artes Liberais". A dupla finalidade, irradiar a face de um país industrioso e moderno, entremostrar a capital da República recém-saneada e reurbanizada. Com o propósito de "elevar o conceito do Brasil no mundo civilizado", o Boletim Comemorativo da Exposição Nacional exultava os progressos concretizados entre 1808 e 1908; com títulos em português, francês e esperanto, no formato de gráficos de coluna, os quadros numéricos ilustravam as potencialidades do país. No introito do Boletim, por sinal, sobrecarregado de imagens auspiciosas, Bulhões Carvalho condensava a pujança e a vitalidade do país.

A vasta rede telegráfica que une pelo pensamento os pontos mais longínquos do nosso território entre si e com todos os centros industriais e intelectuais do mundo; as vias férreas que ligam os Estados e caminham pelo interior, galgando as serras, transpondo os rios, conquistando para a civilização os sertões bravios, desertos e demandando as fronteiras, hoje limitadas por tratados internacionais; as cidades, as vilas antigas e novas, os povoados e as colônias nascentes; a navegação nos rios e lagos e na cabotagem de imensa costa marítima; os correios multiplicando sob todas as formas e todos os meios de comunicação, a correspondência com desenvolvimento tamanho, que 
só por milagre se consideraria possível há cem anos passados: toda essa perspectiva do território assim transformado e movimentado pela atividade dos seus habitantes deve apresentar na Exposição Nacional de 1908, num quadro magnífico, a imagem do progresso do Brasil, fazendo num século de apressada marcha o percurso necessário para alcançar o grau de cultura, que as antigas nacionalidades atingiram em milhares de anos (Bulhões Carvalho, 1908, p.V-VI).

Decidido a repropor uma imagem global do país, o Boletim Comemorativo da Exposição Nacional preenchia severa lacuna, entretanto havia controvérsias quanto ao total da população, os cálculos otimistas estimavam o total de habitantes em 25 milhões, outros, mais modestos, em 18 milhões. A diretoria-geral de Estatística opta por termo médio, o total oscilaria entre o máximo de 22 e o mínimo de 20 milhões, a densidade demográfica média não excederia a 2,40 habitantes por $\mathrm{km}^{2}$.

Quadriculado, o território nacional assim aparecia no Boletim: Distrito Federal, 722 habitantes por km²; Rio de Janeiro 14; Alagoas 11; Pernambuco e Sergipe 9; Ceará e São Paulo 8; Santa Catarina 7; Paraíba e Minas Gerais 6; Bahia e Rio Grande do Sul 5; Espírito Santo e Rio Grande do Norte 4; Paraná, Piauí e Maranhão 1; Pará, Goiás, Amazonas, Mato Grosso, menos de 0,50. Cidades mais povoadas com mais de 500 mil habitantes, Rio de Janeiro; com mais de 200 mil habitantes, São Paulo e Salvador, com mais de 100 mil, Recife.

Quanto à situação do "aparelho didático”, Bulhões Carvalho, constrangido, sentenciava. "Sob o ponto de vista intelectual, não são ainda notáveis os progressos da instrução pública no Brasil” (1908, p.XXXIV). Em seguida, declinava os totais gerais da matrícula e da frequência no ensino público e privado, respectivamente, 565.922 e 391.188 alunos. No âmbito do ensino público primário estadual, as "casas de ensino existentes no país”, "consoante a forma didática e distribuição regional”, o Boletim totalizava 169 “escolas especiais”, isto é, escolas complementares, escolas-modelo, grupos escolares e jardins de infância; e 6.920 "escolas comuns", isto é, escolas elementares e 
isoladas. E como era de se esperar, os 7.089 estabelecimentos de ensino encontravam-se irregularmente distribuídos pela extensão territorial do país.

Se concedido confiabilidade aos subtotais e totais estatísticos consolidados, as maiores quantidades de estabelecimentos de ensino encontram-se em Minas Gerais, São Paulo, Rio Grande do Sul; as menores, no Rio Grande do Norte, Mato Grosso, Espírito Santo e Goiás. A modalidade jardim de infância é quase nula, mas não menos importante, um estabelecimento em São Paulo, e outro no Paraná. ${ }^{76}$ Valiosos os dados a seguir demonstram o descompasso entre a matrícula geral nas escolas públicas, 348.327 alunos, e a frequência real, 240.690 e, por ventura igualmente notar os descompassos regionais: Minas Gerais, matrícula geral de 88.701 alunos e frequência de 47.399; São Paulo, 60.983 e 45.857; Rio Grande do Sul, 46.166 e 33.634; Bahia, 28.120 e 19.235; Goiás, 3.158 e 2.053; Mato Grosso, 4.253 e 3.828; Amazonas, 4.102 e 3.355.

Já na Estatística escolar de 1916, Bulhões Carvalho divulgava os números relativos aos ensinos superior, secundário, profissional e primário nas esferas pública civil, militar e particular nas 21 unidades da federação. Persistente, o estatístico consegue neutralizar a resistência dos poderes locais e o descaso com registros administrativos e civis.

No nosso centro mais adiantado, na própria Capital Federal, segundo o último recenseamento a que aqui se procedeu, há nada menos de 48 analfabetos em 100 habitantes de todas as idades, 40 entre as pessoas maiores de 6 anos e 37 entre aquelas que já completaram três lustros de existência.

Mais da terça parte, portanto, dos indivíduos que, pela idade, já deviam ter saído das escolas primárias, ainda se acham nesta brilhante metrópole, em pleno século XX, à míngua de instrução, no que tem esse de mais rudimentar! (Bulhões Carvalho, 1916, p.XII).

${ }^{76}$ Cf. Apêndice A - Tabela C. 
Cauteloso contrabalançava a apreciação negativa. "Mas também se há de ver que nem por toda a parte é desalentador o espetáculo do ensino; pois se pontos há em que a instrução esteja estacionária, ou sofra alternativas de melhora e descenso, também não falta onde ela se apresente em progresso firme, contínuo, animador" (1916, p.XII). Excluídos aqui os dados referentes ao ensino militar, a situação global dos ensinos superior, secundário, primário e profissional em 1916 era esta: 12.997 cursos (15 federais, 6.986 estaduais, 2.647 municipais, 3.349 particulares), dos quais 25 superiores, 373 secundários, 12.448 primários e 151 profissionais. 20.166 docentes, 671 no ensino superior, 1.603 em institutos profissionais, 2.306 em colégios e $15.586 \mathrm{em}$ escolas primárias.

Quanto à instrução primária pública e privada:

- 12.448 "institutos de ensino elementar", 9.553 públicos e 2.895 privados; dentre os primeiros, 6.918 estaduais e 2.635 municipais; dentre os últimos, 213 com subvenção municipal e 2.682 sem "proteção oficial".

- 15.586 professores, 11.402 em escolas públicas, 4.184 em particulares; 8.068 professores lotados no magistério estadual, 3.334 no municipal, 239 em estabelecimentos subvencionados, 3.945 em estabelecimentos "sem auxílio oficial".

- 638.378 alunos matriculados em cursos primários públicos e privados; 504.706 “inscrições” em estabelecimentos oficiais; 133.672 em institutos particulares; 367.287 em escolas estaduais; 137.419 em municipais, 7.253 em "colégios subvencionados pelos governos municipais"; 126.419 em "casas de educação de iniciativa privada".

- 355.150 alunos do sexo masculino, 283.228 do sexo feminino.

- dos 638.378 alunos matriculados, 447.614 frequentavam as escolas; $256.787 \mathrm{em}$ escolas estaduais; $95.531 \mathrm{em}$ escolas municipais, 5.954 em escolas particulares subvencionadas; 93.342 em escolas não subvencionadas. 
E ao proceder-se à localização de escolas conforme critérios previamente estipulados, isto é, organização didática, pessoal docente, população em idade escolar segundo o sexo, matrícula, frequência, conclusão de curso, concretizava-se uma estatística dotada de método confiável e ineditismo, cujos resultados viriam a público na mesma ocasião em que o Congresso Nacional retomava os debates sobre a erradicação do analfabetismo nacional.

De resto, coube a Oziel Bordeaux Rego, chefe da $4^{\mathrm{a}}$ seção da diretoria-geral, conduzir a coleta de dados, no seu ajuizamento técnico. "A matrícula e a frequência não bastam, porém, para julgarmos com segurança a eficácia do aparelho didático.É necessário ainda o conhecimento de um terceiro fator de real importância, a população escolar”(1916, p.VII). A bem dizer, os números coletados alarmavam. "Em todo Brasil, de 1.000 indivíduos em idade de cursar escola primária, 137 apenas estavam matriculados, e deles, somente 96 frequentavam as escolas." Prudentemente à procura de certezas proporcionadas pela objetividade dos números, Bordeaux Rego estipulava os quesitos da boa estatística, a saber, conhecimento do quadro do pessoal docente, total de alunos concluintes dos cursos, "impersistência nos estudos", dispêndios com o ensino público, dados por ele considerados esquivos. De qualquer modo as cifras consolidadas dimensionavam a organização empírica, a extensão e a distribuição do "aparelho didático" pelos estados, municípios e Distrito Federal. Segundo a estatística de 1916, o "aparelho didático", conforme terminologia técnica, comportava "escolas comuns" e "escolas especiais". O "total do discipulado", a população discente, encontrava-se assim distribuída: 58\% em "aulas estaduais", $21 \%$ em escolas municipais, $20 \%$ em escolas particulares, e $1 \%$ em escolas subvencionadas.

Mato Grosso comparecia com maior número de alunos em escolas estaduais, visto ser nula a participação municipal; Alagoas, Rio de Janeiro, Minas Gerais, Paraná, Sergipe, Amazonas, Ceará, São Paulo possuíam escolas estaduais em quantidades expressivas; já nos 
estados do Rio Grande do Sul, Piauí, Maranhão, Bahia, Pará, Paraíba, Espírito Santo, Rio Grande do Norte, Goiás, Santa Catarina, São Paulo, Pernambuco avultavam a participação dos municípios na oferta de escolas.

No tocante à matrícula geral, como vimos, constatava-se déficit entre os totais gerais da população em idade escolar - 4.642.676 crianças; matrícula geral - 638.378; frequência - 447.614, déficit sujeito a variações regionais. Conquanto, é preciso acautelar a estimativa da população em idade escolar, os executores da estatística contabilizam os dados estocados em recenseamentos anteriores. Além do que, o conceito assumido de "idade escolar" refere-se não à idade de frequentação obrigatória sujeita à variação nas unidades federadas, mas, segundo Bordeaux Rego. "Ao que se nos afigura mais próprio para a assimilação normal do primeiro grau do ensino intelectual, que a maioria dos educando não soe transpor. E é por isso que damos por balizas a esse período os 7 e os 15 anos" (1916, p.CCIX).

Ao cotejar os números coligidos, o estatístico concluía. "A impressão que deixa o exame desse quadro é, sem dúvida, antes de tristeza que de satisfação.” No Distrito Federal, o coeficiente de crianças fora da escola alcançava 58\%, em Santa Catarina, 75\%. O coeficiente de matrícula no Rio Grande do Sul, 23\%, no Pará, São Paulo, Mato Grosso, próximo a 20\%; em Minas Gerais, Paraná, Sergipe, Espírito Santo, Maranhão, Rio de Janeiro "não atingia 15\%"; na Bahia, Pernambuco, Rio Grande do Norte, Goiás, Paraíba, Alagoas, Piauí, Amazonas, Ceará, o coeficiente "estava aquém de 10\%”. Na apreciação de Oziel Bordeaux Rego, os impulsos significativos de escolarização provinham do Distrito Federal, São Paulo e Minas Gerais, contudo, a seu ver, as taxas da matrícula geral demonstravam-se insuficientes no tocante à incorporação das populações infantis presentes e futuras. Mesmo assim, ressalvava as evoluções positivas, desde a Proclamação da República, a proporção entre matrícula geral e população em idade escolar aumentara três se comparada às últimas décadas do Império. 
Em vez de recuo, portanto, o que havido é, indubitavelmente, marcha progressiva. Se a velocidade desse movimento está longe de satisfazer as nossas aspirações, algo consoladora, entretanto, já se nos afigura a certeza de que, apesar da interferência maléfica de tantas causas profundamente perturbadoras da evolução nacional, não há sido de todo perdida a esperança no melhoramento da cultura comum a fase que às esperanças de nosso povo, há vinte e seis anos, abriu a aurora do 15 de Novembro (Bordeaux Rego, 1916, p.CCXXIX).

Reveladores, os números brutos levantados pelas estatísticas de 1908 e 1916 indiciam os males, de uma parte, repetência, de outra, duração mínima da escolaridade. Era sobre esse solo numérico que se assentavam os vigamentos da escolarização da infância. Mais não seja, sob as inexcedíveis inventivas de Bulhões Carvalho e Bordeaux Rego, o "aparelho didático" nacional (e regionais) adquire forma numérica. ${ }^{77}$ Doravante, com as estatísticas da instrução, cujos números colossais impressionavam a todos aqueles às voltas com os direitos da cidadania, reacendia antigo pressuposto filosófico-utilitarista -, qual seja, converter a função do Estado em fonte da felicidade coletiva. Sob impacto da ciência estatística, há a transfiguração das realidades em cifras reconhecíveis. Monocrômicas, as irrefutáveis moles numéricas e sua linguagem objetiva engendram verdades quanto ao ser real do Brasil e dos brasileiros, e delas, as verdades, aduziam-se políticas para os serviços setoriais.

\section{Poder local, passo à frente}

Compreendendo a instrução elementar como cidadela do poder público, algumas câmaras municipais paulistas arriscam instituir a obrigatoriedade escolar. No âmbito do poder local, por exemplo, José Augusto de Barros, prefeito de Mogi Mirim, promulga tal estatuto na forma de lei.

${ }_{77}$ Cf. Apêndice A - Tabela D. 
Artigo $1^{\mathrm{o}}$ - É obrigatório, em todo o território do município o ensino primário para as crianças de 7 a 12 anos.

Artigo $2^{\circ}$ - Excetuam da obrigatoriedade:

As crianças que residirem à distância da escola pública maior de dois quilômetros, para meninos, e de um quilômetro para meninas;

As crianças que sofrerem de inabilidade física ou intelectual, comprovada por atestado médico, ou, em falta deste, do Juiz de Paz ou da autoridade policial do distrito.

Artigo $3^{o}$ - As crianças, em idade escolar obrigatória, poderão receber o ensino: a) nas escolas públicas; b) nas escolas particulares; c) em suas próprias casas.

Parágrafo único. No caso da letra (c) são obrigados a fazer exames nas escolas públicas, na época para isso designada, sob pena de incidirem os responsáveis por elas, na multa de 10\$000 (O ensino primário e as municipalidades..., 1918, p.4).

Os demais artigos e parágrafos da lei incidem na criação de escolas em localidades nas quais, no "perímetro da obrigatoriedade", a população em idade escolar fosse igual ou superior a 100 indivíduos, realização de estatística da população escolar, decretando-se, se necessária, a matrícula ex officio, secundada de multas aos pais, tutores, curadores ou patrões desleixados. Compartilhando dos arroubos de progresso civil e riqueza material, a Câmara Municipal de Atibaia, interior paulista, igualmente legislava a obrigatoriedade nos termos da Lei no 88 de 1892 e do Decreto no 218 de 1893. O ato legislador inovava ao proibir o trabalho de menores de 12 anos em fábricas, oficinas, casas comerciais ou particulares, durante tempo e horas de aulas (A obrigatoriedade do ensino..., 1917, p.3).

Ao votar o anteprojeto de Raul Fonseca, diretor do Grupo Escolar "Cesário Mota”, a Câmara Municipal de Itu sancionava a obrigatoriedade igualmente em acordo com a Lei no 88 e Decreto $n^{\circ}$ 218. Nas considerações, a razão dos legisladores: estimular o nacionalismo pela unificação da língua e conhecimentos da história e 
geografia pátria, difundir a ética do trabalho, conscientizar homens e mulheres de seus direitos e deveres, reduzir o analfabetismo, elevar a moral, incutir energia, revigorar o caráter do povo.

Excluídos da obrigatoriedade, meninos residentes a mais de três e meninas a mais de um quilômetro da escola ou portadores de incapacidade física ou intelectual, atestada por médico. Pais, tutores, curadores ou patrões eram obrigados a matricularem filhos, tutelados, curatelados ou empregados em grupos escolares, escolas isoladas ou particulares; a inobservância da lei autorizava a matrícula ex officio. Aos refratários, multas de $10 \$ 000$ a $50 \$ 000$, outra multa concerniria a 15 faltas consecutivas. Ademais proibia o trabalho de menores de 12 anos em fábricas, oficinas ou casas comerciais no período diário de aulas. Os maiores de 12 e menores de 16, analfabetos, empregados em fábricas, oficinas ou casas comerciais, frequentariam escolas noturnas. A Câmara Municipal efetuaria a estatística anual da população escolar, criaria escolas municipais nos bairros e instaria o governo estadual a criar e a prover escolas. 


\section{E continuam a revelar...}

Nas proximidades do centenário da Proclamação da Independência, Epitácio Pessoa, presidente da República, em clima patriótico, patrocina a Exposição Internacional do Centenário da Independência. $\mathrm{Na}$ abertura, parada militar e juramento à Bandeira Nacional nas escolas primárias da Capital Federal. Na cena celebrante, pavilhões dos estados brasileiros e países da América - Argentina, Estados Unidos, México; Europa - Bélgica, Checoslováquia, Dinamarca, França, Inglaterra, Itália, Portugal, Noruega, Suécia; Ásia - Japão. ${ }^{78}$

Dentre as maravilhas técnicas destinadas a provocar emoção e prazer, a exibição de "No país das amazonas”, premiado documentário produzido pelo fotógrafo português Silvino Santos: pela primeira vez, exibiam-se imagens movimentadas da Região Norte, suas gentes morenas, riquezas vegetais e exuberâncias da fauna. Paralelamente, com Roquette-Pinto à frente, inaugurava-se a primeira transmissão radiofônica no país, o discurso de Epitácio Pessoa, seguido da execução da ópera “O guarani”, de Carlos Gomes. Após recepcionar milhares de visitantes, em 7 de setembro de 1923, encerrava-se a Exposição Internacional, nessa ocasião o poeta pernambucano Joaquim Osório Duque-Estrada entregava a letra do Hino Nacional ao presidente da República.

${ }^{78}$ Cf. Motta (1991, 1992). 
Enquanto tecnologias de governabilidade, excetuando-se o recenseamento geral de 1920, os recenseamentos decenais foram operações malsucedidas. ${ }^{79} \mathrm{O}$ recenseamento geral de 1890 realizara-se na conjuntura instável do Governo Provisório, o de 1900, no governo de Campos Sales, será contestado, suspendendo-se a divulgação dos resultados, o de 1910, cancelado por Hermes da Fonseca. Independentemente do planejamento e execução, havia obstáculos de peso, por exemplo, a resistência ao uso obrigatório do registro civil, as pessoas optavam pelo registro nas paróquias ou associavam o agente recenseador à conscrição militar, ao aumento de impostos ou ainda à tentativa de reescravização.

$1^{\text {o }}$ de setembro de 1920. Convertido em questão patriótica, entrava em andamento o recenseamento geral do Brasil, como dito em outro lugar, até então o "quem somos" e o "quanto somos" eram assuntos controversos. Conduzido pela diretoria-geral de Estatística, novamente Bulhões Carvalho à frente, o recenseamento, inovador nos aspectos técnicos, reclama para si a apreensão inteiriça das realidades nacionais, população, agricultura, indústria e comércio.

Quanto à demografia, a "lista de família” inquire, individualmente, nome, sexo, idade, estado civil, nacionalidade, profissão, grau de instrução, residência e defeitos físicos (cegueira e surdomudez). Por questões aparentemente técnicas, suprimiram-se os quesitos relativos à cor e religião, alegando-se que os "mestiços" se demonstravam refratários à declaração da cor da pele, e a confissão de fé mereceria inquérito específico. Apesar das dificuldades, da resistência em declarar dados pessoais, da imensidão territorial, da precariedade de vias de comunicação e de transportes, levava-se a termo a faina escrutinadora. ${ }^{80}$

Formalizados em quadros numéricos, os resultados parciais são expostos no Pavilhão de Estatística da Exposição Internacional, popularizado como "Pavilhão da Ciência da Certeza". Para além da

${ }^{79}$ Cf. Senra (2006).
${ }^{80}$ Cf. Senra (2006). 
simples contagem, os resultados da faina escrutinadora, ao repercutirem números maciços, multiplicam as imagens perceptivas do país: massa da população 24.139.299 habitantes; juntos, os maiores estados, Minas Gerais, São Paulo, Bahia, Rio Grande do Sul, Pernambuco, totalizavam 59\% da população, Minas Gerais e São Paulo, 34\% ${ }^{81}$

Distribuição desigual da população ocupada nos setores produtivos: agricultura, pecuária, extração - 70,2\%; indústria - 12,9\%; transporte - 2,8\%; comércio - 5,4\%; administração pública, civil e militar - 2,1\%; administração particular - 1,1\%; profissões liberais 1,8\%; "pessoas que vivem de rendas" - 0,4\%; serviço doméstico - 4,0\%; ocupação indefinida - 9.191.044; profissão não declarada - 416.568.

Um dos resultados divulgados no transcorrer da década fere de morte as boas consciências: em cada mil brasileiros de todas as idades, “245 sabiam ler e escrever”, "755 não sabiam ler nem escrever”. Isto é, confirmava-se a permanência dos índices históricos do analfabetismo nacional, em aparência, inamovíveis.

Tabela 3 - Evolução do grau de cultura

\begin{tabular}{c|c|c|c}
\hline & Sabem ler & Não sabem ler & Total \\
\hline 1872 & 1.564 .481 & 6.834 .253 & 8.398 .734 \\
\hline 1890 & 2.120 .559 & 9.324 .332 & 11.444 .891 \\
\hline 1900 & 4.448 .681 & 8.973 .578 & 13.422 .259 \\
\hline 1920 & 7.454 .698 & 16.684 .601 & 24.139 .299 \\
\hline
\end{tabular}

Excluídos os menores de 0 a 6 anos.

Fonte: Diretoria Geral de Estatística. Recenseamento do Brasil. Rio de Janeiro: Tipografia da Estatística. 1929, v.4 População - População do Brasil, por estados e municípios, segundo o grau de instrução por idade, sexo e nacionalidade.

${ }^{81}$ Apanhado da evolução populacional de 1872 a 1950 consta em Carone (1976). Nas cogitações comparativas dos sujeitos de época, no século XX, Portugal, Rússia, Romênia e Sérvia apresentavam índices de analfabetismo mais elevados quando comparados aos índices brasileiros. 
Os números a seguir indicam, conforme sexo e grupos de idades, os coeficientes de "alfabetismo" e analfabetismo nas unidades da federação. Nos estados, Distrito Federal e Território do Acre, quanto ao sexo masculino, os números de indivíduos alfabetizados oscilam entre o mínimo de 74 por mil no Piauí e o máximo de 632 por mil, no Distrito Federal; quanto ao sexo feminino, o mínimo de 67 por mil no Piauí e o máximo de 624, no Distrito Federal. Para tornar os subtotais regionais mais expressivos, optou-se pelo agrupamento por zonas Norte, Sul, Centro e, separadamente, Distrito Federal, Rio de Janeiro e Espírito Santo, por motivos não muito claros.

Tabela 4 - Grau de instrução no grupo de 7 a 14 anos

\begin{tabular}{l|r|r|r|r}
\hline \multicolumn{1}{c}{ Homens } & \multicolumn{3}{c}{ Mulheres } \\
\hline \multicolumn{1}{c}{ Zonas } & Sabem ler & \multicolumn{1}{c}{$\begin{array}{c}\text { Não } \\
\text { sabem ler }\end{array}$} & Sabem ler & Não saber ler \\
\hline Norte & 184.127 & 1.208 .757 & 174.430 & 1.183 .844 \\
\hline Sul & 263.995 & 617.761 & 245.039 & 603.944 \\
\hline Centro & 123.147 & 634.660 & 106.084 & 615.644 \\
\hline Distrito Federal & 60.563 & 35.233 & 60.353 & 36.343 \\
\hline Espírito Santo & 9.978 & 40.458 & 8.187 & 41.601 \\
\hline Rio de Janeiro & 32.835 & 133.699 & 30.393 & 130.942 \\
\hline Brasil & 674.645 & 2.670 .568 & 624.486 & 2.612 .318 \\
\hline
\end{tabular}

Fonte: Diretoria Geral de Estatística. Recenseamento do Brasil. Rio de Janeiro: Tipografia da Estatística, 1929 (v.4 População - População do Brasil, por estados e municípios, segundo o grau de instrução por idade, sexo e nacionalidade).

Cômputo geral: em mil habitantes de cada sexo, 429 homens e 272 mulheres "sabem ler", 571 homens e 728 mulheres "não sabem ler". Os índices de escolarização apresentam acentuada variação regional..$^{82}$ Ora bem, da operação censitária elogiada pela excelência

82 "Por mais que as coisas tenham mudado dos censos de 1872 e 1890 para o de 1920, nenhum outro estado chega a juntar-se à dupla constituída por Rio de Janeiro e Rio Grande do Sul na liderança das taxas mais baixas de 
técnica, sobressaem os totais restritivos da escola primária brasileira: população em idade escolar: 5.704.393, matrícula geral: 1.249.449, frequência escolar: $678.684 .^{83}$

$\mathrm{Na}$ apresentação do Recenseamento do Brasil, um julgamento antigo, contudo considerado atual. "O problema da instrução popular não pode ser resolvido simplesmente pelo aumento progressivo da despesa. A sua solução está na dependência, principalmente, de medidas que obriguem a frequência escolar" (Brasil, 1929, p.VII).

No clima histórico-psicológico propício à compreensão das realidades do país, a expectante década dos centenários, em linguagem de tragédia, os homens públicos os mais diferentes não titubeiam, em nomear, mais uma vez, o analfabetismo de "mal nacional" e "chaga social”. Dotados de poder de atração, sempre colossais, os números impressionam fundamente os debates políticos e culturais, e da justa reação resultam planos construtivos os mais diversos como é possível notar, por exemplo, nas monografias concorrentes aos prêmios ofertados pela Academia Brasileira de Letras. Antes de falecer, em 1917, o editor português, Francisco Alves legara a sua fortuna pessoal, cinco mil contos de réis, à $\mathrm{ABL}$, e por disposição do testador, a academia premiaria anualmente três estudos sobre "O melhor meio de disseminar o ensino primário no Brasil”. ${ }^{84}$ Nos concursos comparecem nomes sonoros, entre muitos, José Augusto Büchler e Pedro Deodato de Moraes, Achilles Lisboa, Manoel Bomfim, Sud Mennucci e Marques Pinheiro, autor da monografia intitulada Contra o analfabetismo, da qual extraímos o seguinte excerto elucidativo.

$\mathrm{O}$ analfabetismo no Brasil tem dois aliados terríveis e quase invencíveis: a grandeza do território e a pouca densidade da população.

analfabetismo. Em resumo, os estados da Região Nordeste são os únicos a constituir-se em formação regional perfeitamente identificável, em termos de analfabetismo, ao término do período de 1872/1890 a 1920" (Ferraro, 2009, p.173).

${ }^{83}$ Cf. Apêndice A - Tabela E.

${ }^{84}$ Cf. Monarcha (2014). 
Logo a lei do ensino obrigatório, sendo uma lei sábia, e indispensável mesmo no Brasil, ainda assim, ela é entre nós absurda e inexequível, se procurarmos aplicá-la diretamente (1923, p.23-25).

No mais, assim dizia-se, o fardo do analfabetismo esmagava os anônimos da história; por desconhecerem a chave da felicidade e da fortuna, a alfabetização, nada lhe restava a não ser o fardo pesado de todos os dias, isto é, a servidão proletária no ganha-pão, deserdado da fortuna, o iletrado sobrevivia no degredo, desditosa, sua vida transcorria ao deus-dará. Com efeito, essa era a mensagem enegrecida da Cartilha do operário, de Theodoro de Moraes, cartilha de alfabetização pela processuação do método analítico destinada ao uso de adolescentes e adultos.

Serviço rude e pesado o de carregador!

Este que se vê na estampa é Rafael.

Pobre Rafael!

Não frequentou a escola.

Não sabe ler, não sabe escrever, não sabe fazer contas.

Cresceu analfabeto.

E agora, para ganhar a vida, precisa fazer o serviço rude e pesado de carregador.

Trabalha tanto na fábrica desde cedo, carrega tantos pesos e, no fim de contas, ganha tão pouco!

Esta é a triste vida dos que perdem tempo e crescem analfabetos.

Esta é a triste sorte dos que não têm coragem de aprender o que não sabem.

Nunca adianta, vivem sempre atrasados e carregados de desgosto (Moraes, 1924, p.24).

Pois bem, no centenário da lei imperial sancionada por Pedro I, mandando "criar escolas de primeiras letras em todas as cidades, vilas e lugares mais populosos do Império", vinha a público Ensino 
primário, resultados provisórios do inquérito sobre a instrução primária no Brasil em 1926, divulgados por ocasião do centenário da lei de 15 de outubro de 1827, referentes ao mesmo ensino. No inquérito aplicase um questionário simples, mas eficiente: aos governos estaduais inquiria-se o número de escolas primárias estaduais, municipais e particulares, alunos matriculados, frequência média de alunos, números de concluintes e total de professores com distribuição por sexo. Excetuando o Acre, após insistentes telegramas e ofícios, os governos estaduais e a prefeitura do Distrito Federal retornam os questionários preenchidos. E, conquanto admitisse a precariedade dos dados relativos as escolas municipais e particulares, Bulhões Carvalho exultava, a seu ver, os resultados do inquérito evidenciavam "incontestável progresso da instrução pública primária”.

Apesar das lacunas, um valioso acervo de dados demonstrativos do grande esforço já despendido, no Brasil, em prol da difusão do ensino primário, com a manutenção, em condições mais ou menos satisfatórias, de milhares de casas de educação popular, nas quais já se acham matriculados mais de um milhão e meio de educandos, recebendo por intermédio do professorado quase exclusivamente feminino, as primeiras noções para a cultura intelectual (Bulhões Carvalho, 1927, p.III).

Para efeito de demonstração, no comentário introdutório, o competente estatístico fez constar uma sinopse didática: em 1926, o país possuía 24 mil escolas de ensino primário desdobradas em 33 mil "cadeiras ou classes", 35 mil professores, em sua quase totalidade mulheres, 1.350 mil alunos matriculados e frequência de $70 \%$ do total.

Comparados entre si, os sistemas escolares delatam acentuada heterogeneidade: São Paulo possuía 6.601 "cadeiras ou classes estaduais", 6.635 professores, 290.288 alunos matriculados, frequência de 190.279; Goiás, 208 cadeiras ou classes estaduais, 222 professores, 11 mil alunos matriculados e frequência de 10.406, por exemplo. 
Otimista, o estatístico concluía que o período de 1920 a 1926 presenciara um aumento de $38 \%$ no número de escolas primárias estaduais, de $56 \%$ no número de "cadeiras ou classes" e de $55 \%$, na matrícula geral. Embora lacunares, os números concernentes às escolas municipais e particulares não desencorajam, diz Bulhões Carvalho.

Malgrado as diferenças regionais, a nomenclatura utilizada na designação dos estabelecimentos é relativamente homogênea: grupos escolares, escolas-modelo, escolas complementares, escolas reunidas, jardins de infância, escolas isoladas. Porém, não há referências às escolas ambulantes e de emergência existentes em regiões remotas, a Amazônia, por exemplo. Nomenclaturas regionais aparecem no Rio Grande do Norte, "escolas isoladas ou rudimentares", no Rio Grande do Sul, "colégios elementares", em Santa Catarina, "escolas reunidas ou grupos escolares de 2a classe", no Distrito Federal, "escolas diurnas" e "escolas noturnas". Em determinadas regiões, consta mínima quantidade de escolas municipais. $\mathrm{Na}$ média, comparado ao total de grupos escolares, o número de escolas reunidas e isoladas é bastante significativo. É de ver que a heterogeneidade demográfica e a economia condicionam a extensão do ensino primário. Desempenhos quantitativamente significativos ocorrem nas regiões abertas à economia de mercado: Distrito Federal, São Paulo, Minas Gerais, secundariamente, Santa Catarina e Rio Grande do Sul. Seja o que for, novamente, o torniquete do analfabetismo é por assim dizer, objeto de comoções e vertigens de pensamentos.

\section{Os censos estaduais}

Encaminhada à Conferência Interestadual de Ensino Primário, a "Memória sobre a educação nacional", assinada por Antonio de Sampaio Dória, delegado da Liga Nacionalista de São Paulo, ultimava o povo analfabeto como uma das causas ruinosas do regime; hoje as suas palavras relembram bíblicas lamentações. 
Se dever há que pareça repelido pela República, é o do combate ao analfabetismo, que lhe cancera as entranhas. A grande maioria dos brasileiros, mazelada pelas endemias, e abandonada pelos governos, jaz imersa na mais rasa ignorância nativa. As virtualidades poderosas da sua raça não se positivam (Conferência Interestadual de Ensino Primário, 1922, p.352).

Torrencial, a fluidez dos números valida juízos idênticos sobre um objeto comum, ao mesmo tempo em que insufla a retórica circulante no Congresso Nacional, imprensa jornalística e estudos técnicos, ademais isso é inegável, empurra certas autoridades públicas para o campo das ações construtivas.

Desde o ponto de vista da Liga Nacionalista de São Paulo, Oscar Thompson, diretor-geral da Instrução, abordava a crucialidade da educação do imigrante e do caboclo. Para o diretor-geral, "indiferentes ao destino da Pátria”, os núcleos caboclos levavam "existência quase selvagem". Para superar o estado de coisas, expede circular solicitando planos de combate ao analfabetismo. Em carta aberta, Sampaio Dória responde ao apelo. E, ao propor um "tipo novo de escola alfabetizante", esse professor de Psicologia e Pedagogia da Escola Normal da Praça rebramava os tropos da Liga Nacionalista. "Governo de origem popular e ignorância rasa do povo são coisas que se chocam, se repulsam, se destroem, como as trevas e a luz, o inferno e o céu” (Sampaio Dória, 1923, p.16).

Eleito presidente do Estado pelo Partido Republicano Paulista, Washington Luís Pereira de Souza decide-se pela alfabetização total, mas a Assembleia Legislativa considera inviável elevar de 17\% para $40 \%$ o montante de gastos com a instrução. Por decisão pessoal, Washington Luís nomeia Sampaio Dória diretor-geral da Instrução com duplo propósito, diminuir as taxas de analfabetismo e evitar o aumento de gastos públicos.

Dados do Recenseamento Federal de 1920 acusavam, para São Paulo, 4.600 milhões habitantes, 1.500 residentes em vilas e cidades; 
das quatro mil classes escolares existentes, 75\% localizavam-se em vilas e cidades, os $25 \%$ restantes em áreas rurais. Para erradicar "a desanalfabetização popular”, Sampaio Dória promove o recenseamento escolar, objetivando localizar os "núcleos de analfabetos". O corpo de recenseadores é constituído de professores de classes ou escolas isoladas, trabalho difícil, considerando-se as extensas áreas, a densidade demográfica rala e a precariedade de estradas e transportes.

O recenseamento visa a estabelecer o número de analfabetos em idade escolar, local de residência e condições de vida. Num mapa, registram-se nome, sexo, idade, filiação, nacionalidade, profissão do pai, residência, frequência escolar ou não, se sabe ler ou não; noutro mapa, esboça-se a carta geográfica do município a fim de orientar a posterior instalação de escolas. Do recenseamento escolar, saltam grandes números: total de 656.114 de crianças entre 6 e 12 anos, 358.978 meninos, 297.136 meninas; do total de crianças de 7 a 14 anos, 175.830 frequentam escolas, 372.145 não o faziam; 373.382 são filhas de pais brasileiros, 282.732 de pais estrangeiros.

Hoje sabemos ao certo a extensão do analfabetismo infantil em São Paulo. É maior que se esperava. E por ele se pode imaginar o que vai por outros Estados, onde a instrução não correr par a par com a de São Paulo. O Brasil deve considerar seriamente a chaga que hoje se the corroí o seio. O recenseamento escolar, aqui, e um brado e um aviso. Que a União se interessava pelo problema e se salvará, ou estaremos na iminência de ver medrar, entre nós, os horrores da anarquia (São Paulo, 1920, p.6).

Sancionada a Lei no 1.750 , dezembro de 1920, expedido o regulamento da reforma, Decreto no 3.356 , março de 1921, a reforma entra em vigência e, com ela, um "tipo novo de escola", visando intensificar o fluxo alfabetizador. De modo polêmico, estipulava-se o ensino gratuito e obrigatório entre 9 e 10 anos de idade, a não reprovação para otimizar a matrícula inicial e a criação do "curso médio", $3^{\circ}$ e $4^{\circ}$ 
ano primário, com taxa de matrícula. Nas escolas isoladas, o professor ministraria dois períodos de aulas com duração de duas horas e meia, demais, oficializa-se o método intuitivo de ensino.

Nas escolas primárias, o método natural do ensino é a intuição, a lição de coisas, o contato da inteligência com as realidades que se ensinam, mediante a observação e a experimentação, feita pelos alunos e orientação pelo professor. São expressamente banidas da escola as tarefas de mera decoração, os processos que apelem exclusivamente para a memória verbal, a substituição das coisas e fatos pelos livros que se devem apenas usar como auxiliares de ensino (São Paulo, 1920, p.27).

A essas medidas, somava-se a unificação das escolas normais primárias e secundárias num mesmo padrão, a valorização da prática de ensino, a autonomia didática dos professores. Divergências com Washington Luís levam o diretor-geral a exonerar-se. Em Questóes de ensino, obra de defesa de princípios, Sampaio Dória ajuizaria "A escola urbana de quatro anos tal como tínhamos antes da Reforma é a mais pura, a mais acabada ideologia delirante. É um aparelhamento que não alcança, nem pode jamais alcançar os fins que visava" (Sampaio Dória, 1923, p.299).

Para Sud Mennucci, chefe do recenseamento escolar de 1920, a reforma consistira num esforço louvável de interiorização da escola. "A solução só podia ser esta: diminuir os anos de obrigatoriedade escolar, e o número de anos de curso primário. $\mathrm{O}$ Estado estava diante de um dilema fatal: ou dar muito a poucos ou dar pouco a todos [...] o que se perdeu em profundidade, ganhou-se em extensão"(Mennucci, 1932a, p.63).

A reforma vigora de 1921 a 1925, de uma parte, altera a organização didática dos grupos escolares, de outra, converte parcela das escolas isoladas em escolas reunidas. $\mathrm{Na}$ observação seca de Guilherme Kuhlmann, diretor-geral da Instrução, comparadas aos grupos escolares, as escolas reunidas eram estabelecimentos de fácil administração e de baixo custo. 
Noutro extremo do território nacional, Manoel Bergström Lourenço Filho executa a reforma da instrução pública do estado do Ceará. O catedrático de Higiene e Ciências Físicas e Naturais e diretor da Escola Normal Pedro II, Fortaleza, João Hyppolito de Azevedo e Sá, propusera a Justiniano de Serpa, presidente de Estado, solicitar a Washington Luís a vinda de um "professor paulista" para renovar as cadeiras de Psicologia, Pedagogia e de Didática da Escola Normal. Lourenço Filho lá permanecerá entre 1922 e 1923. Então, Fortaleza vivenciava um clima de modernização, ao mesmo tempo, estavam na memória coletiva acontecimentos malsãos: a "salvação" levada a cabo pelo presidente da República, Hermes da Fonseca, a deposição da oligarquia Accyoli, a derrubada do presidente de Estado, tenentecoronel Marcos Franco Rabello, a prisão do intendente municipal, Ildefonso Albano, a chamada Sedição de Juazeiro, capitaneada pelo padre Cícero Romão Batista e Floro Bartolomeu (e nalguma medida Pinheiro Machado). ${ }^{85}$

Logo mais Lourenço Filho será nomeado diretor-geral da Instrução. De súbito, a reforma adquire ares de campanha contra o analfabetismo e de ação social pela escola. $\mathrm{Na}$ voz de uma professora primária aderente aos trabalhos da reforma. "Bem sabeis que a escola primária não é só a fonte da instrução das camadas populares; é, mais ainda, a forja onde se devem formar caracteres, onde se deve fornecer ao futuro cidadão uma educação nacional, baseada no culto do civismo" (Mello, 1923b, p.448, grifo do autor).

Auxiliado pelos prefeitos, Arcebispado de Fortaleza, Inspetoria de Obras contra as Secas, Administração dos Correios, Repartição dos Telégrafos e Associação Comercial, o reformador coloca em andamento o Cadastro Escolar. Consolidado, o cadastro apura 161.572 mil crianças em idade escolar, matrícula geral de 36.058. Na sequência, entre 1921 e 1923, instalam-se grupos escolares e escolas reunidas em vários municípios; com isso a matrícula elevava-se de 19.360 alunos para 32.079, evolução positiva, conquanto aquém da demanda, o

${ }^{85}$ Cf. Castelo (1970) e Monarcha (2010a) e (2015). 
que não impede Lourenço Filho de proclamar. "O sertanejo não é impenetrável à máquina e à escola; os governos, em geral, é que têm mantido uma criminosa indiferença pelo problema da cultura popular" (Lourenço Filho, 1923, p.473).

Num futuro próximo, as operações censitárias paulista e cearense servirão de modelo no planejamento dos serviços em educação. Aparentados pelo lema "estatística, condição de eficiência", Fernando de Azevedo, no Distrito Federal, em 1928-1930, e novamente Lourenço Filho, em São Paulo, em 1930, por exemplo, recenseariam as populações escolares como ato preliminar e princípio de eficiência na elaboração de políticas para o setor. De modo geral, a técnica recenseadora ganha maior efetividade ao discriminar a matrícula efetiva da matrícula geral, taxas de alfabetização em separado das taxas de promoção geral, médias de matrícula e frequência.

\section{Do professorado e sua condição existencial}

Uma tabela inédita! Sob o título "Ensino pedagógico estadual", o Boletim comemorativo da Exposição Nacional de 1908 divulgava a localização geográfica e o número de estabelecimentos de preparo de professores. 


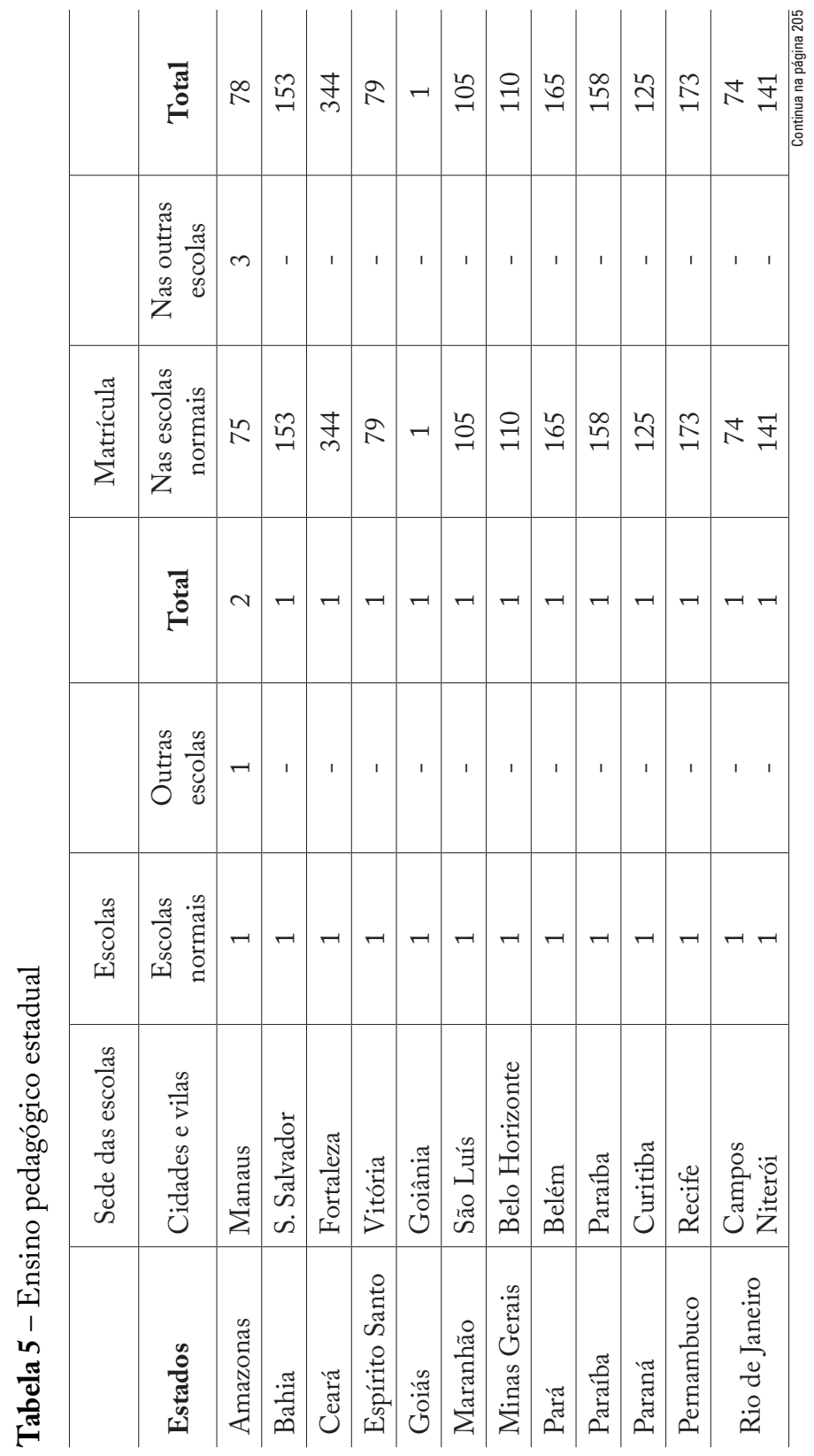


IV. Da politica dos governadores à década dos centenários • 205

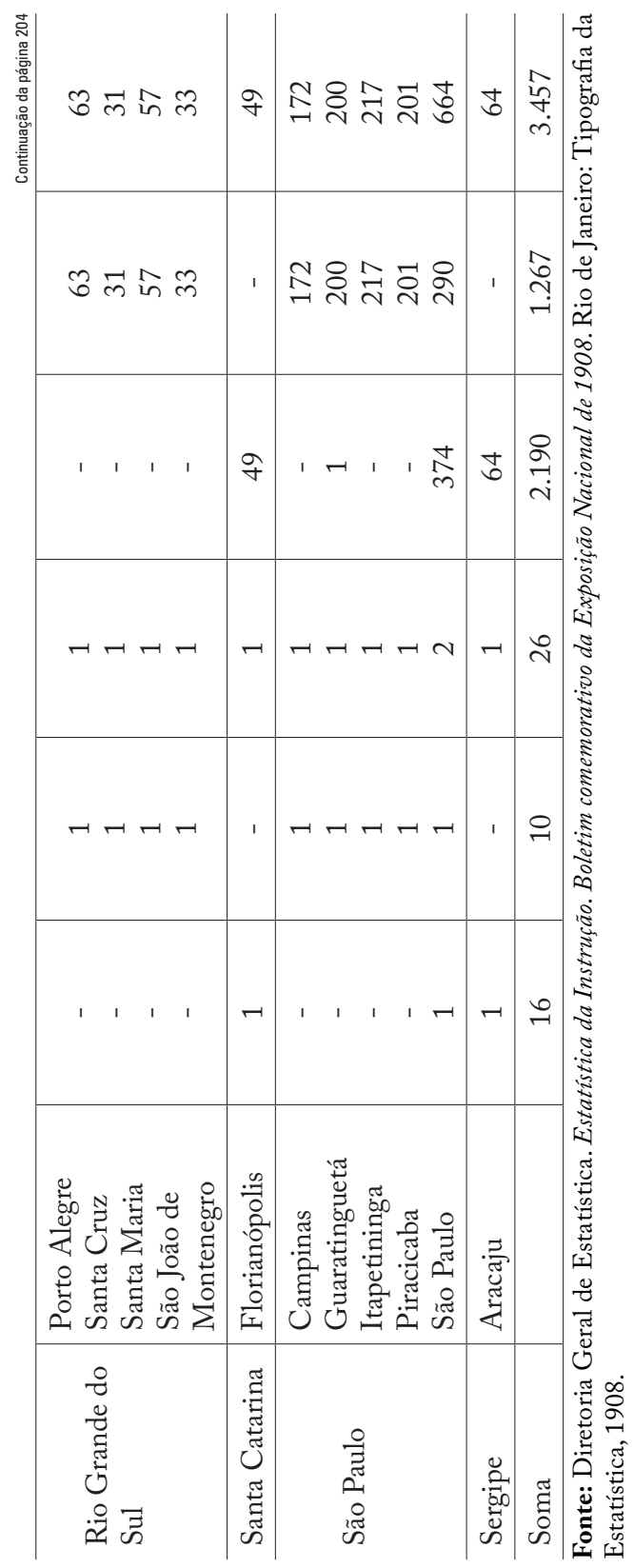


Como se deduz, o "ensino pedagógico" público e privado realizase em 44 estabelecimentos: "19 normais e 25 de outras espécies", quer dizer, escolas normais e instituições de ensino cujos diplomas são aceitos para o magistério; quanto aos estabelecimentos, esses diferem no tamanho, programas de ensino e nível de estudos.

Mais ao largo, nos meios parlamentares, Miguel Calmon, 1912, encaminhava a criação de uma escola normal superior na Capital Federal; Raul Alves, 1917, exacerba-se por uma escola normal em regime de internato e externato para preparar as fileiras de professores do sexo masculino para atuarem em todo o território nacional; mais adiante, com idêntico propósito, isto é, formar as fileiras do magistério primário, Tavares Cavalcanti, 1923, advogaria uma escola normal superior ou faculdade de letras a ser criada no Rio de Janeiro. Tal como aos tempos idos, as projeções mentais de futuros benquistos recaem na figura do mestre-escola/professor primário, com efeito, os faróis de ideias sobressaltam a imagem social do magistério. Relicário de virtudes, anjo tutelar de imensas asas abertas a flanarem sobre a meninice, atribuía-se ao exercício do magistério um código moral drástico.

O magistério é apostolado e quem diz apostolado diz dedicação e desinteresse. Quem o exerce não trabalha para si, mas para os outros, não para o presente, mas para o futuro. $\mathrm{O}$ professor em sua escola é como o enviado na sua missão, prudente, modesto, delicado, perseverante.

$\mathrm{O}$ homem em quem a sociedade deposita a sua grandeza pela perpetuação dos princípios que a sustentam, em quem a família confia as suas esperanças e a pátria os seus defensores de amanhã, não pode se um homem vulgar. O seu ministério é sagrado, a sua função social, imensa.

Verberava DeodatodeMoraes(1919,p.12),professordePedagogia da Escola Normal de Casa Branca, interior paulista, ao paraninfar a turma de alunos-mestres diplomados pela Normal. Comumente nos mais variados meios sociais e intelectuais, por exemplo, nas conferências da Liga de Defesa Nacional, sobressaltavam-se a imagem 
social do professor primário. "A palavra que ele dá ao discípulo é como a hóstia, que, no templo, o sacerdote dá ao comungante. É a eucarística cívica. Na lição há a transubstanciação do corpo, do sangue, da alma da nacionalidade" (Bilac, 1924, p.61). E na década dos centenários, 1920, oficializava-se a data de 15 de outubro como "Dia do Professor", e não faltaram celebrações do trabalho anônimo do mestre e do benefício universal da instrução. Nas palavras aquecidas de Agnello Bittencourt, diretor-geral da Instrução do estado do Amazonas. "Ninguém poderá negar ao obscuro 'mestre-escola' o papel de pioneiro da civilização brasileira, nos surtos de desenvolvimento a que ascendemos, entre as nações sul-americanas."

A gênese da nossa evolução, desde 1827, tem estado e continuará a estar ainda por muitas décadas, nesses pequenos centros de combate ao analfabetismo, que se vai restringindo diante da luz que o professor espalha. Mártir da desconsideração dos tempos é justo que o serventuário do magistério tenha o seu dia, como homenagem à sua obra realizadora de patriotismo e humanidade (Bittencourt apud Lima, 1927, p.30, grifo do autor).

É quando como dito anteriormente, a diretoria-geral de Estatística publica Ensino primário - resultados provisórios do inquérito sobre a instrução primária no Brasil em 1926, divulgados por ocasião do centenário da lei de 15 de outubro de 1827, referentes a esses. Nos números dados a conhecer, as fileiras do professorado primário apresentam adensamento significativo. Considerando-se o número de professores em exercício nas escolas estaduais, municipais e particulares nos estados da região Norte, a distribuição quantitativa é a seguinte: Amazonas - 249 professores; Pará - 1.160; Maranhão - 346. Na região Nordeste: Piauí -109; Ceará - 665; Paraíba do Norte - 574; Pernambuco - 1.466; Alagoas - 663; Sergipe - 301; Bahia - 1.915. Na região Sudeste: Espírito Santo - 586; Minas Gerais - 6.875; Rio de Janeiro - 1.591; Distrito Federal - 2.324; São Paulo - 7.824; Na 
região Sul: Paraná - 1.659; Santa Catarina - 1.070; Rio Grande do Sul - 6.875. Na região Centro-Oeste: Goiás - 222; Mato Grosso - 237.

Adensamento visível se compararmos tais quantidades àquelas consolidadas pela estatística de 1916: 15.586 professores, $11.402 \mathrm{em}$ escolas públicas e 4.184 em particulares; 8.068 professores lotados no magistério estadual (52\% do conjunto); 3.334 no municipal (21\%); 239 vinculados a estabelecimentos subvencionados (2\%); 3.945 a estabelecimentos "sem auxílio oficial" (25\%). E muito embora se falasse em "missão" e "sacerdócio", certamente as condições existenciais das fileiras do magistério nacional não eram das melhores. De fato, amparado em documentação variada, leis, decretos e regulamentos, o potiguar Nestor dos Santos Lima, em Um século de ensino primário, publicado em Natal, no ano de 1927, compilava os vencimentos anuais do magistério público nos estados da federação. Referida ao período de 1924 a 1927, da compilação salta tanto a modicidade dos salários quanto a heterogeneidade de escolas e de tipos de professores.

- $\quad$ Rio Grande do Norte: professores de $1^{\text {a }}$ categoria (capital) 4:200\$; 2a categoria (cidades) - 3:600\$; $3^{\text {a }}$ categoria (vilas); - 3:000\$; 4a categoria (povoações e escolas rudimentares) - 2:400\$. Diretores de grupos - 5:400\$ (capital), 4:800\$ (cidades), 3:800\$ (vilas).

- Maranhão: professores de escola-modelo, grupo escolar e instituto pré-escolar - 2:400\$; professores de escolas isoladas, urbanas e rurais $-180 \$ 2: 160 \$$.

- Paraíba: professores de escolas isoladas: $1^{\text {a }}$ categoria (capital) - 3:000\$; $2^{\mathrm{a}}$ categoria (cidades) - 2:760 $\$ 3^{\mathrm{a}}$ categoria (vilas) - 2:520\$; 4a categoria (povoados) - 2:280\$; professoresadjuntos de $1^{\mathrm{a}}, 2^{\mathrm{a}}, 3^{\mathrm{a}}$ e $4^{\mathrm{a}}$ categoria - 1:560\$, 1:480\$, 1:430\$ e 1:430\$; professores de escolas rudimentares $-1: 248 \$$.

- Paraná: professores normalistas - 2:400\$; efetivos de $3^{\text {a }}$ classe (capital) - 2:160\$; efetivos de $2^{\text {a }}$ classe (cidades) 1:900\$; efetivos de $1^{\text {a }}$ classe (vilas) $1: 440 \$$. 
- Obs.: As quatro categorias percebiam em 1896, 2:800\$, $2: 300 \$, 1: 900 \$$ e $1: 500 \$$.

- Santa Catarina: professor normalista ou de grupo escolar 3:480\$; professor de $4^{\text {a }}$ classe - 1:560\$; Diretor de Grupo Escolar - 4:560\$.

- Bahia: professores de $1^{\mathrm{a}}$ classe $-4: 000 \$, 2^{\mathrm{a}}$ classe $-3: 500 \$$, $3^{\text {a }}$ classe $-2.880 \$$; professores de escola complementar 4:000\$; professor diretor de grupo escolar: gratificação anual de 840\$.

- Minas Gerais: professores de $1^{\mathrm{a}}, 2^{\mathrm{a}}$ e $3^{\mathrm{a}}$ classes - 4:000\$, 3:900\$ e 3:200\$; professor-diretor de grupo escolar da capital - 4:560\$; professor-diretor de grupo escolar de cidade - 3:960\$; professor de grupo escolar da capital - 2:544\$; professor de grupo escolar de cidade - 2:376\$; professor de distrito 1.860 ; professor de colônia - 1:584\$.

- São Paulo: professor rural - 3:480\$; professor urbano 3:480\$; professor de grupo escolar - 4:910\$. Diretor de grupo escolar $1^{\circ}$ grau $-7: 200 \$, 2^{\circ}$ grau $-7: 800 \$, 3^{\circ}$ grau $-8: 400 \$, 4^{\circ}$ grau $-9: 000 \$$.

Como exercício de comparação do poder de compra de professores e diretores convém retomar o levantamento dos militantes anarquistas Hélio Negro e Edgar Leuenroth na brochura O que é marxismo ou bolchevismo: programa comunista, publicado em 1919. O salário mensal de um trabalhador urbano ou rural variaria entre $80 \$ 000$ e $120 \$ 000$, o consumo mínimo duma família operária, dois adultos e duas crianças, orçaria em $207 \$ 000$. Evidente por si, o déficit se acentua se se considerar as crises cíclicas de carestia do decênio de 1920, seguidas de elevação de aluguéis e preços de mantimentos. A despeito de tudo é preciso interrogar: Quem eram professores primários? Qual a condição existencial de uma categoria socioprofissional de natureza intelectual em regiões onde prevaleciam o trabalho manual e o analfabetismo? 



\section{Verbo social, pátria viva}

\section{"O Brasil é um mundo" (ou o grande dia tropical)}

Ama, com fé e orgulho, a terra em que nasceste!

Criança! não verás nenhum país como este!

Olha que céu! que mar! que rios! que floresta!

A Natureza, aqui, perpetuamente em festa,

É um seio de mãe a transbordar carinhos.

Vê que vida há no chão! vê que vida há nos ninhos

Que se balançam no ar, entre os ramos inquietos!

Vê que luz, que calor, que multidão de insetos!

Vê que grande extensão de matas, onde impera

Fecunda e luminosa, a eterna primavera!

Dotados de apelos cálidos, no sentido de dar a conhecer e fazer amar o Brasil, por gerações, os versos romântico-patrióticos desse poema de circunstância, "A Pátria”, de Olavo Bilac (1904, p.15), impressionam a meninice escolar. Desde os fins do século XIX, a pedagogia escolar encontra-se acometida por manifestações de patriotismo e civismo, considerada instituição social capaz de superar divisões e desarmonias, via-se na escola a efígie do nacionalismo. Conhecer as "pequenas pátrias", as regiões brasileiras, amar a "grande pátria”, a Nação, são os apelos duma literatura didática de cunho nacional e nacionalizante, com isso intentava-se estimular o patriotismo, a exemplo das nações 
liberais Estados Unidos, Itália, França e Alemanha, cujos valores ecumênicos e missionários desbordavam em solidarismos.

Tudo leva a crer que a idolatria da nação (e da pátria) preenche o vazio gerado pela ausência de instrução religiosa; e, como não há educação sem fé, opta-se pela adoração do altar da Pátria. No intento de consubstanciar um povo feito de irmãos fraternos, cedo ou tarde, dos Céus encantados e radiantes, a Nação desceria a Terra. Resumidamente, para esse ponto de vista, o agir coletivo harmonioso tem suas raízes na educação comum, donde o contínuo estampar de certificados de civismo, isto é, os compêndios centrados na elegia da natureza, no culto das origens, no caráter do povo e, acima de tudo, no bem coletivo como referencial a ser incutido na infância escolar.

Nessa figuração cívico-nacionalista dos fatos de realidade, o entendimento e o coração da prole da nação são instruídos e afeiçoados não com referência às classes sociais, às crenças religiosas, às doutrinas políticas, mas à Sociedade, ao Estado e à Nação. Que escopos? Suscitar sentimento de lealdade e estima a uma totalidade maior e anterior à existência individual, porquanto isenta de quaisquer egoísmos sociais ou lealdades facciosas. Transfundir espíritos, ou seja, o brasileirismo pela boa vontade cívica, amar e servir o corpo e alma da nação, espalhar a cultura heroica e republicana. De resto, como se afirmava, as escolhas individuais subordinam-se ao bem coletivo, muito embora sabe-se hoje que o pressuposto de sentimento nacional recalcasse a origem e o fundamento das desigualdades entre as classes sociais.

Bussolada pelo nacional e nacionalizante, melhor dizendo, pelo intento de atrair o povo para si e nele reconhecer-se, desponta uma literatura didática desejosa de afetar o leitor com imagens benfazejas, na qual, por assim dizer, há credulidade excessiva; nela, a literatura, destacava-se o gênio distintivo das regiões brasileiras e sua junção num todo unitário, inextrincável, sobremodo pulsátil. ${ }^{86}$ Certamente as origens dessa literatura a exultar a imagem material do país remontam

${ }^{86}$ A nação como semióforo, ou seja, objeto do qual brotam incessantes efeitos de significação, é analisada por Chauí (2000). 
a Por que me ufano de meu pais? - do monarquista Afonso Celso, livreto publicado no $4^{\circ}$ Centenário do Descobrimento do Brasil. Na folha de rosto, o anexim - "Right or wrong, my country"; na sequência, Afonso Celso descreve um país exuberante, incomensurável, imerso num sonho agradável. $\mathrm{O}$ excerto a seguir, embora longo, capta à perfeição o exotismo brasileiro, segundo a visão do autor.

O Brasil é um dos mais vastos países do globo, o mais vasto da raça latina, o mais vasto do Novo Mundo, à exceção dos Estados Unidos. É pouco menor que toda a Europa.

Rivaliza em tamanho com o conjunto dos outros países da América Meridional. Representa uma décima quinta parte do orbe terráqueo. Só a Rússia, a China e os Estados Unidos o excedem em extensão. É quatorze vezes maior do que a França, cerca de trezentas vezes maior do que a Bélgica.

A sua circunscrição territorial menos dilatada, Sergipe, sobreleva a Holanda, a Dinamarca, a Suíça, o Haiti e Salvador. Cada um dos municípios em que se subdivide a mais ampla, Amazonas, equivale a Estados, como Portugal, Bulgária e Grécia. Pará, Goiás, Mato Grosso ultrapassam qualquer nação européia, salvante a Rússia.

O Brasil é um mundo (Figueiredo, 1901, p.9).

Insinuante e agregador, ainda que hoje soe irreal, Afonso Celso, um dos fundadores da Academia Brasileira de Letras, elabora uma mitologia das origens e destinação social do país. De saída diverge, motivo edênico, a fusão das raças como fato benquisto, embora muitos a caluniassem. "Negros, brancos, peles-vermelhas, mestiços vivem aqui em abundância e paz", "Deus não nos abandonará. Se aquinhoou o Brasil de modo especialmente magnânimo, é porque lhe reserva alevantados destinos." Mais à frente de Por que me ufano de meu país? de Afonso Celso, viriam outros artífices desse gênero empenhado na descrição afetuosa das singularidades do país, Alfredo Varela, Livro da mocidade; Olavo Bilac, A pátria brasileira; Júlia Lopes de Almeida 
Histórias da nossa terra; Viriato Correia, Histórias de nossa história; Afrânio Peixoto, Minha terra e minha gente; Olavo Bilac e Manoel Bomfim, Através do Brasil e Olavo Bilac e Coelho Neto, Contos pátrios.

E, mais ao largo no corpo real da pátria, remanesciam litígios de fronteiras entre Brasil e países sul-americanos, de sorte que a demarcação histórico-geográfica dos limites era objeto de disputas contenciosas. Sob as ações de um dos expoentes da tradição diplomática do Segundo Reinado, José Maria da Silva Paranhos, ministro plenipotenciário, aos poucos se resolvem as pendências relativas às fronteiras externas. ${ }^{87} \mathrm{De}$ sorte que os tratados internacionais finalizam o bordado das fronteiras, mesmo assim, ainda é relativo o conhecimento da territorialidade comum, as representações cartográficas mais exatas concernem ao Distrito Federal, Minas Gerais, São Paulo, e Rio Grande do Sul.

No introito da Estatística da instrução, 1916, Oziel Bordeaux Rego desabafa: para estabelecer a divisão administrativa do país, enumerar municípios, cidades, vilas e paróquias, fora obrigado a recorrer ao "precioso Atlas do Império do Brasil", de Cândido Mendes de Almeida, e às fontes antigas, isto é, relatórios de presidentes de províncias, legislação anterior ao Ato Adicional, legislações provinciais, obras de Robert Southey, Ferdinand Denis, Aires de Casal, Costa Pereira, Jaboatam, Silva Lisboa, Fernandes Gama, Accyoli, Saint-Hilaire, Koster, Perdigão Malheiro e Cortines Laxe.

\section{Instruir entendimento e coração da prole da nação}

Um dos pontos altos da literatura didática a exultar a grandeza e o orgulho nacional, quer dizer, a noção abstrata da Pátria (e de povonação), é, sem dúvida, Através do Brasil, de Olavo Bilac e Manoel Bomfim, o primeiro, inspetor escolar, o segundo professor e diretor na Escola Normal do Distrito Federal. O compêndio é decalcado de $L e$ tour de la France par deux garçons, subintitulado "Devoir et patrie", de G. Bruno, pseudônimo, um dos melhores produtos do clima pedagógico

${ }^{87}$ Cf. Escobar (1995, [1940]) e Vianna (1935). 
do começo da Terceira República francesa. ${ }^{88} \mathrm{O}$ entrecho do livro incita o leitor a acompanhar as jornadas de norte a sul do país por dois adolescentes, Carlos e Alfredo em busca do pai desaparecido. Misto de périplo educativo e enciclopédia popular, a narrativa descreve os meandros geográficos e as peculiaridades regionais.

E acreditamos - escrevem Bomfim e Bilac - que isso se dá com o nosso trabalho. Estamos certos que a criança, com a sua simples leitura, já lucrará alguma coisa: aprenderá a conhecer um pouco o Brasil; terá uma visão a um tempo geral e concreta, da vida brasileira - as suas gentes, os seus costumes, as suas paisagens, os seus aspectos distintivos.

Em capítulo seguinte. "E então o professor apelará para a observação da criança, para que ela note a diferença entre o estado selvagem e as indústrias, instituições, obras e costumes que distinguem a civilização; mostrará que essas instituições e indústrias faltam ainda em grande parte algumas terras do interior, onde a civilização ainda não penetrou” (Bomfim; Bilac, 1910, p.15). Desse título foram tiradas 60 edições em cinco décadas. ${ }^{89}$

Em Viagem de uma família brasileira ao norte do país, Coelho Neto tenta emular a façanha de Bilac e Bomfim; logo seria a vez de Minha terra, minha gente, obra de iniciação etnográfica e antropogeográfica, de Afrânio Peixoto, diretor da Escola Normal e da Instrução Pública do Distrito Federal. No compêndio, o autor aborda os problemas de raça, clima e meio social a emperrar a formação da nacionalidade. "Nem lamúrias de uns, nem o lirismo de outros, produzem nada. Pareceu, pois, ao autor novidade útil escrever para as crianças de sua terra um livro sincero, sem reservas nem veemências, no qual procurasse, sobre os problemas essenciais da nossa nacionalidade, dizer-lhes verdades necessárias".

\footnotetext{
${ }^{88}$ Cf. Lajolo (1982, 2000).

${ }^{89}$ Cf. Botelho (2002), Hansen (2007).
} 
A fusão lenta das misturas malfeitas ainda, a seleção reiterada da cultura, a disciplina forçada da vida social, farão dessa massa um povo forte, são e feliz? O esboço de hoje dará um povo voluntarioso, sentimental, inteligente, digno da terra e do tempo em que vive?

Haja liberdade de comunicações, de comércio, de indústria; é o que reclama um país agrícola, distante dos mercados, distante de si mesmo, tão apartados são os núcleos disseminados da sua população. As nossas riquezas tão faladas, quase em ser, sejam exploradas, pois da riqueza virá progresso, conforto, civilização (Peixoto, 1916, p.225).

Guardadas as inclinações pessoais desses autores tão diferentes entre si, há propósitos extraliterários comuns, a fidelidade à ideia do nacional, o despertar de afeto, o amor à causa pública, a consciência da comunidade de destinos, isso no intento de enraizar o sentimento nacional e promover a amabilidade humanitária, em suma. “É, então, ali, a ideia sagrada da Pátria se apresentou, nítida e bela, diante da alma de Anselmo. E ele compreendendo enfim que a sua vida valia menos do que a honra de sua nação, pediu a Deus, com os olhos cheios de lágrimas, que o fizesse um dia morrer graciosamente, abraçado às dobras daquela formosa bandeira, toda verde e dourada, verde como os campos, dourada como as madrugadas de sua terra." Enterneciam Olavo Bilac e Coelho Neto (1904, p.15), em Contos pátrios.

Nem ideia abstrata nem produto raciocinante, figurava-se a pátria, como ente coletivo vivo tal como em Breviário cívico, de Coelho Neto, "Publicação da Liga de Defesa Nacional" ou em Tradições nacionais: episódios históricos e brasileiros notáveis, de Carlos Alberto Gomes Cardim, sinceros produtos e subprodutos da ideia plasmática de nação e nacionalidade. ${ }^{90}$ Enquanto isso, no aquecido circuito de edição e comercialização de obras didáticas, a Livraria e Editora Francisco Alves e a Companhia Melhoramentos destacavam-se na atração de autores

\footnotetext{
${ }^{90}$ A literatura cívico-patriótica endereçada à infância escolarizada é analisada por Correa (2006) e Hansen (2007); a edição e comercialização do livro didático, por Bragança (2000) e Razzini (2010).
} 
didáticos, em maioria lotados em aparelhos escolares. ${ }^{91}$ Nesse gênero em evidência, carregado de audácias divinatórias, o país aparece mais moderno e menos arcaico, não se alude ao latifúndio, à monocultura de exportação, tampouco às condições de vida e trabalho do povo pobre ou aos entrechoques sociais e às disparidades espaços-temporais.

Objetivando incrementar o "são brasileirismo", como escrevera Silvio Romero ou conhecer um país "distante de si mesmo", como queria Afrânio Peixoto, essa literatura de ficção destinada à infância e a juventude (a copiosidade de reedições chama a atenção) assume a feição de certificados de civismo votados à construção simbólica da coletividade social, quer dizer, à supremacia da grande pátria sobre as "pequenas pátrias" ao mesmo tempo em que coligem a antropogeografia e a antropossociologia "da nossa terra e nossa gente".

De par, nos planos regionais, expandem-se a montagem de aparelhos escolares, as causas são as mais diversas, surtos de modernização das oligarquias estaduais, expansão de fronteiras agrícolas, ondas imigratórias, crescente urbanização e claro demanda social por escola. Nos circuitos políticos e nas instâncias do sistema intelectual, um consenso radical, o Brasil, país jovem e promissor, dotado de horizontes geográficos infindos, em que a natureza prodigiosa armara panoramas sedutores e deslumbrantes, carecia de direção e soberania mental. ${ }^{92}$

Vazados em registro de convocatória social, as vozes faladas e as palavras escritas estimam lições intensas extraídas da firmeza cívica e da coragem marcial. Porventura, não mais bastava singularizar a nacionalidade pelos atributos externos, a extensão territorial, a variedade climática, a fertilidade dos solos, as florestas luxuriosas, os rios caudalosos, as cachoeiras majestosas, as praias magníficas, o céu de anil, e, as tradições populares. Porventura, não mais bastavam as ofuscantes tomadas panorâmicas (e extasiantes) enunciadas pelo

${ }^{91}$ Cf. Monarcha (1997) e Bragança (2000).

${ }^{92}$ A ideia de nação é abordada por Gellner (2008); quanto à interpretação imaginária da vida coletiva, ver Brescianni (1998) e Girardet (1987). 
indianismo-romântico dos poetas oitocentistas ou pelo ufanismo orgulhosamente aristocrático de Afonso Celso: era preciso ir além do ficcional maravilhoso, pois se dizia, a pátria não é apenas natureza

Das lições auriverdes ministradas entre os escuros horizontes do presente, as noites estreladas e os fulgores da nova manhã, origina-se uma "religião cívica", crente, fervorosa, assemelhada à dos primeiros cristãos. "Pátria, família e sociedade", "O Brasil para os brasileiros”, “Tudo pela Pátria!”, “Tudo pela República!”, “Tudo pela Humanidade!", "Pátria, Nação, Humanidade e Civismo”. E, muito mais do que antes, clamava-se por um filtro admirável, a ação social da escola e sua cultura letrada na formação de uma identidade coletiva mais congregante, mais hegemônica, mais unitária. Esmerilhava-se a confiança na escola social, nela se concentram as intenções educativas da prole da nação, considerada porvir do amanhã futuro. Em suma, na sua variedade, o pensamento nacionalista e suas "invenções históricas arbitrárias" 93 avultam uma literatura social caracterizada pela cofiança na instrução popular.

Dos extravasamentos das inquietudes morais, desdobra-se um chão forrado de publicações vibráteis, apostólicas mesmo, por vezes, mera ficção verbal, nem por isso menos sonoras, contudo aparentadas no desejo de construir uma consciência didática nacional - O Brasil e a educação popular, de Antonio Carneiro Leão; Educação primária escolar, de Raul Alves de Sousa; Pela instrução primária no Brasil, de A. C. Sales Júnior; Problemas de educação nacional e de instrução pública, de Egas Muniz Barreto de Aragão; O problema da educação nacional, de Azevedo Sodré; Eduquemo-nos, de José Augusto Bezerra de Menezes; Educação nacional, de Monteiro de Souza; Ensino popular no Brasil, de Orestes Guimarães; Educar-se para educar, de Venancio Filho; Educação popular, de Firmino Costa; A educação nacional e Virilização da raça, ambos de Mario Pinto Serva e No Brasil só há um problema nacional: a educação do povo, de Miguel Couto.

${ }^{93}$ Cf. Gellner (2008). 


\section{Tempos idos, tempos novos, num crescendo}

Irmãos do norte! Irmãos do sul, amigos! Unamo-nos em torno da nossa bandeira; que os elos que nos ligam não se dessoldem nunca, para que seja grande a sua glória e poderosa a sua força!

Júlia Lopes de Almeida, “A nossa bandeira” (1907).

$\mathrm{Na}$ linguagem diagnóstica, o liberalismo-federalista ressoa espécime estrangeiro enxertado em florestas tropicais, por consequência, dizia-se, nelas efloresciam vinte hinos e bandeiras das vinte pátrias estaduais e sobre elas, a tremular, o fantasma da cissiparidade. $\mathrm{Na}$ segunda edição de $A$ educação nacional, possivelmente influenciado pelo Os sertões de Euclides da Cunha, a quem demonstrara apreço e admiração, José Veríssimo colocava o problema claramente. "Estas diferenças fundamentais na evolução e índole da nação e da federação encerram os perigos intrínsecos desta forma, perigos que aos políticos previdentes cabe antever e conjurar. Além desses a federação brasileira encerra um outro e gravíssimo, qual é a indicada falta ou pobreza de sentimento nacional, tornando acaso prováveis, e em todo caso possíveis, as tentativas de separação" (Veríssimo, 1906, p.10). Nas imagens anoitecidas, alardeia-se a existência de um país indeterminado, sujeito à incoesão e à indisciplina. "O que me aterra é a possibilidade do desmembramento."

Amedronta-me este espetáculo: este imenso território, povoado por mais de vinte e cinco milhões de homens, que não são continuamente ligados por intensas correntes de apoio e de acordo, pelo sem ideal, pela educação cívica, pela coesão militar, conflitos ridículos sobre fronteiras, dentro da integridade da pátria, explorados pela retórica, envenenados pelo fanatismo; originando guerras fratricidas, a desigualdade entre Estados irmãos, desirmanados pela diferença das fortunas e das prendas (Bilac, 1917, p.23). 
Apreensão verbalizada por Oliveira Vianna em Evolução do povo brasileiro, obra em que fixava na forma de mural o desenrolar históricosociológico-cultural do país. "Repartindo os poderes da soberania entre a União e os Estados, o novo regime cria, ao lado da história geral das suas instituições, uma história local, que se capitula em vinte histórias particulares, correspondentes aos vinte Estados da Federação" (Oliveira Vianna, 1923, p.29). É de então os ciclos afervorados de conferências, palestras, fundação de sociedades patrióticas, pregoante, o poder da palavra acena ensino cívico, linhas de tiro e escotismo, chegara o tempo atiçado das ligas e associações civis votadas a sublimar a proto-história nacional. ${ }^{94} \mathrm{Na}$ tábua de prioridades, a debelação do analfabetismo, a conscrição militar compulsória, o voto obrigatório e secreto, a obrigatoriedade escolar.

Sediada no Rio de Janeiro, com ramificações em Sergipe, Espírito Santo, Pernambuco, a Liga Brasileira contra o Analfabetismo bate-se pelo ensino primário obrigatório, educação nacional, caixas escolares. ${ }^{95}$ A Liga de Defesa Nacional conclama a defesa da pátria, educação cívica, voto secreto, batalhões patrióticos, linhas de tiro, escotismo, moralização da política, ensino da língua materna, valoração do trabalhador, serviço militar e instrução obrigatórios. ${ }^{96}$

A sua vez, a Liga Nacionalista de São Paulo desfralda a bandeira negra do perigo: a fidelidade dos imigrantes e descendentes à sua cultura de origem e a inexistência de patriotismo entre brasileiros. ${ }^{97}$ Sob os influxos da Liga, Sampaio Dória, ao reformar a engrenagem dos serviços de instrução, subordina as escolas ditas estrangeiras às determinações da diretoria-geral da Instrução, além de proibir o ensino em língua estrangeira aos menores de dez anos, as obrigava a guardar os feriados nacionais, a prover ensino de língua portuguesa por professor brasileiro ou português nato, a prover ensino de história e geografia por brasileiro, e sobretudo a entoar os hinos nacionais.

\footnotetext{
${ }^{94}$ As trajetórias das ligas e seus programas são exaustivamente analisados por Nagle (1966).

${ }^{95}$ Cf. Nofuentes (2008) e Sousa (2004).

${ }^{96}$ Cf. Oliveira (2012).

${ }^{97}$ Cf. Bandecchi (1980) e Estatutos da Liga Nacionalista de São Paulo (1917).
} 
Donde campanhas na imprensa, discursos nas tribunas, distribuição gratuita de brochuras para "educar o povo no amor à Pátria, à Lei, à Liberdade e às tradições nacionais”. Em chave socialmente empenhada com frequência destrinçavam-se os mandamentos cívicos. "Amai a liberdade! Defendei a Pátria! Pagai impostos! Votai! Cooperai na política! Não vos esquiveis do dever do júri! Respeitai a lei! Fiscalizai a execução das leis! Falai bem a língua nacional! Não desdenheis a civilidade, o cavalheirismo, as boas maneiras!".

Eis aí, Srs. e Exas. Sras., o decálogo da religião da Pátria que a Liga Nacionalista houve por bem mandar fosse espalhado hoje pelo Estado inteiro. Realizar esses dez mandamentos é ter educação cívica, pois já o referi, educação é ato, educação é prática de preceitos; ter educação é agir no sentido da instruída possuída (Silveira, 1919, p.3).

Nas elocuções hiperbólicas, reserva-se à escola a celebração hagiográfica dos fastos nacionais, o ensino da língua, história e geografia pátrias. Se o analfabetismo possibilitava a troca injusta da vontade geral pela vontade de minorias votantes, concluía-se que, a ativação do ensino cívico seria o corretivo, de tal sorte que o vozerio das ligas e associações converge para a qualificação do voto. "Onde não se permite a válvula das oposições à maioria, sociedades secretas, subversivas, carcomem o solo, sobre que se alteiam os governos descuidados. $\mathrm{O}$ melhor preventivo contra a explosão das rebeliões, sempre iminentes, é dar-lhes uma tribuna, por onde se desabafem, se queixem, preguem as suas ideias, trovejem as suas reclamações.” Encarecia Sampaio Dória (1919, p.142), em O que o cidadão deve saber. Manual de instrução cívica, opúsculo editado pela Tipografia Olegário Ribeiro, Lobato \& Cia. Ltda., com a tiragem espetacular de 10 mil exemplares. Nesse decálogo popular de direito constitucional, o autor explica as noções de júri, serviço militar, estado de sítio, partidos políticos, soberania nacional, Estado e federação.

Ora bem, assim se idealizava a superação da malformação do país. No mais, é bom lembrar que o alistamento eleitoral é reduzido, 
na eleição presidencial de 1918-1919, por exemplo, girou em torno de 1,5\%, nas demais eleições, 2,3\% a 2,4\%, e em 1930, excepcionalmente em 5\%. ${ }^{98}$ Além do que predominam as defraudações habituais praticadas pelo mandonismo local, o "bico de pena", a adulteração das atas pelas mesas eleitorais e a "degola" ou "depuração", isto é, o não reconhecimento dos diplomas dos opositores eleitos.

$\mathrm{Na}$ aura ingente de cogitações nacionalistas, o escotismo de Baden-Powell, sumariado no manual $A$ educação pelo amor substituindo a educação pelo temor, efloresce nos marcos escolares tanto pelo apoio das autoridades quanto pela iniciativa da Associação Brasileira de Escotismo. ${ }^{99}$ Elaborado pelo jornalista e folclorista Amadeu Amaral, o decálogo de imperativos, assim preceitua a ética do boy-scout, préfiguração do adulto reto.

1-A palavra do scout é sagrada; 2 - O scout é leal; 3 - O scout tem o dever de ser útil e de ajudar a outrem; 4 - O scouté amigo de todos e é irmão de qualquer outro scout, 5 - O scouté cortês; 6 - O scout é amigo dos animais; 7 - O scout sabe obedecer; 8 - O scout é alegre sorri e assobia; 9 - O scout é econômico; 10 - O scout é puro de pensamentos, de palavras e de atos (Amaral, 1916, p.4).

E raras, muito raras, foram as vozes a contraditar a pressão da voga nacionalista na subjetividade infantil. A de José Getúlio Frota-Pessoa, certamente, é uma delas. "A força de se inocular na criança essa idolatria, acabaremos formando gerações de fetichistas, para as quais o sentimento da Pátria,ideal e nebuloso, se substituirá pela adoração a esse ídolo concreto e palpável, que se vê fulgir e tremular" (Frota-Pessoa, 1924, p.117).

Num quadro social pintado e repintado a golpes e a contragolpes, translações de futuros, difusão de valores embandeirados e construções de futuro possíveis, avantaja-se o afã de engendrar de uma vontade única devotada a um todo transcendental preexistente aos indivíduos

\footnotetext{
${ }^{98}$ Cf. Buarque de Holanda (1948 [1936], 1960) e Nicolau (2012).

${ }^{99}$ Cf. Nascimento (2008).
} 
e às classes sociais. Resumidamente o corte histórico-cultural é feito pelo nacional, valer dizer, trata-se de transfigurar o país para além das contingências da situação histórica (na lógica nacionalista, há uma inversão de sinais, é a nação que faz o homem e não o inverso). Com isso origina-se uma figura de destino coletivo, uma fé comum, isto é, a escola e sua cultura, para além da alfabetização, modelariam as novas gerações ao formar hábitos mentais e atitudes comportamentais necessários à coesão da vida nacional.

Ensinar o $b a b a$ ou dar os rudimentos de um oficio, abandonando o espírito, a inteligência do jeca-tatu, do caipira e do alfabetizado em geral, no mesmo estado de inconsciência, desorientação ou anarquia, em que eles vivem há quatro séculos, é em nada resolver o problema de nossa cultura e de nossa grandeza. Uns e outros, quer os aprendizes de artífices, quer os alfabetizados se constituirão, talvez mais facilmente do que até agora, pasto da demagogia impenitente, ou das doutrinas extremistas, em voga (Carneiro Leão, 1923, p.133-4).

\section{O elo é a pátria, a reação congregante}

O recenseamento geral de 1920 estimara em 1,6 milhão o total de estrangeiros radicados no Distrito Federal, São Paulo, Paraná, Santa Catarina e Rio Grande do Sul. Desse total, São Paulo abrigava 53\%. Sob a pressão da antífona nacionalista, ascendente e alarmista, a estrangeirização do país soa como perigo iminente. Entrava em marcha o abrasileiramento das áreas do Sul do Brasil. Em relatório à Conferência Interestadual de Ensino Primário, Orestes Guimarães contabiliza 310 escolas mantidas pela Itália: 87 no Rio Grande do Sul, 38 em Santa Catarina, 102 em São Paulo, 39 no Paraná, 11 na Capital Federal, 23 em Minas Gerais, 10 no Espírito Santo. ${ }^{100}$ Em memorial ao ministro da Justiça e Negócios Interiores, esse inspetor federal estribilha o desnacionalismo.

${ }^{100}$ Cf. Conferência Interestadual de Ensino Primário (1922). 
Quistos da alma brasileira, frequentados a dezenas, senão as centenas de milhares de crianças, filhas de estrangeiros, tais escolas, pela dinâmica educativa de que revestem reduzem os novos imigrantes avultadíssimo número de crianças aqui nascidas, as quais, infelizmente, as tornam os piores estrangeiros entre nós, embora com foros de cidadãos brasileiros.

Ao deixarem essas escolas, de cursos de seis a oito anos, as crianças saem perfeitamente estrangeiradas e assim, mais tarde, educarão seus filhos, só com o tempo com o convívio dos balcões e das estradas passarão a papaguear algumas palavras da língua vernácula, mas a leitura, a cultura, enfim, só a podem fazer nos diários, revistas e livros estrangeiros (Guimarães, 1925, p.3-4).

$\mathrm{E}$ a respeito "desses brasileiros feitos estrangeiros que sequer sabíamos assimilar", dizia Afrânio Peixoto. "O senhor Orestes Guimarães, pedagogo de responsabilidade, fez ainda notar que não se toma providência alguma a respeito das escolas alemãs, em outros centros do país, em S. Paulo e no Rio, por exemplo, que continuaram e continuam livremente a funcionar, fazendo de estrangeiros patrícios nossos, que não sabemos nem podemos instruir" (1930, p.112).

1917. No esforço de outorgar identidade à vida coletiva, Wenceslau Brás, presidente da República, decreta o fechamento de centenas de escolas em áreas de colonização no Paraná, Santa Catarina e Rio Grande do Sul por ensinarem em língua alemã. Passo seguinte, o Decreto no 13.014 , de maio de 1918, estipula a criação de escolas subvencionadas em núcleos de descendentes de imigrantes, ao todo, 404 unidades, 120 no Rio Grande do Sul, 168 em Santa Catarina, 116 no Paraná. De par, Orestes Guimarães, professor paulista comissionado em Santa Catarina, é nomeado inspetor escolar federal das Escolas Subvencionadas pela União. ${ }^{101} \mathrm{Na}$ contiguidade, o Decreto no 13.175 ,

${ }^{101} \mathrm{Na}$ sua diversidade, o tema "escolas estrangeiras" é analisado por Kreutz e Luchese (2011). Ver Seyferth (1999). Sobre a obra de Orestes Guimarães, ver Auras (2007). 
de setembro de 1918, abriria crédito de 100:198\$548 para auxiliar 96 escolas oficializadas ou instaladas em núcleos coloniais no Paraná.

No mandato do vice-presidente, Delfim Moreira, o ministério da Justiça e Negócios Interiores concede crédito de 113:937\$580 para a instalação de 167 escolas no Rio Grande do Sul, já o Decreto no 13.014, de 4 de maio de 1918, credita 175:900\$160 para 148 escolas em Santa Catarina. Enfim, alardeia-se o poder agregador da escola primária, instituição social essencial às instituições políticas, ao civismo, à saúde e ao rendimento econômico Se se atribuía à escola a finalidade de homogeneizar as populações - a cada nova geração, seriam concedidos o domínio da língua na forma culta, noções de geografia e história pátria, folclore, civismo e moral; paulatinamente, as finalidades da educação constantes nos regulamentos e regimentos, "o fim da escola é alfabetizar", "promover a educação física, moral e intelectual", o "ensino de letras", são substituídas por outra finalidade, o ideal de construção da identidade nacional. 



\section{Hermeneutas da República iletrada}

\section{Fenomenologia das festas nacionais}

1920 é a década dos centenários, melhor dito da compulsão à lembrança dos fatos salientes da história do país. Além do centenário da Independência, em 1922, celebravam-se os centenários de instalação do ensino jurídico e do nascimento de Pedro II, 1925 - imperador e monarquia são fatos sublimados -, do Poder Legislativo, 1926, e da lei geral das escolas de primeiras letras, 1927. Em tom de odisseia, avaliava-se trajetória do país, para alguns a meio-caminho, para outros, irrealizada. Mormente os esforços almejam estabilizar a flutuante memória nacional, por paradoxo, não será errôneo afirmar que nessa década há simultaneamente excesso de solidez memorial e ausência de memória. No teatro dos balanços, homens públicos de talentos multiformes irmanam-se na construção de memórias (como se sabe a memória não é tão só repetição do passado, o ato retrospectivo tem função propiciatória).

As vozes se avolumam, hieráticos homens públicos de talentos multiformes pronunciam-se sobre o estado de coisas, alguns descreem da pátria, outros fitam o vir a ser, de qualquer modo, abundante, a obra ideológico-escritural dos reformadores e teoricistas lota os proscênios celebrantes, e, por ventura, a organização nacional da instrução é um dos motes centrais, talvez o mais querido, talvez o mais bem aceito. Encarnados na pele de hermeneutas da República iletrada, diferentes 
sujeitos, em diferentes lugares, ao interrogarem em seus escritos "Qual instrução?”, "Qual Brasil?”, “Qual futuro?”, entoam vistosos elucidários. Nos escritos de circunstâncias, predominam objeções a um presente imóvel, melhor, a um passado que não quer passar.

As ideias de organização e progresso vinham, no entanto, tendo expressões locais, como o atestam as reformas de ensino nos Estados de São Paulo, 1920; Ceará, 1922; Minas Gerais, 1927; Espírito Santo, 1927; Pernambuco, 1928, e ainda no Distrito Federal, em 1925 e 1928. Essas reformas agitavam as novas ideias técnicas e os objetivos sociais da educação.

Em 1924, funda-se, no Rio de Janeiro, a Associação Brasileira de Educação, que inicia reuniões de estudos, cursos de conferências e congressos anuais (Curitiba, 1927; Belo Horizonte, 1928; São Paulo, 1929). Ramos dessa associação, ou instituições autônomas fundam-se também nalguns estados. Há um movimento de agitação de ideias semelhantes ao período final do Império, e a que não seriam estranhas as consequências econômicas e sociais provocadas pela Primeira Grande Guerra Mundial, e os progressos da industrialização do país (Lourenço Filho, 1949, p.243).

A década de 1920 transcorre em meio ao clima de guerra civil, decretação do estado de sítio, dissidências interoligárquicas, levantes "tenentistas", marcha da Coluna Miguel Costa-Prestes, agitações populares, carestia de vida, balburdia orçamentária e corrosão das finanças públicas; numa palavra, estalava a crise de hegemonia da república oligárquica. Dos sobressaltos de consciências, deriva uma vertigem de programas de salvação pelo saneamento das relações sociais, em síntese. De modo que, o verbo social dos publicistas forra o chão das festas centenárias com ensaios de sociologia retrospectiva e psicologia social. E ao clamarem por acelerações e mutações da história pátria, suas palavras adquirem caráter ativo e valor documentário, pois marcadas pelo espírito de crítica e pelo desejo de renovação. 
É o caso do severo inquérito conduzido por Vicente Licínio Cardoso, À margem da história da República. Emendar vícios, difundir virtudes republicanas, propor rumos são as expectativas dos depoentes. Antonio Carneiro Leão assina "Os deveres das novas gerações brasileiras", Celso Vieira - "Evolução do pensamento republicano no Brasil", Jonathas Serrano - "O clero e a República”, José Antônio Nogueira - "O ideal brasileiro desenvolvido na República”, Nuno Pinheiro - "Finanças nacionais", Oliveira Vianna - "O idealismo da Constituição", Pontes de Miranda - "Preliminares para a reforma constitucional", Ronald de Carvalho - "Bases da nacionalidade brasileira, uma síntese histórica", Tasso da Silveira - "A consciência brasileira", Tristão de Athayde - "Política e letras", Vicente Licínio Cardoso -"Benjamin Constant, o fundador da República" e o antológico "À margem da história da República”, Gilberto Amado "Instituições políticas e o meio social no Brasil", depoimento judicioso em que as tonalidades auriverdes idelizadas por Afonso Celso cedem aos tons pardo-acinzentados na composição de um mural de sinuosas linhas. Alongadamente, detalhadamente o mural de palavras figura a visão de um país em ruínas. Ouça-se a voz a descrever paisagens físicas e culturais saturadas de perfis antropológicos fantasmáticos. "Povo propriamente não o temos, sem contar o das cidades que não pode se dizer uma população culta, a população do Brasil politicamente não tem existência."

Compõem-se de 15 milhões de desassimilados que no Norte e no Centro constituem, os pescadores e seringueiros do Amazonas, os agregados das fazendas, os vaqueiros e campeadores do sertão, os pequenos negociantes nômades, os operários rurais primitivos e sem fixidez, trabalhando um dia para descansar seis na semana, o matuto ignorante e crendeiro, vivendo numa choupana, quando não desabrigado de todo, e ainda os jagunços da Bahia, os cangaceiros de Pernambuco, os "fanáticos" do Contestado, os capangas das vilas e aldeias do interior, a multidão de pequenos artífices e trabalhadores das cidades e das roças, 
toda uma gens complexa, pouco produtiva, entregue a sua própria miséria e alheamento do mundo, emigrando do Ceará para o Amazonas, nos Estados do Norte se arrastando ao abandono do desconforto de um voluntário, sem saúde, sem hábitos de trabalho, dada às superstições das raças selvagens, inúteis quase como força econômica, e tendo, na sua maioria, é o Brasil, a ideia que nos deu Euclides da Cunha n'Os sertões (Amado, 1924, p.57, grifo do autor).

Homem da palavra exuberante, ideal-tipo do cidadão da República das Letras, no fecho do inquérito, Vicente Licínio retoma ancestral profissão de fé liberal. "Instruir é formar cidadãos, é sanear mentalmente, é fundamentar os laços da coletividade dentro da unidade da Pátria. Instruir é, pois, demonstrar o homem e republicanizar as instituições políticas. Num meio inculto, instruir é de fato governar sabiamente" (Cardoso, 1924b, p.109). ${ }^{102}$

$\mathrm{E}$, como em épocas anteriores da vida nacional, retornava a cena uma vigorosa cultura de reforma, por vezes, perdida em devaneios. Sem pretender estabelecer uma genealogia de mestres e discípulos, é possível dizer que, na vigília comum, subjazem as verdades da razão racionalista: instruir o entendimento, regular as vontades, afeiçoar os corações, construir a unidade de fins, ou por outra, ao se constatar o decaimento do país, receita-se instrução.

Ultimamente o problema vai tomando a mentalidade de espírito de elite no sentido de tornar uniforme e praticamente eficiente a

${ }^{102}$ Comenta Carvalho (2002, p.70): "Não se pode dizer que as críticas desses autores estivessem equivocadas. Todos comparavam um regime republicano idealizado com a dura realidade e tiravam a conclusão inescapável da distância entre o Brasil real e o Brasil legal. No entanto, havia em todos eles uma incapacidade de ver o povo sob uma luz favorável, de perceber o lado positivo das ações do que chamei de povo da rua. Esse povo ativo ou era considerado fanático ou obscurantista ou desordeiro. $O$ povo civil era simplesmente ignorante, analfabeto, doente, um Jeca-Tatu. $\mathrm{O}$ povo das eleições era massa passiva de manobra”. 
propagação do ensino público. É preciso, porém, que o objetivo pedagógico, resumindo toda a obra de educação do povo, vá também até onde a civilização é precária e se torne amplamente eficaz em todas as zonas do país (Fernandes, 1929, p.228).

$\mathrm{Na}$ esteira de obras embaladas pela vontade de reforma saiam escritos sociais irmanados na autenticação dos fatos de realidade, dentre outros, $A$ educação nacional, de Mario Pinto Serva. "Jeca-Tatu só desaparecerá com a escola espalhada por todo o interior do país, escola que eduque física e mentalmente o nosso povo" (1924, p.19); Pela instrução primária no Brasil, de Antonio Salles Júnior. E "O ensino público no Brasil: decepções e esperanças" (no Livro de ouro do centenário da Independência do Brasil), "Cem anos de ensino primário" (no Livro do centenário da Câmara dos Deputados), ambos de Afrânio Peixoto. Esteira ampliada com $D a$ divulgação do ensino primário no Brasil, de Alfredo Lopes da Cruz; Contra o analfabetismo, de Marques Pinheiro; Luta contra o analfabetismo, de como esta campanha favorece o saneamento do Brasil, de Aleixo de Vasconcelos; O ensino que nos convém, de Vicente Licínio; Instrução pública, de Benjamin Franklin Ramiz e Problemas da educação nacional, de Egas Moniz Barreto de Aragão.

No vórtice celebrante, reaviva-se a memória de uma efeméride desbotada pelo tempo, a lei geral de criação das escolas elementares baixada em 1827, com a publicação de "Centenário das primeiras letras", de Max Fleiuss; "Evolução do ensino primário no Brasil”, de Sud Mennucci; "Centenário do ensino de primeiras letras", de Oswaldo Orico; "Um centenário pedagógico", de Rocha Pombo; "O primeiro centenário da organização do ensino primário”, de Antonio Carneiro Leão (1923, p.35). "Que estão fazendo, pois, os outros três milhões de crianças em idade escolar? Estarão os nossos dirigentes com a consciência tranquila por haverem cumprido, patrioticamente, o dever na elaboração da cultura popular?”. ${ }^{103}$

${ }^{103}$ Esses artigos saíram com destaque na revista Educação, órgão da diretoriageral da Instrução Pública e da Sociedade de Educação de São Paulo, nos anos 
A favor da desanalfabetização geral, em edição dedicada ao centenário da Independência, n’O Estado de S. Paulo saía “Cem anos de instrução pública: 1822-1922”, de Sud Mennucci, texto posteriormente ampliado em livro e bem visto pelo público leitor. Ao mesmo tempo, as edições diárias de $O$ Estado de S. Paulo transcrevem um a um os depoimentos concedidos ao inquérito coordenado por Fernando de Azevedo acerca da instrução em São Paulo. Opinavam Antonio de Almeida Júnior, Renato Jardim, José Escobar, Francisco Azzi, Lourenço Filho, Theodoro Braga, Paim Vieira, Rui de Paula Souza, Mario de Souza Lima, Amadeu Amaral, Ovídio Pires de Campos, Raul Briquet, Theodoro Ramos, Reynaldo Porchat, Artur Neiva, Sud Mennucci.

No ano de 1927, viriam a público Um século de ensino, de Ach. Matos, e Um século de ensino primário, de Nestor Lima. À proporção que surge a luz, reafirmava-se antiga certeza, pela instrução popular organizada em dimensão nacional, seria possível superar dissensões e remediar males, só assim, pensava-se, o país deixaria de ser reflexo ou sombra de si. Noutros termos, é o momento da sublimação da consciência infeliz; ilusoriamente, abstratamente desaparecem as realidades antinômicas e, mais uma vez, a construção de uma comunidade orgânica pela vivência das normas de unidade recairá no regaço da instrução popular. Nas tantas construções de futuros, não raramente se confundem a realidade dos fatos com a percepção equívoca do momento.

Não tem conta entre nós os pedagogos da prosperidade que, apegando-se a certas soluções onde, na melhor hipótese, se abrigam verdades parciais, transformam-nas em requisito obrigatório e único de todo progresso. É bem característico, para citar um exemplo, o que ocorre com a miragem da alfabetização do povo. Quanta inútil retórica se tem desperdiçado para provar que todos os nossos males ficariam

de 1927 e 1928; alguns anteriormente publicados em jornais prestigiosos: $O$ País, Correio da Manhã, Diário da Noite. 
resolvidos de um momento para outro se estivessem amplamente difundidas as escolas primárias e o conhecimento do $\mathrm{ABC}$ (Buarque de Holanda, 1948 [1936], p.124).

Compulsivo, o verbo social aspira às verdades da história nacional, entrementes, um dado é inegável, o crisol de balanços, à primeira vista explicitadores de devotamentos generosos, ao sinalizarem os erros do passado e do projeto, projetam o porvir sonhado. De súbito, diferentes sujeitos, em diferentes lugares, com diferentes propósitos, fazem da história historiografia: "A história não deve ser fabricante de elogios ou depósito sebento de críticas póstumas. A história deve explicar: decompor o passado com a experiência do presente, animado o espírito pela crença do futuro" (Cardoso, 1924b, p.107).

\section{Das iniciativas}

$\mathrm{Na}$ antevéspera do centenário da Independência, agosto de 1921, Alfredo Pinto Vieira de Mello, ministro da Justiça, comunicava a Epitácio Pessoa, Presidente da República, a urgência de coordenar os sistemas estaduais de ensino e nacionalizar as escolas primárias. "Passou a fase de literatura, das considerações enfáticas e pessimistas, das estatísticas impressionantes, apontando os males do analfabetismo. Precisamos, antes, de uma resolução, eficientemente prática.”

Dados oficiais recentes, colhidos por este Ministério permitem asseverar que, em várias circunscrições do país, mais de $90 \%$ das crianças estão privadas do ensino e na mais absoluta ignorância. E, como se esse mal não bastasse, surge outro não menos grave: a lenta, mas segura desnacionalização da infância nos Estados do Sul, onde inúmeras crianças brasileiras frequentam escolas, em que o ensino é ministrado exclusivamente em idiomas exóticos, rendendo-se assim a alheia pátria o culto devido à nossa (Vieira de Mello apud Lourenço Filho, 1946, p.8). 
Para o ministro, as ações emergenciais seriam objeto de estudos em evento auspiciado pelo governo federal, para tanto convoca a Conferência Interestadual de Ensino Primário a fim de formular ações conjuntas entre União, Estados e municípios.

$\mathrm{Na}$ comissão preparatória grandes nomes, José Augusto Bezerra de Medeiros, Vitor Vianna, Antonio Carneiro Leão, Orestes Guimarães, Ester Pedreira de Melo, João Batista de Mello e Sousa, Raimundo Pinto Seidl. Sob a presidência de Vieira de Mello, em clima de promoção de síntese de ideias, instalavase a conferência. Presentes, as delegações do Amazonas, Ceará, Rio Grande do Norte, Pernambuco, Sergipe, Rio de Janeiro, Rio Grande do Norte, Rio Grande do Sul, Mato Grosso, Piauí, Bahia, Maranhão, Espírito Santo, Alagoas, Goiás. Presentes também autoridades públicas representantes dos ministérios da Justiça, Fazenda e Agricultura, e intelectuais aderentes as ligas de Defesa Nacional, Nacionalista de São Paulo, Contra o Analfabetismo e Pedagógica de Ensino Secundário, do Rio de Janeiro.

$\mathrm{Na}$ abertura, Vieira de Mello pronuncia-se. "A Constituição Federal, art. 35, n 2, 3, 4, não exclui a intervenção da União mediante acordo com os estados para a solução do problema da difusão do ensino primário, ou antes, para diminuir senão extinguir o analfabetismo, que se alastra no país" (Conferência Interestadual de Ensino Primário, 1922, p.11). Sob a presidência de José Augusto, instalam-se as comissões de trabalho, imperativo, o temário aborda assuntos cruciais, a saber, difusão do ensino primário, auxílio da União, obrigatoriedade escolar, organização das escolas rurais e urbanas, simplificação dos programas de matérias, uniformização do ensino normal, deveres e garantias do professorado; mais ainda, fontes de recursos financeiros, nacionalização do ensino primário, criação do Conselho de Educação Nacional e Patrimônio do Ensino Primário Nacional. Em nome dos estados, Tavares Cavalcanti releva a escola primária como centro de cultura construtor do caráter brasileiro e instância de defesa nacional; ao mesmo tempo em que adverte. 
É uma verdade dolorosa: temos poucas escolas, grande número não provido e em todas a frequência pouco excede a $50 \%$ da matrícula e esta não alcança a 50\% da população em idade escolar nas regiões do país pretendidamente modelares. Nas zonas rurais longínquas onde o próprio trato da terra é sobrevivência do velho ensino dos Jesuítas, o que convém é fazer do professor primário um elemento de progresso, um agente civilizador e não um simples ensinador limitado do alfabeto e das quatro operações que se esquecem quando não se praticam (Conferência Interestadual de Ensino Primário, 1922, p.234).

No clima comocionado, João Batista de Mello e Sousa e Orestes Guimarães, relatores de um plano de nacionalização do ensino, apresentam as delegações um quadro de dispêndios com o ensino primário, pelo ineditismo, os dados gerais impressionam fundamente. "Mudou, definitivamente, a feição do problema: tirou-o da esfera declamatória em que ainda se encontrava e encaminhou-o para o terreno das soluções práticas" (Mennucci, 1932a, p.69). O quadro de dispêndio conjuga dados demográficos gerais, populações escolares de 7 a 14 anos, rendas estaduais e despesas com o ensino primário em números absolutos e percentuais. Santa Catarina despende 21\%; Ceará, 17,8\%; São Paulo, 16,9\%; Distrito Federal, 16,5\%; Mato Grosso, 17,8\%; Rio Grande do Sul, 11,9\%; Minas Gerais, 11,3\%; Amazonas e Pará, 10,4\%; Paraná, 11,1\%; Rio de Janeiro, 11,2\%; Paraíba, 10,1\%; Rio Grande do Norte, 10,7\%; Piauí, 10,1\%; Espírito Santo, 9,8\%; Sergipe, 9,2\%; Maranhão 8,4\%; Alagoas, 7,8\%; Goiás, 7,2\%; Bahia, 4,9\%; Pernambuco, 3\% (Mennucci, 1932a, p.69).

Novembro de 1921. Mello e Sousa, secretário geral e relator, encaminha as teses aprovadas na plenária de delegados. Em nome dos interesses nacionais, apela ao Poder Executivo para a criação de "órgãos propulsores da difusão e da nacionalização do ensino primário”; dentre as tantas deliberações, a participação da União na extensão e nacionalização do ensino, a criação de escolas primárias e normais federais, o ensino em língua vernácula, a proibição de cadernos, livros, 
mapas e quadros didáticos em línguas estrangeiras, a escolaridade obrigatória entre 6 e 11 anos de idade; a esse respeito, em voto separado, o delegado do Rio Grande do Sul declara que, por dispositivo da Constituição estadual, o governo não decretaria a obrigatoriedade. "Pois que semelhante medida atacaria a autoridade paterna e destruiria, ao mesmo tempo, a liberdade espiritual" (Conferência Interestadual de Ensino Primário, 1922, p.350). ${ }^{104}$

Nas deliberações um consenso geral. "A opinião da grande maioria reconhece, pois, a competência da União para intervir na difusão do ensino primário no país, mediante prévio acordo com os Estados, e na forma constante das supracitadas conclusões" (p.300). A União subvencionaria a extensão do ensino primário nas seguintes bases: os estados acordantes aplicariam pelo menos $10 \%$ de sua receita na instrução elementar, os índices variariam de $10 \%$ a $60 \%$ do montante despendido pelo estado acordante, carreando-se os recursos às escolas primárias e normais, desde que equiparadas ao padrão federal a ser adotado.

O alcance patriótico da escola seria potencializado com a criação de escolas normais superiores para preparar professores de normais primárias. Segundo os dados do relator, Mello e Sousa, no país existiriam 30 escolas normais e 12 mil professores primários, a seu juízo, a desanalfabetização total demandava 100 escolas normais, 200 mil professores e uniformização dos métodos de ensino. À parte, veementes, José Rangel, Américo de Moura e Correa de Brito, relatores, enaltecem a federalização das escolas normais. "Se o regime atual caducou, se não temos docentes em número suficiente, não há outro recurso senão apelar para uma organização nova”.

Essa remodelação incumbe, por certo, à União. A federação, fundando, encampando e fiscalizando escolas normais; a União irá assumindo o encargo de formar e aparelhar um corpo de normalistas verdadeiramente nacional. O Brasil carece de um professorado único,

104 Os usos do positivismo no Rio Grande do Sul são analisados por Bosi (1992), Lins (1967) e Tambara (1995). 
saído de escolas com programas e métodos mais ou menos comuns, com a mesma maneira de sentir o patriotismo de todos (Conferência Interestadual de Ensino Primário, 1922, p.234-235).

E, das tantas e entusiásticas deliberações, poucas são concretizadas, contudo a conferência legitima as ações prioritárias. Anos depois, o Decreto no 16.782-A, de 13 de janeiro de 1925, baixado na presidência de Arthur Bernardes, a "Lei Rocha Vaz", criaria o Departamento Nacional do Ensino vinculado ao Ministério da Justiça e Negócios Interiores. Ao Departamento caberia a "aplicação dos meios tendentes à difusão e ao progresso das ciências, letras e artes", "animar e promover a difusão do ensino primário nos estados", por seu lado, a União subvencionaria os salários do magistério até o máximo de 2:400\$ anuais, aos estados competiria fornecer casa para professores, escola e material didático, entrementes o Congresso Nacional não consigna a respectiva dotação orçamentária.

A convergência de vozes se acentuará na $1^{\text {a }}$ Conferência Nacional deEducação, auspiciada pela Associação Brasileira de Educação, entidade civil sediada no Distrito Federal. Instalada em Curitiba, dezembro de 1927, sob o impulso de Lisymaco Ferreira da Costa, o evento reúne 400 congressistas. Em parte das 113 teses debatidas, reeditam-se os acumulados precedentes, unidade nacional pela cultura cívica, literária e moral, uniformização do ensino primário, liberdade de programas, criação de escolas normais superiores. ${ }^{105} \mathrm{Na}$ presidência das relatorias, os nomes autorizados de Belizário Penna, Leoni Kassef, Deodato de Moraes, Orestes Guimarães, Renato Jardim, Ubaldo Ramalhete, Raul Bittencourt e Renato de Alencar. Presentes na plenária, professores, inspetores-escolares, diretores-gerais da instrução, médicos, jornalistas, engenheiros, escritores, políticos. Altissonante a rede de vozes clama pela participação do Governo Federal na elaboração e subvenção de políticas públicas gerais para os serviços da instrução popular.

105 Essas discussões prosseguem nas conferências posteriores da Associação Brasileira de Educação. Cf. Carvalho (1998). 


\section{Revisão do pacto contratual}

Embora não houvesse na Constituição dispositivo claro a respeito da colaboração entre a União e os entes federados quanto ao ensino primário e profissional, outras eram as opiniões dos "constitucionalistas cismáticos"; para eles, as realidades do século XX ultrapassaram a lei geral, a Carta Política. Nos meios políticos e intelectuais desde antes, citava-se o parecer exarado por Araripe Júnior, consultor geral da República.

Em vista da letra do nosso pacto fundamental a União não está inibida de exercitar atos legislativos concernentes à instrução primária, contanto que estes atos respeitem a autonomia estadual e não contravenham ao que as legislaturas respectivas tenham estabelecido. Função supletória bem caracterizada pela Constituição, ela pode ser exercida com aquela amplitude compatível com a dualidade de jurisdições e na conformidade do regime escolar adotado em cada Estado (Araripe Júnior apud Büchler; Moraes, 1923, p.26).

Por seu turno, os "constitucionalistas ortodoxos", ao pretextarem a defesa das franquias individuais, reforçam argumentos contrários à legislação social e à participação da União na oferta dos serviços de saúde pública e instrução popular. No começo do século, Teixeira Brandão, já havia denunciado os desacertos constitucionais, a seu ver, a Constituição federalista quebrara a unidade do ensino público ao atribuir aos estados a instrução primária, e à União e aos estados, conjuntamente, o ensino secundário e superior.

Nesse descarte, por parte do Estado, de um assunto que se liga à sua própria defesa, ou da negligência dessa obrigação social tem derivado o aumentar-se do analfabetismo ou o subministrar-se uma instrução falha nas suas bases, nos seus princípios e nos seus fins: 
os dois males da República, causas eficientes dos seus desastres, do falseamento das suas instituições e, por ventura de presumíveis calamidades, se, antevendo-as na sua fatalidade evolutiva, o governo não tomar a firme resolução de opor-se um paradeiro que obste o naufrágio das instituições democráticas ou o predomínio do governo de facções (Teixeira Brandão, 1907, p.32).

Assertivo, esse eminente médico-psiquiatra lotado no Hospício Nacional diagnosticava o mal e agitava perigos. "Porquanto a liberdade política é incompatível com a ignorância que engendra a anarquia, pois a igualdade incompreendida pela multidão ignara gera a utopia igualitária; as decepções da vida política amortecem as esperanças, acarretam a indiferença pelos negócios públicos, e a apatia da vontade. Nessa situação, pode-se dizer, o regime democrático deixa de existir de fato."

Teórico de prestígio, sua crítica sociológica moldura inumeráveis condenatórias dos desgovernos do governo, Alberto Torres, por assim dizer, ditara os argumentos mais cabais do pensamento dissidente. No seu entendimento o Estado arbitrado pela Carta Política tornara-se anacrônico, como outros sujeitos, para Alberto Torres o espírito do tempo requeria uma ordenação contratual fiada por um executivo forte, a seu ver, estabilidade das instituições políticas e governabilidade dos regimes democráticos estavam na dependência direta da instrução popular nacionalmente distribuída. Numa inversão idealista, apostrofava. "Formar o homem nacional é o primeiro dever do Estado moderno" (Torres, 1914, p.229). Esse sociólogo sistematiza suas teses revisionistas em $A$ organização nacional, inicialmente planejara o livro em três partes, constituição, instrução e economia, mas apenas a primeira é concretizada. Valendo-se da sua formação jurídica e experiência como juiz do Supremo Tribunal Federal, conjecturava uma nova constituição para o país, e nela, inseria caprichados parágrafos sobre a educação nacional e as competências da União. 
$\S 70$ Será leigo o ensino ministrado nos estabelecimentos públicos.

$\S 8^{\circ} \mathrm{O}$ ensino primário e o profissional agrícola, no campo, serão gratuitos, sendo condição do exercício dos direitos políticos e civis a posse de um título de habilitação pelas escolas primárias e o exercício de uma profissão, com a necessária habilitação técnica. Nenhum indivíduo será declarado maior, para os efeitos da capacidade física e mental sem que satisfaça os requisitos deste artigo.

§ 9o Todo cidadão tem direito aos meios de trabalho, de educação e de cultura, competindo ao Poder Público supri-los, de acordo com as aptidões demonstradas.

$\S 10^{\circ}$ Os governos das províncias [sic] e o federal promoverão a educação gratuita, até os cursos superiores, dos brasileiros que demonstrarem capacidade (Torres, 1914, p.340).

Nos debates, as questões do momento: intervenção da União nos estados e Distrito Federal, expulsão de militantes estrangeiros, decretação do estado de sítio, voto secreto e obrigatório, voto da mulher, regulamentação do trabalho ou liberdade de contrato entre patrões e empregados, ensino leigo ou religioso nas escolas oficiais, participação da União na sustentação do ensino primário. Deputado constituinte pela Bahia, Afrânio Peixoto, convicto propugnador de uma escola única, apresentava emenda propondo a centralização do ensino elementar. "Não é ele que dá o núcleo à formação da personalidade civil e moral?". Ao mesmo tempo reclamava a democratização do ensino secundário, a fiscalização do ensino profissional e a criação de um fundo escolar nacional. Confiante, vê na criação de uma escola normal superior na Capital da República, o "instrumento de nacionalização e de unidade espiritual do ensino".

O Brasil não se pode desinteressar da formação dos brasileiros. Há mister um orçamento "nacional" da educação, com fundos próprios, imposto especial ou patrimônio de terras devolutas para termos a "nossa" escola única, disseminada, profusa, usina "em série" 
de formação dos "mesmos" brasileiros, educados e cultos, e não, como agora, diversos pela alma e pela capacidade, isolados nos seus confinamentos regionais, nortistas e gaúchos, litorâneos e sertanejos, nordestinos e sulistas, Brasil que se desagrega porque a educação fundamental não pode fazer brasileiros, mas alguns cearenses, baianos, mineiros, paulistas ou rio-grandenses... Só este problema justifica uma reforma da Constituição (Peixoto, 1930, p.11).

Embora assinada por 66 parlamentares, a emenda não iria adiante, à revelia dos fatos, o governo força os signatários a desapoiála. Um dos tantos a lamentar o desfecho da reconstituinte, Fernando de Magalhães, deblaterava.

Há cem anos, o preceito constitucional velava pela pátria única com a escola única, entretanto, o regime da federação desarticulada, golpeou pelo Ato Adicional por contaminação americana, a previdência dos legisladores de 1824: a Constituição republicana corroeu a coesão nacional, firmando o princípio da escola primária regional, estreitada no emperro das pequenas pátrias, com seus dirigentes, os seus costumes, seus exclusivismos, suas tradições, suas justiças, seus exércitos e suas bandeiras.

A reforma constitucional de 1925, atropelada no desejo da compreensão, sacrificou por um acordo de conveniências o advento da escola única. E para poder conspurcar a nacionalização do ensino primário, garantia única da integridade intelectual e territorial do país (Magalhães, 1927, p.294).

No mais, a emenda constitucional de 3 de setembro de 1926 autorizava o Poder Executivo a legislar as questões abertamente sociais, assim promulgava-se o Código de Menores, a lei de expulsão de estrangeiros acusados de subversão, a decretação do estado de sítio, a limitação do habeas corpus. Seja o que for, por força das realidades histórico-sociais, sempre movediças, o Brasil ortodoxamente liberal e 
federalista entrara em desuso. Se o país não possuía um sistema escolar dotado de sentido nacional e finalidade social, era preciso construílo, porque a moralidade da raça, objeto capital da instrução pública, residia na sua saúde e vigor. ${ }^{106}$ Não obstante as diferenças pessoais, ao decifrarem distorções sociais e contornarem desajustes políticos, diferentes homens públicos, ao reivindicarem visões fáticas da vida civil, figuram para si o papel de hermeneutas da República iletrada. Em linguagem hermética ou desataviada, expõem os modos de sentir, pensar e praticar instrução pública, e nela a alfabetização geral, na contrastada formação sociocultural do país. E, ao dissertarem sobre os meios de viabilizar planos de desanalfabetização geral, transportam o Brasil indomado e rejeitado ao primeiro plano da vida nacional. No país das franjas sociais insondáveis e dos grotões desconhecidos, a instrução popular, como bem dissera Oswaldo Orico, seria o "fio de Ariadne", fio sutil a entrelaçar as existências numa mesma cadeia de vibração, a pátria dentro da humanidade. Vivaz e polifônica, sobremodo descortinadora de diagnósticos, a macedônia de soluções até aqui entremostradas, decantam as visões de intelectuais que, ao clamarem para si o gênio do entendimento, entrecruzavam ciência e governo, conhecimento e atitudes decisórias.

${ }^{106}$ Interpretação acurada da revisão constitucional de 1925-1926 consta em Cury (2003). 


\section{Parte V \\ Do imediato pós-30 à mitologia do Estado Novo}

Mas não se espante. Teremos a nossa cultura. Devemos, pois, trabalhar para isso. O essencial é que não se perca tempo, pois já perdemos séculos... Somos uma nação continental, no entanto a nossa população mal chega a povoar a vigésima parte do nosso solo ubérrimo. Mal temos explorado a centésima parte de nossa riqueza natural. Quase tudo está por fazer-se, como o senhor mesmo o reconheceu há pouco.

-- É verdade. O Brasil é ainda o grande desconhecido. É uma fabulosa riqueza em potencial. Vivem em nós todas as idades préhistóricas e históricas, desde o homem da pedra lascada até o cidadão supercivilizado do Rio e São Paulo, sem esquecer outras zonas do litoral. O Oeste é ainda um enigma de mistérios.

Ferdinando Martinho Filho, Professores anônimos: romance social (1943) 



\section{Sentido do Brasil, república agrícola}

\section{Consorciar o homem a terra}

Nas pessoas de Joaquim Francisco de Assis Brasil, advogado e estadista gaúcho, e Luiz Pereira Barreto, médico e intelectual paulista, a doutrina fisiocrata, a terra como fonte de riqueza, encontrara abrigo e ressonância. $\mathrm{O}$ primeiro bate-se pelas técnicas de mecanização da lavoura e educação agrícola, sua propriedade, a Granja de Pedras Altas, é citada pela exemplaridade; o último, um dos mentores da Sociedade Paulista de Agricultura, bate-se pela racionalização da lavoura em moldes norte-americanos. Em poucas palavras, o agrocentrismo e suas divisas revalorizam a terra fecunda, boa mãe e fonte do ser verdade da substância nacional. Ao mesmo tempo se rediscute o trabalho na lavoura realizado em moldes desusados (ou se se preferir pré-capitalistas). De fato, esforços a evidenciar a imbricação do tema do agrocentrismo nas associações classistas e instituições políticas remontam à Sociedade Nacional de Agricultura e à Sociedade Brasileira para Animação da Agricultura. ${ }^{107}$ Da crítica à industrialização, à monocultura, à urbanização, defluem reivindicações dos setores à margem da economia agrícola monopolizada pelo exclusivismo concedido à cultura e à exportação do café.

Ademais, desde a virada do século, o apreço por uma escola conforme o meio cultural e geográfico tornara-se assunto opulento

$\overline{{ }^{107} \text { Cf. Mendonça (1997). }}$ 
no verbo social de Silvio Romero a Alberto Torres. Opulência magnificada pela Sociedade dos Amigos de Alberto Torres e nos escritos agrocêntricos de Antonio Carneiro Leão, Belizário Penna e Sud Mennucci, sujeitos sociais aparentados na rejeição de um provável feudalismo vigente nos desvãos geográficos. Aos olhos de muitos, conquanto reservas prodigiosas, interior, campo e sertão subsistiam à custa de atroz medievalismo e servidão. No auge da projeção política e intelectual, Fernando de Azevedo é uma das vozes a alardear a existência de um povo amortalhado na ignorância.

O quadro sombrio da vida, que arrastam esses grupos disseminados pelo interior e recolhidos em choças de pau a pique, em ranchos de sapé ou em casebres em ruína, contrasta violentamente com a suavidade bucólica ou a grandeza soberba das paisagens, que se desenvolvem, para o prazer dos olhos, à contemplação dos forasteiros, mas a cuja própria beleza a miséria física e social já tornou quase indiferentes e insensíveis às populações locais (Azevedo, 1937a, p.49).

Num dos primeiríssimos livros a repercutir a tese da escola orientada para o aprendizado de técnicas exploratórias da pequena propriedade, Pela educação rural, Antonio Carneiro Leão proclamava. "Soou, afinal, para o Brasil a hora da construção econômica. Consolidando politicamente o país, o que se pode julgar realizado com a estabilidade da República, o problema é não já de construção da nacionalidade, no ponto de vista político, mas da consolidação nacional no ponto de vista econômico" (Carneiro Leão, 1918, p.5). À figura do cidadão portador de direitos, o publicista agrega à do trabalhador produtivo e cultivador esclarecido.

Logo se fazia sentir a influência do pensamento agrocêntrico de Félix-Jules Méline e seu elogio ao princípio ativo da terra nutriz. $\mathrm{Na}$ condição de ministro da Agricultura e primeiro-ministro da França, à época da Terceira República, Méline manifestara-se pela modernização da atividade agrícola, políticas protecionistas para o setor e ensino 
modificador da mentalidade camponesa. Nos seus ensaios doutrinais, Retour à la terre et la surproduction industrielle e Le salut par la terre et le programme économique de l'avenir, o ministro aclama a valoração da terra. É de supor que à consigna de Saint-Simon, "Tudo na indústria, para a indústria”, Méline houvera por bem contrapor "Tudo na agricultura, para a agricultura”. Para esse pertinaz doutrinador do agrocentrismo, da terra feracíssima, brota a felicidade nacional.

Com o fim do século XIX, o espetáculo muda bruscamente e encontra-se entregue ao desconhecido; há de repente uma lacuna, um corte seco e profundo. Em menos de cinquenta anos, tudo é atingido de cima a baixo, a indústria, a agricultura, o comércio, os transportes, os meios de produção, de consumo, de circulação e as relações entre os homens são profundamente modificados.

Não resta mais que um único campo de ação e de expansão capaz de absorver todas as forças sem emprego, e que tem a vantagem de ser inesgotável, ao menos por alguns séculos, é a terra que dá consolo a todas as misérias e que não deixa nunca morrer de fome aqueles que a amam e que se confiam a ela... Então, retornemos a terra e dirijamos para ela o máximo possível a atenção do grande público; tentemos se interessar pela questão e em breve ela será tão apaixonante quanto a indústria. Mostremos a ele que tanto a prosperidade do dia quanto a serenidade do dia seguinte têm esse preço (Méline, 1905, p.36).

Promessa bíblica de messe farta, as consignas agrocêntricas "retour à la terre" e "salut par la terre"-, prosperam em certas instâncias do magistério brasileiro.

O que diz Méline da Europa tem muita aplicação ao nosso país. Aqui, como lá, se tem dado o êxodo dos campos. As cidades atraem as populações rurais com o engodo de uma vida mais brilhante, mais movimentada e os bairros da roça se despovoam. Os que ficam, pertencem, não raro, ao tipo do caboclo tão bem caracterizado 
nos artigos publicados no Estado de S.Paulo pelo doutor Monteiro Lobato, que parece conhecer a fundo o assunto de seus trabalhos (Couto, 1917, p.13).

Ponto de vista disseminado, a terra como fonte nutriz corrobora a urgência de ações votadas à fixação da população rural, quer apelando-se a uma pedagogia escolar sensível ao primado agrícola quer apelando-se ao apego a terra. ${ }^{108}$ Porquanto, não é de se estranhar que a comissão de expertos, integrada por Antonio de Sampaio Dória (relator), Américo de Moura e Plínio Barreto, reunida para aprovar o uso de livros didáticos, assim se manifestasse. “Também não há obras que despertem o amor a terra, ao ar livre, à cultura dos campos. Sobretudo, para as escolas rurais, conviria abolir os livros que sugiram a sedução da cidade, e o desamor à vida produtiva e saudável dos campos. Animar a produção daquelas obras é um beneficio prestado às crianças nascidas e habituadas com as 'fazendas', e uma necessidade pública de países agrícolas como o nosso" (Anuário do Ensino..., 1918, p.152).

Excetuando-se os compêndios de dignificação da agricultura e idilização da vida rural de Mario Bulcão, outrora inspetor-geral da Instrução de São Paulo, Rumo ao campo, Noções de agricultura e educação cívica e Vida infantil: uma viagem imaginária pelos estados do Brasil, aprovados e adotados em São Paulo, Minas Gerais, Pará, Paraná, Capital Federal, não eram muitos os títulos sobre a temática rural. Em Rumo ao campo, segundo livro da série "Vida infantil", aproximadamente 32 edições, Bulcão enuncia noções de civilidade,

108 "Abolição acomodou-se à República e durante anos viveram ainda patriarcado semiescravocrata e República federativa quase tão simbioticamente como outrora patriarcado escravocrata e Império unitário. Várias sobrevivências patriarcais ainda hoje convivem com o brasileiro das áreas mais marcadas pelo longo domínio do patriarcado escravocrata - agrário ou mesmo pastoril - e menos afetadas pela imigração neoeuropeia (italiana, alemã, polonesa, etc.) ou japonesa; ou pela industrialização e urbanização da economia, da vida social e da cultura” (Freyre, 1949, p.670). 
civismo, rudimentos de agricultura, "higiene animal e vegetal" e cantos românticos relativamente à vida na natureza.

$\mathrm{Na}$ roça vive-se mais. Com maior tranquilidade, corre a vida mais feliz. Os gozos da cidade não se comparam à tranquilidade da vida do lavrador. Este trabalho, sem o luxo das cidades, pode fazer economias e assegurar melhor a existência de todos da família, já que produz-se de tudo um pouco. É um erro quererem todos educar os filhos como doutores. Se o mundo fosse cheio de sábios, morreriam todos de fome (Bulcão, 1925, p.179).

De par coexistiam compêndios e cartilhas editados por associações classistas, $A B C$ do agricultor, de Francisco Dias Martins e Cartilha agricola, de Ezequiel Ubatuba ou títulos de diletantes, como Alfeu Domingues, $O$ ensino agrícola nas escolas primárias e Silvio de Andrade Maia, As escolas rurais e o êxodo dos campos. Nesse rol de títulos e autores, habita um corpo de crenças e valores destinados a convencer a massa de lavradores a vibrarem o conteúdo fisiocrático da terra pela exploração racional. De modo geral, os conteúdos desse gênero textual contrapõem a sobriedade da vida rural às ilusões da cidade, reprova-se a vida nas cidades, invariavelmente descritas como antros povoados de proletários e subproletários viventes em penúria e sobrecarregada de vícios morais e doenças. De outra forma, descabida a vontade de viver a vida citadina, elemento disgênico no organismo nacional, deveria ser combatida.

Não vos deixeis embriagar pelas seduções das cidades. Elas não são, como vos parecerem, a fonte de grandezas e de venturas, mas de vícios e de misérias, são ninhos de ambições desenfreadas, de hipocrisias mal contidas, de maldades horripilantes. Ali, no torvelinho das excitações e dos prazeres, o nosso sangue se envenena, os nossos músculos se enfraquecem, o nosso organismo se depaupera, as nossas faculdades se atrofiam, gastam-se a nossa saúde a força física da nossa raça. A cidade é uma ilusão perversa (Moraes, 1919, p.8). 
A esse juízo condenatório, Pedro Deodato de Moraes saturava com palavras idealizadas o vigor e a serenidade, melhor, a pureza existencial no campo. "A vida campestre, ao contrário, longe de ser agitada e mecânica, aproxima os homens uns dos outros, dá ao corpo robustez e riqueza, desenvolve o sentimento da vida íntima, é cheia de ensinamentos práticos que exigem mais iniciativa, invenção e experiência pessoal” (Moraes, 1919, p.15). Em boa-fé, esse professor normalista superioriza o terreno paterno em Rumo ao campo... a escola social, enfática predicação aos professorandos da Escola Normal de Casa Branca, predicação, diga-se de passagem, retomada não sem certo estardalhaço por ocasião da $1^{\text {a }}$ Conferência Nacional de Educação.

O sertão brasileiro será eternamente triste, inculto e estéril enquanto o professor primário para ele não transportar os modernos preceitos das ciências práticas e das artes úteis. Todo mal, como todo bem de um país, vem da escola primária. É na escola popular que devem nascer a tradição agrícola e o prestígio do trabalho da roça. Parti. Ide ao campo (1 ${ }^{\text {a }}$ Conferência Nacional de Educação, 1997 [1927], p.194).

Donde o zelo em despertar gosto e encanto pela vida rural. É quando se publica Saudade, do professor Thales Castanho de Andrade, livro de leitura em que se encampa no plano da ficção o discurso oficial acerca da urgência de estancar a depopulação rural. Bem recepcionado, Saudade constituir-se num dos tesouros do nacional-popular; os demais são Narizinho arrebitado, "segundo livro de leitura para uso das escolas primárias”, de Monteiro Lobato; As férias no Pontal, de Rodolfo Ihering, Coração brasileiro, de F. Faria Neto e Campos e arrebóis, de Túlio Espínola. Se o nacionalismo traveja a indivisibilidade da sociedade de classes, portanto da nação como corpo social orgânico, o agrocentrismo instrui as diferenças econômicas e as funções produtoras das classes. 


\section{Trazer os desvãos para o século XX}

A tese construtivista a projetar nas vastidões territoriais os fundamentos da nação e da nacionalidade, elege o interior do país como lócus da autenticidade e contraponto ao artificialismo da cidade, para muitos simples "civilização de cópia" dos centros europeus e norte-americanos. Quaisquer que fossem as apostas, de fato, o sistema econômico era determinado pela monocultura de exportação.

Nas vozes as mais autorizadas, o interior guardava em si o sublime mistério da nacionalidade. Donde intensos e afetivos apelos cujos sinais são invertidos, não se explica o mundo rural como origem mítica das sociedades, mas futuro previdente, donde ainda a intenção de retornar às profundezas da terra e raça, história e geografia, celebrá-las, significa valorizar o homem comum, o anônimo pédescalço. Com efeito, o homem do campo, esquecido de si (e pelos outros), dizia-se, era detentor imprevidente e improdutivo da terra, estático nos vazios geográficos de sua existência recolhida, transcorria num tempo indiviso e imóvel, quer dizer, intocado pelos modos de pensar e viver das civilizações avançadas e suas modernas técnicas de trabalho. De sorte que a expressão "zona rural" soa como contrafação da economia de sobrevivência das vilas, arraiais e bairros rurais. Nesses cenários silenciosos de população rala, habitavam pequenos proprietários, arrendatários, colonos, parceiros, meeiros, tipos desde sempre submetidos aos mandatários locais. Noutras palavras, maratimbas, caipiras, caboclos, cafuzos, caiporas, curibocas, tabaréus, paroaras compunham os reservatórios dos políticos locais, fenômeno analisado pela literatura sociológica sob a epígrafe "coronelismo, enxada e voto". ${ }^{109}$

$\mathrm{O}$ mote era este, soerguer o povo pequeno, trazer os rincões desfrequentados pela racionalidade técnica para a história das relações de produção capitalistas e para a geografia na nação. Como dissera Oliveira Vianna no ensaio introdutório ao Censo Geral de

${ }^{109}$ Cf. Leal (1975). 
1920, sobriamente intitulado O povo brasileiro e a sua evolução. "É no campo que se forma a nossa raça e se elaboram as formas íntimas da nossa civilização o dinamismo da nossa história, no período colonial, vem do campo do campo, as bases em que se assenta a estabilidade admirável da nossa sociedade, no período imperial" (Oliveira Vianna, 1923, p.282).

\section{$\mathrm{O}$ recrudescer do agrocentrismo}

Intelectuais formuladores de sínteses sociológicas decisivas no tocante a formação social brasileira, em conjunturas de exames e reexames do país, Euclides da Cunha, Alberto Torres e Oliveira Vianna assomam como ascendentes intelectuais dos críticos do republicanismo liberal-estadualista e seu implacável laissez-faire. Ex-aluno no colégio de Menezes Vieira, Alberto Torres ingressara aos 14 anos na escola de Medicina do Rio de Janeiro e, aos 16, na faculdade de Direito de São de Paulo. Na mocidade vivida no final do século XIX, na companhia de Antonio da Silva Jardim, declarara-se abolicionista e republicano, no decênio de 1910, sobressaíra como propositor de uma organização nacional em tom diverso do verbalismo patriótico de Olavo Bilac. Aos olhos dos discípulos, esse sociologista prima como pensador adverso à imaginação arbitrária e a seus excessos. Em O problema nacional brasileiro e em $A$ organização nacional, compreende o industrialismo e o urbanismo como fenômenos desagregadores.

O Brasil tem de ser uma república social, por força de seu destino, e da fatalidade de seu surto na era da questão social, e tem de ser, intuitivamente, uma república agrícola. É preciso, porém uma república social, previdente e conservadora, para que o povo não sinta um dia a necessidade de arrancar à força o que os governos lhes podem dar dentro da ordem, sem prejuízo de terceiros. Poderse-ia, talvez, temer que os proletários, aglomerados nas cidades, não aceitassem de bom grado à volta ao trabalho rural; e que a 
falta de preparo e indolência a que se habituaram trouxessem certa dificuldade à execução da ideia (Torres, 1914, p.132). ${ }^{110}$

Republicano moderado, contraditor do domínio econômico das grandes potências e monopólios internacionais, esse dublê de jurista e sociólogo, concebe uma organização econômica esteada em pequenos produtores. "O Brasil tem por destino evidente ser um país agrícola: toda a ação que tender a desviá-lo desse destino, é um crime contra a sua natureza e contra os interesses humanos" (Torres, 1982 [1914], p.74). Incitante desaprova a instrução em moldes urbanos. "Organizávamos uma 'instrução pública' que, da escola primária às academias, não é senão um sistema de canais de êxodo da mocidade do campo para as cidades e da produção para o parasitarismo" (1982 [1914], p.273).

\section{Ressurgência da obra}

Na Era Getuliana, segundo formulação de Humberto Grande, as ideias torreanas retornam à cena. Editam-se estudos de divulgação, exegese e síntese para guiar leitores que "quiserem se aventurar no oceano alto do pensamento de Torres, pela leitura direta das suas obras", conforme Oliveira Vianna, no prefácio de As ideias de Alberto Torres, livro curioso no qual Alberto Gentil reúne extratos do pensamento do mestre, por exemplo. "Se o analfabetismo é o estado mental de quase toda a população, o nível da nossa mentalidade superior desceu até à incapacidade para o raciocínio". A sua vez, A. Saboia Lima publica Alberto Torres e sua obra; já Edgard Roquette-Pinto, em Ensaios de antropologia brasileira, não hesita em revalidar as teses do "homem de gênio".

110 "Ruralismo - O Brasil é essencialmente agrícola e assim deve ser. A terra é a base da riqueza, tudo mais é diversionismo perigoso. $\mathrm{O}$ autor crê em uma espécie de divisão internacional do trabalho, em visão ingênua que não percebe as vantagens de uns e as desvantagens dos outros (dos ligados à terra, como pretende ser o seu país). Tem atitude de desconfiança ante a indústria, insiste na ideia de indústrias naturais, como em seu tempo, às vezes encobrindo interesses escusos de forças por ela tão combatidas" (Iglésias, 1993, p.35-36). 
De onde, então, provém a insuficiência? Única e exclusivamente de um elemento decisivo: falta de organização nacional. (Alberto Torres). O Brasil, pregava o homem de gênio, tem de ser obra de arte da política. É uma nação que será o que as classes cultas fizerem dela. Organização nacional, no Brasil, quer dizer principalmente, educação do povo, nacionalização da economia, e circulação de ideias e da riqueza (1933, p.125, grifo do autor).

É quando são reeditados na prestigiosa série "Brasiliana" da Companhia Editora Nacional, $O$ problema nacional brasileiro e $A$ organização nacional, livros que bussolariam parcela do pensamento social crítico-dissidente na década de 1930. Com efeito, no trabalho de exegese e divulgação do pensamento do mestre, perfilam homens irmanados na esperança de um Brasil unido e melhorado: Alcides Gentil, Aprígio Gonzaga, Celso Kelly, Atílio Vivacqua, Belizário Penna, Everardo Backheuser, Fernando de Azevedo, Leoni Kassef, Lourival de Almeida, Mario Casassanta, Edgard Roquette-Pinto, Simões Lopes, Sud Mennucci, Mario Augusto Teixeira de Freitas e outros mais. ${ }^{111}$ Passo seguinte, intelectuais empáticos às correntes estatizantes concretizam certos propósitos torreanos, qual seja a criação de um instituto de estudos nacionais, com efeito, em 1932, no Rio de Janeiro, fundava-se a Sociedade dos Amigos de Alberto Torres, com núcleos em Minas Gerais, Espírito Santo, Rio de Janeiro, Bahia, Pernambuco, Goiás, São Paulo. A entidade apega-se às soluções torreanas: ensino rural, exploração de recursos naturais, representação classista, soluções acatadas como objetivas numa conjuntura de fomento da consciência da singularidade (e/ou identidade) do país, seu destino ulterior, bem como de repúdio ao anarquismo, socialismo e individualismo liberal. ${ }^{112}$

${ }^{111}$ Cf. Lima (1935).

112 Cf. Barbosa Lima Sobrinho (1968). Contemporaneamente, a obra de Alberto Torres é analisada por Marson (1979), ver também Fausto (2001). Quanto à perspectiva torreana dos fins públicos da educação, ver Almeida (1963). 
Dentre as iniciativas da Sociedade dos Amigos de Alberto Torres, constam estudos sobre as secas do nordeste, proteção à natureza, instalação de lactários, higiene infantil, cursos para professores de escolas regionais e realizações muitíssimo bem-sucedidas, o $1^{\circ}$ Congresso de Ensino Rural, semanas ruralistas, clubes rurais. No mais, para além da crítica ao exclusivismo agroexportador, há aparatosos consensos: diversificação da estrutura produtiva rural, cooperativismo, povoamento, colonização, educação rural e uma urgência não declarada, arregimentar, estabilizar e qualificar a força de trabalho rural.

\section{Vibração emocional}

Entre as tormentas e desconformidades da Era Getuliana, a tese da escola condizente com os quadros sociais e naturais do

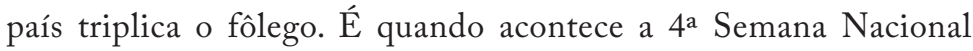
de Educação, promovida pela Associação Brasileira de Educação, organizada sob o tema geral "A escola regional". Nesse evento, Fernando de Magalhães pronuncia a conferência de abertura "A emancipação mental do Brasil pelo ensino rural". Na sequência discursam C. A. Barbosa de Oliveira, "A escola regional nos seus aspectos urbano, rural, marítimo e fluvial"; Armando Pinna, "A escola marítima e fluvial e os seus cursos de pesca”; Belizário Penna, "A educação rural: o problema brasileiro e sua enorme importância social e econômica"; H. Rolfs, "O ensino agrícola no grau médio e sua organização no Brasil”; Everardo Backheuser, "A escola ativa nos centros urbanos". ${ }^{113}$ E sob a trilogia povoar-escolarizar-unir, acontecem o $1^{\circ}$ Congresso Brasileiro de Ensino Rural, promovido pela Sociedade "Luiz Pereira Barreto" com o apoio do governo de

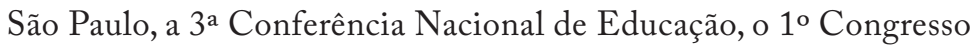
Nacional de Ensino Regional e, por último, o $8^{\circ}$ Congresso Nacional de Educação da $\mathrm{ABE}$, de par ocorre a fundação da Sociedade Brasileira de Educação Rural.

${ }^{113}$ Cf. A escola regional... (1931). 
Nesse quadro de iniciativas, popularizam-se os Clubes Agrícolas Escolares decalcados dos Clubs Works norte-americanos, vulgarizados como "4-H Clubs": "health" (saúde), "hand" (exercitar a mão), "head" (cultivar a inteligência), "hearth" (formar o coração). Em São Paulo, o ruralismo escolar e nele a prática do clubismo ganha rumos certeiros com a atuação de Thales de Andrade em postos administrativos, ou seja, na Escola Normal de Piracicaba, na Assistência Técnica do Ensino Rural e à frente do Departamento de Ensino. É quando vicejam os "Clubes do Milho", apoiados pela Sociedade dos Amigos de Alberto Torres e oficializados sob a denominação de "Clubes Agrícolas Escolares" por iniciativa do interventor federal general Daltro Filho. ${ }^{114}$ Mais à frente, o Decreto-lei estadual no 8.951, de 1938, cria os grupos escolares rurais, o mais bem-sucedido, o do Butantã, subúrbio da capital, cuja direção é exercida por Noêmia Saraiva de Matos Cruz, pessoa de projeção no $1^{\circ}$ Congresso Brasileiro do Ensino Regional.

\section{O gênio de Sud}

Sem procurar inserção na intriga biográfica, é possível dizer que na Era Getuliana, Sud Mennucci assume a condição de vulto paradigmático da "Cruzada pela escola rural" e "ensino rural". Naquele passo, era recepcionado como construtor político dotado de honesto entusiasmo; ademais, notabilizara-se como defensor do mundo rural e suas possibilidades.

Filho de imigrantes italianos, Sud Mennucci cursara o ensino elementar no Grupo Escolar "Moraes Barros" e, em 1908, diplomarase professor primário na Escola Complementar de Piracicaba, interior paulista, a "Meca do ruralismo brasileiro", por sediar a Escola de Agricultura "Luiz de Queiroz".

No magistério, leciona em escolas isoladas, grupos escolares do interior; nos serviços de instrução, ocupa cargos importantes, delegado regional de ensino em Campinas e Piracicaba, e chefe dos

${ }^{114}$ Cf. Andrade (1933). 
recenseamentos escolares nas reformas capitaneadas por Sampaio Dória e Fernando de Azevedo em São Paulo e Distrito Federal, bem mais tarde chefiará em São Paulo os trabalhos do recenseamento de 1940. Embora portador do diploma de normalista, apenas, projeta-se como homem "de sete instrumentos" - crítico, ensaísta, historiador, sociólogo, geógrafo e jornalista. ${ }^{115} \mathrm{Na}$ temperatura alta do Governo Provisório, 1930-1934, presidido por Getúlio, Sud Mennucci ocupa por duas vezes a diretoria de Ensino da Secretaria de Educação e Saúde Pública do estado de São Paulo. No embaralhado ideológico da hora, Sud adere à Legião Revolucionária de São Paulo, organizada por Miguel Costa e o tenente João Alberto, interventor federal no mesmo Estado. ${ }^{116}$

Nacionalista (e corporativista), o Manifesto à Nação, expedido em 1931 pela Legião Revolucionária, postula eleições indiretas para a presidência da República, representação parlamentar por classe social, poder legislativo integrado por técnicos e não por políticos profissionais, e por fim posiciona-se contrariamente aos latifúndios e à ditadura de qualquer classe, fosse burguesa, fosse proletária. ${ }^{117} \mathrm{De}$ súbito, a Legião Revolucionária é reconvertida no efêmero Partido Popular Paulista, cujo programa partidário é redigido por Plínio Salgado, cuja plataforma programática propugna a continuidade das ações revolucionárias mediadas por um Estado forte, bem como a extensão da instrução popular "a fim de se combater o patriotismo lírico e o pessimismo". No desenrolar da década de 1930, a Sud Mennucci concede-se as investiduras de "Pai do ruralismo brasileiro", "Campeão do ruralismo nacional", "Pontífice da ruralização do ensino". Em suma, sob a fronde das ideias torreanas, Sud Mennucci publica $A$ crise brasileira de educação, obra premiada no concurso "O melhor meio de disseminar o ensino primário no Brasil”, levado a efeito pela Academia Brasileira de Letras. No parecer exarado pela comissão indicada pela

\footnotetext{
${ }^{115}$ Cf. Melo (1954).

${ }^{116}$ Cf. Mennucci (1931).

${ }^{117}$ Cf. Carone (1975).
} 
ABL, Roquette-Pinto, relator, Miguel Couto e Aloísio de Castro, solene elogio ao realismo do autor.

O livro de Sud Mennucci é o mais claro, o mais lógico, o mais prático. É também o mais original no modo de encarar o problema e na solução que propõe. Sud Mennucci no seu livro indica, pois, de maneira realmente superior, todas as condições sociais em que se define o problema considerado. E indica, com clareza, simplicidade, entusiasmo, de maneira prática, soluções modernas e possíveis. Deve receber o primeiro prêmio Alves (Mennucci, 1934, p.7).

É de Sud Mennucci a sentença trovejante. "O alfabeto em vez de ser um auxiliar, um amparo, um sustentáculo da lavoura, virou um tóxico violento. Põe na cabeça da juventude aldeã o desejo louco de aprender para libertar-se do fardo agrícola” (Mennucci, 1934, p.45). Nas páginas de $A$ crise brasileira de educação, o autor endossa a crítica ao regime de latifundiário de propriedade, a seu ver, o pleno domínio do meio físico implicaria a revisão do regime de propriedade, não em moldes soviéticos ou romenos, isto é, a coletivização da propriedade fundiária, mas, nos moldes franceses, isto é, em pequenos lotes. Igualmente movidos pelo diapasão torreano viriam Cem anos de instrução pública, O que fiz e o que pretendia fazer, Aspectos piracicabanos do ensino rural, Pelo sentido ruralista da civilização, A ruralização, Discursos e conferências ruralistas. Quanto aos pródromos relativos ao ensino rural, não hesitava.

$\mathrm{O}$ que foi que nos faltou? Faltou o complemento natural da política imigratória. Faltou-nos a visão clara de que só a obra educativa, corrigindo o erro fundamental dos escravocratas, poderia tornar a dar ao homem do campo brasileiro aquela noção do valor supremo do trabalho, que nós the havíamos roubado em quase quatro séculos de instituição servil (Mennucci, 1944a, p.21). 
No conjunto da obra teórica, Sud repropõe a organização das escolas normais rurais em três níveis, o pedagógico, o higiênico/ sanitário e o agrícola. Os estabelecimentos comportariam professores "propriamente ditos", "professores-médicos" e "professores-agrônomos." Como diretor do Departamento de Ensino, em decreto-lei por ele lavrado, mas não promulgado, estipula a criação de cinco normais rurais, grupos escolares e escolas isoladas vocacionais, além de uma inspetoria técnica do Ensino Rural integrada por inspetores-escolares, inspetoresmédicos e inspetores-agrônomos. Em O que fiz e pretendia fazer: defesa e fundamentação da reforma do ensino de 1932, Sud reafirma a necessidade de escolas ajustadas às cidades e aos meios rurais e marítimos com o intuito de formar "três mentalidades absolutamente diversas e que, no entanto, reciprocamente se complementem para o equilíbrio social do organismo nacional" (Mennucci, 1932b, p.118-119).

$\mathrm{Na}$ condição de diretor-interino, Sud lavra o Decreto no 6.047, de 19 de agosto de 1933. "Artigo 1º - O governo do Estado São Paulo instalará uma Escola Normal, rural, em Piracicaba, que manterá íntima colaboração com a Escola Superior de Agricultura 'Luiz de Queiroz"'. Por falta de verba, o decreto é revogado sem que se concretizasse a experiência de formar professores rurais.

Simultaneamente aos fatos anteriormente narrados, na escalada nacional, em 1931, na sede do Rádio Clube do Brasil, Sud Mennucci profere a conferência "A reforma do ensino rural em São Paulo"; em 1934, no Congresso Pedagógico Regional, pronuncia a conferência "Aspectos piracicabanos do ensino rural"; em 1933, a convite da Sociedade dos Amigos de Alberto Torres, participa do Curso da Escola Regional, no Distrito Federal, lá profere a célebre conferência “A guerra à zona rural”. Nesse evento, Celso Kelly, Anísio Teixeira, Fernando de Azevedo, respectivamente, diretores do ensino no Rio de Janeiro, Distrito Federal, São Paulo, proferem as demais conferências. Em 1934, na Bahia, o reformador participa do 1 Congresso Brasileiro do Ensino Regional; em 1935, "A vida rural e a educação nacional", na sede da ABE para o curso da Universidade Rural, na Exposição 
do $1^{\circ}$ Centenário da Revolução Farroupilha, Porto Alegre; em 1939, a pedido do Grêmio Universitário "Alberto Torres" da Faculdade de Direito de São Paulo, a conferência "O pensamento de Alberto Torres”. E por iniciativa de Joaquim Moreira de Sousa, diretor-geral do Ensino do Ceará, a criação de uma normal rural ocorreria não em São Paulo, mas em Juazeiro, Ceará. ${ }^{118}$ A Sud Mennucci coube a honra de paraninfar as primeiras professoras imbuídas das promessas ruralistas. Transbordante de certezas, para a solenidade, dezembro de 1937, ele compôs "Hino Juazeiro".

Professorandas. À medida que se contemplam os vários aspectos que, como um feixe de luz, se reúnem nesta festa, mais avulta e mais cresce o significado desta cerimônia.

Vede-lhe a colocação da Escola: pleno interior do Brasil, naquilo que nós outros, supercivilizados habitantes da orla do litoral, convencidos e presumidos de nossa cultura de empréstimo, chamamos o "sertão", o que implica dizer "Farwest", isto é, a zona que se atrasou nas conquistas do século, que se foi deixando ficar à margem das vitórias modernas e não acompanhou o rito da expressão humana. Porque para nós outros, "caranguejos das praias", como no apelidou expressiva e pitorescamente um historiador colonial, só o que nos chega de fora, com o rótulo e o sinete do estrangeiro, representando o adiantamento da civilização (Mennucci, 1944a, p.3).

No tempo, estabelecimentos semelhantes são criados no Pará, Bahia, Pernambuco, Alagoas, Sergipe, Goiás, Rio Grande do Sul, cujos planos didáticos são submetidos à apreciação do reformador. ${ }^{119}$ No retorno à vida democrática, sucedem os $1^{\circ}$ e $2^{\circ}$ Congressos Normalistas de Educação Rural, Campinas, 1945, e Piracicaba, 1947. Sud Mennucci é eleito vice-presidente de honra do primeiro evento. Com temário amplo, as comissões debatem temas ligados à saúde,

${ }^{118}$ Cf. Sousa (1944) e Souza (1994).

${ }^{119}$ Cf. Monarcha (2007). 
higiene, formação do professor, carreira do magistério, povoamento, assimilação dos imigrantes e descendentes, demografia, escola rural, prédios escolares. No segundo evento, debatem-se a alfabetização de adultos e os programas de matérias das normais.

Sob o protagonismo de diferentes sujeitos, em diferentes momentos, em diferentes lugares, os discursos respeitantes ao país interior, o Brasil distante de si, deixam de ser mensagem mística saturada de idealidades compensatórias para serem programas da alçada técnica e civilizatória. Nos enunciados agrocêntricos, para muito além das visões tardo-românticas, o homem, radicado na bela natureza, fazia-se sentir a concepção organicista e/ou corporativista de sociedade, quer dizer, a especialização produtiva das classes insertas em meios geográficos diversos. Em suma, das vozes a profetizarem futuros e até aqui ouvidas a plenos pulmões, é possível discernir urgências, relevando-se, obviamente, as circunstâncias históricas: visão fisiocrática da produção de riquezas, elogio do usufruto da pequena e média propriedade, alargamento do mercado interno, oposição ao exclusivismo concedido ao regime industrial e à monocultura de exportação, combate aos fluxos migratórios, regulação de força de trabalho agrícola, ampliação das terras agricultáveis. De outro modo, entrecruzavam-se a razão de Estado com os postulados da economia política, visando a elevação do corpo e do espírito das populações. Para esse ponto de vista, saúde e instrução constituem os princípios da riqueza da nação, porquanto assuntos a serem apreciados pelo ângulo da economia política - desde que saudáveis e ativas, as populações representam as fontes de produção, distribuição, consumo de bens materiais e de ativação monetária. 



\section{Da escola de instrução primária e seu magistério}

\section{Estatísticas na Era Getuliana}

Ainda na fase do Governo Provisório, Francisco Campos, no ministério da Educação e Saúde Pública, instala a diretoriageral de Informações, Estatística e Divulgação, sucessora das atribuições da extinta $4^{a}$ seção da diretoria-geral de Estatística. De imediato materializa-se a demanda anteriormente formulada por Fernando de Magalhães, presidente da $\mathrm{ABE}$, a saber, uma convenção intergovernamental para efetuar estatísticas educacionais nacionais.

Apoiado pelo ministro, Mario Augusto Teixeira de Freitas, leva a termo o Convênio Interadministrativo de Estatísticas Educacionais e Conexas em parceria com a União, estados e o Território do Acre. Os números levantados pela estatística nacional troam. Conforme a "linguagem severa dos números", para cada $325 \mathrm{~km}^{2}$ há uma escola; para cada grupo de 1.421 habitantes, uma escola; em cada grupo de 100 alunos matriculados, 69 são frequentes; em cada grupo de 100 alunos frequentes, 47 são aprovados; em cada centena de alunos aprovados, oito concluem o curso primário.

$\mathrm{Na}$ analítica calçada em números, os problemas são estes: extensão deficiente e rendimento ineficiente, donde deserção e êxodo de alunos. "Todos agiam livremente e na proporção que supuseram de acordo com suas possibilidades. E se fez o caos educacional, uma balburdia indescritível, desigualdades chocantes, 
desperdícios inacreditáveis, nulificação quase dos resultados reais" (Teixeira de Freitas, 1937, p.160).

Outros entraves referem-se aos antigos modos de ensinar e aprender calcados no papel, lápis, tinta, giz, recursos incapazes de transformar "o ensino de ouvir em ensino de praticar", no dizer diagnóstico do diretor do Inep (Lourenço Filho, 1940). Ora bem, entre as décadas de 1920 e 1940, as estatísticas estaduais e nacionais, cuja frialdade numérica concretiza realidades vitais, suscitando ações imediatas sob o ímpeto de competentes estatísticos - Bulhões Carvalho, Bordeaux Rego, Teixeira de Freitas -, a heterogeneidade nacional, com seus ritmos próprios e variados, adquirem visibilidade regional e totalidade nacional. Contudo, em si mesma, a linguagem dos números não desvela o todo real, a não ser se anexada aos discursos políticos, interpretações historiográficas e sínteses sociológicas, vale dizer, os números maciços aguçam o pensamento social. Colossais, as paisagens estatisticamente construídas sustentam análises das mais variadas, ao mesmo tempo em que autorizam a argumentação de homens graves dispostos a se legitimarem como intérpretes do país. Doravante, sob a saturação dos serviços de estatísticas, a noção jurídico-política, historicamente considerada de "povo republicano", sujeito coletivo dotado de direitos, dará lugar à noção objetiva de “população", agregado natural, diferenciado por comparação.

Decênio de 1940. Vem a público os dados consolidados pelo recenseamento geral da República; precedidos da "Introdução" da Série Nacional sob o título A cultura brasileira, de Fernando de Azevedo, os dados escrutinados assinalam mínima densidade demográfica em 2/3 dos 8.500 .000 de superfície; a média teórica indicava 6 habitantes por $\mathrm{km}^{2}$, sendo que a distribuição real era de menos 1 habitante por $\mathrm{km}^{2}$.

Grosso modo, perdurava o povoamento insulado e descontínuo herdado da Colônia e do Império. Desde a Colônia, a ocupação do território figurava desenho idêntico - concentração nas franjas litorâneas de Leste, vazios espetaculares e rarefação demográfica nas 
áreas central e setentrional. ${ }^{120}$ Daí que o antigo alerta de Fernando Magalhães, um dos fundadores da ABE, "povoar, unir, educar", por assim dizer, permanecera desouvido. Além mais, no vozerio dos doutrinários da ocupação do Brasil distante de si, sobressaía a frase hipotasiada de Fernando de Azevedo - "a escola faz a nação" e, por ser acanhada a extensão da escola, concluía-se ser exíguo o espaço social e cultural da nação, fenômeno resumido na equação negativa: dispersão + deseducação = déficit de sociabilidade e unidade.

O precário enquadramento das populações nas estruturas jurídico-estatais pela via de sistemas escolares de maior alcance é analisado por Teixeira de Freitas em Dispersão demográfica e escolaridade, tese apresentada no $9^{\circ}$ Congresso Brasileiro de Geografia, em Florianópolis, 1940; o estatístico concluía que a área "não escolarizável" por "escolas do tipo comum" seria de 7.186 .809 a $7.468 .719 \mathrm{~km}^{2}$, isto é, de $84,44 \%$ a $87,75 \%$ da superfície territorial, por sua vez as áreas escolarizáveis não seriam superiores a $1.500 .000 \mathrm{~km}^{2}$, irregularmente distribuídas pelas zonas litorâneas e aglomerados interioranos.

Simultaneamente, o recenseamento geral de 1940 apurava no grupo da população de "10 anos e mais" o índice geral de analfabetismo de 57\%. Quanto ao grupo de "5 anos e mais”, a distribuição da instrução por sexo e cor também é negativa. ${ }^{121}$

A categoria "pardos" abarcava os declarados como caboclos, mulatos e morenos. Menos da metade da população em idade escolar está matriculada. Por sua vez, os alunos inscritos nas zonas rurais não alcançavam a metade da matrícula total, dados que levaram o diretor do Instituto Nacional de Estudos Pedagógicos, em conferência na Academia Brasileira de Letras, a convite da Liga da Defesa Nacional, a interpelar. "Por que tipos de escolas se têm exercido a educação primária no país?" Passo seguinte replicava. "Dois tipos fundamentais existem: o da escola isolada e o da escola agrupada, este último especialmente difundido nos últimos trinta anos".

\footnotetext{
${ }^{120}$ Cf. Apêndice A - Tabela F.

${ }^{121}$ Cf. Apêndice A - Tabela G.
} 
O primeiro é o da escola de um só professor, a que se entregam 40, 50 ou, às vezes, mais crianças. Funciona quase sempre em prédio improvisado. É de pequeno rendimento, em geral, pelas dificuldades decorrentes da matrícula de alunos de todos os graus de adiantamento, falta de direta orientação do professor, falta de fiscalização, falta de material, falta de estímulo ao docente. É a escola típica dos núcleos de pequena densidade de população, a escola da roça, a escola geralmente capitulada de "rural".

A segunda toma o nome de "escolas reunidas", se poucas classes possui; de "grupo escolar", se as mantém numerosas. Aqui o prédio oferece melhores condições de conforto e higiene, mesmo quando adaptado. As classes apresentam, em geral, efetivo menos numeroso que o das escolas isoladas, e os alunos se distribuem por elas segundo os respectivos graus de adiantamento. Aí temos a escola comum dos meios urbanos (Lourenço Filho, 1940, p.85-87).

E esmiuçava mais ainda as diferenças regionais, vários estados experimentavam "instituições de tipo diverso": Alagoas e Paraíba, “escolas-granjas”, Rio de Janeiro, “escolas rurais típicas”, Acre, Paraná, Mato Grosso, "escolas ambulantes”, Amazonas, "escolas de emergência”, Pará, "escolas auxiliares suburbanas”, Rio Grande do Norte, "escolas rudimentares". E declinava números coletados pelo Inep, em 1937, o país possuía 31.566 escolas isoladas e 3.176 escolas agrupadas, dessas, 2.069 denominavam-se grupos escolares. Realidades agravadas pelo excesso de regentes leigos: em 1937, 25\% no ensino estadual de todo o país, 69\%, no municipal; 68\%; no particular. Acre e Pará lideravam com $90 \%$ e $62 \%$ de leigos. ${ }^{122}$

E muito embora as legislações municipais, estaduais e federal estatuíssem o ensino obrigatório, a instrução primária esbarrava no déficit demográfico, inviabilizando o trabalho alfabetizante articuladamente a construção do caráter nacional pela ação social da escola. Improfícua, como regra, a escola existente caracterizava-

${ }^{122}$ Cf. Apêndice A - Tabela H. 
se pelo baixo rendimento, infrequência de alunos, instabilidade de professores. Se há evolução positiva na matrícula geral, fenômeno a suscitar vontade de conferir sentido e orientação nacional à educação popular, as estatísticas globais, ao apurarem a abstinência, a reprovação e a deserção, indiciavam diminuta escolaridade real.

Em suas análises técnicas, Teixeira de Freitas concluía pela "regressão cultural" não por falta de escolas, mas pela ineficiência de ensino e baixo rendimento dos sistemas escolares; para ele, fatos prejudiciais ao preparo cultural e psicológico das gerações vindouras. Os coeficientes regionais de alunos repetentes no período de 1934 e 1937 indicavam em 10 lugar Alagoas, com 53\% de alunos reprovados; em 2o, Espírito Santo - 35\%; em 3ㅇ, Santa Catarina - 30\%; em 4º, Bahia - 27\%; em 5o Sergipe e Rio de Janeiro - 25\%; em 6º Minas Gerais - 22\%; em 7o Paraná, São Paulo e Acre - 21\%; em 8º Rio Grande do Norte - 19\%; em 9o, Distrito Federal - 18\%; em 10, Maranhão e Pará - 17\%; em 11을 Piauí - 14\%; em 12º Ceará e Paraíba -12\%; em 13을 Mato Grosso - 11\%; em 14\%, Amazonas 10\%; em 15, Pernambuco e Rio Grande do Sul - 8\%; em 16º Goiás - 5\%. ${ }^{123} \mathrm{Na}$ maioria dos casos, as zonas afastadas e desfrequentadas são atendidas por escolas isoladas, cujas rotinas evocam as velhas escolas régias, alunos de diferentes idades numa única classe, bancos compridos, caixotes, luz de lampião, mestres improvisados, em suma, escolas que testemunhavam a sobrevivência do passado num presente despossuído de futuro.

\section{Magistério rural e sua composição}

Em estudo inédito apresentado no $8^{\circ}$ Congresso Brasileiro de Educação, Maria Aparecida Oliveira expôs a composição e a exiguidade das fileiras do magistério rural segundo formação e sexo.

${ }^{123}$ Cf. Teixeira de Freitas (1937). 
268 - Carlos Monarcha

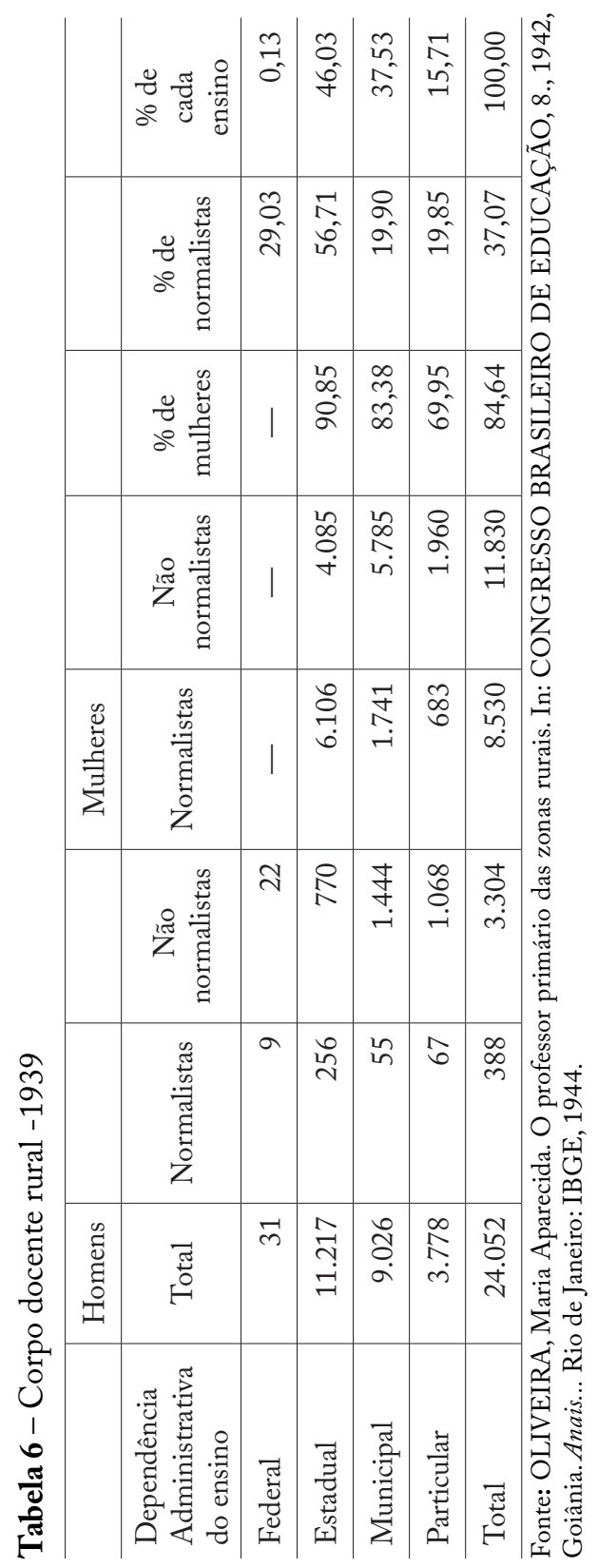


O sexo feminino concorre com o maior contingente de professores, $84,64 \%$, por sua vez a quantidade de professores diplomados, $37,07 \%$, estava aquém do desejável. $\mathrm{O}$ ensino estadual reúne o maior número de professores, 46,63\%, quanto à mínima percentagem do ensino federal, 0,13\%, assim se explica, o Governo Federal mantinha alguns estabelecimentos no Distrito Federal. No estudo da técnica do Serviço de Estatística de Educação e Saúde, no ano de 1939, o país totalizava 332 estabelecimentos para a formação de professores, desses apenas 20 destinavam-se à formação do professorado rural.

Quanto à dependência administrativa, Alagoas possuía dois estabelecimentos estaduais e dois particulares; Amazonas, um estadual; Bahia, um estadual e um particular; Ceará, dois estaduais; Pará, três estaduais e um particular; Paraná, dois estaduais e dois particulares; Pernambuco, nove estaduais. Das 22 unidades federadas, sete mantinham escolas normais rurais, cujos diplomas são reconhecidos somente no estado de expedição. Dos 20 estabelecimentos, seis formam "alunos-mestres" em curso elementar de dois anos; do total de 1.046 alunos-mestres, 224 concluem o curso, ou seja, 21,41\% da matrícula efetiva.

O único meio de evitar esses desastres seria colocar nos centros rurais um "imã maravilhoso", capaz de, com sua força de atração, impedir a desagregação desses núcleos, com seu brilho ofuscar as luminárias das cidades, com sua tempera vencer a inópia, a incompreensão, o preconceito e o fanatismo.

É o professor primário rural que compete, simbolizado nesse “imã” ser, em cada ponto obscuro do país, a célula formadora dos núcleos rurais. A responsabilidade é imensa - o futuro de nossa Pátria. A missão é nobre e gigantesca - construir o Brasil (Oliveira, 1944,p.360).

Por outro ângulo de apreciação. Indubitavelmente, a heterogeneidade das fileiras do magistério nacional era significativa. Se diplomado por um instituto de formação de maior ou menor prestígio, 
o professor goza de certa autoridade, além de encarnar o acesso ao conhecimento e, de algum modo, aparecer simbolicamente vinculado ao poder público. Se mestre-escola em recantos afastados, em maior parte prático improvisado, vê-se desprovido de reconhecimento, no mais das vezes, seu ensino limita-se a conhecimentos irregulares, mal se pode falar em pedagogia a despeito dos muitos progressos da disciplina.

Quanto aos professores, prendê-los na dependência exclusiva do governo federal é o único meio de pô-los a coberto da política de campanário.

O pobre mestre-escola, sobretudo nas regiões afastadas dos grandes centros, não tem sido até hoje mais do que um farrapo nas mãos dos todo-poderosos chefetes locais.

Cabo eleitoral malgré lui, sujeito aos vaivéns da política, sempre na aterrorizada expectativa de uma remoção, - só a custa de renúncias e subserviências consegue manter a conquista do amargo pão diário (Camargo, 1931, p.55).

São Paulo, por exemplo, contava com escolas isoladas rurais, com curso de dois anos e programas simplificados, situadas em lugares diversos - propriedades agrícolas, núcleos coloniais e centros fabris distantes das sedes municipais. Na fala desabafada do diretor do departamento de Ensino, Antonio de Almeida Júnior: "Salvo algumas dezenas de casos felizes, a escola rural está mal instalada e o professor vive nela em situação de dependência." E refinava a descrição do descalabro. "Dãolhe uma tulha velha ou uma sala pequena e anti-higiênica para as suas aulas. Arranjam-lhe pensão em casa de um sitiante que desconhece as condições mais elementares de conforto. Sujeitam-na, certas vezes, a vexames e humilhações" (São Paulo, 1936, p.13).

De resto no conjunto do país, o magistério primário era tão diversificado quanto às próprias escolas elementares o eram. Diversificação espelhada nos vencimentos próximos ao mínimo 
vital. Conforme estudo do Inep, em Alagoas, o professorado vencia mensalmente salário de $165 \$ 0$ a $500 \$ 0$; Bahia, de $384 \$ 0$ a $645 \$ 0$; Ceará, de $100 \$ 0$ a 400\$0; Espírito Santo, de 200\$0 a 420\$0; Goiás, de $250 \$ 0$ a 384\$0; Maranhão, 310\$0; Rio de Janeiro, de $400 \$ 0$ a $850 \$ 0$; Mato Grosso, de $180 \$ 0$ a $330 \$ 0$; Minas Gerais, de $99 \$ 0$ a $370 \$ 0$; Paraíba, de $83 \$$ a $430 \$$; Pará, de $150 \$ 0$ a $350 \$ 0$; Paraná, de $100 \$ 0$ a $420 \$ 0$; Pernambuco, de $300 \$ 0$ a $400 \$ 0$; Piauí, de $120 \$ 0$ a $384 \$ 0$; Rio Grande do Norte, de 250\$0 a 416\$0; Rio Grande do Sul, 360\$0 a 720\$0; Santa Catarina, de $130 \$ 0$ a 375\$0; São Paulo, de $240 \$ 0$ a $900 \$ 0$; Sergipe, de 205\$ a 338\$; Território do Acre, de 400\$0 a 700\$0; Distrito Federal, de 240\$0 a 1: 200\$0. Conquanto fossem concedidas pequenas vantagens aos professores das zonas rurais e dos subúrbios de difícil acesso, o estudo "Vencimentos do professor primário" (1942) concluía que o "ordenado mensal do mestre-escola equiparava-se ao ganho mínimo do mais modesto trabalhador."

\section{Da apoteose da lei}

Nas décadas iniciais do século XX, a matrícula escolar geral nas unidades federadas apresentava-se contrastada, as causas possíveis eram as mais diversas; de uma parte, a amplitude da economia de mercado, o desenvolvimento urbano-industrial e comercial, e a crescente demanda social favoreciam o incremento da matrícula geral; de outra parte, a rarefação demográfica e o absenteísmo escolar engendravam obstáculos a expansão e ao rendimento escolar. Como era usual, nas vozes expectantes, poderoso reagente químico, o estatuto da obrigatoriedade escolar promoveria a padronização linguística pela alfabetização, conhecimento das instituições jurídico-políticas e fomento das riquezas da nação.

Nas falas diagnósticas, a eficácia da obrigatoriedade estaria na dependência da abertura e manutenção de vias de comunicação, serviços de saneamento rural, assistência escolar e auxílio supletivo da União, em parceria com as iniciativas dos estados e municípios. E, a 
bem dizer, numa espécie de síntese de opiniões, concluía-se pelo ensino primário como prioridade de Estado, antiga e irrealizada promessa intermitentemente anunciada pela cultura política da Monarquia e da República. Se a massa do povo é refratária à instrução, assim se pensava, era preciso encontrar meios de demovê-la. ${ }^{124}$

Entre as cabeças esclarecidas, a declaratória de uma lei geral relativa à obrigatoriedade soa inadiável. Assim o melhor a fazer é expor o essencial das visões em circulação, no caso as visões de Antonio de Sampaio Dória, Miguel Couto, Fernando de Azevedo, Orestes Guimarães e Alberto Conte, homens públicos diferentes entre si, embora compartilhassem idêntica profissão de fé: à vontade de servir, acrescia-se a vontade de conduzir pela persuasão ou coerção, no mais, órgão do poder, o Estado, ao luzir a instrução popular, fiaria as conquistas civilizacionais.

Em Instrução pelo Estado coaduna-se a instrução primária obrigatória com os princípios que regem a ação social do Estado?, dissertação apresentada em concurso de ingresso na cátedra de Direito Constitucional da Faculdade de Direito de São Paulo, Sampaio Dória retoma a trilogia clássica da ação jurídico-social do Estado, a saber, a defesa do país, no caso de agressões externas, a manutenção da segurança interna no caso de desordem civil e, por fim, a distribuição de justiça entre querelantes em dissídios individuais e coletivos. No seu pensar, tal trilogia carecia de atualização. "Na mesma missão de distribuir a justiça e manter a ordem, não se inclui, acaso, o assegurar as condições que previnem as graves iniquidades?" (Sampaio Dória, 1922, p.52). Argumentativo, posiciona-se pela obrigatoriedade escolar dos 7 aos 14 anos com vistas à formação mental e ao disciplinamento da vontade coletiva, ações necessárias aos "povos em menoridade de civilização" "O povo não pode ser composto de imbecis, de ignorantes, de indiferentes à democracia, em povos analfabetos é o despenhadeiro para a demagogia. Mil vezes uma autocracia hábil à onipotência da plebe sem cultura" (Sampaio Dória, 1922, p.100).

${ }^{124}$ Cf. Apêndice A - Tabela I. 
$1^{\circ} \mathrm{A}$ instrução primária obrigatória é a mais fértil sementeira da riqueza pública, que a ação social do Estado promove;

$2^{\circ} \mathrm{A}$ instrução primária obrigatória é o mais sábio preventivo pela ordem pública, cuja mantença é ação jurídica do Estado;

$3^{\circ}$ A instrução primária obrigatória não só se concilia com os princípios que regem a ação social do Estado, mas é a ação social mais característica;

$4^{\circ} \mathrm{A}$ instrução primária, por fim, posto não privativa do Estado, mas dever supletivo da insuficiência particular, é a condição primeira da democracia íntegra e pura. A democracia não vinga senão nos povos instruídos (Sampaio Dória, 1922, p.100).

O chamamento final assemelha-se ao de um herdeiro do entendimento iluminista. "A instrução é o gênio misterioso, que conduz os povos à independência, à liberdade e à riqueza.”

República adentrada em manifestação em nome da Academia Brasileira de Letras, Miguel Couto, afamado médico sanitarista, manifestava-se em termos da economia política: o homem é a primeira riqueza da nação e o mais rendoso emprego do capital. "I - É compulsória a educação elementar, obrigados os pais e irmãos mais velhos a ministrá-la aos seus filhos ou irmãos mais moços e os governos aos desamparados. II - Vinte por cento, pelo menos, das rendas dos municípios dos estados e da União destinam-se à educação elementar do povo (A reforma da Constituição..., 1925, p.159-160)”. Manifestação subscrita por personalidades notórias, Amadeu Amaral, Afrânio Peixoto, Athaulfo de Paiva, Coelho Neto, Constâncio Alves, Dantas Barreto e Goulart de Andrade.

Noutro lugar e noutra circunstância mais exatamente em “A educação nos sertões” Miguel Couto carregaria ainda mais nas soluções radicais.

A União penetrará pelo interior do Brasil, onde é sempre recebida quando portadora do bem, - para fundar escolas em todas as aldeias e 
aldeolas, vilas e viletas, lugarejos e estações de ferro com uma população escolar de 40 crianças no âmbito de dois quilômetros e construirá grandes Institutos, em número variável em cada Estado, onde serão internadas sob a tutela do governo todas as crianças domiciliadas em lugares não servidos por escolas (Couto, 1937, p.153).

Marco documentário no rol dos debates fantasmáticos respeitantes aos "perigos da desnacionalização" representados pelos núcleos de colonização estrangeira, Orestes Guimarães em Sugestões sobre a educação popular no Brasil encaminha ao ministro da Justiça e Negócios Interiores medidas de erradicação da desordem didática nas escolas rurais, isoladas ou singulares, dentre as sugestões, a obrigatoriedade escolar entre 9 e 11 anos para crianças residentes num raio de três quilômetros da escola.

$1^{\text {a }}$ - evitará o possível congestionamento ou excesso de lotação das escolas, o que trará grande benefício à eficiência do ensino, sem prejudicar aos menores de oito anos;

$2^{\mathrm{a}}$ - assegurará melhor a regularidade da frequência. Nas zonas rurais, devido à disseminação das suas populações, à distância das escolas, aos maus caminhos, as crianças menores de nove anos não são, nem podem ser assíduas (Guimarães, 1924, p.108-109).

Para esse inspetor federal das Escolas Subvencionadas, após os cinco primeiros anos, contados da instalação duma escola, a obrigatoriedade se estenderia às crianças de 12 a 15 anos.

Há pais, tutores e protetores de crianças, sobretudo estes últimos, que descuram por completo, da alimentação de seus filhos, tutelados ou protegidos. Uns, por se levantarem tarde, outros, por desleixo, outros, finalmente, por inconcebível maldade, mandam as crianças à escola, sem lhes darem um pedaço de pão, queijo ou carne. Milhares de crianças permanecem cinco horas nas escolas, sem a mais ligeira refeição! (Guimarães, 1924, p.123, grifo do autor). 
Posição não menos original concerne a Fernando de Azevedo, em "O Estado e a educação", intervenção na 5a Conferência Nacional de Educação, antevéspera da Assembleia Geral Constituinte. Para escudar tese doutrinária, recorre a Durkheim e a Dewey; em sua evolução, o Estado acata as ideias condizentes com as mutações sociais e políticas da vida moderna. No seu entender, a "função educacional" implicava a reordenação das relações entre escola e sociedade de modo a converter a "competição estéril dos grupos" em harmonia social. Em síntese construtiva, predizia o dever ser do Estado moderno como instituição mediadora de interesses múltiplos e coletivos, conquanto competitivos entre si.

Por fim, a visão radical de Alberto Conte: igualmente ao seu quase homônimo, Augusto Comte, ele não é democrata nem socialista, liberal ou iliberal, é um homem da ordem e do progresso. Em "Estado e educação: necessidade de uma ditadura educacional e de um novo sentido da educação popular", artigo doutrinário igualmente veiculado às vésperas da Assembleia Constituinte de 1934, seguro de si, esse professor tomava partido pela "ditadura republicana" - governo de salvação social em nome e interesse do povo, nos moldes filosóficos de Augusto Comte. (Aqui o melhor a fazer é dar a palavra a José Maria, historiador das coisas brasileiras. "A autoridade moralizante do comtismo erige a República ditatorial em forma perfeita do Estado") (Bello, 1940, p.31). Ao alardear a necessidade urgente de clarear a consciência coletiva, Alberto Conte pintava e repintava um quadro sombrio.

Pois bem, o Estado devia assumir essa delicada e importantíssima tarefa de educar, comme il faut, o povo, não só no sentido de alfabetizálo e dar a uma parte dele instrução secundária, profissional secundária e superior, mas no sentido de fazer de todo esse povo um povo de mentalidade alta, despindo-os das superstições, das fraquezas e temores místicos exagerados que o tornam um joguete nas mãos dos espertalhões e de perigoso instrumento contra o próprio Estado. 
E se para levar a cabo essa tarefa o Estado tiver que usar de poder discricionário, justificar-se-ia uma ditadura educacional cuja duração tem de ser pelo menos de 20 anos, ou seja, o tempo indispensável para poder-se arrancar o povo mistificado e sempre pronto a defender os seus próprios exploradores, das garras desses seculares exploradores (Conte, 1934, p.6, grifo do autor).

E, ao expressar intolerância com a incultura popular, Alberto Conte reclama o pleno exercício da autoridade pública, recurso prático de proteção contra as estultices de si e dos outros de sorte a evitar a fatalidade das ações incompreensíveis fossem individuais fossem coletivas.

Quanto ao memorável A reconstrução educacional no Brasil, ao Povo e ao Governo: Manifesto dos Pioneiros da "Educação Nova" (1932), os signatários ao pleitearem a educação como "direito biológico" da pessoa endossavam a trilogia clássica, laicidade, gratuidade, obrigatoriedade. No plano jurídico-formal, o desfecho das antiquíssimas demandas viria com a Carta Política de 1934, na qual se abre um capítulo para a educação e cultura nos moldes da Constituição de Weimar, 1919.

Artigo 150 - Parágrafo único:

a) Ensino primário integral e de frequência obrigatória, extensivo aos adultos;

b) Tendência à gratuidade do ensino educativo ulterior ao primário a fim de o tornar mais acessível;

Artigo 156 - A União e os Municípios aplicarão nunca menos de dez por centro e os Estados e o Distrito Federal nunca menos de vinte por cento da renda resultante dos impostos na manutenção e no desenvolvimento dos sistemas educativos.

Parágrafo único - Para a realização do ensino nas zonas rurais, a União reservará, no mínimo vinte por cento das quotas destinadas à educação no respectivo orçamento (Brasil, 1934, art. 150, 156). 
Segundo o texto constitucional, da União emanariam as diretrizes da educação nacional e, em conjunto com os estados, difundiria a instrução pública em todos os seus graus. Paixão fundamental e irremovível, velho e antigo marco cravado no tempo da história e da cultura política nacionais, o ensino elementar obrigatório e de Estado concretizava-se no plano jurídico-formal, contudo, se a lei é dura como pode ser visto em minúcias nos mais diferentes dispositivos legais e elucubrações pessoais, por muito tempo a prática da obrigatoriedade permanecerá in vacuo. 



\section{Marcha territorial}

Dissolvido o Congresso Nacional, incremento de força política num momento tempestuoso, o Estado Novo reforça a centralização e a intervenção do poder federal na política, sociedade, economia, educação e cultura. Simultaneamente coloca em andamento um plano de integração antropogeográfica. $\mathrm{O}$ fenômeno unificador principiara em 1936, com a decretação da obrigatoriedade de execução do Hino Nacional em estabelecimentos de ensino, associações desportivas e de radiodifusão, e prosseguira ao extinguir os partidos políticos, hinos, pavilhões e escudos estaduais e municipais. Conforme a Constituição de 10 de novembro 1937.

Art. $1^{\circ}$ - O Brasil é uma República. O poder político emana do povo e é exercido em nome dele e no interesse do seu bem-estar, da sua honra, da sua independência e da sua prosperidade.

Art. $2^{\circ}-\mathrm{A}$ bandeira, o hino, o escudo e as armas nacionais são de uso obrigatório em todo o País. Não haverá outras bandeiras, hinos, escudos e armas. A lei regulará o uso dos símbolos nacionais.

Distrito Federal, praia do Russel. Sob um céu azul, ocorre cativante simulacro, ombreando propósitos comuns, Getúlio, ministros de Estado, corpo diplomático, alta hierarquia da Igreja Católica; por todos os lados aglomeram-se multidões, à frente dos desfiles, colunas de escolares e normalistas. Sinalizando uma só alma, mil mãos agitam 
bandeirolas. A emoldurar os monumentais altares da Igreja e da Pátria, em mastros enfileirados drapejam as 22 bandeiras estaduais. Concentrado em si, D. Sebastião Leme celebra a missa campal. Inaudito ritual encerra o ato cênico, isto é, a cremação das bandeiras estaduais, logo em seguida substituídas por 22 réplicas de um mesmo pavilhão, uno e protetor, a Bandeira do Brasil.

Cenográfico, o ato coletivo sobredoura a unidade-unitária da Pátria, em aparência, assim pensava-se representar a nação, suas gentes, seu governo (contudo, antes de ser um tecido de ideias, valores e símbolos a revestir o corpo da pátria, o nacionalismo estadonovista exterioriza imperativos objetivos). Seja como for, soberbas, tais encenações de antifederalismo, hoje fantasmagorias de uma história passada, simbolizam a supremacia do corpo orgânico da pátria sobre as "pequenas pátrias", melhor, o fim dos regionalismos desagregadores, ou seja, o estadualismo vigente, relíquias de um federalismo dito estiolado. Nas vontades de reforma envolvidas na racionalização das práticas de governo, todo impulso vital emanaria de um centro diretor, órgão de comando previdente e provedor, acima de tudo, neutralizador da ação centrífuga dos regionalismos. Modernizar pela ação do Estado é o credo abastecedor dos sujeitos às voltas com projeções construtivas de futuros. Em suma, com a queima das bandeiras estaduais, quer-se assinalar o advento de uma nova idade na história nacional, passagem mediada pela substituição da força pelo consenso; numa palavra, totalizar uma direção geral para a sociedade conforme ideias, valores e significações comuns.

Grandes iniciados, Getúlio e ideólogos do Estado Novo, novo por ser autêntico, quer dizer, distinto das "ideologias exóticas e dissolventes", liberalismo, socialismo, integralismo, comunismo, segundo os discursos e as doutrinas oficiais, destilavam o ímpeto de infundir comunhão espiritual das orlas do Atlântico às funduras do Planalto Central. Encampada como programa oficial, a escalada de unificação, pela via da extensão do poder de Estado como realidade jurídico-territorial, duplica o feixe de poder centralizador. Ou, por outra, a exaltação da unidade 
nacional, como é usual de ser, leva a política a desembocar na mística unitarista. ${ }^{125}$ Novamente acionava-se a máquina de formação do sentido mítico da nacionalidade enquanto comunidade restaurada. Quer dizer, a construção identitária aciona uma epopeica demanda das origens, por exemplo, a "marcha para Oeste", empresa mítico-retórica cujo canto de partida fora anunciado por Getúlio em discurso radiofônico na noite de 31 de dezembro de 1937.

Caminhamos para a unidade, marchamos para o centro, não pela força de preconceitos doutrinários, mas pelo fatalismo de nossa definição racial. O verdadeiro sentido de brasilidade é a Marcha para Oeste. No século XVIII de lá jorrou a caudal de ouro que transbordou na Europa e fez da América o continente das cobiças e tentativas aventurosas (Vargas, 1938, p.124).

Mito e empolgação da pátria virtual se consubstanciam na incorporação dos inominados sertões ao circuito encantatório da civilização do valor de troca. Para os porta-vozes dessa "comunidade imaginada" em que a sensação pessoal e cultural de pertencer a um todo vital é sintomática, ${ }^{126}$ por assim dizer, a marcha para o centro, nada mais é senão fluxo desimpedido dos fiéis da economia de mercado. Se ocupação e a urbanização das regiões nordeste, sul e sudeste estavam consolidadas, diferentemente era a situação de Goiás, Mato Grosso, Acre, Rondônia, Amazonas, regiões etnolinguísticas dadas por abandonadas ainda que interconectadas pelas linhas telegráficas cravadas pela Comissão Rondon. Donde o desatar de metas contraentrópicas a fim de mobiliar o extenso assoalho nu, no intento de coincidir as fronteiras terrestres e marítimas com as fronteiras econômicas, mormente modificar a hierarquia das formas

125 Cf. Girardet (1986). Em Gellner (2008, p.17, grifo do autor). "O nacionalismo não é o despertar de uma velha força, latente e adormecida, embora seja assim que de fato se apresenta".

${ }^{126}$ Cf. Anderson $(1991,2007)$. 
de existência, nas vozes dos portadores de futuros, a unidade nacional e a unidade política condicionam-se mutuamente. É mais do que antes concebia-se o Estado como força constitutiva e ordem visível.

No rol das questões excruciantes, de uma parte, a subjunção do Estado e nação, aprofundamento do poder central, controle das oligarquias regionais, integração territorial, ativação do mercado de produção e consumo, expansão das terras agricultáveis, distribuição e consumo de bens e circulação monetária; de outra, a resolução de questões sociais e demográficas: esvaziamento de conflitos entre latifundiários e excedentes de mão de obra, colonização dos vazios, estancamento da depopulação pela via da assistência rural, qualificação da mão de obra, instalação de cooperativas de produção e comercialização. Em síntese, a afirmação da unicidade das classes produtivas e de pessoas úteis é sobressignificada.

$\mathrm{Na}$ retórica de mobilização, as autoridades acenam com linhas de penetração, comunicações, transportes, serviços sanitários e escolas. ${ }^{127} \mathrm{E}$ certamente depois das antológicas expedições da Comissão Rondon, as viagens científicas encetadas pelo Instituto Oswaldo Cruz, a marcha da Coluna Prestes-Miguel Costa, a "marcha para o Oeste" assinalaria o quarto marco memorial na redescoberta do "Brasil real", tema central da pedagogia histórica da Era Getuliana. É o que ensinava Getúlio Vargas para crianças, cartilha de Alfredo Barroso, publicada sob as diretivas do Departamento de Imprensa e Propaganda (DIP).

"O verdadeiro sentido da brasilidade é a marcha para o Oeste"! exclamou, certa vez em discurso, o presidente Getúlio Vargas. Dando o exemplo ao povo brasileiro, ele mesmo iniciou, em viagem que passará à nossa história, essa Marcha para Oeste, viajando, em avião até Goiânia e visitando os pontos mais pitorescos do "Hinterland" goiano. Os resultados dessa viagem não se fizeram esperar e numerosas providências estão contribuindo para dar maior vida e maior atividade

${ }^{127}$ Cf. Lenharo $(1985,1986)$. 
às regiões ocidentais do Brasil, cuja riqueza sem medida estava exigindo uma valorização imediata, em benefício total de nosso país (Barroso, 1942, p.5).

Nacionalismo oficial, propaganda estatal, reescrita historiográfica, sanitarismo e ensino primário de Estado gratuito e obrigatório convergem na determinação de promover o enquadramento jurídicoestatal das populações esquecidas de si e dos outros. Até então indizível, corrigia-se a geografia pela sua história a favor da empresa integracionista, a "marcha para Oeste", nacionalismo unitário e vontades centralizadoras reencontravam-se. De sorte que, na duração do Estado Novo, o debate sobre a extensão da escola elementar em ambientes geográficos e culturais isomorfos é sobressaltado ao incorporar as questões referidas à demografia, à segurança nacional e à colonização interna.

\section{A máquina mitológica}

O ideólogo da "marcha para o azul" é o poeta verde-amarelo Cassiano Ricardo, diretor do Departamento Estadual de Imprensa e Propaganda de São Paulo, o célebre DEIP. Seu ambicioso Marcha para Oeste: a influência da "bandeira" na formação social e política do Brasil, 1940, estetiza em prosa a ocupação dos vazios, estetização, adensada por Heitor Villa-Lobos na composição para o canto coral "Marcha para Oeste". E, a bem dizer, aqui e ali surgiam obras expressivas da pulsão marchadora: O Brasil em marcha, de Paula Aquiles; Uma revolução em marcha, de Leão Machado; O rio Paraná no roteiro da marcha para o oeste, de Teófilo de Andrade; A marcha para Oeste - Couto de Magalhães e Getúlio Vargas, de Ildefonso Escobar e Oeste, ensaio sobre a grande propriedade pastoril, de Nelson Werneck Sodré do qual cito a seguinte passagem. "Corrigidas pela marcha evolutiva da produção, as anomalias que se traduzem na instabilidade e na pobreza, o Oeste assumirá condições bem diversas e poderá estruturar uma fase nova 
no seu desenvolvimento - fase de riqueza e de libertação" (1941, p.4).

Em Cassiano Ricardo, o motivo legendário "expedições bandeirantes", uma das míticas narrativas das origens identitárias da nação, remonta a nascente do país-nação. "Quando entra no mato a primeira bandeira, termina a história de Portugal e começa a do Brasil" (p. 229). ${ }^{128}$ Mediada pela nostalgia das origens heroicas, na prosa ricardiana, bandeiras e bandeirantismo testemunharam o entrosamento das cores raciais em soberbas paisagens naturais. Não é simples reevocação do passado heroico, para ele, Ricardo, imagem marcializada, as bandeiras do século XVII prefiguravam a iridescente democracia caldeada por brancos, índios e negros. Profecia de destino e culto do heroísmo, em si e por si, a marcha simboliza a origem da nação em devir. ${ }^{129}$ Noutros termos, providas de valor de intemporalidade, bandeiras e bandeirantismo da Era Getuliana assinalam o redescobrimento do povo em sua diversidade.

Ontem, eram os bandeirantes só os que partiram do planalto de Piratininga seus subfocos de irradiação; hoje são todos quantos tomam parte na nova marcha destinada a preencher os vazios demográficos, regiões que pedem "novos bandeirantes equipados de nova técnica" para o seu melhor aproveitamento econômico e social... as duas palavras "bandeirismo" e desenvolvimento se justapõem (Ricardo, 1940, p.652).

$\mathrm{Na}$ arte político-literária do escritor verde-amarelo, o país ressurge como exterioridade de imagens cromáticas: o céu de anil, o verde das florestas, o vermelho do pau-brasil, o amarelo-dourado do sol. Noutras palavras, a natureza é mais referida do que vista; e não será demasiado dizer que sob esse Brasil aquarelado, coexistissem a

128 "O espaço físico unificado constitui o lastro empírico sobre o qual os outros elementos constitutivos da Nação se apoiam: a unidade étnico-cultural, a unidade econômica, política, o sentimento comum de ser brasileiro" (Lenharo, 1986, p.56). ${ }^{129}$ Cf. Esterci (1972). 
violência dos conflitos ideológicos e sociais, estremecimentos políticos e traumas profundos.

No plano aparente da ontologia social do país, a "marcha para o azul”, marcha real e simbólica em direção às funduras baldias, o planalto central, reencontraria a quintessência do país e seu povo. Queria-se defrontar as questões de ordem geral, incorporar o país distante de si e diferente na mentalidade ao país demográfico e econômico. E do pulsar marchador, originaram-se os territórios federais, criações justificadas em nome da segurança de fronteiras externas e povoamento das áreas vazias. De fato, ao desmembrar porções do Amazonas e Pará, criamse os territórios de Guaporé, atual Rondônia, Amapá, Ponta-Porã, hoje integrado ao Mato Grosso do Sul, Iguaçu e Rio Branco. ${ }^{130}$ Nesse desatar de iniciativas reconstrutoras, o "batismo de Goiânia", nova capital de Goiás, estala como acontecimento venturoso, mais à frente ampliado com as iniciativas coordenadas pelo ex-tenente João Alberto, a Expedição Roncador-Xingu e a Fundação Brasil Central. Até então, a demografia do país registrava 10 milhões de habitantes nas "cidades e vilas" e 30 milhões no "campo".

\section{Festa pública, Goiânia no mapa}

Sobejava o sol no firmamento azul, Goiânia rescendia a concreto fresco e seiva do cerrado, o canteiro de obras é notório, quando, entre luzes e festas, é inaugurada em 2 de julho de 1942. Planejada para ser a capital de Goiás, em substituição à colonial Goiás Velha, a "nova metrópole", marco avançado da civilização, cuja pedra fundamental fora relançada em 1933, torna-se realidade sob o impulso de Pedro Ludovico Teixeira, interventor federal, e do projeto urbanístico idealizado por Atílio Correia de Lima.

Para tirar partido da perspectiva e monumentalidade, escolherase o art déco, estilo que interpenetra desenho industrial e arquitetura. Expressão da vontade de ordem, o plano-piloto radioconcêntrico

${ }^{130}$ Cf. Guerra (2011). 
organiza a cidade em zonas funcionais, a central abriga o setor administrativo; a norte, o setor comercial e industrial; a sul, o setor residencial, praça de esportes, praça central e terrenos reservados à futura edificação da catedral, palácio arquiepiscopal, centros de educação e ensino, ${ }^{131}$ em duas palavras, modernismo tecnocrático e devoração do cerrado se entrecruzavam. Festejava Pedro Ludovico Teixeira.

A cidade moderna é o repositório de todos os afetos do homem. Ali tem ele seu lar, sua família, os seus amigos, as reservas para a sua subsistência e os focos de sua cultura. A cidade moderna educa e civiliza. É o fator mais valioso para reforçar a homogeneidade das pátrias (Congresso Brasileiro de Educação, 1944, p.33).

No centro da festa pública, a figura estelar do interventor federal, saudado "Fundador de Goiânia”, é ladeada por Mario Augusto Teixeira de Freitas e José Carlos de Macedo Soares, esse presidente do IBGE e orador oficial dos apelos prometeicos.

O Brasil possui no sentido "imperialista" das bandeiras - essas grandes forças vivas e móveis a que tanto deve a formação social do país - o melhor signo para a nova era da sua história, cujo objetivo especial tem de traduzir-se, como tão bem definiu o próprio Chefe de Estado, no "reatamento da campanha dos construtores da nacionalidade", a fim de sanar os vácuos demográficos do nosso território e fazer com que as fronteiras econômicas coincidam com as fronteiras políticas (Congresso Brasileiro de Educação, 1944, p.15).

Cidade de 42 mil habitantes, inaugurada, Goiânia assinalava a tomada de posse do Brasil central. ${ }^{132} \mathrm{Na}$ voz do secretário-geral do IBGE, Teixeira de Freitas (1942), o evento evidenciava passo decisivo na interiorização da capital da República. Expectativa, é bom lembrar,

\footnotetext{
${ }^{131}$ Cf. Azevedo (1941).

${ }^{132}$ Cf. Vidal e Souza (2002).
} 
deflagrada pela Constituição de 1891 e robustecida por Floriano Peixoto ao nomear o belga Luis Cruls, diretor do Observatório Astronômico do Rio de Janeiro, para liderar a comissão exploradora do Planalto Central a fim de demarcar o quadrilátero de terras apalavrado pela Constituição. O "Quadrilátero Cruls", como ficara conhecido, passa a constar no Pequeno Atlas do Brasil publicado no ano de lançamento da pedra fundamental da futura capital da República, 1922. Ainda que temporariamente Goiânia sedia a comunhão nacional, e, como a cavalgar um promontório, o interventor federal precipitava o olhar do centro às extremidades do país.

Saúdo a Amazônia, tão cheia de mistérios e tão rica de promessas; as terras dos palmares babaçuais esplêndidos do Parnaíba longínquo. Saúdo o nordeste, de atitudes heróicas e fecundas ante as durezas do clima que o flagela; os Estados do leste de riquezas tão numerosas e de um labor tão intenso em benefício da economia nacional. Saúdo as terras dos vales históricos do Paraíba e do Tietê, onde vicejam os cafezais, os algodoais e tantas outras riquezas; as regiões admiráveis dos pinheirais paranaenses e catarinenses.

Saúdo os pampas do sul, berço de heróis, celeiro do Brasil; as terras que, a leste e a oeste de Goiás, com ele se irmanaram na grandeza das suas glebas, na variedade dos seus produtos e no labor intrépido dos seus filhos. Saúdo o Brasil todo, símbolo da pujança, dignidade e elevação moral (Congresso Brasileiro de Educação, 1944, p.58).

Verdadeira imersão batismal, a inauguração da cidade radiosa soa simultaneamente como farol a iluminar as escuridões fechadas e centro propulsor das forças civilizadoras no desconhecido (quer dizer, a exteriorização da consciência da territorialidade da pátria, assinala material e imaginariamente a posse do país interior). Em poucas palavras, o espetáculo proporcionado pela Goiânia inaugurada é a metonímia do país em seu devir uno, coeso, vibrátil, progressivo, civilizador. 
Em 1942, Getúlio assinava o Decreto-lei no 4.092, autorizando as cerimônias cívicas concernentes ao feito admirável. Sujeitos da inteligência técnica fraternizados numa comunidade de visões encenam um espetáculo de colorido leve, agradável e formalmente provido de consistência, conquanto rigorosamente políticoideológico na essência. Encadeado num mesmo laço ontológico, acontecem o $8^{\circ}$ Congresso Brasileiro de Educação promovido pela $\mathrm{ABE}$, a $2^{\mathrm{a}}$ Exposição Nacional de Educação, Cartografia e Estatística, as assembleias gerais dos conselhos nacionais de Estatística e Geografia e a Semana Ruralista patrocinada pelo ministério da Agricultura.

$\mathrm{Na}$ exbibitio desbravadora, os estandes dos ministérios e repartições oficiais, as maquetes dos edifícios da Imprensa Nacional, do Instituto Médico Legal e do Serviço de Alimentação e Previdência Social, os projetos arquitetônicos de estabelecimentos penais e educacionais, os quadros murais ilustrativos da riqueza mineral, potência agrícola e pastoril, estatísticas escolares, livros didáticos e materiais de ensino. Os estandes de São Paulo e do Rio Grande do Sul monopolizam as atenções: fotos de cenas escolares, títulos da Livraria Globo, panorâmicas das escolas técnicas e profissionais; o estande do Paraná, idem, com estatísticas e fotos escolares, depois, painéis e impressos das ligas Brasileira de Higiene Mental e Esperantista Brasileira.

Na monotonia e rusticidade do planalto do Brasil central, sucessão de personalidades notórias e eventos propiciatórios. Sobrecarregada de atrativos, a 2a Exposição Nacional de Educação, Cartografia e Estatística expõe inéditos conhecimentos, a Carta geográfica do Brasil, na escala de 1: 500 000, o Vocabulário geográfico de Goiás, a Bibliografia geográfica e cartográfica do Estado de Goiás. Em palavras mais diretas, predominava a vontade de mostrar e contar homens e coisas, seres e artefatos, redirecionar fenômenos coletivos, penetrar na essencialidade das coisas, reconstruir realidades. 


\section{Escolarizar os vazios da nação}

Com o apoio do IBGE e poderes públicos, realiza-se o $8^{\circ}$ Congresso Brasileiro de Educação, presidido por José Augusto Bezerra de Medeiros. Em cartas, circulares, cartazes, notas de publicidade, palestras radiofônicas, IBGE, Inep e DIP divulgam o evento país afora. Ao referir-se aos congressos abeanos até então realizados, Teixeira de Freitas penitenciava-se. "De tais Congressos, só três tiveram por sede cidades interiores - Belo Horizonte, São Paulo e Curitiba”.

Nenhum deles, portanto, deu lugar a um contato íntimo dos nossos educadores com os aspectos particularíssimos e genuinamente brasileiros de nossa vida sertaneja, daquela vida apagada, morosa, retardada que se vive em mais de $80 \%$ do território nacional. Vida essa que, no seu rudimentarismo, nos seus desajustamentos, no seu abandono, na inexistência ou na precariedade dos seus elementos de civilização e de cultura, propõe aos dirigentes do país em geral, e aos educadores em particular, os mais complexos, os mais sérios, os mais angustiantes problemas. Problemas de cuja urgente e aceitada solução depende a sobrevivência da Nação através dos tempestuosos tempos que a humanidade está vivendo (Teixeira de Freitas, 1942, p.381).

Congresso e congressistas viriam a ser um marco memorioso na legitimação da empresa integracionista, amplo, o temário sindicava a adaptação da escola elementar aos ambientes diversos. No intuito de produzir consciência social educativa e professores aptos a redirecionarem mentalidades ditas tradicionais, os delegados debatem as teses relativas a práxis didática a ser acionada em regiões afastadas. $\mathrm{E}$, ao jurarem o trabalho qualificado em código social, congresso e congressistas validavam a escola de trabalho e a atividade profissional. Nas vozes, a escola rural reaparece como peça central na aventura de ocupação de lugares viventes em formidáveis silêncios, estimulada a tese do "desafogo das grandes cidades" desdobra o fôlego. Em 
demonstração de unidade, aglomeram-se as "forças morais e culturais do Brasil" para elaborarem as bases antropossociológicas da escola regional. Possuído por uma visão de esplendores, solene o padre José Bruno Teixeira, diretor do Departamento de Educação do Ceará, anuncia a emancipação do homem rural. "É, portanto a nossa hora, a hora do Brasil."

A hora de fazermos surgir a verdadeira civilização brasileira, mas sobretudo a civilização do sertão, a civilização do Oeste, paralela à civilização litorânea e completando-a, para integrar a grandeza da Pátria. É a civilização do sertanejo e do caboclo, sadio e instruído, robusto de corpo e forte de espírito, iluminado pelos clarões da Fé e abrasado pelos ardores do patriotismo, embora continue de "alpercatas e chapéu de couro", na faina sagrada do labor cotidiano, desfraldando uma bandeira que é a própria bandeira do Brasil (Teixeira, 1944, p.15).

Atividade intelectual e política-ideológica se fundem. Ao lado dos professores, as novas identidades profissionais em evidência, demógrafos, estatísticos, sanitaristas, técnicos em educação, sociólogos, geógrafos e psicólogos. Unidos na empresa de interiorização das estruturas civilizacionais, comparecem os mais diversos intermediários do presente histórico. No face a face, na Comissão de Honra, o presidente da República, Interventor Federal em Goiás, ministros de Estado. Na Comissão Patrocinadora Nacional, interventores federais, governador do Acre, cardeal-arcebispo do Rio de Janeiro, inspetor-geral do ensino do Exército, diretores do Ensino Naval, da Escola de Aeronáutica, dos departamentos de Educação, de Rodagem e da Criança, dos institutos de Cinema Educativo e de Agronomia, do Conselho Nacional de Imprensa, da Escola Nacional de Educação Física. Mais além, presidentes do IBGE, Associação Brasileira de Imprensa, Cruzada Nacional de Educação, Comissão Censitária Nacional, por último o comandante da 2a Região Militar, secretário de Educação e Cultura do Distrito Federal e reitores das universidades do Brasil e Católica. 
$\mathrm{Na}$ Comissão Organizadora Nacional, o grande Cândido Mariano Rondon, Fernando de Azevedo, Fernando de Magalhães, José Getúlio Frota-Pessoa, Branca Fialho, Gustavo Lessa, Levi Carneiro, Odilon Braga, Sud Mennucci. Na Executiva, Artur Torres Filho, Celso Kelly, Francisco Venancio Filho, Jonathas Serrano, José Augusto, Juraci Silveira, Lourival Fontes, Lourenço Filho e Otávio Tomaz Newland Neto.

Igualmente presentes, as personalidades notórias de Antonio de Almeida Júnior, Celina Padilha, Dom Amaro van Emelen, Gervásio Leite, Helena Antipoff, Joaquim Moreira de Sousa, Jacir Maia, Mário Pinto Serva, Noêmia Saraiva de Matos Cruz, Ulysses Pernambucano e Maurício Vinhas de Queiroz.

Global e minudente, o tema geral do congresso - "A educação primária fundamental: objetivos e organização; (a) nas pequenas cidades e vilas do interior; (b) na zona rural comum; (c) nas zonas rurais de imigração; e (d) nas zonas rurais de alto sertão" - sinaliza uma urgência, a extensão da escola para além dos centros urbanos.

Aladas pela ventania de vozes promissoras, exorbitam-se imagens saneadoras. "Nas zonas de alto sertão as escolas deverão aproximar as populações primitivas, bem como os remanescentes indígenas, dos círculos sociais civilizados, dando um sentido de culto nacional às manifestações de arte popular" (Congresso Brasileiro de Educação, 1944, p.89).

Complementando o tema geral, uma macedônia de temas especiais: "O provimento de escolas para toda a população em idade escolar e de escolas especiais para analfabetos em idade não escolar; o problema da obrigatoriedade", "Tipos de prédios para escolas primárias e padrões de aparelhamento escolar, consideradas as peculiaridades regionais", "O professor primário das zonas rurais: formação, aperfeiçoamento, remuneração assistência”, "A frequência regular à escola: o problema da deserção escolar, assistência aos alunos, transporte, internatos e semi-internatos", "Encaminhamento dos alunos que deixam a escola primária para escolas de nível mais alto 
ou para o trabalho", "O rendimento do trabalho escolar: o problema das medidas", "As missões culturais como instrumento de penetração cultural", "As colônias-escolas como recurso para a colonização intensiva das zonas de população rarefeita ou desajustada", "A coordenação dos esforços e recursos da União, dos estados e municípios e das instituições particulares, em matéria de ensino primário”.

Acatadas por maioria, as decisões vão à plenária. Raul Bittencourt relata as conclusões do tema geral: a educação primária teria por finalidades desenvolver a personalidade (objetivo individual), integrar o educando na sociedade brasileira em geral (objetivo nacionalista); formar o sentimento de solidariedade humana (objetivo humano), ajustar o educando ao ambiente regional (objetivo vocacional).

As leis reguladoras do ensino primário indicariam os meios e as normas de organização escolar conforme as regiões. Além da educação visando à uniformidade cultural mínima, as escolas atenderiam aos propósitos regionais, quer sob a forma de educação sanitária, quer sob a forma de ensino pré-vocacional. Nas zonas de imigração a substituição das "escolas estrangeiras" por escolas nacionais para o ensino de português, geografia e história pátria, educação cívica e celebração das datas nacionais.

No alto sertão, a solução do problema educacional demandaria vias de comunicação para unir as regiões distantes com os "núcleos de maior densidade demográfica e de civilização já sensível”; aprovisionamento das escolas com jornais, cinemas, rádios, bibliotecas ambulantes e associações; planificação precedida de inquérito das condições geográficas, demológicas e culturais da região considerada. $\mathrm{E}$, ao invocarem solidez sociológica, congresso e congressistas determinavam o lugar da escola no âmbito do projeto estratégico de melhoramentos pela via da mudança cultural provocada. Nas palavras diagnósticas do mato-grossense, Gervásio Leite. "A instrução primária na zona rural, por isso, necessita, sobretudo de equilíbrio, de ser, primordialmente, fator de valorização do homem em função do meio em que vive, fazendo do Jeca-Tatu, essa indiferença acocorada, 
um elemento enérgico, ativo no enriquecimento nacional" (Congresso Brasileiro de Educação, 1944, p.135). Ou como esclarece um certo Francisco L. Azevedo na tese "As 'colônias-escolas' como recurso para a colonização das zonas de população rarefeita ou desajustada."

Nas regiões de rarefação demográfica, a falta de contato entre os elementos seus componentes, provoca o fenômeno social de estacionamento, do qual decorre, com o passar do tempo, a formação dos grupos arcaicos que, agindo isoladamente, enfraquecendose por degenerescências físicas ou mentais, tendem a desaparecer ou permanecer num estado em que constituem peso morto para a sociedade (Congresso Brasileiro de Educação, 1944, p.553).

No tumultuado fertilizador, congresso e congressistas em uníssono sancionam o anexim: "Educar é mais do que alfabetizar, é preparar para o meio.” A percepção esclarecida apregoa soluções condizentes com os meios geográficos, antropológicos e culturais, concordantes com finalidades práticas: granjas escolares, internatos rurais, clubes de trabalho, semanas ruralistas, assistência técnica, sanitária, formação do professorado rural. E, para radicar as massas humanas em solos e climas da hinterlândia pré-moderna, essa mesma percepção propugna a reforma do regime de propriedade agrária, fomento da produção, crédito agrícola, comunicações, transportes, alfabetização de jovens e adultos, missões de assistência técnica e cultural, abrasileiramento das "escolas estrangeiras", unidade intelectual e moral pelo ensino obrigatório.

Raciocinava-se, ao envolver as populações na soberania nacional, a educação elementar transcenderia as culturas tradicionais e os limites comunitários pela ação social da escola, assim o centro civilizacional atingiria os territórios culturais pré-modernos, nos quais, dizia-se, remanesciam formas antigas de sentir e pensar, viver e produzir, e sobremodo relações arcaicas entre o homem, a terra e o trabalho. Tudo isso porque tanto a economia de mercado e as trocas competitivas quanto a democracia social e a representação popular 
seriam incompatíveis com a desculturação geral. Do até agora exposto, resta a seguinte impressão: congresso e congressistas viam-se como artífices da Pátria Nova... mais do que fundar, refundavam... mais do que construir, reconstruíam...

\section{Ente fundamental, o professor rural}

Coube a Sud Mennucci, sociólogo tarimbado em matéria de instrução popular e aplaudido teórico do agrocentrismo, relatar o tema "O professor primário das zonas rurais: formação, aperfeiçoamento, remuneração e assistência”. No relatório, ele revalidava o argumento vital de Alberto Torres, transplantada para o interior, campo e sertão, a escola urbana e sua cultura concretizavam-se como norma invertida ao ofertar uma educação negativa.

A escola rural não pensa nisso, é livresca e pedante, e não se lembra de que essa população brasileira só terá oportunidade - quando a tem - de receber a educação ministrada nas escolas primárias. E como essa população terá de viver de seus braços, em fainas manuais, que não podem deixar de ser as que o meio ambiente consente e permite, a única maneira de adquirir hábitos de trabalho e conhecimentos para fazê-lo produtivo, será preciso dar à escola primária a feição especializada que consiga valorizar o homem como fator de progresso, pelo aproveitamento de suas energias, conduzidas e disciplinadas com o espírito racional (Mennucci, 1944b, p.290).

Para o relator, mais do que antes, o ensino rural adquiria nítida função sociocultural ao integrar-se no formidável afresco antropogeográfico constituído pelos seringais amazônicos, várzeas pastoris, planaltos paulistas, encostas vinhateiras gaúchas, canaviais pernambucanos, caatingas cearenses, campos goianos, encostas capixabas e serras catarinenses. Solidários à produção de bens e riquezas, os aparelhos educativos em ambientes agrícolas, pastoris, marítimos e 
ribeirinhos teriam inequívoco caráter profissional e de formação de hábitos mentais. A contrapelo da visão de mundo industrializante, Sud revalidava antiga profissão de fé fisiocrata.

Sem a cultura da gleba, e, portanto, sem o trabalho do homem da roça, o planeta seria um deserto. É inútil que a indústria progrida e se aperfeiçoe e obtenha graus de rendimento fora de todos os limites: ela será sempre satélite da terra. Sem que esta lhe proporcione a matériaprima, que só se arranca do campo, pela agricultura, a indústria não poderia subsistir (Mennucci, 1944b, p.295).

Construtor imaginativo projetava, face às dificuldades materiais, o professorado rural ganharia mais que o urbano, seria assistido pelas autoridades pedagógicas, sanitárias e agrícolas, o Estado organizaria cooperativas de serviços odontológicos, farmacêuticos e médicos, além de ofertar melhoramentos "que são o conforto da cidade", rádio, telefone, luz elétrica, cinema, jornais, revistas e bibliotecas circulantes. Esperançoso senão confiante encerrava o relatório com uma moção política conforme o "espírito do Estado Novo".

Sua Excelência, o Senhor Presidente da República, que traçou o programa magnífico do "rumo ao Oeste", como retorno à marcha tradicional do povo brasileiro, e que se revelou admirável ruralista no celebrado discurso da Bahia, de agosto de 1933, sente as necessidades do homem da terra.

É, pois, para ele, para esse grande guia da nacionalidade, que desejo se faça um apelo no sentido de que, comemorando esta expressiva e significativa inauguração da cidade de Goiânia, no coração do Brasil, funde e mande instalar, desde já, uma escola normal rural, em cada estado e território da Nação, as quais, atendendo às peculiaridades regionais, hão de coroar a obra da grande transformação que Getúlio Vargas está operando em nossa Pátria (Mennucci, 1944b, p.300). 
Com essa apoteose do professorado e da escola rural, a rigor uma carta enviada ao futuro da nação e da nacionalidade, Sud finalizava seu relatório. Convertidas em paradigma da razão agrocêntrica e da ética de restituição de direitos usurpados do campo, a contraofensiva congressual oficializava o modo de dizer e o modo de fazer ensino rural. Legitimada e institucionalizada, a empresa de ocupação dos vazios, acentuava os efeitos civilizatórios da escola (e da instrução) condizentes com os meios geográficos e culturais.

Sob a proteção de Ceres, congresso e congressistas lavram uma norma comum, a potencialização máxima da seiva do país e da força de suas gentes. Por paradoxo, não será demasiado dizer que, ao demandarem infraestrutura de serviços, obras públicas, estradas, comunicações, hospitais, escolas profissionais, por assim dizer, os melhoramentos citadinos, congresso e congressistas decidiam-se pela urbanização do interior, campo e sertão. Fácies primitivas da vida vivida no Brasil, o povo na sua diversidade - índios, caboclos, cafuzos, mulatos, sertanejos, caipiras, caiçaras, curibocas, matutos, tabaréus, vaqueiros, seringueiros, lavradores, pescadores, mestiços, pretos, paroaras, populações arcaicas de um Brasil arcaico, ora à mercê do nomadismo ora insulado na inanidade dos tempos ora ainda ermado em trabalhos e dias antigos que escapavam à história e geografia, era chamado à nova grandeza nacional.

\section{O essencial dedutível}

E como dito e redito nos capítulos anteriores, assemelhada a uma estrutura profunda, melhor, marco de esperança cravado em presentes passados e desejados futuros, incólume, a confiança no halo da instrução, atravessa as temporalidades das formas políticas e suas instituições. Entre o desatar da pátria monárquica e da pátria republicana, entre paixões desconcertantes, interesses litigiosos, devoções ardentes, projeções utópicas, e condenações de descasos, o mapa da cultura política das épocas de formação de um país quase- 
continente, ritualiza na ordem das certezas, a instrução popular como sumo civilizatório, fonte de melhoramento material, fator de concórdia coletiva. Com efeito, nas vozes dos sujeitos às voltas com a efetuação de cortes histórico-culturais, a instrução popular surge e ressurge como moto-contínuo das relações sociais (e de produção) e, por desdobramento, concludente morigeração de normas, valores, crenças e atitudes. Em contraposição a malformação do corpo coletivo, para um país mais verdadeiro e lídimo, receitava-se o letramento geral. Sob o ardor dilatado de um céu estelar ou sob a luz de um intenso meiodia, diferentes sujeitos sociais, em diferentes lugares, com diferentes propósitos, irmanavam-se numa mesma razão discursiva, conquanto cada qual conforme sua visão do mundo, cada qual com sua concepção de processos de vida social, cada qual com sua voz esclarecida. 



\section{Fontes e bibliografia}

\section{Fontes impressas}

I) Periódicos

A Escola Pública, São Paulo

Educação, órgão da Diretoria de Ensino, São Paulo

Revista Brasileira de Estatística, Rio de Janeiro

Revista Brasileira de Estudos Pedagógicos, Rio de Janeiro

Revista de Ensino, órgão da Associação Beneficente do Professorado Público de São Paulo

Revista do Instituto Histórico e Geográfico Brasileiro, Rio de Janeiro

Revista Nacional, São Paulo

Revista Pedagógica, Rio de Janeiro

O Estado de S. Paulo

Diário Popular, São Paulo

II) Leis, decretos, regulamentos e regimentos

BRASIL. Constituições do Brasil: 1824, Ato Adicional, 1891, Reforma de 1926, 1934 e 1937; e leis constitucionais posteriores. São Paulo: Cristo-Rei, 1944.

BRASIL. Constituição. Constituição da República dos Estados Unidos do Brasil. Rio de Janeiro, 16 jul. 1934.

BRASIL. Constituição. Constituição dos Estados Unidos do Brasil. Rio de Janeiro, 10 nov. 1937. 
BRASIL. Decreto no 1.331- $A$, de 17 de fevereiro de 1854. Aprova o Regulamento para a reforma do ensino primário e secundário do Município da Corte. Coleção de Leis do Império do Brasil, Palácio do Rio de Janeiro, v.1, pt.1, p. 45,17 fev. 1854.

BRASIL. Decreto-lei no 7.247, de 19 de abril de 1879. Reforma do ensino primário, secundário e superior no município da Corte em todo o Império. Rio de Janeiro, 1879. Coleção das leis do Império do Brasil.

BRASIL. Decretos do Governo Provisório da República dos Estados Unidos do Brasil. Rio de Janeiro: Imprensa Nacional, 1890.

BRASIL. Ministério da Justiça e Negócios Interiores. Notícia bistórica dos serviç̧os, instituiçôes e estabelecimentos pertencentes a esta repartição elaborada por ordem do respectivo ministro Dr. Amaro Cavalcanti. Rio de Janeiro: Imprensa Nacional, 1898a.

ESPÍRITO SANTO. Regulamento geral da instrução pública da Província do Espirito Santo. Vitória: Tipografia do Horizonte, 1882.

MATO GROSSO. Regulamento da instrução pública primária. Cuiabá: Tipografia Oficial, 1910.

PARÁ. Direção Geral da Instrução Pública do Estado do Pará. Ensino primário. Regulamento, programa, horário, instruçoes pedagógicas. Pará: Ed. Tavares Cardoso, 1890.

SÃO PAULO. Código de Instrução Pública da Provincia de São Paulo. Organizado pela comissão composta dos Srs. Dr. Antonio Joaquim Ribas, Dr. João Dabney de Avellar Brotero e Dr. Diogo de Mendonça Pinto. São Paulo: Tipografia 2 de Dezembro, de Antonio Louzada Antunes, 1857.

SÃO PAULO. Assembleia Legislativa do Estado de São Paulo. Decreto no 27, de 12 de março de 1890. Estabelece a Escola Normal e converte em Escolas Modelos as Escolas anexas. Palácio do Governo do Estado de São Paulo, 12 mar. 1890.

SÃO PAULO. Relatório apresentado ao Exmo. Sr. Dr. Secretário do Interior por Oscar Thompson, Diretor Geral da Instrução Pública. In: ANUÁRIO do Ensino do Estado de S. Paulo. Publicação organizada pela Diretoria Geral da Instrução Pública com autorização do Governo do Estado. São Paulo: Tipografia Augusto Siqueira \& C., 1918.

SÃO PAULO. Lei no 1.750, de 8 de dezembro de 1920. Reforma a Instrução Pública do Estado de São Paulo. São Paulo, 1920.

SÃO PAULO. Decreto nº 3.356, de 31 de maio de 1921. Regulamenta a Lei $\mathrm{n}^{\circ} 1.750$, de 8 de dezembro de 1920, que reforma a Instrução Pública. São Paulo, 1921. 
III) Anais, anuários, relatórios, Falas do Trono

ANUÁRIO do ensino do estado de São Paulo. Publicação organizada pela Diretoria Geral da Instrução Pública, com autorização do Governo do Estado. São Paulo: Augusto Siqueira \& C., 1918.

ATAS e pareceres do congresso de instrução pública do Rio de Janeiro. Rio de Janeiro: Tipografia Nacional, 1884.

CONFERENNCIA INTERESTADUAL DE ENSINO PRIMÁRIO, 1922, Rio de Janeiro. Anais... Rio de Janeiro: Empresa Industrial "O Norte", 1922. Convocada em nome do Sr. Ex. Dr. Epitácio Pessoa, Presidente da República, pelo Sr. Ministro da Justiça e Negócios Interiores e realizada de 12 de outubro a 16 de novembro do mesmo ano.

CONGRESSO BRASILEIRO DE EDUCAÇÃO, 8., 1942, Goiânia. Anais... Rio de Janeiro: IBGE, 1944.

CONGRESSO NORMALISTA DE EDUCAÇÃO RURAL, 1., 2., 3., 1948, São Paulo. Anais... São Paulo: Associação dos Antigos Alunos da Escola Normal "Dr. Francisco Tomás de Carvalho" - Associação dos Ex-Alunos da Escola Normal “Carlos Gomes”, 1948.

DOCUMENTOS com que o ilustríssimo e excelentíssimo senhor Dr. José Antonio Saraiva, presidente da Província de S. Paulo, instruiu o relatório da abertura da Assembleia Legislativa Provincial no dia 15 de fevereiro de 1855. São Paulo: Tipografia 2 de Dezembro de Antonio Louzada Antunes, 1855.

FALAS do Trono desde o ano de 1823 até o ano de 1889. Prefácio de Pedro Calmon. Brasília, DF: INL, Mec, 1977.

O IMPÉRIO do Brasil na exposição universal de 1876 em Filadélfia. Rio de Janeiro: Tipografia Nacional, 1875.

\section{IV) Estatísticas e recenseamentos}

BRASIL. Diretoria Geral de Estatística. Recenseamento Geral do Império de 1872. Rio de Janeiro: Tipografia Leuzinger, Tipografia Comercial, 1876.

BRASIL. Diretoria Geral de Estatística. Relatório dos trabalhos estatísticos apresentado $\mathrm{Ilm}^{\circ} \mathrm{Exm}^{\circ}$ Sr. Conselheiro Dr. José Bento da Cunha Figueiredo, Ministro e Secretário de Estado dos Negócios do Império pelo Diretor Geral conselheiro Manoel Francisco Correia em 31 de dezembro de 1876. Rio de Janeiro: Tipografia de Hipólito José Pinto, 1877. 
BRASIL. Diretoria Geral de Estatística. Sexo, raça e estado civil, nacionalidade, filiação culto e analfabetismo da população recenseada em 31 de dezembro de 1890. Rio de Janeiro: Oficina da Estatística, 1898b.

BRASIL. Diretoria Geral de Estatística. Relatório apresentado ao Dr. Miguel Calmon Du Pin e Almeida, ministro da Indústria, Viação e Obras Públicas pelo Dr. José Luiz S. de Bulhöes Carvalho. Rio de Janeiro, 1906.

BRASIL. Diretoria Geral de Estatística. Estatística da instrução. Boletim Comemorativo da Exposição Nacional de 1908. Rio de Janeiro: Tipografia da Estatística, 1908.

BRASIL. Diretoria Geral de Estatística. Relatório apresentado ao Dr. João Pandiá Calógeras, Ministro da Agricultura, Induistria e Comércio, pelo Dr. José Luiz S. de Bulhöes Carvalho, Diretor Geral de Estatística. Rio de Janeiro: Tipografia da Estatística, 1915.

BRASIL. Diretoria Geral de Estatística. Estatística da instrução. Primeira parte: Estatística escolar. Rio de Janeiro: Tipografia da Estatística, 1916, v.1.

BRASIL. Diretoria Geral de Estatística. Recenseamento do Brasil. Rio de Janeiro: Tipografia da Estatística, 1929 (População: População do Brasil, por estados e municípios, segundo o grau de instrução por idade, sexo e nacionalidade, v.4).

IBGE. Recenseamento geral do Brasil: 1940. Rio de Janeiro: Serviço Gráfico do Instituto Brasileiro de Geografia e Estatística, 1950 (Série Nacional, v.2. Censo demográfico: População e habitação).

SÃO PAULO. Recenseamento escolar. Relatório apresentado ao Exmo. Sr. Dr. Alarico Silveira, Secretário de Estado dos Negócios do Interior, pelo Sr. Dr. A. de Sampaio Dória, Diretor Geral da Instrução Pública. São Paulo: [s.n], 1920.

SÃO PAULO. Secretaria da Educação e da Saúde Pública. Diretoria do Ensino. Os problemas da escola primária na zona rural. Entrevistas concedidas ao "Diário de São Paulo" pelo prof. A. Almeida Júnior, Diretor do Ensino. São Paulo: Siqueira, Sales Oliveira, 1936. (Boletim n.4).

\section{V) Livros, capítulos de livros, opúsculos \& correlatos}

A ESCOLA Regional: conferências proferidas durante a $4^{a}$ Semana Nacional de Educação, 13 a 18 de maio de 1931. Rio de Janeiro: Biblioteca da Associação Brasileira de Educação, 1931.

A RECONSTRUÇÃO educacional no Brasil, ao povo e ao governo. Manifesto dos Pioneiros da "Educaçấo Nova”. São Paulo: Nacional, 1932. 
A REVOLUÇÃO de 7 de abril de 1831 e Evaristo Ferreira da Veiga. Por um fluminense amante da Constituiçáo. Rio de Janeiro: Tipografia Imparcial e Constitucional de J. Villeneuve e Comp., 1862.

ALENCAR, José de. Sistema representativo. Introdução Walter Costa Porto. Brasília: Senado Federal, 1997. (Memória brasileira, n.3). Edição fac-similar. [1868].

ALMEIDA, Miguel Calmon Du Pin. As promessas e os resultados da pedagogia moderna. Rio de Janeiro: Tipografia do Jornal do Comércio, de Rodrigues \& C., 1915. Conferência realizada, em $1^{\circ}$ de agosto de 1915 , no saláo de honra do "Liceu de Artes e Ofícios" da Bahia.

AMADO, Gilberto. As instituições políticas e o meio social no Brasil. In: CARDOSO, Licínio. (Org.). À margem da história da República. Rio de Janeiro: Anuário do Brasil, 1924, p.57-78.

AMERICUS. Cartas politicas. Londres: Impressora por R. Greenlaw, 1825. v. 1.

ANDRADA E SILVA. Jose Bonifácio de, [O moço]. In: CÂMARA DOS DEPUTADOS. [Discurso]. Anais da Câmara dos Deputados, sessão de 28 de maio de 1879. Rio de Janeiro: Tipografia Nacional, 1879, p.428-438.

ANDRADE, Elyseo Castanho de. Os Clubes Agricolas Escolares. Instituição, propaganda e oficialização entre nós da educativa associal infantil. Piracicaba: Tipografia de obras do "Jornal de Piracicaba", 1933.

ARAÚJO, Oscar. Le fondateur de la Republique brésilienne, Benjamin Constant. Paris: Boulanger, 1891.

ARMITAGE, John. História do Brasil: desde o período da chegada da família de Bragança, em 1808, até a abdicação de D. Pedro I, em 1831, compilada à vista dos documentos públicos e outras fontes originais formando uma continuaçáo da História do Brasil. São Paulo: Tipografia Brasil, de Rothschild \& Cia, 1914.

AZEVEDO, Fernando de. O Estado e a educação. In: _. A educação e seus problemas. São Paulo: Nacional, 1937b, p.103-130. (Biblioteca pedagógica).

. O problema da educaçáo rural. In: . A educação e seus problemas. São Paulo: Nacional, $1937^{\mathrm{a}}$, p.45-74. (Biblioteca pedagógica brasileira).

AZEVEDO, Francisco L. As "colônias-escolas" como recurso para a colonização das zonas de população rarefeita ou desajustada. In: CONGRESSO BRASILEIRO DE EDUCAÇĀO, 8., 1942, Goiânia. Anais... Rio de Janeiro: IBGE, 1944.

BAIN, Alexander. Ciência da educação. Tradução Adolpho Portella. Lisboa: Livraria Clássica Editora de A. M. Teixeira, 1905. 
BARBOSA, Rui. Reforma do ensino primário e várias instituiçôes complementares da instrução pública. Rio de Janeiro: Ministério da Educação e Saúde, 1947, [1882] (Obras completas, v.9).

BARROS, Roque Spencer Maciel de (Org.). Obras filosóficas de Pereira Barreto. São Paulo: Humanitas, 2003.

BASTOS, Maria Helena Camara; FARIA FILHO, Luciano Mendes de (Org.). $A$ escola elementar no século XIX: o método monitorial/mútuo. Passo Fundo: EDIUPF, 1999.

BILAC, Olavo. A defesa nacional: discursos. Rio de Janeiro: Edição da Liga de Defesa Nacional, 1917.

. A pátria e a escola. In: BILAC, Olavo. Últimas conferências e discursos. Rio de Janeiro: Livraria Francisco Alves, 1924, p.59-64.

. Poesias infantis. Rio de Janeiro: Francisco Alves, 1904.

BOMFIM, Manoel. América Latina: males de origem. Rio de Janeiro: Topbooks, 1993. [1905].

BORDEAUX RÊGO, Oziel. Introdução. In: BRASIL. Diretoria Geral de Estatística. Estatística da instrução. Primeira parte: Estatística escolar. Rio de Janeiro: Tipografia da Estatística, 1916, v.1, p.X-CCXXXII.

BORGES, Abílio César. Dissertação lida no Congresso Pedagógico Internacional de Buenos Aires em 2 de maio de 1882. Bruxelas: Tipografia e Litografia E. Guyot, 1884.

- Vinte anos de propaganda contra o emprego da palmatória e outros meios aviltantes no ensino da mocidade. Rio de Janeiro: Tipografia Cinco de Março, 1876.

BRAZILIENSE, Américo. Os programas dos partidos e o Segundo Império. São Paulo: Tipografia de Jorge Seckler, 1878.

BREVES, Arthur. Hodierno conceito da educação. São Paulo: T. Stocco, 1907.

BUARQUE DE HOLANDA, Sergio. Raizes do Brasil. 2ed. rev. e ampl. Rio de Janeiro: J. Olympio, 1948. [1936].

BÜCHLER, José Augusto; MORAES, Pedro Deodato de. O melhor modo de divulgar o ensino primário no Brasil. Sáo Paulo: Melhoramentos, 1923. Monografia apresentada à Academia Brasileira de Letras.

BULHÓES CARVALHO, José Luiz Sayão de. Introdução. In: BRASIL. Diretoria Geral de Estatística. Ensino primário: resultados provisórios do inquérito sobre a instrução primária no Brasil em 1926, divulgados por ocasiáo do centenário da lei de 15 de outubro de 1827, referente ao mesmo ensino. Rio de Janeiro: Tipografia da Estatística, 1927. 
BULHÓES CARVALHO, José Luiz Sayão de. Introdução. In: BRASIL. Diretoria Geral de Estatística. Estatistica da instrução. Boletim comemorativo da Exposição Nacional de 1908. Rio de Janeiro: Tipografia da Estatística, 1908, p.3-11.

. Introdução. In: BRASIL. Diretoria Geral de Estatística. Relatório apresentado ao Dr. João Pandiá Calógeras, Ministro da Agricultura, Indústria e Comércio, pelo Dr. José Luiz S. de Bulhöes Carvalho, Diretor Geral de Estatística. Rio de Janeiro: Tipografia da Estatística, 1915, p.iii-xii.

CAETANO DE CAMPOS, Antonio. Relatório sobre escolas de $1^{\circ} \mathrm{e} 2^{\circ}$ graus anexas à Escola Normal. São Paulo: Tipografia de Vannorden e C., 1891.

CAMARGO, Cristovam. O grave problema da instrução popular no Brasil. Rio de Janeiro: Ediçóes Alba, 1931.

CAMPOS SALES, Manuel Ferraz de. Da propaganda à presidência. Brasília, DF: Ed. UnB, 1983. [1908].

CARDOSO, Licínio (Dir.). À margem da história da República. Rio de Janeiro: Anuário do Brasil, $1924 b$.

. Benjamin Constant, o fundador da República. In: CARDOSO, Licínio (Org.). À margem da história da República. Rio de Janeiro: Anuário do Brasil, $1924^{\mathrm{a}}$, p.292-317.

CARNEIRO LEÃO, Antonio. Os deveres das novas geraçōes. Rio de Janeiro: Sociedade Editora de Propaganda dos Países Americanos, 1923.

1918.

. Pela educação rural. Rio de Janeiro: Tipografia "Revista dos Tribunais",

CARVAlHO, Carlos Leôncio de. Primeira Exposição Pedagógica do Rio de Janeiro. Rio de Janeiro: Tipografia Nacional, 1884.

CASTRO, Tito Lívio de. A mulher e a sociogenia. Prefácio Silvio Romero. Rio de Janeiro: Francisco Alves \& C., 1893. (Obra póstuma publicada sob a direção de Manoel da Costa Paes).

COARACY, Vivaldo. O caso de São Paulo. São Paulo: Estabelecimento Gráfico Irmãos Ferraz, 1931. Publicado pela Liga de Defesa Paulista.

CORRÊA, Gustavo. Psicopatologia da educação. Rio de Janeiro: Tipografia Revista dos Tribunais, 1916.

COSTA, José Afonso de Paula. Dissertação pedagógica. Ligeiro estudo sobre a arte da leitura. Qual método de leitura verdadeiramente científico apresentado à comissão examinadora presidida pelo $\mathrm{Exm}^{\circ} \mathrm{Sr}$. Dr. Antonio Carlos Ribeiro de Andrada Machado e Silva, em fevereiro de 1884 (Homero de 96), por José Afonso de Paula Costa. (Guaratinguetá). São Paulo: Tipografia a vapor de Jorge Seckler e C., 1884. 
COUTO, Miguel. A educação nos sertóes. In: COUTO, Miguel. Medicina e cultura. Rio de Janeiro: Oscar Mano \& Cia, 1937, v.2. (Série Miguel Couto, dirigida pelo Dr. Miguel Couto Filho).

CUNHA, Euclides da. Contrastes e confrontos. Porto: Empresa Literária e Tipográfica, 1907.

. Da independência à República. In: CUNHA, Euclides da. À margem da história. Nota editorial e cotejo e estabelecimento do texto por Orlando Morel Pinto. São Paulo: Cultrix; Brasília, DF: INL, 1975. [1909].

DÓRIA, Franklin Menezes, Barão de Loreto. A instrução. In: A DÉCADA republicana. Rio de Janeiro: Companhia Tipográfica do Brasil, 1899, v.2, p.7-65.

ESTATUTOS da Liga Nacionalista de São Paulo. [Sáo Paulo]: Tipografia Cardozo \& Comp., 1917.

FERNANDES, Henrique Costa. Administraçōes maranhenses (1822-1929). São Luis: Imprensa Oficial, 1929.

FERREIRA JÚNIOR, Alexandre Dias. Histórico da fundação da república brasileira. São Paulo: Tipografia a vapor de Jorge Seckler \& Comp., 1890.

FLEIUSS, Max. História administrativa do Brasil. São Paulo: Melhoramentos, 1922.

FRAZÃO, Manuel José Pereira. Cartas do professor da roça: artigos relativos à instrução pública da Corte, publicadas no Constitucional de março e abril de 1863. Rio de Janeiro: Tipografia Paula Brito, 1864.

FROTA-PESSOA, José Getúlio. A educação e a rotina: teses heterodoxas. Rio de Janeiro: Livraria Editora Leite Ribeiro, 1924.

GENTIL, Alcides. As ideias de Alberto Torres. São Paulo: Nacional, 1932. (Brasiliana, v. 3). Síntese com índice remissivo.

GONÇALVES DIAS, Antonio. Instrução pública em diversas províncias do Norte (julho 1852). Arquivo Nacional, Rio de Janeiro, n.29, p.333-364, 1957 [1852].

GRÉARD, Octave. Éducation et instruction. 10. éd. Paris: Hachette, 1889, v.1. GUIMARÃES, Orestes. A nacionalização do ensino primário. Memorial apresentado ao $\mathrm{Exm}^{\circ}$ Sr. Dr. M.D. Ministro da Justiça e Negócios Interiores da República, pelo professor Orestes Guimarães. Inspetor Federal das Escolas Subvencionadas pelo Governo Federal no Estado de Santa Catarina. [S.1.: s.n.], 1925. Datilografado.

. Sugestôes sobre a educą̧ão popular no Brasil. Florianópolis: Livraria Moderna, Paschoal Simone \& Cia., 1924. 
HAMEL, Joseph. L'enseignement mutuel ou histoire de l'introduction et de la propagation de cette méthode par les soins du docteur Bell, de J. Lancaster et d'autres. Paris: Chez L. Colas, 1818.

HISTÓRIA da pedagogia compilada por um professor. Rio de Janeiro: Livraria Francisco Alves, 1914.

LACERDA, Nelson Nogueira de. A mais antiga escola normal do Brasil. (18351935). Esboço de história administrativa e episódica, com 30 gravuras fora dos textos e a partitura do hino à Escola Normal de Niterói. Rio de Janeiro: Oficina Gráfica do Diário Oficial, 1938.

LIBERATO BARROSO, José. A instrução pública no Brasil. Rio de Janeiro: B. L.Garnier Ed., 1867.

LIMA, Nestor dos Santos. Um século de ensino primário. Natal: Tipografia d'A República, 1927.

LOURENÇO FILHO, Manoel Bergström. A pedagogia de Rui Barbosa. Prefácio de Wilson Martins. 4. ed. rev. e ampl. Brasília, DF: Inep, 2001 [1954] (Coleção Lourenço Filho, v.2).

. Congressos e conferências de educação. Rápida resenha histórica. In: BRASIL Ministério da Educação e Saúde. Primeiro congresso nacional de educação. Rio de Janeiro: Serviço de Documentação, 1946, p.5-11.

MARQUES PINHEIRO. Contra o analfabetismo. Rio de Janeiro: Editora Brasileira Lux, 1923.

MEDEIROS, José Augusto Bezerra de. Pela educação nacional. Rio de Janeiro: Tipografia do Jornal do Comércio, 1918.

MÉLINE, Félix-Jules. Retour a la terre et la surproduction industrielle. Paris: Hachette, 1905.

MELLO, José Baptista de. Evolução do ensino na Paraíba. 3. ed. Atualização ortográfica e glossário de Alarico Correia Neto. João Pessoa: Conselho Estadual de Educação, 1996. [1936]. (Biblioteca Paraibana).

MEMÓRIA de Martim Francisco sobre a reforma dos estudos da capitania de São Paulo. Revista Brasileira de Estudos Pedagógicos, Rio de Janeiro, v.6, n.18, p.464-482, dez. 1945. [1816].

MENNUCCI, Sud. 100 anos de instrução pública: 1822-1922. São Paulo: Editores Salles Oliveira, Rocha \& Cia, 1932a.

. A crise brasileira de educação. 2ed. São Paulo: Ed. Piratininga, 1934.

. Discursos e conferências ruralistas. São Paulo: [s.n.], 1946. 
MENNUCCI, Sud. Homenagem que Sud Mennucci prestam os seus amigos do Centro do Professorado Paulista, Academia Paulista de Letras e Imprensa Paulistana e admiradores, promoventes do festival de 28 de dezembro de 1931 no Teatro Municipal de São Paulo. São Paulo: Tipografia Siqueira, 1931.

. O que fiz e o que pretendia fazer: defesa e fundamentação da reforma do ensino de 1932. São Paulo: Casa Piratininga, 1932b.

MOACYR, Primitivo. A instrução e a República: reforma Benjamin Constant 1890-1892. Rio de Janeiro: Imprensa Nacional, 1941, v.1.

. A instrução e o Império. Reformas do ensino: 1854-1888. São Paulo: Nacional, 1938 (Brasiliana, v.87).

. A instrução e o Império: subsídios para a história da educação no Brasil (1823-1853). São Paulo: Nacional, 1936 (Brasiliana, v.66).

. Ensino público no Congresso Nacional. Rio de Janeiro: Tipografia do “Jornal do Comércio", de Rodrigues e Comp., 1916.

MORAES, Pedro Deodato de. Rumo ao campo... A escola social. São Paulo: Tipografia Piratininga, 1919.

MOTA, Cândido. São Paulo e a República. São Paulo: Empresa Gráfica da "Revista dos Tribunais", 1935.

MOTTA JÚNIOR, Cesário. Relatório apresentado ao Senhor Dr. presidente do Estado pelo Dr. Cesário Motta Júnior, secretário de Estado dos Negócios do Interior em 28 de março de 1894. São Paulo: Tipografia Vanorden, 1894.

NEGRO, Hélio; LEUENROTH, Edgar. O que é marxismo ou bolchevismo: programa comunista. São Paulo: A Plebe, 1919.

NEIVA, Arthur; PENNA, Belizário. Viagem científica pelo norte da Bahia, sudoeste de Pernambuco, sul do Piauí e de norte a sul de Goiás. Brasília, DF: Senado Federal, 1999. (Coleção Memória Brasileira). Memórias do Instituto Oswaldo Cruz, Rio de Janeiro, Manguinhos, t.8, 1916.

OLIVEIRA VIANNA. O povo brasileiro e a sua evolução. São Paulo: Monteiro Lobato \& C., 1923.

OLIVEIRA, Antonio de Almeida. O ensino público. São Luis: Tipografia do País, 1874.

OLIVEIRA, José Feliciano de. O ensino em São Paulo: algumas reminiscências. São Paulo: Tipografia Siqueira, 1932.

OLYMPIO, Mathias (Org.). A instrução pública no Piauí. Teresina: Sociedade Auxiliadora de Instrução, 1922. 
PARANHOS, José Maria da Silva, Barão de Rio Branco. Esquisse de l'histoire du Brésil. In: SANTA-ANNA NERY, Frederico José de (Dir.). Le Brésil en 1889: avec une carte de l'empire en chromolithographie des tableaux statiques des graphiques et des cartes - publié par les soins du Syndicat du comité Franco-Brésilien pour l'Exposition Universelle de Paris avec la collaboration de nombreux écrivains du Brésil. Paris: Libraire Charles. Delagrave/Syndicat du Comité Franco-Brésilien, 1889, p.61-105.

PEIXOTO, Afrânio. Marta e Maria: documentos de ação pública. Rio de Janeiro: Tipografia da Sociedade Gráfica Editorial, 1930.

PEREIRA BARRETO, Luiz. A propósito da universidade. In: BARROS, Roque Spencer Maciel de (Org.). Obras filosóficas de Pereira Barreto. São Paulo: Humanitas, 2003, v.3.

PEREIRA JUNIOR, J. F. C. Programa do ensino da Escola Normal da Corte. In: VIANNA, A. F. Relatório apresentado à Assembleia Geral Legislativa na quarta sessão da vigésima legislatura pelo Ministro e Secretário de Estado dos Negócios do Império Antonio Ferreira Vianna. Rio de Janeiro: Imprensa Nacional, 1889.

PIRES DE ALMEIDA, José Ricardo. História da instruçâo pública no Brasil: 1500 a 1889. Tradução de Antonio Chizzotti. São Paulo: EDUC; Brasília, DF: Inep, Mec, 1989 [1889].

PRESTES, Gabriel. A reforma do ensino público. São Paulo: Leroy King Book Walter, Tipografia King, 1892.

PRESTES, Gabriel. Instrução pública. Discurso proferido na Câmara dos Deputados de São Paulo. São Paulo: Tipografia do "Estado de S. Paulo", 1893.

. Relatório da Escola Normal apresentado ao Sr. Alfredo Pujol. M. D. Secretário dos Negócios do Interior pelo diretor Gabriel Prestes. São Paulo: Tipografia do Diário Oficial, 1894.

PUJOL, Alfredo. Relatório apresentado ao Exmo. Sr. Dr. Presidente do Estado de S. Paulo em 30 de março de 1896 pelo Secretário de Estado dos Negócios do Interior e Instrução Pública. São Paulo: Tipografia do Diário Oficial, 1896.

RAMIZ GALVÃO, Benjamin Franklin. Relatório do Ministério da Instrução, Correios e Telégrafos. Rio de Janeiro: Imprensa Nacional, 1890.

RICARDO, Cassiano. Marcha para oeste: a influência da "bandeira" na formação social e política do Brasil. Rio de Janeiro: J. Olympio, 1940, 2v.

RODRIGUES, João Lourenço. Um retrospecto: alguns subsídios para a história pragmática do ensino público em São Paulo. São Paulo: Instituto Anna Rosa, 1930. 
RODRIGUES, Milton C. da Silva. Educação comparada: tendências e organizaçôes escolares. São Paulo: Nacional, 1938 (Série Atualidades pedagógicas, v.31).

ROQUETTE-PINTO, Edgard. Ensaios de antropologia brasiliana. São Paulo: Nacional, 1933 (Brasiliana, v.37).

SÁ E BENEVIDES, José Maria Corrêa de. Elementos da filosofia do direito privado. São Paulo: Tipografia União do Largo de S. Francisco, 1884.

SAMPAIO DÓRIA, Antonio de. Instrução pelo Estado: coaduna-se a instrução primária obrigatória com os princípios que regem a açáo social do Estado? São Paulo: Monteiro Lobato, \& C., 1922.

. O que o cidadão deve saber: manual de instrução cívica. São Paulo: Tipografia Olegário Ribeiro, Lobato \& Cia. Ltda. 1919.

. Questóes de ensino: a reforma de 1920, em São Paulo. São Paulo: Monteiro Lobato \& Cia., 1923.

SANTA-ANNA NERY, Frederico José de (Dir.). Le Brésil en 1889: avec une carte de l'empire en chromolithographie des tableaux statiques des graphiques et des cartes: publié par les soins du Syndicat du comité Franco-Brésilien pour l'Exposition Universelle de Paris avec la collaboration de nombreux écrivains du Brésil. Paris: Libraire Charles. Delagrave/Syndicat du Comité Franco-Brésilien, 1889.

. Barão de Santa-Anna Nery. Le pays des Amazones: I'El-Dorado, les terres à caoutchouc. Paris: Librairie Guillaumin e Cie, 1899.

SERVA, Mário Pinto. A educação nacional. Pelotas: Ed. Livraria Universal, 1924. SILVA, J. N. S. Investigaçōes sobre os recenseamentos da população geral do Império e de cada Provincia de per si. Rio de Janeiro: Tipografia Nacional, 1870. Relatório do Ministério dos Negócios do Império.

SODRÉ, Nelson Werneck. Oeste, ensaio sobre a grande propriedade pastoril. Rio de Janeiro: J. Olympio, 1941. (Documentos brasileiros).

TAVARES BASTOS, Aureliano Cândido. A Provincia: estudo sobre a descentralização no Brasil. 2. ed. São Paulo: Nacional, 1937 [1870] (Brasiliana, v.105).

. Cartas do solitário: estudos sobre reforma administrativa, ensino religioso, africanos livres, tráfico de escravos, liberdade da cabotagem, abertura do Amazonas, comunicaçōes com os Estados Unidos. 2ed. Rio de Janeiro: Livraria Popular de A. A. da Cruz Coutinho, 1863.

TEIXEIRA BRANDÁO. A educação nacional no regime republicano. Rio de Janeiro: Imprensa Nacional, 1907. 
TEIXEIRA DE FREITAS, Mário Augusto. O que dizem os números sobre o ensino primário. São Paulo: Melhoramentos, 1937 (Biblioteca de educação, v. 27).

TORRES, Alberto. A organização nacional. (Primeira parte: a Constituição). Rio de Janeiro: Imprensa Nacional, 1914.

. O problema nacional brasileiro: introduçáo a um programa de organização. 4. ed. São Paulo: Nacional; Brasília, DF: Ed. UnB, 1982 [1914] (Temas brasileiros, 38).

VARGAS, Getúlio. A nova politica do Brasil. Rio de Janeiro: J. Olympio, 1938 (Realizaçôes do Estado Novo, v.6).

VASCONCELLOS, Aleixo de. Luta contra o analfabetismo, de como esta campanha favorece o saneamento do Brasil. Rio de Janeiro: Empresa Gráfica Editora, 1924. (Memória apresentada ao Congresso Nacional dos Práticos realizado em setembro de 1922).

VERÍSSIMO, José. A educação nacional. 2ed. aum. Rio de Janeiro: Livraria Francisco Alves, 1906.

. A educação nacional. Pará: Editores Tavares Cardoso \& C., Livraria Universal, 1890.

. A instrução e a imprensa no Brasil. In: LIVRO do centenário. Rio de Janeiro: Imprensa Nacional, 1909, v.1, p.5-12.

O positivismo no Brasil. In: VERÍSSIMO, José. Estudos de literatura brasileira. Rio de Janeiro: Garnier, 1901, p.53-72. 1a série.

. O século XIX. In: O SOCIALISMO brasileiro. Seleção e introdução Evaristo de Moraes Filho. Brasília, DF: Ed. da UnB, 1981 [1899].

VIANNA, Hélio. Formação brasileira. Rio de Janeiro: J. Olympio, 1935 (Problemas políticos contemporâneos, n.5).

\section{VI) Artigos em periódicos}

AMARAL, Amadeu. As promessas do escotismo. Revista de Ensino, órgão da Associação Beneficente do Professorado Público de São Paulo, ano 15, n.1, p.4-5, jun. 1916.

AZEVEDO, Aroldo. Goiânia, uma cidade criada. Revista Brasileira de Geografia, Rio de Janeiro, p.2-19, jan. 1941.

BELLO, José Maria. O sertão. Revista do Brasil, São Paulo, ano 3, v.9, p.124-126, set. 1918. 
BITTENCOURT, Raul J. Perspectiva histórica dos ideais de educação no Brasil. Revista Brasileira de Estudos Pedagógicos, Rio de Janeiro, v.7, n.20, p.233-240, fev. 1946.

. A educação brasileira no Império e na República. Revista Brasileira de Estudos Pedagógicos, Rio de Janeiro, v.9, n.49, p.41-76, jan./mar. 1953.

BREVES, Arthur. Instrução pública. Diário Popular, São Paulo, p.2, 23 fev. 1891.

CAETANO DE CAMPOS, Antonio. Justa homenagem: discurso proferido perante a turma de professorandos, em 17 de dezembro de 1890. O Estado de $S$. Paulo, São Paulo, p.5, 18 dez. 1890.

CARDOSO, Vicente Licínio. À margem do Segundo Reinado: história política. Revista do Instituto Histórico e Geográfico Brasileiro, Rio de Janeiro, t.98, v.152, p.1.039-1.087, 1927.

CONTE, Alberto. Estado e educação: necessidade de uma ditadura educacional e de um novo sentido da educação popular. Revista de Educação, São Paulo, v.5, n.5, p.3-6, mar. 1934.

COUTO, José. A escola e o cidadão operário. Revista de Ensino, órgão da Associação Beneficente do Professorado Público de São Paulo, ano 16, n.1-2, p.11-16, jun./set. 1917.

D'ÁVILA, Antonio. Um livro que comoveu o mundo. Educą̧ão, órgão do Departamento de Educação de São Paulo, v.35, n.50/52, p.142-143, 1946.

O ENSINO primário e as municipalidades. Mogi Mirim: estabelece a obrigatoriedade do ensino primário. Revista de Ensino, órgão da Associação Beneficente do Professorado Público de São Paulo, ano 17, n.3/4, p.1-3, dez. 1917/mar. 1918.

[FIGUEIREDO, Afonso Celso de Assis, Visconde de Ouro Preto]. Em que condiçôes pode-se instituir no Brasil o ensino obrigatório? Revista do Instituto Histórico e Geográfico Brasileiro, Rio de Janeiro, t.103, v.157, p.258-272, 1924. Transcrição.

LOURENÇO FILHO, Manoel Bergström. O ensino no Ceará: resumo geral de estatística de 1922. Revista Nacional, São Paulo, ano 2, n.7, p.470-475, jul. 1923.

. A uniformizaçáo do ensino primário no Brasil. Educação, órgão da Diretoria Geral da Instrução Pública e da Sociedade de Educação, de São Paulo, v.2, n.1, p.9-18, jan. 1928.

. Estatística e educação. Revista Brasileira de Estatística, Rio de Janeiro, ano 1, n.1, p.66-85, jan./mar. 1940. 
MAGALHÃES, Fernando. Centenário da organização do ensino primário no Brasil. Revista da Academia Brasileira de Letras, Rio de Janeiro, ano 18, v.25, nov. p.293-298, 1927.

MELLO, Maria de Jesus. A educaçáo cívica e as festas escolares. Revista Nacional, São Paulo, v.2, n.7, p.448, jul. 1923b.

MENNUCCI, Sud. Discurso pronunciado na cerimônia de colaçáo de grau das primeiras professoras ruralistas do Brasil -, turma de 1937, na Escola Normal Rural de Juazeiro, do Ceará, pelo Prof. Sud Mennucci. Educação, Boletim do Departamento de Educaçáo, São Paulo. v.31, p.3-11, jan./jun. 1944a. Impressa em 1945.

MORAES, Deodato. Rumo ao campo. CONFERÊNCIA NACIONAL DE EDUCAÇÃO, 1a.., Curitiba. Anais... Brasília: Inep, 1997 [1927], p.194-196).

MOREIRA DE AZEVEDO, Manuel Duarte. A instrução pública nos tempos coloniais do Brasil. Revista do Instituto Histórico e Geográfico Brasileiro, Rio de Janeiro, v.55, pt.2, p.141-158, 1892.

NOTAS sobre o finado Barão de Macaúbas. Revista do Instituto Histórico e Geográfico Brasileiro, Rio de Janeiro, v.55, pt.2, p.79-86, 1892.

A OBRIGATORIEDADE do ensino. A Câmara de Atibaia acaba de decretar o ensino obrigatório no seu município. Revista de Ensino, órgão da Associação Beneficente do Professorado Público de Sáo Paulo, ano 15, n.4, p.3-5, mar. 1917.

A REFORMA da Constituição e a educação. Revista da Academia Brasileira de Letras, Rio de Janeiro, ano 16, v.19, n.46, p.159-160, out. 1925.

SILVA, Alfredo do Nascimento. Um átomo de história pátria. Histórico da Sociedade Amante da Instrução. Revista do Instituto Histórico e Geográfico Brasileiro, Rio de Janeiro, v.55, pt.2, p.97-136, 1892.

SILVEIRA, Carlos da. Culto cívico. Conferência realizada no Politeama de Araraquara, no dia 7 de setembro de 1918, por incumbência da Liga Nacionalista. Revista da Escola Normal de S. Carlos, São Carlos, ano 4, n.7, p.3-17, dez. 1919.

TEIXEIRA, José Bruno. Educação rural. In: CONGRESSO BRASILEIRO DE EDUCAÇÃO, 8., 1942, Goiânia. Anais... Rio de Janeiro: IBGE, 1944, p.15.

TEIXEIRA DE FREITAS, Mario Augusto. Dispersão demográfica e escolaridade. Revista Brasileira de Estatística, Rio de Janeiro, v.1, n.3, p.497-527, jul./set. 1940.

. O batismo cultural de Goiânia. Revista Brasileira de Estatística, Rio de Janeiro, v.3, n.10, p.379-382, 1942.

VENANCIO FILHO, Francisco. A evolução da educação no Brasil. Formação, Rio de Janeiro, v.3, n.23, p.21-53, jun. 1940. 
VENCIMENTOS do professor primário. Revista Brasileira de Estatística, Rio de Janeiro, ano 3, n.11, p.476-477, jul./set. 1942.

\section{VII) Circulares do Apostolado Positivista}

LEMOS, Miguel; TEIXEIRA MENDES, Raimundo. A obrigatoriedade e 0 novo projeto de reforma da instrução pública. Rio de Janeiro: E. R. da Costa, 1886.

. Contra o ensino obrigatório. Rio de Janeiro: Igreja do Apostolado Positivista do Brasil, 1902.

- Ainda contra o ensino obrigatório, a propósito do projeto apresentado ao conselho municipal desta cidade estabelecendo o ensino primário obrigatório. Rio de Janeiro: Igreja Positivista do Brasil, 1908.

\section{VIII) Comunicações em anais de congressos}

COSTA, Manoel Olímpio Rodrigues da. Métodos e programas de ensino nas escolas primárias. Adoção de compêndios. In: ATAS e pareceres do Congresso de Instrução Pública do Rio de Janeiro. Rio de Janeiro: Tipografia Nacional, 1884, p.1-5.

GARCIA, José Manoel. 5a questão: das escolas primárias, disciplinas que devem ser ensinadas, material escolar. Parecer do Dr. José Manoel Garcia. In: ATAS e pareceres do Congresso de Instruçáo Pública do Rio de Janeiro. Rio de Janeiro: Tipografia Nacional, 1884a , p.2-8.

. Métodos e programas de ensino nas escolas primárias. Adoção de compêndios. In: CARVALHO, Carlos Leôncio de. Primeira Exposição Pedagógica do Rio de Janeiro. Rio de Janeiro: Tipografia Nacional, 1884b, p.1-10.

MAGALHÃES, Benjamim Constant Botelho de. Escolas Normais. Sua organização, plano de estudo, métodos e programas de ensino. In: ATAS e pareceres do Congresso de Instruçáo do Rio de Janeiro. Rio de Janeiro: Tipografia Nacional, 1884 , p.1-5.

MENNUCCI, Sud. O professor primário das zonas rurais: formação, aperfeiçoamento, remuneração e assistência. In: CONGRESSO BRASILEIRO DE EDUCAÇÃO, 8., 1942, Goiânia. Anais... Rio de Janeiro: IBGE, 1944b, p.290-300. 
OLIVEIRA, Maria Aparecida. O professor primário das zonas rurais. In: CONGRESSO BRASILEIRO DE EDUCAÇÃO, 8., 1942, Goiânia. Anais... Rio de Janeiro: IBGE, 1944, p.359-364.

SOUSA, Joaquim Moreira de. Memória sobre as humildes origens da Escola Normal Rural do Juazeiro no Ceará. In: CONGRESSO BRASILEIRO DE EDUCAÇÃO, 8., 1942, Goiânia. Anais... Rio de Janeiro: IBGE, 1944, p.613-626.

\section{IX) Cartilhas, compêndios, manuais}

ALMEIDA, Júlia Lopes de. Histórias de nossa terra. Rio de Janeiro: Francisco Alves, 1907.

. A nossa bandeira. In: . Histórias de nossa terra. Rio de Janeiro: Francisco Alves, 1907, p.4-10.

BARROSO, Alfredo. Getúlio Vargas para crianças. Rio de Janeiro: Empresa de Publicações Infantis, 1942.

BOMFIM, Manoel; BILAC, Olavo. Através do Brasil: leitura para o curso médio das escolas primárias. Rio de Janeiro: Francisco Alves, 1910.

BILAC, Olavo; COELHO NETO. Contos pátrios (para crianças). Rio de Janeiro: Francisco Alves, 1904.

BULCÃO, Mario. Rumo ao campo. 32ed. São Paulo: Ed. Benjamim Costallat \& Miccolis, 1925.

CALKINS, N. A. Primeiras liçôes de coisas: manual de ensino elementar para uso dos pais e professores. Vertido da 40ed. e adaptado às condições do nosso idioma e países que o falam pelo conselheiro Ruy Barbosa. Rio de Janeiro: Imprensa Nacional, 1886.

[FIGUEIREDO, Afonso Celso de Assis]. Porque me ufano do meu país. Rio de Janeiro: Laemert \& C. Livreiros - Editores, 1901.

COELHO NETO; BILAC, Olavo. A terra fluminense (educação cívica). Rio de Janeiro: Imprensa Nacional, 1898.

FRANKLIN, Benjamin. A ciência do bom homem Ricardo ou meios de fazer fortuna. Lisboa:Tipografia da Sociedade Propagadora dos Conhecimentos Uteis, 1825.

LEPRINCE DE BEAUMONT, Jeanne Marie. Tesouro de meninas, ou, diálogos entre uma sábia aia e suas discipulas. Tradução de Joaquim Ignácio de Frias. Lisboa: Tipografia de José Batista Morando, 1846, $2 \mathrm{v}$. 
LISBOA, José da Silva. Cartilha da escola brasileira para instrução elementar na Religião do Brasil. Rio de Janeiro: Tipografia Nacional, 1831.

. [Visconde de Cairu]. Escola brasileira ou instrução útil a todas as classes extraida da Sagrada Escritura para uso da mocidade. Rio de Janeiro: Tipografia de P. Plancher-Seignot, 1827, v.1.

MORAES, Theodoro de. Cartilha do operário. 2ed. São Paulo:Tipografia Siqueira, 1924.

OTÁVIO, Rodrigo. Festas nacionais. Rio de Janeiro: Francisco Alves, 1893.

PEIXOTO, Afrânio. Minha terra, minha gente. Rio de Janeiro: Francisco Alves, 1916.

RIBEIRO, Hilário. Geografia da Provincia do Rio Grande do Sul adaptada às classes elementares adornada com mapas coloridos. Pelotas: Editores, Carlos Pinto \& Comp., 1880.

. Cartilha nacional ou novo primeiro livro de leitura. 9ed. Rio de Janeiro:

Livraria Francisco Alves, 1887.

ROMERO, Sílvio. A história do Brasil ensinada pela biografia dos seus heróis. 2ed. corr. e aum. Prefácio e vocabulário João Ribeiro. Rio de Janeiro: Livraria Clássica de Alves \& Cia, 1892.

SAFFRAY. Lições de coisas. Traduzido da última edição francesa para uso das classes de instrução primária por M. C. Mesquita Portugal. Porto: Livraria Chardron; Rio de Janeiro: Livraria Alves, 1881.

\section{X) Narrativas de viagens, literatura, biografias}

ALVES, Isaías. Esboço da vida e obras do amigo dos meninos. Bahia: Imprensa Oficial do Estado, 1924.

ESCOLA NORMAL PRIMÁRIA. A Caetano de Campos no $48^{\circ}$ aniversário de seu falecimento. Homenagem da Biblioteca "Caetano de Campos". [S.l: s.n.], 1938.

FRAGA, Clementino. Médicos educadores: Carneiro Ribeiro, Francisco de Castro, Oswaldo Cruz, Pacífico Pereira, Azevedo Sodré, Miguel Couto. Rio de Janeiro: Ed. A Noite, 1941.

GIESBRECHT, Ralph Mennucci. Sud Mennucci: memórias de Piracicaba, Porto Ferreira, São Paulo. São Paulo: Imprensa Oficial, 1997. 
IBGE. Bulhões Carvalho, um médico cuidando da estatística brasileira. Rio de Janeiro: IBGE, 2007.

MARTINHO FILHO, Ferdinando. Professores anônimos. Romance social. São Paulo: Livraria Francisco Alves, 1943.

MEDEIROS E ALBUQUERQUE. Minha vida: memórias. 2. ed. Rio de Janeiro: Calvino Filho, editor, 1933 (1867-1893,v.1).

MOTTA, Cássio. Cesário Motta e seu tempo. São Paulo: Indústria Gráfica João Bentivegne, 1947.

NAVARRO, Moacyr. Miguel Couto vivo. Rio de Janeiro: Edições “A Noite”, 1947.

RIBEIRO, Leonidio. Afrânio Peixoto. Rio de Janeiro: Edições “Conde”, 1950.

RODRIGUES, João Lourenço. Escorço biográfico do professor Gabriel Prestes. O Estado de S. Paulo, São Paulo, p.5, 9 set. 1945; p.5, 14 set. 1945; p.5, 28 set. 1945; p.5, 2 out. 1945; 2 out. 1945; p.5, 11 out. 1945.

ROMERO, Sílvio. Novos estudos de literatura contemporânea. Rio de Janeiro: Garnier, Livreiro-Editor, 1898.

TEIXEIRA, Múcio. Novos ideais: poesias. Introdução de Sílvio Romero. Rio de Janeiro: Tipografia Nacional, 1880.

TEIXEIRA MENDES, Raimundo. Benjamin Constant: esboço de uma apreciação sintética da vida e da obra do fundador da república brasileira. Rio de Janeiro: Imprensa Nacional, 1937.

VERÍSSIMO,José. Cenas da vida amazônica: com um estudo sobre as populações indígenas e mestiças da Amazônia. Lisboa: Tavares Cardoso \& Irmão, 1886.

VERÍSSIMO, Ignácio José. José Veríssimo visto por dentro. Prefácio de Arthur Cezar Ferreira Reis. Manaus: Governo do Estado do Amazonas, 1966 (Série Raimundo Monteiro, v.8).

WALSH, Robert. Notícias do Brasil. Belo Horizonte: Itatiaia; São Paulo: Edusp, 1985. [1830] v.2. (Coleção reconquista do Brasil, v.75).

\section{Bibliografia}

\section{I) Livros, capítulos de livros, opúsculos \& correlatos}

ALONSO, Ângela. Ideias em movimento: a geração 1870 na crise do Brasil-Império. São Paulo: Paz e Terra, 2002. 
ANDERSON, Benedict. Comunidades imaginadas: reflexiones sobre el origen y la difusión del nacionalismo. Traducción Eduardo L. Suarez. México: Fondo de Cultura Económica, 2007.

. Nação e consciência nacional. Tradução de Lólio Lourenço de Oliveira. São Paulo: Ática, 1991 (Temas políticos, v.9).

ARAÚJO, José Carlos; FREITAS, Anamaria Gonçalves Bueno de; LOPES, Antonio de Pádua Carvalho (Org.). As escolas normais no Brasil: do Império à República. Campinas, SP: Alínea, 2008.

ARENDT, Hannah. Da revolução. São Paulo: Ática; Brasília, DF: Ed. da UnB, 1988.

BANDECCHI, Brasil. Liga Nacionalista. São Paulo: Parma, 1980. (Cadernos de história, v.14).

BARBOSA LIMA SOBRINHO, Alexandre José. Presença de Alberto Torres. Sua vida e pensamento. Rio de Janeiro: Civilização Brasileira, 1968 (Retratos do Brasil, v.62).

BASILE, Marcello Otávio Neri de Campos. O império brasileiro: panorama político. In: LINHARES, Maria Yedda (Org.). História geral do Brasil. Rio de Janeiro: Campus, 2000, p.188-245.

BELLO, José Maria. História da República: primeiro período: 1889-1902. Rio de Janeiro: Civilização Brasileira, 1940.

BITTENCOURT, Agnello. Pródromos educacionais do Amazonas. Manaus: Instituto Histórico e Geográfico do Amazonas, 1981.

BOSI, Alfredo. Arqueologia do Estado-Providência: sobre um enxerto de ideias de longa duração. In: BOSI, Alfredo. Dialética da colonização. São Paulo: Companhia das Letras, 1992, p.273-307.

BOTELHO, André. Aprendizado do Brasil: a nação em busca dos seus portadores sociais. Campinas, SP: Ed. da Unicamp, 2002.

BOWEN, James. A history of Western education. London: Methuen, 1986 (The modern West Europe and the New World, v.3).

BRAGANÇA, Aníbal. A política editorial de Francisco Alves e a profissionalização do escritor no Brasil. In: ABREU, Márcia (Org.). Leitura, história e história da leitura. Campinas, SP: Mercado de Letras-FAPESP, 2000, p.451-476.

BRESCIANNI, Stella. Forjar a identidade brasileira nos anos 1920-1940. In: HARDMAN, Francisco Foot (Org.). Morte e progresso: cultura brasileira como apagamento de rastros. São Paulo: Ed. da UNESP, 1998, p.27-61. 
BUARQUE DE HOLANDA, Sérgio. O Brasil monárquico: declínio e queda do Império. Rio de Janeiro: Bertrand Brasil, 1960 (História geral da civilização brasileira, t.2, v.4).

CARONE, Edgard. Revoluçōes do Brasil contemporâneo: (1922-1938). Rio de Janeiro: Difusão Europeia do Livro, 1977 (Corpo e alma do Brasil, v.51).

. Tenentismo: acontecimentos, personagens, programas. Rio de Janeiro: Difusão Europeia do Livro, 1975 (Corpo e alma do Brasil, v.43).

. A Primeira República (1889-1930). Rio de Janeiro: Difusão Europeia do Livro, 1976 (Corpo e alma do Brasil, v.29).

CARVALHO, José Murilo de. A involução da participação eleitoral no Brasil, 1821-1930. In: . ; CAMPOS, Adriana Pereira (Org.). Perspectivas da cidadania no Brasil Império. Rio de Janeiro: Civilização Brasileira, 2011, p.37-58.

. A vida política. In: CARVALHO, José Murilo de (Coord.). A construção nacional: 1830-1889. Rio de Janeiro: Objetiva, 2012, p.83-130. (História contemporânea do Brasil).

sileira, 2001.

Cidadania no Brasil: o longo caminho. Rio de Janeiro: Civilização Bra-

. Os bestializados. O Rio de Janeiro e a república que não foi. São Paulo: Companhia das Letras, 1987.

. Os três povos da República. In: CARVALHO, Maria Alice Resende de (Org.) República no Catete. Rio de Janeiro: Museu da República, 2002, p.61-87.

CARVALHO, Marta Maria Chagas de. Molde nacional e fôrma civica: higiene, moral e trabalho no projeto da Associação Brasileira de Educação (1924-1931). Bragança Paulista: Edusf, 1998.

CASALECCHI, José Ênio. O Partido Republicano Paulista: política e poder (1889-1926). São Paulo: Brasiliense, 1987.

CASTELO, Plácido Aderaldo. História do ensino no Ceará. Fortaleza: Departamento de Imprensa Oficial, 1970. (Coleção Instituto do Ceará. Monografia n.22).

CHAUÍ, Marilena. Brasil: mito fundador e sociedade autoritária. São Paulo: Fundação Perseu Abramo, 2000.

CRUZ COSTA, João. O desenvolvimento da filosofia no Brasil no século XIX e a evolução nacional. São Paulo: Indústria Gráfica José Magalhães, 1950.

CURY, Carlos Roberto Jamil. A educação na revisão constitucional de 1925-1926. Bragança Paulista: Edusp, 2003. 
CURY, Carlos Roberto Jamil. Cidadania republicana e educação: o Governo Provisório do marechal Deodoro e congresso constituinte de 1890-1891. Rio de Janeiro: DP\&A, 2001.

DIACON, Todd A. Rondon: o marechal da floresta. Tradução Laura Teixeira Motta. São Paulo: Companhia das Letras, 2006.

DOLHNIKOFF, Miriam. O pacto imperial: origens do federalismo no Brasil do século XIX. São Paulo: Globo, 2005.

DUBY, Georges. Historia social y ideologías de la sociedad. Buenos Aires: Anagrama, 1976.

DUSSEL, Inés; CARUSO, Marcelo. La invención del aula: una genealogía de las formas de enseñar. Buenos Aires: Alfaguara, Ediciones, 1999.

ESCOBAR, Ildefonso. Sintese histórica da formação dos Estados, Distrito Federal e Território da República dos Estados Unidos do Brasil e divisas interestaduais. Rio de Janeiro: IBGE, 1995 [1940]. (Memória institucional, n.6). Edição fac-similar de originais manuscritos.

FALCON, Francisco. História das ideias. In: CARDOSO, Ciro; VAINFAS, Ronaldo (Org.). Dominios da história: ensaios de teoria e metodologia. Rio de Janeiro: Campus, 1997, p.91-126.

FAUSTO, Boris. A Revolução de 1930: historiografia e história. São Paulo: Brasiliense, 1970.

. História do Brasil. São Paulo: Edusp, FDE, 2000 (Didática, 1). . O pensamento nacionalista autoritário. Rio de Janeiro: J. Zahar, 2001.

FERRARO, Alceu Ravanello. História inacabada do analfabetismo no Brasil. São Paulo: Cortez, 2009.

FERRAROTTI, Franco. El pensamiento sociológico de Auguste Comte a Max Horkheimer. Barcelona: Ediciones Península, 1975.

FREYRE, Gilberto. República. In: MORAIS, Rubens Borba de; BERRIEN, William (Dir.). Manual bibliográfico de estudos brasileiros. Rio de Janeiro: Record, 1949.

GELLNER, Ernest. Naciones y nacionalismo. Traducción de Javier Setó. Madrid: Alianza Editorial, 2008 (Alianza ensayo).

GIRARDET, Raoul. Mitos e mitologias politicas. Tradução Maria Lúcia Machado. São Paulo: Companhia das Letras, 1987. 
GONTARD, Maurice. Les enseignements primaire et secondaire en France de 1815 à 1945. In: MIALARET, Gaston ; VIAL, Jean (Dir.). Histoire mondiale de l'Education. Paris: PUF, 1981, p.251- 287 (de 1815 a 1945, v.3).

GUERRA, Amanda Estela. Breve histórico da configuração político-administrativa do Brasil. Evolução da divisão territorial do Brasil (1872-2010). Rio de Janeiro: IBGE, 2011.

HAIDAR, Maria de Lourdes Mariotto. O ensino secundário no Império brasileiro. São Paulo: Grijalbo-Edusp, 1972.

HÉBRARD, Jean. Três figuras de jovens leitores: alfabetização e escolarização do ponto de vista da história cultural. In: ABREU, Márcia (Org.). Leitura, história e história da leitura. Campinas, SP: Mercado de Letras, 1999, p.33-78. (História da leitura).

IGLÉSIAS, Francisco. Trajetória politica do Brasil: 1500-1964. São Paulo: Companhia das Letras, 1993.

KREUTZ, Lúcio; LUCHESE, Terciane Ângela (Org.). Imigração e educação no Brasil: histórias, práticas e processos escolares. Santa Maria: Ed. da UFSM, 2011.

KUBO, Elvira Mari. A legislação e a instrução pública de primeiras letras na $5^{a}$ Comarca da Provincia de São Paulo. Curitiba: Secretaria de Estado da Cultura e do Esporte, 1986.

LAJOLO, Marisa. Introdução. In: BILAC, Olavo; BOMFIM, Manoel. Através do Brasil. São Paulo: Companhia das Letras, 2000, p.4-9. . Usos e abusos da literatura na escola, Bilac e a literatura escolar na República Velha. Rio de Janeiro: Globo, 1982.

LEAL, Victor Nunes. Coronelismo, enxada e voto: o município e o regime representativo no Brasil. Prefácio Barbosa Lima Sobrinho. São Paulo: Alfa-Omega, 1975.

LEITE, Gervásio. Um século de instrução pública. História do ensino primário em Mato Grosso. Goiânia: Rio Bonito, 1970.

LEMOS, Renato. Benjamin Constant: vida e história. Rio de Janeiro: Topbooks, 1999.

LENHARO, Alcir. Colonização e trabalho no Brasil: Amazônia, Nordeste e Centro Oeste. Campinas, SP: Ed. da Unicamp, 1985.

1986. . Sacralização da política. Campinas, SP: Papirus; Ed. da Unicamp, 
LESAGE, Pierre. L'enseignement mutuel. In: VIAL, Jean; MIALARET, Gaston (Dir.). Histoire mondiale de l'Éducacion. Paris: PUF, 1981, p.241- 250 (de 1815 a 1945, v.3).

LESSA, Renato. A invenção republicana: Campos Sales, as bases e a decadência da Primeira República brasileira. São Paulo: Vértice; Rio de Janeiro: IUPERJ, 1988.

LIMA, A. Saboia. Alberto Torres e sua obra. São Paulo: Nacional, 1935 (Brasiliana, v.63).

LINS, Ivan. História do positivismo no Brasil. São Paulo: Nacional, 1967 (Brasiliana, v.32).

LUSTOSA, Isabel. D. Pedro I. São Paulo: Companhia das Letras, 2006.

MARCÍlIO, Humberto. História do ensino em Mato Grosso. Cuiabá: Secretaria de Educação e Cultura, 1963.

MARCÍlIO, Maria Luiza. A cidade de São Paulo: povoamento e população (1750-1850). São Paulo: Edusp, 2014.

. A população do Brasil em perspectiva histórica. In: COSTA, Iraci Del Nero da (Org.). Brasil: história econômica e demográfica. São Paulo: IPE-USP, 1986, p.11-28.

. História da escola em São Paulo e no Brasil. São Paulo: Instituto Fernand Braudel; Imprensa Oficial de São Paulo, 2005.

MARSON, Adalberto. A ideologia nacionalista de Alberto Torres. São Paulo: Duas Cidades, 1979.

MEDEIROS E ALBUQUERQUE. Hino à Proclamação da República do Brasil. Música de Leopoldo Miguez. In: FRATANTONIO, Antonio S. Hinário pedagógico. São Paulo: Irmãos Vitale, 1960.

MENDONÇA, Sonia Regina de. O ruralismo brasileiro (1888-1931). São Paulo: Hucitec, 1997 (Estudos rurais).

MENEZES, Djacir. O Brasil no pensamento brasileiro. Rio de Janeiro: Mec, Inep, 1957.

MICHELET, Jules. O povo. Tradução e notas de Paul Viallaneix. São Paulo: Martins Fontes, 1988.

MONARCHA, Carlos. A reinvenção da cidade e da multidão: dimensóes da modernidade brasileira: a Escola Nova. São Paulo: Cortez; Autores Associados, 1989.

. Escola Normal da Praça: o lado noturno das luzes. Campinas, SP: Ed. da Unicamp, 1999. (Coleção momento). 
MONARCHA, Carlos. Lourenço Filho e a Biblioteca de Educaçáo. In: MONARCHA, Carlos (Org.). Lourenço Filho: outros aspectos, mesma obra. Campinas, SP: Mercado de Letras, 1997, p.27-58.

. Cânon da reflexão ruralista no Brasil: Sud Mennucci. In: WERLE, Flávia Obino Corrêa (Org.). Educação rural em perspectiva internacional: instituições, práticas e formação do professor. Ijuí: Unijuí, 2007, p.19-52.

. Brasil arcaico, Escola Nova: ciência, técnica e utopia nos anos 20-30. São Paulo: Ed. da UNESP, 2009.

. Lourenço Filho. Brasília: Mec, Inep; Recife: Fundação Joaquim Nabuco: Massangana, 2010a (Educadores).

. Notícia documental e bibliográfica sobre as "Missóes de Professores Paulistas”. In: COSTA, Célio Juvenal; MELO, José Joaquim Pereira; FABIANO, Luiz Hermenegildo (Org.). Fontes e métodos em História da Educação. Dourados, MS: Ed. UFGD, 2010, p.243-266.

. Para o azul, para o centro, marcha para o Brasil profundo: escolarizar os vazios da nação. In: VIDAL, Diana Gonçalves; SCHWARTZ, Cleonara Maria (Org.). História das culturas escolares no Brasil. Vitória: EDUFES, 2010b, p.125156. (Horizontes da pesquisa em história da educação).

. Finisterras: Bergström Lourenço Filho sertóes adentro. Rio de Janeiro: e-papers, 2015.

MORAES FILHO, Evaristo. O ensino da filosofia no Brasil. Rio de Janeiro: Biblioteca Nacional, 1959. (Decimália da Biblioteca Nacional).

MOREIRA, João. Introdução ao estudo do curriculo da escola primária: exposição crítica das correntes de pensamento e das condições histórico-sociais que influíram na formação do currículo da escola primária, comum, tendo em vista sua repercussão no Brasil e sua influência na evolução de nosso ensino elementar. Rio de Janeiro: Inep, 1955.

MOTA, Carlos Guilherme. José Bonifácio. In: MOTA, Lourenço Dantas (Org.). Um banquete no trópico. 2. ed. São Paulo: SENAC, 1999, p.75-111.

MOTTA, Marly (Org.). Livro do Centenário da Câmara dos Deputados (18261926). Rio de Janeiro: ALERJ, 1991.

MOTTA, Marly. A nação faz 100 anos: a questáo nacional no centenário da Independência. Rio de Janeiro: Ed. FGV, 1992.

NASCIMENTO, Jorge Carvalho do. A escola de Baden-Powell: cultura escoteira, associação voluntária e escotismo de Estado no Brasil. São Paulo: Imago, 2008. 
NEVES, Lúcia Bastos Pereira das. Escolas normais. In: VAINFAS, Ronaldo (Org.) Dicionário do Brasil imperial. Rio de Janeiro: Objetiva, 2002, p.236-237.

NICOLAU, Jairo. História do voto no Brasil. Rio de Janeiro: Zahar, 2002. . Eleiçōes no Brasil: do Império aos dias atuais. Rio de Janeiro: Zahar, 2012 (Nova biblioteca de ciências sociais).

PAIVA, Vanilda Pereira. Educação popular e educação de adultos. Contribuição à história da educação brasileira. São Paulo: Loyola, 1973.

PENNA, Lincoln de Abreu. República brasileira. Rio de Janeiro: Nova Fronteira, 1999.

PRADO JÚNIOR, Caio. Formação do Brasil contemporâneo. São Paulo: Companhia das Letras, 2011.

PROST, Antoine. Doze liçôes sobre a história. Tradução de Guilherme João de Freitas Teixeira. Belo Horizonte: Autêntica, 2008 (Coleção história e historiografia).

RAZZINI, Márcia de Paula Gregório. São Paulo: cidade dos livros escolares. In: BRAGANÇA, Aníbal; ABREU, Márcia (Org.). Impresso no Brasil: dois séculos de livros brasileiro. São Paulo: Ed. Unesp, 2010, p.101-120.

REIS FILHO, Casemiro dos. A educação e a ilusão liberal. São Paulo: Cortez, 1981. (Educação contemporânea).

RÉMOND, René (Org.). Por uma história política. 2ed. Tradução Dora Rocha. Rio de Janeiro: FGV Ed., 2003.

RODRIGUES, José Honório. A Assembleia Constituinte de 1823. Petrópolis: Vozes, 1974.

SENRA, Nelson de Castro. História das estatísticas brasileiras. Rio de Janeiro: IBGE, Centro de Documentação e Disseminação de Informações, 2006 (Estatísticas legalizadas, v.2).

SEYFERTH, Giralda. Os imigrantes e a política de nacionalização do Estado Novo. In: PANDOLFI, Dulce (Org.). Repensando o Estado Novo. Rio de Janeiro: Editora FGV, 1999, p.257-288.

SOUZA, José Boaventura de. Escola Normal Rural de Juazeiro do Norte: uma experiência pioneira. Juazeiro do Norte: Edições IPESC, 1994.

TAMBARA, Elomar. Positivismo e educação: a educação no Rio Grande do Sul sob o Castilhismo. Pelotas: Ed. UFPEL, 1995. 
TANURI, Leonor Maria. O ensino normal no Estado de São Paulo: 1889-1930. São Paulo: Faculdade de Educação da Universidade de São Paulo, 1979 (Estudos e documentos, v.16).

VERDENAL, René. A filosofia positiva de Auguste Comte. In: CHÂTELET, François (Dir.). A filosofia de Kant a Hussel. Tradução Alexandre Pomar e outros. Lisboa: Publicações Dom Quixote, 1981, p.95-182.

VEYNE, Paul. Como se escreve a história. Tradução de Antônio José da Silva Moreira. Lisboa: Edições 70, 1971.

VIANA, Hélio. História das fronteiras do Brasil. Rio de Janeiro: Edição da Biblioteca Militar, 1948.

VIDAL E SOUZA, Candice. Batismo cultural de Goiânia: um ritual da nacionalidade em tempos de Marcha para o Oeste. In: BOTELHO, Tarcisio Rodrigues (Org.). Goiânia: cidade pensada. Goiânia: Ed. UFG, 2002, p.71-102.

VOVELLE, Michel. Ideologias e mentalidades. 2ed. Tradução Maria Julia Cottvasser. São Paulo: Brasiliense, 1991.

\section{Dissertações e teses}

CARTOLANO, Maria Teresa Penteado. Benjamin Constant e a instrução pública no inicio da República. Campinas, SP, 1994. Tese (Doutorado em Educação) Faculdade de Educação da Universidade Estadual de Campinas.

CHIZZOTTI, Antonio. As origens da instrução pública no Brasil: análise interpretativa da legislação pública nas origens de sua constituição, seus pressupostos e as indicações para a filosofia da educação. São Paulo, 1975. Dissertação (Mestrado em Educação) - Pontifícia Universidade Católica de São Paulo.

CORREA, Carlos Humberto Alves. Circuito do livro escolar: elementos para a compreensáo de seu funcionamento no contexto educacional amazonense 18521910. Campinas, SP, 2006. Tese (Doutorado em Educação) - Faculdade de Educação da Universidade Estadual de Campinas.

ESTERCI, Neide. Mito da democracia no país das bandeiras: análise dos discursos sobre colonização e migraçáo no Estado Novo. Rio de Janeiro, 1972. Dissertação (Mestrado em Antropologia Social) - Universidade Federal do Rio de Janeiro.

HANSEN, Patrícia Santos. Brasil um país novo: literatura cívico-pedagógica e a construção de um ideal de infância brasileira na Primeira República. 2007. Tese (Doutorado em História Social) - Faculdade de Filosofia e Ciências Humanas da Universidade de São Paulo, São Paulo, 2007. 
NAGLE, Jorge. Educação e sociedade no Brasil: 1920-1929. Araraquara, 1966, 2v. Tese (Livre-docência) - Faculdade de Ciências e Letras, Araraquara.

NEVES, Fátima Maria. O método lancasteriano e o processo de formação disciplinar do povo (São Paulo, 1808-1889). Assis, 2003. Tese (Doutorado em História) Faculdade de Ciências e Letras, Universidade Estadual Paulista "Júlio de Mesquita Filho", campus de Assis.

NOFUENTES, Vanessa Carvalho. Um desafio do tamanho da Nação: a campanha da Liga Brasileira Contra o Analfabetismo (1915-1922). Rio de Janeiro, 2008. Mestrado (Dissertação em História Social da Cultura) - Pontifícia Universidade Católica do Rio de Janeiro, 2008.

OLIVEIRA, Tiago Siqueira de. A Liga da Defesa Nacional: um projeto de modernização para o Brasil. Marília, 2012. Dissertação (Mestrado em Ciências Sociais) - Faculdade de Filosofia e Ciências, Universidade Estadual Paulista "Júlio de Mesquita Filho", campus de Marília.

SOUSA, Clotildes Farias de. Por uma pátria de luz, espirito e energia: a campanha da Liga Sergipense contra o Analfabetismo (1916-1950). Sergipe, 2004. Dissertação (Mestrado em Educação) - Universidade Federal de Sergipe.

VILLELA, Heloísa O. S. A primeira escola normal no Brasil: uma contribuição à história da formação de professores. Niterói, 1990. Dissertaçáo (Mestrado em Educação) - Universidade Federal Fluminense.

\section{III - Artigos em periódicos}

ALMEIDA, Rui Guimarães de. A política de educação de Alberto Torres. Revista Brasileira de Estudos Pedagógicos, Brasília, DF, v.2, n.5, p.212-220, nov. 1963.

AURAS, Gladys Mary Teive. O professor paulista Orestes Guimarães e a modernização da instrução pública catarinense (1911-1918). Cadernos de História da Educação, p.107-120, n.6, jan./dez. 2007

BASTOS, Maria Helena Camara. Método intuitivo e liçôes de coisas por Ferdinand Buisson. História da Educação, Pelotas, v.17, n.37, jan./abr. 2013.

CHOPPIN, Alain. História dos livros e das ediçôes didáticas: sobre o estado da arte. Educação e Pesquisa, São Paulo, v.30, n.3, p.549-566, set./dez. 2004.

COLLICHIO, Terezinha A. Ferreira. Dois eventos importantes para a história da educação brasileira: a Exposição: a Exposição Pedagógica de 1883 e as Conferências Populares da Freguesia da Glória. Revista da Faculdade de Educaçāo, São Paulo, v.13, n.2 p.5-14, 1987. 
GUERRA, Amanda Estela; SANTOS, Márcia Maria Duarte dos. O Atlas do Império do Brasil: uma proposta de definição dos limites do Brasil no século XIX. In: SIMPÓSIO LUSO-BRASILEIRO DE CARTOGRAFIA HISTÓRICA, 4., 2011, Porto. Anais... Porto: Faculdade de Letras, Universidade do Porto, 2011. Trabalho 28.

MONARCHA, Carlos. Convocando os hermeneutas da República iletrada: o Prêmio Francisco Alves. História da Educação, Pelotas, v.18, n.44, p.149-164, set./dez. 2014.

PECHMAN, Sérgio; FRITSCH, Lílian. A reforma urbana e seu avesso: algumas consideraçóes a propósito da modernização do Distrito Federal na virada do século. Revista Brasileira de História, São Paulo, v.5, n.8/9, p.1391-1196, set. 1984/ abr. 1985 .

PESAVENTO, Sandra Jatahy. Imagens da nação, do progresso e da tecnologia: a Exposição Universal de Filadélfia de 1876. Anais do Museu Paulista: história e cultura material, São Paulo, v.2, n.1, p.151-168, 1994.

ROCHA, Marlos Bessa Mendes da. O ensino elementar no decreto Leôncio de Carvalho: visão de mundo herdada pelo tempo republicano? Revista Brasileira de Educação, Rio de Janeiro, v.15, n.43, p.125-147, jan./abr. 2010.

TRINDADE, Iole Maria Faviero. A Cartilha Maternal e algumas marcas de sua aculturação. Revista Brasileira de História da Educação, Campinas, SP, n.7, p.109134, jan./jun. 2004.

VECHIA, Ariclê. O plano de estudos das escolas públicas elementares na Província do Paraná. Revista Brasileira de História da Educação, Campinas, SP, n.7, p.160, jan./jun. 2004.

VIVEIROS, Jerônimo José de. Apontamentos para a história da instrução pública e particular do Maranhão. Revista Brasileira de Estudos Pedagógicos, Rio de Janeiro, v.17, n.45, p.29-84, jan./mar. 1952.

\section{IV - Obras de referência}

A CIÊNCIA a caminho da roça: imagens das expediçóes científicas do Instituto Oswaldo Cruz ao interior do Brasil entre 1911 e 1913. Rio de Janeiro: Casa de Oswaldo Cruz: Ed. Fiocruz, 1991.

BELLO, Ruy. Subsidios para a história da educação em Pernambuco. Recife: Secretaria de Educação e Cultura, 1978.

BRETAS, G. F. História da instrução pública em Goiás. Goiânia: CEGRAF, UFG, 1991. 
BRIQUET, Raul. Educação (De 1500 a 1889) - Brasil colônia - Brasil Reino Brasil Império. In: MORAIS, Rubens Borba de; BERRIEN, William (Dir.). $M a-$ nual bibliográfico de estudos brasileiros. Rio de Janeiro: Record, 1949, p.238-250.

BRIQUET, Raul. História da educação: evolução do pensamento educacional. São Paulo: Renascença, 1946.

CHAIA, Josefina. A educação brasileira: índice sistemático da legislação 1808 a 1889. Marília: Faculdade de Filosofia, Ciências e Letras, 1963, 3v. (Coleçấo de boletins).

ESCOBAR, José Ribeiro. Histórico da instrução pública paulista feito para o Anuário do Ministério da Educação. Revista de Educação, São Paulo, v.3, p.158190, set. 1933.

FISCHER, Jango. Índice alfabético do dicionário bibliográfico brasileiro de Sacramento Blake. Rio de Janeiro: Imprensa Nacional, 1937.

HANDBOOK of Latin American Studies. Cambridge: Harvard University Press; Gainesville: Florida University Press; Texas: University of Texas Press Austin and London, 1935-1970.

INEP. Bibliografia sumária da história da educação no Brasil. Revista Brasileira de Estudos Pedagógicos, Rio de Janeiro, v.33, n.77, p.158-168, out./dez. 1959.

LOURENÇO FILHO, Manoel Bergström. Bibliografia pedagógica brasileira (1812 a 1900). Revista Brasileira de Estudos Pedagógicos, Rio de Janeiro, v.1, p.100-123, 1944.

.Educação (de 1889 a 1941): Brasil República. In: MORAES, Rubens Borba de; BERRIEN, William (Dir.). Manual bibliográfico de estudos brasileiros. Rio de Janeiro: Record, 1949, p.238-250.

MELLO, Mário. A instrução em Pernambuco. Revista Nacional, São Paulo, n.12, p.788-790, dez. 1923a.

MELO, Luís Correia de. Dicionário de autores paulistas. São Paulo: [s.n.], 1954. (Comissão do IV centenário da cidade de São Paulo).

OLIVEIRA, M. Santos. História da instrução pública. In: DICIONÁRIO histórico, geográfico e etnográfico. Rio de Janeiro: IHGB, 1922, t.1, p.373382.

PERES, Eliane; TAMBARA, Elomar. Livros escolares e ensino da leitura e da escrita no Brasil (séculos XIX-XX). Pelotas: Seiva, 2003.

PILOTO, Erasmo. A educaşão no Paraná: síntese sobre o ensino público elementar e médio. Rio de Janeiro: INEP, 1954 (Publicação 3). 
SACRAMENTO BLAKE, Augusto Vitorino Alves. Dicionário bibliográfico brasileiro. Rio de Janeiro: Tipografia Nacional, 1883-1902, 7v.

SANTOS, Wanderley Guilherme dos. Roteiro bibliográfico do pensamento politico-social brasileiro: 1870-1965. Belo Horizonte: Ed. UFMG; Rio de Janeiro: Casa de Oswaldo Cruz, 2002. Origem.

TAMBARA, Elomar. Bosquejo de um ostensor do repertório de textos escolares utilizados no ensino primário e secundário no século XIX no Brasil. Pelotas: Seiva Publicações, 2003.

VENANCIO FILHO, Francisco. Fontes para a história da educação no Brasil. Revista Brasileira de Estudos Pedagógicos, Rio de Janeiro, v.5, p.369-374, set. 1945.

VILAR, Pierre. Iniciação ao vocabulário da análise histórica. Tradução José Pecegueiro. Revisão João Serra. Lisboa: Edições João Sá da Costa, 1985. 



\section{Instituições consultadas}

Arquivo Nacional (RJ)

Arquivo Público do Estado de São Paulo

Associação Brasileira de Educação (RJ)

Biblioteca do Instituto Histórico e Geográfico de São Paulo

Biblioteca Brasiliana Guita e José Mindlin (USP)

Biblioteca "Mario de Andrade" - Seção de Obras Raras e Seção de Hemeroteca - (SP)

Biblioteca "Nadir Gouvêa Kfouri” - Pontifícia Universidade Católica de São Paulo

Biblioteca da Faculdade de Direito (USP)

Biblioteca do Museu Paulista (USP)

Biblioteca Central da Unicamp

Biblioteca Nacional - Acervo Geral, Seção de Obras Raras - (RJ)

Casa de Oswaldo Cruz (Fiocruz, RJ)

Instituto Brasileiro de Geografia e Estatística (RJ)

Instituto de Estudos Brasileiros (USP)

Biblioteca da Faculdade de Ciências e Letras - Unesp-Araraquara. 

Apêndice A - Outras tabelas 

Tabela A - Número de professores por 10.000 habitantes livres - 1872

\begin{tabular}{|c|c|c|c|}
\hline Provivíncias & Habitantes livres & Professores & $\%$ \\
\hline Alagoas & 312.268 & 226 & 7,2 \\
\hline Amazonas & 56.631 & 33 & 5,8 \\
\hline Bahia & 1.211 .792 & 771 & 6,4 \\
\hline Ceará & 689.773 & 426 & 6,2 \\
\hline Espírito Santo & 59.478 & 94 & 15,8 \\
\hline Goiás & 149.743 & 179 & 12,0 \\
\hline Maranhão & 284.101 & 258 & 9,1 \\
\hline Mato Grosso & 45.851 & 19 & 4,1 \\
\hline Minas Gerais & 1.669 .276 & 1.453 & 8,6 \\
\hline Pará & 247.779 & 301 & 12,1 \\
\hline Paraíba & 354.700 & 183 & 5,2 \\
\hline Paraná & 116.162 & 106 & 9,1 \\
\hline Pernambuco & 746.753 & 526 & 7,0 \\
\hline Piauí & 178.427 & 101 & 5,7 \\
\hline Rio de Janeiro & 716.120 & 1.701 & 23,8 \\
\hline $\begin{array}{l}\text { Rio Grande } \\
\text { do Norte }\end{array}$ & 220.959 & 104 & 4,7 \\
\hline $\begin{array}{l}\text { Rio Grande } \\
\text { do Sul }\end{array}$ & 367.022 & 559 & 15,2 \\
\hline Santa Catarina & 144.818 & 168 & 11,6 \\
\hline São Paulo & 680.742 & 870 & 12,8 \\
\hline Sergipe & 153.620 & 127 & 8,3 \\
\hline
\end{tabular}

Fonte: Diretoria Geral de Estatística. Relatório dos trabalhos estatísticos apresentado $\mathrm{Ilm}^{\circ}$ Exm $^{\circ}$ Sr. Conselheiro Dr. José Bento da Cunha Figueiredo, Ministro e Secretário de Estado dos Negócios do Império pelo Diretor Geral conselheiro Manoel Francisco Correia em 31 de dezembro de 1876. Rio de Janeiro: Tipografia de Hipólito José Pinto, 1877. 
Tabela B - Porcentagem da população livre que sabe ler e escrever - 1872

\begin{tabular}{|c|c|c|c|c|}
\hline Províncias & População total & $\begin{array}{c}\text { Habitantes } \\
\text { livres }\end{array}$ & Instruídos & $\%$ \\
\hline Alagoas & 348.009 & 312.268 & 41.860 & 13,4 \\
\hline Amazonas & 57.610 & 56.631 & 7.613 & 13,4 \\
\hline Bahia & 1.379 .616 & 1.211 .792 & 249.072 & 20,6 \\
\hline Ceará & 721.686 & 689.773 & 79.560 & 11,5 \\
\hline Espírito Santo & 82.137 & 59.478 & 9.732 & 16,4 \\
\hline Goiás & 160.395 & 149.743 & 22.656 & 15,1 \\
\hline Maranhão & 359.040 & 284.101 & 68.571 & 24,1 \\
\hline Mato Grosso & 51.745 & 45.851 & 9.721 & 21,2 \\
\hline Minas Gerais & 2.039 .735 & 1.669 .276 & 224.539 & 13,5 \\
\hline Pará & 275.237 & 247.779 & 60.395 & 24,4 \\
\hline Paraíba & 376.226 & 354.700 & 41.212 & 11,6 \\
\hline Paraná & 126.722 & 116.162 & 31.816 & 27,4 \\
\hline Pernambuco & 834.314 & 746.753 & 146.663 & 19,6 \\
\hline Piauí & 202.222 & 178.427 & 27.770 & 15,6 \\
\hline Rio de Janeiro & 1.057 .696 & 716.120 & 213.756 & 29,8 \\
\hline $\begin{array}{l}\text { R. G. do } \\
\text { Norte }\end{array}$ & 233.979 & 220.959 & 39.822 & 18,0 \\
\hline $\begin{array}{l}\text { Rio Grande } \\
\text { do Sul }\end{array}$ & 434.813 & 367.022 & 95.303 & 26,0 \\
\hline $\begin{array}{l}\text { Santa } \\
\text { Catarina }\end{array}$ & 159.802 & 144.818 & 21.926 & 15,1 \\
\hline São Paulo & 837.354 & 680.742 & 141.067 & 20,7 \\
\hline Sergipe & 176.243 & 153.620 & 29.138 & 19,0 \\
\hline
\end{tabular}

Fonte: Diretoria Geral de Estatística. Relatório dos trabalhos estatísticos apresentado ao $\mathrm{Ilm}^{\circ} \mathrm{Exm}^{\circ}$ Sr. Conselheiro Dr. José Bento da Cunha Figueiredo, Ministro e Secretário de Estado dos Negócios do Império pelo Diretor Geral conselheiro Manoel Francisco Correia em 31 de dezembro de 1876. Rio de Janeiro: Tipografia de Hipólito José Pinto, 1877. 


\begin{tabular}{|c|c|c|c|c|c|c|c|c|c|c|c|}
\hline & 坖 & 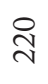 & $\stackrel{\ddot{n}}{\sim}$ & 슨 & $\frac{\dot{d}}{m}$ & nू & $\lesssim$ & $\ddot{m}$ & $\infty$ & $\begin{array}{l}\text { ro } \\
\text { nె } \\
\text { ri }\end{array}$ & $\stackrel{\infty}{\underset{N}{N}}$ \\
\hline & 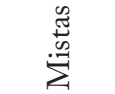 & 1 & I & $\hat{ᄋ}$ & $\underset{-}{\bullet}$ & I & ข & $\tilde{m}$ & 1 & $\stackrel{0}{N}$ & $\hat{n}$ \\
\hline & 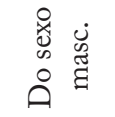 & 1 & 1 & 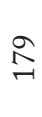 & $\stackrel{n}{\wedge}$ & 1 & $\stackrel{\infty}{\sim}$ & 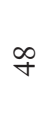 & 1 & กิ & L \\
\hline & 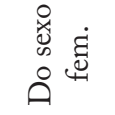 & 1 & 1 & $\stackrel{\infty}{\infty}$ & $\Re$ & 1 & $\stackrel{\infty}{\sim}$ & กิ & 1 & 守 & 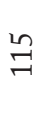 \\
\hline & శ్ & $v$ & $v$ & $\widetilde{N}$ & $\neg$ & $\sim$ & 1 & $\nabla$ & $m$ & $\approx$ & $\widehat{\sim}$ \\
\hline & 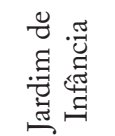 & 1 & 1 & 1 & 1 & 1 & 1 & 1 & 1 & 1 & 1 \\
\hline : & 总总 & $v$ & 1 & -1 & $\neg$ & -1 & 1 & $m$ & 1 & $\approx$ & $\widehat{N}$ \\
\hline 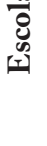 & 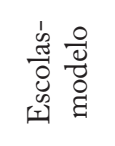 & 1 & 1 & 1 & 1 & - & 1 & - & 1 & 1 & 1 \\
\hline & 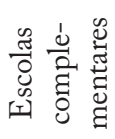 & 1 & $\sim$ & $\vec{\sim}$ & 1 & 1 & 1 & 1 & $m$ & 1 & 1 \\
\hline 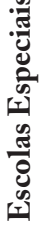 & 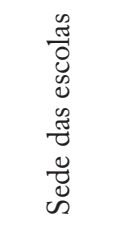 & $\begin{array}{l}\mathscr{8} \\
\stackrel{0}{0} \\
\stackrel{\Xi}{Z}\end{array}$ & 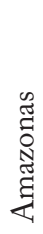 & $\frac{\stackrel{\widetilde{J}}{\mathcal{J}}}{\text { صै }}$ & 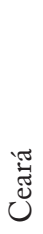 & 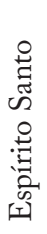 & 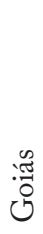 & 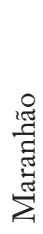 & 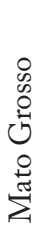 & 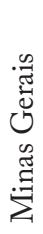 & 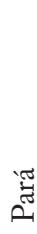 \\
\hline
\end{tabular}




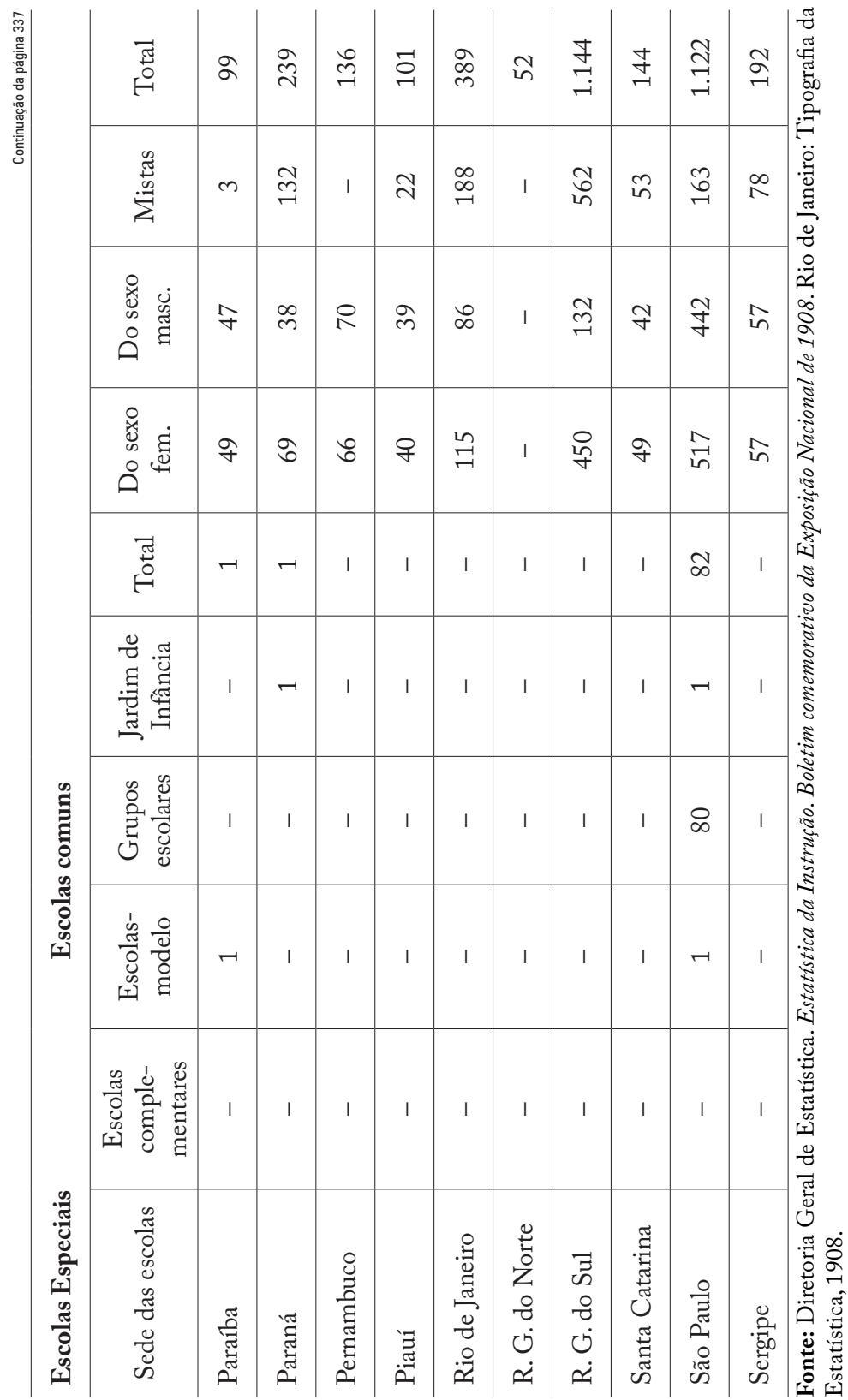




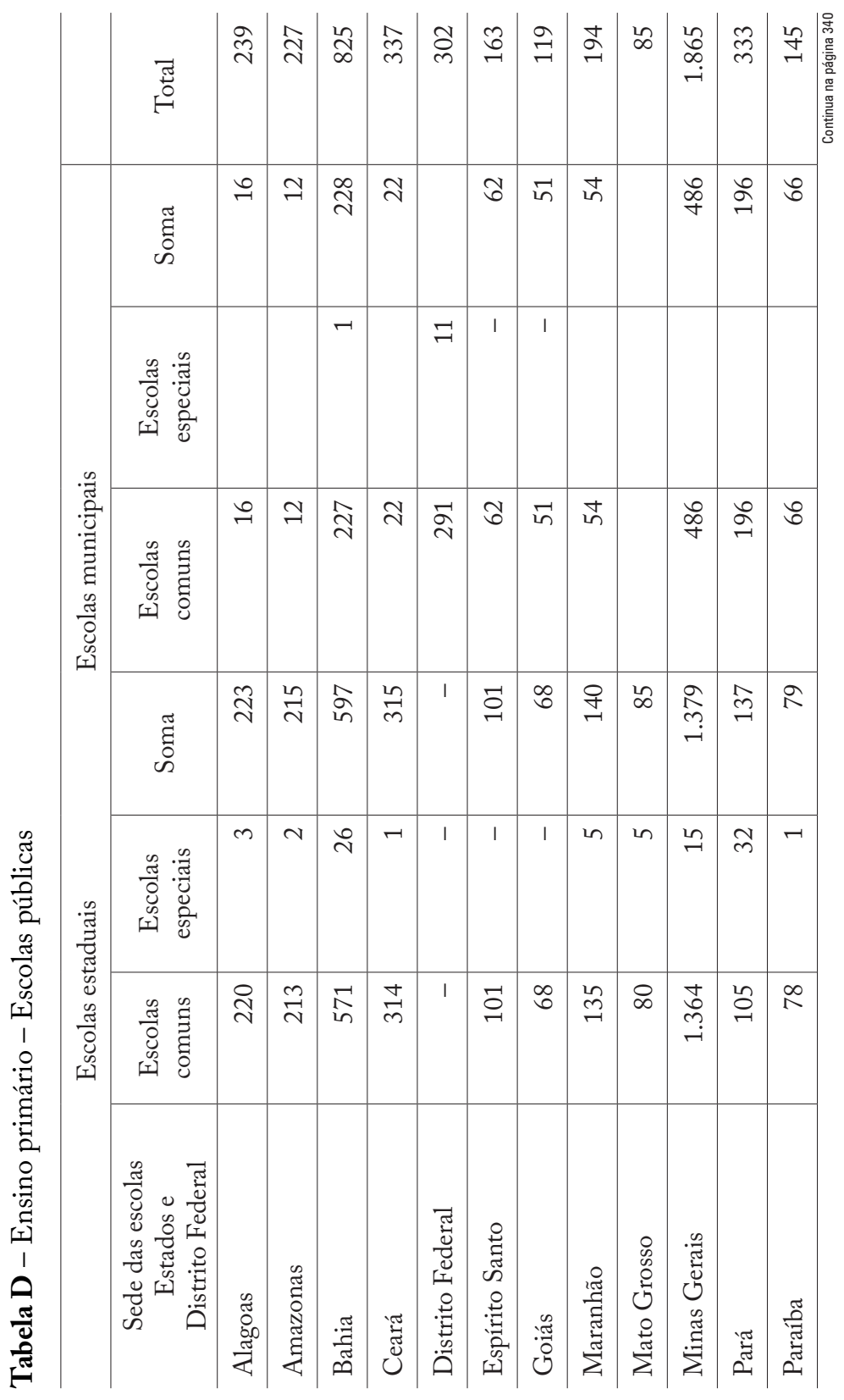




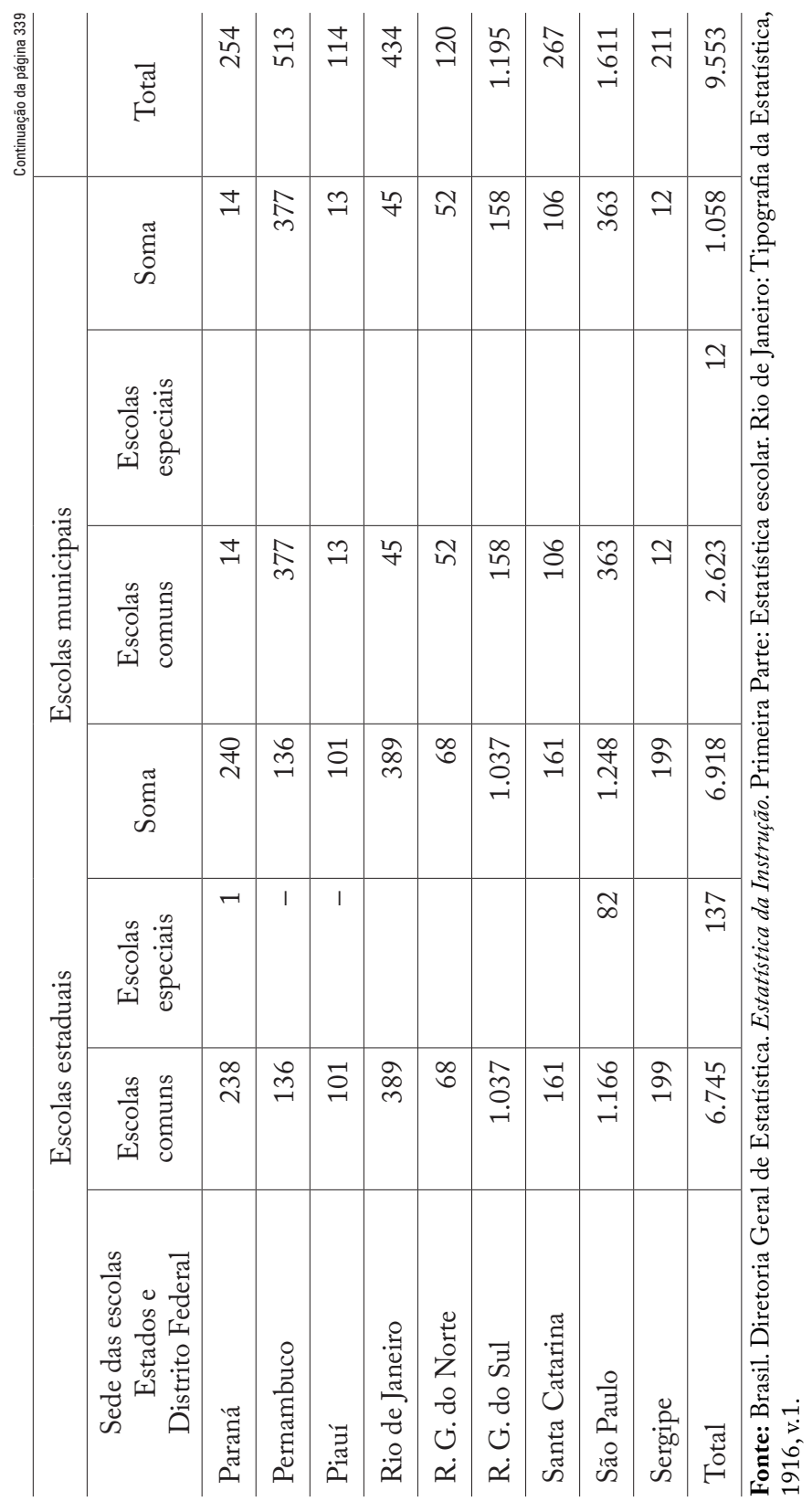


Tabela E - Número de escolas de instrução primária em 1920 nos estados e Distrito Federal

\begin{tabular}{l|r|r|r}
\hline Estados e Distrito Federal & \multicolumn{1}{|l|}{$\begin{array}{l}\text { Escolas } \\
\text { comuns }\end{array}$} & $\begin{array}{l}\text { No de alunos } \\
\text { matriculados }\end{array}$ & Por escola \\
\hline Alagoas & 528 & 16.059 & 30 \\
\hline Amazonas & 232 & 8.249 & 36 \\
\hline Bahia & 1.695 & 68.782 & 41 \\
\hline Ceará & 697 & 31.671 & 45 \\
\hline Distrito Federal & 680 & 11.955 & 165 \\
\hline Espírito Santo & 365 & 16.537 & 45 \\
\hline Goiás & 245 & 9.679 & 40 \\
\hline Maranhão & 415 & 21.043 & 51 \\
\hline Mato Grosso & 232 & 8.961 & 39 \\
\hline Minas Gerais & 3.694 & 254.445 & 69 \\
\hline Pará & 620 & 31.154 & 50 \\
\hline Paraíba do Norte & 439 & 19.816 & 45 \\
\hline Paraná & 723 & 27.625 & 38 \\
\hline Pernambuco & 1.290 & 52.445 & 41 \\
\hline Piauí & 226 & 8.571 & 38 \\
\hline Rio de Janeiro & 1.076 & 58.852 & 55 \\
\hline Rio Grande do Norte & 337 & 16.330 & 48 \\
\hline Rio Grande do Sul & 3.244 & 136.599 & 42 \\
\hline Santa Catarina & 881 & 46.984 & 53 \\
\hline São Paulo & 369 & 289.291 & 77 \\
\hline Sergipe & 13.400 & 36 \\
\hline Brasil & 2148 & 1.249 .449 & \\
\hline & & & 51 \\
\hline
\end{tabular}

Fonte: Diretoria Geral de Estatística. Recenseamento do Brasil. Rio de Janeiro: Tipografia da Estatística, 1929 (v.4 População - População do Brasil, por estados e municípios, segundo o grau de instrução por idade, sexo e nacionalidade). 


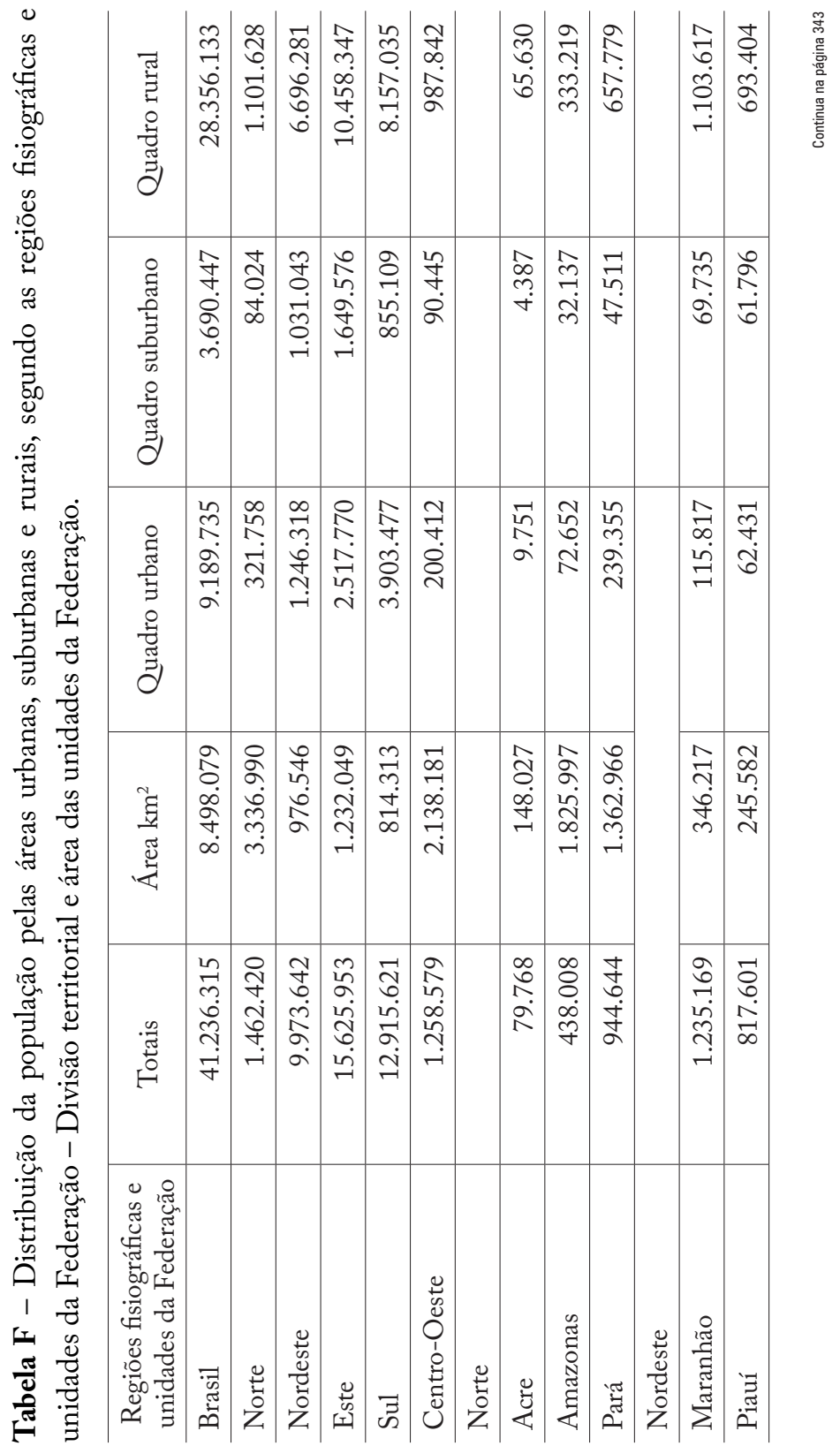




\begin{tabular}{|c|c|c|c|c|c|c|c|c|c|c|c|c|c|c|c|c|}
\hline ְ. & 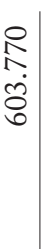 & 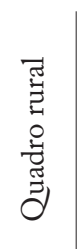 & 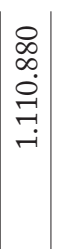 & 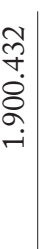 & 童 & $\mid \begin{array}{l}\alpha \\
0 \\
0 \\
0 \\
0 \\
\tilde{c}\end{array}$ & 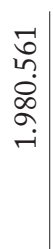 & 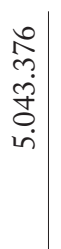 & $\begin{array}{c}\alpha \\
\delta \\
\vdots \\
\vdots \\
\vdots \\
i\end{array}$ & 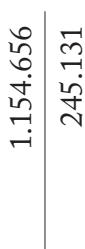 & 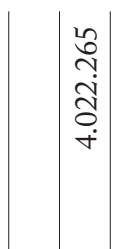 & 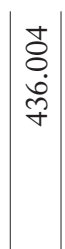 & 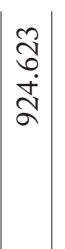 & & 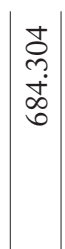 & 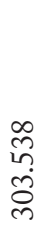 \\
\hline 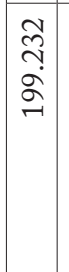 & & 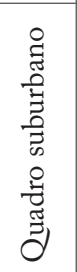 & 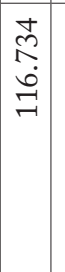 & 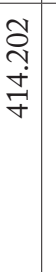 & 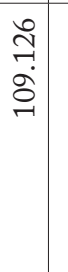 & $\begin{array}{l}\overrightarrow{0} \\
\dot{0} \\
\dot{8} \\
\text { in }\end{array}$ & 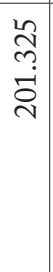 & 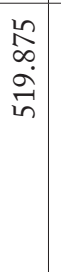 & $\begin{array}{l}\infty \\
\stackrel{\infty}{\infty} \\
\stackrel{+}{+} \\
\end{array}$ & 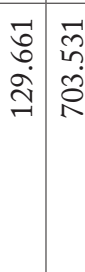 & 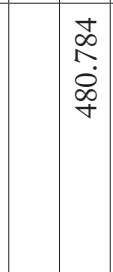 & $\begin{array}{c}\mathcal{N} \\
\tilde{\omega} \\
\stackrel{\infty}{\alpha}\end{array}$ & 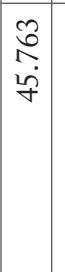 & $\begin{array}{l}0 \\
\vec{i} \\
\vdots \\
\overrightarrow{\hat{~}}\end{array}$ & 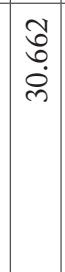 & \\
\hline 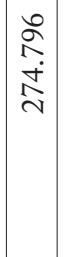 & & 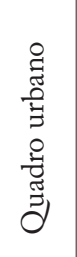 & 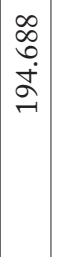 & | & 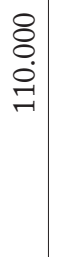 & 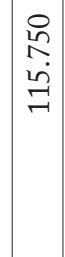 & 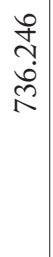 & 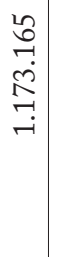 & 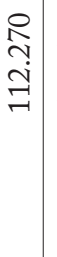 & 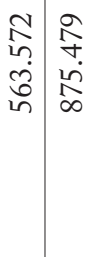 & $\begin{array}{l}\hat{N} \\
\stackrel{0}{0} \\
0 \\
0 \\
i \\
i\end{array}$ & $\begin{array}{l}\stackrel{2}{ } \\
\infty \\
\dot{I} \\
\vec{\sim}\end{array}$ & 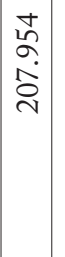 & 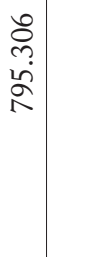 & 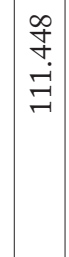 & $\begin{array}{l}t \\
0 \\
\infty \\
\infty \\
\infty\end{array}$ \\
\hline 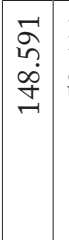 & & 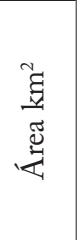 & 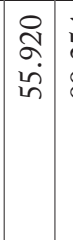 & 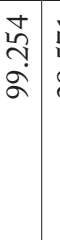 & $\begin{array}{l}\vec{n} \\
i \\
\infty \\
i \\
\end{array}$ & 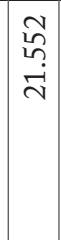 & 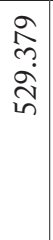 & $\mid$\begin{tabular}{l|} 
\\
$D$ \\
$\infty$ \\
$\omega$ \\
$\infty$ \\
$i n$ \\
$i n$
\end{tabular} & 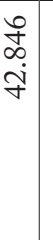 & 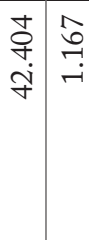 & 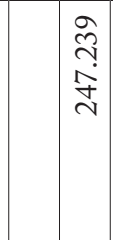 & $\begin{array}{l}\hat{\alpha} \\
\infty \\
\alpha \\
\sigma \\
\sigma\end{array}$ & \begin{tabular}{|l|}
$\infty$ \\
$\sigma$ \\
$\dot{d}$ \\
$\dot{\alpha}$
\end{tabular} & 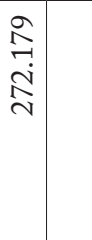 & 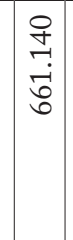 & $F$ \\
\hline $\begin{array}{l}\tilde{\sigma} \\
\hat{\sigma} \\
\stackrel{0}{0} \\
0 \\
\dot{i}\end{array}$ & 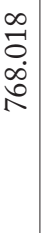 & 苞 & 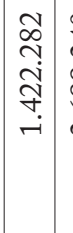 & 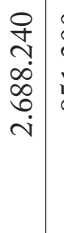 & 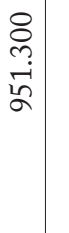 & $\begin{array}{c}0 \\
\tilde{Z} \\
\tilde{J} \\
\tilde{H} \\
i n\end{array}$ & $\begin{array}{l}\tilde{z} \\
\overrightarrow{7} \\
0 \\
\sigma \\
\dot{\sigma} \\
\dot{m}\end{array}$ & $\mid \begin{array}{l}0 \\
f \\
0 \\
0 \\
\hat{n} \\
b\end{array}$ & $\begin{array}{l}\hat{0} \\
\stackrel{0}{0} \\
\stackrel{0}{n} \\
\end{array}$ & 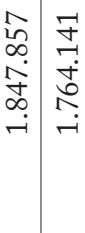 & 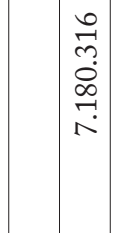 & 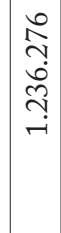 & 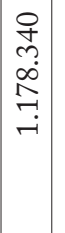 & 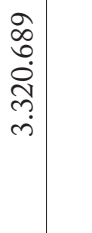 & $\begin{array}{l}\vec{J} \\
\vec{f} \\
\stackrel{\Xi}{\emptyset} \\
\infty\end{array}$ & 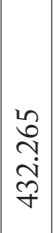 \\
\hline U. & 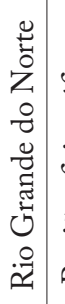 & 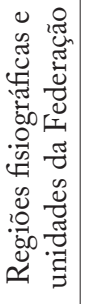 & 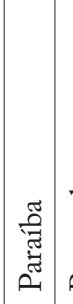 & 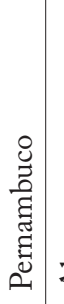 & ": & 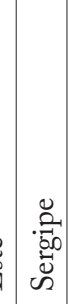 & 孚 & 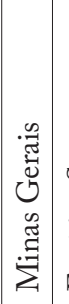 & 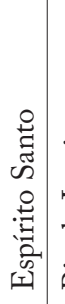 & 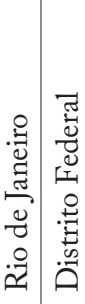 & 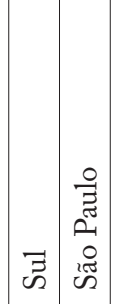 & 氶 & 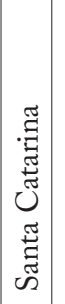 & 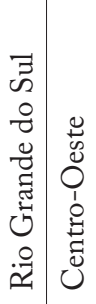 & : & $\begin{array}{l}0 \\
0 \\
0 \\
0 \\
0 \\
8 \\
0\end{array}$ \\
\hline
\end{tabular}


Tabela G - Pessoas de 5 anos e mais, por sexo, segundo a instrução e a cor

\begin{tabular}{|c|c|c|c|}
\hline Instrução e cor & Total & Homens & Mulheres \\
\hline Totais & 34.796 .665 & 17.358 .587 & 17.458 .078 \\
\hline Sabem ler e escrever & 13.292 .605 & 7.344 .772 & 5.947 .833 \\
\hline Brancos & 10.339 .796 & 5.662 .197 & 4.677 .599 \\
\hline Pretos & 954.905 & 553.469 & 401.434 \\
\hline Amarelos & 117.713 & 71.321 & 46.392 \\
\hline $\begin{array}{l}\text { Pardos e de cor } \\
\text { não declarada }\end{array}$ & 1.880 .193 & 1.057 .785 & 822.408 \\
\hline $\begin{array}{l}\text { Não sabem ler } \\
\text { nem escrever }\end{array}$ & 21.295 .490 & 9.908 .255 & 11.387.235 \\
\hline Brancos & 11.587 .489 & 5.340 .045 & 6.247 .444 \\
\hline Pretos & 4.186 .728 & 1.979 .605 & 2.207 .123 \\
\hline Amarelos & 80.000 & 35.195 & 44.805 \\
\hline $\begin{array}{l}\text { Pardos e de cor } \\
\text { não declarada }\end{array}$ & 5.441 .273 & 2.553 .410 & 2.887 .863 \\
\hline $\begin{array}{l}\text { De instrução } \\
\text { não declarada }\end{array}$ & 208.570 & 105.560 & 103.010 \\
\hline Brancos & 28.608 & 65.377 & 63.231 \\
\hline Pretos & 1.004 & 15.546 & 15.458 \\
\hline Amarelos & 2.239 & 1.095 & 1.144 \\
\hline $\begin{array}{l}\text { Pardos e de cor não } \\
\text { declarada }\end{array}$ & 46.719 & 23.542 & 23.177 \\
\hline
\end{tabular}

Fonte: IBGE. Recenseamento geral do Brasil: 1940. Rio de Janeiro: Serviço Gráfico do Instituto Brasileiro de Geografia e Estatística, 1950 (Série Nacional, v.2. Censo demográfico: População e habitação). 


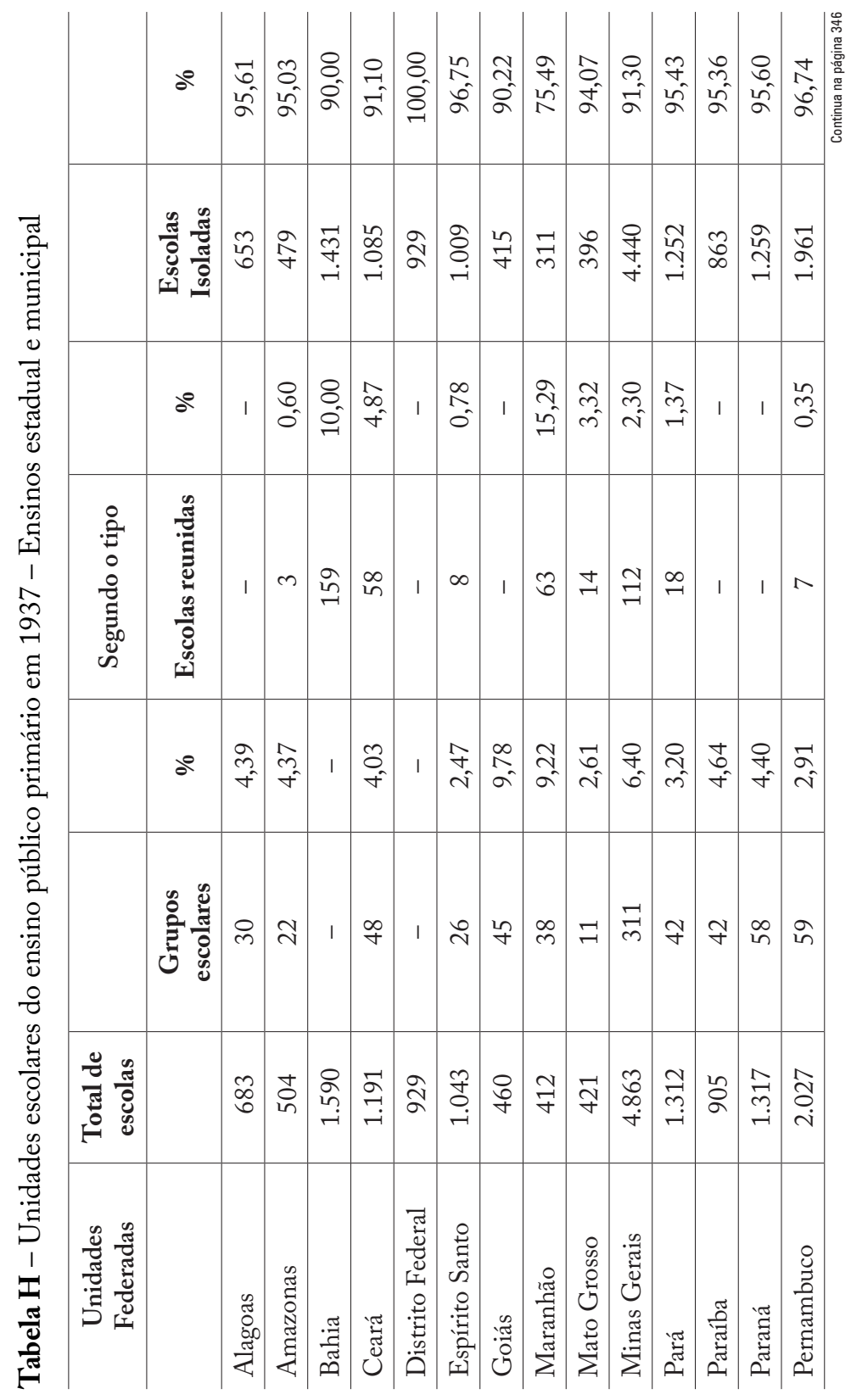




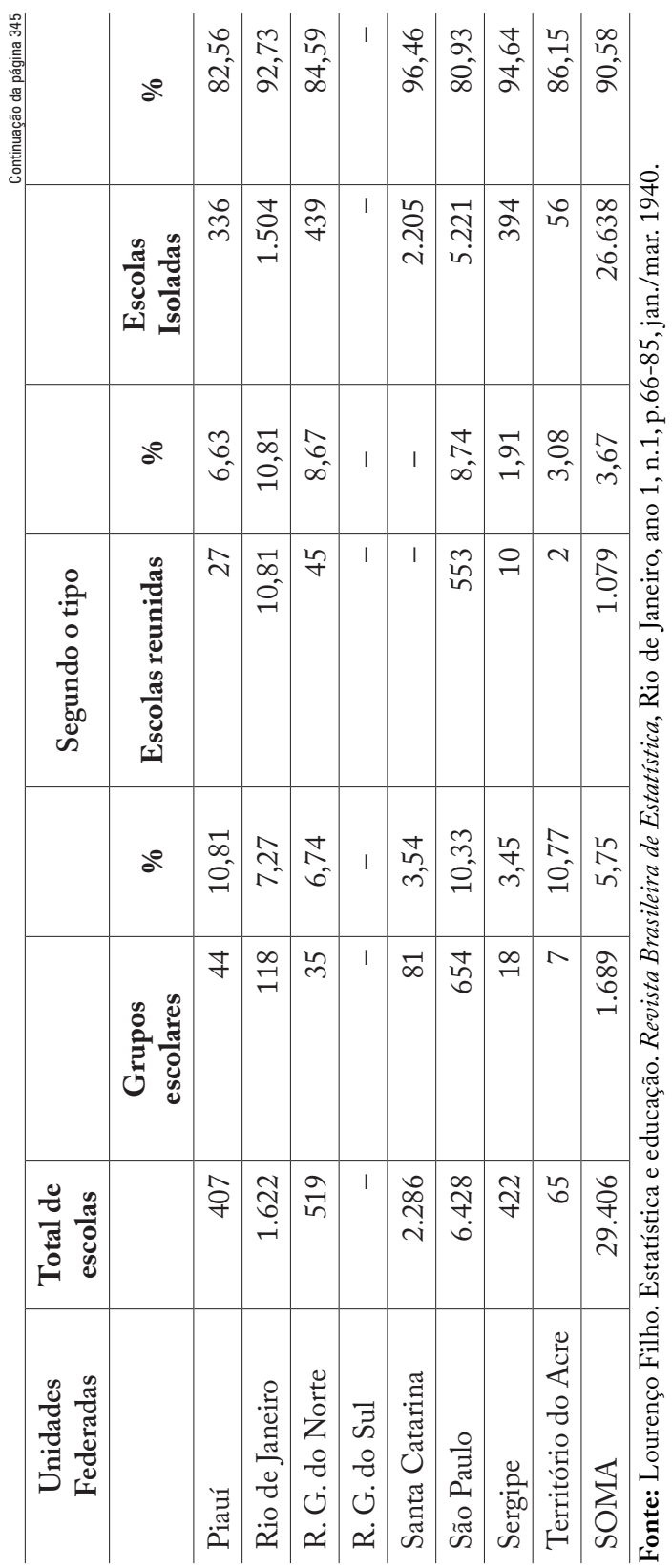




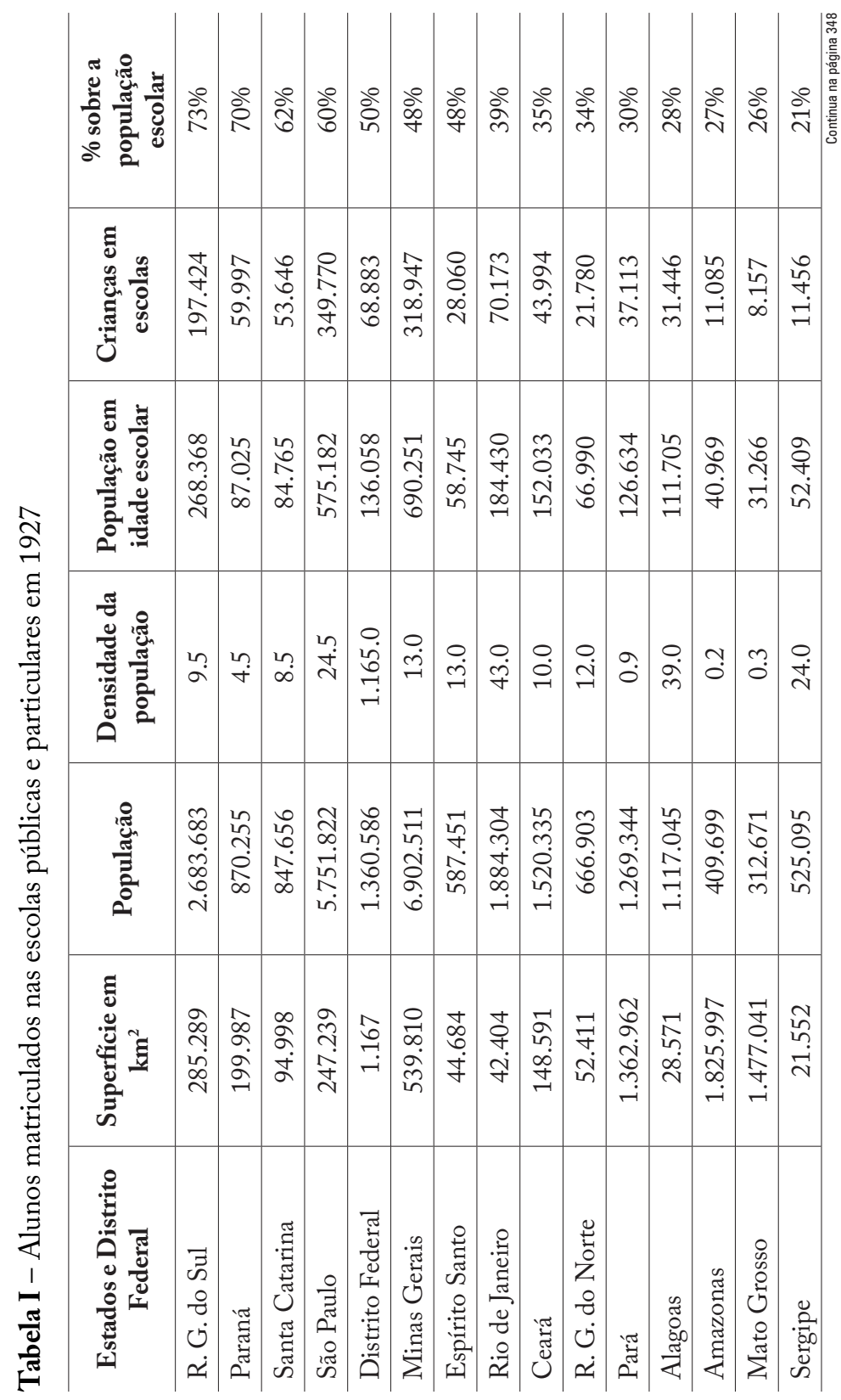




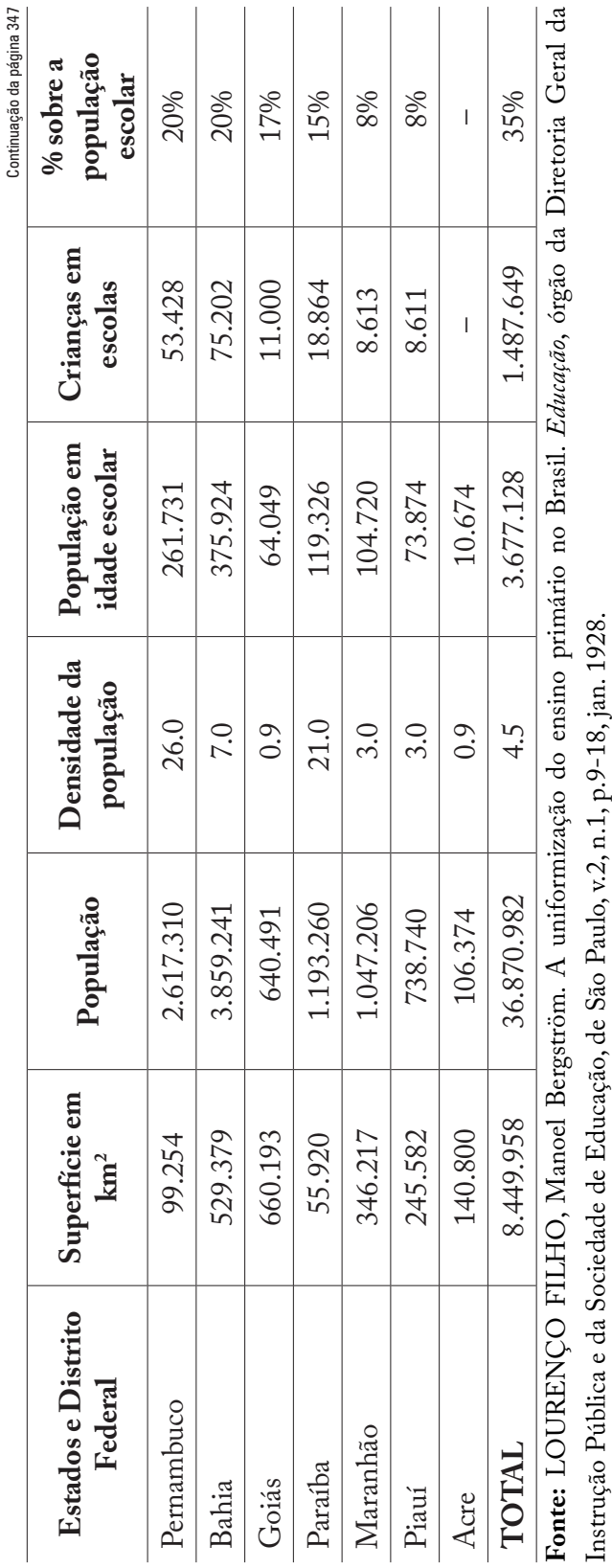


Apêndice B - Imagens antigas, quase esquecidas 

1. Lugares de escolas nas lentes da câmera óptica

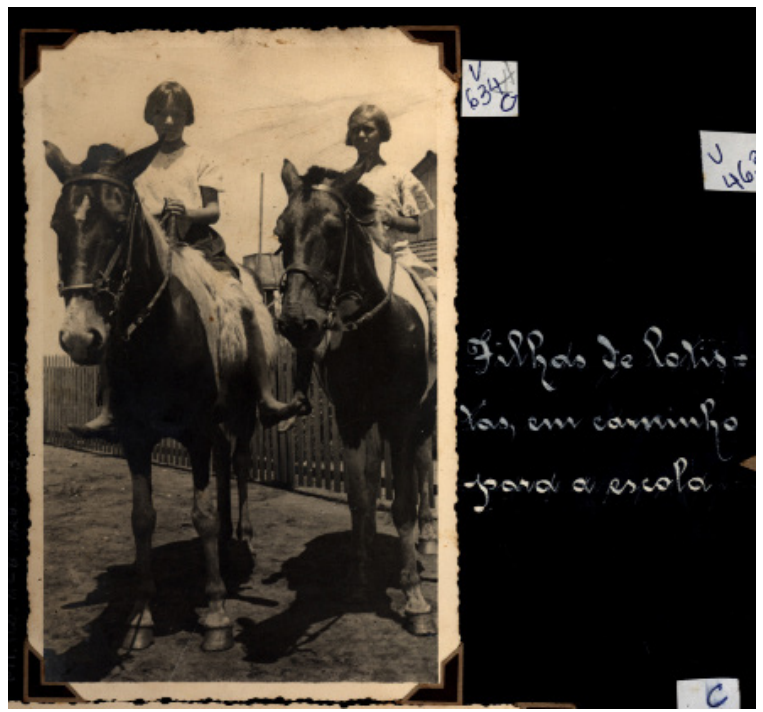

A caminho da escola - núcleo de colonização - SP (APESP)

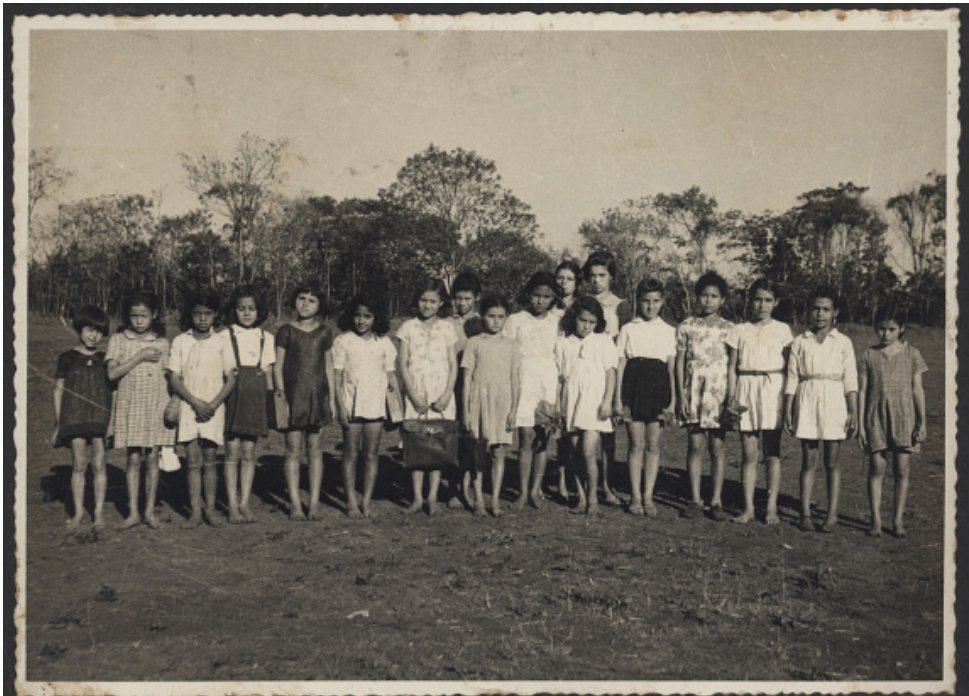

Alunas em núcleo de colonização - SP (APESP) 


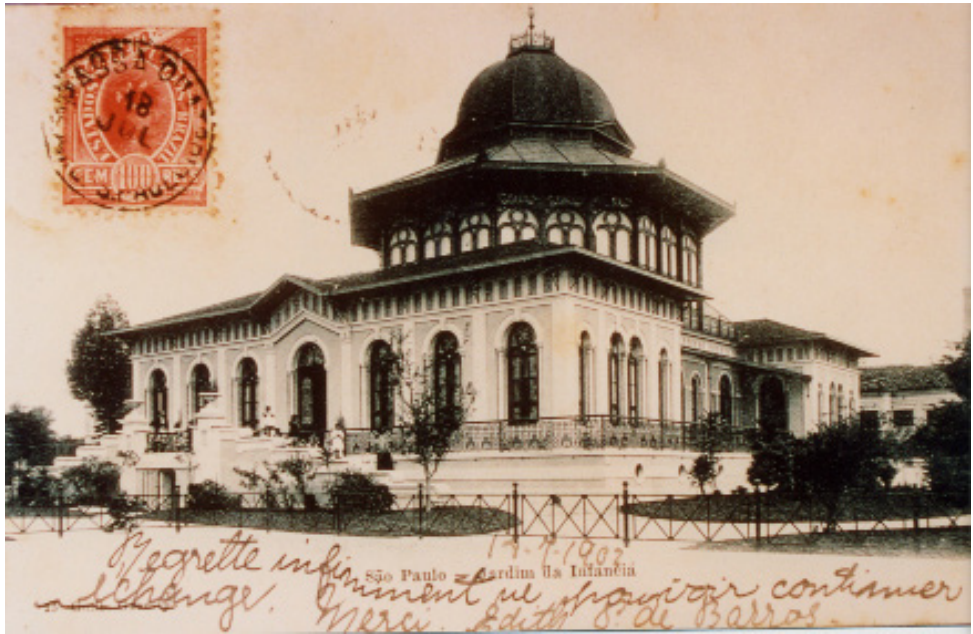

Cartão postal - Jardim de Infância da Escola Normal da Praça - SP - 1911 (MP-USP)

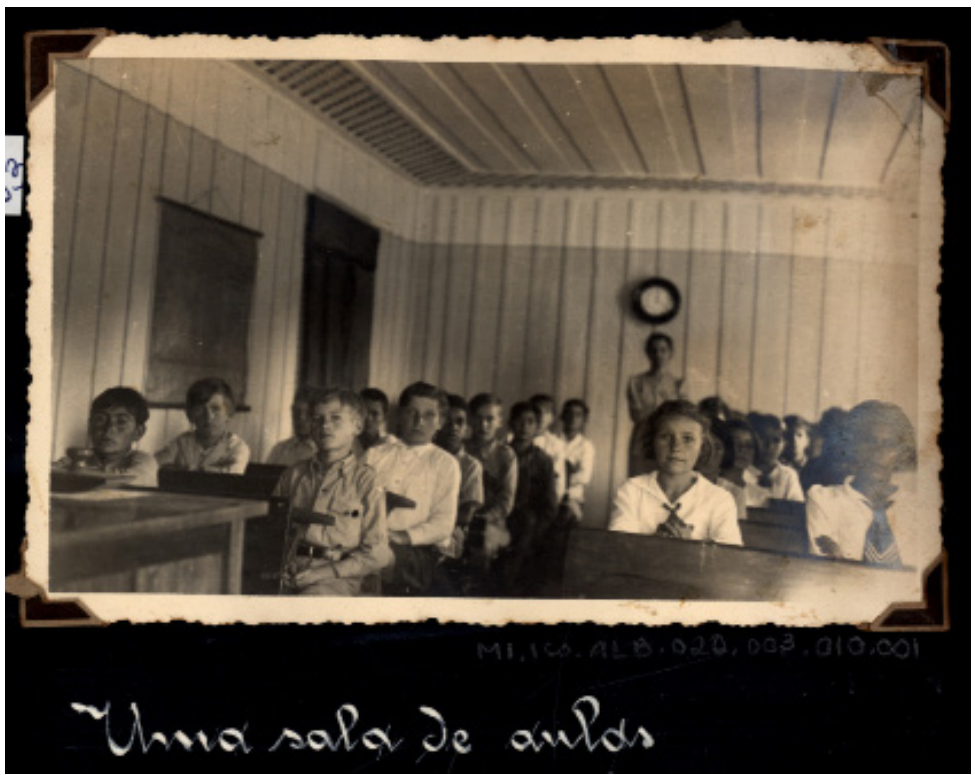

Cena rural - (SP) (APESP) 


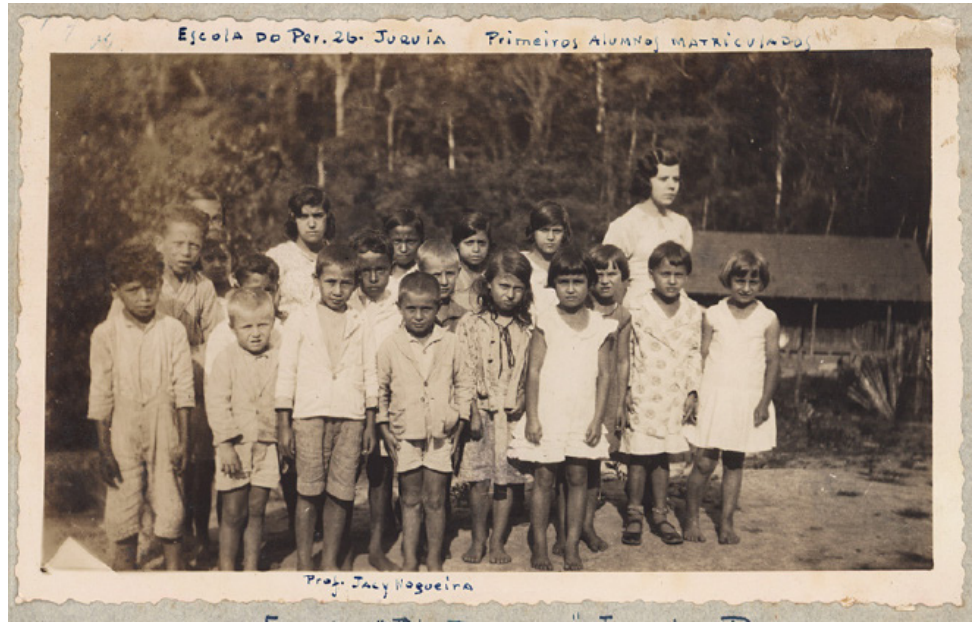

Escola de perímetro - SP (APESP)

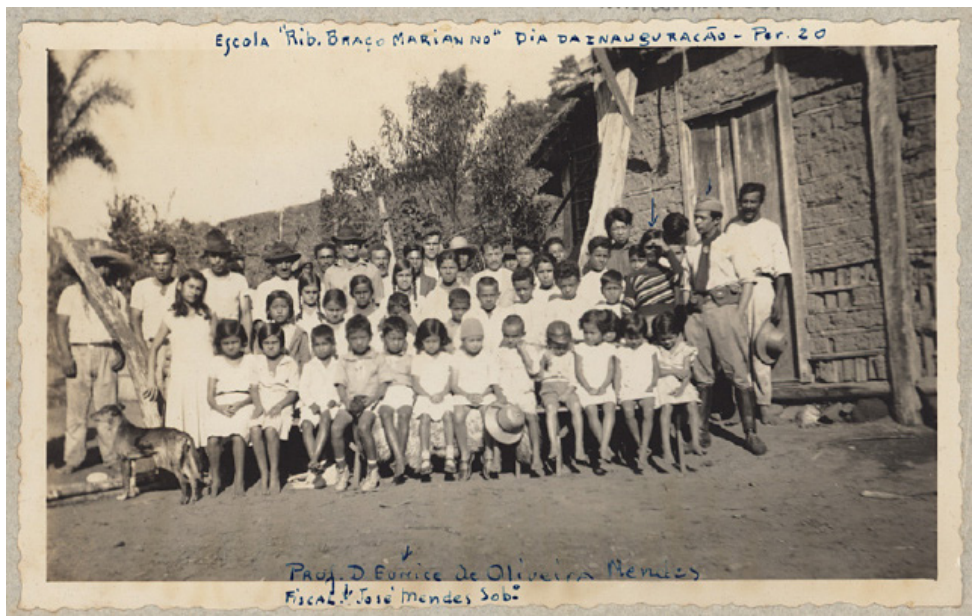

Escola de perímetro em dia de inauguração - SP (APESP) 


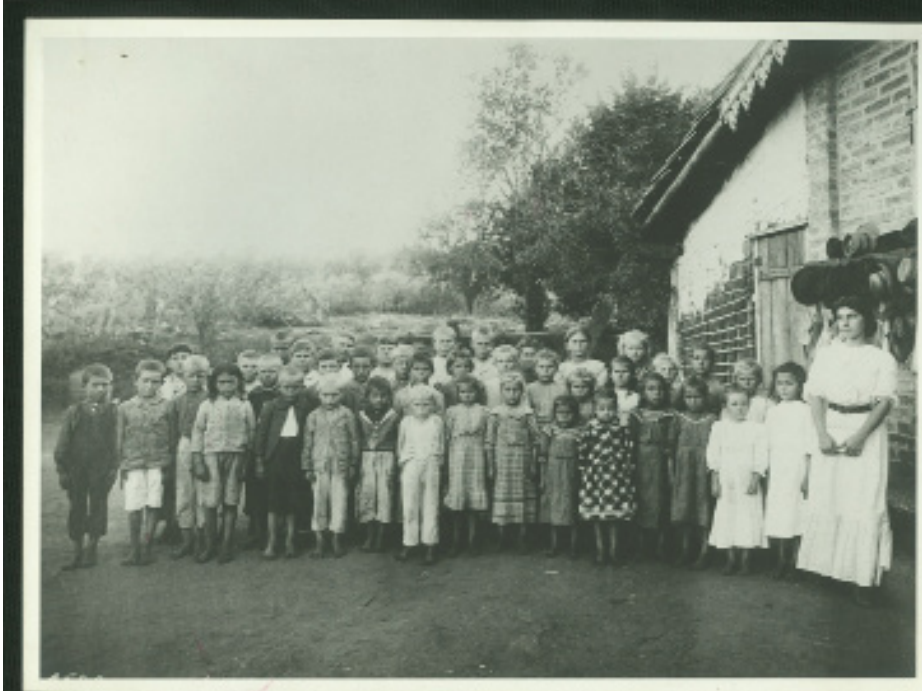

Escola em núcleo colonial - SP - 1915 (APESP)

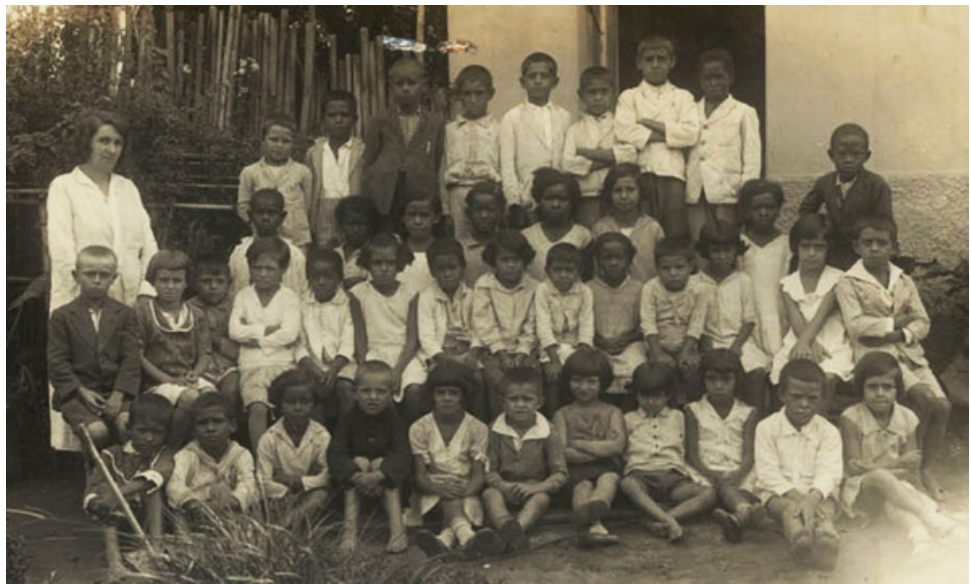

Escola mista urbana - SP (APESP) 


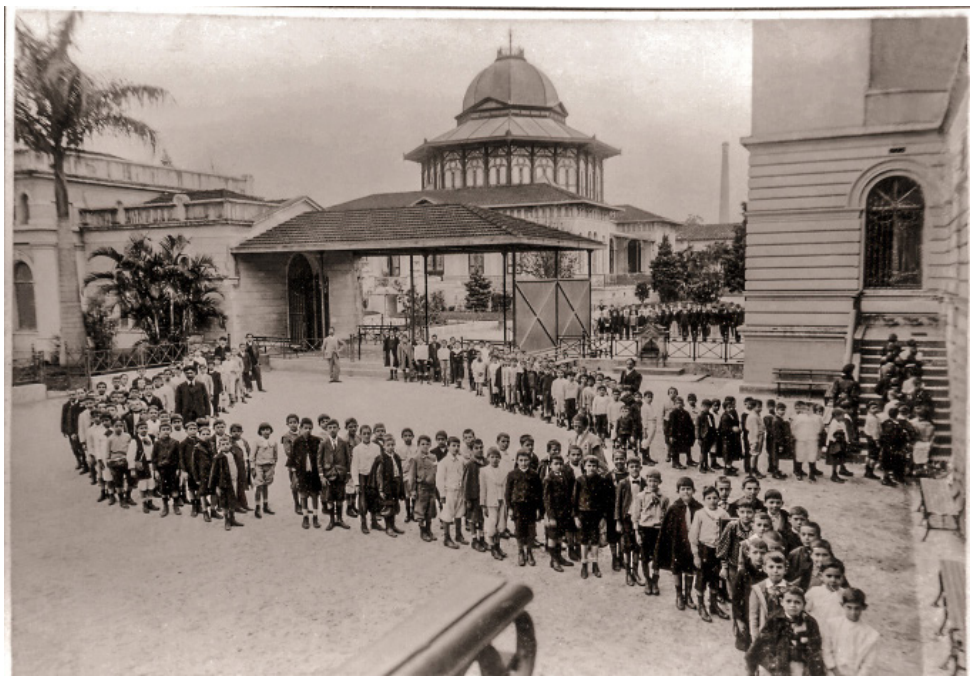

Escola Normal da Praça - SP (APESP)

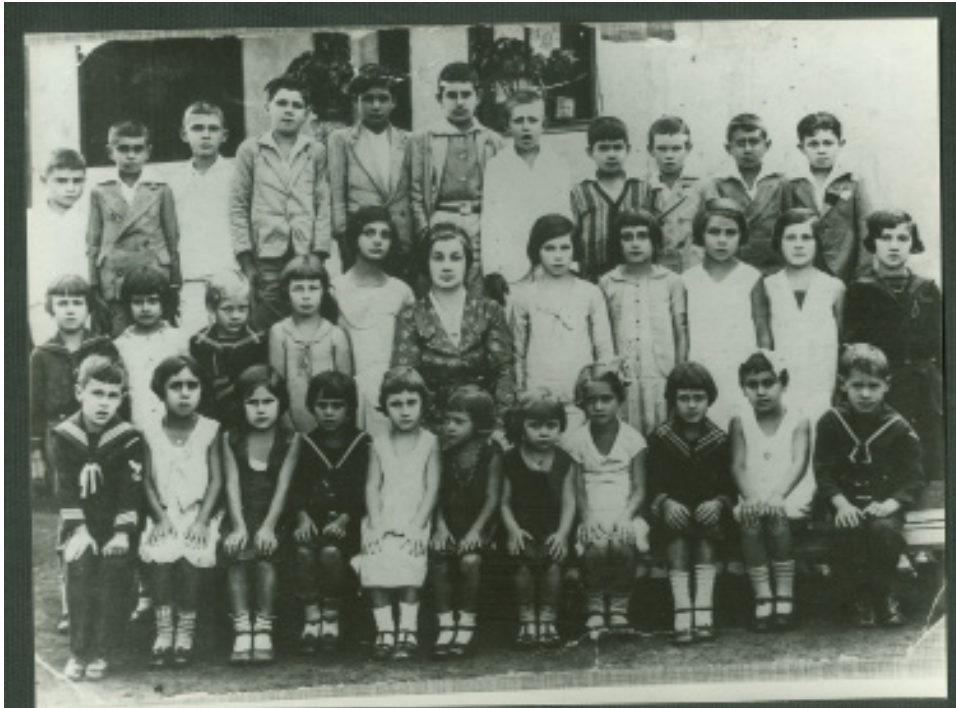

Escola particular - SP (APESP) 


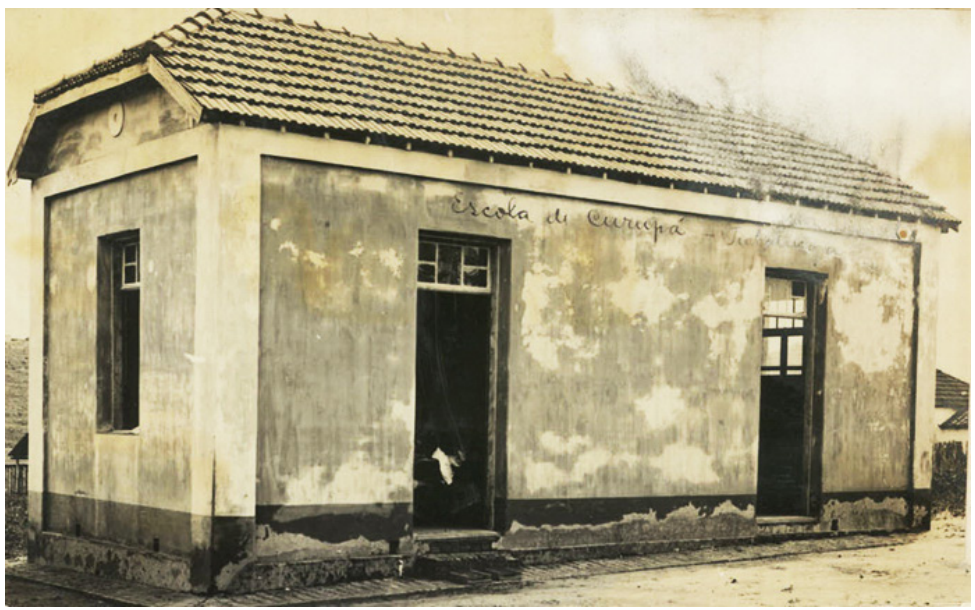

Escola rural mista - SP (APESP)

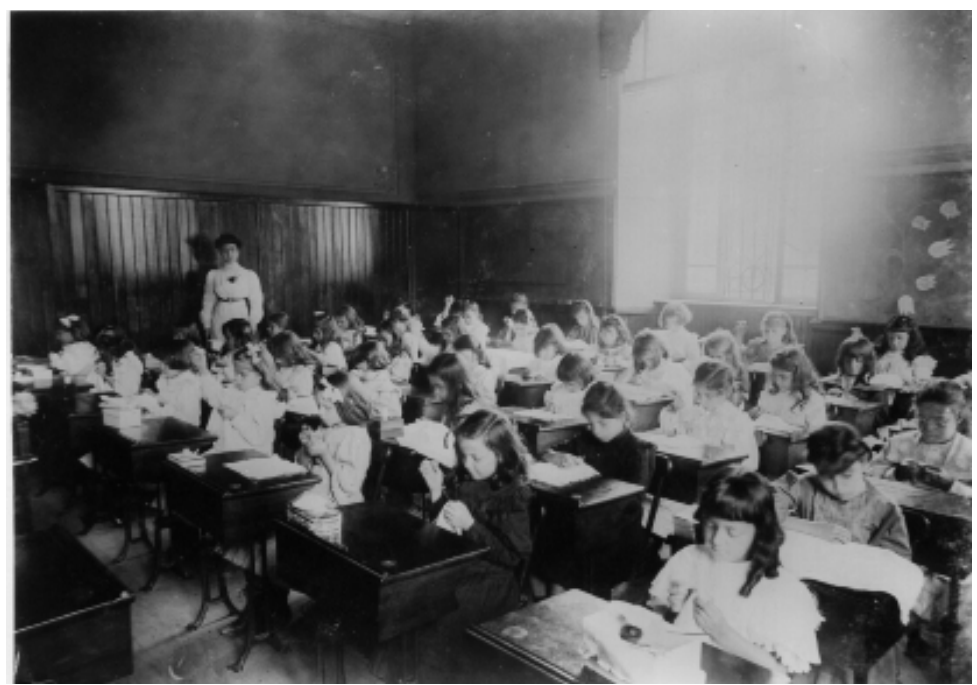

Escola-modelo feminina - abrindo a caixa de costura - SP (APESP) 


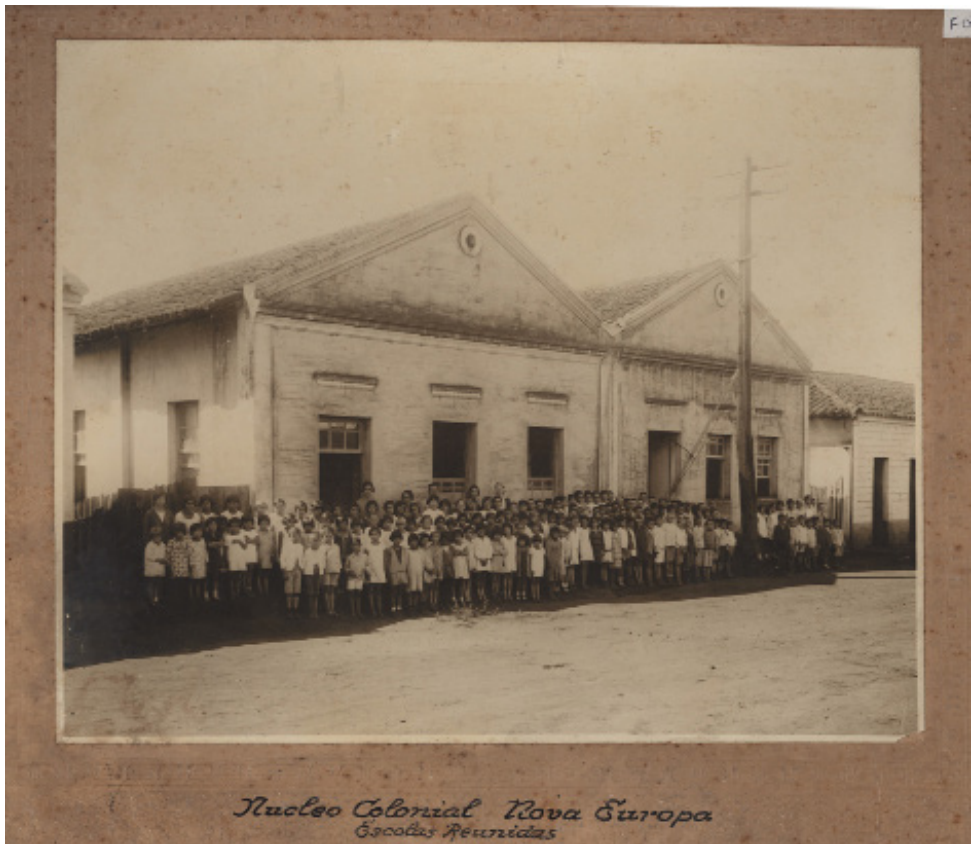

Escolas reunidas - SP (APESP) 


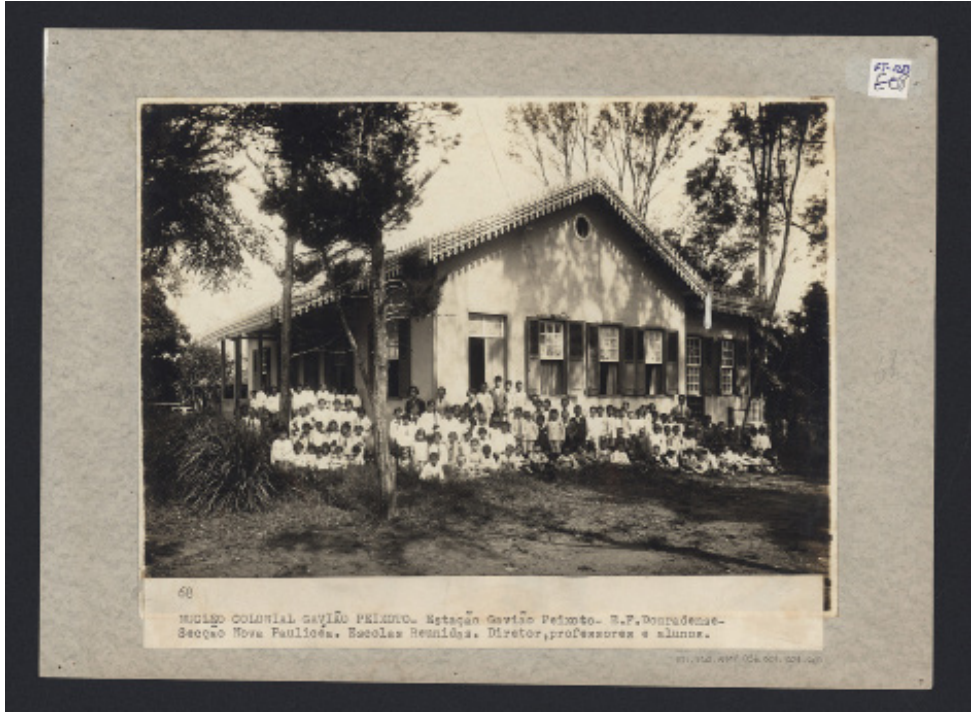

Escolas reunidas - SP (APESP)

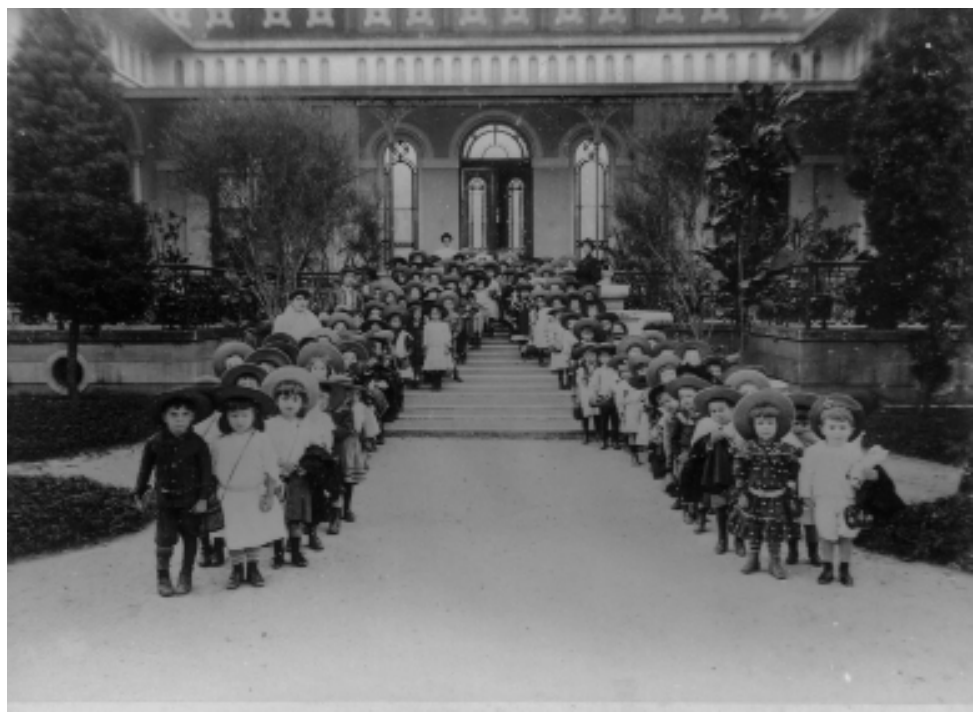

Jardim de Infância da Escola Normal da Praça - 1909 (APESP) 


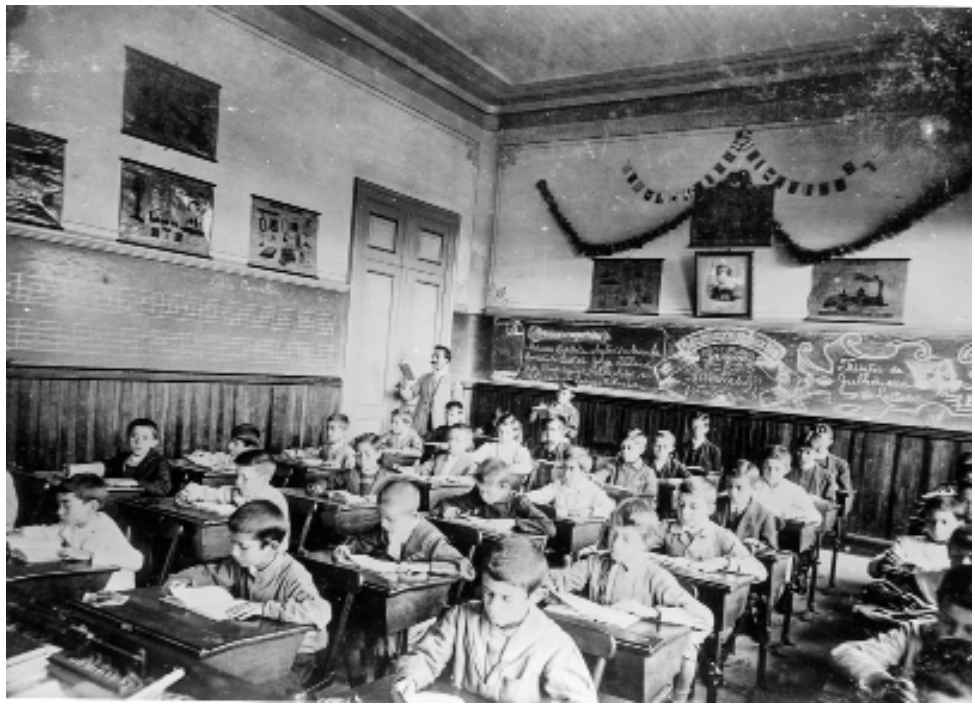

Leitura silenciosa - Escola-modelo masculina -SP (APESP) 


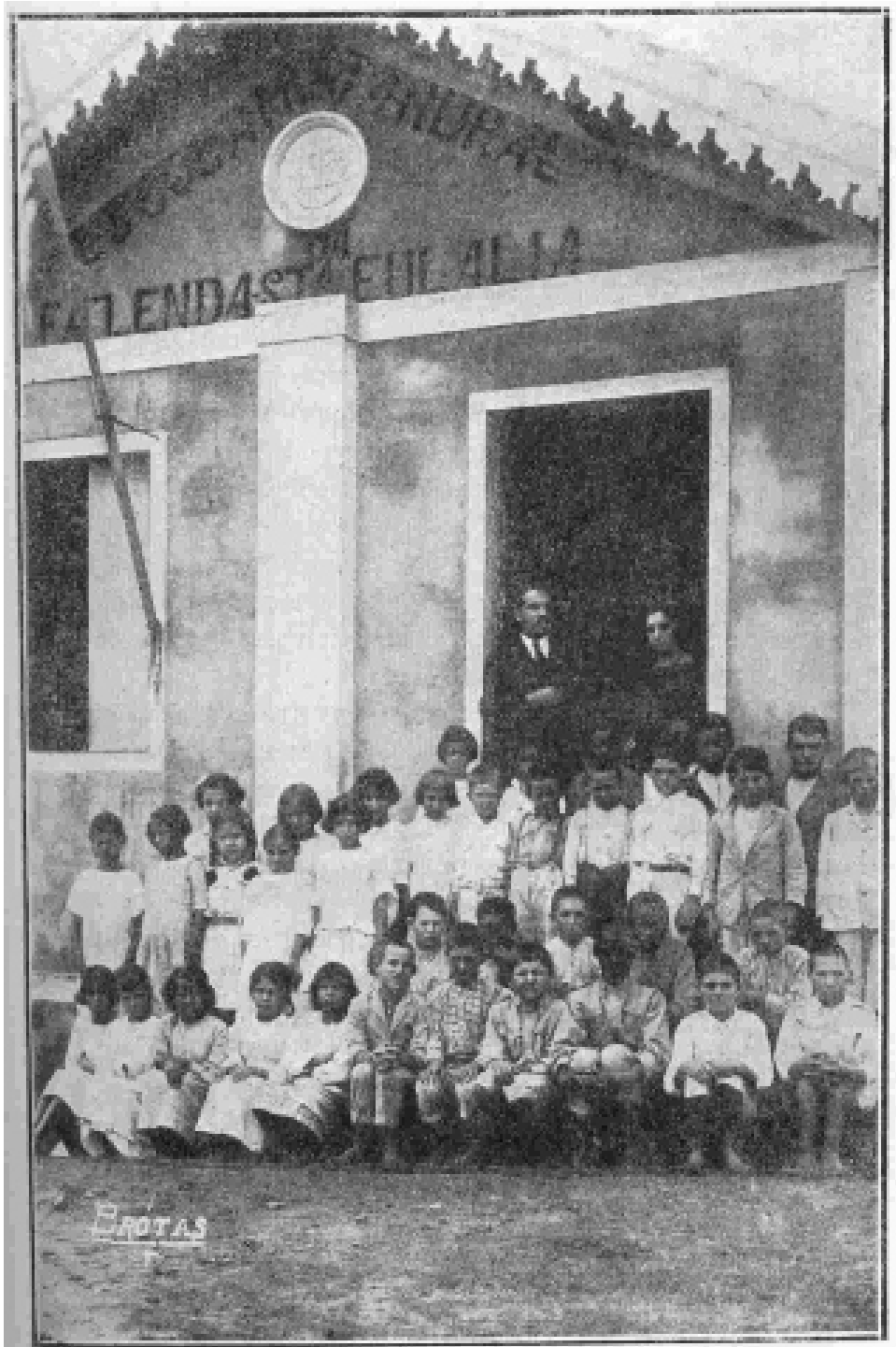

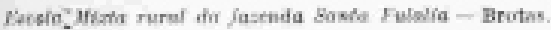

$\mathrm{Na}$ fazenda - SP (APESP) 


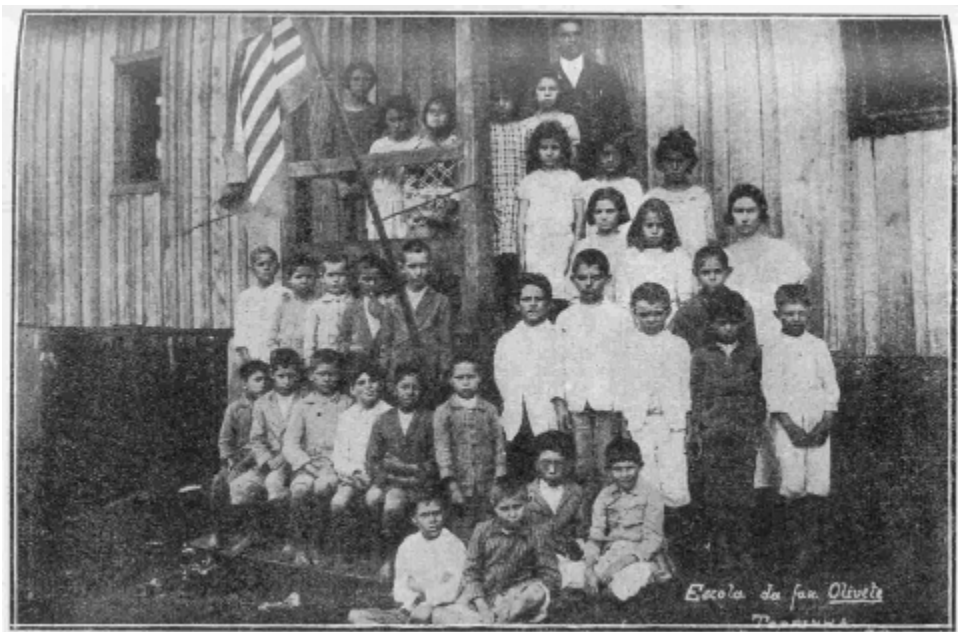

Eocola dn fascode Otivete - Torrinha

$\mathrm{Na}$ fazenda -SP (CRPHE)

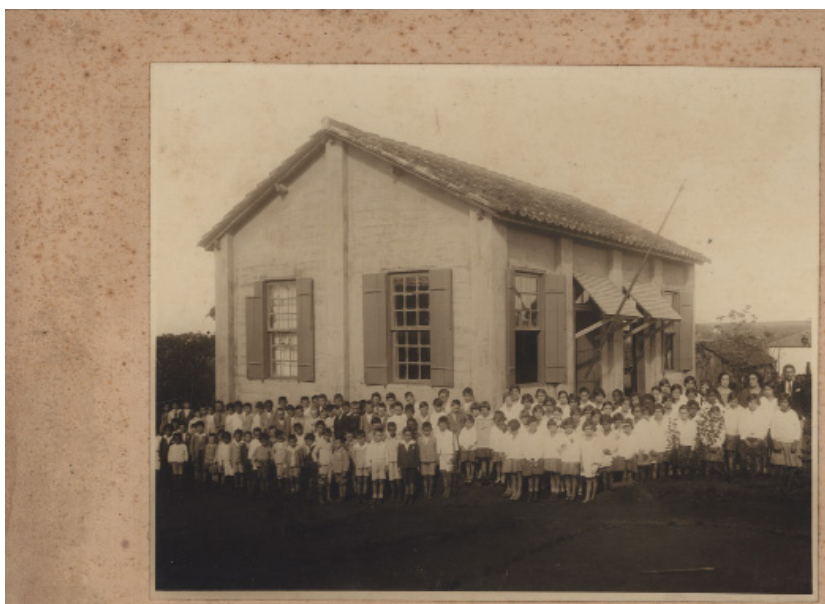

Nucleo Colonial Grviao Arixoto. óscolas Reuridas

$\mathrm{Na}$ roça - SP (APESP) 


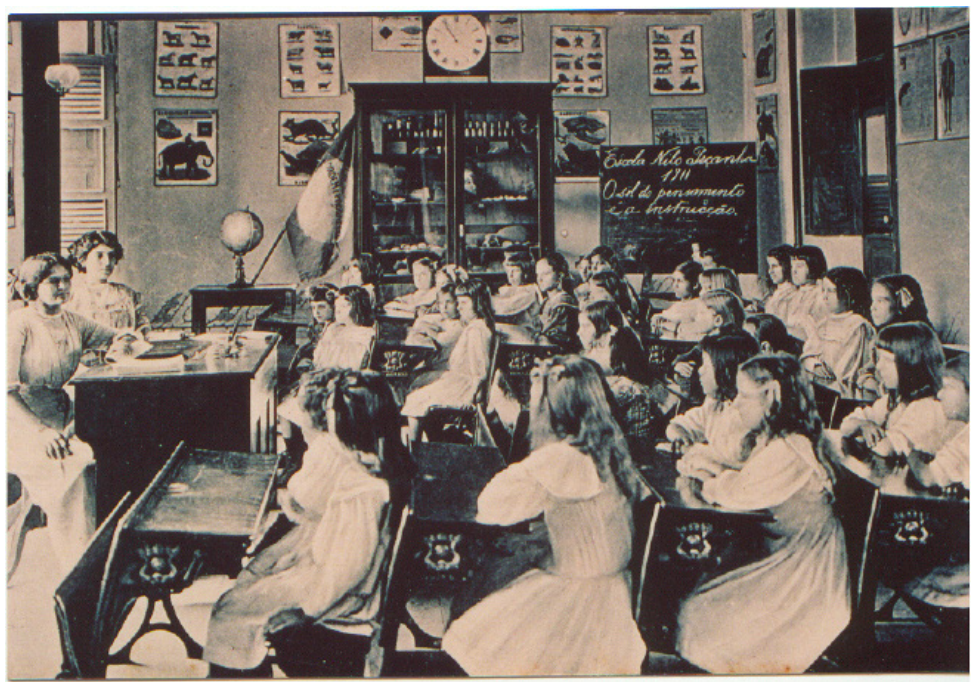

No quadro-negro, a sentença: $\mathrm{O}$ sol do pensamento é a instrução - Grupo Escolar - SP (MP-USP)

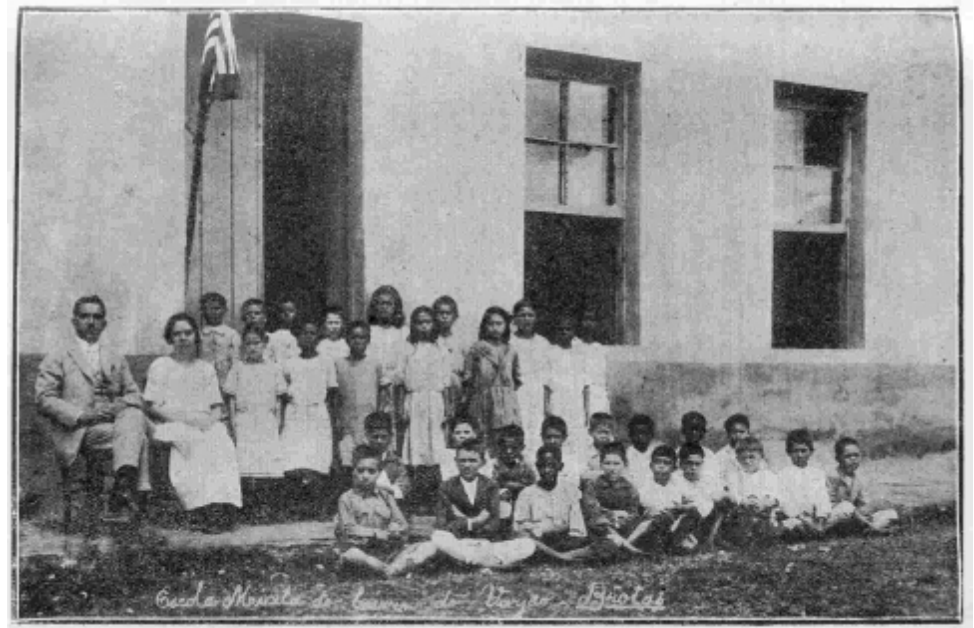

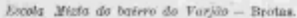

No subsolo da roça - SP (CRPHE) 


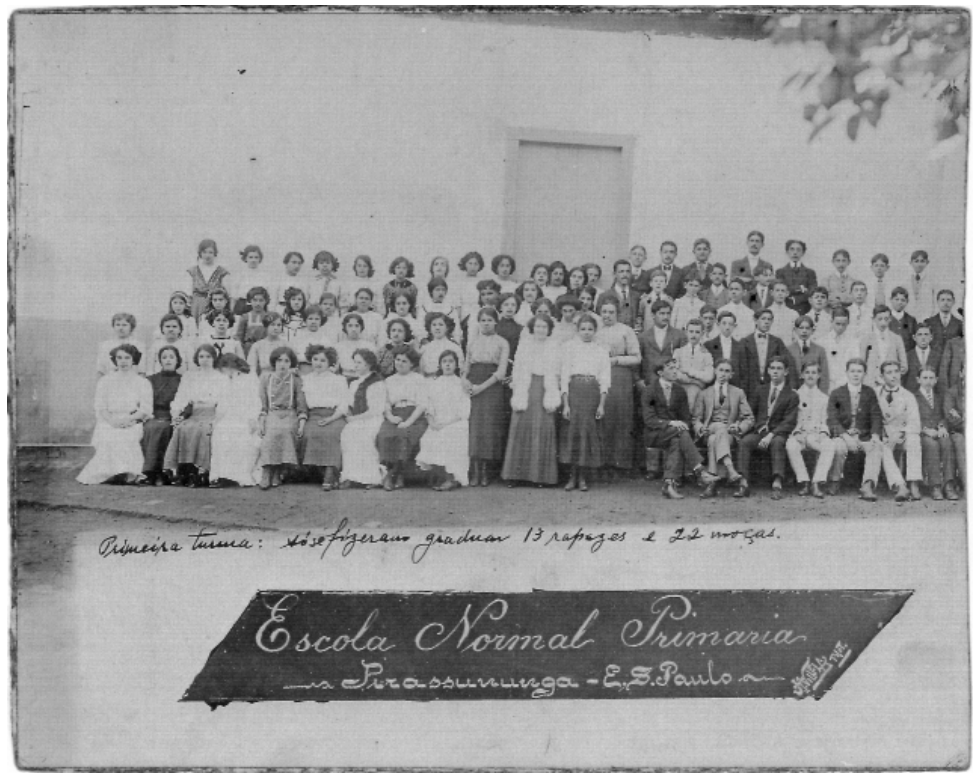

Primeira turma de professorandos da Escola Normal de Pirassununga - SP -1911 (APESP)

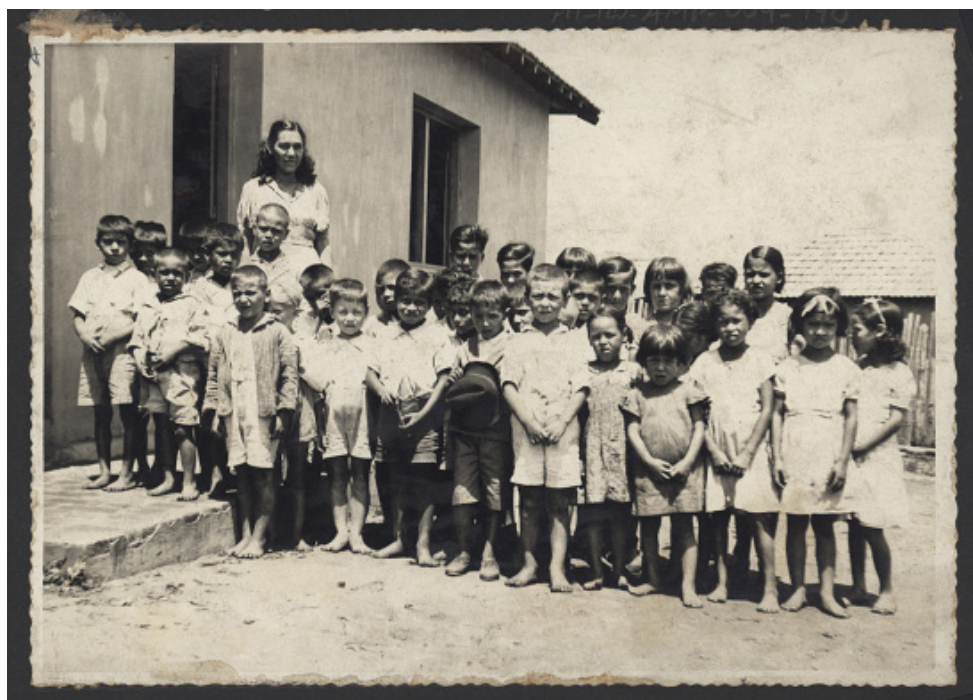

Professora e alunos de escola isolada -SP (APESP) 


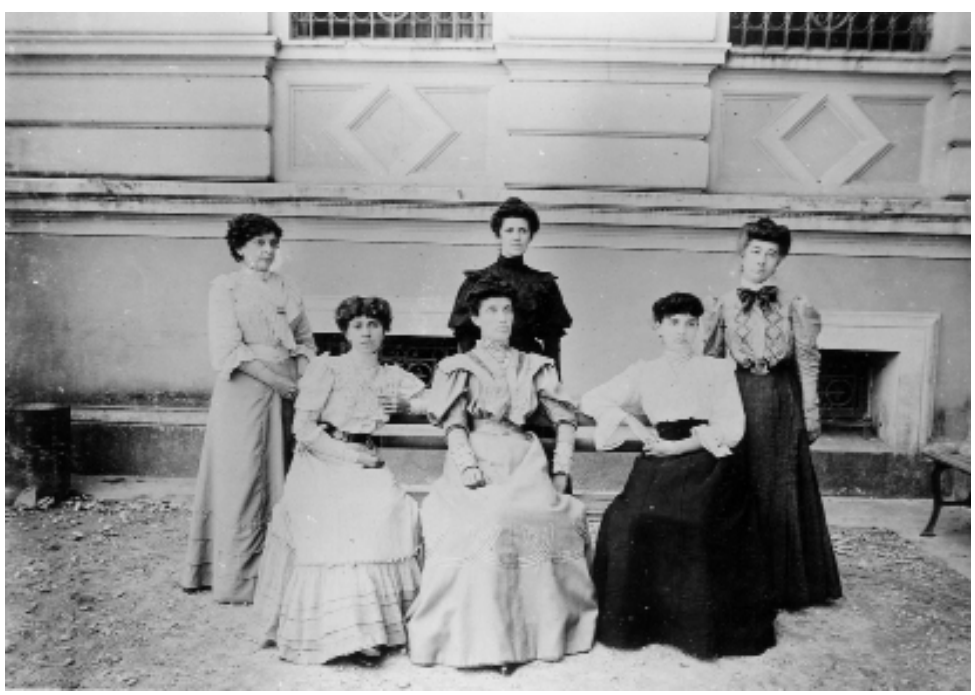

Professoras da Escola Normal da Praça - SP -1911 - (APESP) 
2. Infância escoteira nas manhãs de abril

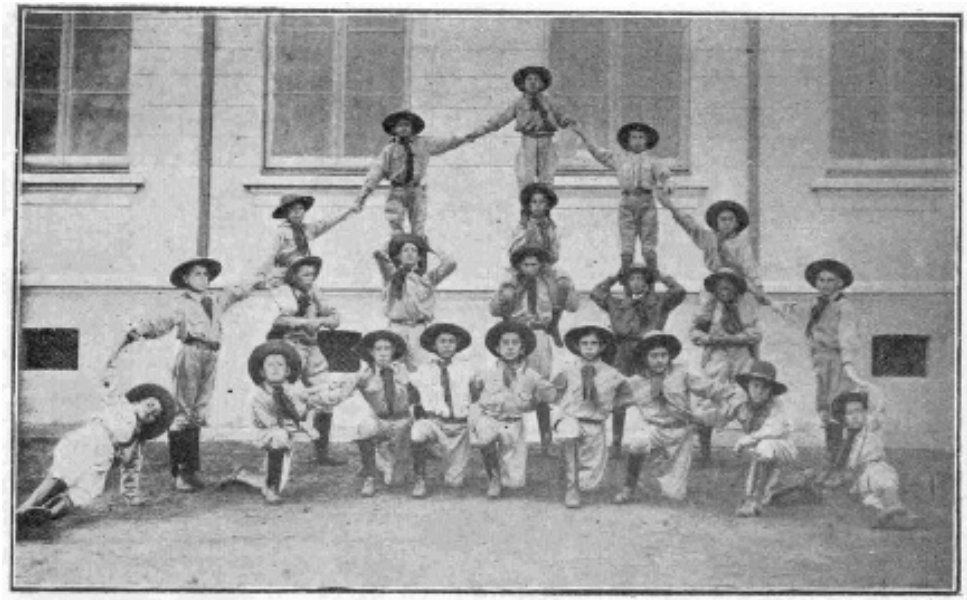

Escoicisos de Alrinepolis

Acrobacias - SP - 1922 (CRPHE)

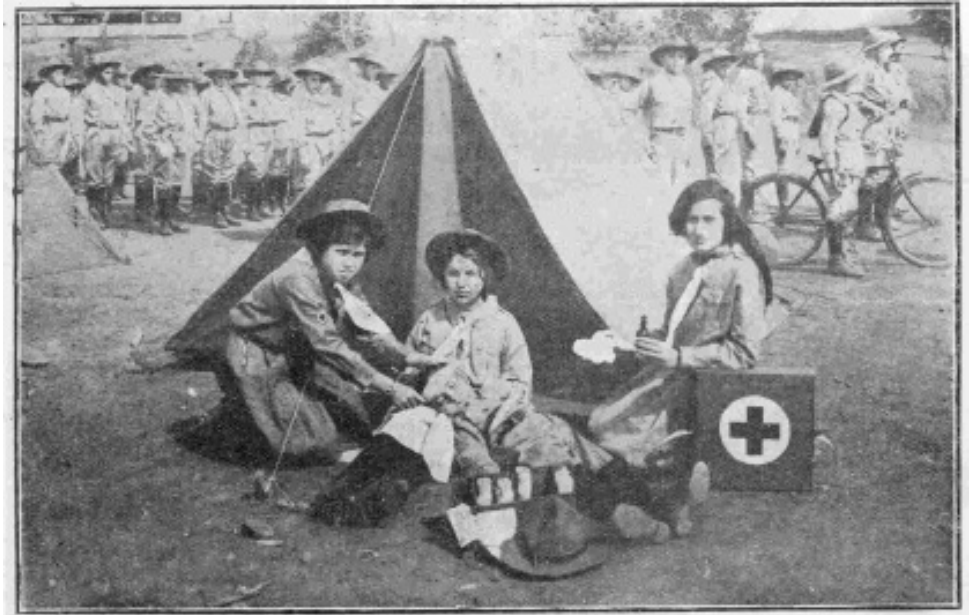

Eecoteiros de 5. Jose do Bio Parilo - A Crux Vermelha.

Escoteiras em ação - SP - 1933 (CRPHE) 


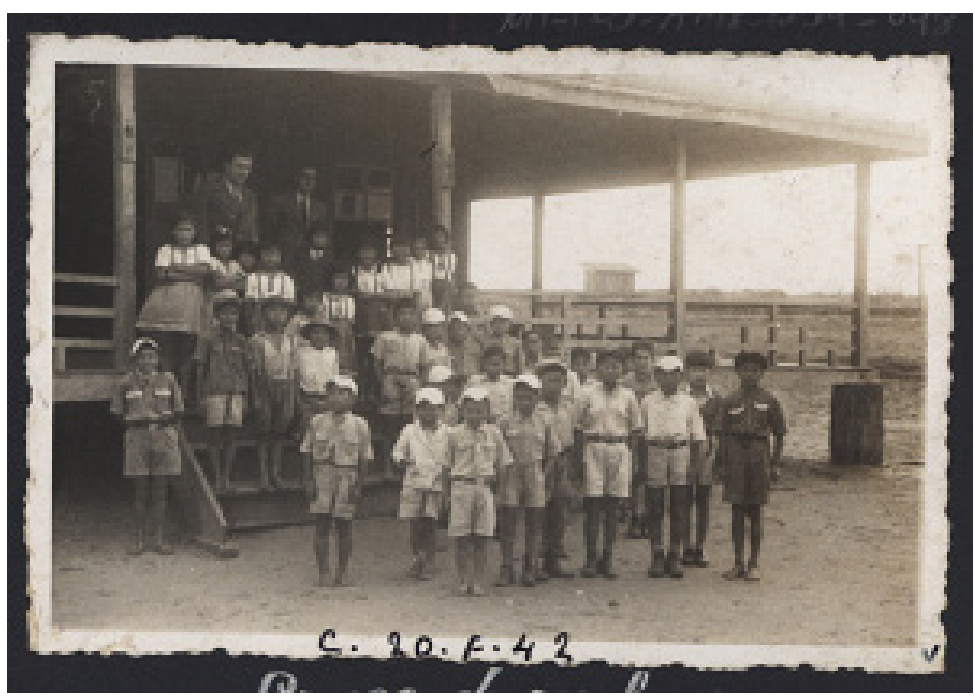

Escoteiros em núcleo de imigrantes - SP (APESP)

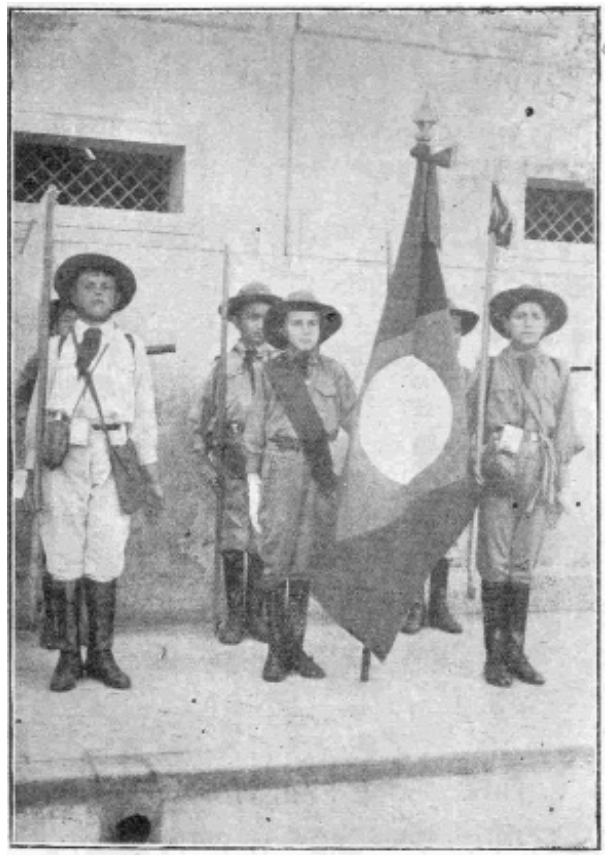

Em Itatila.

A Bandeira da commiøão repóonal

Exibindo a farda (CRPHE) 


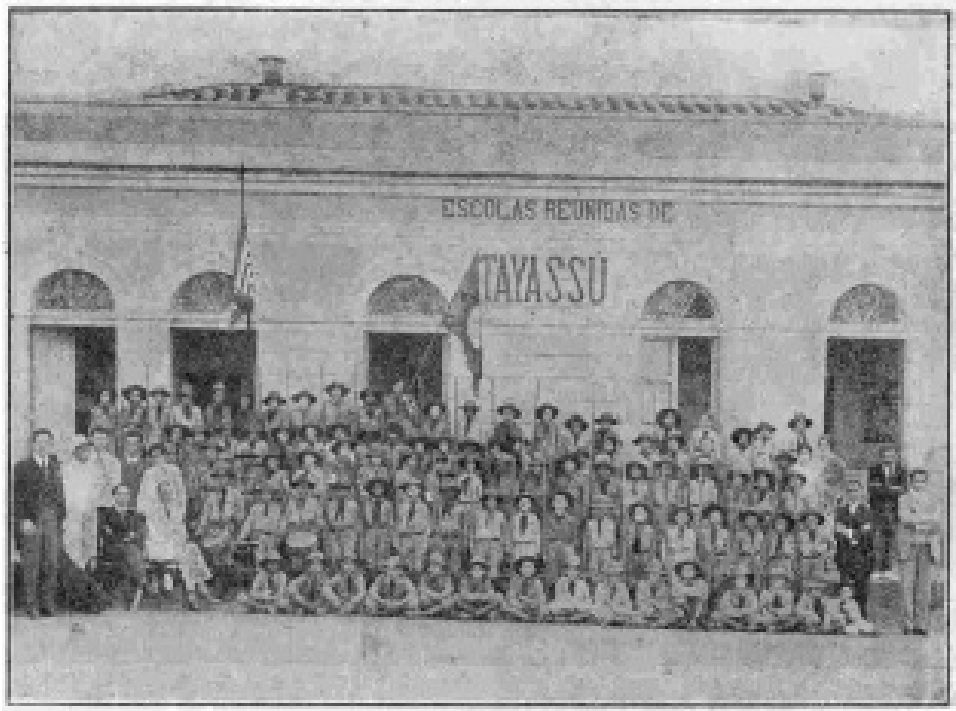

Bacotefros de Taymà

Formação escoteira - SP -1922 (CRPHE)

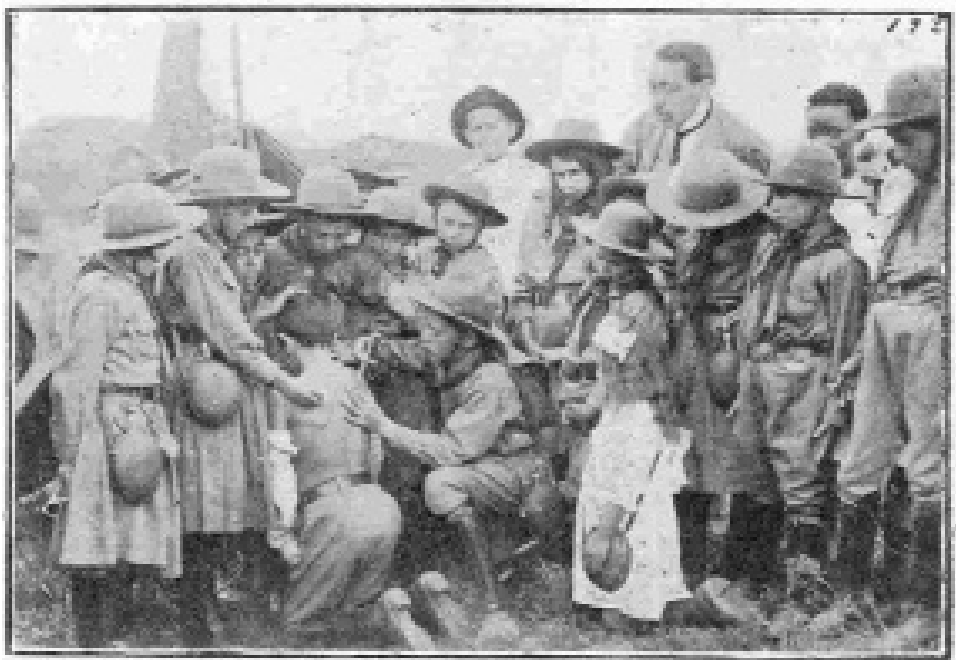

Escoteiros de Pilar. - Uma injecrôno snti-aphidica.

Primeiros socorros - SP (CRPHE) 


\section{Da higiene e saúde, panorama}

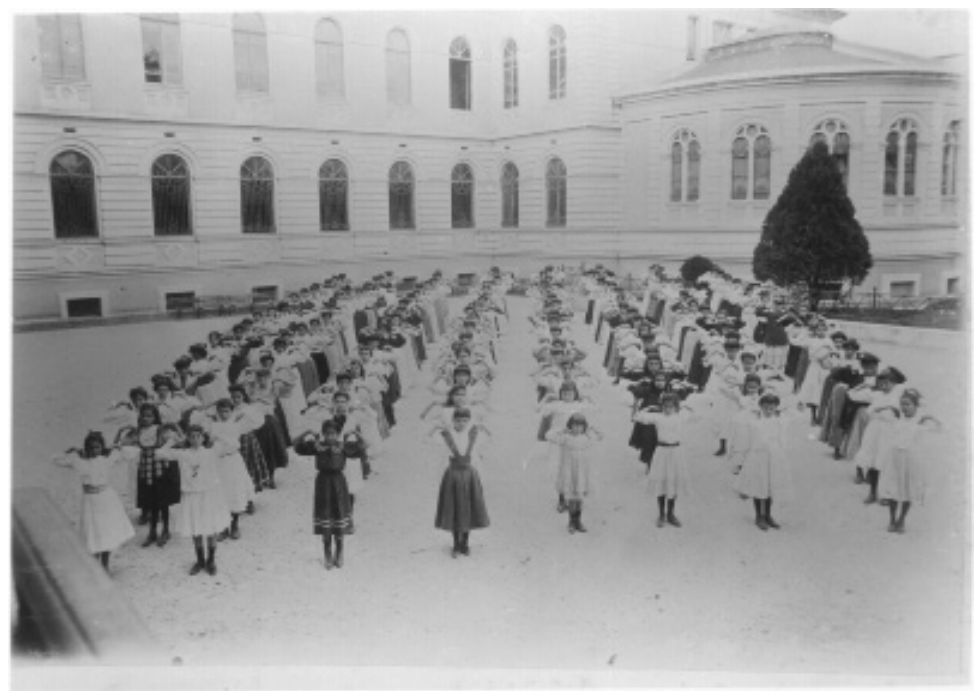

A harmonia do movimento - SP (APESP) 


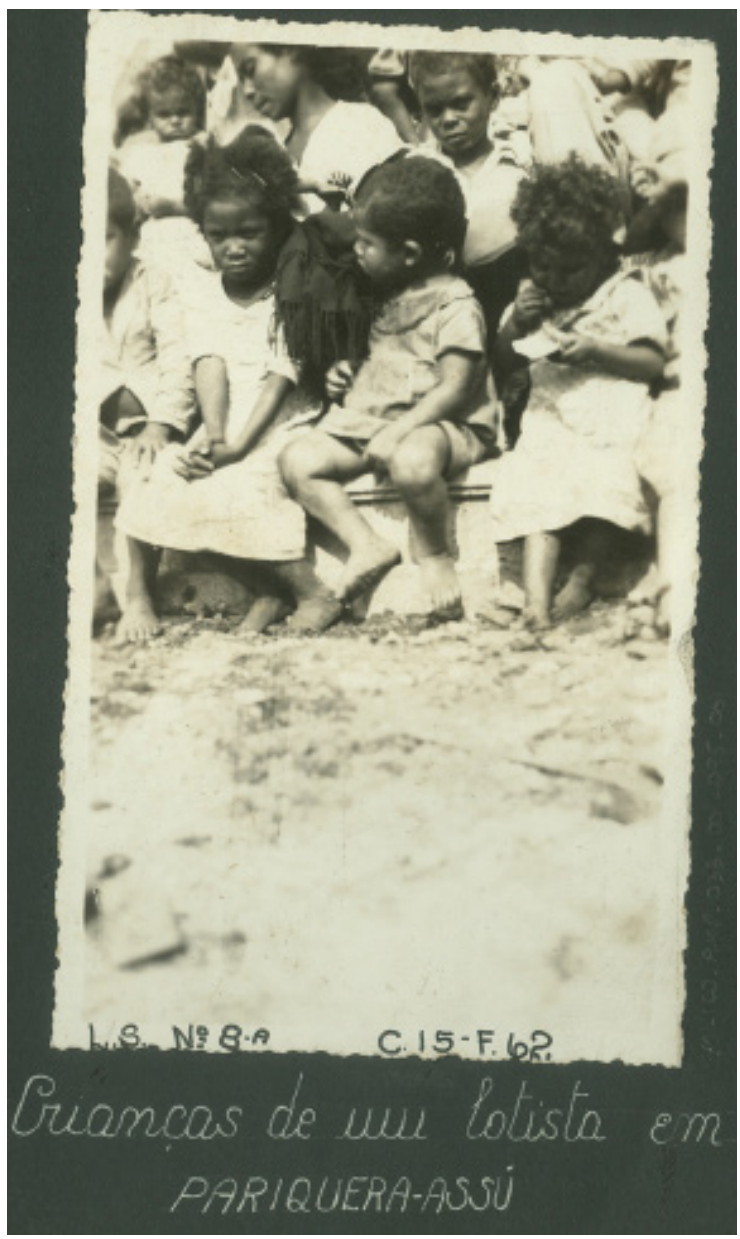

Crianças de um lotista - Pariquera-Açu - SP (APESP) 


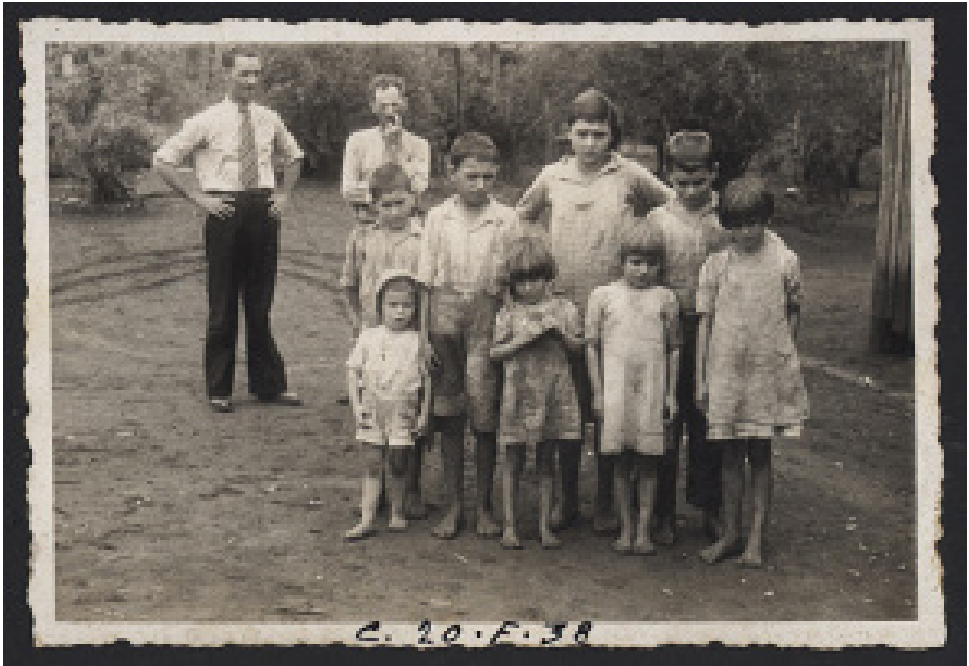

Crianças tracomatosas em núcleo colonial - SP (APESP)

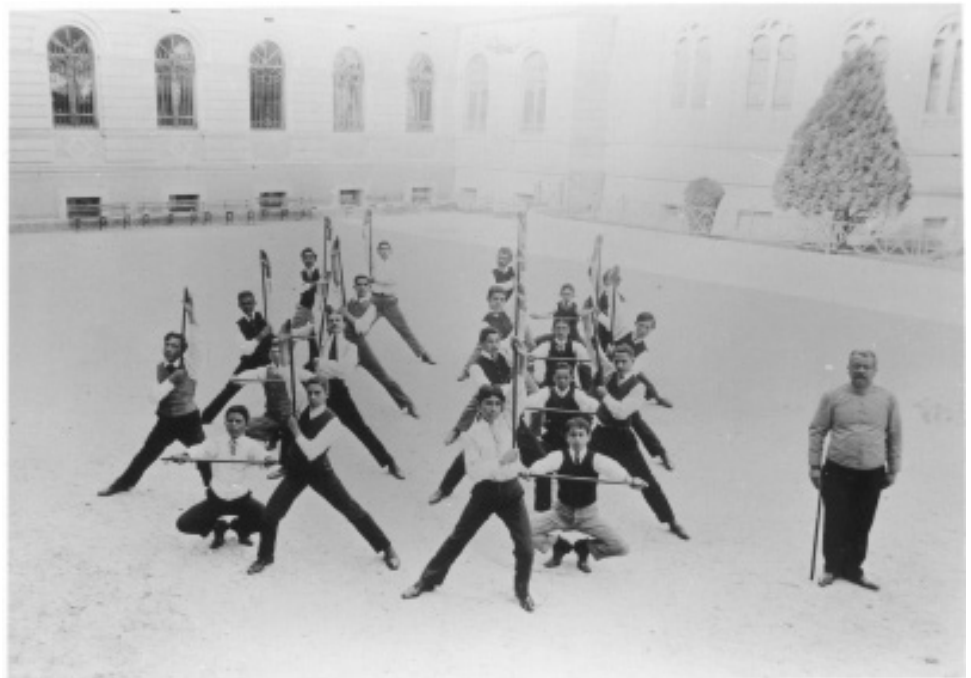

Educando o corpo - Escola Normal da Praça -SP (APESP) 


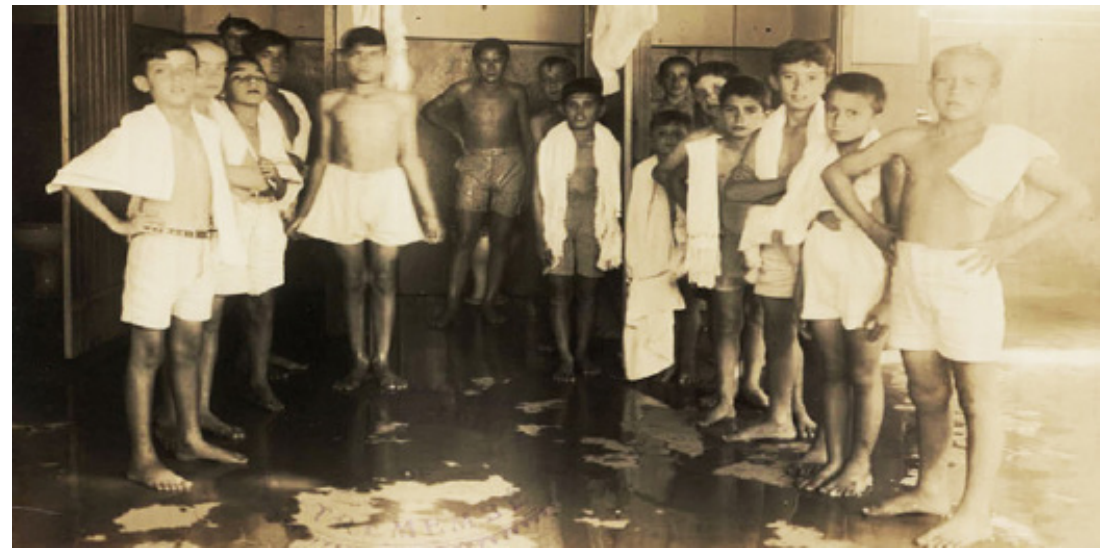

Hora do banho no Grupo Escolar - SP (APESP)

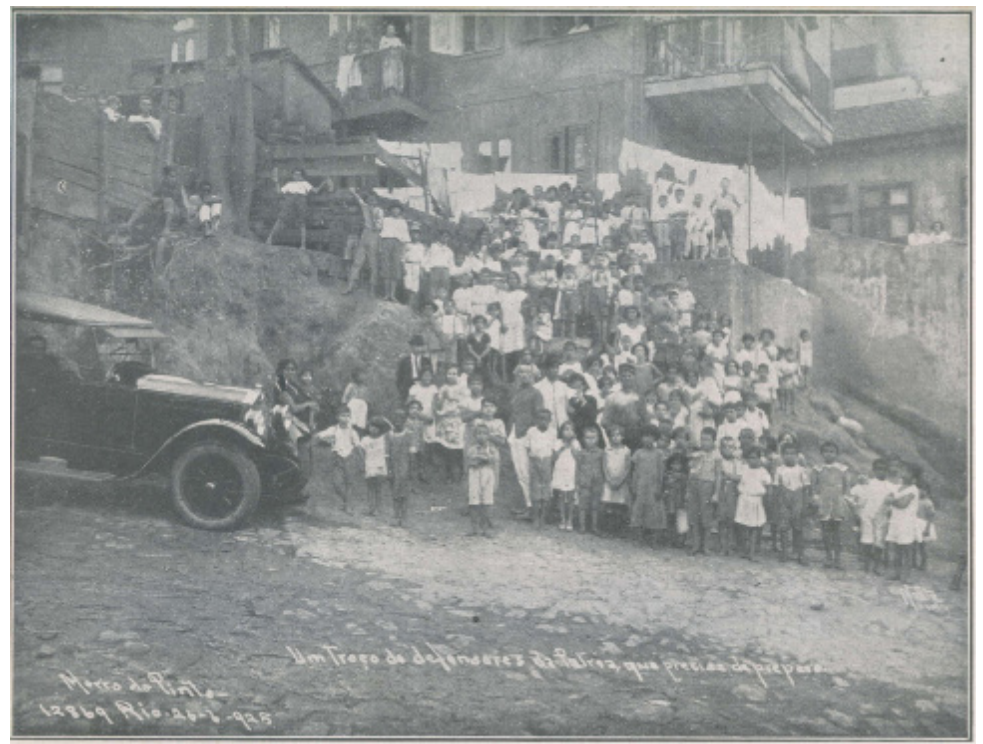

Miséria pública - Distrito Federal - 1925 (CRPHE) 


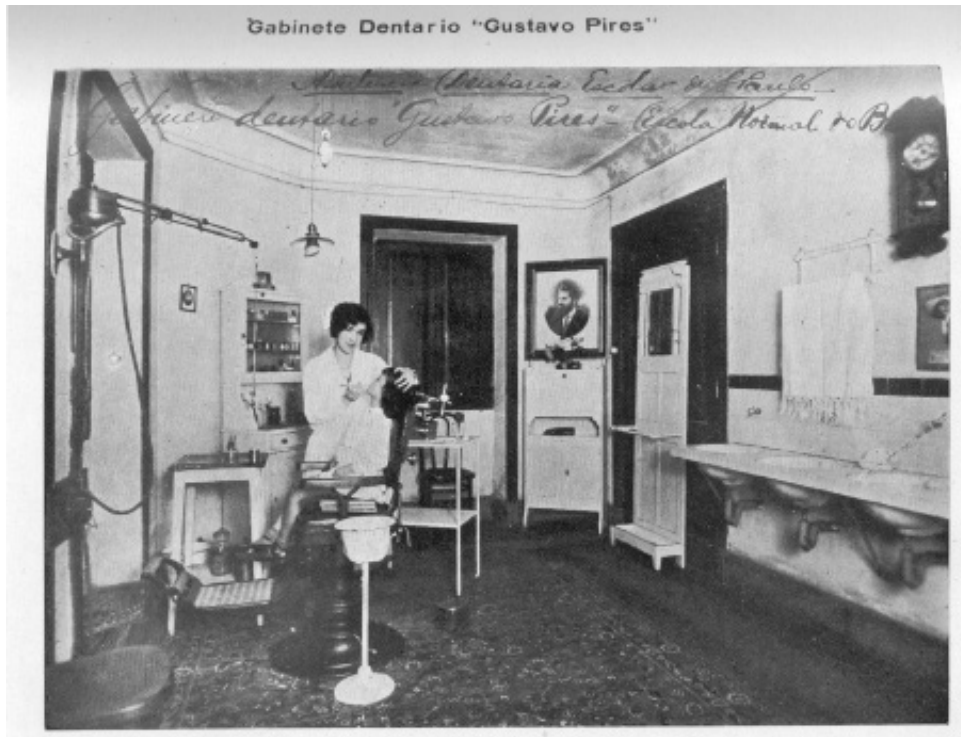

Cliché 10 - A cirurgís dentist, Maria de Lourdos Brasiliano Silveira attendendo uma aluma da Eacola Mo delovio. Braz, annexa á Eacola Normal.

No dentista -Escola-modelo anexa à Normal do Brás - SP (APESP)

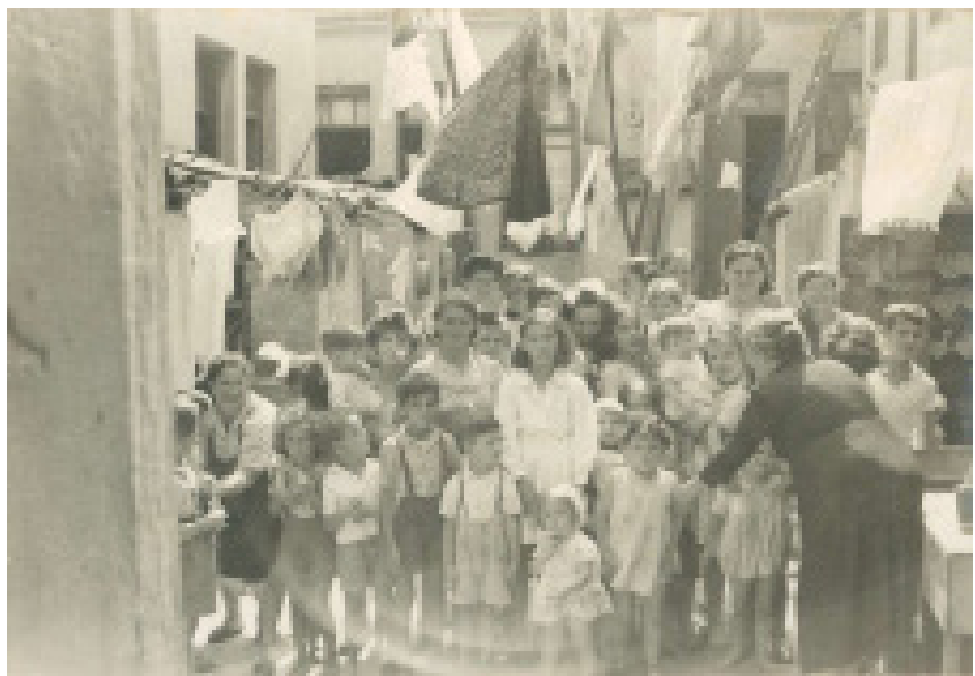

No labirinto dos subúrbios - SP(DPH) 
4. Compreender o mundo, os compêndios

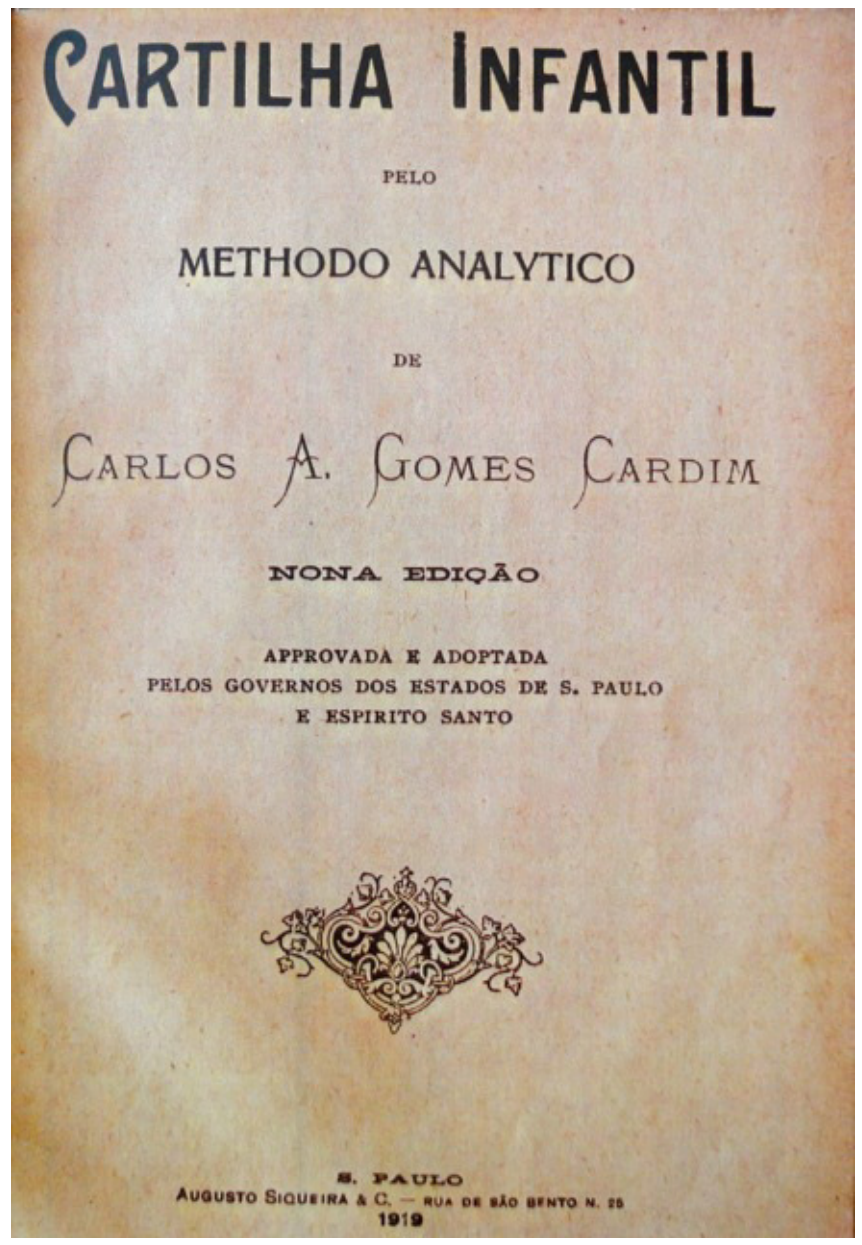

Alfabetizando a infância (CRPHE) 


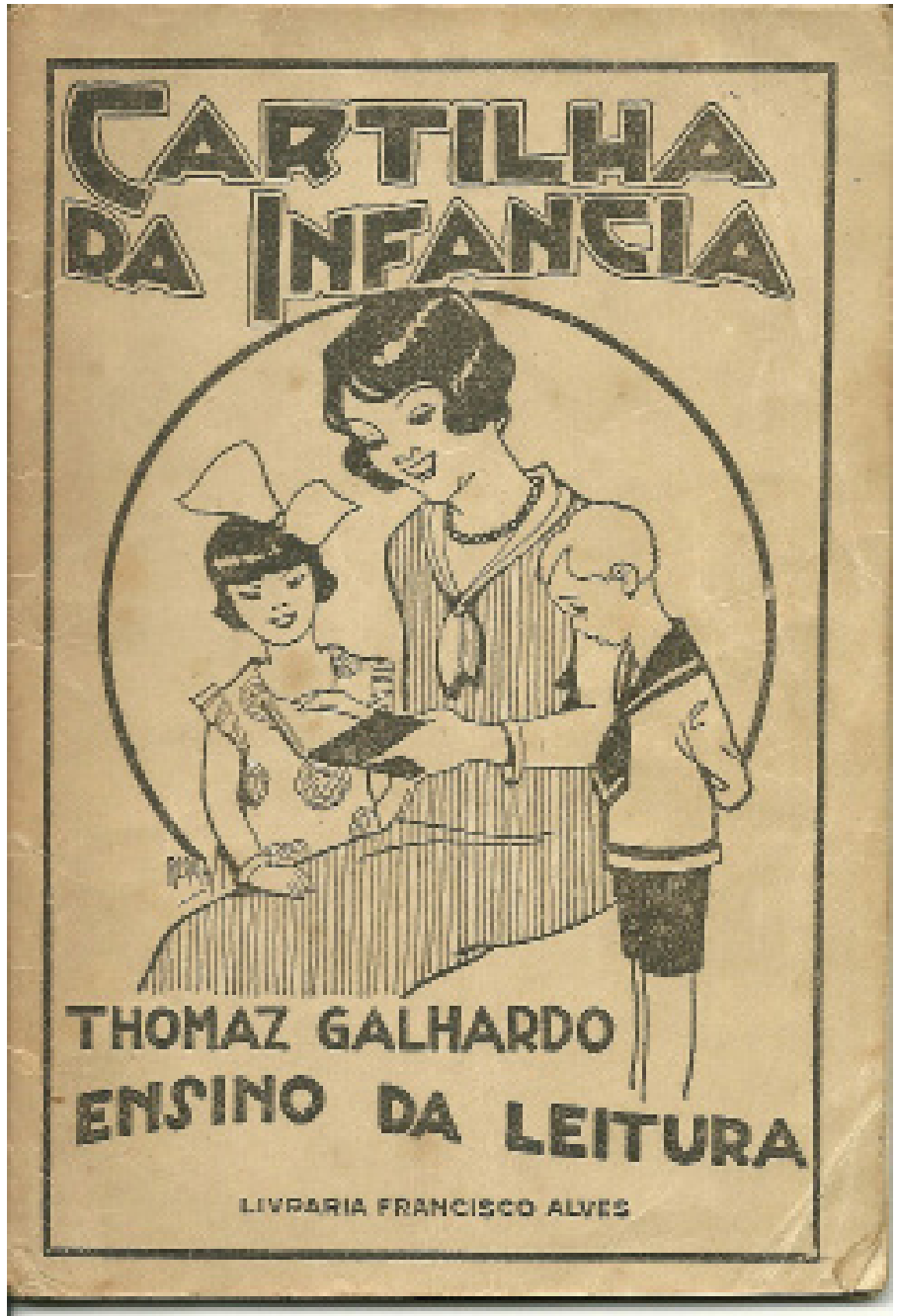

Alfabetizando a infância (CRPHE) 


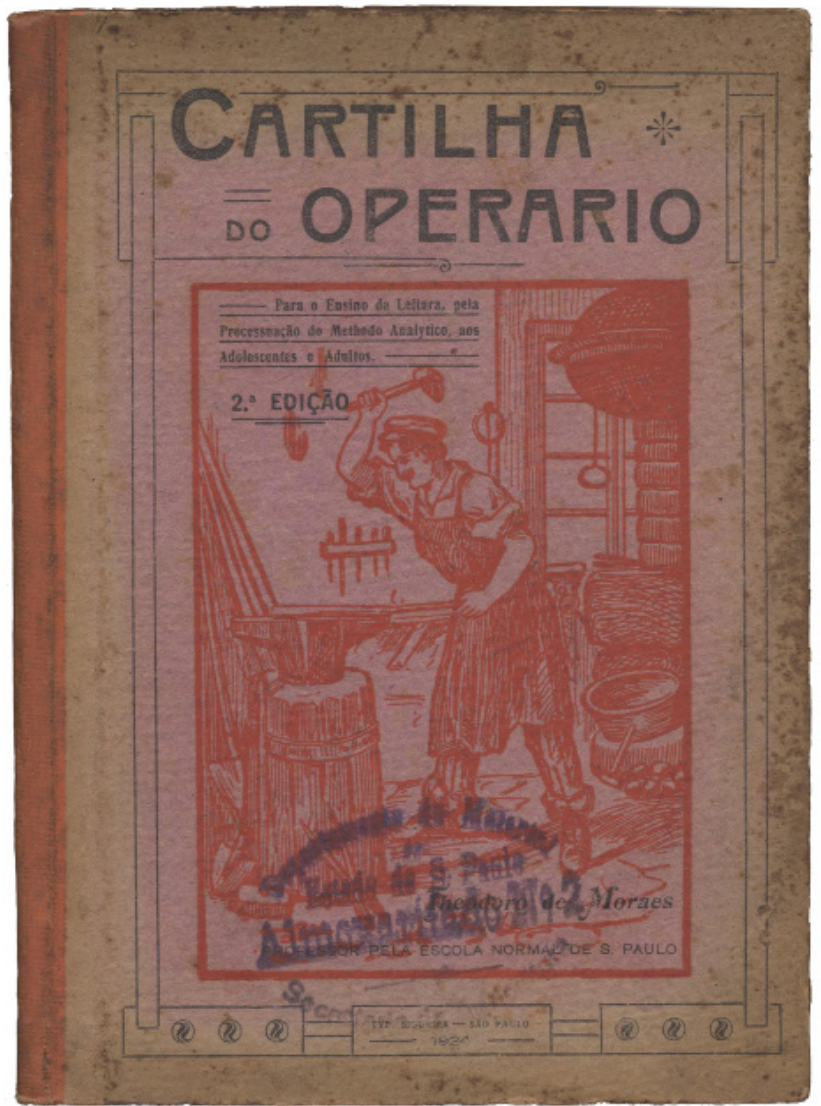

Alfabetizando adultos (CRPHE) 


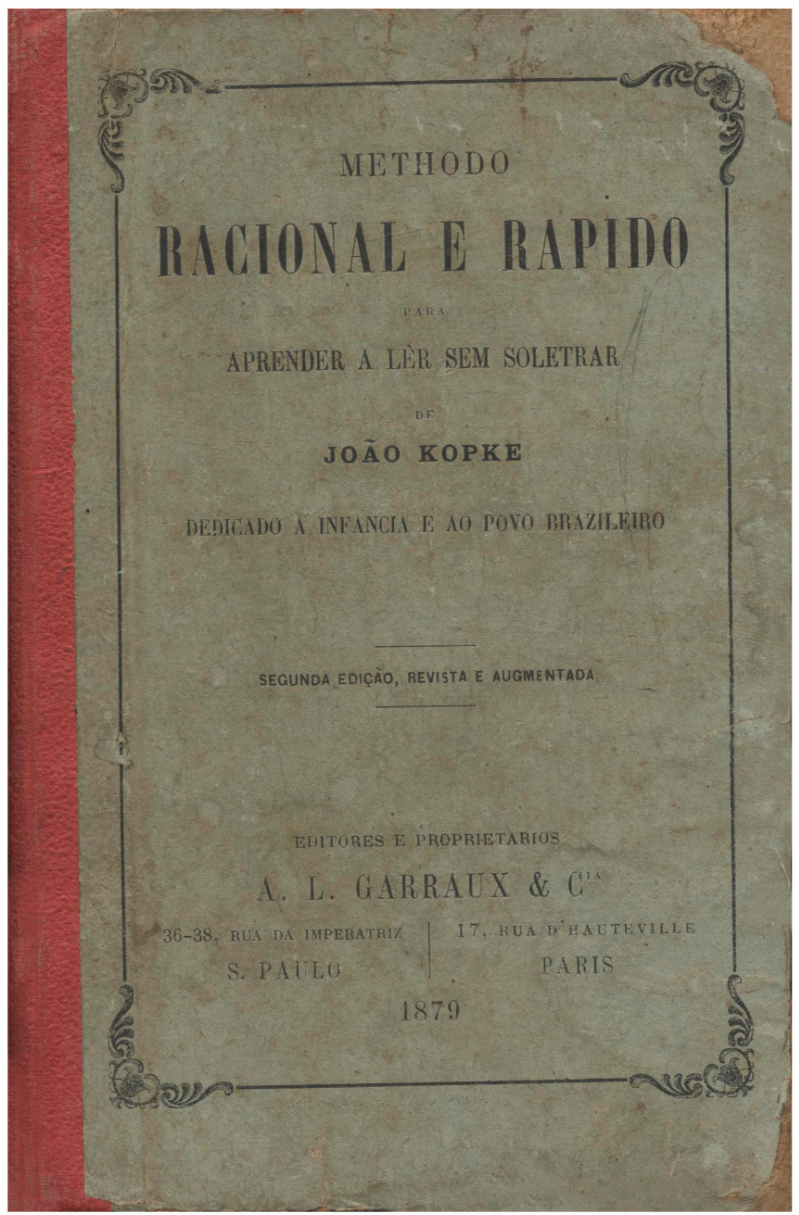

Alfabetização racional - 1879 - (CRPHE) 


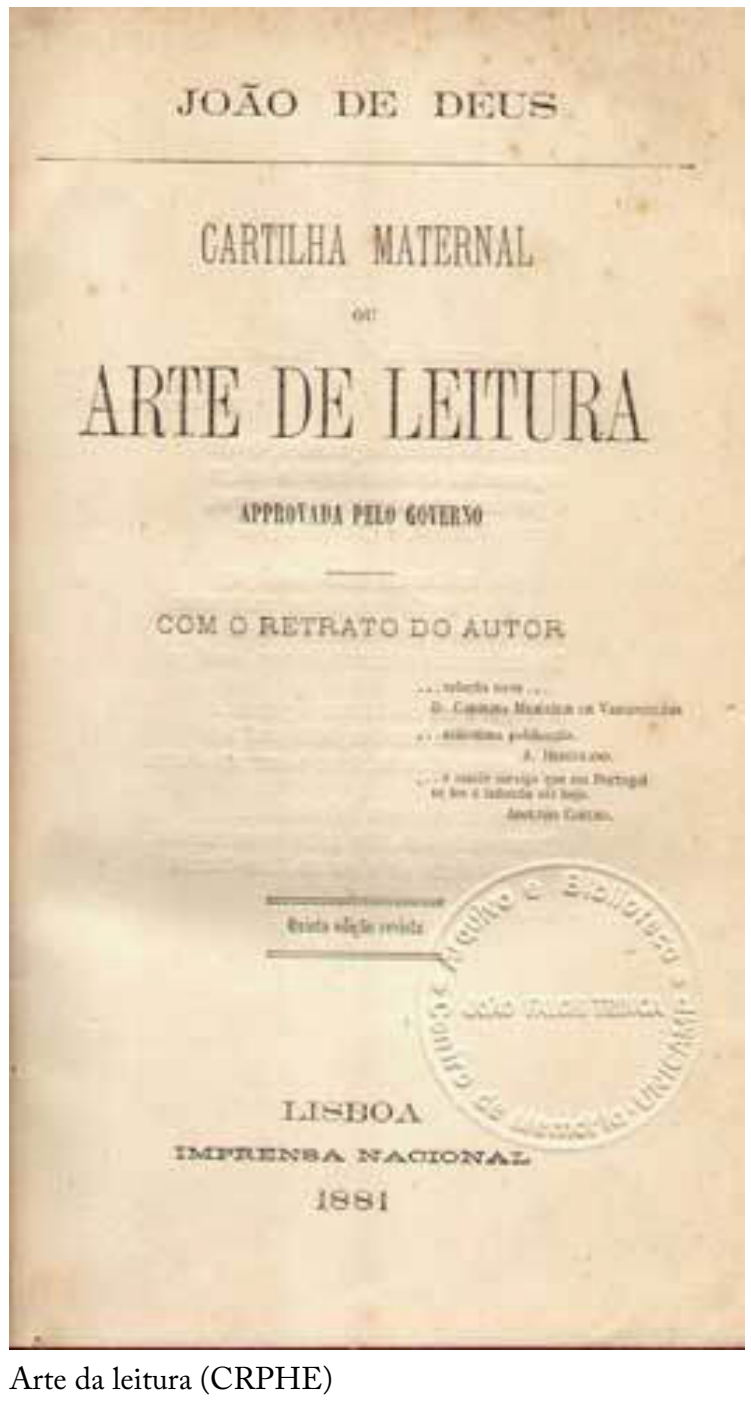




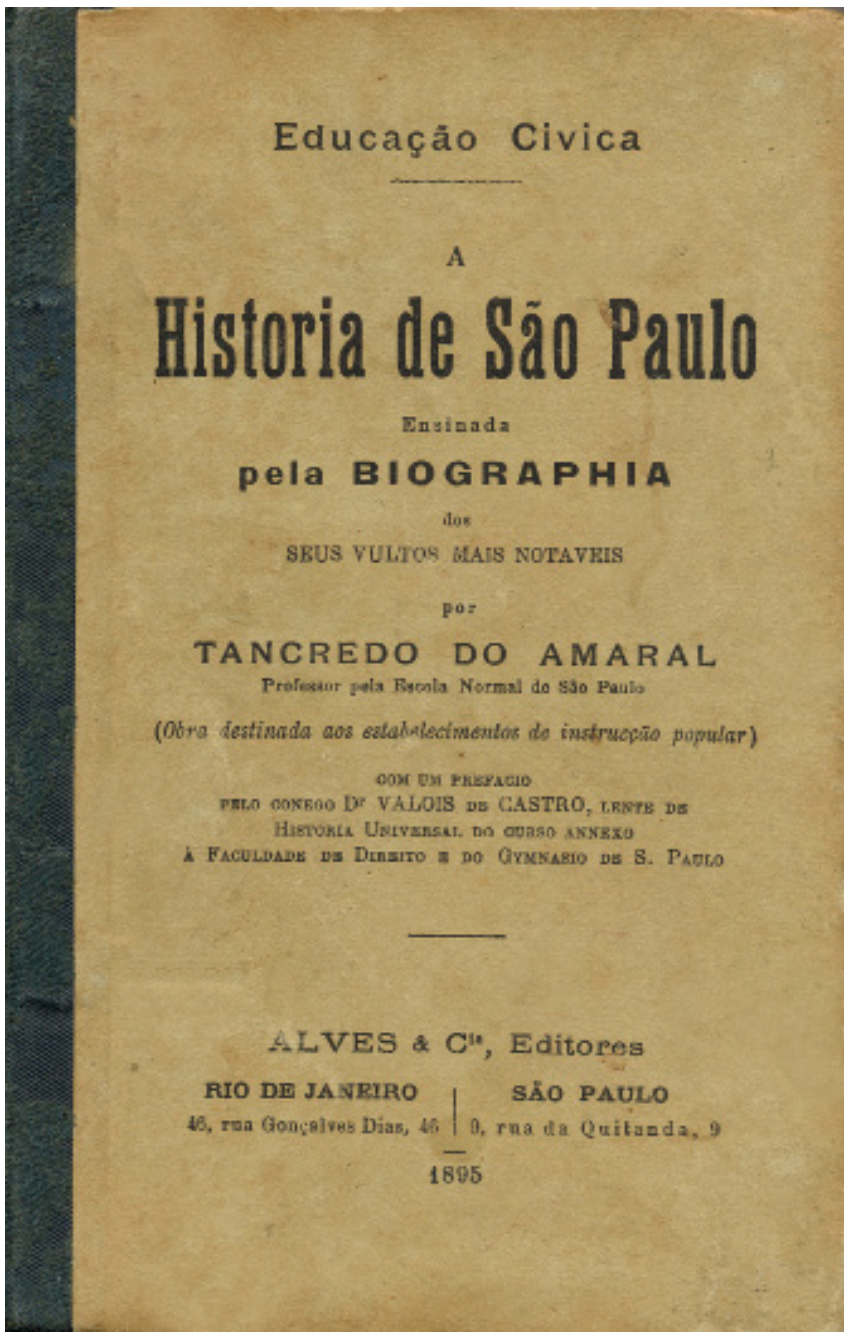

Biografia dos heróis nacionais (CRPHE) 


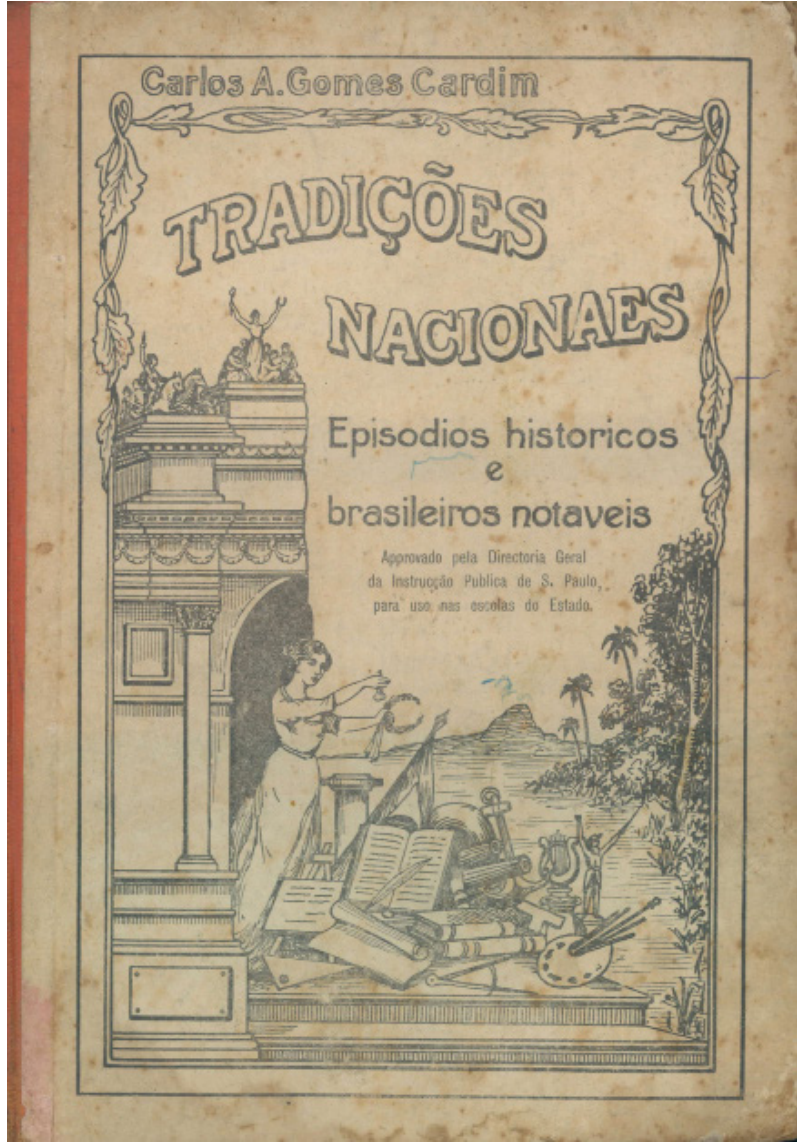

Cultuando exemplos (CRPHE) 


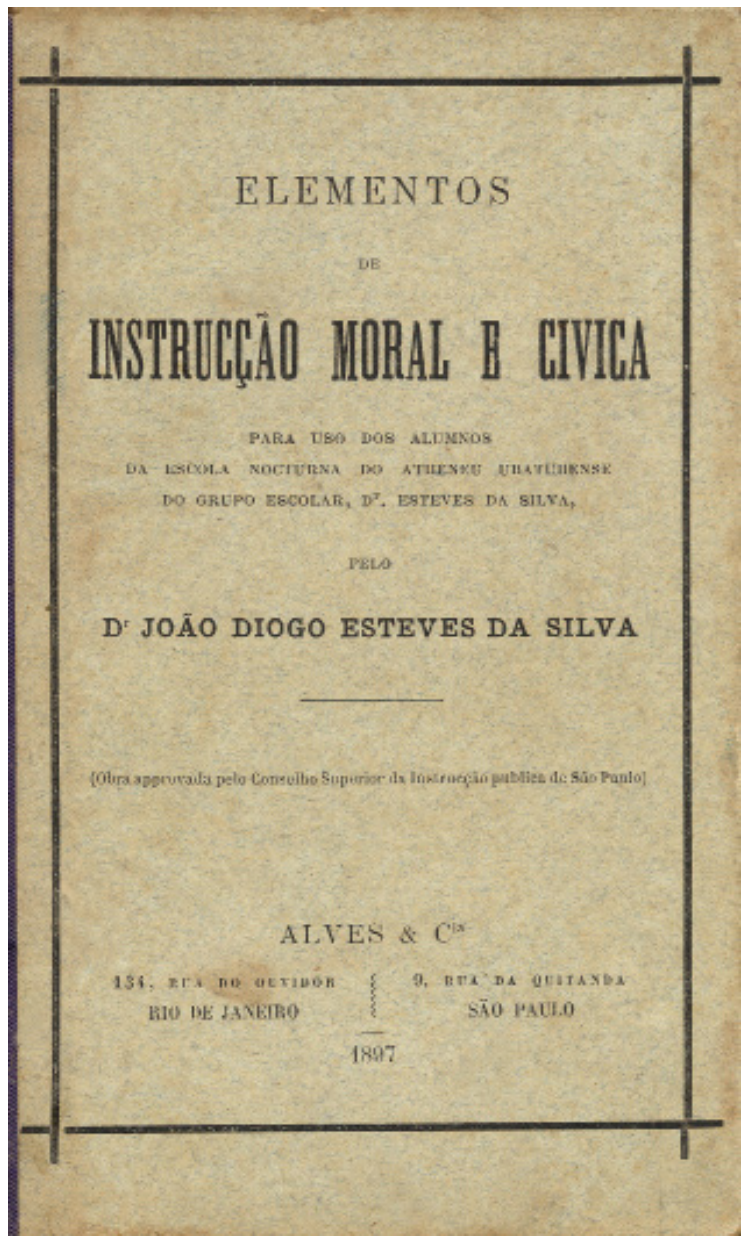

Da moral e civismo (CRPHE) 


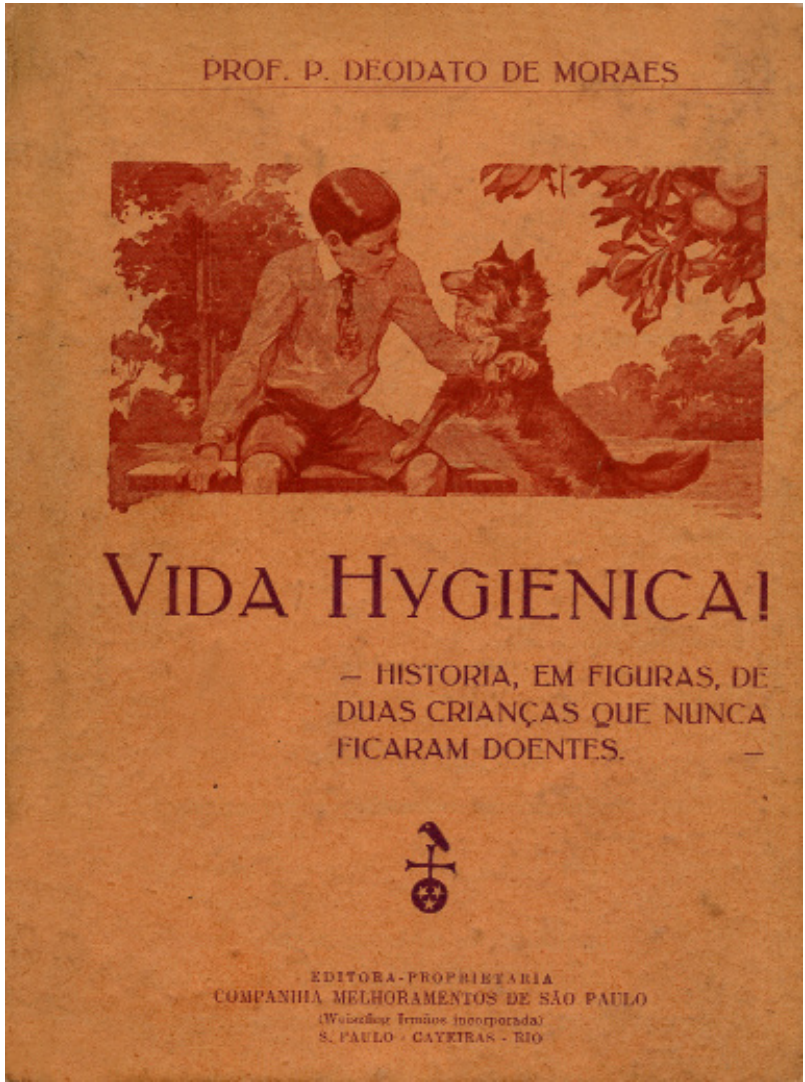

Da salubridade (CRPHE) 


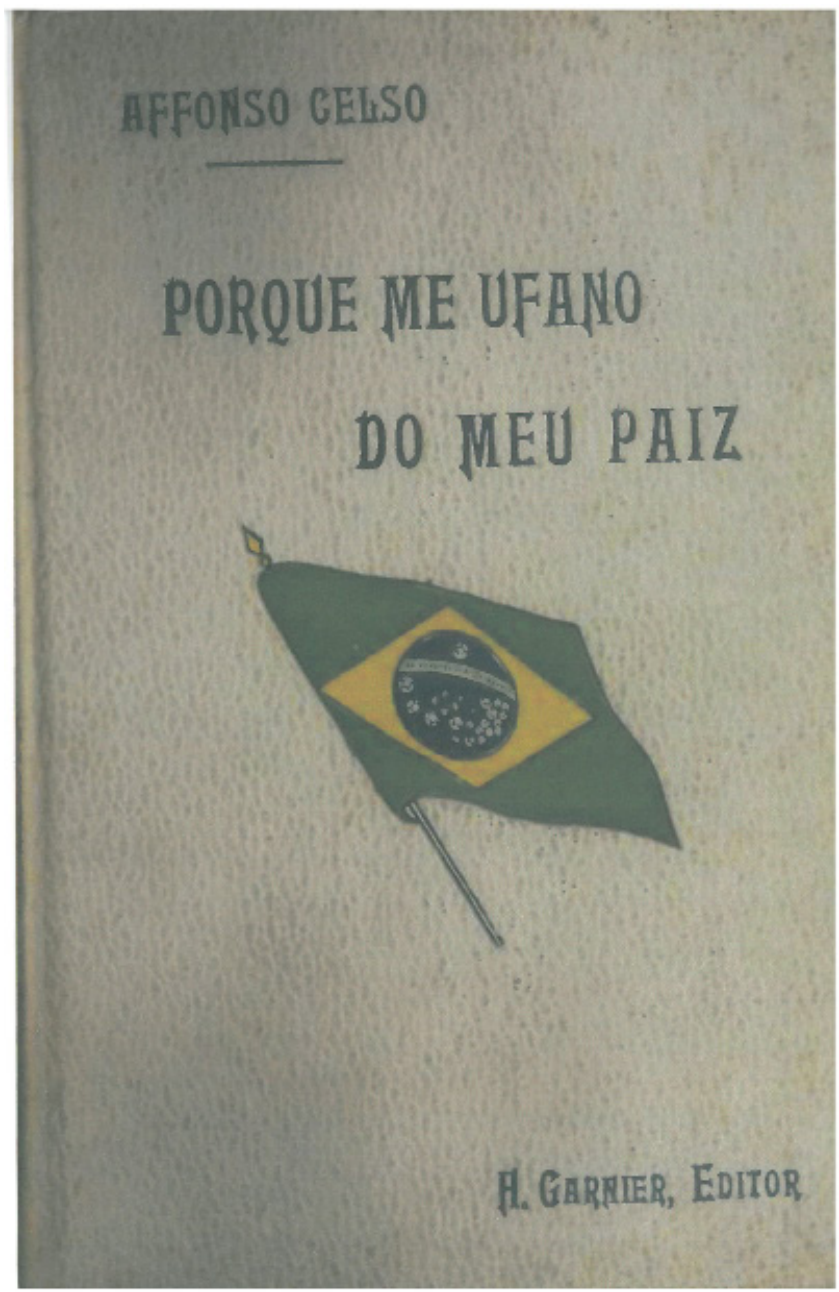

Do ufanismo (CRPHE) 


\section{FLORILRGIO BRASLLEIRO}

D)

\section{IX)}

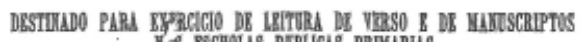
IIS ESCHOLAS PCBLLCAS PRIMARIAS

Por.

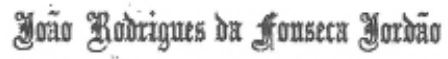

Professor Publico no Municipio da COrte.

Obra adoptada pelo Conselho Superior da Instruefto Publiea, eom approvacio do Governo Imperial,

para uso das eseholas joblitas do ensiao primario, e do Imperial Collegio de Pedro If.

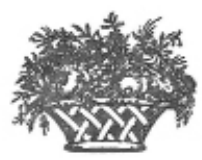

RIO DE JANEIRO.

JENDE-SE NA LIVRARIA CLASSICA DO EDITOR

NICOLAO-ALVES

48 Rua de Gonçalves Dias 48

$\overline{1874}$

Leitura de versos e manuscritos - (CRPHE) 


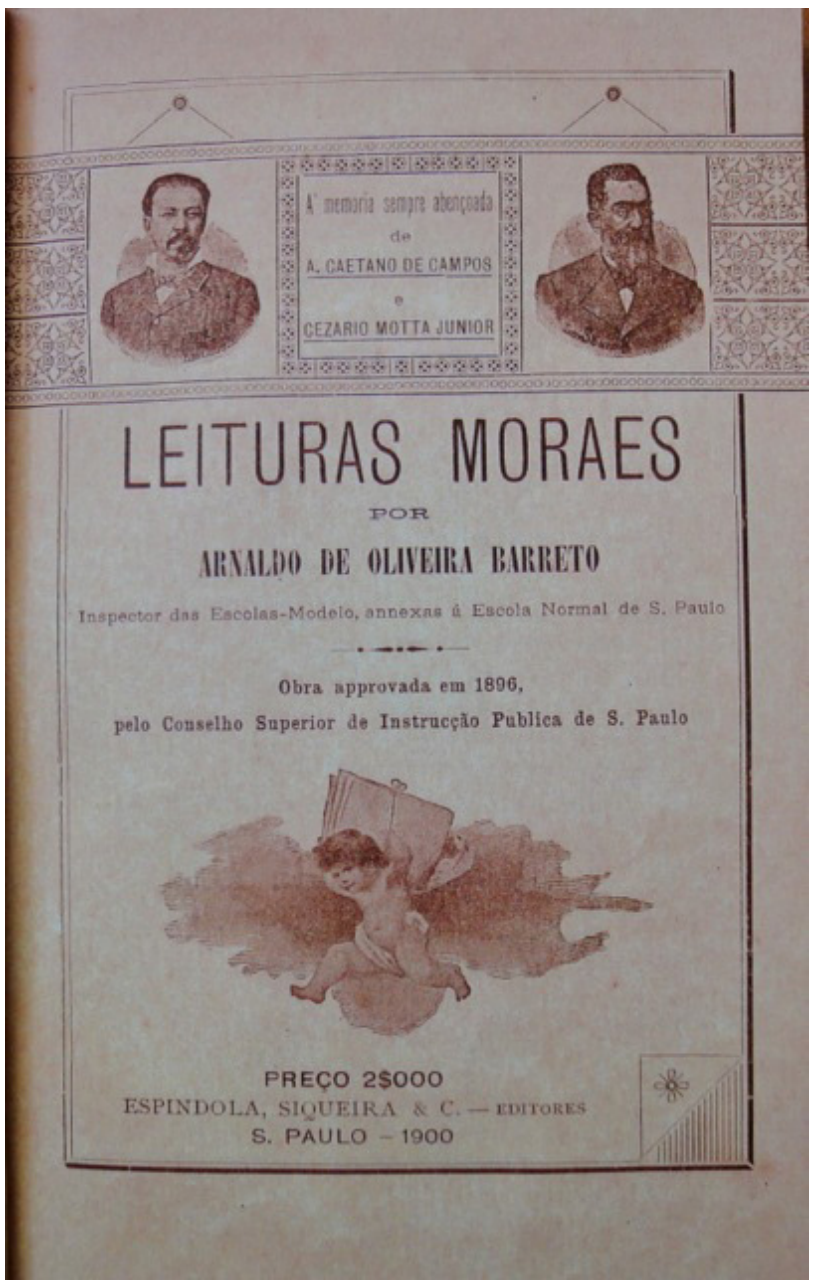

Leituras morais (CRPHE) 

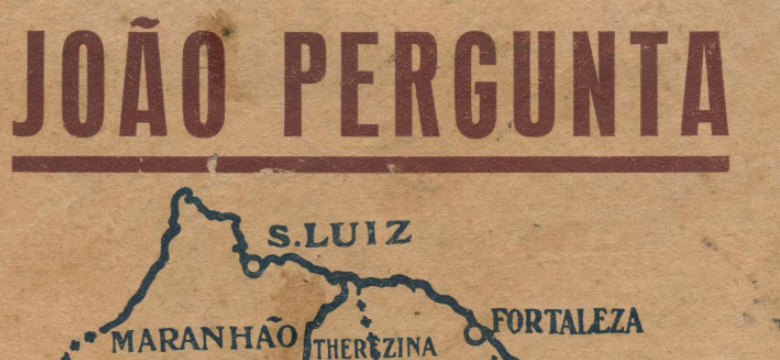
CEARA

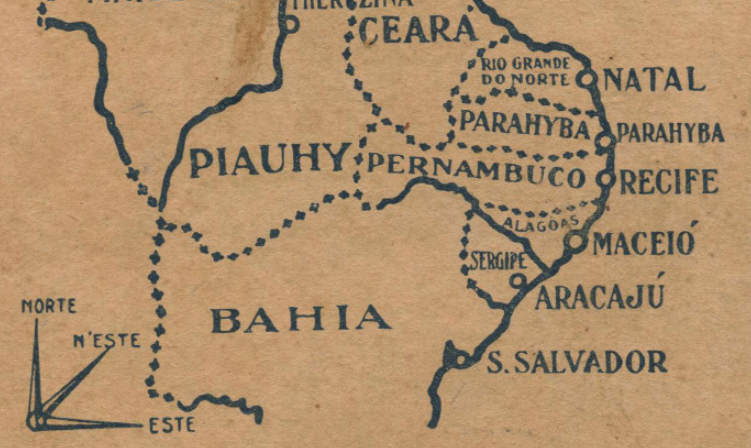

Livro de Leitura destinado ás crianças do Nordéste Brasileiro por

\section{NEWTON CRAVEIRO}

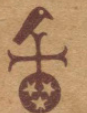

Livro de leitura para o meio rural (CRPHE) 


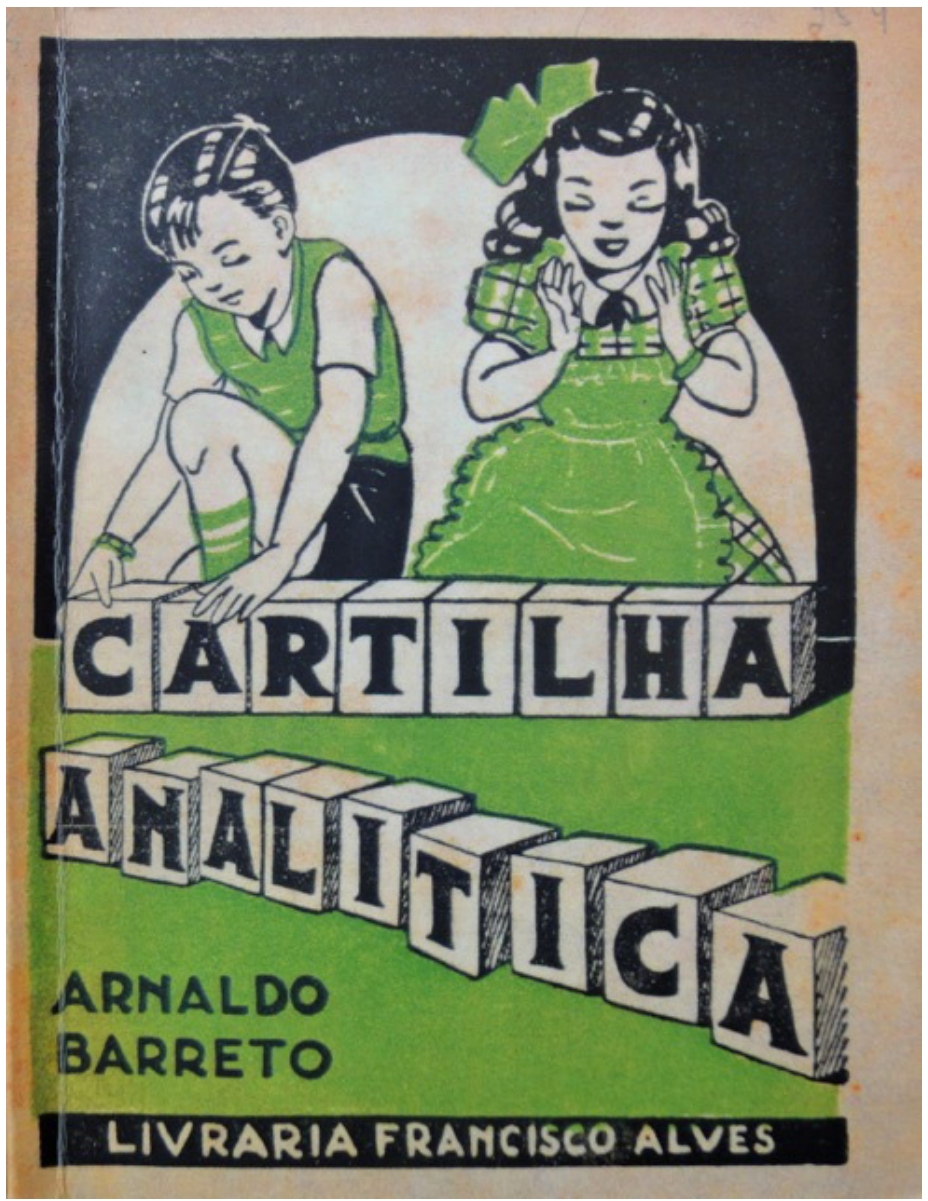

Métodos modernos (CRPHE) 


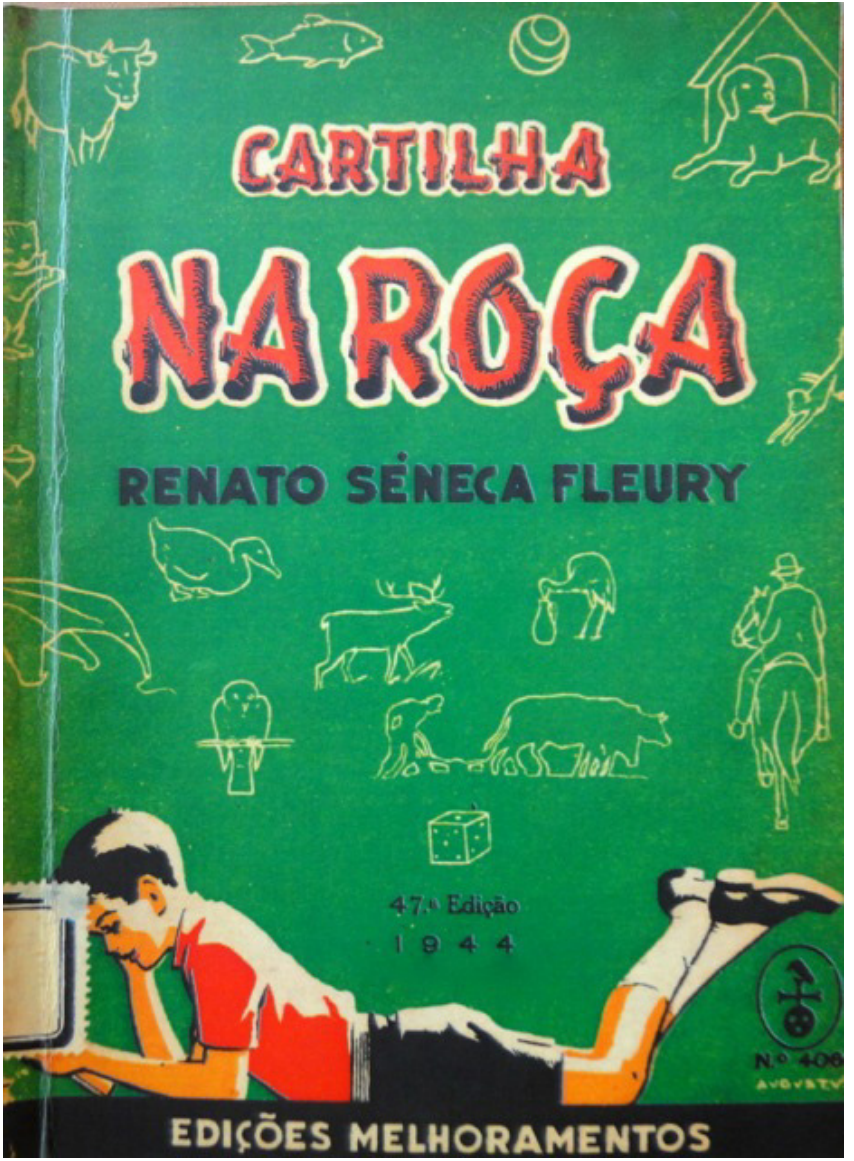

$\mathrm{Na}$ roça (CRPHE) 


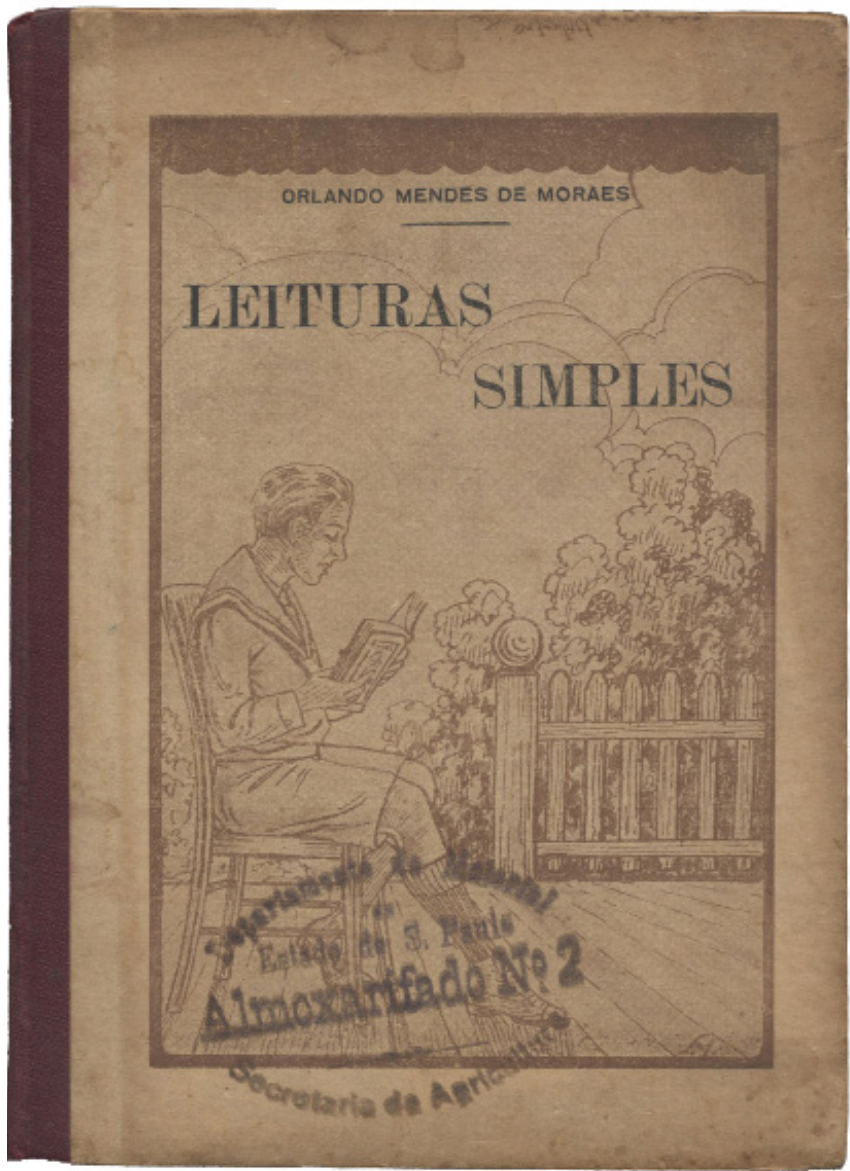

Primeiras leituras - 1931 (CRPHE ) 


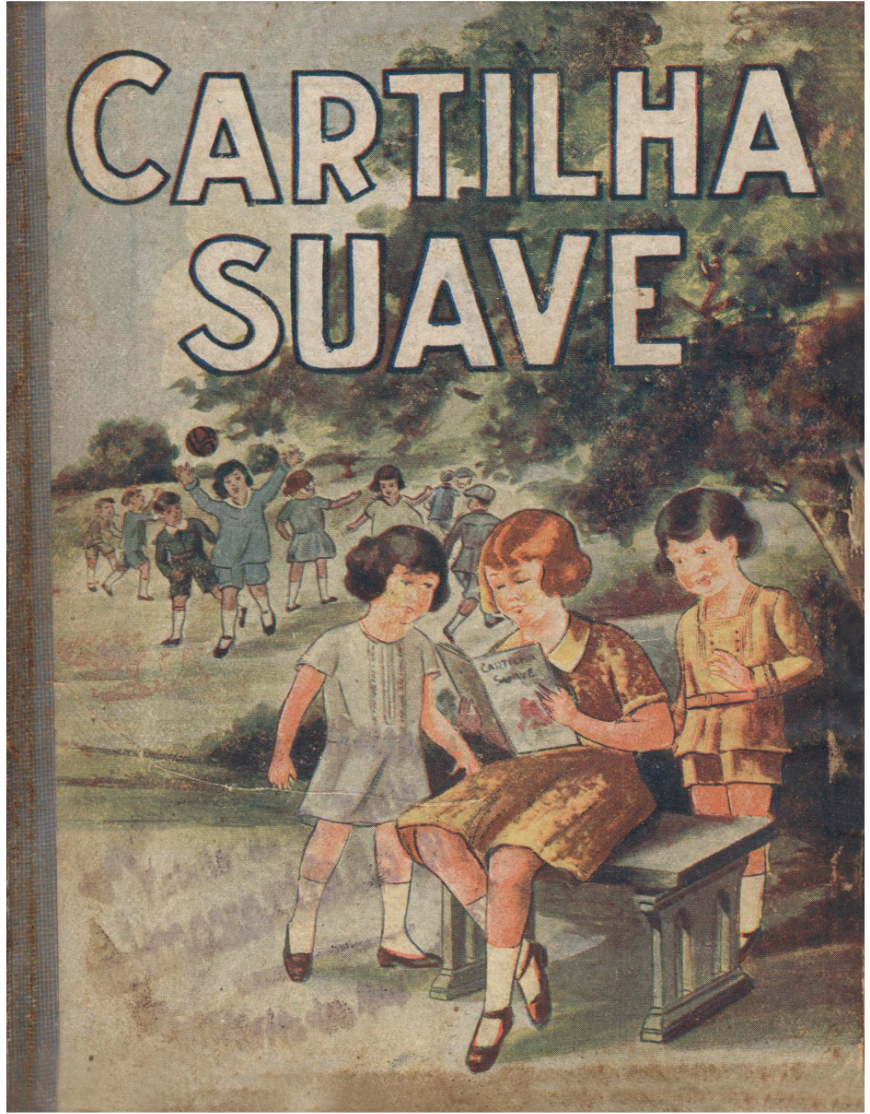

Suavizando as dores da aprendizagem (CRPHE) 


\title{
ESCOLA BRASILEIRA
}

\author{
O U \\ IATSTRUCÇẢO UTIL \\ $\boldsymbol{A}^{\prime}$
}

TODAS AS CLASSES

BXTRA HID A

DA SAGRADA ESCRIPTURA

PARA USO DA MOCIDADE.

P 0 B

JOSE' DA SIIVA IISBOA, VISCONDB DB CAYRU'; SENADOR DO IMPERTO, MBMBAO DA SOCIEDADE PHILOSOPHICA DB PHLLADLPHIA, =70.

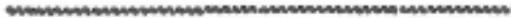

Os que sccendsw huma luserna, nlo a mottem debaixo do alqueine, mas a poo sobro - candisiro, a fm de qus laza a todos que est]̄o na Casti. - S. Math. V. 5.

VOL. I.

RIO DE JANEIRO, NA TYPOGRAPHIA DE P: PLANGHER-SEIGNOT.

$$
1827 .
$$

Útil instrução (CRPHE) 


\section{Celebrações sob o céu azul}

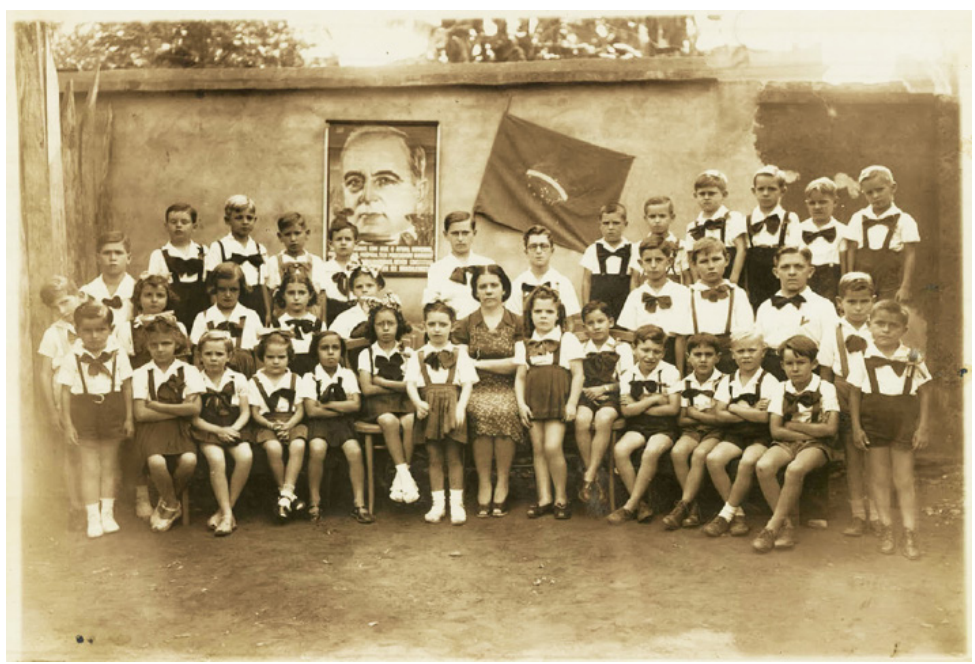

À sombra de Getúlio - escola particular - SP (APESP) 


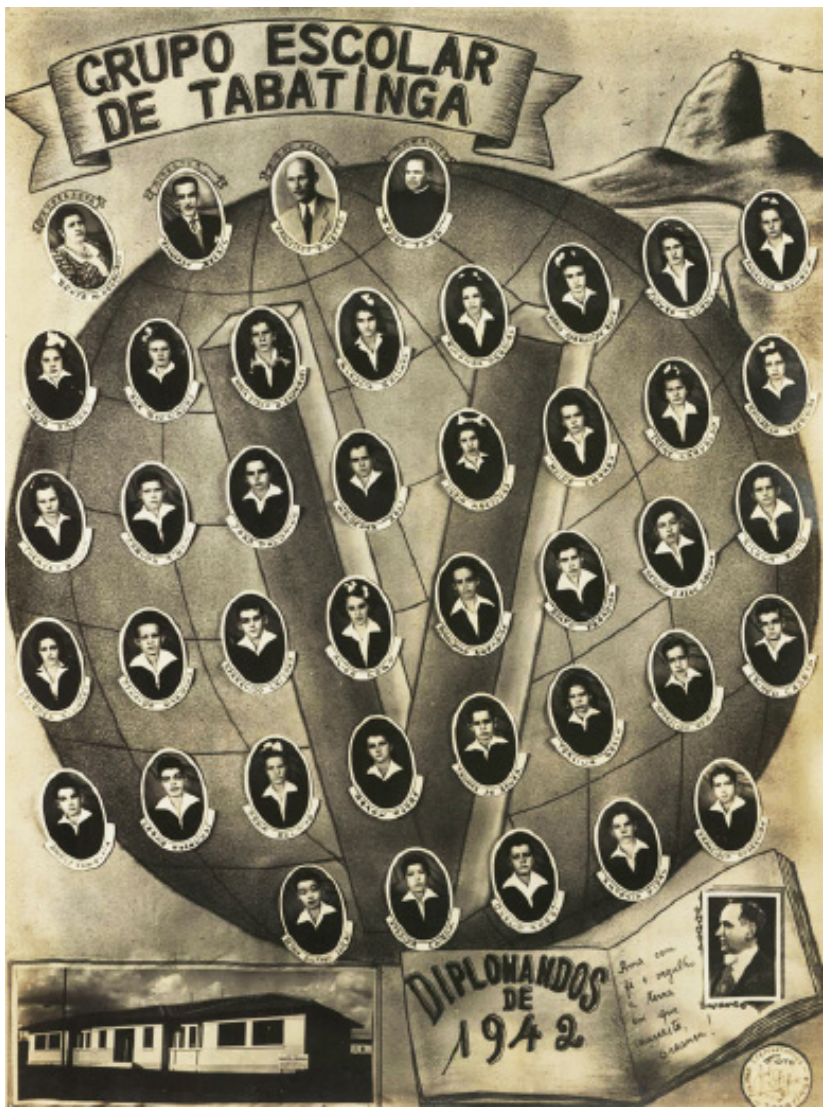

Ama com fé e orgulho a terra em que nasceste, criança! - SP (APESP) 


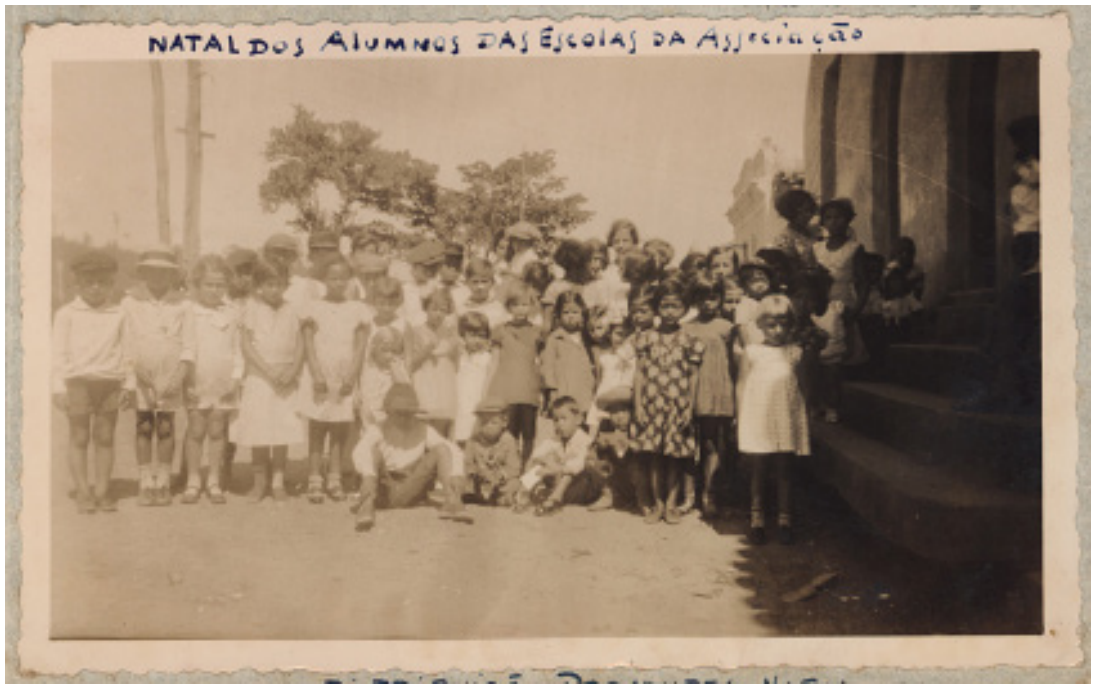

Celebração do Natal - SP (APESP)

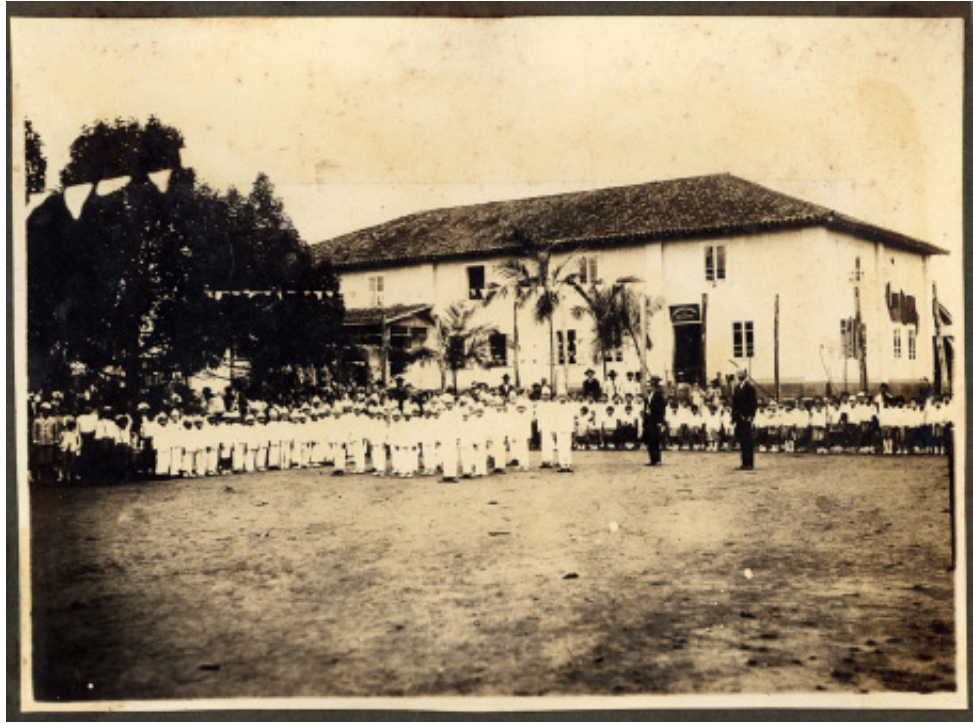

Festa da Árvore - SP (APESP) 


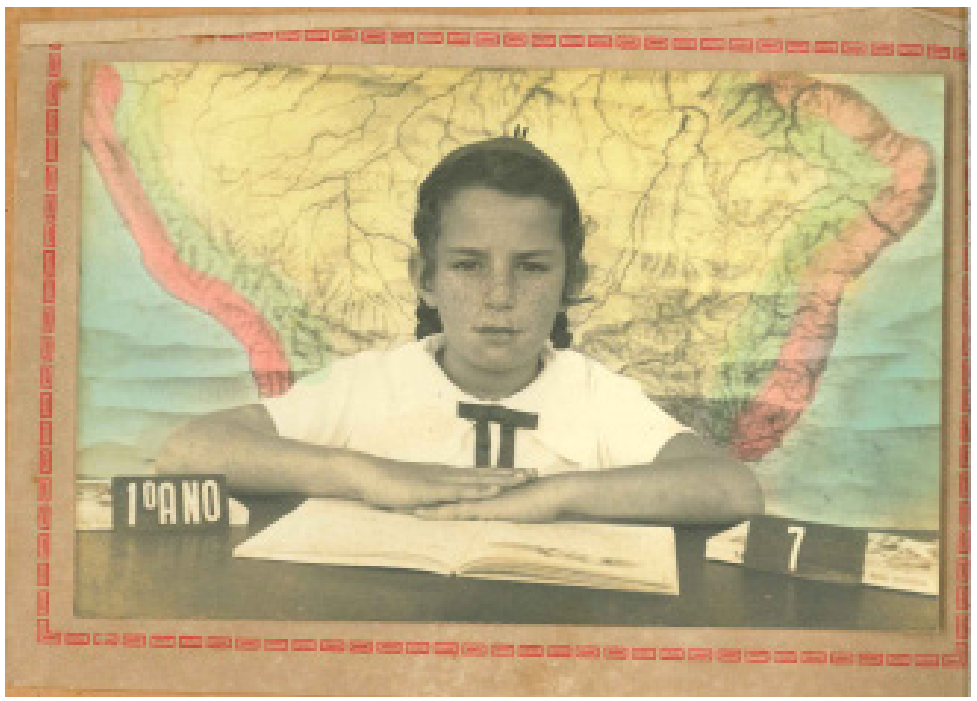

O dia esperado (CRPHE)

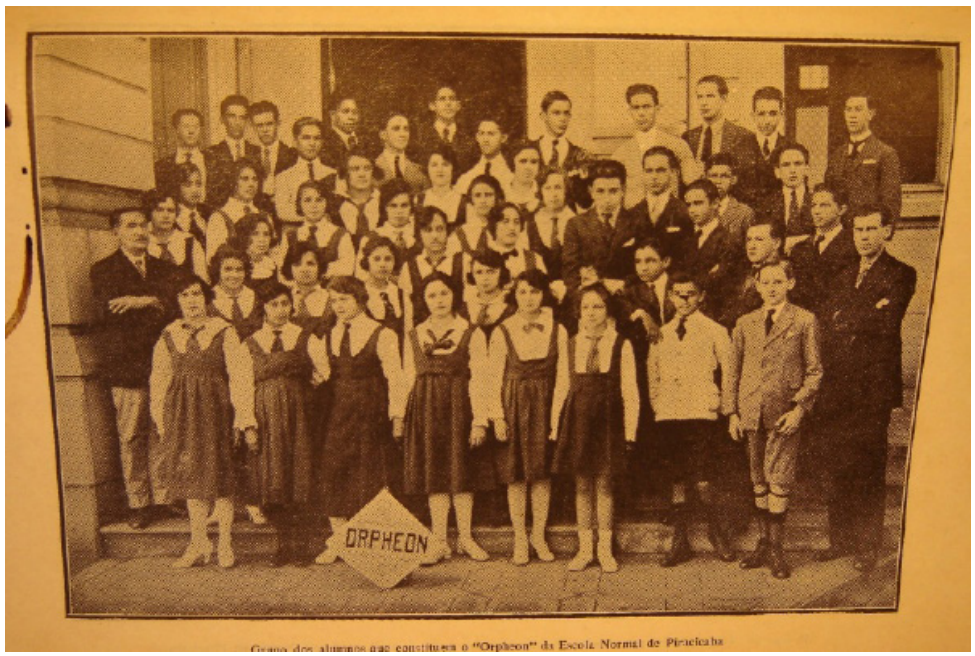

Orfeão da Escola Normal de Piracicaba - SP (CRPHE) 


\section{PAVILHÃO ESCOLAR DO ESTADO DE SÃO PAULO}

INSTITUIDO DELO DECR. 3467 DE 1: DE JUPHO DE 1922

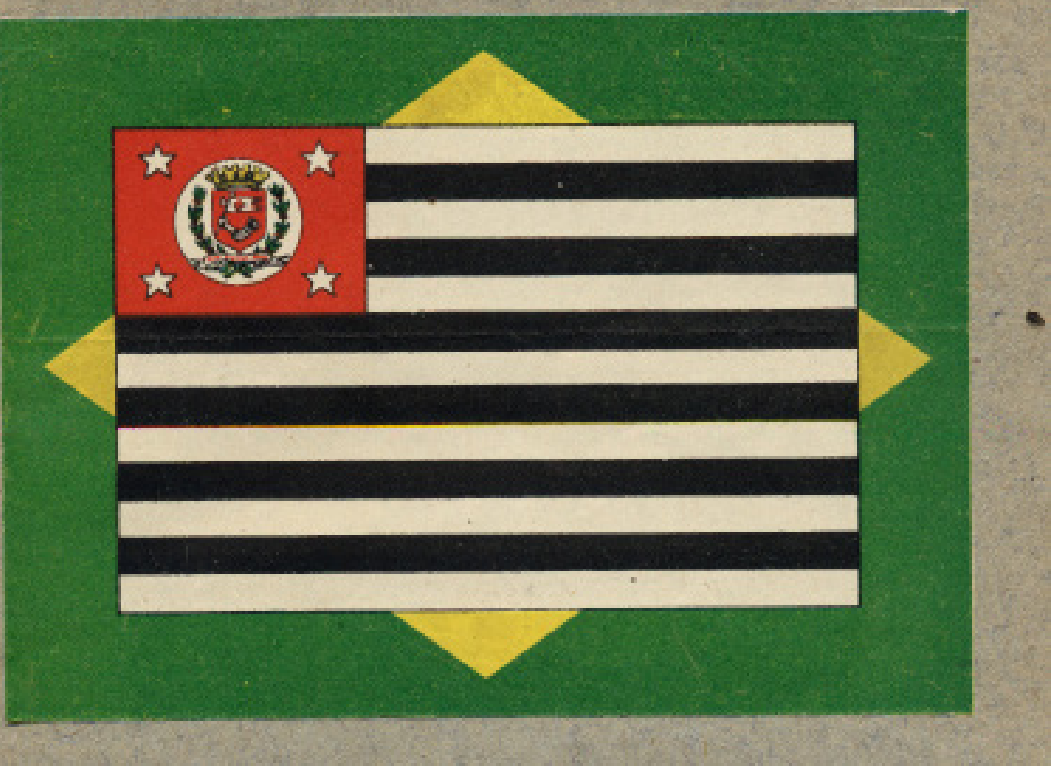

Pavilhão Escolar do Estado de São Paulo (CRPHE) 


\section{Entrecruzando recordações}

\section{Ao Fornecedôr \\ DAS ESCOLAS PUBLICAS}

Carabina escolar de fabricaçao propria, distinctivos e medalhas para premios

Rua Josẻ Bonifacio, 29-Telephone, x6.58 S. PAULO

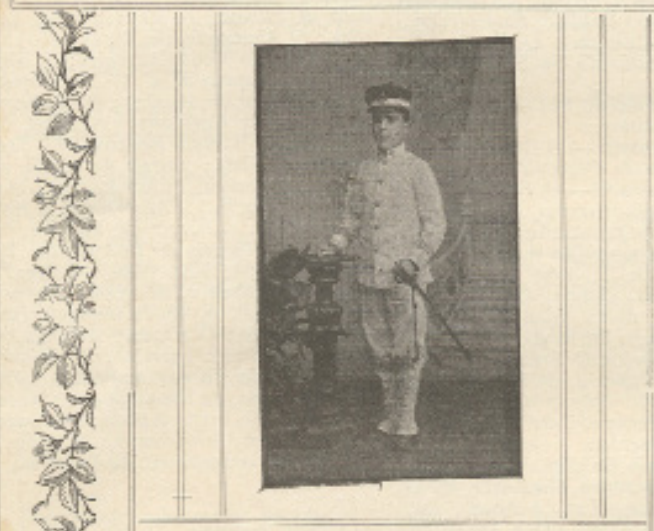

Fardamentos escolares e fabrica de bonés. Unica casa neste ramo que fornece tudo que é preciso para os Grupos escolares. Lyceus e Collegios particulares * * * * SECCATO DE FXFRCICIOS MILTTARES Amamentos, Espadas, Tambires, Cametas, Divisns. Especialidade en Pstandartes bordados, Bandeiras

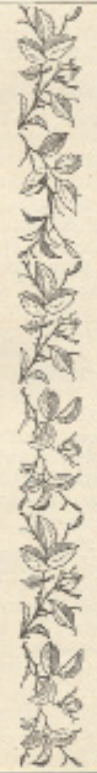

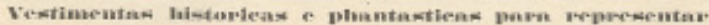
CASA DE CONFIANÇA - IMPORTAÇĀO DIRECTA A. BOGGIANI

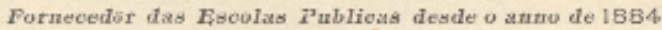

Belo uniforme (CRPHE) 


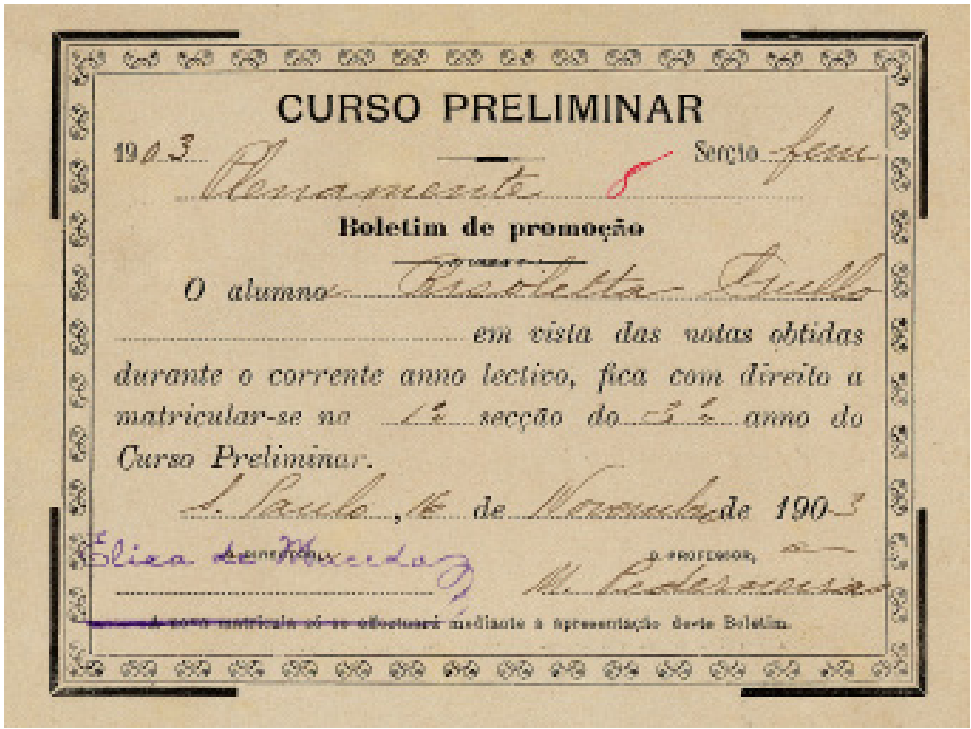

Boletim de Promoção (CRPHE)

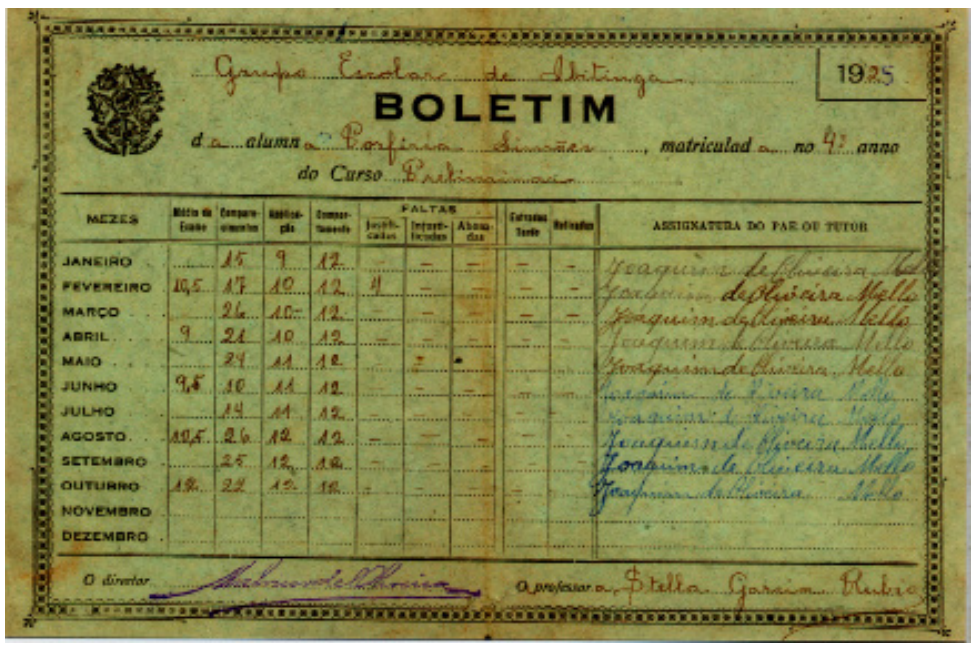

Boletim escolar (CRPHE) 


\section{Conacina \\ Qutuluo \\ Cpininerio dia du eseota.}

Segrander-fines, 18

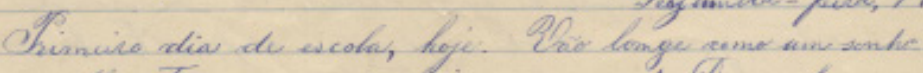

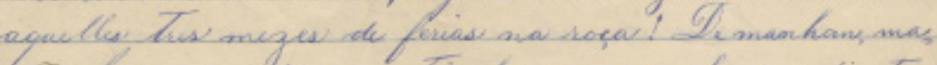

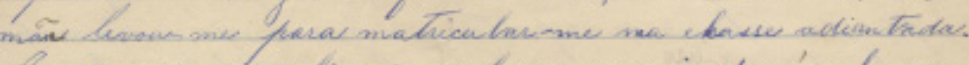

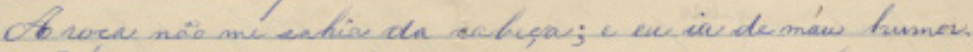
ote suar estaman chias de meminas; dis dreas liversias

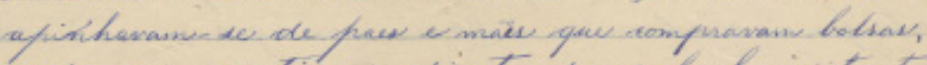

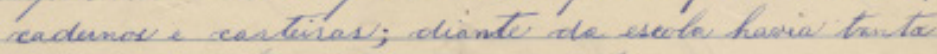

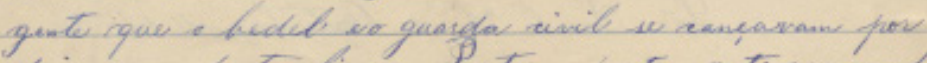
deicar a fouta liver Santo a fouta, enti que me lo.

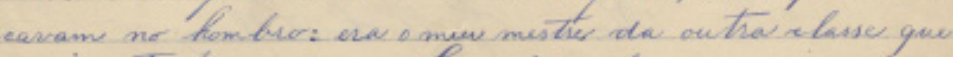

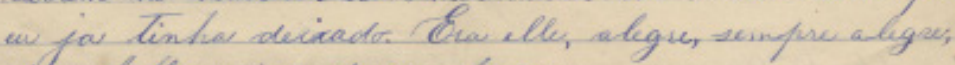
de reabulles invios dexgreenhadose.

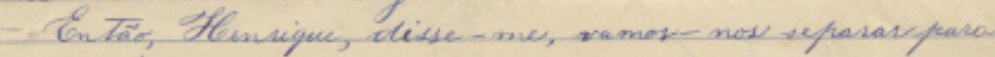
Lempiee!

Bum e vadia us mas aquellas pelasizas me doesam dentró d'alma.

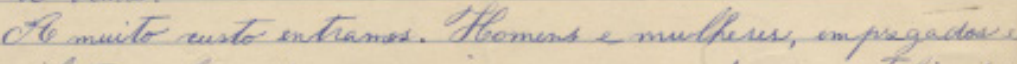

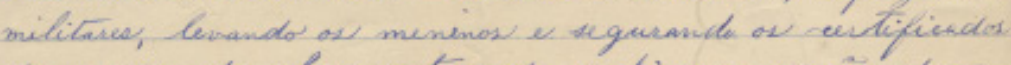
de areesso da clase atraguda, enchiame saguai da wu

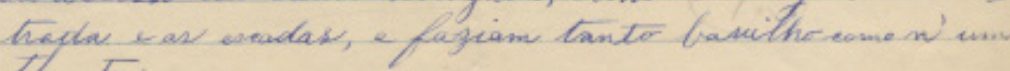
Thear to.

tom raudede binvi a vis aque lla sata grandes larga,

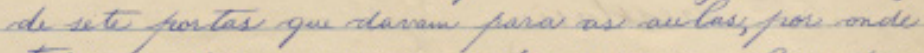

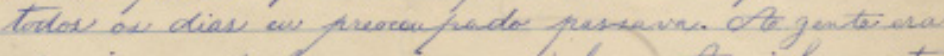

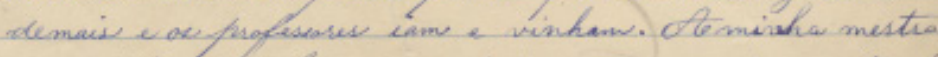

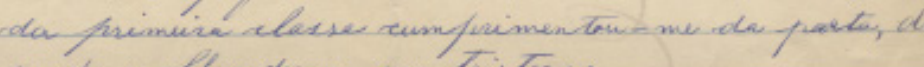

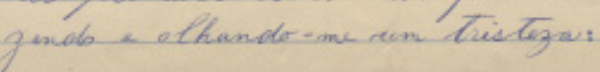

\section{Copiando Coração de Amicis (APESP)}




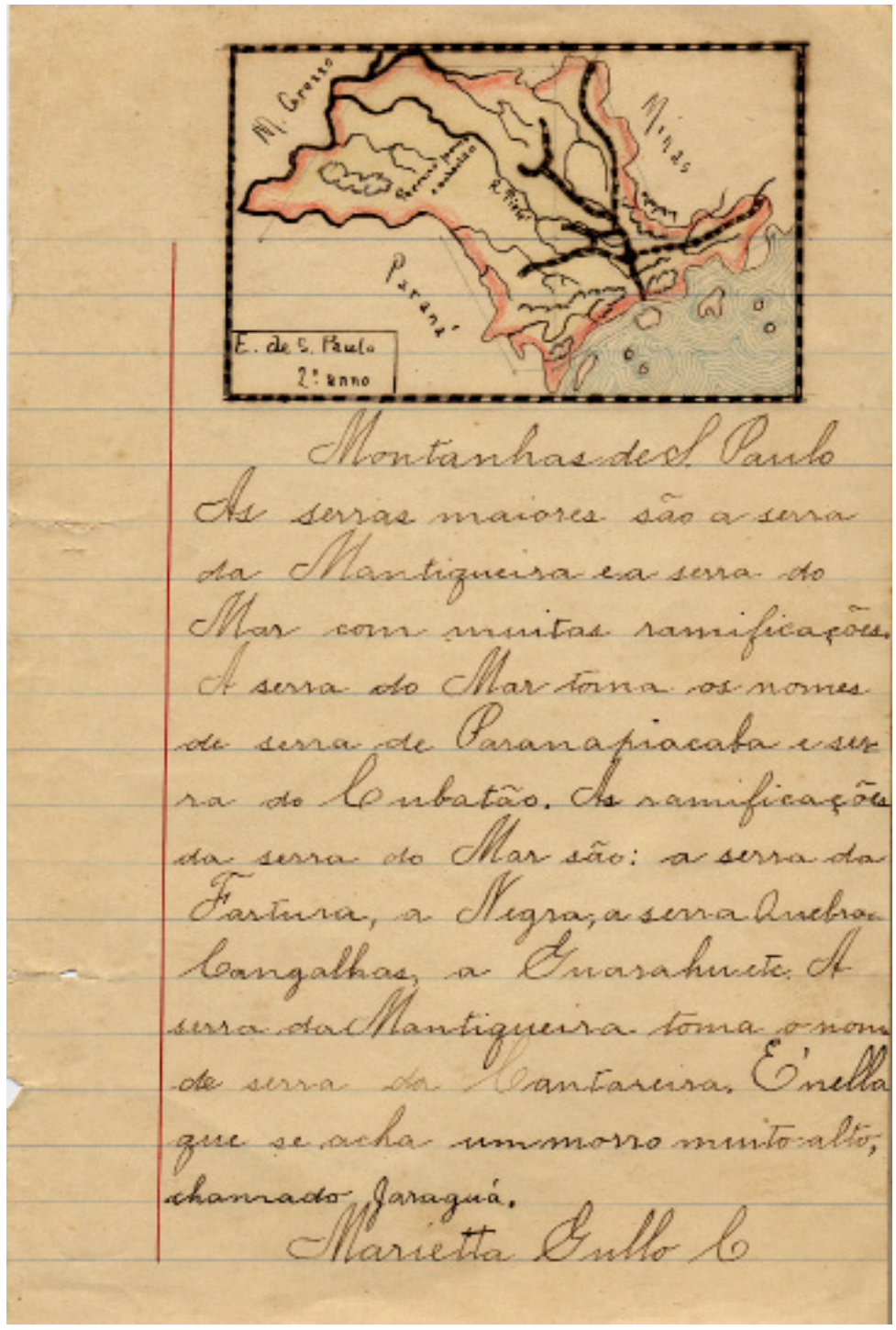

Esboço da pequena pátria (APESP) 
400

Arugo Escolor Cymaria gose. 2:a.....

Linguragen

Pinc de Litiolise.

Qunida extlega

Pele dia de loge wertio te fechestas Itefe completas mane um ammo de Jyecosa existencia.

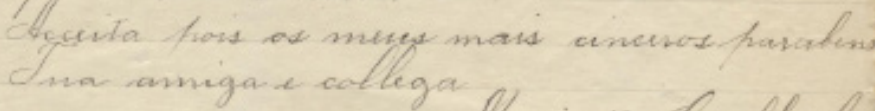
amiga collega llavitta Lutlo la

Exercício de linguagem (APESP) 


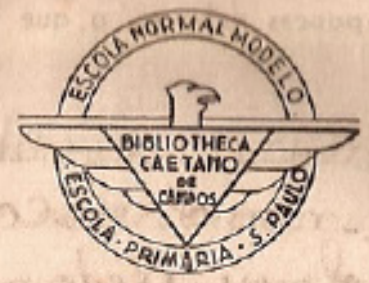

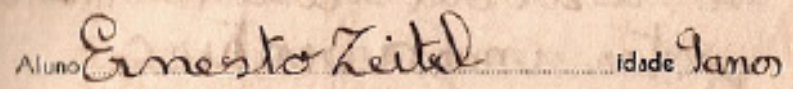
cum 2 Eanoli periosotarde

\section{FICHAODE LEITURA}

Nome do obreiritmeticada Emilia Nore do suter? Tomting Lobato Nocionalidede do autor Brasileiro

Data do inicio da leitura $16-8-43$

Dato da tera inç̧⿻ do leitura $21-8-43$

Conhece outyas obras do nesmo autor? $\mathrm{Sim}$

Quis? Reforma da Ratunesa, Anentivap de camp Stadent as lacadonde Pedrinno.

Que achou do liwo? from

E' realidede ou ticgão? fice clo.

pross ou verso? Prosa

Qual o penonajein gue sis a impressionou 70 Mrconde

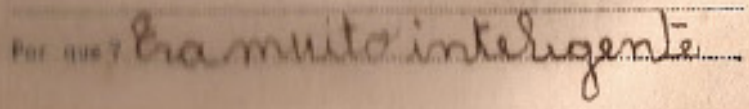

Minha leitura (CRPHE) 


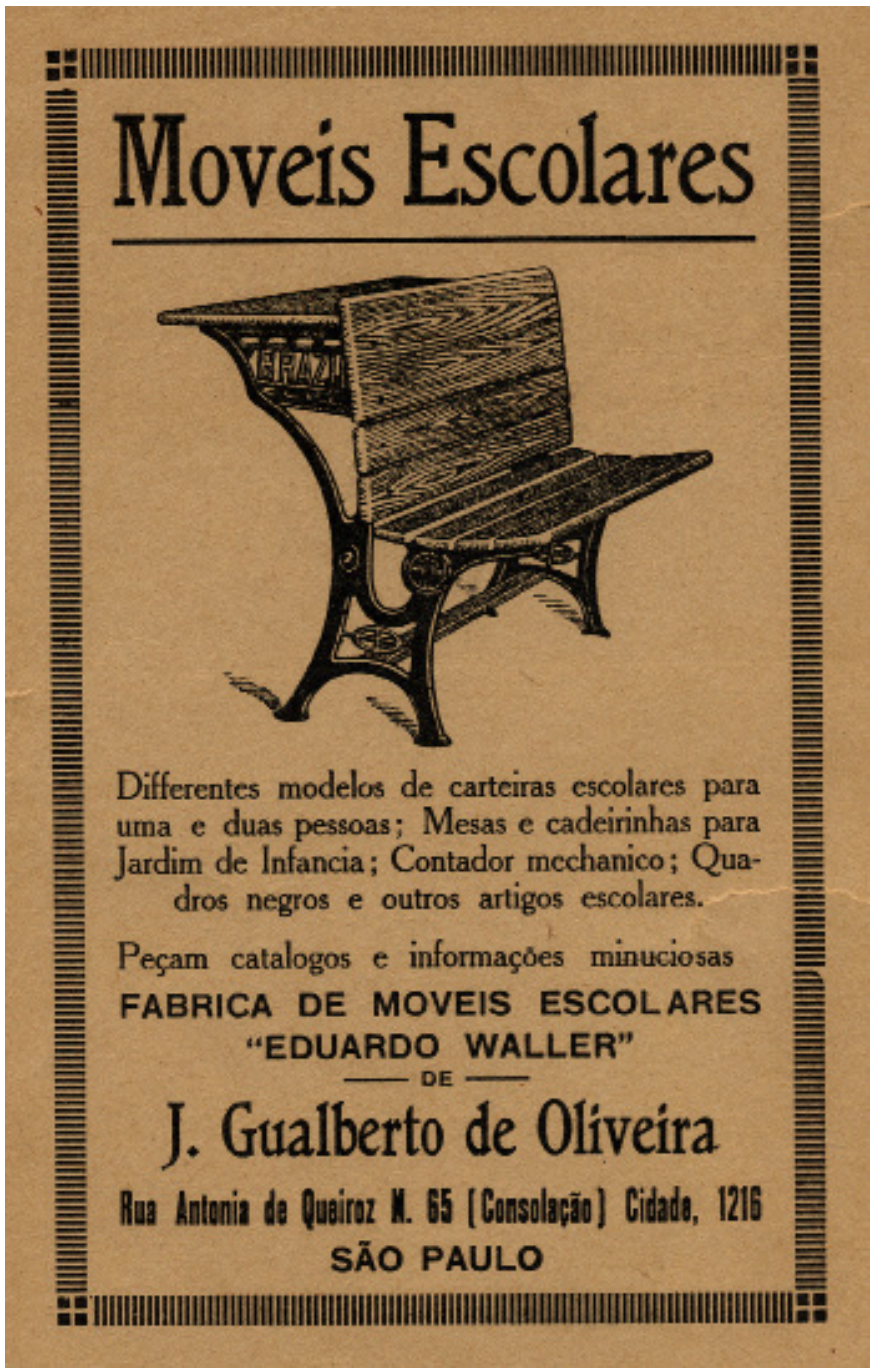

Moderno reclame (CRPHE) 
403

Deserifreá. 3-10-94. Chinguem deve ser curiade. Peve un facto muito im fortante no visurio de Nafoles. (1) cidadaio brazilir. Lilva Pardim com outho compranheis feram passei ar em Vaproles eo bive Aturdion teve. a curiosidade de is ver $\sigma$ visuvio efoi reams o seu compranhiro.

Chegaram a umaresta allura e $\sigma$ compranheiro ao quiz ve bir mas mias - Dilva Sardim quig ver a te a boea e foi sorinho quando ehe gow na boec do visurvio efoi atrabido dentro.

Rammun Gullo bastelcars

Ninguém deve ser curioso - 1894 (APESP) 
404

BIBLIOTECA CENTRAL DE EDUCACÃO São Parlo, 28 de Youlvulrae 194 ४

Fu, ahaixo assinado, desejando gozar das regalias concedidas aos consulentes desta Biblioteca, prometo

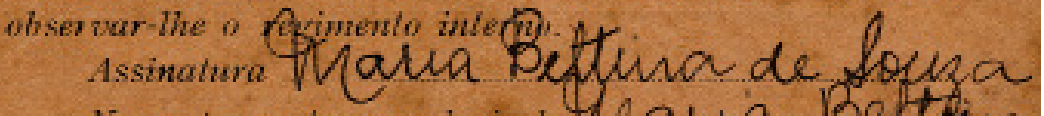
Nome por extenso e legios tharia Bettina de fouza.

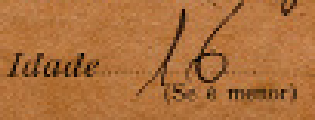

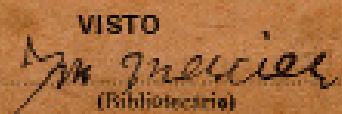

Retirando livros na biblioteca (CRPHE) 
7. Nos núcleos de imigrantes, perspectivas

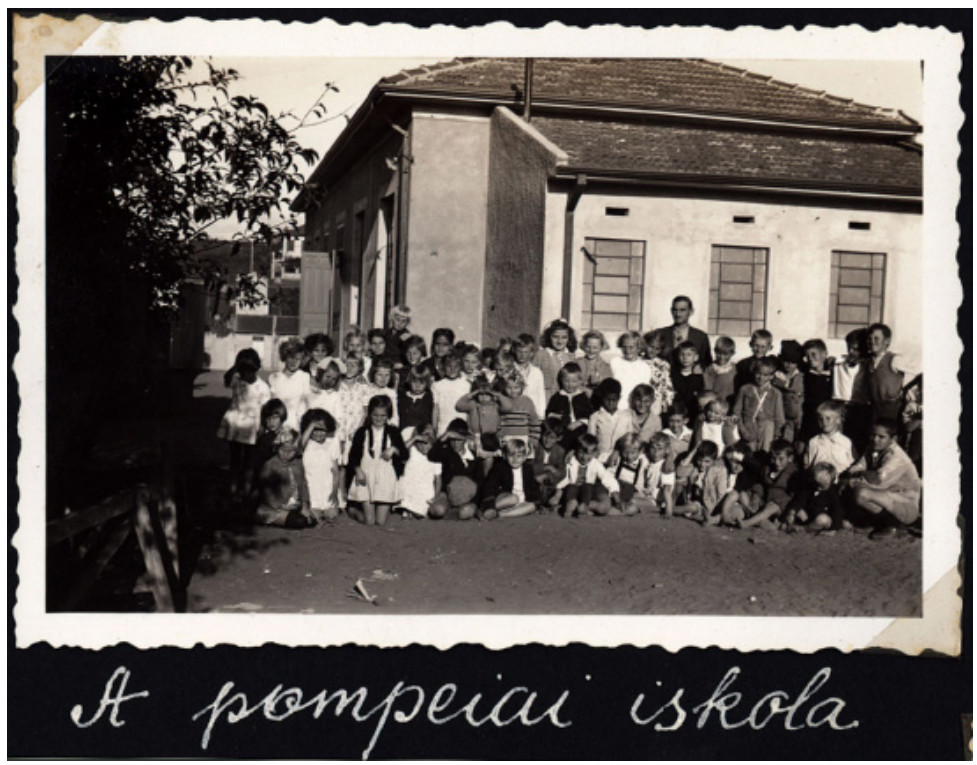

A pompeai iskola - SP (APESP) 


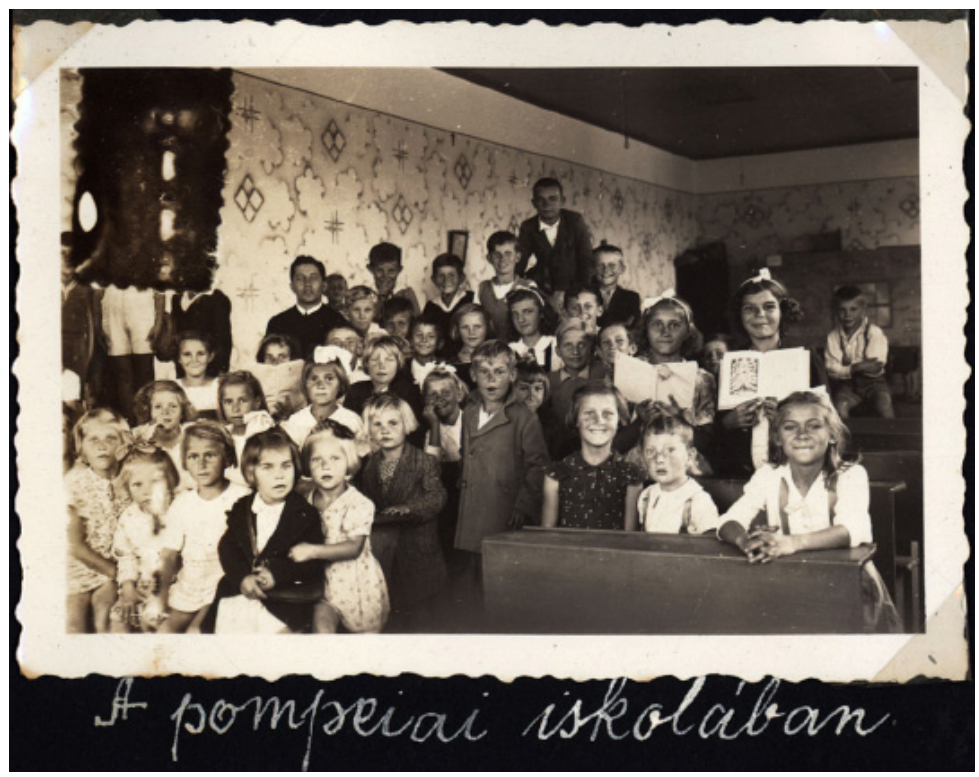

Alunos de origem húngara - SP (APESP)

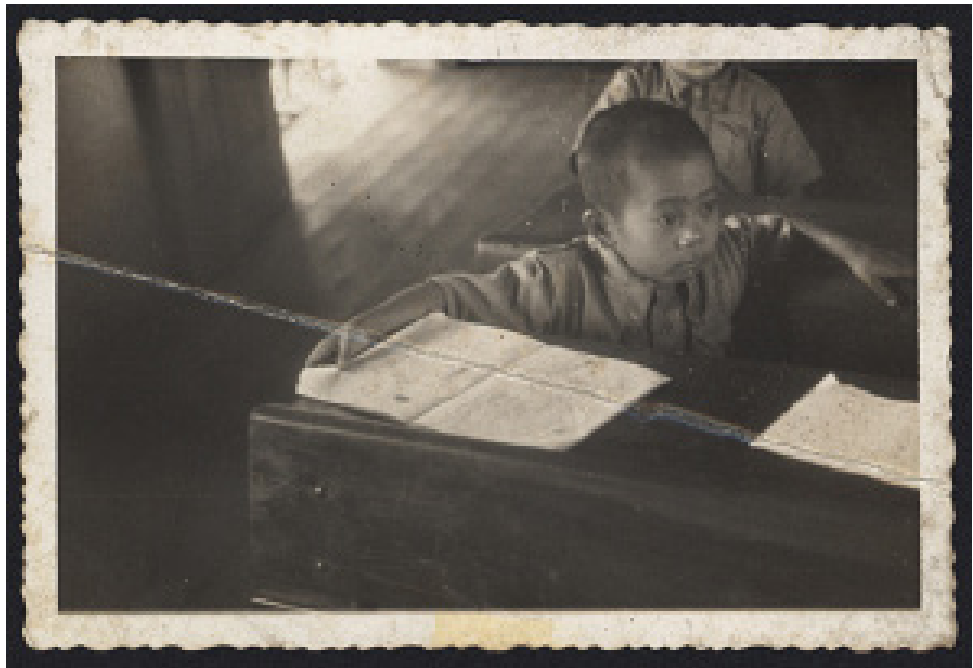

Atento ao professor - SP (APESP) 


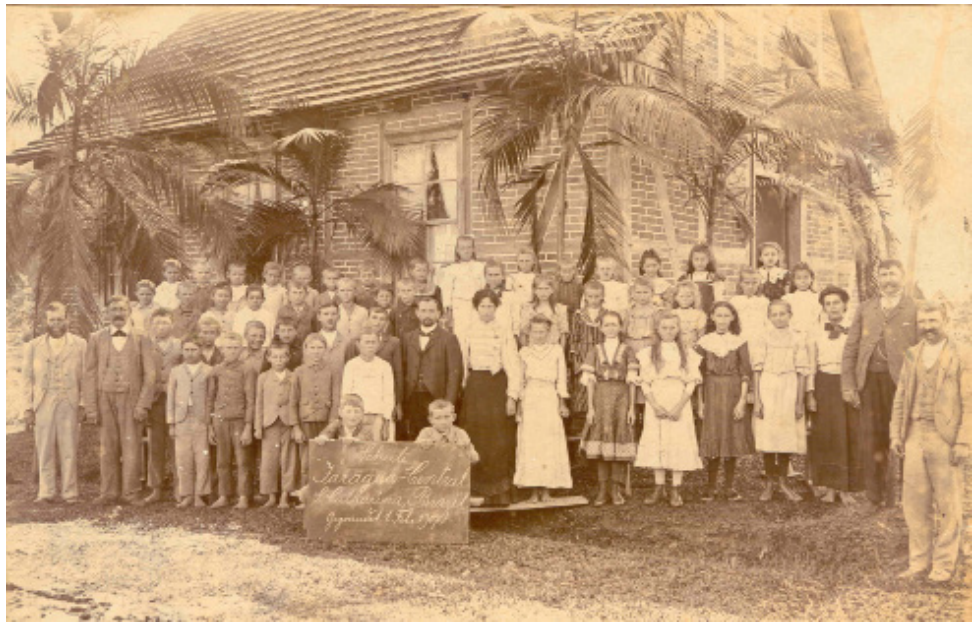

Colégio evangélico, antiga escola alemã - SC (AAHJS)

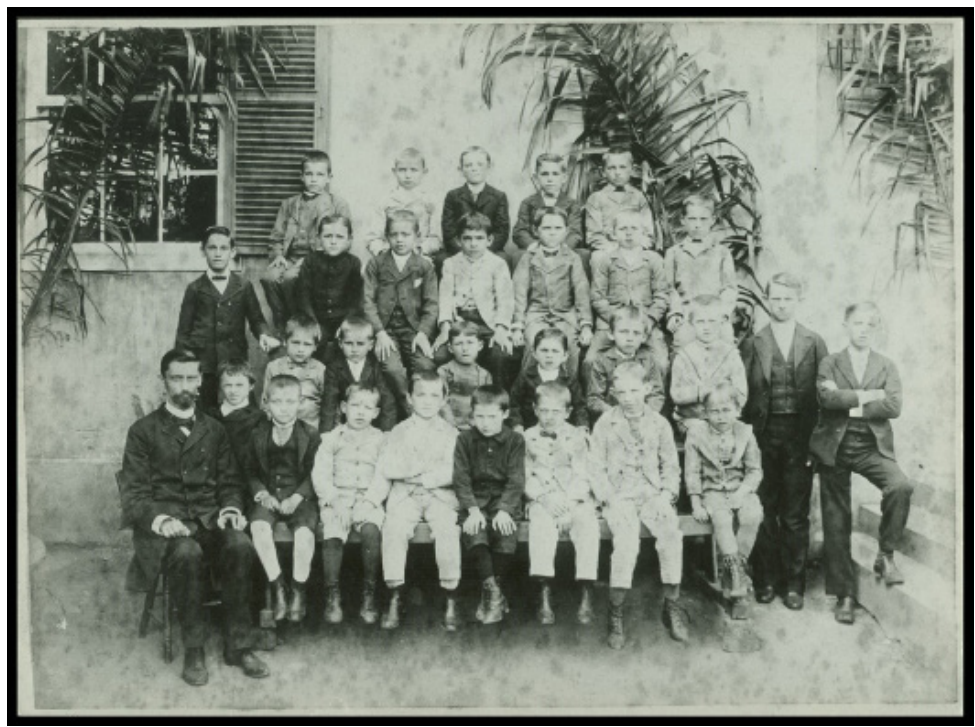

Escola alemã - Rio Claro - SP - 1900 (APESP) 


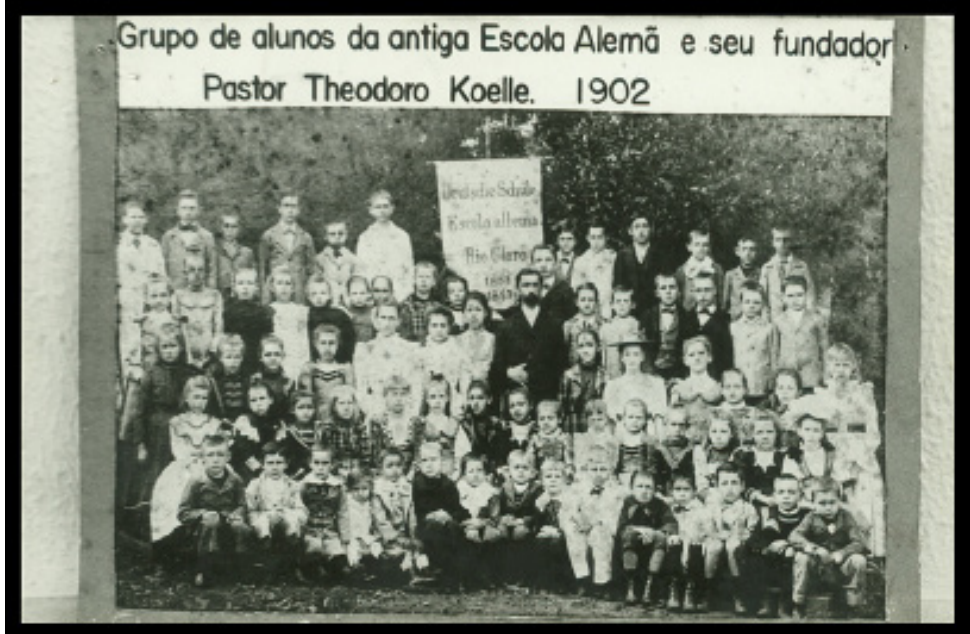

Escola alemã e seu fundador pastor Theodoro Koelle - SC (AAHJS)

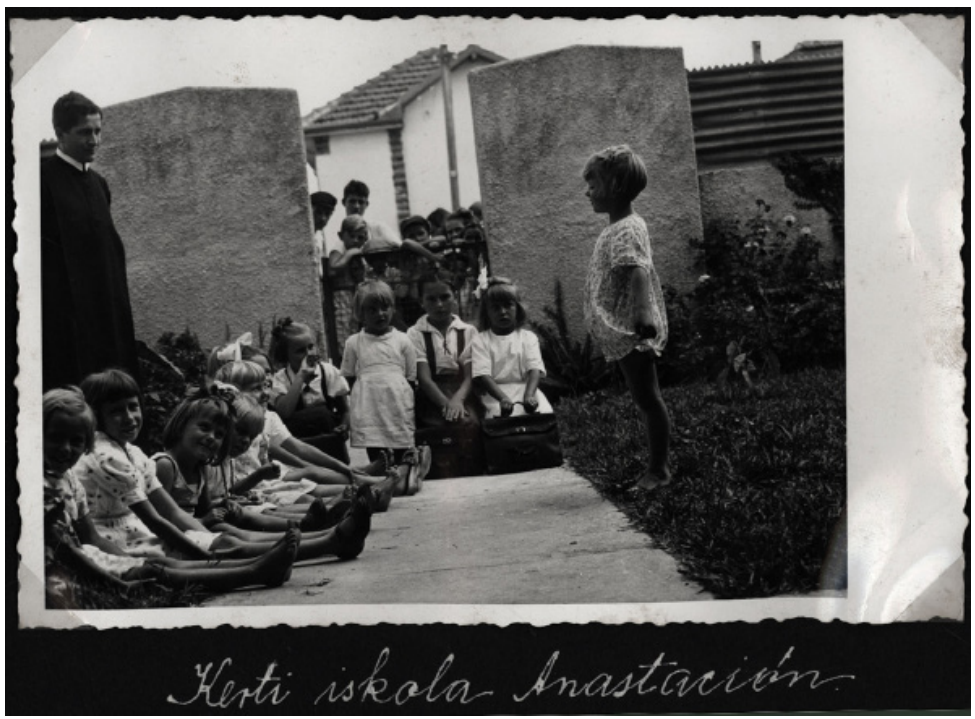

Escola húngara - SP (APESP) 


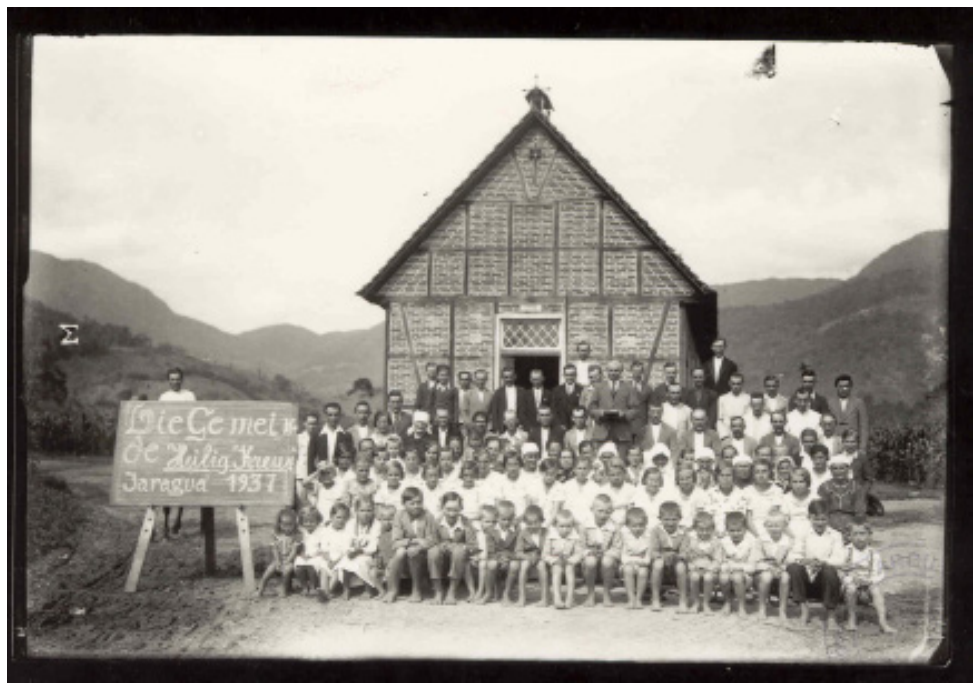

Escola Jaraguá - Prof. Wendelin Schmidt com livro na mão -SC (AAHJS)

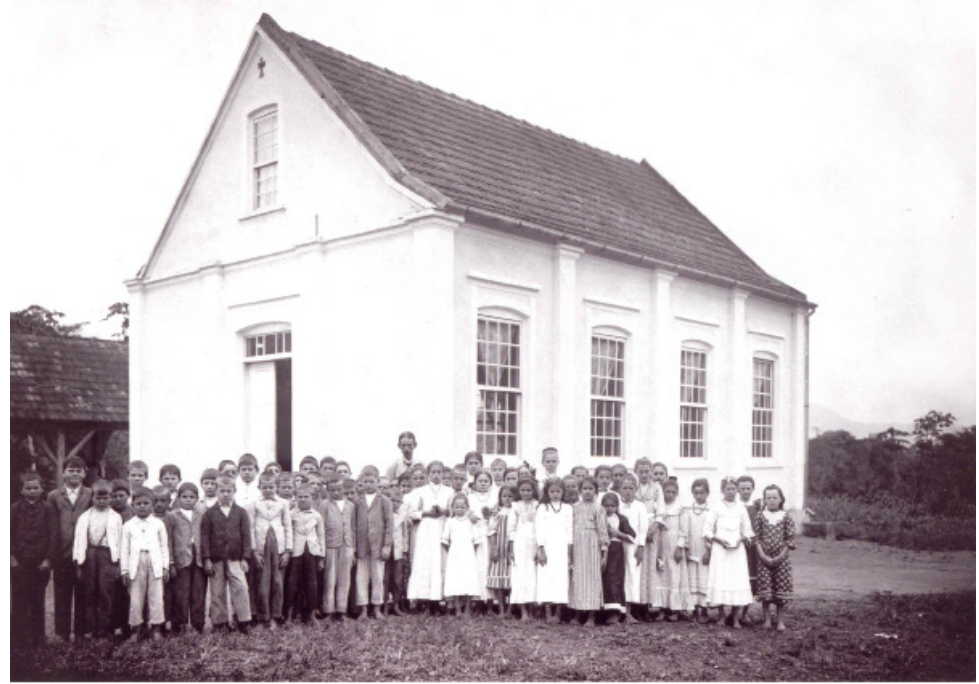

Escola Prof. Abramo Pradi - Jaraguá do Sul - SC (AAHJS) 


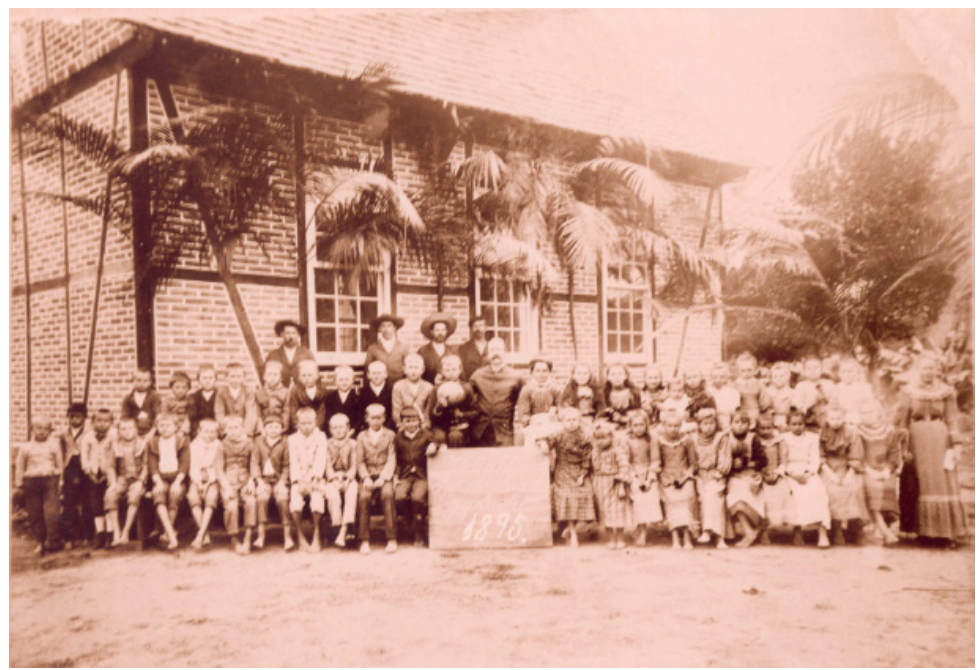

Escola Rio da Luz - Comunidade evangélica - SC (AAHJS)

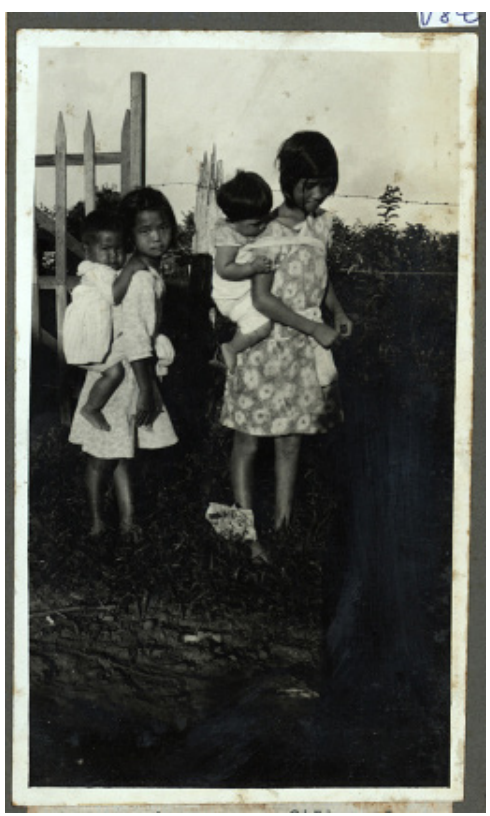

Filhas de imigrantes japoneses - SP (APESP) 


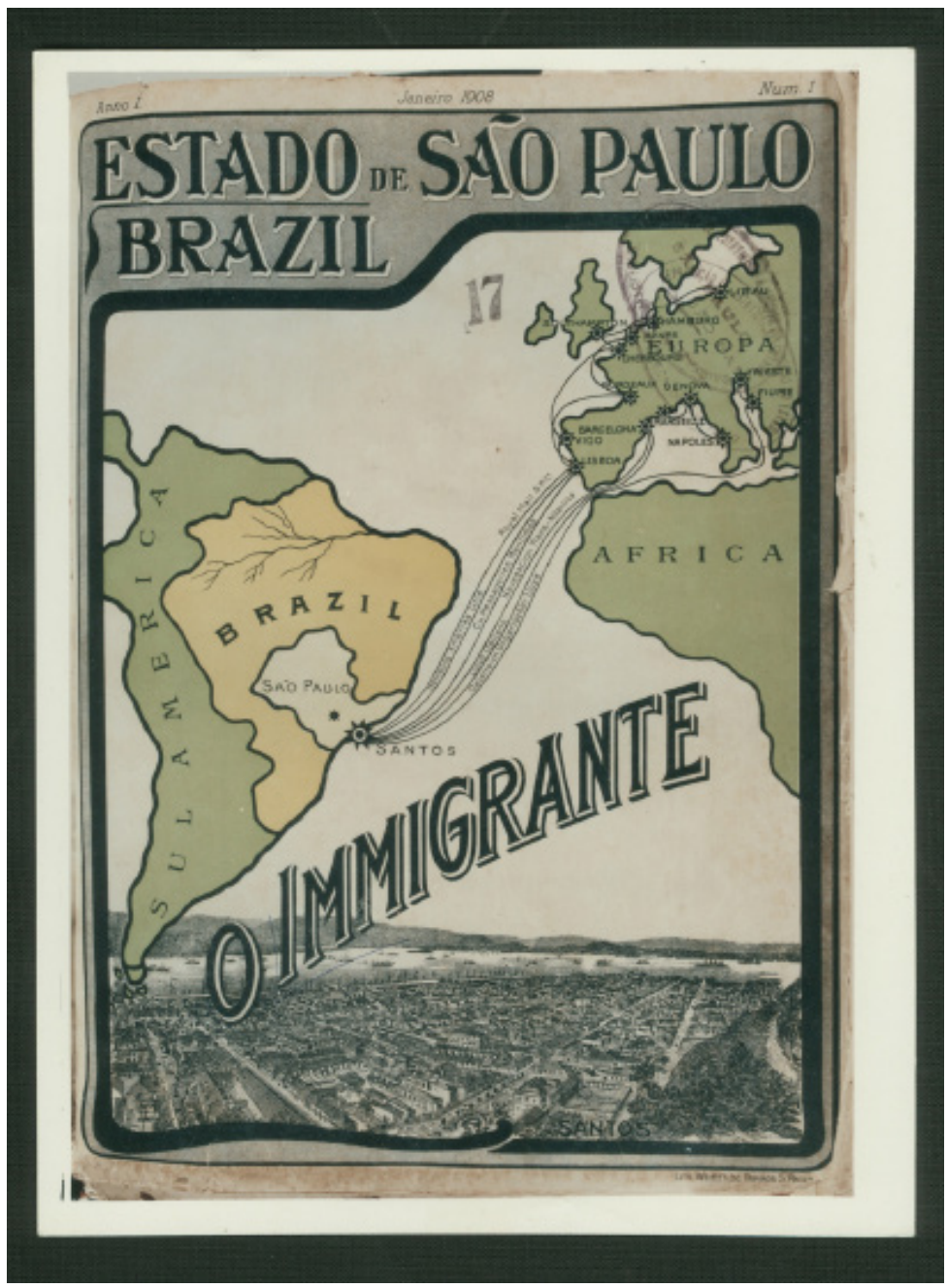

No mapa, o fluxo imigratório 


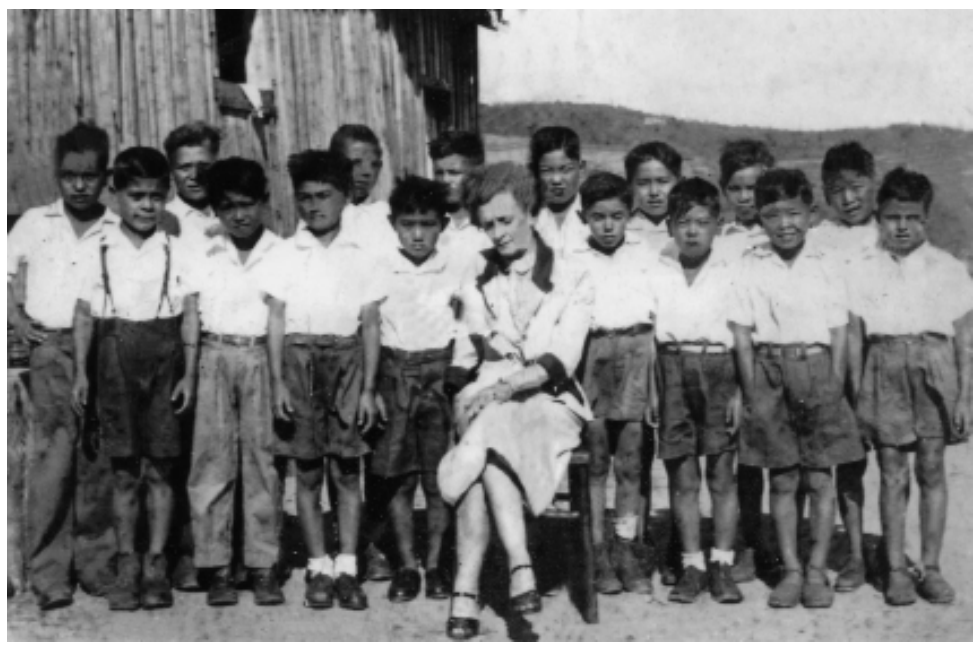

Núcleo de colonização japonesa - SP (CRPHE)

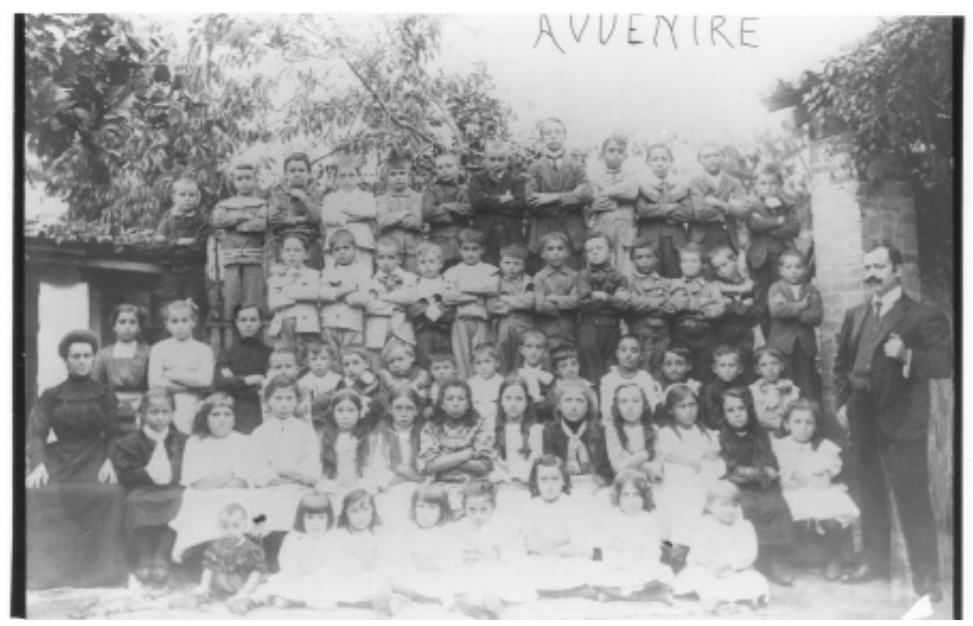

Si parla italiano - Escola Avenire - SP (DPH-SMC) 


\section{Crédito das imagens}

Acervo Arquivo Histórico de Jaraguá do Sul "Eugênio Victor Schmökel" PR - (AAHJS)

Arquivo Público do Estado de São Paulo - (APESP)

Casa de Oswaldo Cruz - Rio de Janeiro - (COC)

Centro de Referência para Pesquisa Histórica em Educação - Faculdade de Ciências e Letras da Universidade Estadual Paulista - campus de Araraquara - (CRPHE)

Departamento do Patrimônio Histórico da Secretaria Municipal de Cultura de São Paulo (DPH-SMC)

Museu Paulista da Universidade de São Paulo - (MP-USP) 



\section{Índice onomástico}

A

Abreu e Lima, José Inácio de 50

Aguiar, Antonio Pinheiro 94

Aires de Casal 214

Alberto, João 257, 285

Albuquerque, Pedro Autran da Matta e 103

Albuquerque, Salvador Henrique de 49

Alcântara, Pedro de 33, 35

Alencar, José 69, 111

Alencar, Renato de 237

Almeida Júnior, Antonio de $\quad 232,270$

Almeida, Cândido Mendes de 98, 214

Almeida, Júlia Lopes de 213, 219

Almeida, Lourival de 254

Almeida, Manuel Ribeiro de 94

Almeida, Miguel Calmon du Pin e 29

Almeida, Miguel Calmon du Pin e 178, 206, 302

Almeida, Rui Guimarães de 326

Alonso, Ângela 317

Alves, Isaías 316

Alves, Constâncio 273

Alves, Raul 206, 218

Amado, Gilberto 229, 303

Amaral, Amadeu $\quad 222,232,273,311$

Amaral, Tancredo do 166

Americus 26-30, 104, 303

Amicis 165, 398

Anderson, Benedict 318

Andrada, Antonio Carlos de 22, 23, 84
Andrada, Martim Francisco Ribeiro de 21-

23, 26, 29, 47, 307

Andrada e Silva [O moço] 70, 71, 110, 303

Andrade, Elyseo Castanho de 303

Andrade, A. F. M. 98

Andrade, Aguiar de 22

Andrade, Maria Guilhermina Loureiro de 96, 156

Andrade, Thales Castanho de 250

Andrade, Teófilo 283

Antipoff, Helena 291

Aragão, Egas Moniz Barreto de 231

Araripe Júnior 238

Araújo, Antonio Bahia da Silva 119, 120

Araújo, José Carlos 318

Arendt, Hannah 131,318

Araújo, José Paulo de Figueroa Nabuco de 52

Araújo, Oscar de 149, 303

Armitage, John 24,303

Assis Brasil, Joaquim Francisco de 245

Assunção, Manuel Paulino de 94

Athayde, Tristão de 229

Auras, Gladys Mary Teive 326

Azambuja, Joaquim Maria Nascentes de 103

Azevedo, Fernando de $\quad$ 203, 232, 246, 254,

257, 259, 264, 265, 272, 275, 291

Azevedo, Francisco L. 293, 303

Azevedo e Sá, João Hyppolito de 202

Azzi, Francisco 232 
B

Backheuser, Everardo $\quad$ 254, 255

Baden-Powell 222

Baena, Antonio Ladislau Monteiro 52

Bain, Alexander 89, 303

Balmat, Alexandre 49

Bandecchi, Brasil 220,318

Bandeira Júnior, Antonio Francisco 97

Bandeira, Antonio Herculano de Souza 107

Bandeira, Esmeraldino 180

Barbosa de Oliveira, C.A. 255

Barbosa, Januário da Cunha 27, 29, 76

Barbosa, Rui $\quad 69,76,79,80,87,89,118,126$,

$133,134,135,170$

Barbosa Lima Sobrinho 179, 254, 318

Barreto, Arnaldo de Oliveira 166

Barreto, Plínio 248

Barreto, Tobias 64

Barros, José Augusto de 188

Barros, Roque Spencer Maciel de 304, 309

Basedow: 90, 177

Basile, Marcello Otávio Neri de Campos 318

Bastos, Maria Helena Camara 304, 326

Beaumont, Jeanne Marie Leprince de 53, 315

Beaurepaire, Jacques Antonio Marcos de 52

Bell, Andrew 40

Bellegarde, Henrique Luiz de Niemeyer 52

Bello, José Maria 176, 275, 311, 318

Bentham, Jeremy 27

Berlinck, Eudoro Brasileiro 52

Bernardes, Arthur 237

Bilac, Olavo $151,166,207,211,213-216$,

$252,304,315$

Bittencourt, Raul J. 237, 292

Bittencourt, Agnello 207

Blanchard, Pedro 53

Bocaiuva, Quintino $\quad 64,97,132,133$

Bomfim, Manoel 304, 315, 321

Bordeaux Rego, Oziel 186-188, 214, 264, 304

Borges, Abílio César $\quad 85,304$

Borges, Pedro Manoel 98
Bosi, Alfredo 236, 318

Botelho, André 318

Bowen, James 100, 318

Braga, Odilon 291

Braga, Theodoro 232

Bragança, Aníbal 318,324

Brandão, Alberto 76

Brás, Wenceslau 224

Braziliense, Américo $\quad 64,68,96,134,155$,

304

Brescianni, Stella 217, 318

Briquet, Raul 78, 232, 328

Breves, Arthur 143

Brito Aranha 96

Brotero, João Dabney de Avelar 56, 114, 300

Browne, Márcia 156

Bruno, G. 214

Buarque de Holanda, Sergio $\quad 61,304,319$

Büchler, José Augusto 195, 238, 304

Buckle 86

Buisson, Ferdinand $\quad 89,106,326$

Bulcão, Mario: 248, 249, 315

Bulhões Carvalho, José Luiz Sayão de 153, 181-184, 188, 192, 197, 198, 264, 302, 304, 305

C

Cabanis 28

Caetano de Campos, Antonio $\quad 142,143$,

154-156, 161, 305, 312, 316

Calkins, Norman Allison 89

Calógeras, João Pandiá 181, 302, 305

Camargo, Cristovam 305

Camargo, Vicente Tomás Pires de

Figueiredo 40

Campos Sales $\quad 169,192,305,322$

Campos, Américo de 155

Campos, Bernardino de 157, 162

Campos, Francisco 263

Campos, Ovídio Pires de 232

Cardoso, Vicente Licínio 80,149, 229, 230,

231, 312, 
Carneiro Leão, Antonio $\quad$ 218, 223, 229, 231, 234, 246, 305

Carneiro Leão, Honório Hermeto 36

Carone, Edgard $\quad 170,193,257,319$

Cartolano, Maria Teresa Penteado 152, 325

Caruso, Marcelo: 42, 320

Carvalho, Bernardino de 46

Carvalho, Carlos Leôncio de $\quad 20,76,77,89$,

$112,123,305,314$

Carvalho, Felisberto 103 (??), 151

Carvalho, José Luiz Sayão de Bulhões 181

Carvalho, José Murilo de 319

Carvalho, Ronald de 229

Casalecchi, José Ênio 26 (??), 319

Casassanta, Mario 254

Castelo, Plácido Aderaldo 319

Castilho, Antonio Feliciano 50

Castilho, Francisco Alves da Silva 50

Castilhos, Júlio de 165

Castro, Felipe Ferreira de Araújo 55

Castro, José Antônio Pedreira de Magalhães 134

Castro, Aloísio de 258

Castro, Tito Lívio de 86,305

Cavalcante, João Barbalho Uchoa $\quad$ 103, 108

Cavalcanti, Amaro 78,300

Chauí, Marilena 212,319

Chermont, Justo Leite 162

Chizzotti, Antonio $37,309,325$

Coaracy, Vivaldo: 167, 305

Choppin, Alain 93,326

Coelho Neto 166, 214-216, 273, 315

Coelho, Augusto 103

Collichio, Terezinha Alves Ferreira $\quad 119,326$

Comenius 158

Comte $63,65,95,133,144,149,150,156$,

$163,164,275,320,325$

Condillac 27,90

Condorcet 22

Conduru, Felipe Benício de Oliveira 40

Constant, Benjamin $\quad 64,78,133,141,149$, 150-154, 156, 161, 229, 303, 305, 308, 317, 321,325
Conte, Alberto $\quad 272,275,276,312$

Cony, Augusto Cândido Xavier 108

Coqueiro, João Antonio 102

Corrêa, Gustavo 305

Correia, Manoel Francisco $\quad$ 109, 301, 335,

336

Correia, Viriato 214

Coruja, Antonio Álvares Pereira 52

Costa, Amélia Fernandes da 107

Costa Pereira 214

Costa Pereira, José Saturnino 52

Costa, Firmino 218

Costa, João Bittencourt 150

Costa, José Afonso de Paula e 83, 84, 305

Costa, Lisymaco Ferreira da 237

Costa, Manoel Olímpio Rodrigues 93, 314

Costa, Miguel 228, 257, 282

Cousin, Vitor 90

Couto Ferraz, Luiz Pedreira do 36, 37, 38, 111,112

Couto, Miguel $\quad$ 177, 218, 258, 272, 273, 306, 316,317

Cruls, Luiz 124, 287

Cruz, Alfredo Lopes da 231

Cruz Costa, João 64, 319

Cruz, Guilherme Francisco 76

Cruz, Noêmia Saraiva de Matos 256, 291

Cruz, Oswaldo $174,176,282,308,316,327$,

Cruz, Policarpio José Dias da 50

Cunha, Euclides da $\quad 65,130,175,219,230$,

252,306

Cury, Carlos Roberto Jamil $\quad 319,320$

\section{D}

D'Ávila, Antonio 166, 312

Daligault 103

Daltro Filho 256

Dantas, Rodolfo Epifânio de Souza 97

Darwin 28, 65, 86

Delermando, Cirilo 50

Denis, Ferdinand 214

Deus, João de 84 
Dewey, John 275

Diacon, Todd A. 175,320

Dolhnikoff, Miriam 35, 320

Domingues, Alfeu 249

Dordal, Ramon Rocca 166

Dória, Franklin Menezes 38, 78, 154, 306

Duarte, Marcelino Pinto Ribeiro 49

Duby, Georges 11,320

Dunshee de Abranches 149

Duque-Estrada, Luiz Carlos 90, 103

Duque-Estrada, Joaquim Osório 191

Durkheim, Émile 275

Dussel, Inés 42,320

\section{E}

Emelen, Amaro van 291

Escobar, Ildefonso $\quad 24,214,283,320$

Escobar, José Ribeiro 232, 328)

Espínola, Tomás do Bomfim 79

Espínola, Túlio 250

Esterci, Neide $\quad 284,325$

F

Falcon, Francisco $\quad 11,320$

Falloux 37

Faria Filho, Luciano Mendes de 304

Fausto, Boris $110,170,254,320$

Feijó, Diogo Antonio 33, 34

Fernandes, Henrique Costa 163, 306

Fernandes, Henrique Costa $\quad 163,306$

Fernandes, Oliveira 120

Ferraro, Alceu 195, 320

Ferrarotti, Franco 144,320

Ferreira Júnior, Alexandre Dias 132, 306

Fialho, Branca 291

Figueiredo, Afonso Celso de Assis 76,117, 312,315

Figueiredo, José Bento da Cunha 301,335, 336

Firmo, Xavier Inácio 56

Fleiuss, Max 43, 231, 306

Fonseca, Deodoro da 133, 135, 138

Fonseca, Hermes da $\quad 170,180,192,202$
Fontes, Lourival 291

França, Antonio Ferreira 29

França Leite 156

Franklin, Benjamin 53, 231, 309

Frazão, Manoel José Pereira 76, 97, 105, 107,306

Freeze, João Henrique 53

Freitas, Anamaria Gonçalves Bueno de 318

Freitas, Joaquim Pedro Corrêa de 96

Freyre, Gilberto $135,248,320$

Frias, Joaquim Inácio de 53

Fritsch, Lilian 174, 327

Fröebel 90, 92, 108, 158

Frontin, Paulo de 174

Frota-Pessoa, José Getúlio 222, 291, 306

\section{G}

Galhardo, Tomás Paulo do Bom Sucesso 94, 166

Galton, Francis 86

Galvão,J. R. 94

Galvão, Franklin Ramiz 141, 231, 309

Gama, Fernandes 214

Garcia, José Manoel 38, 39, 93, 314

Gardien 55

Gellner, Ernst $\quad 217,218,281,320$

Gentil, Alberto 253

Giesbrecht, Ralph 316

Girardet, Raoul 217,281,320

Godofredo Furtado 64

Gomes, Carlos 191

Gomes Cardim, Carlos Alberto 166, 216

Gonçalves Dias, Antonio 35, 48, 306

Gontard, Maurice 37,321

Gonzaga, Aprígio 254

Gorceix, Henri 124

Goulart de Andrade 273

Grande, Humberto 253

Gréard, Octave 42, 306

Guanabara, Manoel José da Silva 90,103

Guerra, Amanda Estela 321, 327

Guimarães, Aprígio Justiniano da Silva 76 
Guimarães, Orestes 218, 223, 224, 234, 235, 237, 272, 274, 306, 326

Guizot 37,38

\section{H}

Hacilman, W. 108

Haeckel 65, 86

Haidar, Maria de Lourdes Mariotto 77, 321

Hamel, Joseph 40, 41, 307

Hansen, Patrícia Santos 215, 216, 325

Hartly 27

Haussmann 174

Hawthorne, Daniel 52

Hébrard, Jean 48, 321

Helvécio 27

Hippeau, Celéstin 90,107

Hobbes 27

Hudson, Otaviano 94

Hume 27

\section{I}

Ibirapitanga, Antonio Gentil 50

Iglésias, Francisco $\quad 33,134,253,321$

Ihering, Rodolfo 250

Inglês de Souza, Herculano Marcos 118

J

Jaboatam 214

Jacobina, Antonio de Araújo Ferreira 94, 138

Jardim, Antonio da Silva 64, 155, 252

Jardim, Renato 232, 237

Jordão, João Rodrigues da Fonseca 96

Jussieu, Laurent Pierre de 55

\section{K}

Kassef, Leoni $\quad 237,254$

Kelly, Celso $\quad 254,259,291$

Koeffer, Carlos $\quad 50,51$

Köpke, João 94, 155, 166

Kreutz, Lúcio $\quad 224,321$
Kubo, Elvira Mari 46, 116, 321

Kuhlmann, Guilherme 201

L

Lacerda, Nelson Nogueira de 307

Lacerda, Joaquim Maria de 96

Lajolo, Marisa 215, 321

Lamarck 65

Lancaster 28, 29, 40, 41

Lane, Horace 156

Le Bon, Gustave 86

Leal, Victor Nunes $169,251,321$

Leão, José 155

Leão Machado 283

Leitão, Antonio Candido 76

Leitão, Antonio da Cunha $\quad 119,120$

Leite, Gervásio 291, 292,321

Leme, Sebastião 280

Lemos, Miguel 64,163

Lemos, Renato 321

Lenharo, Alcir $\quad 282,284,321$

Lesage, Pierre 42, 322

Lessa, Gustavo 291

Lessa, Renato 169,322

Leuenroth, Edgar 209,308

Levi Carneiro 291

Lima, Araújo $\quad 22,35$

Lima, Nestor dos Santos 20,32, 50, 207,

208, 232, 307

Lima, A. Sabóia $\quad 253,322$

Lima, Afonso Herculano 76

Lima, Atílio Correia de 285

Lima, César Augusto Viana de 76,107

Lima, José Dias da Cruz 97

Lima, Mario de Souza 232

Lima, Pedro de Araújo 35

Lins, Ivan 64, 236, 322

Liberato Barroso 73, 74, 116, 307

Lisboa, Achilles 195

Lisboa, José da Silva 54, 55, 316

Lobo, Aristides da Silveira 133, 139

Locke 27, 90, 158 
Lombroso 86

Lopes, Adelina 166

Lopes, Antonio de Pádua Carvalho 318

Lopes Trovão 64

Lourenço Filho, Manoel Bergström 202, 307, 312, 323, 328, 348

Luchese, Terciane Ângela 224, 321

Lustosa, Isabel 21, 322

\section{M}

Macedo, de Antonio Victor 85

Macedo, Joaquim Teixeira de 76,107

Machado de Assis 97

Machado, Martim Francisco Ribeiro de

Andrada 21, 26, 29, 47

Magalhães, Benjamin Constant Botelho 78, 133, 149

Magalhães, Fernando 265

Magalhães, Valentim 159

Maia, Jacir 291

Maia, Silvio de Andrade 249

Man, Horace 75

Marcílio, Humberto $\quad 34,322$

Marcílio, Maria Luiza $\quad 114,322$

Marques Pinheiro 195, 231, 307

Pombal, marquês de 20

Macedo Soares, José Carlos 286

Marques, Abílio A. S. $\quad$ 155, 156

Marson, Adalberto 254, 322

Martins, Alfredo da Cunha 163

Martins, Francisco Dias 249

Mascarenhas, Francisco de Paula 94

Matos, Ach. 232

Mattos Pereira, Antonio Jansen 90, 91

Maudsley, Henry 86

Medeiros, Borges de 165

Medeiros e Albuquerque 129, 153, 317

Medeiros, José Augusto Bezerra de 218, 234, 289, 307

Medrado, Alcides Catão da Rocha 76

Méline, Félix-Jules 246, 307

Melo, Ester Pedreira de 234
Melo, João Crisóstomo do Couto 40

Melo, Joaquim Pedro de 56

Melo, Luís Correia de 328

Mello, José Baptista 307

Mello, Maria de Jesus 313

Mello e Sousa, João Batista de 234

Mendonça, Joaquim Ribeiro de 155

Mendonça, Sonia Regina 322

Menezes Vieira, Joaquim José de 151, 252

Menezes, Djacir 322,

Mennucci, Sud 150,195, 201,231,232,235,

246, 254, 256-260, 291, 294, 295, 307, 308,

$313,314,316,323$

Mesquita, Julio de 64

Michelet, Jules 146, 322

Miguez, Leopoldo 129,322

Miranda Azevedo 64, 155

Moacyr, Primitivo $\quad 30,73,308$

Monarcha, Carlos 116, 131, 155, 195, 202,

217, 260, 322, 323, 327

Moniz, Antonio Alves Branco 53

Monteiro, Joaquim dos Remédios 120

Monteiro Lobato 248, 250

Monteiro de Souza 218

Monteverde, Emilio Achilles 50, 55

Moraes Filho, Evaristo 30, 311, 323

Moraes, Deodato de $195,206,237,313$

Moraes, Theodoro de 196, 316

Morais, Alexandre J. Melo 53

Moreira de Azevedo, Manuel Duarte 19 , 26, 313

Moreira, João 323

Mota, Candido 99

Mota, Carlos Guilherme 323

Mota, Joaquim Inácio Silveira da 75

Motta Júnior, Cesário 162, 308

Motta, Cássio 317

Motta, Marly Silva da 323

Moura, Caetano Lopes de 55

Muller, Lauro $\quad 64,174$

Muniz, Antonio Ferrão 76

Muniz Tavares 22 
N

Nabuco, Joaquim 64

Nagle, Jorge 220,326

Nascimento, Jorge Carvalho do 323

Negro, Hélio 209

Neiva, Arthur 176

Neves, Fátima Maria 326

Neves, Lúcia Bastos Pereira das 324

Newland Neto, Otávio Tomaz 291

Nicolau, Jairo 25, 70, 136, 222, 324

Nofuentes, Vanessa Carvalho 220, 326

Nogueira, José Antônio 229

\section{$\mathrm{O}$}

Oliveira, Antonio de Almeida $\quad 88,98,308$

Oliveira, Cândido Batista de 51

Oliveira, João José Barbosa de 108

Oliveira, José Feliciano de 64, 159, 308

Oliveira, Maria Aparecida $\quad 267,268,315$

Oliveira, Mariano $\quad$ 163, 166

Oliveira, Tiago Siqueira 326

Oliveira Vianna $32,134,220,229,251,252$, 253, 308

Olympio, Mathias 308

Orico, Oswaldo $\quad 231,242$

Otávio, Rodrigo 166

\section{$\mathbf{P}$}

Pacheco, Praxedes 103

Padilha, Celina 291

Paiva, Athaulfo de 273

Paiva, Vanilda Pereira 324

Paranhos, José Maria da Silva $\quad 35,124,214$

Parley 52

Passalácqua, Camilo 103

Passos de Miranda Filho 179

Patrocínio, José do 126

Paz, José Ramos 96

Pechman, Sérgio 174,327

Peixoto, Afrânio $\quad 80,214,215,217,224,231$,

240, 273, 309, 316, 317

Peixoto, Floriano $\quad$ 135, 138, 287
Penna, Belizário $\quad$ 176, 237, 246, 254, 255,

308

Perdigão Malheiro 214

Pereira Barreto, Luiz $\quad 64,67,156,245,255$,

309

Pereira Júnior $\quad$ 102, 309

Pereira Passos, Francisco 174

Pereira, José Saturnino da Costa 52

Pernambucano, Ulysses 291

Pesavento, Sandra Jatahy 89,327

Pessoa, Epitácio 191, 233, 301

Pestalozzi 90, 96, 158, 177

Pinheiro, Joaquim Caetano Fernandes 55

Pinheiro Machado 170, 202

Pinheiro, Nuno 229

Pinna, Armando 255

Pinto, Diogo de Mendonça 56,114, 115,

300

Pires de Almeida, José Ricardo 31, 43, 91, 92, 95, 112, 113, 309

Pontes, Antonio Marciano da Silva 103

Pontes de Miranda 229

Porchat, Reynaldo 232

Portella, Joaquim Pires Machado 103

Porto-Carrero, Luisa Leopoldina Tavares 107

Portugal, Tristão da Cunha 53

Prado Júnior, Caio $\quad 36,324$

Prado, Eduardo $\quad 124,149$

Prado, Guilherme 166

Prestes, Gabriel $\quad$ 146, 156-159, 161, 317

Prost, Antoine 324

Prudente de Moraes 138, 142, 154, 155

Puiggari, Romão 166

Pujol, Alfredo $\quad$ 160, 309

Q

Queiroz, Maurício Vinhas de 291

Quesnay, François 138

\section{R}

Rabello, Marcos Franco 202

Ramalhete, Ubaldo 237 
Ramos, Theodoro 232

Rangel, José 236

Rangel Pestana 64,134,154-156, 161

Razzini, Márcia de Paula Gregório 216, 324

Rebouças, André 124,126

Rego, António 51

Reis, Aarão 64

Reis Filho, Casemiro dos 324

Reis, Luis Augusto Reis 107

Rémond, René 11,324,

Ribas, Antonio Joaquim 56, 114, 300

Ribeiro, Demétrio 134,165

Ribeiro, Hilário 94-97

Ribeiro, João $\quad$ 165, 166, 316

Ribeiro, Júlio 156

Ribeiro, Lourenço José 52

Ribot 86

Ricardo, Cassiano 283, 284

Rocha, Marlos Bessa Mendes da 327

Rocha, Mateus José da 53

Rodrigues Alves, 169

Rodrigues, Antonio Marques 51

Rodrigues, João Lourenço 309, 317

Rodrigues, José Honório 324

Romero, Silvio $\quad 64,86,119,120,147,155$, 217, 246, 305, 317

Rondon, Candido Mariano 291

Roquette-Pinto, Edgar 191, 253, 254, 258, 310

Rousseau 90,158,177

\section{$\mathrm{S}$}

Sá e Benevides, José Maria Correia de 118, 310

Saboia Lima 253

Sacramento Blake $29,37,78,79,114,328$, 329

Saffray 316

Saint-Hilaire 214

Saldanha Marinho 134

Salgado, Plínio 257

Salles Júnior, Antonio 231

Salles, Alberto 64
Sampaio Dória, Antonio de 198-201, 220, 221, 248, 257, 272, 273,302, 310

Santa-Anna Nery, Frederico José de 70, 124, $125,309,310$

Santos, Márcia Maria Duarte dos 327

Santos, Silvino 191

Saraiva, José Antônio 47, 69, 301

Sarmento, Casimiro José de Morais 56

Seidl, Raimundo Pinto 234

Senra, Nelson $139,192,324$

Serpa, Joaquim Jerônimo 55

Serrano, Jonathas 229

Serva, Mario Pinto $\quad 218,231,291,310$

Seyferth, Giralda 224, 324

Silva Jardim, Antonio da $\quad 64,155,252$

Silva Júnior, Dias da 107

Silva, Alfredo do Nascimento 121, 313

Silva, Antonio Carlos Ribeiro de Andrada

Machado e 84,305

Silva, Augusto Freire da 97

Silva, João Cândido de Deus 53

Silva, José Bonifácio de Andrada e 70,110

Silva, José Jorge Paranhos da 94

Silva, Josino do Nascimento 108

Silveira, Carlos da 313

Silveira, Joaquim José da 55

Silveira, Juraci 291

Silveira, Tasso da 229

Simon, Jules 154

Simões Lopes 254

Soares, Carlos Augusto 103

Soares, Francisco de Paula 50, 51

Sodré, Lauro $\quad 64,150$

Sodré, Nelson Werneck 283,310

Sousa, Clotildes Farias de 326

Sousa, João Batista de Mello e 234, 235

Sousa, Joaquim Moreira de 260, 291, 315

Sousa, Raul Alves de 218

Southey, Robert 214

Souza, José Boaventura de 324

Souza, José Paulino Soares de 40

Souza, Justiniano José de 53

Souza, Rui de Paula 232

Souza, Washington Luís Pereira de 199

Spencer, Herbert $\quad$ 144, 158 
Stockler, Francisco de Borja Garção 26, 30 Stuart Mill 27

\section{$\mathrm{T}$}

Taine 65

Tambara, Elomar 236, 324, 328, 329

Tanuri, Leonor 155,325

Tautphoeus 105, 155

Tavares Bastos 35, 62, 75, 106, 116, 310

Tavares Cavalcanti 206, 234

Tavares de Lira 180

Teixeira, Anísio 259

Teixeira Brandão 238, 239, 310

Teixeira de Freitas, Mario Augusto 254, 263,

264, 265, 267, 286, 289, 311, 313

Teixeira Mendes, Raimundo $64,149,163$, $164,165,314,317$

Teixeira, José Bruno 290, 313

Teixeira, Múcio $\quad 67,317$

Teixeira, Pedro Ludovico 285, 286

Thompson, Oscar 199,300

Torres Filho, Artur 291

Torres, Alberto $\quad 239,246,252,253,254,255$, 256, 259, 260, 294, 306, 318, 322, 326

Torres, Artur 291

Trindade, Iole Maria Faviero 327

U

Ubatuba, Ezequiel 249

Uchoa Cavalcanti 90,103,108

V

Vanerio, Eusébio 97

Varela, Alfredo 213

Vargas, Getúlio 282, 283, 295, 315

Vasconcellos, Aleixo de 177
Vasconcelos, Bernardo Pereira de 33

Vechia, Ariclê $\quad 46,327$

Veiga, Evaristo da 33

Venancio Filho, Francisco 34, 218, 291,

313, 329

Verdenal, René 144, 325

Veríssimo, José $59,63,64,83,126,127,149$, $151,153,162,219,311,317$

Veyne, Paul 10,325

Viana, Ulisses Machado Pereira 79

Vianna, Vítor 234

Vianna, Hélio 311, 325

Vidal e Souza, Candice 325

Vieira, Celso 229

Vieira de Mello, Alfredo Pinto 233

Vieira, Manuel Inácio Belfort 162

Vieira, Paim 232

Vilar, Pierre 329

Villa-Lobos, Heitor 283

Villela, Heloísa 326

Vivacqua, Atílio 254

Viveiros, Jerônimo José de 40, 51, 327

Viveiros, José Francisco de 101

Vovelle, Michel 11,325

X

Xavier, João Theodoro 116

W

Walsh, Robert $\quad 45,317$

Werneck, Antônio Luiz dos Santos 134

Z

Zaluar, Emílio 97 
Sobre o livro

$\begin{aligned} \text { Formato } & 15 \mathrm{~cm} \times 21 \mathrm{~cm} \\ \text { Tipologia } & \text { Adobe Caslon Pro } \\ \text { Papel } & \text { Pólen } 80 \mathrm{~g}\end{aligned}$


Compartindo do investimento de formar súditos da monarquia ou cidadãos da República, irrequietos e desacomodados, ora em chave realista ora fantasiosa, publicistas provindos de horizontes diversos, guardadas as ipseidades, convergem na urgência de uma instrução primária de Estado, gratuita e obrigatória (e no evoluir do tempo, laica), como marco da estratégia geral de governo pacificado e liberação de forças produtivas. Desnecessário dizer que nesses sobrevoos de imaginação a instrução popular aparece como propedêutica ao homem social pela efetividade da cultura. No aglomerado de vozes, paz pública, razão de Estado e economia política se entrecruzam. Endosso prático e anteparo firme viriam da instrução organizada como instituição nacional, valioso tonificante, poderoso moto-contínuo, adorável anjo da paz. Eis, leitor, o todo e o porquê de $A$ instrução pública nas vozes dos portadores de futuros (Brasil- séculos XIX e XX).

Carlos Monarcha

Editora filiada à

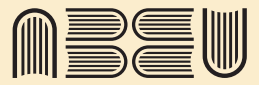

Associação Brasileira das Editoras Universitárias

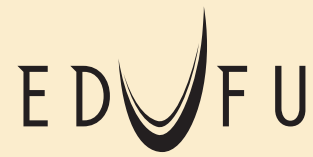

Editora da Universidade Federal de Uberlândia www.edufu.ufu.br

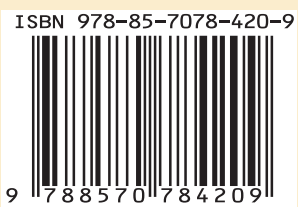

